Macciuci, Raquel

Autonomía del arte y

compromiso en la obra de tres

escritores españoles exiliados

en la Argentina: Ramón Gómez

de la Serna, Francisco Ayala y

Rafael Alberti

\section{Tesis presentada para la obtención del grado de Doctora en Letras}

Directores: Pochat, María Teresa; Cowes, Hugo W.; De Diego, José Luis

Este documento está disponible para su consulta y descarga en Memoria Académica, el repositorio institucional de la Facultad de Humanidades y Ciencias de la Educación de la Universidad Nacional de La Plata, que procura la reunión, el registro, la difusión y la preservación de la producción científico-académica édita e inédita de los miembros de su comunidad académica. Para más información, visite el sitio

www.memoria.fahce.unlp.edu.ar

Esta iniciativa está a cargo de BIBHUMA, la Biblioteca de la Facultad, que lleva adelante las tareas de gestión y coordinación para la concreción de los objetivos planteados. Para más información, visite el sitio www.bibhuma.fahce.unlp.edu.ar

\section{Cita sugerida}

Macciuci, R. (2002) Autonomía del arte y compromiso en la obra de tres escritores españoles exiliados en la Argentina: Ramón Gómez de la Serna, Francisco Ayala y Rafael Alberti [en línea]. Tesis de doctorado. Universidad Nacional de La Plata. Facultad de Humanidades y Ciencias de la Educación. Disponible en: http:// www.fuentesmemoria.fahce.unlp.edu.ar/tesis/te.127/te.127.pdf

Licenciamiento

Esta obra está bajo una licencia Atribución-No comercial-Sin obras derivadas 2.5 Argentina de Creative Commons.

Para ver una copia breve de esta licencia, visite http://creativecommons.org/licenses/by-nc-nd/2.5/ar/.

Para ver la licencia completa en código legal, visite http://creativecommons.org/licenses/by-nc-nd/2.5/ar/legalcode. 


\title{
AUTONOMÍA DEL ARTE Y COMPROMISO EN LA OBRA DE TRES ESCRITORES ESPAÑOLES EXILIADOS EN LA ARGENTINA: RAMÓN GÓMEZ DE LA SERNA, FRANCISCO AYALA Y RAFAEL ALBERTI
}

\author{
ÍNDICE
}

Introducción

I. VANGUARDIA. LAS CATEGORÍAS VERTEBRADORAS: AUTONOMÍA DEL ARTE,

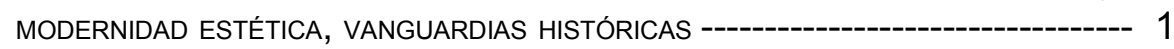

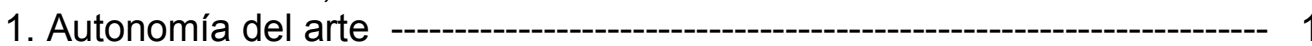

1.1. La conformación de la esfera autónoma del arte.

Sus consecuencias en la esfera social y artística

1.1.2. Consecuencias de la autonomización de la esfera artística:

separación arte - praxis vital. La institución arte y la estética ----------- 5

2. Vanguardia . Consideraciones previas -- 9

2.1. Vanguardia y modernidad. Sobre las dos modernidades -------------------- 10

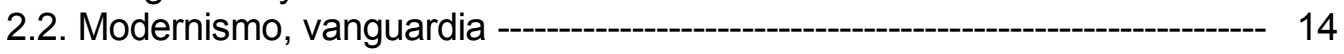

2.3. Distintos alcances del concepto vanguardia.

Las vanguardias históricas --

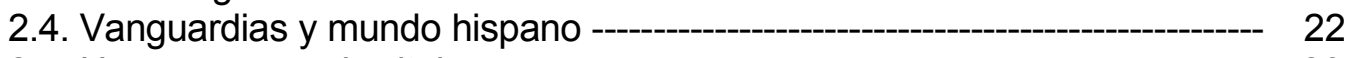

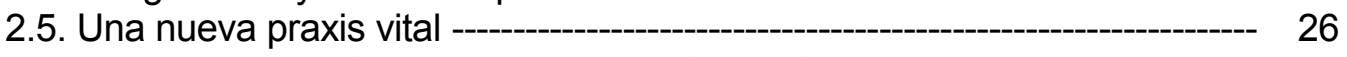

2.6. El peso del significante: El momento formal frente al momento del contenido. Creador y receptor de la obra de vanguardia -

2.7. Vanguardia y progreso científico y tecnológico -- 39

3. Reflexiones finales sobre la vanguardia - --o-y 43

II. COMPROMISO. HACIA LA DEMARCACIÓN DE

UN MARCO TEÓRICO

1. Principales perspectivas ----------------------------------------------------------- 48

1.2. Arte frente a necesidades prácticas. Resistencia

a la autonomía del arte

1.3. El concepto de compromiso a partir de las vanguardias.

El debate Lukács-Adorno

1.3.1. Benjamin ante el teatro brechtiano - - 65

1.3.2. La rehabilitación de la relación arte - vida ------------------------------- 66

1.4. Artistas, escritores, intelectuales, hombres de letras --------------- 71

1.4.1. Benda y Sartre ---------------------------------------------------- 82

1.5. Síntesis sumaria de los problemas en torno al compromiso del artista

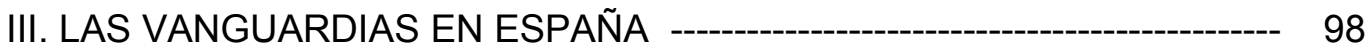

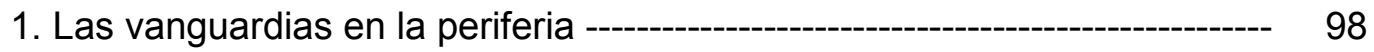

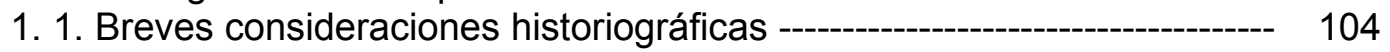

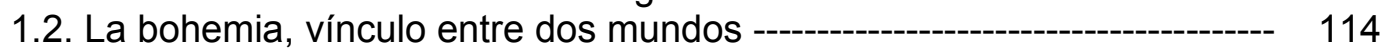

3. La vanguardia según Ortega ----------------------------------------------------- 18

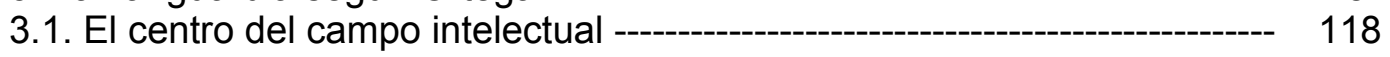


2.2. Sobre una sinonimia equívoca: arte nuevo, arte deshumanizado, vanguardia

\subsection{Ortega y Benjamin} 142

4. Vanguardias en España: más que arte nuevo

4.1. Exordio del siglo XX. El umbral de las vanguardias

4.2. El contexto político de las vanguardias: la Dictadura de Primo de Rivera

4.3. Vanguardia, intelectuales y dictadura

4.4. Hacia la rehumanización de la literatura. Los nuevos temas de entreguerras

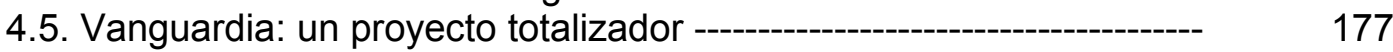

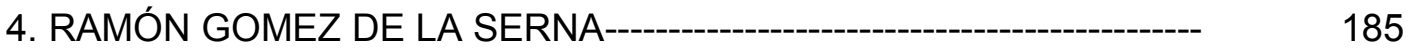

1. Círculos concéntricos ramonianos ------------------------------------------- 185

2. Las novelas de los años veinte -- 193

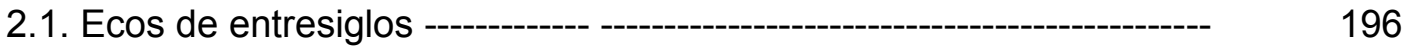

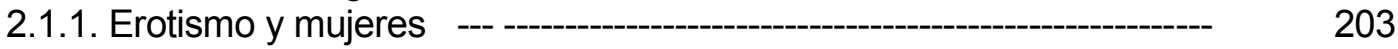

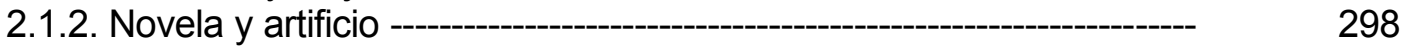

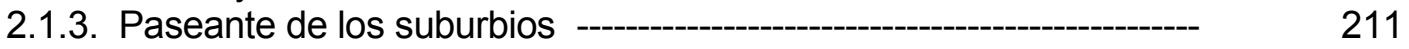

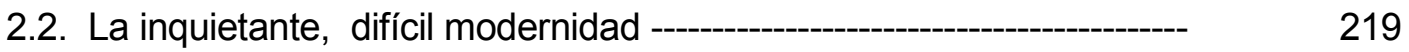

3. Miedo al siglo. Un vanguardismo finisecular ----------------------------- 226

5. FRANCISCO AYALA ----- 232

1. Revista de Occidente o el vanguardismo modernizador ---------------- 232

1.1. Cazador en el alba y otros relatos de vanguardia ------------------- 235

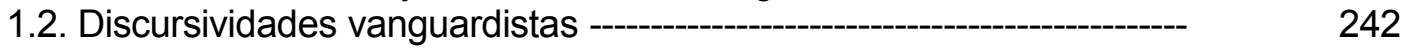

1.3. La presencia de Ortega ------------------------------------ 256

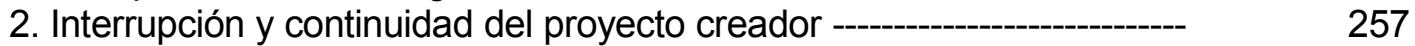

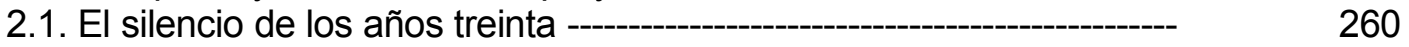

2.2. La misión del intelectual --- 266

6. RAFAEL ALBERTI --- 272

1. El síntoma de alumno externo ----- 272

1.1. La poesía nueva. Un diálogo privilegiado

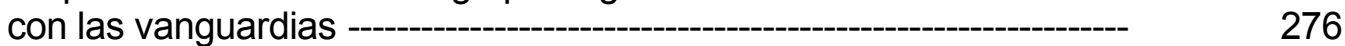

2. Angel terrenal ---on 286



2.2. Poeta sin aureola --- 297

3. Los zapatos de la poesía -- 305

3.1. Derroteros de las vanguardias - 308

7. DESPUÉS DE LAS VANGUARDIAS: EL UMBRAL DEL EXILIO ----- 317

1. "Final de plata amargo" ---

2. Ayala. Revisar el pasado, recuperar la institución ----o-- 321

3. Alberti. Claveles y espadas, viejos y nuevos lectores - - 328

4. Gómez de la Serna. Sin Pombo, bajo el signo del aislamiento --------- 336

OBRAS CITADAS -- 342 


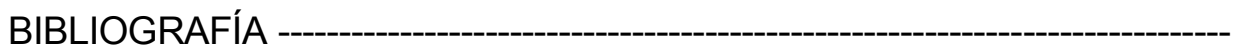




\section{INTRODUCCIÓN}

La problemática que estudia la presente tesis me enfrentó a una serie de problemas teóricos sobre los que tuve que reflexionar e indagar antes de adentrarme en la exploración y labor personal propiamente dichas. Realizaré una breve reseña de las que pueden considerarse piedras sillares de mi investigación, sin menoscabo de un ulterior desarrollo pormenorizado y riguroso.

En primer lugar, encontré que la idea de autonomía del arte requería una previa consideración acerca de vanguardia, una categoría muy ligada a ella y que por necesidad se haya imbricada en los autores y el período objeto de esta investigación. Es más, en algún momento pensé que el encabezamiento de esta tesis podría haber sido "Vanguardia y compromiso..." o "Autonomía del arte, vanguardia y compromiso...". El título definitivo obedece al mayor grado de pertinencia con respecto al de vanguardia, dados el enclave y la extensión que otorgo al concepto autonomía artística. A pesar de que -como he anunciado- mis afirmaciones serán fundamentadas en los momentos correspondientes de la exposición, considero oportuno esbozar en estas notas introductorias las ideas que explican la razón primera de la elección del objeto de estudio y la aportación original que se aspira lograr desde la línea de investigación seguida.

En las dos últimas décadas del siglo $X X$ se ha podido observar una intensificación de los estudios sobre la literatura de vanguardia española. Los autores canónicos de las tres primeras décadas de la centuria junto a otros que empezaron a ser recuperados de un prolongado olvido, han sido revisados a partir de categorías distintas de la consolidadas por la tradición crítica. De forma especial, el cambio influye en los poetas y prosistas de la llamada generación del 27, que hoy se estudian en el marco del arte de vanguardia, aunque difícilmente arraigue en las historias literarias el nombre generación de la vanguardia que temprana y lúcidamente propuso Luis Cernuda. 
El cambio de perspectiva no es superfluo; la sola utilización del término vanguardia inscribe las letras españolas de ese período en el vasto campo de los fenómenos estéticos que afectaron a los países europeos desde los comienzos mismos de la modernidad, liberando así a la literatura de los años veinte de la insularidad a la que fue condenada por la crítica. Por otra parte, el término vanguardia hace más notoria la necesidad de examinar nuevamente y profundizar el hilo conductor que vincula a poetas y narradores de la década estudiada con las expresiones vanguardistas iniciadas alrededor de 1910, con Ramón Gómez de la Serna como figura central.

De manera similar opera el término vanguardia con respecto a los muy pertinentes arte nuevo o ismos que se impusieron en España para designar la renovación estética que se desarrolló y tuvo su culminación en las tres primeras décadas del pasado siglo, en consonancia con la tendencias culturales y estéticas de los países del centro de Europa: el efecto universalizador que promueve la voz tomada del léxico militar anima al diálogo con las letras y el arte de otros ámbitos culturales, tanto del viejo como del nuevo continente.

Desde el momento en que la producción literaria de Ramón Gómez de la Serna, Francisco Ayala y Rafael Alberti se inserta, como anillos concéntricos, en la experiencia vanguardista, y esta a su vez en el amplio contexto de las transformaciones de la esfera artística europea desde mediados del siglo XIX hasta mediados de la centuria siguiente, son más vastas y complejas las exploraciones que se abren. De la misma manera se multiplican los debates y puntos de vista, y el campo de investigación se vuelve más fecundo, permitiendo inscribir la cuestión en un marco teórico que activa los vínculos sociales y artísticos de España con las restantes culturas del continente. Se evita de este modo reincidir en la explicación de los sucesos de la península a partir de su carácter peculiar, cuando no exótico; lineamiento difícilmente sostenible en la actualidad, tal como lo demuestran numerosos estudios a los que me referiré más adelante. 
Para consolidar esta línea de indagación he dejado en suspenso -pero no desconsiderado- las prestigiadas clasificaciones por género, los siempre útiles ordenamientos cronológicos, el muy arraigado método de las generaciones.

Acerca del segundo término del binomio planteado en el título, en el primer tramo de la investigación puede observar que en forma contraria al auge de los estudios sobre la vanguardia en los últimos años, el compromiso traza un campo que despierta escasamente el interés de la crítica actual, al mismo tiempo que los alcances y el significado del término se diluyen en múltiples connotaciones simplificadoras. Sin embargo, la idea de la función de la literatura que el término compromiso supone, acompaña de forma inseparable el trayecto del arte hacia la modernidad estética y subyace en los debates sobre la autonomía desde sus comienzos hasta la actualidad. Fue preciso entonces delimitar y precisar la categoría, otorgarle el sentido que adquirió en el período estudiado y vincularla con la cuestión más amplia y menos connotada de función social del arte. Sólo así se pudo desembarazar el concepto de los prejuicios negativos que le restan preeminencia en los estudios académicos -sólo basta leer los títulos de los libros especializados de la última década para observar la ausencia de este problema. Es preciso estar adevertido que en la raíz del desinterés por el tema pueden influir, además de las actuales corrientes del pensamiento, en las que no corresponde ahondar aquí, el empobrecimiento de la complejidad y del alcance teórico del compromiso, fruto quizás del fervor un tanto endeble desde el punto de vista epistemológico con que fue abordado en épocas anteriores.

En directa relación con el propósito de romper compartimentos, he intentado acercar períodos y categorías que sólo en los últimos años han comenzado a perder sus fronteras taxativas. Si las vanguardias merecían un tratamiento más universal, también merecían conectarse entre sí vanguardia y república, vanguardia y guerra civil, vanguardia y compromiso. Como se verá, el problema es arduo y las posiciones a veces poco conciliables, no obstante, se puede observar una paulatina aproximación de dos momentos históricos y dos 
estéticas que se vieron como antagónicas, hasta enemigas, comenzando por la opinión de los propios protagonistas.

La justificación de los presupuestos teóricos trazada hasta aquí no me exime de detenerme en otro aspecto que quizás ponga en estado de alerta a los hispanistas: me refiero a los tres escritores seleccionados, es decir, al recorte del objeto de estudio. Como se verá a continuación, las razones están estrechamente ligadas al marco teórico y su justificación me obligará a retomar conceptos ya vertidos.

No es frecuente que aparezcan reunidos en un mismo estudio crítico los autores que encabezan el título de esta tesis. La tradición marca un camino según el cual Ramón Gómez de la Serna abre las exploraciones sobre las vanguardias en España, en el que Rafael Alberti integra un capítulo sobre la generación del 27, en el que Francisco Ayala pone de manifiesto el hasta hace escaso tiempo renacido interés por la narrativa deshumanizada o de vanguardia. Los dos últimos nombres encuentran además un destacado lugar en el subgrupo de autores o literatura del exilio republicano, categoría que juega un papel relevante en este trabajo, pero sin quedar cercenada del resto en una sección aparte, como ocurrió durante décadas.

La reunión de los tres autores, quienes tienen entre sí más reconocidas y fijadas diferencias que similitudes, constituye el punto de partida para realizar un itinerario diferente de los más acrisolados por la obra de tres figuras descollantes de las letras españolas del pasado siglo. $Y$ del presente, si hacemos justicia a la longevidad y vitalidad intelectual de Francisco Ayala.

Asimismo, Gómez de la Serna, Alberti y Ayala obligan a poner el problema teórico de la tensión autonomía del arte/compromiso al servicio de un enfoque particular, dirigido a integrar aspectos que con dificultad van logrando salir de constelaciones aisladas. Me refiero en primer lugar a una partición derivada del empleo de distintos modelos de análisis según pese más el rasgo autonomía o el rasgo compromiso en la voluntad del crítico. El rasgo autonomía ha estado 
asociado con estudios de honda raigambre formal; el rasgo compromiso con análisis ricos en aspectos temáticos y vinculados con las series histórica y social. Cada línea ha realizado el recorte más adecuado y dado lugar a conclusiones en cierto punto, maniqueas. Adelanto el ejemplo de la condena frecuente del Alberti de los años treinta por aquellos críticos admiradores de su poesía pura. Similar razonamiento subyace en el juicio de un sector de la crítica que sostiene que las vanguardias españolas fueron un fenómeno de índole estética y no política, sin detenerse a pensar que esa actitud, si fuera verdadera, tendría igualmente una lectura política.

Con el fin de superar estos binomios y otras clases de reduccionismos, creí imprescindible encuadrar mi investigación en el marco general de las transformaciones y la progresiva autonomización de la esfera del arte que acompañaron los procesos modernizadores en el mundo occidental, rubricados por la afirmación de la burguesía como clase rectora. Por lo tanto, la singladura de la modernización de España, focalizada en los procesos habidos en la esfera del arte, constituirá un permanente centro de interés. En esta dirección, el devenir de la modernidad en las tres primeras décadas del siglo XX proporcionará claves imprescindibles para entender las actitudes que los autores objeto de estudio asumieron según las circunstancias históricas y personales y la manera en que estas se revelaron en sus respectivas obras.

El análisis de este proceso determinó la fijación de los límites temporales y genéricos de la obra de Gómez de la Serna, Ayala y Alberti en la que se centró mi estudio: consecuentemente con la renuncia a utilizar cronologías lineales y clasificaciones preestablecidas para los tres escritores, he considerado pertinente analizar la producción de los años veinte, el momento de la vanguardia española considerado más destacado, innovador y dinámico. Esta fase, que será el núcleo de la investigación, se complementará con el estudio de sus trayectorias cuando la vanguardia ya ha perdido su papel hegemónico en el campo del arte y en la serie histórica tienen lugar las grandes alteraciones políticas y sociales que derivaron en 
la proclamación de la II República y cinco años después, en la guerra civil española.

Para cerrar la hipótesis principal, se atenderá a los primeros pasos en el exilio de los escritores estudiados, tomando la categoría exilio en un sentido suficientemente amplio con el fin de incorporar a Gómez de la Serna, a pesar de los criterios que aconsejan mantenerlo fuera. Las razones por la que consideré más pertinente incluirlo en el numeroso grupo de los españoles republicanos que tomaron el camino del destierro después de la derrota de 1939 serán expuestas en el momento oportuno; sólo baste por el momento anticipar que los conflictos y las controversias que sobrevuelan la producción ramoniana de los primeros años en Argentina se comprenden mejor encuadradas dentro de un -aunque ambiguoestatuto de exiliado que fuera de él.

Es aceptado que el momento inicial de la nueva vida de los artistas e intelectuales emigrados a causa de la guerra o de la derrota republicana representa un momento clave para su biografía estética o literaria, en tanto los expatriados deben cerrar forzosamente un período y enfrentarse a la incertidumbre del futuro. Los necesarios replanteos ante la nueva circunstancia del destierro se hallan muy condicionados por la manera en que en las décadas anteriores concibieron el arte, experimentaron las vanguardias y elaboraron un proyecto creador.

En el fondo de este y los demás problemas que se han de tratar subyace un problema cardinal que ha acompañado a la literatura desde el momento mismo de su proceso de constitución en un espacio propio y diferenciado, me refiero a la tensión entre la inscripción en una esfera autónoma o el cumplimiento de una función social, con los múltiples grados y consumaciones en favor de una o de otra alternativa.

Resta mencionar aún algunos aspectos formales. Las etapas seguidas en la investigación determinaron en cierto modo la estructura de la tesis: se inicia con dos capítulos teóricos sobre vanguardia y compromiso respectivamente. 
Continúan un capítulo que proporciona el contexto histórico, artístico y literario del período estudiado y tres dedicados a los autores objeto de la investigación, Ramón Gómez de la Serna, Francisco Ayala y Rafael Alberti. He desechado el ordenamiento cronológico -Alberti figura en último lugar, no en el segundo que le correspondería por fecha de nacimiento y primeras publicaciones. Considero que la secuencia elegida se adecua mejor al desarrollo de la hipótesis. El estudio termina con un capítulo que reúne a los escritores en Argentina, la primera estación -para Gómez de la Serna la única- del exilio.

El acercamiento a sus obras no se ha regido por un módulo uniforme. Las distintas trayectorias determinaron la demarcación de los corpus por analizar y del lapso abarcado en las diferentes situaciones. Por tanto, he otorgado a cada autor la atención que se deriva de la pertinencia de los materiales disponibles respecto de la cuestión estudiada.

Por último, esta tesis no finaliza con una recapitulación y unas conclusiones. En todo momento del proceso de investigación -relevamiento de datos, estudio y elaboración-procuré evitar caer en el error que, a mi juicio, podía malograr los resultados: esto es, regirme por el imperativo de amoldar una serie de fenómenos complejos y múltiples a las categorías y los supuestos establecidos en el marco teórico. Intenté recorrer el camino opuesto, que éstos se irradiaran en el campo estudiado propiciando acercamientos flexibles, no atados a ningún preconcepto $y$, si fuera posible, abriendo rumbos a futuras investigaciones. Resumir en unas breves páginas finales lo múltiple y lo diverso conllevaba realizar las operaciones que había considerado metodológica y científicamente lesivas para mi tesis doctoral. 


\section{VANGUARDIA}

\section{LAS CATEGORIAAS VERTEBRADORAS:}

AUTONOMIA DEL ARTE, MODERNIDAD ESTÉTICA, VANGUARDIAS HISTÓRICAS

\section{AUTONOMÍA DEL ARTE}

Para lograr entender los alcances de la oposición autonomía del arte compromiso que centraliza el problema abordado en esta tesis, es necesario recordar el proceso de conformación de la esfera autónoma del arte como un subsistema independiente dentro de la serie de subsistemas que integran el conjunto social todo. En este sentido, el fundamental estudio sobre las vanguardias de Peter Bürger proporciona un material imprescindible. El representante de la Escuela de Frankfurt, siguiendo la línea de pensamiento iniciada por sus maestros, delimita el concepto de autonomía del arte como la independencia del arte respecto de la sociedad y advierte sobre las distintas interpretaciones posibles de la definición. Una de ellas, tal vez la más difundida, es considerar que la esencia del arte es la desvinculación del arte y la sociedad, con lo cual se estaría suscribiendo la concepción del arte que sostiene l'art pour I 'art, impidiendo de esta manera las explicaciones histórico sociales de tal consideración. $\mathrm{Si}$, por el contrario, se acepta que la mencionada independencia sólo es producto de la imaginación del artista, se está ignorando el status de la obra de arte y la posibilidad de estudiar la relatividad histórica del fenómeno. Las dos posiciones descriptas ignoran que la complejidad del concepto autonomía del arte reside en dos razones fundamentales: por una lado, describe algo real, que es la desaparición del arte como ámbito particular de la actividad humana, es decir, vinculado a la praxis vital; por otro, que la relatividad histórica del fenómeno no se puede percibir, está naturalizada, en tanto "es una categoría de la sociedad burguesa que al mismo tiempo desvela y oculta su real desarrollo histórico". [Bürger, 1974: 84].

La génesis materialista del concepto de autonomía que suscribo para mi estudio hace referencia al proceso que concluyó a finales del siglo XIX, momento 
en que el arte logró independizarse de las funciones de representación de otros poderes -en primer lugar el poder religioso y seguidamente el cortesano. El fenómeno se explica como el proceso por el cual se separaron las artes del contexto de las prácticas rituales, y, posteriormente, y en la misma medida, del sistema económico político'. Esta transformación paulatina alcanza su máxima concreción con el esteticismo, cuando se llega a la plena diferenciación de los fenómenos artísticos. Más adelante se verá de qué manera la autonomía del arte guarda una relación estrecha con las llamadas vanguardias históricas, pues siguiendo el mismo lineamiento teórico, las vanguardias sólo se explican acabadamente si se tiene en cuenta la crítica que dirigieron a la autonomía artística que alcanza su culminación con los movimientos esteticistas.

Paradójicamente, como se verá más adelante, en la medida en que el arte se emancipa de la función de representación de la iglesia o la monarquía, puede ser concebida como una herramienta puesta al servicio de una idea o de un objetivo social.

\subsection{La CONFormación de La eSfera aUtónoma del aRTE. sus CONSECUENCIAS EN LA ESFERA} SOCIAL Y ARTÍSTICA.

El proceso de autonomización de la esfera estética no es lineal ni definitivo, y nunca está libre de sufrir retrocesos, en la medida que el poder desee servirse nuevamente del arte. Tanto la política cultural fascista como el estatuto del arte bajo el régimen de Stalin en la Unión Soviética son ejemplos paradigmáticos de la pérdida de autonomía y del retorno a la sujeción de un poder estatal en el siglo XX. Igualmente se comprueba esta oscilación en las constantes condenas fundadas en razones morales o éticas que todavía en la actualidad pueden acometer a una producción artística. [Bürger, 1974, 1991].

La perspectiva histórica del proceso de la conformación de la esfera artística como ámbito independiente del dominio político o religioso nos informa

\footnotetext{
${ }^{1}$ El proceso ha sido estudiado desde diversas perspectivas. En el capítulo dedicado al compromiso se verá que Jean-Paul Sartre describe la misma trayectoria histórica pero poniendo el foco en las relaciones que el escritor establece a través del tiempo con las distintas instancias de poder político y cultural.
} 
además que la consecución de la autonomía del arte se halla vinculada al surgimiento y consolidación de una clase social: la esfera autónoma se pudo consumar gracias al advenimiento de la burguesía, que permitió la desvinculación de los sistemas económico y político del sistema cultural.

Antes de alcanzar este rango debió efectuarse una transformación clave: la prolongación por parte de los artistas del medio de producción artesano con posterioridad a la división social del trabajo, probable razón de que el producto haya obtenido valor como algo singular. La permanencia en el nivel de producción artesanal en el seno de una sociedad dominada cada vez más por la división del trabajo con la consiguiente separación de los asalariados de sus medios de producción, fue la condición previa para que el arte fuera concebido como algo diferente -como algo "autónomo". Se consuma de esta manera un hecho iniciado siglos antes, la negación del estatuto artesanal del arte, hecho de incalculables consecuencias para la condición del arte en la sociedad moderna y los debates suscitados alrededor de esta cuestión. Cuando el artista de la sociedad renacentista fue influido por el pensamiento cortesano, comenzó a negar los vínculos del arte con la manufactura y a afirmar su carácter puramente ideal: fue una respuesta "feudal" a la transformación de las relaciones de producción².

Bürger revisa las tesis de distintos especialistas que intentaron explicar la génesis de la esfera autónoma -Hinz, Müller, Krauss, Hauser, Winckler, Bredekamp-, y concluye que estos no supieron entender el proceso como un devenir complejo, como un todo, por lo cual encontraron, para un mismo hecho, explicaciones contradictorias. Para el representante de la Escuela de Frankfurt, ningún fenómeno explica por sí solo la independización del ámbito de lo estético

${ }^{2}$ El problema es más complejo y confluyen en él distintos aspectos entre los cuales no es menor la relación del arte y la vida cotidiana. Facundo Tomás ha abordado el problema en dos libros recientes $[1998,2000]$ donde vincula el creciente distanciamiento del artista del público mayoritario con las polémicas en torno a la aparición del intelectual en el siglo XIX y con las actuales revisiones posmodernas de los criterios estéticos: "Cierto que esa separación [de los intelectuales respecto del resto de la sociedad] es un proceso histórico cuyos orígenes habría que buscarlos en ese mismo protohumanismo del siglo XIII donde al principio señalaba el arranque de la racionalidad europea, y que no se empieza a enunciar abiertamente hasta los siglos XVI-XVII, adquiriendo nuevas dimensiones con el romanticismo y prolongándose durante el XIX..." [Tomás, 2000:180] 
-bien se trate del desarrollo de los mercados, bien de la presencia inédita de los coleccionistas.

En el estudio del proceso debe considerarse también como un factor sumamente importante la liberación de una capacidad de percepción y construcción de la realidad vinculada hasta entonces con finalidades de culto. El carácter contradictorio del proceso de autonomización se evidencia con la aparición del placer estético: aunque en un principio estaba vinculado al poder aurático, hizo posible la creación del ámbito del arte.

La separación del arte de la praxis vital obedece a unas determinadas condiciones históricas. En el Renacimiento, la unión del arte con la ciencia favoreció un primer alejamiento de lo ritual, pero el proceso estuvo sujeto a múltiples contradicciones, y así puede verse que bajo la apariencia de arte sacro avanza la emancipación de lo estético. Hasta la misma Contrarreforma, ejemplo paradigmático del arte puesto al servicio de un efecto, provocó su liberación: el barroco obtiene el efecto de la forma, no del tema. De esta manera, los artistas desarrollan un afinado sentido para el efecto de forma y colores, aunque la Iglesia quería convertir el arte en propaganda religiosa.

Otra contradicción se comprueba en la coincidencia de la aparición de un ámbito de percepción de la realidad, donde la racionalidad de los fines no incide, con la ideologización del fenómeno mediante prácticas como el culto al genio. Por último, el proceso de autonomización está estrechamente relacionado con la emergencia de una nueva clase social. Se puede afirmar con certeza que la diferenciación del subsistema social artístico pertenece a la lógica del desarrollo de la sociedad burguesa. Con la tendencia a la progresiva división del trabajo, también los artistas se convierten en especialistas. [Bürger, 1974: 92]

\subsubsection{Consecuencias de la autonomización de la esfera artística: separación arte - praxis vital. La institución arte y la estética}


Como se ha anticipado, la constitución de la esfera artística culmina a fines del siglo XIX, al alcanzar, con el esteticismo, el punto máximo de su autonomía y a la vez, el punto de inflexión que abrirá las puertas a los movimientos de vanguardia.

El aspecto objetivo de este proceso de independización de la esfera artística lo constituye el sometimiento del ámbito artístico a la progresiva especialización de función. Existe además un aspecto subjetivo que se manifiesta en la disminución de la experiencia, entendiendo como tal al conjunto de percepciones y reflexiones asimiladas, que pueden volverse a aplicar a la praxis vital. No quiere decir que el sujeto convertido en especialista de un ámbito parcial ya no perciba ni reflexione, sino que las experiencias que el especialista obtiene en su ámbito parcial no vuelven a aplicarse a la praxis vital. La experiencia estética con su propia especificidad, tal como la desarrolla el esteticismo, constituye la forma paradigmática de esta disminución de la experiencia en el ámbito del arte. La vivencia estética es entonces el aspecto positivo de aquel proceso de diferenciación del subsistema social artístico, cuyo aspecto negativo es la pérdida de función social de los artistas. Mientras el arte interprete la realidad o satisfaga las necesidades residuales ${ }^{3}$, aunque esté separado de la praxis vital, remitirá todavía al mundo inmediato. A finales del siglo XIX el esteticismo, al convertir el arte en su propio contenido, pretenderá romper la relación del arte con la sociedad. Hasta entonces, aun cuando el arte hubiera alcanzado un status independiente, no estaba excluido el carácter político de los contenidos, sólo se restringía la posibilidad del efecto. La ruptura con la sociedad constituye el núcleo de la obra del esteticismo. [Bürger, 1974: 103].

La autonomía del arte es una categoría de la sociedad burguesa. Permite describir la desvinculación del arte respecto de la vida práctica,

${ }^{3}$ Bürger toma de Habermas la expresión "necesidades residuales" para referirse a aquellas necesidades del individuo en la sociedad burguesa que no pueden ser satisfechas por no obedecer a la racionalidad de los fines ni al proceso material de la vida, como por ejemplo, la necesidad de comunicación mimética con la naturaleza, de una convivencia solidaria, de experiencias comunicativas que conceden margen a la fantasía y a la espontaneidad de la conducta. Marcuse utiliza el concepto de cultura afirmativa para referirse al confinamiento en una esfera superior, no cotidiana, de la aspiración de la humanidad a valores como bondad, libertad, solidaridad. 
históricamente determinada; describir pues el fracaso en la construcción de una sensualidad dispuesta conforme a la racionalidad de los fines en los miembros de la clase que se halla, al menos periódicamente, liberada de constricciones inmediatas.

La separación del arte de sus conexiones con la vida práctica es un proceso histórico que está, por tanto, socialmente condicionado. La categoría de autonomía no permite percibir la aparición histórica de su objeto. La separación de la obra de arte respecto de la praxis vital, relacionada con la sociedad burguesa, se transforma así en la (falsa) idea de la total independencia de la obra de arte respecto de la sociedad. La autonomía es una categoría ideológica en el sentido riguroso del término y combina un momento de verdad (la desvinculación del arte respecto de la praxis vital) con un momento de falsedad (la hipostatización de este hecho histórico a una "esencia" del arte). [Bürger, 1974:199]

La idea, ya desarrollada, de que el arte satisface las necesidades residuales no proviene del análisis de las objetivaciones artísticas singulares sino del status del arte en la sociedad burguesa. Esto quiere decir que las obras no surgen individualmente, sino en el interior de las instituciones que regulan y establecen la función de la obra de arte. La categoría institución arte hace referencia a las condiciones estructurales que establecen la relación de un determinado estrato o clase social con las obras de arte. Es importante señalar aquí que Bürger se refiere a dos posibles acepciones de la categoría institución: el primero es el aparato de producción y distribución del arte; el segundo, las ideas sobre el arte que dominan en una época y que determinan la recepción de las obras. [Bürger, 1974: 62-65]

La consolidación de la institución del arte es un proceso de gran complejidad, paralelo al proceso de autonomización. La delimitación conceptual de esta categoría es clave para comprender la reacción iconoclasta de la vanguardia a principios del siglo XX.

Según Harry Levin, gran parte de los desencuentros entre la crítica sociológica y la crítica formal se evitarían si se aceptara que la literatura es 
siempre parte integral de la vida; esta idea conlleva aceptar la función particular que está destinada a cumplir la literatura en la estructura de todo el organismo social. Así se puede entender cómo el arte puede pertenecer a la sociedad y sin embargo conservar su autonomía dentro de sus propios límites.

\begin{abstract}
Como otras instituciones, como la iglesia, como la ley, se cuida de una fase única de la experiencia humana y controla un cuerpo especial de procedimientos y precedentes; incorpora una disciplina autoperpetuadora, al mismo tiempo que responde a las principales tendencias de cada período sucesivo; es continuamente accesible a todos los impulsos de la vida en general, pero debe traducirlos a términos propios y adaptarlos a formas peculiares. [Levin, 1991:103-104].
\end{abstract}

Se puede considerar que hacia el final del siglo XVIII, la institución arte está completamente formada; no obstante, todavía actuarán dentro de ella contenidos de carácter político que se oponen a su principio de autonomía. Especialmente con el realismo, la ficción fue el medio para reflexionar sobre la situación del individuo en la sociedad, la novela estaba al servicio de la comprensión del mundo burgués. Será en la segunda mitad del XIX cuando la tensión entre la institución y el contenido de las obras tienda a desaparecer. La separación de la praxis vital afecta ahora al contenido de la obra; la temática pierde importancia a favor de una concentración de los artistas sobre el medio mismo. Sólo en el momento en que los contenidos pierden su carácter político y el arte desea simplemente ser arte, se hace posible la autocrítica al sistema social artístico. Este estadio se alcanza al final del siglo XIX con el esteticismo4. [Bürger, 1974: 54]

En estrecha relación con los procesos mencionados anteriormente, interesa aludir a la aparición de la estética como disciplina filosófica autónoma. Según Bürger, la estética se sistematiza al final del siglo XVIII, con el despliegue de la sociedad burguesa y la conquista del poder político por una burguesía económicamente fortalecida, lo cual colabora con la aparición de un nuevo concepto de arte autónomo, que es un concepto moderno.

\footnotetext{
${ }^{4}$ Para un panorama más amplio sobre la institución artística y literaria V. Williams, 1994 y 1997, Bourdieu, 1983 y 1995, Bürger 1985-85 y 1992, Altamirano-Sarlo, 1983, Pozuelo Yvancos, 1995 y 2000.
} 
La denominación arte incluye a partir de ese momento la poesía, la música, el teatro, la pintura, la arquitectura, y permite una comprensión de la actividad artística como distinta de cualquier otra actividad. Las diversas artes fueron liberadas de sus conexiones con la vida. Concebidas como un todo homogéneo, reino de la creatividad sin objeto y del agrado desinteresado, quedaron enfrentadas a la vida social y a lo racional que aparece estrictamente orientado hacia la definición de fines que determinan el porvenir.

Sólo con la constitución de la estética como una esfera natural del conocimiento filosófico aparece el concepto de arte, cuya consecuencia es que la creación artística afecte a la totalidad de las actividades sociales y se enfrente a ellas en abstracto. Desde el helenismo, y especialmente desde Horacio: 'delectare' y 'prodesse' era un binomio inseparable. La configuración de un ámbito del arte liberado de toda finalidad va a hacer que la teoría considere el 'prodesse' como un elemento ajeno a la estética y que la crítica rechace la tendencia doctrinaria de una obra como extraña al arte. [Bürger, 1974. 93].

La institución arte camina a su conformación definitiva simultáneamente con la lucha de la burguesía por su emancipación. Los estudios integrados en las teorías estéticas de Kant y Schiller parten del supuesto de una completa diferenciación del arte como esfera separada de la praxis vital. Si embargo, hasta que la separación de la praxis vital que siempre ha caracterizado al status institucional del arte en la sociedad burguesa no afecte también al contenido de la obra, la autonomía no llega a su total consumación.

La novela realista del siglo XIX estaba todavía al servicio de la autocomprensión del mundo burgués. La ficción es el medio para una reflexión sobre la situación del individuo en la sociedad. Con el esteticismo, la temática pierde importancia en favor de una concentración siempre intensa de los productores de arte sobre el medio mismo. El arte se convierte en sí mismo en un problema desde el momento en que excluye todo "lo ajeno al arte". La coincidencia de institución y contenido descubre la pérdida de función social como esencia del arte en la sociedad burguesa y provoca con ello la autocrítica 
del arte. El mérito de los movimientos históricos de vanguardia es haber verificado esta autocrítica.

Sólo un arte que se aparta completamente de la praxis vital (deteriorada), incluso por el contenido de sus obras, puede ser el eje sobre el que se pueda organizar una nueva praxis vital. [Bürger, 1974]

Parte de la crítica considera que con Flaubert la literatura se consagra definitivamente como objeto, coincidiendo con el momento en que el escritor dejó de ser un testigo universal para transformarse en una conciencia infeliz. La conciencia burguesa comienza entonces a perder el optimismo y la confianza en un universo armónicamente organizado según sus valores y postulados [Barthes, 1967].

\section{Vanguardia . Consideraciones previas}

La tensión entre autonomía del arte y compromiso adquirió un fuerte estado de polémica entre intelectuales y artistas a partir de la segunda mitad de la década del 20 en España -con marcas peculiares pero no ajenas al debate que tenía lugar en los países de Occidente donde se habían gestado los principales movimientos estéticos del siglo XX. Estas circunstancias no se comprenden si no se analiza el papel ambiguo, paradójico y contradictorio que jugaron las vanguardias históricas -o ismos, o arte nuevo ${ }^{5}$ - en el complejo escenario histórico y cultural de las tres primeras décadas de esta centuria.

Me limitaré, como lo hice en los temas anteriores, a resumir los principales aspectos teóricos sobre las vanguardias, necesarios para poder desarrollar luego lel tema principal de este estudio. Es preciso antes delimitar los conceptos y explicar las causas de la superposición de las categorías que utilizaré más adelante.

\subsection{VANGUARDia Y MOdernidad. Sobre LAS DOS MOdernidades}

\footnotetext{
${ }^{5}$ Acerca de los diferentes términos para designar a las vanguardias históricas, considero que vanguardia puede alternar con ismos, aunque este segundo término hace referencia a los aspectos más formales y tangibles del arte, mientras vanguardia hace mención a un orden más ideológico y abstracto. Por último, arte nuevo y arte deshumanizado son las fórmulas acuñadas por Ortega y Gasset, para muchos críticos equivalentes a arte de vanguardia.
} 
Como se ha anticipado, para establecer cabalmente el alcance del término vanguardia es preciso primero tener en cuenta el concepto de modernidad estética, ya que ambos por momentos se confunden y, desde algunas perspectivas, las diferencias no serían relevantes.

En primer lugar, se debe atender a la diferenciación, que Matei Calinescu reseña pormenorizadamente, entre modernidad histórica y modernidad estética. Muchas páginas se han escrito sobre la modernidad en los últimos años; no es mi propósito transitar por ese inmenso problema teórico, pero sí me interesa dejar sentadas algunas premisas imprescindibles para abordar la cuestión, previo esbozo del proceso por el cual se puede hablar de una modernidad histórica, o modernidad a secas, y de una modernidad estética.

En un sentido amplio se entiende por modernidad el momento de la historia de la civilización occidental producto del progreso científico y tecnológico, de la revolución industrial, de la economía arrolladora y de los cambios sociales del capitalismo. En el campo político se caracteriza por la constitución de la soberanía popular y la separación de poderes; en el filosófico, por la fe desmedida en la razón y la centralidad del sujeto. [Vázquez Medel, 1994]. Si bien los cimientos definitivos de la modernidad se establecen en el Renacimiento, su momento culminante llegaría en el siglo de las luces, cuando parece lograrse la unidad ética, estética y científica que configuró la nueva conciencia desde el siglo XVII en adelante ${ }^{6}$. [Subirats, 1991]

Por lo tanto, el campo de la estética no sólo no fue inmune al pensamiento moderno, sino que para pensadores como Subirats, la idea de progreso surge del campo de la creación y del arte. Lo cierto es que hacia fines del siglo XVII, algunos autores franceses que se consideraban modernos, con Charles Perrault en primera línea, iniciaron la discusión conocida como Querelle des Anciens et de Modernes, cuando pensaron aplicar a la literatura y el arte las ideas del progreso y del avance científico que habían permitido independizar la razón de la escolástica y de las restricciones originadas en la idolatría renacentista por la antigüedad. Los modernos se apoyaron fundamentalmente en tres argumentos: de la razón, del gusto, de la

${ }^{6}$ Sobre el advenimiento del mundo moderno puede consultarse, entre la abundante bibliografía existente, Jauss, 1976; Berman, 1989; Casullo, 1991; Subirats, 1989 y 1991. 
religión. Debido a la proyección sobre el tema de este estudio, me detendré en una reflexión clave sobre el argumento del gusto. En consonancia con el concepto racionalista del progreso, los pensadores de los siglos XVI y XVII creyeron en el carácter universal y eterno de todos los valores y sostuvieron la existencia de un modelo de belleza transcendente y único. La belleza existía fuera del tiempo, objetiva y eternamente y los artistas podían aproximarse más o menos a ese ideal, de acuerdo a su talento; en este terreno, los modernos no cuestionaron el concepto de belleza que habían heredado de los antiguos.

Un germen esencial de la confrontación de modernidad y modernidad estética estará en la paulatina modificación del concepto ideal de belleza del siglo XVIII, que fue perdiendo sus notas trascendentes para derivar en un concepto puramente histórico. Calinescu cita como antecedente importante de lo que será la idea romántica de gusto, entendido como un juicio cuya validez dependía de la experiencia histórica, la afirmación del crítico inglés Richard Hurt, quien en 1762 sostuvo que el clásico y el gótico eran dos mundos autónomos, cada uno con sus propias reglas a partir de las cuales debían examinarse las obras de uno u otro estilo. Dejaré entre paréntesis la importante ramificación que el binomio clásico/gótico tuvo en las diversas polaridades románticas: mundo pagano/mundo cristiano, o antiguo/ moderno, o clásico/moderno, para atender al nuevo tipo de belleza que se instituye. Para los románticos, la belleza se basaba en lo característico, en lo interesante, en las posibilidades de fundir de distinta manera lo sublime con lo grotesco. La búsqueda de perfección se entendía como huida de la historia y como camino directo al academicismo. El cuestionamiento de los prejuicios más rígidos llevó a los románticos a afirmarse en el relativismo histórico sin ambigüedades y en el propósito de ser hombres de su tiempo, lo cual significó convertir la estética en una ética.

En el marco de la creciente reconsideración de los principios universales defendidos por la razón y el neoclasicismo, la figura de Stendhal aparece como la de un perspicaz y agudo observador que al definir el romanticismo anticipa las principales premisas de la modernidad estética inaugurada más tarde por Baudelaire y enfatizada por las vanguardias: cambio, relatividad, actualidad. Para el autor de $L e$ 
rouge et le noir el romanticismo conllevaba una conciencia de vida contemporánea era el presente transmitido artísticamente-, noción que encierra el rasgo de fugacidad en una esfera reducida, de identidad difícilmente aprehensible porque no se puede definir según las tradiciones pasadas y, al mismo tiempo, provisional, porque afirma su existencia en la confirmación del futuro.

Esboza ya una serie de ideas que serán centrales para la modernidad estética: el buen gusto es moda, el público generalmente no está preparado para entender las innovaciones y las intuiciones del artista, quien en la mayoría de los casos deberá esperar para sus hallazgos la ratificación del futuro. El creador romántico es visto como una especie de soldado temerario frente al prudente clasicista. El público se halla sometido a las reglas del academicismo y el romántico deberá sacudirlo y animarlo a dejar las viejas normas, aunque ese público no esté preparado para disfrutar de lo nuevo y quizás no sea merecedor de ello. Las bases del arte como ámbito de seres diferentes y alejados de la gente común, ya echadas en tiempos remotos, como se ha visto en las páginas precedentes, fijan ahora una posición más sólida; al mismo tiempo se profundizan las divergencias entre el proyecto moderno del artista y el de la burguesía.

Según Calinescu, no es posible precisar en qué momento se produce la división de las dos modernidades, pero es notorio que hacia mediados del siglo XIX la confrontación entre la modernidad estética y la modernidad histórica se delinea claramente. En este punto del desarrollo de la civilización occidental ya es posible definir la modernidad estética como una actitud radicalmente antiburguesa, que nace con el romanticismo, que se manifiesta asqueada de los valores de la clase media y expresa su disconformidad con variados gestos, que van desde la rebelión, el apocalipsis o la anarquía, hasta el aislamiento aristocrático. En tanto, la modernidad que podemos llamar histórica, encarnada en la burguesía, continuará alentando sus principios fundantes: la confianza en el progreso y en la bondad de la ciencia y la tecnología, el interés por el tiempo, que puede ser dominado y puesto a su servicio, el culto a la razón y la defensa de la libertad, como principio abstracto e ideal, o como soporte ideológico del pragmatismo y el culto a la acción y el éxito. Sin 
embargo, ambas modernidades se atraen y repulsan por igual, sus enfrentamientos y controversias no pueden concebirse sin una mutua interacción e influencia.

En la otra acera, la modernidad estética se caracterizó más que por sus aspiraciones positivas, por una tenaz pasión negativa. Con el romanticismo comienza el sentimiento de desarraigo y disgregación del artista, junto con la aversión hacia el filisteísmo, término síntesis de todos los defectos del hombre burgués: prosaísmo, vulgaridad, interés por los aspectos materiales disimulados tras un falso intelectualismo. En esta época el apelativo 'filisteo' comienza a imponerse como un término inseparable de la pertenencia a una determinada clase social. El concepto, nacido en Alemania, pasó de ser una calificación estética para convertiste en ideológica, opuesta a revolucionario. En Francia, por el contrario, la descalificación del burgués se decantó hacia el campo de la estética, por lo cual los movimientos conocidos como arte por el arte, decadentismo y simbolismo están imbuidos de una aguda crítica a los valores modernos de la burguesía.

Aunque el arte por el arte se puede considerar promulgado por Kant cuando defiende la esfera autónoma, interesa recordar que será Théophile Gautier quien le otorga un sentido de radical protesta contra el humanitarismo romántico y el utilitarismo de la clase burguesa. La célebre fórmula épater le bourgeois encierra una afirmación agresiva de la inutilidad del arte. El arte por el arte es entonces el primer producto de la rebelión contra la modernidad burguesa. Sin embargo, el mismo Gautier defenderá una nueva clase de belleza basada en el aprovechamiento de la fealdad de la vida moderna, consciente de que no es posible rechazar la civilización moderna; sienta así las bases de una estrategia que será fundamental para la modernidad artística: la conversión de las imágenes de la civilización en materiales significantes para la modernidad estética.

\subsection{Modernismo, vanguardia}

Como he anticipado en las páginas anteriores, para los objetivos de mi tesis considero necesario plantear y deslindar en la medida de lo posible, las llamadas vanguardias históricas del gran movimiento de la modernidad estética, el cual, para 
algunos teóricos merece denominarse, en un sentido amplio, vanguardia. De esta manera, el largo período de más de una centuria, iniciado en la literatura y el arte con el Romanticismo, consolidado por Baudelaire, santificado a fines del siglo XIX por las diferentes escuelas esteticistas e intensificado al límite por las vanguardias, sería un único movimiento que concluiría a mediados del siglo $X X$, cuando se verifican los primeros signos de la posmodernidad. En la actualidad, son cada vez más numerosos los especialistas que se inclinan por integrar la categoría vanguardia en la más abarcadora de Modernismo, con una alcance superior -hasta los años sesenta- que el convencional Modernismo hispanoamericano. El rechazo de las divisorias del tipo Modernismo/ vanguardia y Modernismo/ 98 esgrimido por Juan Ramón Jiménez, Federico de Onís, Lily Litvak y Ricardo Gullón, continúa en estudios recientes. Ródenas de Moya en su estudio sobre la narrativa española vanguardista defiende un modernismo inclusivo que pese a disparidades muy dignas de atender, se amalgama mediante principios comunes desde finales del ochocientos hasta las primeras cuatro décadas del siglo XX. Las diferencias le permiten distinguir por sus rasgos peculiares el modernismo y la vanguardia, pero sin dejar de advertir que las parcelaciones rígidas terminan encubriendo las esenciales continuidades del arte hasta los umbrales de la cultura posmoderna. A su afán de romper con sistematizaciones empobrecedoras, puede reprochársele que no siempre se verifican las diferencias que propone entre la modernidad estética representada por Baudelaire y el Modernismo iniciado en el entresiglos ${ }^{7}$. [Ródenas de Moya, 1998]

Sin abonar el debate con discrepancias menores, los juicios expuestos recomiendan desandar el camino de los ismos hasta los movimientos que les precedieron, sin los cuales no se pueden comprender en su totalidad los gestos y los postulados de ruptura de las primeras dos décadas del siglo $X X$, pues sus raíces se internan en el conflicto ya convertido en un axioma de los estudios sobre la modernidad: el artista moderno, a partir del romanticismo, pero con especial recrudecimiento hacia finales de siglo XIX, sentirá la irresoluble contradicción de

${ }^{7}$ Ródenas de Moya recuerda que la modernidad estética abarca también al arte realista-mimético, al que, muy en la línea de Adorno, no considera crítico con los procesos de reificación que había producido la industrialización y mercantilización de los vínculos sociales. 
saberse atado al pasado que niega y, simultáneamente -resultado de la búsqueda de un tiempo utópico en el futuro- sentirse fundador de una nueva tradición.

Por otra parte, sabe también que sus logros serán limitados y parciales. La lúcida conciencia de estar atrapado en una paradoja constante se manifiesta en una serie de actitudes contradictorias, que oscilarán entre la utopía, el nihilismo o la evasión, y cuyas manifestaciones tendrán distintos rostros, según nos situemos en simbolismo-decadentismo-modernismo de entresiglos, o en las vanguardias históricas ${ }^{8}$.

\subsection{Distintos alcances del concepto vanguardia. Las vanguardias históricas}

Acerca de la idea de vanguardia, Calinescu considera que, a pesar de que el término se puede rastrear desde la Edad Media, e incluso, desde la antigüedad clásica, la vanguardia, tal como se entiende hoy en los estudios de arte y literatura, no existió hasta el último cuarto de siglo XIX. Aparece en el momento en que los artistas, alineados en posiciones antiburguesas, asumen la misión de destruir desde los cimientos el sistema de valores burgués, con todas su engañosa aspiración de universalidad. Una vez más es evidente que la categoría vanguardia se sobrepone con el período que se conoce como Modernismo, vacilación que es preciso incorporar forzosamente en un estudio sobre el tema.

En España la reacción antiburguesa se puede constatar desde el Romanticismo9. Aunque de forma mitigada, el deseo de épater le bourgeois atraviesa la literatura de todo el siglo XIX y llega hasta el siguiente, creando un motivo conductor al cual considero debe prestarse atención porque alcanza su máxima expresión hacia 1900, pero persistirá mientras la burguesía sea blanco de

\footnotetext{
${ }^{8}$ La agrupación de los tres grandes ismos decimonónicos no significa un desconocimiento de sus diferencias que en la actualidad cuenta con nuevos y ameritados estudios. Sin embargo, a los fines de trazar un línea divisioria, más operativa que real en muchos casos, entre estéticas de fin de siglo y vanguardias, es suficiente $-y$ aconsejable- unificar estos movimientos a partir de lo que tienen en común, tanto en lo que hace a los rasgos y tendencias comprendidas por una misma atmósfera finisecular como en las actitudes semejantes que los artistas adoptaron frente a la relación arte sociedad en el marco del proceso de autonomización del arte. Por similares motivos no me internaré en la ya inoperante controversia del fin de siglo español entre modernismo y generación del 98.
}

${ }^{9}$ V. Gonzalo Sobejano, 1967: 178-223. 
los ataques de los artistas modernos. "Epatar" será uno de los recursos predilectos de la vanguardia. Los célebres juegos y ataques a los "putrefactos"10, de los escritores y artistas del 27 en la Residencia de Estudiantes estaban impregnadas de este espíritu.

Para retomar el hilo del razonamiento sobre la vanguardia, obviaré los prolijos rastreos del significado y el empleo del vocablo desde la antigüedad, para iniciar una breve descripción de la historia del concepto a partir del momento en que se asocia con la autoconciencia de una misión determinada del artista. Durante la Revolución Francesa el término vanguardia, a partir de su denotación bélica, adquiere un valor metafórico, muy apto para asociar a la idea de tiempo irreversible y de entusiasmo por lo nuevo y el progreso que asumieron los revolucionarios, extendiéndose fácilmente, por esta razón, al campo de la política, el arte y la literatura.

Se considera que a partir de 1790 vanguardia pasa a formar parte de las herramientas teóricas del pensamiento político radical. Desde entonces será incorporado fácilmente a diversas filosofías revolucionarias y con ese valor lo adopta el romanticismo para aplicarlo al contexto artístico literario. El uso de vanguardia como sinónimo de lugar mesiánico del artista en la sociedad se verifica por primera vez en 1825, acuñado por Olinde Rodrigues, discípulo de Saint-Simon, en el diálogo $L^{\prime}$ artiste, le savant et l' industriel. Rodrigues recoge la idea de su maestro, quien al final de su vida situó al artista, junto a los científicos e industriales, pero ocupando la primacía, al frente del gobierno del estado ideal que proyectara para su socialismo utópico.

El hecho fundamental de este momento es la conciencia de la vanguardia de estar adelantada con respecto a su tiempo. Los artistas se sienten pertenecer a una elite, aunque comprometida con un programa antielitista: la participación de todas las personas en los beneficios de la vida. El inconveniente surge de la imposición de un programa enteramente didáctico, apareciendo así un problema que será tratado específicamente en el capítulo dedicado al compromiso.

\footnotetext{
${ }^{10}$ Se aplicaba a todas aquellas personas o cosas que se tenían por inactuales o trasnochadas. Su significado abarcaba desde lo ridículo (principalmente en modas y costumbres) hasta lo 'académico' y pompier en arte. [Catálogo "Los putrefactos", 1995: 24]
} 
A finales del siglo XIX y principios del XX la vanguardia continúa su programa antielitista desde el elitismo y mantiene la certeza de ocupar un lugar de avanzada, de tener un misión que cumplir y de poseer los privilegios y las responsabilidades de las clases dominantes. En estos puntos y en la convicción de que todo debe cambiar radicalmente, la vanguardia artística coincide con la vanguardia marxista-leninista, pero se diferencia de esta en otorgar al arte un potencial transformador independiente, es decir, no sometido a la dirección de los políticos, que propugnan el acatamiento a los propósitos didácticos de los revolucionarios. Por último, ambas aspiran por igual a un cambio radical de la existencia y a una anarquía utópica"1.

Las desavenencias entre la vanguardia artística y la vanguardia política comienzan a insinuarse claramente hacia mediados del siglo XIX, momento en que el término se aplicaba con frecuencia al lenguaje político con una carga subversiva y revolucionaria. Cuando el término vanguardia se traslada al ámbito de la literatura y el arte designa al artista que concebía su papel esencialmente como propaganda de partido. Este significado posiblemente llevó a Baudelaire a criticar, en 1860, tanto el término como el concepto, con clarividente anticipación del conflicto que se instalaría más tarde entre la rebeldía vanguardista y la disciplina ante las reglas y los mandatos.

Un poco más adelante, hacia 1870, comienza un discontinuo diálogo entre vanguardia política y vanguardia artística, que continuará con altibajos hasta la segunda mitad del siglo XX. Por entonces vanguardia comienza a designar "al pequeño grupo de escritores y artistas avanzados que transferían el espíritu de la crítica radical de las formas sociales al domino de las formas artísticas". [Calinescu, 1991:115]. Mientras la vanguardia política allanaba los caminos del sentido y de la recepción para favorecer la propaganda política, la vanguardia artística pretendía demoler las tradiciones formales del arte y explorar en libertad nuevos espacios hasta entonces vedados. Para esta vanguardia, revolucionar el arte equivalía a revolucionar la vida; de esta manera se alejaron de las expectativas del gran público, apegado a la mímesis y a la representación y reacio a las dificultades formales de

\footnotetext{
${ }^{11}$ Aquí Calinescu cree conveniente aclarar: "(incluso Marx era un anarquista de corazón, y cuando polemizaba contra Bakunin y sus seguidores no estaba en desacuerdo con su meta -la destrucción del estado-, sino sólo con los medios prácticos que recomendaban para lograrlo)". [1991: 108]
} 
las obras. Sin embargo, el alejamiento entre arte y política tuvo pronto exponentes del sentido contrario, como es el caso de Arthur Rimbaud, simpatizante de la Comuna y creyente en el papel profético del poeta para crear un lenguaje nuevo y alcanzar lo desconocido. Este sentido de vanguardia como búsqueda y exploración con independencia de colisiones con el sentido proveniente del campo de la política, a las que me referiré más adelante- continuó afirmándose en arte y literatura, para lo cual fue imprescindible el surgimiento, a partir de 1870, de un "nuevo estilo" muy diferenciado, que en términos generales se reconocía por su extremismo en el arte. Sin embargo, falta aún que surja otro nuevo significado, que se dará a principios de la centuria siguiente, cuando en los años veinte, vanguardia sirva para designar a todas las nuevas escuelas que rechazan el pasado y afirman el culto a lo nuevo. Este núcleo de movimientos artísticos recibirá el nombre de vanguardias históricas.

Las cualidades descriptas hasta aquí para trazar una línea claramente deferenciada entre las vanguardias históricas y las rupturas de los movimientos estéticos que le precedieron se perfilan con claridad pero se muestran insuficientes, falencia que ha dado lugar a que la categoría abarque períodos y conceptos diferentes según la tradición crítica desde la cual se estudia. A pesar de que hoy se tiende a rechazar las coordenadas establecidas desde la crítica anglosajona es interesante tenerlas en cuenta, porque el problema supera la focalización de una $u$ otra tradición crítica.

Así los estudios de origen norteamericano utilizan el término Modernisme como sinónimo de vanguardia, opuesto a romanticismo y naturalismo por un extremo y al postmodernismo por otro. En Italia se establece un claro límite entre avanguardia o avanguardia storica y neo-avanguardia o experimentalismo. En España, a diferencia de la perspectiva angloamericana, "la noción de vanguardia era desde un principio, opuesta a la de modernismo", pero, según se ha visto en páginas anteriores, el enfrentamiento tajante y aún la diferencia establecida por los primeros críticos ha sido reconsiderada. El mismo Calinescu [1991:101], a pesar del propósito que enuncia en el capítulo sobre la vanguardia, de disipar "la confusión entre modernidad o modernismo y la vanguardia, confusión que es frecuente en la crítica angloamericana", retrotrae el inicio de la vanguardia al último cuarto del siglo 
XIX y propone una explicación que borra la especificidad de la vanguardia histórica frente a la modernidad estética.

Los mejores estudiosos de la vanguardia tienden a estar de acuerdo en que su aparición está históricamente conectada con el momento en que algunos artistas socialmente alineados sienten la necesidad de desbaratar y demoler completamente todo el sistema de valores burgués, con todas sus filisteas pretensiones de universalidad. [Calinescu, 1991:122]

La superposición conceptual se amplía cuando el autor, a continuación menciona y cita los criterios de Roland Barthes recogidos en Essais critiques, donde vanguardia queda asociada al momento en que algunos artistas consideran a la burguesía como una fuerza estéticamente retrógrada. Para precisar esta idea del semiólogo francés es oportuno recordar los postulados expuestos en El grado cero de la escritura. Aquí considera que a mediados del siglo XIX comienza la modernidad -sin precisarlo, se refiere a la modernidad estética- acompañando la búsqueda de una "literatura posible". Cuando, bajo el peso de la Historia, -los acontecimientos posteriores a 1848 en Francia $^{12}$ - la literatura se ve separada de la sociedad que la consume, la escritura clásica pierde su universalidad y surgen las literaturas modernas.

\begin{abstract}
Veremos, por ejemplo, que la unidad ideológica de la burguesía produjo una escritura única, y que en los tiempos burgueses (es decir clásicos y románticos), la forma no podía ser desgarrada ya que la conciencia no lo era; y que por lo contrario, a partir del momento en que el escritor dejó de ser testigo universal para transformarse en una conciencia infeliz (hacia 1850), su primer gesto fue elegir el compromiso de su forma, ya sea asumiendo, ya sea rechazando la escritura de su pasado. Entonces, la escritura clásica estalló y la Literatura en su totalidad, desde Flaubert a nuestros días, se transformó en una problemática del lenguaje. [Barthes, 1967: 10].
\end{abstract}

\footnotetext{
${ }^{12}$ En 1948 estalló en París un movimiento revolucionario en el que por primera vez la clase obrera participaba con demandas propias, diferentes de las de los burgueses: soluciones al problema de la desocupación y el hambre. Un gobierno provisional inició los cambios y aplicó la ley de sufragio universal. En las primeras elecciones triunfaron las opciones moderadas y reformistas y su primera acción fue, afirmándose en los principios del liberalismo económico, cerrar los Talleres Nacionales, destinados a solucionar el problema del desempleo en París. La medida originó una revuelta general que fue violentamente reprimida, con centenares de ejecuciones y cerca de 25000 detenidos. Los acontecimientos marcan el triunfo de la alianza de burgueses moderados, burgueses conservadores y aristocracia y el aislamiento de los trabajadores y la burguesía radical. La burguesía desde entonces deja de ser una fuerza revolucionaria y opta por la vía de la reforma.
} 
Otro autores de reconocida autoridad en el tema también han utilizado como sinónimos vanguardia y modernidad. El estudio pionero de Renato Poggioli distingue una protohistoira de la vanguardia, que se inicia con el Sturm und Drang y el primer romanticismo y continúa con la fase preparatoria del parnasianismo y el arte por el arte. Ya en terreno propiamente vanguardista, establece tres etapas, la primera, desde el naturalismo hasta Apollinaire, pasando por el decadentismo y el simbolismo; la segunda es inaugurada por el futurismo y el cubismo y seguida de todos los ismos aparecidos hasta el final de la gran guerra. A continuación habla de una tercera y una cuarta etapas cuya frontera no especifica con exactitud. Es claro que la tercera comienza después del conflicto bélico del 14 y que el dadaísmo protagoniza el máximo intento de destrucción y superación de la institución artística. La cuarta y última llega hasta sus propios días -el estudio de Poggioli es de 1964-e incluye a movimientos como el existencialismo y a autores tan diversos como Samuel Beckett y Alain Robbe-Grillet. Los nombres de escritores y artistas prodigados a lo largo de su libro son de por sí reveladores de una idea de vanguardia asimilada a arte moderno; algunos de ellos, aparte de los ya nombrados, no dejan lugar a dudas: serían precursores indiscutibles Mallarmé, Rimbaud, Cézanne, y representantes conspicuos Proust, Joyce, Kafka, Svevo, Eliot, Picasso, Stravinski, lonesco, Gênet. A igual conclusión llega Ródenas de Moya cuando recuerda que Robert Alter inscribió a Unamuno en un listado integrado por Gide, Mann, Proust, Joyce, Virginia Woolf, Broch y Faulkner'13. Añade además que Gómez de la Serna sólo puede ser comprendido a partir de este criterio. [Ródenas de Moya, 1998: 48 y 49]

Similar trazado había realizado Guillermo de Torre, quien en su Literaturas de vanguardia, de 1965, prolonga la vanguardias hasta el Existencialismo. Y en un hilo razonador que ha originado incontables análisis, Ortega y Gasset incluye en su "arte nuevo" rasgos que tanto pueden ser vanguardistas como modernistas.

El criterio de Mireia Freixa no requiere más comentario que el propio título de su estudio, Las vanguardias del siglo XIX, en el cual recoge documentación y

\footnotetext{
${ }^{13}$ Recuerda este razonamiento al seguido por Ana María Barrenechea en su artículo "Unamuno en el movimiento de renovación de la novela europea". La reconocida especialista considera que sólo la procedencia periférica de Unamuno le impide figurar entre los más destacados renovadores de la narrativa moderna, Joyce, Kafka, Woolf.
} 
material de diversa naturaleza sobre el arte decimonónico. Es interesante asimismo consignar su definición de vanguardia:

... el grupo de vanguardia nace de una minoría que se opone a la sociedad establecida; es un movimiento de élite que entra en lógicas oposiciones con la realidad de la sociedad masiva y que sitúa al artista en un plano de absoluta soledad. [Freixa, 1982: 12]

Por último, es ineludible recalar en el concepto de arte moderno según Adorno. Para el autor de la Teoría estética, existe una unidad del arte moderno, el único arte legítimo del presente, desde Baudelaire hasta la neovanguardia [Bürger, 1987:117]. Desde el marco del marxismo crítico que sostiene su pensamiento, el máximo representante de la Escuela de Frankfurt elaboró la teoría que fue recibida con entusiasmo por la inteligencia progresista europea, que encontró en su tesis una forma de contrarrestar el dogmatismo marxista. Adorno sostiene que únicamente la renovación incesante y la transgresión de las formas artísticas puede denunciar la reificación del orden burgués y resistir al imperativo de la racionalidad de los fines. Sólo mediante la vanguardización permanente es posible evitar la cosificación de la sociedad capitalista.

Siendo ya momento de intentar una síntesis, se puede afirmar que en la primera mitad del siglo XIX, el término vanguardia, tanto en un sentido político como cultural, hacía referencia a la radicalización y fuerte utopización de una de las vertientes de la modernidad. Para Calinescu, la implicaciones militares del concepto explican la connotación de militancia, inconformismo, exploración precursora y valiente, así como de apuesta al futuro y a la victoria final del "tiempo" en alianza con el progreso. Hacia 1870, en Francia, vanguardia se utilizó para designar el pequeño grupo de escritores y artistas que transfería el espíritu de crítica radical de las formas sociales al dominio de las formas artísticas.

Es indudable que prevalece en los críticos una idea de elitismo asociada a la vanguardia, de movimiento minoritario que se revuelve contra una realidad hostil, la del artista que se siente alienado y relegado en un nivel de soledad y aislamiento. Como se verá más adelante, tal perspectiva dominante, excluye de una 
fundamental concepción de vanguardia que buscó un nuevo lenguaje basado en otros presupuestos estéticos e ideológicos.

\subsection{VANGUARDIAS Y MUNDO HISPANO}

Un punto de vista que no se debe ignorar en esta investigación corresponde al de Jorge Schwartz sobre las vanguardias latinoamericanas. Su punto de partida temporal para los ismos del nuevo continente es el "Manifiesto futurista" de Marinetti, que repercute de inmediato en Buenos Aires y en Salvador de Bahía. Coincide con otros especialistas en situar el siguiente mojón alrededor de Vicente Huidobro, en los años que van desde 1914 a 1922, año adoptado por Borges para marcar el inicio de una nueva era literaria diversa del ya caducado modernismo de Darío, Lugones, Rodó. Es además un año clave, no sólo para Latinoamérica sino para la vanguardia internacional, que da obras como Ulysses, The Waste Land, Trilce, Desolación, produce revistas como Proa de Buenos Aires, y ve nacer el estridentismo, sucesos de importancia a los que podrían añadirse muchos otros. Dos años después se inicia el cierre, con la aparición del último movimiento de vanguardia, el Surrealismo. Sin embargo, será hacia finales de la década del veinte cuando Latinoamérica registre el último ismo en Nicaragua. $Y$ añade Schwartz un dato interesante para comprender su visión: las vanguardias latinoamericanas sufrirán un notable cambio especialmente en lo referido a su carácter experimental y a la aparición de preocupaciones de índole político-social que deben comprenderse en el contexto internacional. La serie de giros hacia las preocupaciones ideológicas son numerosas, basta recordar algunas de las más destacadas: Vallejo abandona los ismos con su "Autopsia del surrealismo"; en 1927 concluye el ciclo de la revista Martín Fierro en Buenos Aires, Oswald de Andrade cambia la vanguardia antropofágica por la acción social. El debate entre las opciones estéticas y los proyectos ideológicos queda instalado y hallará todavía una derivación en 1938, cuando Diego Rivera, León Trotsky y André Bretón redactan en México el "Manifiesto por un Arte Independiente". 
Apuntando en la focalización en las vanguardias españolas que me interesa, es de destacar de la perspectiva de Schwartz que pese a que rastrea el fenómeno en el siglo XIX, encuentra un quiebre fundamental en la invalidación que la vanguardia hace del modernismo. Señalo asimismo que pese a recomendar no establecer divisiones antagónicas rígidas entre vanguardia estética y vanguardia política, considera que debe hablarse de dos Vallejos, dos Borges, dos Nerudas, de acuerdo con la actitud que asumen estos autores ante los ismos y su posterior disgregación. Aunque no iguala a todos los ismos en el tono y el objeto de sus ataques y revueltas y las preocupaciones político sociales -el futurismo destacará por su violenta reacción antiburguesa, el expresionismo alemán y el surrealismo francés por su sensibilidad ante la cuestión social-, sus afirmaciones no dejan de ser contradictorias con su propio postulado de que "el surgimiento de los ismos europeos dio un gran margen para la experimentación artística, desvinculándola, en mayor o menor grado, de todo pragmatismo social". De cualquier modo, su percepción de la polaridad vanguardia política y vanguardia artística es la de un enfrentamiento que produce diversas influencias en la producción cultural de los años veinte, las cuales varían de acuerdo al momento, los contextos y las experiencias individuales de los fundadores de los movimientos. Se trata de procesos modificables, pues "las causas, la producción y el consumo son elementos dinámicos, en cambio permanente" de lo que deriva la no pertinencia de limitar la vanguardia a un perfil único ni generalizar tipos rígidos de izquierdas o derechas. [Schwartz, 1991: 33-34]

En el mismo libro encontramos el capítulo introductorio de Alfredo Bosi, que pese a funcionar como prólogo constituye en realidad otra visión, no enfrentada con la de Schwartz, pero sí complementaria y hasta divergente para algunas cuestiones. Bosi amplía el horizonte de las vanguardias, situando sus raíces en los prerrománticos y restándole primacía al momento central de los años veinte. Otorga tanta relevancia a los aspectos formales y experimentales del movimiento como al principio sustancial de la libertad. A Bosi no le preocupan los momentos políticos o estéticos de los ismos porque cree que ambos son parte de un solo 
proceso que se asocia a un movimiento continental hacia la búsqueda de las propias raíces.

\begin{abstract}
Después de Macumaíma, de las Memorias sentimentais de João Miramar, de los Siete ensayos de interpretación de la realidad peruana, de Adán Buenosyres (que el autor empezó a escribir en 1930), NO PARECE LícITO SEPARAR, POR ESPÍRITU DE GEOMETRÍA, LA ASIMILACIÓN DEL PRINCIPIO DE LIBERTAD FORMAL Y EL AUTO EXAMEN ANTROPOLÓGICO, PUES AMBAS TENDENCIAS COEXISTIERON Y SE ENLAZARON EN LOS PROYECTOS MÁS CREATIVOS QUE SIGUIERON A LOS MANIFIESTOS DE LAS VANGUARDIAS ${ }^{14}$.

Llegó el momento en que, estimulado por el conocimiento del otro, el artista latinoamericano se miró a sí mismo y encontró un rostro humano, por la tanto universal, en sus cantos y mitos, en las pasiones de la cotidianeidad y en las figuras de la memoria. [Bosi, 1991:20]
\end{abstract}

En consecuencia con su visión extensa y plural de la vanguardia, registra hasta bien entrado el siglo XX las conquistas de las primeras décadas, pues para Bosi pervive el mismo espíritu de integración de lo nuevo y lo autóctono en la posvanguardia de Alegría, Arguedas, Guillén, Palés Matos, Carpentier, Rulfo... "todos beneficiados del viento de libertad que sopló en los años 20". [Bosi, 1991: 20]

Los enfoques de Schwartz y Biso tienen puntos de contacto con los problemas que plantea la modernidad en España. Uno de los interrogantes que aparece a la hora de analizar la vanguardia es si la diferenciación entre modernismo y vanguardia, muy apropiada desde puntos de vista como el formal o el de las mentalidades, es extensivo a todos los autores. Valen aquí las advertencias sobre la multiplicidad y complejidad del fenómeno vanguardista. De la misma manera, es empobrecedor fijar una divisoria tajante entre las vanguardias artísticas y las políticas, pero sería igualmente erróneo desconocer los arduos debates que tuvieron lugar. Sin duda en España también se puede hablar, y se habla, de dos Alberti, de dos Ayala o de dos García Lorca, así como de un giro hacia las preocupaciones ideológicas en la década del treinta. El riesgo de disolver las generalizaciones maniqueas es pensar que las vanguardias encierran las respuestas a todos los problemas, eclipsando así el otro polo del debate, las estéticas defensoras del arte con función social y de valor

\footnotetext{
${ }^{14}$ Subrayado mío.
} 
comunicacional de la obra literaria, cuyo discrepancia con los ismos sirvió de contrapeso constante, con mayor o menor resonancia, en el sistema artístico.

Nuevamente es necesario detenerse en el ritmo diferente de los procesos sociales y estéticos en España. La crítica ha señalado reiteradamente la llegada tardía de la novela realista a España y su fuerte conexión con la renuente modernización del país y de sus instituciones. Por consiguiente, el desencanto y el alejamiento de escritores como Galdós del proyecto de la burguesía se produce más tarde que en el resto de los países europeos. La proyección de estas circunstancias en el subsistema social artístico adquieren también otra fisonomía, especialmente en la resolución de la pugna entre realismo y naturalismo. Este punto se va a retomar en posteriores páginas pues se conecta con el tema del compromiso y de la intervención del escritor en la esfera pública. [Oleza, 1986].

\subsection{UnA NUEVA PRAXIS VITAL}

Hasta aquí se ha visto que vanguardia, modernidad y modernidad estética tienen vínculos ineludibles entre sí. No obstante, es posible lograr una descripción más acotada de la categoría vanguardia circunscripta específicamente a los movimientos de las llamadas vanguardias históricas, que se desarrollaron en la primera mitad del siglo XX alcanzando el momento estelar hacia los años veinte. No resulta operativo para el propósito de esta tesis entender 'vanguardia' en un sentido tan extenso que incluya al existencialismo y otros movimientos surgidos después de la II Guerra mundial Ver de Torre. ojo

El imprescindible estudio de Peter Bürger permite abordar la cuestión a partir de dos premisas de distinta naturaleza, la primera y fundamental por su originalidad es la basada en la diferente actitud del arte de vanguardia ante la institución artística; la segunda atiende a los aspectos formales de la obra de vanguardia.

Es preciso retomar aquí las nociones acerca de la autonomía artística tratadas en el capítulo inicial, porque según Bürger, las escuelas esteticistas, al llegar 
a la máxima concreción la autonomía estética y a la consolidación de la institución arte mediante la plena diferenciación de los fenómenos artísticos, permiten los ataques de los ismos contra el arte por el arte.

Para hablar de movimientos históricos de vanguardia, Bürger parte del dadaísmo, el primer surrealismo, la vanguardia rusa posterior a la revolución de octubre, el futurismo italiano y el expresionismo alemán; todos tienen en común que "no se limitan a rechazar un determinado procedimiento artístico, sino el arte de su época en su totalidad, y, por tanto, verifican una ruptura con la tradición. Sus manifestaciones extremas se dirigen especialmente contra la institución arte, tal y como se ha formado en el seno de la sociedad burguesa". [Bürger. 1991, 54]. Una consideración aparte merece el cubismo, pues aunque cuestiona los sistemas de representación, no cuestiona la institución arte.

El reconocimiento de la institución arte hizo posible la toma de conciencia sobre el medio artístico, es decir, la posibilidad de disponer y reflexionar sobre él sin la sujeción a un determinado estilo o canon. La vanguardia no desarrolló ningún estilo, sino que convirtió en un principio la disponibilidad de todos los medios artísticos del pasado. Desde el momento en que la vanguardia no elige desde un determinado principio estilístico, sino que cuenta con él como medio artístico, permite percibir el medio artístico en su totalidad.

Sin duda la tesis de mayores consecuencias del pensador de la escuela de Frankfurt es que a partir de las escuelas de vanguardia el subsistema social artístico alcanza el estado de autocrítica ${ }^{15}$, esto es, deja de rebelarse como los anteriores movimientos contra las escuelas precedentes y pasa a cuestionar a la institución arte. Se toma conciencia entonces de la existencia de un aparato de producción y distribución del arte cuyas ideas y juicios dominan en una época dada y determinan esencialmente la recepción de las obras. Las vanguardias se levantarán contra el aparato de distribución y contra el estatuto del arte en la sociedad burguesa tal como lo describe el concepto de autonomía. Lo estético logró desplegarse en toda su pureza después que el esteticismo desligara al arte de toda conexión con la vida,

\footnotetext{
${ }^{15}$ El concepto de autocrítica traslada a la esfera del arte la tesis de Marx sobre la autocrítica como categoría historiográfica, que a partir de entonces se distingue de la crítica inmanente porque esta funciona dentro de la institución social y aquella opera desde una distancia de las concepciones que se cuestionan, los cual es posible porque se produce una crítica radical a la propia institución.
} 
momento en que se hace visible la otra cara de la autonomía: la carencia de función social del arte. Autonomía significa por tanto el modo de función del subsistema social artístico: su independencia relativa respecto de la pretensión de aplicación social

Esteticismo y vanguardias coinciden en la concreción de la máxima autonomía, en tanto en sus prácticas estéticas los contenidos de las obras pierden su carácter político y el arte desea ser simplemente arte, resultado de lo cual se hace posible la autocrítica del subsistema social artístico. Con el esteticismo, la temática pierde importancia en favor de una concentración siempre intensa de los productores del arte sobre el medio. El arte se convierte en sí mismo en un problema desde el momento en que excluye todo "lo ajeno al arte". Es sólo entonces cuando se pone en tela de juicio el aparato de producción y distribución del arte, las ideas que sobre el arte dominan en una época dada y que determinan esencialmente la recepción de las obras, es decir, cuando se cuestionan los tres pilares de la autonomía estética: finalidad, producción y recepción. Conviene subrayar en este punto que la vanguardia no ataca el estatuto del arte en la sociedad burguesa, sino la separación de la praxis vital de los hombres. Cuando los artistas de vanguardia cuestionan el funcionamiento del arte en la sociedad burguesa, no quieren decir que el contenido de las obras deba ser socialmente significativo, por el contrario, coinciden con el esteticismo en distanciar el contenido respecto de la praxis vital, que no era otra que la racionalidad de los fines de la sociedad burguesa. Cuando los vanguardistas hablan de reunir el arte con la praxis vital, están pensando en una nueva praxis; en este sentido, la vanguardia no sería posible sin el momento previo del esteticismo, pues sólo al apartarse el arte de la praxis vital de la burguesía, incluso en el nivel del contenido, pueden pensar en buscar una nueva.

De la misma manera, se puede afirmar que en tanto el esteticismo y el arte por el arte permitieron el máximo de autonomía y de pureza, fue posible que las vanguardias cuestionaran otra de sus consecuencias, el aspecto subjetivo de la autonomía, que no es otro que las muy debatidas y analizadas cuestiones de la carencia de función social del artista y de la pérdida de la experiencia. La primera consideraba el aspecto objetivo y la segunda, el subjetivo. 
A la pérdida de función social del artista me referiré en el capítulo siguiente. La pérdida de la experiencia es el efecto en el sujeto de la diferenciación de ámbitos parciales en la sociedad burguesa, de los cuales la esfera artística es uno de los subsistemas. La experiencia disminuye cuando el individuo ve reducida su posibilidad de aplicar a su praxis vital el conjunto de percepciones y reflexiones asimiladas. El hombre especialista en un ámbito parcial continúa percibiendo y reflexionando, pero sus experiencias del ámbito parcial ya no pueden volcarse a la praxis vital. Al diferenciarse el subsistema social artístico, el hombre puede alcanzar la experiencia estética como algo específico y diferenciado, pero tiene una contrapartida negativa, su desvinculación de la praxis vital. Los vanguardistas intentarán conectarlas nuevamente, intentarán que aquello que más incomoda a una sociedad organizada según la racionalidad de los fines se convierta en principio organizativo de la existencia. Recusan también, como el esteticismo, la racionalidad del mundo burgués, pero intentan, a partir del arte, una nueva praxis vital.

\subsection{El peso del significante: El momento formal frente al momento del contenido. Creador Y RECEPTOR DE LA OBRA DE VANGUARDIA}

Es hora de tratar la segunda premisa de Bürger, que hace referencia al aspecto formal de las obras de vanguardia. Desde mediados del siglo XIX la dialéctica entre la forma y el contenido en las creaciones artísticas se decanta cada vez más a favor de la forma. Con las vanguardias históricas, esta tendencia no sólo se acentúa sino que hace posible, al no imponerse un estilo ni una norma, convertir en principio estético la disponibilidad de los medios artísticos de las épocas pasadas.

Como ha sido preciso adelantar en diversos momentos, existe acuerdo unánime en que la modernidad estética comienza a mediados del ochocientos cuando Baudelaire vincula romanticismo con belleza contemporánea y, siguiendo a Stendhal, sostiene que existen distintas clases de belleza. Lo distintivo de la idea de Baudelaire será el énfasis puesto en asociar modernidad y novedad, que en otro momento identificará con inmediatez, con un presente sensual apresado en su misma transitoriedad y opuesto al pasado endurecido por tradiciones rígidas e 
inmóviles. Baudelaire es el artista que descubre e instaura una noción de modernidad contradictoria y paradójica, en tanto es mitad fugitiva y contingente, y mitad eterna e inmutable. La belleza es por tanto efímera y eterna.

A los fines de este trabajo interesa destacar dos consecuencias clave de la noción de modernidad estética: será también a partir del autor de Les Fleurs du mal, que la imaginación se instituye en el supuesto primordial del arte de lo cual resulta que modernidad estética es incompatible con realismo. En segundo lugar, Baudelaire pasa a convertirse en el paradigma del artista alienado de la cultura y la sociedad oficial burguesa. El rechazo de los móviles materiales y mercantiles de la burguesía se traducen en una exaltación del gusto aristocrático, del individualismo y el culto a lo artificial; se aplaude la deformación de la naturaleza y se rechaza a la masa y a las tendencias democratizadoras en tanto avivan el instinto natural considerado monstruoso frente a la inteligencia y la razón. Lo bello y lo noble son productos del arte, y el arte producto de la disciplina y voluntad.

Paralelamente al desprecio de la naturaleza crece la admiración por la nueva realidad urbana y por la máquina, portadora de nuevos atributos mecánicos y científicos. De la contradicción entre el rechazo por el pasado y la nostalgia por una forma de vida aristocrática desplazada por una clase media vulgar, surge su programa: una vez alcanzada la plena conciencia del conflicto, el presente fugaz puede hacerse creativo y engendrar su belleza, que es la belleza de lo transitorio.

Si el arte por el arte y el esteticismo constituyen el gozne, el punto de inflexión imprescindible para que se produzca la crítica a la institución artística propiciada por las vanguardias, es ineludible recordar que ese movimiento en el ámbito de las letras y la cultura en lengua española se llamó modernismo y que modernismo fue finalmente el término menos conflictivo para designar y reunir todos aquellos rasgos comunes que compartían los movimientos surgidos en Francia a finales del siglo XIX, atomizados en su afán de diferenciarse: parnasianismo, decadentismo, simbolismo.

Por otra parte, es evidente que el modernismo representa un momento fundamental del triunfo de la forma sobre el contenido que caracteriza al arte moderno. Aunque desde este punto de vista es grande la distancia entre 
modernismo y vanguardismo, y el lector iniciado sabrá discernir entre uno y otro movimiento si se enfrenta a dos obras modélicas, existen actitudes de los artistas modernos que anticipan las posturas de las vanguardias históricas. Así sucede con las afirmaciones antipasatistas de Ramón del Valle Inclán -recogidas por Calinescu-que proclaman haber encontrado en el modernismo la posibilidad de dar alas a un impulso liberador. desafecto a la tradición, aunque de carácter marcadamente personal, el autor de las Sonatas subraya el carácter personal de la obra artística diferenciándose así de los postulados vanguardistas que buscaron anular la creación individual.

He preferido luchar por crear mi estilo personal en lugar de buscar uno ya conocido imitando a los escritores del siglo XVII... Así es como debe ser un modernista confeso: buscándome a mí mismo y no en otros... [Calinescu, 1991: 80]

Continuando con el propósito de deslindar la vanguardia del modernismo, es posible sostener que desde el punto de vista formal, uno de los conceptos clave para distinguir la obra de arte vanguardista de todos los movimientos precedentes es sin duda el de obra inorgánica. La obra orgánica tal como se verifica desde el Renacimiento, es concebida como un organismo vivo y como una totalidad, en la cual la parte y el todo se integran sin mediaciones. El material es respetado según su aparición en cada momento concreto de la vida.

La obra inorgánica en cambio, se construye a partir del material, arrancando de su contexto vital los elementos que la constituyen, despojándolos de su función y de su significado; el material es sólo material, un signo vacío al cual el artista da significado. El resultado es el aislamiento del material, la descomposición, el montaje de la obra con fragmentos. El sentido final resulta de la reunión de las partes, sin su correspondiente contexto. A diferencia de la obra orgánica, que ocultando su artificio da apariencia de naturaleza, y cuyos elementos tienen sentido en función de la totalidad, la obra inorgánica exhibe el procedimiento, se ofrece como producto, como artefacto. Para Bürger el montaje es el principio básico del arte vanguardista; al presentarse compuesta de segmentos de la realidad, acaba con la idea de totalidad y sus componentes tienen una independencia casi absoluta. 
A partir de los collages cubistas, mediante la inclusión de materiales que no han sido elaborados por el artista, se rompe la unidad de la obra en tanto producto absoluto de la subjetividad del artista; el cuadro deja de ser un continuo. Una de las consecuencias más notables de la obra inorgánica es que al incorporar fragmentos de realidad -un trozo de periódico, de cristal- ya no remiten a la realidad como signo, sino que son realidad. Adorno, citado por Bürger, ha señalado que si bien en una obra cubista hay un principio constructivo, no hay una unidad del significado.

En una obra inorgánica, las partes se emancipan de un todo que las engloba, dejan de interesar los sucesos en su singularidad para dar prioridad al principio constructivo. La crítica hermenéutica será insuficiente para dar cuenta de esta nueva relación entre las partes y el todo, pero no dejará de tener un lugar destacado, junto a las nuevas formas de aprehender el fenómeno artístico. Bürger propone una síntesis de los métodos clásicos y los que tratan de comprender las obras inorgánicas, un método al que llama hermenéutica crítica, capaz de aceptar que el todo de la obra ya no está constituido por la armonía de las partes, sino por la conexión contradictoria de las partes heterogéneas. La investigación se centrará entonces en las contradicciones entre los niveles de la obra y el crítico habrá de deducir en primer lugar el sentido del todo.

Otra importante consecuencia de la fragmentación de la obra de arte y de la consiguiente pérdida de la totalidad es la hipótesis sobre la interpretación del procedimiento realizada por Walter Benjamin, quien atribuye al autor de la obra inorgánica una actitud de melancolía ${ }^{16}$, resultado de haber perdido la esperanza de crear una obra orgánica. La imposibilidad de alcanzar una configuración unitaria del mundo, que se convertirá por tanto en un objeto de deseo, origina un repliegue hacia sí mismo, según una interpretación freudiana de la situación ${ }^{17}$. La obligada fijación en lo particular, en el fragmento, no le permite afianzar ningún concepto sobre la conformación de la realidad, porque la realidad, en constante formación, se le escapa, provocándole una honda añoranza. El artista se debate entre el

${ }^{16}$ Benjamin postuló este supuesto en Origen de la tragedia alemana, en la cual expuso el concepto de alegoría a partir de su conocimiento del arte de vanguardia. [Bürger: 1987, 130-134]

17 V. del Pino, 1995: 12-13. 
ansia de totalidad de lo clásico y la necesidad de crear el arte atomizado del presente.

La actitud que la obra inorgánica requiere del lector - contemplador ha dado lugar a las difundidas consideraciones sobre la recepción de las obras de vanguardia.

La gravitación de los aspectos formales en el arte creció de tal manera desde la segunda mitad del siglo XIX, que las producciones artísticas tendieron cada vez más a autonomizar sus discursos y a ignorar el referente. La comprobación de esta tendencia llevó a Adorno a formular la afirmación, con pretensión de validez general, de que el contenido del arte radica en su técnica.

El vuelco del arte hacia los procedimientos tuvo al menos dos consecuencias antagónicas sobre la relación arte-vida.

El efecto más celebrado ha sido el hecho de que el abandono del principio mimético permitió a las vanguardias explorar otros mundos y ampliar la experiencia de lo real ya que el sujeto de conocimiento no se limitará a la realidad inmediata ni aceptará dócilmente los convencionalismos de la representación llamada realista. José Luis de Diego proporciona una ajustada síntesis de dos enfoques paradigmáticos sobre la cuestión que buscan superar la antinomia realismo/vanguardia. En primer término, reseña las reflexiones de Roland Barthes acerca de la relación lenguaje y realidad, literatura y realidad: la irresoluble inadecuación del lenguaje a lo real -el orden unidimensional frente al orden pluridimensional- lleva a los escritores a un constante esfuerzo, siempre renovado, por acortar las distancias entre el lenguaje y lo real. El realismo decimonónico emprendió uno de esos intentos: la ilusión de sus cultivadores de anular la mediación del significado y remitir directamente al referente se desvirtuó en una serie de artificios retóricos. Las vanguardias desistieron de crear este "efecto de realidad" y anularon la referencialidad del signo, dando lugar al arte no figurativo.

Seguidamente, de Diego encuentra una explicación de la reacción de las vanguardias contra las estéticas de la representación en las reflexiones de Jakobson sobre el realismo artístico. El discurso poético de las vanguardias, funciona a la 
manera del concepto de la ostrenenie introducido por los formalistas rusos, ilustrada por Jakobson con su célebre acertijo del arenque pintado de verde y trasladado de la cocina al salón ${ }^{18}$. De esta manera consigue provocar la sospecha sobre lo que transmiten los sentidos y ver con una nueva mirada aquello que la costumbre y los códigos establecidos aplanan u opacan.

\begin{abstract}
Los formalistas rusos insistieron en concebir el discurso poético como un modo de desautomatización de la percepción. De este modo, aproximarse a la realidad es ver con nuevos ojos lo que nuestros ojos reales y automatizados ya no están en condiciones de ver. Los ejemplos, en este sentido, son numerosos. Quizás la literatura más citada sea la de Kafka. Lo cotidiano encierra un reverso de horror e irracionalidad: narrar este reverso como "real" es lo que funda lo kafkiano. (...) En consecuencia, como el arenque de la adivinanza, la realidad se encuentra enmascarada; la literatura opera entonces como una advertencia: detrás de la supuesta realidad existe otra que nuestra percepción ya no distingue, aproximarse a lo real implica -debería implicar- desarrollar esta advertencia. [de Diego, 1994: 88].
\end{abstract}

En otro orden de las reflexiones sobre la relevancia de la forma en la obra vanguardista, no deben omitirse importantes antecedentes en la propia tradición española. Haciendo un camino inverso, desde las vanguardias al pasado, los autores de vanguardia establecieron una filiación con el simbolismo, pero también con el barroco -Góngora especialmente- e incluso con el medioevo -Juan de Mena y su Laberinto de Fortuna. Mediante el ejercicio genealógico redimieron a obras y autores condenados por la posteridad debido a su carácter hermético.

El canon literario español no será el mismo después del arte nuevo, sin embargo, deben matizarse las nociones más difundidas: no sólo fue recuperado Góngora. El cancionero y las formas líricas tradicionales constituyeron también fuentes de inspiración. Por otra parte, el hermetismo barroco no debe asimilarse a la dificultad vanguardista, ni la forma de percepción es equivalente. El método de apropiación de las objetivaciones intelectuales del que el receptor disponía hasta principios del siglo XX deja de servir. La obra inorgánica ya no produce una impresión general que permita captar un sentido, y tampoco es útil analizar las

\footnotetext{
${ }^{18}$ Se trata de una adivinanza: "'Qué es algo verde que está colgado en el salón? -Bueno, un arenque. -¿Por qué en el salón? -Porque no había lugar en la cocina. -¿Por qué verde? -Porque se lo ha pintado. -¿Pero por qué? -Para que resulte difícil adivinar" [Jakobson, 1969 (Citado por de Diego, 1994:88)]
} 
partes separadamente, dado que ya no se subordinan a la intención de la obra. El receptor recibe así un golpe, una conmoción -shock- y, si el propósito buscado por el artista se concreta, aquel se cuestionará, al verse privado de sentido, su propia praxis vital.

No siempre las expresiones vanguardistas estuvieron acompañadas de un gesto radical contra la institución arte, y aun cuando este existiera, pronto perdió su efecto y fue "consumido" y banalizado. Pero a pesar de este fracaso, la misma configuración de la obra, inorgánica, carente de centro y de unidad, en la cual lo decisivo para el sentido no son las partes singulares sino el principio de construcción, necesariamente provocó a un cambio en la recepción de las obras de arte.

Pasado el momento del shock, subsistirá la noción de estar frente a un nuevo objeto que se resiste a la captación del sentido. El receptor, ante el carácter enigmático de la obra vanguardista, tratará de desentrañarlo, pero sólo podrá hacerlo si se resigna a no comprender a partir de las relaciones de las partes y el todo, sino a centrarse en los principios constitutivos. La recepción, por tanto, sufre una fractura homóloga a la que produce el carácter inorgánico en el creador, esto es, el lector y el espectador comparten la melancolía. Para Bürger en este punto reside la gran revolución de las obras de vanguardia: la renuncia a la interpretación del sentido y la aceptación de que los elementos constitutivos de la obra no contribuyen a la producción de un sentido sino que es un mero relleno de un modelo estructural. A pesar de que, como ya se ha visto, la independencia de las partes no anula totalmente la gravitación del todo, sólo sobrevive una precaria unidad sumergida ahora en la contradicción. A partir de la vanguardia el todo de la obra consiste en la conexión contradictoria de partes heterogéneas.

El costado negativo del privilegio de la forma fue que los programas estéticos de las vanguardias, definidos como superación y negación de la mímesis -en el sentido naturalista de réplica o copia de la realidad- llevaron a los artistas a producir los elementos formales de la composición plástica independientemente de la percepción sensible. La consecuencia fue la condena de la obra de arte como experiencia de lo real y la impugnación de los elementos expresivos, narrativos y 
lingüísticos que posibilitan articular una experiencia estética como una forma de conocimiento.

En la dirección que siguen las reflexiones de Eduardo Subirats sobre el arte moderno, interesados en analizar la ruptura de la síntesis ideal de ciencia, estética y ética que propugnó el iluminismo, el filósofo español proporciona otra hipótesis para distinguir modernismo de vanguardia $\mathrm{y}$, al mismo tiempo, expone los conflictos que surgen de la obra inorgánica y de la hegemonía de la forma según las concibió el arte del siglo XX. La despreocupación por los contenidos según los transmitía la obra orgánica provocó la eliminación de los elementos subjetivos que implica toda meditación y la pérdida de los valores interiores y personales en un proceso ascendente que encuentra en Mondrian el ejemplo más acabado. Su obra constituye la máxima y más agresiva expresión de un orden abstracto y absoluto:

\begin{abstract}
La concepción del arte y la arquitectura como expresión simbólica y representación de la realidad en un sentido ideal, lo mismo que en un sentido realista, en la cual los aspectos constructivos, racionales y prospectivos del arte se entrelazaban con los poéticos y expresivos -tal como se ha dado en todo gran arte del siglo XX, desde Munch y Matisse hasta hoy-, es suplantada, en la primera generación de artistas de vanguardia y más tarde en el funcionalismo, por la representación artística de un sistema lingüístico gramaticalmente trabado por la sintaxis, carente de cualquier dimensión interior, de un discurso estructurado pero vacío. [Subirats, 1989, 72]
\end{abstract}

Subirats [1989: 53-81] explica la contradicción irresoluble entre los aspectos emancipadores y restrictivos de la vanguardia mediante la doble función del componente cartesiano del arte moderno, elemento unificador que encierra a la vez un factor liberador y revolucionario y un factor corrosivo de sus mismos postulados emancipadores. Si bien esta cuestión se desarrollará en el próximo apartado, dedicado a la vinculación de los ismos con la ciencia y la tecnología es oportuno destacar aquí que para el pensador catalán -interesado especialmente en la arquitectura como área que concentra el máximo impulso utópico de la vanguardia- no pesa tanto el principio de la inorganicidad como el sustrato cartesiano del arte moderno ${ }^{19}$, emergente en la integración de dos principios

${ }^{19}$ Subirats ilustra la tensa contradicción entre cartesianismo de signo universal y admiración por la historicidad específica de las identidades regionales o nacionales mediante el análisis de la 
opuestos: la duda absoluta y la voluntad positiva de elaborar un pensamiento firme de principios y valores universales. En el costado afirmativo, la estética cartesiana se vincula estrechamente a la investigación de las ciencias y las matemáticas. Aunque Descartes no pretendió proponer una doctrina estética, su filosofía propone un acercamiento a la realidad y provee de elementos asimilables desde una perspectiva estética, como son el rechazo de la imaginación y la fantasía, la negación de la memoria histórica y la tradición, la negación de la memoria biográfica individual, el rechazo absoluto de la naturaleza interior del hombre o el cuestionamiento de los elementos sensibles de la experiencia; todos elementos claramente presentes en los artistas más representativos de las vanguardias históricas. Así puede observarse en los retratos de Braque o Picasso, refractarios a la antigua mímesis que ponía de relieve lo individual de cada persona. Igualmente, el purismo o el neoplasticismo plantean una exigencia purificadora de los medios plásticos tendientes a disolver los aspectos sensibles, naturales, miméticos, imaginativos o individuales en un universo de valores absolutos e incorruptos.

También desde el punto de vista formal, interesa destacar que la filosofía cartesiana privilegia las formas de conocimiento como la geometría y matemáticas, asentadas sobre bases de validez autónoma y absoluta, evidente en el carácter intelectualista de los manifiestos vanguardistas, cuya materia simbólica sobresaliente será el cristal. Lo cristalino y la luz se convertirán en las transustanciaciones de un orden geométrico ideal puro, común al espíritu y a la naturaleza, y el hierro pasará a ser el soporte de las formas geométricas abstractas. El idealismo espiritualista fue a coincidir con los valores cientificistas o racionalistas del arte abstracto, fundamento de las síntesis de arte y civilización científica y tecnológica. Volveré sobre las consecuencias de la ambivalencia irresoluble de la intención revolucionaria y la vinculación a formas de poder y control en que derivaron. En este punto me interesa detenerme en la tesis de Subirats acerca de la relación de la estética cartesiana con el empobrecimiento de

correspondencia de Le Corbusier, donde se muestra fascinado por la integración al medio natural de las casas del campo valenciano, o por el ritmo de los sambistas brasileños mientras predicaba en sus conferencias una estética agresivamente cartesiana y antisensualista y una la arquitectura divorciada de la naturaleza y el sacrificio de la memoria histórica en beneficio del maquinismo. 
la experiencia de la que habló Benjamin. La abstracción y desidinvidualización de la expresión artística, unidas al imperativo de asumir en el arte los principios de la racionalización científica, que en la práctica se adaptaba a las exigencias de la producción industrial, acarrearon la progresiva pérdida de la dimensión humana en la producción y recepción de la obra vanguardista y, a su vez, empobrecieron la experiencia artística y desvalorizaron el arte. Finalmente, se perdió la relación del receptor y la obra. El cristal perdió su impulso utópico de perfección y espiritualidad para convertirse en una sustancia neutra y atemporal, en la que la historicidad, la biografía del individuo, su vida interior no pueden dejar huella. Del rechazo y la indiferencia por la experiencia humana, por la historia, y en definitiva, por el elemento poético, nace uno de los más duros cargos contra la vanguardia.

\subsection{Vanguardia y PROGRESO CIENTíFICO Y TECNOLógico}

En los apartados anteriores se ha visto cómo el fenómeno de las vanguardias no se comprende sin sus relaciones inextricables con la modernidad, tanto histórica como estética. El proyecto utópico de la modernidad se afianzó en el culto a la razón, en el ideal de la libertad, la fe en el progreso ilimitado de alcance universal. La modernidad estética, en cambio, se caracterizó por una posición antagónica, iconoclasta y cuestionadora de los valores burgueses. Sin embargo, las vanguardias históricas, herederas de este pathos, confiaron en cambiar el fracasado orden burgués por una nueva utopía: no se puede ignorar el valor semántico y simbólico que adjudicaron a la máquina y al avance científico en la consecución de un orden en el cual los valores económicos, tecnológicos y espistemológicos se aunaban para alcanzar una dimensión que debía a influir en todos los órdenes de la existencia. La máquina y el maquinismo tuvieron en el contexto artístico e histórico de las vanguardias un valor espiritual que los convirtieron en el principio de una utopía.

A esta altura deseo subrayar la importancia de esta visión del maquinismo para establecer una diferencia entre el modernismo y la vanguardia, pues será a partir de la máquina que la modernidad estética en su momento vanguardista, volverá a asumir los valores de la modernidad histórica, aunque modificando los 
objetivos: decisivamente antiburguesa, considera que el avance científico y tecnológico contribuirá a alcanzar un bienestar de alcance universal, retomando así la dimensión radical del progreso, heredera de la filosofía de la historia de la Ilustración.

Para comprender la relación dual, ambivalente de las vanguardias históricas con el maquinismo, Eduardo Subirats se remonta a Descartes. Se debe al filósofo francés la entronización de la máquina como elemento emancipador en tanto constituía la expresión máxima sobre la naturaleza y el medio decisivo para intervenir en ella. Su básico potencial técnico y la racionalidad que le es intrínseca daba a la máquina su poder liberador. La racionalidad -resultado de la conexión del principio económico y funcional con el conocimiento científico- tuvo al comienzo una aplicación técnica, pero pronto pasó a ser un modelo organizativo de la sociedad en su conjunto. Con las vanguardias de principios del siglo XX la máquina adquiera un valor cultural universal, convirtiéndose en un símbolo de validez general y en un principio socialmente formador. Sin embargo, la máquina es igualmente inseparable de un sentimiento de desconfianza y escepticismo que se proyecta hasta la actualidad, generando un vacío solo explicable si se analizan los ideales de los que fueron cimientos del arte siglo XX. Para hombres como Mendelsohn, Le Corbusier, Oud, Léger, entre otros, la máquina era una potencia ordenadora. Su papel organizador de la cultura debe entenderse hoy como resultado de una búsqueda de racionalidad en el contexto de la gran guerra, que había desatado los aspectos más negativos e irracionales de las viejas identidades culturales e históricas. A pesar de que destacadas voces, como la de Spengler, consideraron la máquina como un factor de empobrecimiento y disolución, después de la primera guerra mundial los movimientos artísticos la celebraron como una fuerza racional y democrática que igualaría las clases y liberaría al hombre de las tareas de sobrevivencia más pesadas. En el momento más optimista y activo de los ismos, la máquina, lejos de servir a los postulados tecnocráticos de la cultura y el poder -como finalmente ocurrió- tuvo una dimensión espiritual propia capaz de constituirse en principio de una utopía de salvación y esperanza. De esta manera, la unidad de los aspectos racionalistas de 
la nueva concepción formal -estética cartesiana- y los aspectos prácticos y productivos ligados a la sociedad industrial se cumplieron como un objetivo revolucionario en artistas como Schlemmer, Malewitch, Mendelsohn o los futuristas italianos.

El momento utópico de la máquina no fue duradero; la causa del desgaste de las posiciciones teóricas y formales de la vanguardia, según Subirats, son de origen externo e interno. Son externas las razones que entroncan con la polarización ideológica de la sociedad, dividida entre el comunismo y el fascismo, y con el enrarecimiento del clima político y social al final de los años veinte, que se sumó al sentimiento de escepticismo y descreímiento de las cualidades civilizadadoras de la ciencia y la tecnología surgidas tras la gran guerra.

De carácter interno es la pérdida del valor cultural transgresor, utópico y revolucionario del programa racionalista y el abandono del propósito de desarrollar una forma revolucionaria capaz de transformar los valores de la sociedad industrial. En este punto, Subirats sitúa la fecha simbólica de fractura y de abandono del impulso renovador en el Pabellón elaborado por Mies van der Rohe para la Feria Internacional de Barcelona en 1929, que inaugura la tendencia, acentuada a mediados del siglo XX, a cultivar un formalismo capaz de convertirse en un paradigma generalizable, carente de auténticos impulsos culturales y sociales, esto es, un repertorio gramaticalmente sistematizado, separado de los contenidos culturales, éticos, políticos y del impulso histórico que le otorgaron los pioneros.

De esta manera se puede aseverar que hacia finales de los años treinta se produce una doble escisión; entre la forma y su significado cultural o social, y entre progreso científico-tecnológico y el interés humano por la autonomía y la supervivencia. En el reverso de la síntesis de maquinismo y arte de vanguardia, acrecentado durante todo el siglo XX, se halla la transformación de los ideales transgresores y utópicos, inherentes a la racionalidad tecnológica y económica del maquinismo, en su contrario: la integración coactiva de la cultura artística e histórica a las exigencias del desarrollo tecnológico. En segundo lugar, aparece la 
consecuencia iconográfica de esa transformación: la asociación simbólica de la máquina con lo destructivo y demoníaco.

El cuestionamiento de la estética cartesiana puede encuadrarse en la crítica de la racionalización, de larga tradición en el pensamiento del siglo $\mathrm{XX}$, representada en las figuras de Weber, Freud, Adorno, Horkheimer. Las objeciones encuentran el punto débil en la sustitución de la realidad vital del ser humano por una paradigma tecnológico o, en palabras de Subirats, en la expansión de un modelo de actuación tecnológico sobre los procesos vitales, individuales o colectivos, sin reconocimiento de su real autonomía y especificidad.

Este proceso de reducción de la experiencia y de reducción de la autonomía reflexiva de la experiencia humana, descubre su máxima magnitud en el terreno del arte y de la modernidad estética. Walter Benjamin advirtió que los procedimientos de la arquitectura moderna -desaparición del ornamento, la estética de lo geométrico y cristalino, los nuevos materiales industriales- imponían una limitación y un empobrecimiento de la experiencia individual. Si se compara de un retrato romántico y un retrato cubista ${ }^{20}$ se observa que la revolución estética de la vanguardia consistió en la independización de los elementos pictóricos de su sentido expresivo y representativo. Declarada y llevada a cabo de distintas maneras esta revolución, se puede constatar que en los diversos programas vanguardistas se abogaba por la independización del arte de la realidad, y por consiguiente de la experiencia individual para convertirse en una composición pura. Así lo esotérico deviene una lógica y la realidad particular desaparece para convertirse en un principio abstracto y universal: una secuencia de figuras geométricas y espacios no perspectivistas.

La elevación simbólica de lo individual a un valor último e irreductible instituido en el arte occidental desde el Renacimiento pierde su vigencia, a consecuencia de lo cual desaparecen del arte moderno los momentos subjetivos, el carácter individual y la dimensión interior. En forma similar, al finalizar la Edad Media la pintura había sido liberada de la representación simbólica de lo trascendente. En esta tendencia se

\footnotetext{
${ }^{20}$ No entraré en la indagación sobre si el cubismo pertenece o no a las vanguardias históricas; Bürger considera que aunque no persiguió la superación del arte en la praxis vital, sí sería vanguardista en lo concerniente al cuestionamiento del sistema de representación de la perspectiva central vigente desde el Renacimiento.
} 
sitúa la tesis anti-humanista de Ortega y Gasset, a la que habré de referirne más adelante.

La conciencia de la violencia intrínseca con que la racionalidad artística y utópica aproximaba sus valores éticos y estéticos al nihilismo vital y a la angustia, se observa en los escritos de sus más relevantes defensores -Mondrian, Klee, Kandinsky. Pero más allá del costado subjetivo, existen unas consecuencias concretas y objetivas de la aplicación de la racionalidad artística y de su función como factor de integración racionalizadora. La identificación de la razón con la violencia opresiva y de la tecnología con la destrucción subyace en la equiparación de la máquina con el demonio, es decir, con la fuerza irracional e incontrolable. Las críticas que desde los comienzos de la modernidad estética subrayan los aspectos negativos del avance científico tecnológico se agudizan cuando las vanguardias, a través de las utopías de una sociedad integralmente racionalizada, no pueden evitar la ambigüedad de la irracionalidad que reina donde el principio racional se instala plenamente. La racionalidad coactiva del arte vanguardista genera al mismo tiempo un principio irracional de desorden y conflictividad. Esta contradicción, la más decisiva de la modernidad, queda manifiesta en los paisajes desolados de De Chirico o en las máquinas de Duchamp o Picabia; la guerra, el maquinismo, la ciudad industrial, la velocidad, adquieren una ambivalente expresión de exaltación y angustia. El temor que en la cultura preindustrial suscitaba la naturaleza se desplazó a la tecnología y a la máquina -en principio, garantes del control de esa misma naturaleza. En los mejores exponentes del arte de vanguardia, el mundo utópico de un orden cultural fundado en la razón científico-técnica y el de la destrucción y la angustia están íntimamente relacionados. En sus obras el conflicto entre el logos del progreso y la angustia no encuentra conciliación. [Subirats, 1989, 1991]

\section{Reflexiones finales sobre la vanguardia}

Mucho se ha hablado acerca de que las vanguardias no supieron resolver la contradicción entre su cuestionamiento a la reificación arte y la posterior incorporación al circuito de mercancía ni tuvieron respuesta para su incorporación a 
la institución artística a la que atacaban. Según el clásico estudio de Edoardo Sanguinetti [1965], la sustracción a las leyes del mercado mediante la producción de objetos artísticos ajenos a la demanda, la incorporación al circuito comercial y a los museos son parte del mismo fenómeno. Los vanguardistas no pudieron evitar la mercantilización y la canonización de las obras. La superivencia de la institución arte constituye una de las instancias del fracaso del proyecto de las vanguardias históricas.

Del mismo modo, no les fue posible resolver la paradoja entre la utopía de un nuevo orden social que entrañaba una esperanza de emancipación y el desencuentro con el público de masas, como tampoco superaron la tensión entre el carácter fuertemente normativo de sus postulados y la voluntad transgresora de sus prácticas artísticas.

Por otra parte, el talante provocador y agresivo de los artistas del arte nuevo no se condice con su sometimiento a los valores de la racionalización científicotécnica y del progreso económico; ni la resistencia al orden administrado, con el valor mercancía adquirido por las obras vanguardistas.

En la actualidad la vanguardia continúa siendo objeto de incontables trabajos realizados desde múltiples perspectivas. Las conclusiones suelen guardar estrecha relación con la línea seguida por el crítico; es poco discutible hoy que la mirada sobre el pasado constituye una forma de conocer y juzgar el presente.

Es fácilmente verificable que cuando dominaba la crítica sociológica, las miradas más severas sobre la vanguardia se correspondían con el interés del crítico por los contenidos y la capacidad comunicativa del arte; en cambio, no prestaban atención al "sentido de la forma" y a la carga de rebeldía que subyacía en los contenciosos con la tradición literaria de la academia.

Se podría trazar un mapa opuesto, en el cual la ponderación sin restricciones, -implícita o explícita- de la vanguardia revela la predilección por la perspectiva formal. Esta visión suele presentarse acompañada de una encubierto menoscabo del lugar simbólico de las estéticas realistas. A la sombra del auge de los estudios estructuralistas o posestructuralistas, las vanguardias se expanden sobre la totalidad del sistema, ocupando incluso los sitios de las demás escuelas, hasta 
proporcionar desde sí mismas una explicación para la totalidad del espectro de los fenómenos estéticos del período en que florecieron.

Un conveniente distanciamiento de los enfoques críticos "panvanguardistas" hace surgir interrogantes que merecen tomarse en cuenta: los cambios producidos en el paso de los años veinte a los treinta, ¿se explican únicamente por un giro en el interior del movimiento -protagonizado por el surrealismo- al tenor de la agudización de los conflictos políticos y sociales? ¿No deben conceder los especialistas un papel importante a las tensiones con los modelos que mantuvieron su adhesión a los principios de la representación? El denostado realismo, ¿sufrió un ostracismo radical o fue la crítica posterior quien anuló matices y claroscuros?

Otro fenómeno directamente ligado a los estudios sobre la vanguardia es la construcción de un "orden de mérito" regido por el paradigma que identifica modernismo-vanguardia-modernidad. Es así como el crítico acostumbra identificar la obra vanguardista de un autor con su momento artístico más alto, casi siempre también el más hermético. Jorge Schwartz no duda en la superioridad artística de Trilce sobre Poemas humanos, de Vallejo; así se consideran también Poeta en Nueva York de García Lorca o Sobre los ángeles de Alberti, poemarios que son colocados en la cima de la producción lírica de los dos poetas. A esta altura de las reflexiones no me propongo asentir o negar tales juicios, sino concluir la presentación del marco teórico sobre la vanguardia con un alerta acerca del riesgo que corre el especialista de parcelar el fenómeno complejo y múltiple de la modernidad estética restringiéndolo a un único itinerario.

Joan Oleza ha analizado agudamente el problema, con particular atención a literatura española, demostrando la polaridad de unos estudios altamente determinados por la hegemonía de una u otra orientación teórica.

Si con la estética marxista más ortodoxa la crítica literaria se pasó media vida predicando que la mejor literatura subvertía siempre la realidad social del capitalismo, con la estética que circula entre Barthes y de Man se ha pasado la otra media pidiéndole a la literatura que subvierta la literatura. [Oleza, 1993: 116] 
Consecuencia de la primacía de un determinado discurso teórico, quedaron segregados de la modernidad artística aquellos modelos que tenían como objetivo fundamental la exploración de lo real-contemporáneo y del entrecruzamiento arte vida. El nombre más representativo de la condena de la tradición realista es el de Theodor Adorno, quien excluyó la vida y las prácticas cotidianas de la esfera del arte y, paralelamente, otorgó a la vanguardia el privilegio exclusivo de denunciar la alienación en la socidad capitalista. En el mismo rumbo, la aplicación rígida del paradigma sustentado en el principio de la función poética dio resultados simétricos

Era el paradigma estructuralista-semiótico que produjo en literatura un boom formalista (G. della Volpe dixit) elaboró como base de apoyo un canon literario que con origen en el Romanticismo alemán de los Schlegel-Novalis y en la obra de Baudelaire, se prolongaba a través del decadentismosimbolismo-modernismo, alcanzaba a las vanguardias y resurgía como neovanguardia a mediados de los 60: Rimbaud, Lautréamont, Mallarmé, Valéry, Pound, Eliot, eran los grandes nombres de la poesía; el Flaubert de $L^{\prime}$ éducation sentimentale, el Gide de Les Faux Monnayeurs, Musil, Proust y en menor medida Joyce o Faulkner, los grandes de la novela; Bataille, Blanchot, el grupo Tel Quel, y muy especialmente la joven Kristeva, Barthes, Todorov, Genette, Foucault o Lacan dominaban el mundo del pensamiento literario. [Oleza, 1993: 115]

Si la crítica marxista clásica y la crítica post-estructuralista configuraron sendas representaciones de la vanguardia, el giro epistemológico representado por el pensamiento posmoderno ha permitido reconsiderar viejos y productivos interrogantes lukacsianos, aunque aplicados en el presente sobre otros recortes historiográficos:

¿Trátase aquí de una oposición entre la literatura moderna y la clásica (o inclusive el clasicismo), como algunos escritores lo recalcan particularmente cuando convierten mi actividad crítica en objeto de ataques? Creo que este planteamiento es fundamentalmente equivocado. Se oculta tras del mismo una equiparación del arte del presente con la evolución de determinadas tendencias literarias, que conduce, a partir del naturalismo y el impresionismo en disolución, a través del expresionismo, hasta el surrealismo. Cuanto tales autores hablan del arte moderno, aparecen exclusivamente como representantes de este arte los de la línea evolutiva que acabo de señalar. [Lukács, 1938: 288-289 
Continuando con el pensamiento de Oleza, se puede constatar que una manifestación semejante a la de Lukács contra la visión unilateral de la modernidad estética se expresa hoy reformulada con nuevas aportaciones teóricas, porque "la evolución de la literatura es -especialmente en el capitalismo y especialmente en la época de su crisis [¿qué categoría y circunstancia deberíamos usar hoy?, prefiero dejar el el interrogante en suspenso] extraordinariamente complicada". [Lukács, 1938: 289]

El debate de la postmodernidad ha levantado la veda sobre estas cuestiones, ha desacralizado el discurso de la modernidad (la necesidad de "ser modernos"), sus interpretaciones y sus cánones, y ha abierto múltiples vías para un profundo replanteamiento de lo estético y de su función social. [Oleza, 1993: 117-118]

Quizás el actual desarrollo de las especulaciones teóricas hayan conjurado ya los riesgos de que la vanguardia, en su sentido más extenso, se convierta en una suerte de sinécdoque que conduce al investigador a tomar la parte por el todo, la vanguardia como el arte moderno, y el arte moderno definido por una de sus posibles direcciones. 


\section{COMPROMISO}

\section{HACIA LA DEMARCACIÓN DE UN MARCO TEÓRICO}

\section{Principales perspectivas}

Para el estudio de la categoría compromiso se parte de la constatación de que el concepto es notoriamente más impreciso y menos delimitado que el de vanguardias o el de autonomía artística. El término, como se verá, comparte el campo semántico con nociones afines, como arte con función social, realismo, papel del intelectual... La indagación, compleja por la misma extensión y asociaciones que conlleva, ha procurado hallar un método y una sistematicidad a partir de tres ejes fundamentales desde donde se ha tratado de explicar el compromiso. El propósito es meramente ordenador y no desconoce que las parcelas se comunican entre sí, y que, para mayor complejidad, los debates en torno a la función del arte se hallan especialmente atravesados por las circunstancias políticas de la época en que se producen.

En primer lugar, el compromiso acompaña de forma inseparable el trayecto del arte hacia la modernidad estética y subyace en los debates sobre la autonomía desde sus comienzos hasta la actualidad. La introducción de las más nuevas teorías sobre la vanguardia otorgó a esta perspectiva planteamientos renovados, pero siempre subordinados a la idea -ya apuntada en el anterior capítulo- de que el arte moderno se fundamenta en la revolución de la forma, entendida esta revolución como ruptura con los presupuestos del arte realista.

Una visión diferente, crítica con la concepción de la modernidad estética dominante, proviene de las reflexiones y replanteos desatados por los debates en torno a la posmodernidad y la posvanguardia.

Por último, una tercera línea se apoya, más que en fundamentos estéticos, en consideraciones morales y éticas que se remontan al papel que el hombre de letras, o el filósofo, o el artista, jugaron desde los inicios mismos de la cultura occidental. 
En las primeras décadas del siglo $\mathrm{XX}$ la interrelación entre literatura y política se vuelve una cuestión de gran interés en el campo de la cultura, especialmente reavivada por la primera guerra mundial y la revolución bolchevique; pero la preocupación se retrotrae, al menos en el marco de la modernidad, al siglo XVIII, habiendo constituido posteriormente un decisivo foco de debate en el Romanticismo.

Es de destacar que compromiso, el término hoy más aceptado para designar una determinada concepción del papel del intelectual y del ejercicio de la literatura del arte, no fue el más utilizado en la época en que se centra esta investigación. La palabra compromiso se impone en los estudios literarios asociada al engagement sartreano para referirse a una actitud moral característica de un sector de los intelectuales de izquierda en los años cuarenta y cincuenta. [Jiménez Millán, 1990: 145]

En la actualidad "compromiso" y "literatura comprometida" se utilizan toda vez que se quiere tratar una realidad no homogénea, compuesta por "una serie de tendencias, a veces distantes entre sí, o más específicamente, un conjunto de prácticas ideológicas orientadas por un proyecto de inserción en las luchas sociales" [Jiménez Millán, 1985: 97]. En los años veinte y treinta las fórmulas más frecuentes para llamar a esta práctica fueron "literatura de avanzada", y con diferente alcance, "nuevo romanticismo" o "arte rehumanizado".

\subsection{Arte frente a necesidades prácticas. Resistencia a la autonomía del arte}

Para analizar la noción de literatura que la categoría compromiso plantea y los debates que concita -con independencia de los términos- es preciso retrotraer el estudio al momento en que comienzan a delinearse los distintos subsistemas sociales y a concebirse el arte emancipado de las servidumbres del poder, religioso o cortesano, libre de toda utilidad o función. La cuestión, sin embargo, es aún más remota: en términos muy generales, puede pensarse que las disquisiciones sobre la función del arte son inseparables de la posesión 
de un saber, en este caso la palabra, oral o escrita, y del ejercicio de la libertad y la inteligencia ${ }^{1}$.

Retomando la llustración como enclave en que comienza a perfilarse el intelectual independiente, cabe señalar que siglos antes se verifican, según Bürger, distintas críticas a la incipiente autonomía, unidas a la defensa del arte orientado hacia fines didáctico-morales, como es el caso de las manifestaciones de Savonarola en el siglo XV. El mismo caso sirve para ilustrar cuan tempranamente se produce un litigio entre el placer estético y la recepción masiva, que comienza a asociarse con la carencia de valores artísticos ${ }^{2}$.

Pero será a finales del siglo XVIII, resultado del proceso de autonomización que ya se ha mencionado, cuando a la par del surgimiento de la estética y de la configuración del concepto arte, la utilidad se comience a ver como un elemento perturbador en la producción artística. Desde la época helenística, y sobre todo a partir de Horacio, la conjunción de delectare y prodesse era un principio de naturalidad artística; a partir de que el arte se constituye en una esfera autónoma distinta de cualquier otra actividad, los propósitos de retornar al pensamietno iluminista -que vinculaba el arte a necesidades prácticas- y de introducir contenidos cognitivos o doctrinarios con una finalidad extra-artística, han sido rechazados por la crítica dominante, a excepción de algunas voces que adquirieron primacía en determinados momentos históricos. Es de señalar no obstante, aunque parezca paradójico, la estrecha relación existente entre la consecución de un estatuto autónomo para el arte y la idea de una posible función social, pues sólo en la medida en que el arte deja de ser representativo -estar al servicio del culto o de la corona- puede destinarse a otros propósitos.

\footnotetext{
${ }^{1}$ En su artículo "El escriba sentado", Vázquez Montalbán considera, a partir de un testimonio escrito del antiguo Egipto, que desde los comienzos de la civilización el escriba "conoce la ventaja que le otorga ser poseedor del lenguaje como instrumento", "aunque la significación sea la convenida por los señores o por los brujos". También en Grecia antigua "se convenía que la especialización del brujo de las palabras fuera peligrosa para los demás brujos y para los fines del poder. Temían que el escriba pudiera levantarse tras rechazar el mero papel de reproductor de ideología y creerse Prometeo, el que roba la palabra o el fuego o el saber a los dioses para dárselo a los hombres" [1989: 14]

${ }^{2}$ La interpretación de la posición de Savonarola a favor de un arte ascético-religioso y partidario de la recepción masiva frente al poder aurático ha sido objeto de un debate que no trataré de dilucidar aquí; sólo me interesa subrayar un antecedente lejano de la tensión entre arte autónomo y arte volcado a una función moral, aunque en este caso se entienda por tal el arte ascético-religioso. V. Bürger: 1987, 89-90.
} 
La idea de que el arte puede cumplir una función social se halla entonces estrechamente vinculada a la concepción de autonomía. Si se está de acuerdo en que Kant instaura la premisa de la carencia de función del arte y que Schiller, siguiendo al filósofo de Königsberg, sienta las bases de la modernidad estética concibiendo lo estético como un espacio desvinculado de la vida cotidiana y poseedor de un lugar privilegiado entre la razón y los sentidos, debe aceptarse también que gracias a esa independencia Schiller otorgará al arte una función social decisiva: la elevación espiritual de la humanidad que no podría realizarse por ningún otro medio. El filósofo centra su análisis en la época del terror de la Revolución Francesa y llega a la conclusión de que en las clases bajas se advierten impulsos brutales y anárquicos desencadenados por la ruptura del vínculo del orden civil; pero las clases civilizadas dan un espectáculo aún más repugnante de languidez: una depravación de carácter más censurable aún porque se alimenta de la misma cultura. La ilustración del entendimiento de la que se enorgullecen como clase no muestra influencia ennoblecedora ni sirve para educar en los asuntos morales. La barbarie de unos y la ineficacia de otros demuestran que no se debe confiar en la bondad natural del hombre ni en la capacidad formadora de su entendimiento. [Bürger: 1987: 93-100]

En Schiller es decisiva la interpretación social del problema, pues lo entiende como resultado de un proceso histórico y no de una naturaleza humana perenne. El desarrollo de la cultura ha destruido la unidad de sensibilidad y espíritu que conocieron los griegos y al hombre sólo le es posible desarrollar una parte de sus aptitudes, mientras el resto apenas se insinúa y se convierte en una copia de su especialidad o su ciencia, sin desarrollar la armonía de su ser, de su entera humanidad. De esta diferenciación de actividades -división del trabajo- se genera la sociedad de clases, que no se podrá suprimir mediante la revolución política, porque la revolución sólo la pueden hacer los hombres que, formados en la división del trabajo, no han podido acceder a la humanidad. La contradicción es insalvable porque para que pueda conciliarse nuevamente sensibilidad y entendimiento es necesario un hombre previamente formado en esa comunidad. 
En esta situación irremediable de una sociedad basada en la división del trabajo, el arte tiene la misión de unir las dos mitades escindidas del hombre y facilitar la formación de la totalidad de las disposiciones humanas. El arte, debido a su renuncia a la intervención inmediata en la realidad, es apropiado para restaurar la totalidad humana. La conquista de una sociedad racional dependería pues de la realización previa de la humanidad por medio del arte. Es de gran interés entonces la fundamental función social que Schiller atribuye al arte, precisamente por considerarlo desvinculado de la vida práctica. [Bürger: 1974].

Se puede observar que Schiller inicia una línea de reflexión en la cual la función social de la obra artística estará asociada de forma indefectible al carácter autónomo de la obra de arte, dirección que retomará más tarde Theodor Adorno.

Cuando se trata del compromiso, sin embargo, han tenido mayor peso las tesis que indagan esta categoría a partir de la ruptura o el desconocimiento de la esfera autónoma del arte. La oposición autonomía y función social del arte trazó desde esta perspectiva una línea divisoria tajante entre ambas concepciones que ha permanecido en pie, con numerosos matices e intentos de acercamiento, al menos hasta el último cuarto del siglo XX.

Se trata de tesis que pese a las divergencias e incluso oposición respecto de las evaluaciones y conclusiones, tienen en común afirmarse en el marco teórico de la modernidad. Como se ha visto en el apartado dedicado a las características formales de la vanguardia, la modernidad estética se entendió principalmente como un aplastante triunfo de la forma en la dialéctica forma - contenido. Acerca de esta idea preeminente, hoy se escuchan voces discordantes que citaré más adelante, en este mismo apartado. Me interesa primero señalar el alto grado de relación que tiene la victoria de los procedimientos con la desvalorización del arte con función social. En este sentido, la autonomía de la esfera artística, la proclamación de la falta de finalidad del arte, tuvo anticipados opositores que continuarán defendiendo el postulado horaciano de deleitar y aprovechar. Ya se ha recordado el temprano antecedente de Savonarola. El siglo XIX registra de forma sostenida voces 
adversas a la autonomía y partidarias de considerar el arte como un medio al servicio de los proyectos regeneradores de la humanidad. Por ejemplo, en 1865 Pierre-Joseph Proudhon ataca a aquellos que no dirigen la expresión estética al mejoramiento del hombre; a la vez atribuye a la literatura un papel fundamental en la consecución del proyecto utópico fourierista

\begin{abstract}
Toda creación del arte, como de la industria o de la política, cumple necesariamente un fin: se realiza por algo en concreto. Es absurdo creer que haya alguna cosa que tenga lugar en la sociedad - ¿y por qué no en el universo?- por el mero hecho de producirse. Sentado este principio, no hay para el arte más que dos alternativas: o la pintura tendrá como fin, en la mayoría de sus obras, tanto las más serias como las más ligeras, las más sabias como las más caprichosas, exponer la vida humana, representar los sentimientos, las pasiones, los vicios y las virtudes, los trabajos (...) en una palabra, las formas, en sus manifestaciones más típicas, individuales y colectivas, y todo para lograr el perfeccionamiento físico, intelectual y moral de la humanidad, su justificación, y, finalmente, su glorificación.

O bien, bajo el pretexto de la libertad, de la independencia del arte, del genio, del ideal, de revelación, inspiración sueño y fantasía, se pondrá al servicio, ya sea del idealismo religioso, del iluminismo, del fanatismo o del quijotismo, ya sea al servicio del ocio, del lujo, la voluptuosidad o el epicureísmo. Ello significa que, sin haber querido poseer un fin altamente, moral, práctico y positivo, la escuela del arte por el arte adquirirá otro totalmente irracional, quimérico e inmoral. [Proudhon, 1865: 166]
\end{abstract}

Si se analiza el debate en el seno mismo de la esfera literaria $^{3}$, se encuentra que las tesis sobresalientes tienen un común punto de partida hacia mediados del siglo XIX -ya se ha visto la importancia de este momento histórico en el advenimiento de la modernidad estética. Es aceptado que en 1848 tiene lugar una profunda crisis del orden burgués cuya consecuencia es lo que se ha dado en llamar la aparición de la conciencia desdichada del escritor: el hombre de letras que había puesto su oficio al servicio de la omnicomprensión del mundo burgués rompe con los valores sustentados por la nueva clase en el poder ${ }^{4}$. La entidad del arte y la situación del artista en el

\footnotetext{
${ }^{3}$ No dejo de advertir que la reconsideración de toda una producción literaria que había permanecido fuera del foco de los investigadores -literatura popular, novela proletaria, folletínintroduce problemas interesantes para la cuestión que se. Aunque forman parte de un corpus y de una categoría literaria que no han sido incluidos en esta investigación, deberé hacer alusión a esta práctica a la hora de referir las hipótesis existentes sobre la difusión de la literatura con función social.

${ }^{4}$ Los hechos que alrededor de 1850 desembocan en una nueva burguesía, según Roland Barhes, resultan de la conjunción de tres importantes cambios geo-políticos: la violenta modificación de la demografía europea; la sustitución de la industria textil por la metalúrgica, es
} 
mundo industrial será objeto de constantes replanteamientos, e identificará una época de ambigüedades y vacilaciones.

\begin{abstract}
Hasta ese entonces la ideología burguesa daba la medida de lo universal, lo llenaba sin discusión; el escritor burgués, único juez de la desgracia de los otros hombres, al no tener frente a sí ningún otro a quien mirar, no se encontraba desgarrado entre su condición social y su vocación intelectual. Barthes: 1967, 66]
\end{abstract}

Para algunos críticos, la crisis resultante del desgarramiento de la conciencia burguesa es el común origen de dos rumbos estéticos que marcan una posición diferente en la manera de entender la relación del artista con la sociedad: el esteticismo y el naturalismo. Hacia 1850 comienza a surgir la idea del escritor-artesano, recluido en su taller, solitario e incansable forjador de palabras: la forma se constituye en un valor, resultado de un esfuerzo, que reemplaza la idea del artista inspirado por el genio. Sin embargo, el deslumbramiento aristocrático por el preciosismo del lenguaje entrará en crisis cuando se vuelva evidente que se produce una fractura entre la vocación social y la vocación artesanal del escritor, cuyo representante paradigmático es Flaubert.

El caso Dreyfus en Francia favorece la aparición de la figura del intelectual junto a la de la palabra que lo designa: aquel artista o pensador que se caracterizará por su actitud crítica e independiente con respecto al orden sociopolítico establecido. Según la acreditada tesis de Pierre Bourdieu, Zola contrarresta -no de forma voluntaria- el creciente descrédito y la sospecha de vulgaridad que le ocasionaban el éxito de público cuando, al exponerse públicamente en 1893 con su célebre J'accuse, establece las bases para transformar la independencia del escritor en una opción deliberada y legítima de intervención en la vida política.

\footnotetext{
Para ello, tenía que producir una figura nueva, la del intelectual, inventando para el artista una misión de subversión profética, inseparablemente intelectual y política, propia para hacer que apareciera como un propósito estético, ético y político idóneo para
}

decir el nacimiento del capitalismo moderno; la secesión (comenzada en las jornadas de junio de 1948) de la sociedad francesa en tres clases enemigas, es decir, la ruina definitiva de las ilusiones del liberalismo. [Barthes: 1967, 55]. V. Además la nota 7 del cap. 1. 
agrupar a unos partidarios militantes, todo lo que sus adversarios describían como el efecto de un gusto vulgar o depravado. [Bourdieu: 1995, 197]

El célebre sociólogo francés otorga al gesto de Zola un valor fundante, el de la culminación del proceso de autonomía literaria, pues con la figura del intelectual, el autor de Germinal logra trasladar al campo político las reglas no escritas del campo intelectual, cuya particularidad consiste en reivindicar lo universal.

\begin{abstract}
Así, paradójicamente, la autonomía del campo intelectual es lo que posibilita el acto inaugural de un escritor que, en el nombre de las normas propias del campo literario, interviene en el campo político, constituyéndose así en intelectual. [Bourdieu: 1995, 197]
\end{abstract}

Se trata en suma de una fractura profética por la cual el escritor rompe con el orden establecido, afirma los valores independientes de la verdad y la justicia frente a toda razón de estado y se asume custodio de los mismos con respecto a las leyes de la política o la economía. Las intervenciones del intelectual en el campo de la política se harán por tanto en nombre de la autonomía y de la independencia que el campo cultural ha alcanzado respecto de los demás ámbitos sociales. De esta manera, según Bourdieu, el intelectual se diferencia del escritor del siglo XVII, separado de los debates de la política y la sociología y destinado a la diversión; se diferencia asimismo del legislador que aspira a ejercer su influencia espiritual aconsejando al príncipe -del cual es ejemplo sobresaliente J.J. Rousseau- y se diferencia de los que después de cambiar un estatuto, a menudo de segundo orden, en el campo intelectual por el del hombre de acción, denuncian el idealismo de los intelectuales para justificar la negación de las reglas del campo del arte.

El intelectual entonces afirmará en su propio mundo los valores de libertad, independencia, justicia, para garantizar que no claudicará en pos del poder temporal ni de los imperativos de la política; se establece en "el defensor de unos principios universales que no son más que el producto de la universalización de los principios específicos de su propio universo". [Bourdieu: 1995, 198] 
Es importante para la tesis de Bourdieu recordar que la aparición del intelectual se vio acompañada por una creciente diferenciación y autonomía del cuerpo de los profesionales de la política, que hasta 1848 se había mantenido indiferenciado -incluso aliado con el de los escritores. A partir de entonces son frecuentes las diatribas de los hombres de letras contra los hombres de la política o, en algunos casos, como en el de Flaubert, en el silencio y la reclusión. Entre los factores que acentúan este proceso se encuentra el reto de los partidarios del arte social, que postulaban la introducción de los debates políticos en el seno del campo intelectual. Para la tesis de Bourdieu es fundamental recordar que la imagen más acuñada de escritor comprometido y ejemplar, encarnada por Zola, ignora casi siempre que el padre del naturalismo intervino en el campo político pero con las armas de su propio campo, el intelectual, las mismas que habían construido los artistas puros y que el propio autor de Germinal utilizaba tanto para defender a Manet de los ataques de la academia como para atacar a Proudhon y sus propuestas moralizantes de la pintura.

Por los mismos años, el término y la preocupación del escritor por intervenir en la vida pública aparecen en España. Los hechos considerados desencadenantes varían según los diferentes especialistas; lo cierto es que se constatan fenómenos cuya vinculación interesa desentrañar en las siguientes páginas: presencia y manifestaciones de las vanguardias históricas, mayor protagonismo de las vanguardias políticas, preocupación del escritor por su papel en la vida pública.

Por el momento, es posible dilucidar dos entradas para estudiar el tema en España; una se vincula con la aparición del intelectual y, por lo tanto, con la creciente preocupación del hombre de letras por los acontecimientos de la esfera pública5. Según la conocida tesis de Inman Fox, el intelectual como ${ }^{5}$ Se verá más adelante que la aparición del intelectual tiene para algunos críticos el costado
negativo de la consolidación de un grupo o casta que se aleja del pueblo con la convicción de
pertenecer a una clase selecta y superior con la misión de conducir a la masa y sacarla de su
ignorancia. [V. Tomás, 1998 y 2000]. Francisco Caudet también a la clase intelectual,
coincidente en gran parte con el Modernismo. La coincidencia del centenario la llamada
Generación del 98 con el de la publicación de La barraca fue ocasión de un nuevo foco de
indagación y debate: "... en mayo de 1905 España era, políticamente, un erial y, literariamente,
poco había que esperar de los autores de la generación del 98, envejecidos y salvo contadas
excepciones, Galdós de manera señera, poco nuevo tenían que decir; en cuanto a la
generación del 98, que años atrás había tenido brotes de rebeldía, ya esta recogiendo amarras,
56 
concepto referido a los miembros de una clase, casi siempre en abierta oposición al orden establecido, aparece a finales del siglo XIX, en directa relación con el caso Dreyfus respondiendo a una realidad local con numerosas coincidencias con las conmociones de la sociedad francesa, ya que a finales de 1897 tiene lugar un pedido de revisión de los procesos de los condenados de Montjuic 6 .

\begin{abstract}
... los problemas de los últimos años de la Restauración en España producirían reacciones muy semejantes en los ambientes intelectuales: la falta de confianza en el sistema parlamentario, un sentido crítico frente al poder de los militares, y una actitud anticlerical, etc. Es decir, la ineficacia del gobierno y de la sociedad corrompida por los intereses creados de la burguesía en la administración de la justicia y social [sic] hacía que los intelectuales fueran tomando conciencia de una misión especial en la "regeneración" de su país. [Inman Fox, 1988:18]
\end{abstract}

Fulgencio Castañar proporciona otra hipótesis acerca del comienzo de la preocupación del escritor por tomar partido e intervenir con sus propias armas intelectuales en la vida pública. Coincidiendo con la línea teórica ya reseñada, que considera la función social del arte como resultado de un proceso dialéctico paralelo a la consecución de la autonomía, remonta al Romanticismo los orígenes de las estéticas asumidas por la literatura comprometida y señala que no es posible indicar la procedencia exacta. Las ideas que emergen con fuerza en la segunda década del siglo $X X$ y finalmente se imponen, provenían del pasado: en la centuria anterior se torna visible la tensión entre los partidarios de la autonomía artística y quienes defienden la conexión entre literatura y sociedad.

Las distintas posturas estéticas dependen de un entramado de causas, en las que la posición político-ideológica es una más entre varias. Así puede

ya estaba buscando refugio -Antonio Machado fue una notable excepción- en los predios del egotismo. Blasco Ibáñez parecía estar remando contra corriente. En medio de ese panorama su figura se agiganta". [Caudet, 1998, 77]. V. además Oleza, Joan y Lluch, Javier, 2000.

${ }^{6}$ El "proceso de Montjuic" sentó a 305 hombres en el banquillo de los acusados a raíz de tres atentados anarquistas producidos entre 1893 y 1896 dentro del plan "propaganda por el hecho". El proceso tuvo gran repercusión internacional y fue seriamente criticado por la prensa extranjera debido a las graves irregularidades cometidas. Cinco hombres fueron ajusticiados en los fosos del castillo de Montjuic. Se considera que el atentado que costó la vida a Cánovas del Castillo el 8 de agosto de 1897 (...) fue la venganza por las ejecuciones de Montjuic en la mano del anarquista Michele Angelillo. 
encontrarse que la coincidencia política se disuelve en ocasiones frente al proyecto literario, pues había quienes sostenían que era preciso proyectar la búsqueda de reformas o revolución social en la novela, narrando y describiendo los distintos estados de miseria y degradación social, y quienes, a pesar de apoyar también las transformaciones del sistema social, consideraban que el arte se degradaba si se alejaba de la belleza y la transmisión de valores morales positivos.

En el itinerario del arte hacia fórmulas de mayor compromiso con la realidad social inmediata y con propuestas de cambios tendientes a un orden más justo, tienen especial incidencia las prédicas de Fourier y Saint-Simon.

\subsection{El CONCEPTO de COMPROMISO A PARTIR de LAS VANGUARDIAS. EL dEBATE LUKÁcs -}

\section{Adorno}

A partir de los movimientos históricos de vanguardia tanto la intención de la vanguardia como la característica de las obras -que he llamado el momento del significante- llevaron a un replanteamiento del concepto de compromiso, cuyo núcleo de mayor proyección teórica fue el célebre debate Lukács Adorno, cuyos conceptos principales se condensan en Historia y conciencia de clase y en Teoría estética respectivamente.

Según Bürger, el eje del debate lo constituyeron las características de las obras; no se ocuparon del aspecto institucional, de la crítica de las vanguardias a la institución arte. Como hemos visto, tanto Lukács como Adorno tuvieron en cuenta los aspectos formales -carácter inorgánico- de la obra de vanguardia, pero con valoraciones opuestas. Ambos coinciden en hacer una evaluación acerca de las obras orgánicas e inorgánicas.

Para Adorno la vanguardia es el modelo a seguir y la obra orgánica la instancia que debe ser superada si se busca un cuestionamiento a la sociedad del capitalismo. Condena la obra orgánica porque aun cuando el contenido explícito sea contestatario, siempre tiende a ser conciliatoria, y el arte sólo tiene sentido en cuanto niega el mundo administrado. Las vanguardias tienen el mérito de combatir la reificación de los objetos propia del sistema capitalista. 
El autor de la Teoría estética sostiene que la obra vanguardista es la única expresión auténtica de la situación actual del mundo; es la expresión históricamente necesaria de la alienación en una sociedad capitalista avanzada que se evidencia firmemente establecida, al mismo tiempo que han desaparecido las esperanzas en una alternativa socialista. En este contexto, las vanguardias representan una protesta radical opuesta a cualquier forma de conciliación posible. Sostiene, igualmente, que en la forma reside el contenido social de la obra. La forma es significativa, transmite, oculta, o da luz a lo que ocurre en la sociedad. Considera erróneo, desde la perspectiva artística, relacionar compromiso con inmediatez. El filósofo alemán relaciona compromiso con distancia social. La fidelidad fotográfica sólo reproduce lo ideológico, por esto el arte sería un agente de la sociedad capitalista y el realismo socialista representaría un sostén del sistema tanto como la industria cultural. Para superar esta contradicción propone una tensión entre distancia e inmediatez, una nueva relación con lo social, que permita que la referencia a lo social no termine solamente en el planteo de los estados sociales defectuosos. El arte comprometido - para ser crítico- debe buscar la modificación de la situación que genera los defectos. El extrañamiento, la exigencia, la dificultad, son atributos de la obra de arte que favorecen una relación no automática con la realidad. Propone Adorno que no haya manera de reconciliar la obra con la sociedad, y desde este punto de vista, cree que la forma orgánica es una evaluación positiva del contenido. En cambio, la obra de arte vanguardista, a partir de su principio estructural inorgánico, es emancipadora porque pone de manifiesto una ideología que está vinculada al sistema.

El riesgo de una idea de compromiso afirmada exclusivamente en la forma es convertir en tabú las afirmaciones políticas en la obra de vanguardia. La labor del artista debe convertir la actitud polémica en fuerza productiva estética. El trabajo revolucionario del artista se equipara así al trabajo social. La manera de tomar contacto con la realidad no debe hacerse a través de una estética realista ni bajo el imperativo del compromiso, que es una forma de control. Propone una nueva forma de relacionar el arte con la realidad en la que el mundo cotidiano tienda a ser desenmascarado, como apariencia e ilusión 
falsa. Epifanía, corrimiento del velo, un relámpago en la tormenta, iluminación profana, son algunos de los tropos usados por Adorno para sintetizar esta propuesta. Para que la iluminación tenga lugar es necesario una transformación de lo empírico: el arte en la sociedad capitalista, cuando supera la realidad empírica concreta la referencia, porque va a lo esencial de lo social. Desde su condición de irracional el arte critica la irracionalidad del mundo. Para Adorno la verdad es que sólo es verdadero lo que no se acomoda a este mundo. [Adorno, 1983, 1984].

El pensamiento de Lukács llega a conclusiones absolutamente contrarias. El autor de Historia y conciencia de clase considera al arte de vanguardia como la culminación de una decadencia que se inició en el año clave de 1848, cuando la burguesía perdió la capacidad de representar la sociedad burguesa como una totalidad. De su tesis se desprende una cronología que incluye en la modernidad estética tanto las escuelas finiseculares como las vanguardias históricas, pues trata como partes de un mismo fenómeno el impresionismo, el expresionismo y el surrealismo. Desde la perspectiva de Lukács quizás el juicio más singular sea su evaluación del naturalismo, al que considera un movimiento desarraigado del realismo y anticipación del proceso del abandono por parte del artista del papel crítico e indagador de la realidad.

El arte vanguardista no sólo es signo de la alienación en la sociedad capitalista sino también de la incapacidad de los artistas burgueses de reconocer las verdaderas fuerzas históricas que trabajan por transformar la sociedad. Considera que la protesta de la vanguardia es abstracta, carente de perspectiva histórica y ciega para reconocer las fuerzas que luchan contra el capitalismo. Aunque el autor de Sociología de la literatura no utiliza la palabra compromiso ni trabaja especialmente sobre ese concepto -prefiere referirse a los escritores y las tendencias literarias que representan el progreso- su defensa de la novela realista como llave estética que permite poner al descubierto los vicios y carencias de la sociedad capitalista, encierra una teoría del arte con función social y le permite a su vez proponer un arte realista en el presente. La crítica de Lukács a la vanguardia no reside en negar la realidad fragmentada y desgarrada de la cual el montaje y la pérdida de organicidad 
serían un síntoma, ni en desconocer la calidad de la producción artística, ni, aún más, el sincero cuestionamiento al orden capitalista que impulsa a los artistas; el punto crítico se sitúa en que estos no van más allá de la realidad tal como se presenta, y toman la superficie -el desgarro y la desintegración del todo- como la realidad, olvidando que la dispersión de las partes en el fondo mantiene una unidad, que es la unidad de lo diverso. La independización de los elementos traduce el momento de la crisis del sistema, pero representan los elementos objetivos fundamentales de la totalidad de la coherencia social en el capitalismo. Lukács no cuestiona el arte de vanguardia por la dificultad de recepción que supone la obra inorgánica, pero subraya su pobreza de contenido:

\footnotetext{
Como consecuencia de una actitud ajena o inclusive hostil frente a la realidad se produce en el arte de "vanguardia" en grado creciente una pobreza de contenido cada vez mayor, que en el curso de la evolución llega a una carencia fundamental de contenido, y lo que es más, a la hostilidad respecto del contenido. [Lukács: 1938, 301]
}

Frente a la actitud del artista de vanguardia, que se contenta con la percepción individual y subjetiva de la realidad, el gran escritor realista -desde Cervantes hasta el presente- irá al fondo de las causas que motivan ese aparente estado de cosas fragmentario y caótico. En todo realismo auténtico e importante se puede constatar una búsqueda de las relaciones de los individuos entre sí, de las situaciones en que los individuos actúan, una captación variada y rica de la realidad como reflejo de sus corrientes ocultas bajo la superficie. El gran escritor realista podrá de esta manera anticipar, a través de "tipos", las tendencias sociales que se concretarán en el futuro, porque es capaz de captar lo subterráneo e invisible aún para el resto de los hombres. Si el escritor ha captado acertadamente las tendencias evolutivas de la sociedad y las funciones sociales de determinados tipos de individuos, únicamente lo podrá determinar el tiempo.

En la asociación de proyección futura y lucidez anticipatoria se sustenta el concepto de vanguardia ideológica y de misión del artista de Lukács: vanguardia es la capacidad de percibir y representar las tendencias vivas, pero 
ocultas todavía, de la evolución de la sociedad, pues "captar y plasmar tales corrientes subterráneas constituye la gran misión histórica de la verdadera vanguardia de la literatura", que sólo pueden llevar a cabo los grandes escritores realistas. No basta sentirse subjetivamente vanguardista ni realizar innovaciones técnicas, la verdadera vanguardia reside en los contenidos sociales y humanos, en la amplitud, la profundidad y la verdad de aquello que el artista anticipa. La alianza de escritor y profeta es sumamente relevante en el teórico húngaro. [Lukács:1938: 307]

Adorno en cambio cree que la renuncia a los niveles alcanzados por la técnica artística implica una voluntad sospechosa de ideología, pues la obra orgánica cae por su forma en la ilusión de un mundo perfecto. Esta apreciación coincide, en parte, con la opinión de Roland Barthes, para quien los grandes relatos del siglo XIX narrados en tercera persona y en pretérito indefinido realizan una abstracción de la multiplicidad de tiempos vividos y superpuestos. Liberada de las raíces existenciales de la experiencia, la novela realista se orienta hacia una relación lógica con otras acciones, con otros procesos, para mantener así una jerarquía en el imperio de los hechos. La realidad se presenta así transparente, familiar, reconocible. El mundo constituye una red de relaciones coherentes y seguras, aun cuando sean patéticas. Hasta el más trágico cuadro retratado en una novela realista lleva tranquilidad al lector porque el mundo aparece cerrado y definitivo [Barthes: 1967].

Para Bürger, los análisis de Lukács y Adorno adolecen de la misma perspectiva parcial: no tuvieron en cuenta el ataque de las vanguardias a la institución arte, ignorando por lo tanto el papel de la institución en el efecto de una obra, esto es, la carencia de todo efecto en el arte, de lo que resulta que ninguna obra nueva puede reclamar, en exclusiva, validez eterna o temporal. Adorno, por su parte, no deja de ser normativo porque convierte a la vanguardia en un modelo "y se impone de un modo no menos severo que en el caso de Lukács". [Bürger, 1974: 155]

Pese a que el fracaso de las vanguardias en su intento de destruir la institución artística las convirtió en un movimiento estético más, consiguieron acabar con la posibilidad de que una tendencia artística pueda pretender 
validez general; una de cuyas pruebas más evidentes es la actual simultaneidad del arte realista y vanguardista. Perdida así la idea de considerar relevantes las normas estéticas, el interés de la investigación científica giró de las consideraciones normativas hacia la función, esto es, investigar el efecto social en el encuentro de los estímulos presentes en la obra con un público sociológicamente definible dentro de un determinado marco institucional, la institución arte.

La desatención a la institución llevó a los dos pensadores enfrentados a tesis opuestas en la formulación de sus teorías materialistas de la cultura, pero fue la causa de la común incomprensión de la dramaturgia de Bertold Brecht, cuyo teatro representa el intento más acabado de conciliar posiciones desde el credo vanguardista. Brecht propuso una forma de compromiso que estaba tan lejos de Lukács como de Adorno. Su teatro comparte con las vanguardias el carácter inorgánico de las obras, en las cuales el argumento es discontinuo, el todo consta de partes independientes que deben y pueden compararse con las partes correspondientes de la realidad. Pero se distancia de las vanguardias en que Brecht pretendió modificar la institución arte, pero no destruirla.

Bürger cree que sólo se puede sortear este punto sin salida entendiendo la vanguardia histórica como un momento de flexión del arte en la sociedad burguesa. A partir de esta hipótesis, y después de analizar la obra de Brecht, afirma el autor de Teoría de la vanguardia que el compromiso político en el arte debe pensarse desde el ataque a la institución arte y de la inorganicidad de la obra. El artista de vanguardia también tuvo en cuenta el compromiso político y moral, pero la relación del compromiso con la obra está llena de tensiones. En la obra orgánica, el compromiso debe ser el principio unificador de la obra, incluso en su aspecto formal, de lo contrario destruye la esencia; cuando la obra consigue organizarse en torno al compromiso, el peligro es que sea neutralizada por la institución arte y que se perciba como un simple producto artístico.

Por el contrario, la vanguardia demostró que el efecto social de una obra está determinado de modo decisivo por la institución en la cual funciona. De la misma manera, la estructura inorgánica cambia el problema del compromiso. Al 
no estar la parte sometida a un todo, los contenidos políticos tienen una independencia estéticamente legítima, su efecto no resulta de la totalidad de la obra sino de un aspecto parcial. Así el motivo político puede actuar independientemente, y hasta permite superar la dicotomía arte puro, arte político, pues al admitir que motivos políticos y no políticos pueden ir juntos en una misma obra, hace posible un nuevo tipo de arte comprometido. De esta manera, gracias a la independencia de los motivos políticos, el receptor puede descontextualizarlos, confrontándolos con su propia realidad vital, como sucede en el teatro de Brecht. El argumento no es continuo, cada parte puede compararse con los hechos correspondientes de la realidad. Sin pretender destruir la institución arte, el dramaturgo alemán demuestra que el arte pude ponerse en contacto con la realidad.

La posibilidad de explicar el principio estructural vanguardista de lo inorgánico, permitió a Bürger pensar una propuesta superadora sobre los motivos políticos y no políticos de las obras. Ni Lukács ni Adorno tuvieron en cuenta el ataque de las vanguardias dirigido a la institución arte, lo que los llevó a atacar, por diferentes razones, la obra de Brecht. Ambos pensadores coincidieron además en trazar una línea divisoria tajante entre vanguardia artística y vanguardia política.

En la actualidad la idea de Bürger según la cual tanto la controversia de Lukács y Adorno "ha pasado a la historia" [: 1974: 168] tiene una aceptación generalizada. Sin embargo, perduran muchos de los penetrantes análisis de los dos grandes pensadores así como las resonancias de su célebre polémica parecen subsistir en los acercamientos presentes a los problemas por ellos planteados: improntas lukasianas o adornianas emergen, revisadas, en las querellas contemporáneas y a menudo, de forma no declarada, alimentan los discursos críticos contemporáneos.

\subsubsection{Benjamin ante el teatro brechtiano}

En la línea del pensamiento que lo caracteriza, reacio a las polaridades o tesis excluyentes Walter Benjamin intentó integrar la vanguardia y el 
compromiso y sortear la dicotomía insalvable entre las dos posiciones antes reseñadas. Sus fecundas reflexiones, ajenas a un sistema estructurado y orgánico (no en vano Adorno lo instaba a ajustarse a "la implacable, excelente teoría especulativa") son citas obligadas en una exploración sobre la función del arte.

El más joven pensador de la Escuela de Frankfurt se mostró muy favorable al intento de Bertolt Brecht por hallar un módulo estético que conciliara vanguardia y función social. Coincidió con su compatriota en creer que es posible una fórmula intermedia que armonice el compromiso -la "tendencia correcta"- con la calidad literaria. La tendencia política incluye necesariamente una tendencia literaria correcta; la tendencia literaria, contenida en cada tendencia política "correcta" constituye la calidad de la obra. Al analizar el teatro de Brecht, Benjamin busca demostrar que la figura del autor clásico debe transformarse en un "productor", que incorporando a su quehacer los nuevos métodos de reproducción técnica, se replantee las ideas consagradas sobre formas o géneros. El artista debe convertirse en un activo interventor que busque la transformación de las estructuras sociales; el lugar del intelectual en la lucha de clases sólo podrá fijarse sobre la base de su posición en el proceso de producción. Brecht es el ejemplo de la forma en que el concepto de transformación funcional se destina a modificar formas e instrumentos de producción. Frente a la idea de renovación espiritual que proclaman los fascistas, Benjamin está a favor de la renovación de las técnicas.

El artista debe comprometerse con su trabajo de manera que pueda instruir a otros productores y poner a su disposición un aparato mejorado. Un aparato de producción será tanto mejor cuanto más capaz sea de convertir a los espectadores o lectores en colaboradores. El teatro épico de Brecht representa el intento más logrado de alcanzar esa meta a través de sus conocidos recursos del montaje, la risa, el extrañamiento, la enajenación del espectador de las situaciones que vive hasta llevarlo a la reflexión sobre su situación en el proceso de producción. Frente a la tramoya costosa, los efectos refinados y la escenográfica fastuosa, que sólo resultan una fórmula en contra de los auténticos productores, Brecht no intentará reproducir esos medios sino 
rescatar lo más primitivo de la escena: el podio, el drama una acción sencilla que permita exponer situaciones. El fin último es la modificación de la interdependencia funcional de la escena y el público, texto y puesta en escena, director y público; los postulados sobre el receptor activo de la vanguardia quedan a la vista.

El teatro épico no aspira a colmar al público con sentimientos (aunque sean los de la rebelión) sino a enajenarlo de las situaciones que vive, y para lograrlo, no hay mejor instrumento que la risa. La carcajada es el momento más alto de su modelo dramático. [Benjamin, 1991].

Las innovaciones brechtianas no fueron comprendidas ni por Lukács ni por Adorno. El primero las condenó por su vanguardismo, el segundo porque no perseguían la destrucción de la institución arte.

\subsubsection{LA REHABILITACIÓN DE LA RELACIÓN ARTE - VIDA}

Hasta aquí he resumido brevemente el giro de ciento ochenta grados que la noción de compromiso sufrió después de las vanguardias. La revisión y superación representadas por Bretch, Benjamin y el mismo Bürger parecen haber encontrado una solución a las contradicciones y encerronas en que el magisterio de la forma y la polarización de las posturas de Lukács y Adorno habían dejado al debate estético. Pero estas respuestas no dejan de estar situadas en la misma línea unidireccional de la comprensión de la modernidad estética: existe un preconcepto por el cual las especulaciones sobre la literatura y el arte se legitiman si están encuadradas en el concepto de arte moderno según se entiende desde Flaubert y Baudelaire hasta las vanguardias. La aceptación de este postulado provoca que Bürger afirme que los argumentos de Lukács y Adorno sólo se afianzan en las características de las obras, con lo cual el autor de la Teoría de la vanguardia desatiende la fundamental preocupación de Lukács por el contenido social y humano de la novela, aspecto que ha vuelto a tomarse en cuenta en las perspectivas más recientes, pero que nunca estuvo ausente de las críticas coetáneas a las propias vanguardias históricas. 
Hoy, a la luz de las indagaciones sobre la literatura y el arte posmoderno $^{7}$, el problema ha encontrado otras respuestas partiendo de un cuestionamiento central a la idea de modernidad estética predominante hasta mediados del siglo XX por lo menos. Los trabajos de Joan Oleza Simó iluminan los problemas planteados por la contraposición autonomía del arte-compromiso desde un concepto de modernidad estética no restringido a los movimientos inscriptos en el orbe del modernismo - simbolismo - vanguardia. Sostiene Oleza que contrariamente a la idea más establecida, la sensibilidad estética moderna nace bifronte, pues al mismo tiempo que el Romanticismo y los hermanos Schlegel proclamaban la autonomía del arte respecto de la realidad y el presente, Víctor Hugo, Stendhal y Balzac reivindicaban el derecho del arte a explorar y descifrar lo real. El debate de principios del siglo XX entre tradición y vanguardia no sería más que un nuevo episodio de la gran controversia que cifra todo el arte moderno: ¿qué hacer, en poesía, con la realidad?, ¿qué hacer, en la realidad, con la poesía?, ¿qué hacer en la realidad y la poesía, con la historia y la ficción?

Asimismo, es errónea la idea de que el modelo realista constituía el lado conservador del binomio tradición-experimentación. Las grandes novelas realistas, afirma Oleza, nacieron con voluntad de vanguardia y así lo demuestran los anatemas que el realismo romántico y luego el objetivo o el naturalista recibieron desde la academia. Una concepción idealista, que creía en los valores esenciales y perennes del arte, sirvió a los críticos del siglo XIX para descalificar a los hoy más canónicos narradores realistas.

El dilema sería entonces la relación entre arte y vida cotidiana y entre ética y estética, que pone en tela de juicio la autosuficiencia del universo estético respecto de los otros universos de cultura. [Oleza, 1996, 39]. Me interesa destacar que al añadir 'cotidiana' a la palabra 'vida', el profesor de la Universidad de Valencia evita el equívoco y el amplio alcance del vocablo

\footnotetext{
${ }^{7}$ No ignoro los riesgos metodológicos que implica introducir en esta tesis el problema del arte posmoderno, de tan complejo y vasto alcance, pero las nuevas consideraciones acerca del realismo conducen a una distinta concepción y evaluación de la literatura con función social sumamente sugerentes para mi estudio.
} 
'realidad' utilizada con frecuencia, así como los nuevos problemas que la palabra 'vida', sin determinante, abriría.

Desde este punto de vista, se puede afirmar que existe una modernidad estética menos conocida encarnada en los novelistas que cultivaron las diversas formas de realismo del siglo XIX. A partir de la crisis de la cosmovisión burguesa de 1848 dichos escritores comienzan a separase de la clase dominante mediante un proceso en el cual convergerán pocos años las clases medias y el proletariado al mundo de las letras. El proyecto creador pasa del cuestionamiento al poder a la búsqueda de fórmulas que permitan utilizar la literatura como una herramienta de cambio. De esta manera, el modelo realista-naturalista dejará de ser un instrumento de análisis cuasi científico para convertirse en un instrumento de transformación social, sentando las bases del futuro realismo social. Entre las obras y escritores que Oleza considera pioneros de esta estética, se encuentran el último Zola, Máximo Gorki, Vicente Blasco Ibáñez, Manuel Ciges Aparicio, el Felipe Trigo de El médico rural y Jarrapellejos, el Baroja de La busca y Aurora roja entre otros. [Oleza Simó:1999, 95-111].

La tesis de Oleza adquiere gran relevancia en este trabajo porque permite entrar en el problema del compromiso y del arte con función social sin el estigma que acompaña a las estéticas de cuño realista y establece una filiación que recupera para la modernidad estética los movimientos que las teorías de matriz formalista habían desechado:

\footnotetext{
¿Es que sólo es moderna la tradición que arranca del Romanticismo alemán, pasa por Baudelaire y Mallarmé, se expande a través del modernismo internacional, culmina en las vanguardias, y se reitera sin fin en las neovanguardias? ¿Hay que considerar entonces a la llustración, al Romanticismo socializante, al Realismo y al Naturalismo, las Vanguardias del compromiso revolucionario, al Existencialismo, al Realismo social o la Neorrealismo de la segunda posguerra, al realismo crítico de los años 50 y al realismo de la experiencia de los 80 como manifestaciones escleróticas de una Antiguo Régimen estético? ¿Es todo lo que convoca al encuentro entre arte y vida, a la implicación de escritores y lectores en al práctica social, un anacronismo? ¿O esa idea es sólo el resultado de una concepción de la Modernidad unilateral, y a menudo conservadora, que se afirma desde los hermanos Schlegel hasta el deconstruccionismo norteamericano, pasando por Theodor W. Adorno o por R. Barthes? Cada uno de ustedes debe optar por una respuesta,
} 
porque ése es el dilema estético de base desde los románticos hasta hoy mismo: ¿qué papel ha de jugar la vida social en el arte?, ¿cuál ha de jugar el arte en la vida social?. [Oleza Simó: 1999]

La tesis de Oleza tiene la doble virtud de integrar el problema en las reflexiones teóricas en torno a la modernidad y de desacralizar la vanguardia, poniéndola a la misma altura de otras experiencias estéticas de la modernidad.

La separación de arte y vida es uno de los puntos débiles de la vanguardia, uno de los flancos por donde arreciarán los cargos y se abrirán camino las propuestas estéticas que recuperan el realismo.

Proporciona de esta manera, a la luz de las teorías más recientes, un encuadre que es a la vez histórico y estético

Resulta esclarecedor y útil para avanzar en la indagación compatibilizar las concepciones de fuerte impronta teórica, como es la de Peter Bürger, con la idea de compromiso tal como se entiende desde una perspectiva más ética que estética, enfocada especialmente en la relación del escritor con las circunstancias político - sociales de su época y en la influencia que ejercen en su obra.

En esta segunda línea de pensamiento, Fulgencio Castañar establece un criterio que debe tenerse en cuenta. Aunque su estudio está dedicado a la novela comprometida española anterior a la guerra civil de 1936-1939, la concepción es válida para los restantes géneros. Castañar entiende por compromiso los rasgos específicos que emanan de la actitud del autor frente a la sociedad de su tiempo y del valor que le asigna a la obra artística como medio para transformar la realidad histórica. Es asimismo expresión de la actitud del escritor ante las condiciones en que viven determinados sectores sociales.

El escritor, hombre de su tiempo, espectador de las duras condiciones en que viven distintos grupos sociales, tras sentirlo profundamente reacciona y trata de que se modifiquen las situaciones injustas por los medios que tiene a su alcance, entre otros, la ficción novelesca.

Las circunstancias mandan y muchos escritores se comprometen ante el grave estado de cosas; para ellos la abstención es imposible; hay que definirse; el alejarse de la realidad conflictiva 
para seguir con la pureza artística lo ven -en un análisis de hondas raíces marxistas- como un "vasallaje a la burguesía". La razón que esgrimen es que la obra del escritor, aunque sea por omisión, tiene una relación directa con los factores que inciden en la vida de la sociedad. [Castañar: 1992: 62]

El crítico español considera el compromiso como una exigencia histórica asumida por gentes de distinta orientación ideológica inmersas en una tendencia general del arte de su tiempo, que llegó a afectar a todos los géneros literarios y las modalidades artísticas, haciéndose visible tanto en España como en Europa. El compromiso es por tanto el resultado de una actitud personal provocada por las circunstancias históricas en que se encuentra el país y ante las que el artista cree que tiene el deber insoslayable de incidir a través de su obra.

\subsection{Artistas, escritores, intelectuales, hombres de letras}

La preocupación por el papel del hombre de letras en la sociedad abre un abanico de reflexiones que se tocan con las planteadas hasta aquí, pero siguiendo caminos ajenos a los derivados de ambas modernidades. La mayor parte de los pensadores que se tratarán a continuación no desconocen que el concepto del compromiso adquiere un peso singular en el siglo $\mathrm{XX}$, coincidiendo con la autonomía del campo, en palabras de Bourdieu; sin embargo, consideran que el problema puede rastrearse en el pasado, bajo otras designaciones y apariencias.

Se puede verificar igualmente que la meditación sobre el compromiso aparece asociada en casi todos los casos con la idea de intelectual, y de manera semejante a lo que ocurre con el compromiso, los autores no restringen el concepto a la aparición de la figura clásica, a fines del XIX en Francia, sino que analizan las diferentes formas que el intelectual adquirió a lo largo de la historia.

Como se ha anticipado en distintos momentos de este estudio, desde una perspectiva que parta de los procesos modernizadores en Occidente, la figura del artista, luego intelectual, que se ve obligado a optar por el arte puro y 
el silencio ante la realidad política y social inmediata, o la intervención en los asuntos públicos, comienza a mediados del siglo XIX y alcanza su plena evidencia con la intervención de Émile Zola en el caso Dreyfus. Según Bourdieu, el novelista francés instaura la figura del intelectual que se compromete con su tiempo a partir de las premisas y códigos de la autonomía artística, enfrentándose a otras formas de participación, entre ellas, la del hombre de acción, partidario de una intervención más atada a las leyes de la política que a las del campo intelectual.

El triunfo de la modalidad de actuación pública establecida por Zola no es definitivo y sufre un duro revés en las primeras décadas del siglo $X X$, culminando en los años treinta, los años de la II República española y de la guerra civil.

Después de la revolución bolchevique de 1917, las tendencias dispersas tendientes a cultivar un arte social adquieren mayor organicidad. Dos años después, la aparición de la revista Clarté, fundada por Henri Barbusse, corrobora con su epígrafe "Liga de solidaridad intelectual para el triunfo de la causa internacional" que escritores y artistas debatían sobre su papel en el escenario convulso que se dibujaba en los países occidentales ${ }^{8}$. La creciente alteración del ámbito artístico y literario con los acontecimientos sociales y políticos traerá aparejado un paulatino rechazo de las reglas del campo intelectual, reemplazadas por las del ámbito político [Rico, 1984, 619]. El escritor además de verse impelido a tomar posición -a abandonar los postulados del arte puro y a asumir el papel del intelectual- ve insuficiente su participación desde los presupuestos autónomos del campo, y en mayor o menor medida se identificará con partidos, ideologías o movimientos. El debate fue arduo y adquirió en aquellos años tintes que hoy deben ser analizados con especial rigor.

\footnotetext{
${ }^{8}$ Es oportuno recordar que Lukács incluye a Barbuse entre los escritores realistas que no se dejan llevar por el escepticismo del arte moderno; sin embargo, hoy es recordado menos por su obra narrativa que por su movimiento internacionalista que buscaba superar las rivalidades que habían llevado a Europa a la ruina. La revista del mismo nombre, dirigida por Raymond Lefevre, se guiaba por un propósito de educación revolucionaria y aspiraba a llegar a un amplio número de lectores, pero no logró captar más que a sectores radicales de la clase media. En América tuvo importantes conexiones, en Perú con el grupo "Claridad", al que pertenecía José Carlos Mariátegui, en Brasil con el grupo "Clarté" y en Argentina con Claridad, publicación del grupo de Boedo dirigida por Antonio Zamora. V. King, 1989: 41-43.
} 
Si Barbusse se convierte en un paradigma a seguir por aquellos escritores que sienten la obligación de comprometerse con un proyecto de alcances políticos concretos, en 1927 un libro esencial, La traición de los intelectuales (La trahison des clercs) de Julien Benda, se convertirá en el más destacado defensor de la posición contraria, retorno del intelectual -el clérigo en tanto sucesor de los clérigos que en el pasado fueron los depositarios de la cultura y se mantuvieron alejados de los poderes temporales- al único modo legítimo de participar en la vida pública: partir de postulados éticos universales ajenos a todo interés partidario o circunstancias históricas inmediatas.

Volveré más adelante sobre las repercusiones inmediatas del llamado de Benda. Me interesa subrayar ahora que después de cincuenta años en que el libro sufrió diferentes interpretaciones, ha vuelto a convertirse en núcleo de distintas reflexiones sobre el compromiso del intelectual, con independencia del contexto de la modernidad.

Tzvetan Todorov ha abordado la cuestión en "Los tábanos modernos", donde traza el perfil del hombre de acción -aquel que parte de valores que para él caen por su propio peso-y del intelectual -el que hace de los valores el objeto mismo de su reflexión, situándose tan distante del sabio que reduce la verdad a la pura adecuación de los hechos, como de la fe del militante. Frente a estos, el intelectual "aspira a una verdad del descubrimiento y de consenso, hacia la que uno se acerca al aceptar el examen reflexivo y el diálogo" y su función, que es una función social, estará al servicio de "revelar, y eventualmente, modificar el complejo de valores que sirven de principio regulador en la vida de un grupo cultural". [Todorov, 1993, 262]

Para lograr su cometido -el desempeño de una función social efectiva y beneficiosa- el intelectual ha de resistirse a dos de los principales obstáculos o desvíos: servirse de su función para favorecerse individualmente, acrecentando su riqueza o su poder; o dejar que la sociedad -el poder político, el estado, el partido, la revolución- lo pongan a su servicio, anulando así su identidad de intelectual y su independencia.

Todorov divide el poder en temporal y espiritual, el cual a su vez puede ser laico y religioso. A partir del siglo XVIII el lugar del religioso queda vacante 
y en el XIX serán los poetas románticos quienes aspiren a ocupar el sitio. Ya se ha hecho referencia a los episodios de 1848 y a la ruptura del escritor con la burguesía: El autor de Nosotros y los otros utiliza el término "perdonavidas" para resumir la nueva actitud del artista desavenido con el poder, tanto si rechaza a la sociedad en bloque como si se refugia en el arte puro.

Con el caso Dreyfus se abre un nuevo estatuto para el hombre de letras que pasará a llamarse intelectual, pero pronto este actor social abandona su rango para convertirse en un simple militante que provoca la reacción de Benda, quien considera que los clérigos contemporáneos traicionan sus ideales al sustituir las metas universales por reivindicaciones particulares de raza o nación, los valores espirituales por apetencia materiales, y el rigor de la razón por las intuiciones Al dejar de diferenciarse de los laicos traicionan su identidad de clérigos. Aunque Benda no pudo evitar sus prejuicios y se equivocó en muchas de sus previsiones, su prédica adquiere vigencia otra vez a finales del siglo $\mathrm{XX}$, después del fracaso de los nacionalismos y de las utopías de izquierda. El intelectual vuelve a encontrarse ante la misma disyuntiva que se había registrado en la antigüedad clásica: elegir entre el orador comprometido con los asuntos de la ciudad o el poeta retirado. El intelectual de hoy debe encontrar la forma de comprometerse con los asuntos de la polis desde un papel que no es el del profeta, ni el del negador, ni el del revolucionario sino el de crítico de la sociedad presente que, atento a los conflictos del día a día no se conforma con pertenecer a una sociedad sino que actúa sobre ella.

Todorov propone el ejemplo de Sócrates para demostrar que el problema no surge en los tiempos modernos. Ya el filósofo ateniense se había negado a participar del gobierno de la ciudad pero también a llevar una vida contemplativa. Para él filosofar era implicarse en los asuntos atenienses, incluso aun cuando desembocara en una condena injusta. Su función, la función del intelectual en su ciudad, fue comparada por el mismo Sócrates con la de un tábano que despierta y hostiga a un caballo, que por su mismo poder y dimensiones, se adormece confiado. La misión del filósofo -del intelectual- es zaherirlo, reprenderlo, el día entero y en todas partes. 
El nombre de Julien Benda ha sido rescatado lúcidamente Norberto Bobbio. El destacado pensador fallecido recientemente Bobbio elogia de Benda su firmeza en bregar por la independencia del intelectual -aquello que para Bourdieu sería utilizar las reglas del propio campo. Bobbio profundiza algunas de la ideas enunciadas por Bourdieu y Todorov: considera que la postura de Benda es modélica en cuanto a la distancia que debe mantener el intelectual de las pasiones políticas.

\begin{abstract}
Los valores clericales son "desencarnados": no tienen relación alguna con el mundo. El intelectual tiene el deber de honrarlos con independencia de cualquier resultado que con ellos crea que puede alcanzar. Son abstractos o estáticos, en el sentido de que son idénticos a sí mismos, por encima de toda diferencia de tiempo o lugar. Son desinteresados, en cuanto que no miran a ningún fin práctico. Además, son racionales, ya que su adhesión implica el ejercicio de la razón a diferencia del entusiasmo, del valor, de la fe o del amor humano, que reposan sólo en el sentimiento Los dos valores supremos clericales que Benda declara haber honrado son, en el orden intelectual, la verdad y, en el orden moral, la justicia. [Bobbio,1998: 40]
\end{abstract}

Bobbio revisa las pricipales obras de Benda, de las cuales interesa especialmente, por su repercusión y por el año de su publicación, la ya citada La trahison des clercs de 1927. El pensador italiano retomará la condena de Benda a los intelectuales que abandonan la única preocupación válida de los clercs, cual es la preocupación por la verdad y la razón. El sometimiento a causas de otra naturaleza - de raza, nación o partido- ajenas al mundo de la cultura al cual pertenecen, es considerada una traición y un alejamiento de la genuina condición:

\footnotetext{
El intelectual sólo es fuerte cuando tiene cabal conciencia de su índole y su función característica, y muestra a los hombres que tiene conciencia; es decir, se les declara que su reino no es de este mundo, que LA AUSENCIA DE VALOR PRÁCTICO ES PRECISAMENTE LO QUE CONSTITUYE LA GRANDEZA DE SU ENSENAANZA Y QUE PARA LA PROSPERIDAD DE LOS REINOS DE ESTE MUNDO, LO NeCESARIO ES LA MORAL DEL CÉsAR Y No LA DE ELLOS. Con semejante actitud el intelectual se ve crucificado, pero lo respetan y su palabra logra grabarse en la memoria de la gente $^{9}$.[Benda: 1974, 178]
}

\footnotetext{
${ }^{9}$ Subrayado del autor.
} 
La recuperación de Benda a finales del siglo XX conlleva el riesgo de no percibir totalmente el contexto en el cual pronunciaba su alegato, la dificultad de su puesta en práctica y las interpretaciones desviadas, o parciales, o simplificadoras que podían hacerse de su discurso. En 1927, el ensayista francés defiende una idea de compromiso que va en sentido opuesto a las corrientes dominantes:. Para estimar en su justa medida las polémicas en torno al papel del intelectual a finales de los veinte, es conveniente reconocer la compleja disyuntiva de escritores y artistas que consideraban insuficiente y poco útil una actitud especulativa y alejada de la acción, por lo que muchos de ellos optaron por la toma de partido y la militancia. El análisis de la obra de Benda en su totalidad le permite demostrar a Bobbio que su condena de todas las pasiones políticas por igual, las de izquierda y derecha, no le impidieron en su momento situarse junto a la izquierda frente a los totalitarimos nacionalfascistas. Así lo hizo ante la guerra de España y de Somalia y ante los acontecimientos de Munich. Pero lo fines del presente estudio, considero necesario atender al impacto de La trahison des clercs en el contexto histórico y social de finales de la década del veinte, pues en el momento de su publicación la influyente obra adquirió un significado diferente del otorgado por Bobbio al final de la pasada centuria y a la luz de toda la obra del citado autor.

En su libro de 1927 fustiga tanto al comunismo como al nacionalismo, encarnados en una gran masa que se entrega a la pasión "realista"10 bajo las dos grandes formas que puede adquirir -pasión de clase y pasión nacional. Frente a sendas opciones, otro grupo de hombres lucha en inferioridad de condiciones por no abandonar la condición de clérigos, por no caer en el mundo de los laicos, por predicar el valor del orden espiritual que no reconoce fronteras.

\footnotetext{
... hombres (sabios, artistas, filósofos) que muestran al mundo un alma que ignora las naciones, [y] muestran al mundo un lenguaje universal, predican el culto de lo humano, o al menos de lo cristiano; esforzándose en fundar, en oposición a las naciones, un gran imperio universal y de principio espiritual. [Benda: 1974, 170]
}

${ }_{10}$ El término "realista" es utilizado por Benda como opuesto a la razón y sus postulados, circunstancia que opera de forma determinante en el aumento de las pasiones malsanas. 
Es preciso analizar cómo se inscribía en los debates de la época la convocatoria al mantenimiento del ámbito intelectual no contaminado con el orden temporal y a olvidar la preocupación por "la posesión de los bienes que no se comparten" reemplazándola por un "principio abstracto y superior" y un "perfeccionamiento de la moralidad" [Benda, 1974, 172]. Ha de pensarse asimismo que si el libro más famoso de Benda es el escrito en el año 1927 es porque el pensamiento suscripto en La trahison des clercs tuvo un repercusión especial, quizás mayor y cualitativamente más relevante que el elaborado en su obra posterior, sin duda más madura y compleja, como bien lo demuestra Norberto Bobbio. ${ }^{11}$

En la segunda mitad de los años veinte, en los principales países europeos se registraba una polarización creciente de los debates ideológicos entre fascismo y comunismo, mientras las opciones intermedias iban perdiendo adeptos debido a la imposibilidad de ser puestas en práctica. La obra de Benda no es, sin embargo, un caso aislado: tiene importantes puntos de coincidencia con la corriente de pensamiento nacida en Francia hacia 1930, representada fundamentalmente por Jacques Maritain y Emmanuel Mounier, conocida bajo el nombre de Personalismo, propulsora de una tercera posición condensada en la idea del "humanismo integral". Para los pensadores católicos, el valor otorgado a la persona se constituía en salvaguarda de su dimensión espiritual, opuesta a la dimensión social culpable de la masificación y alienación del hombre. De los dos filósofos, fue Maritain el mas intransigente con los intentos de intervención política, oponiéndose tenazmente al ala política de Esprit, llamada la La troisième force; Emmanuel Mounier, en cambio, terminó comprometiéndose con la realidad inmediata. Por otra parte, la "tercera posición" preconizaba un humanismo integral que alertaba sobre los peligros del materialismo comunista,

\footnotetext{
${ }^{11}$ Prueba de la resonancia del libro es el espacio que Benjamin le dedica en 1934 en "Sobre la situación social que el escritor francés ocupa actualmente". El pensador alemán reflexiona sobre el papel que puede jugar el escritor en una sociedad atravesada por cambios revolucionarios. Considera que Benda no deja de proponer una opción humanista evasiva y teñida de ideología católica: "No resulta difícil descubrir en esa Europa tan utópica una celda conventual disimulada y de tamaño sobrenatural, en cuyo retiro se refugian 'los espirituales' para tejer el texto de un sermón, sin que les preocupe que, de predicarse, se predicará ante bancos vacíos". [Benjamin, 1993: 76]
} 
a quien quería librar batalla disputándole la exclusividad de la defensa de las clases oprimidas.

Desde otro punto de vista, el norteamericano Waldo Frank coincidía con los católicos franceses en la búsqueda de una tercera vía, distante del comunismo y de aquellos que, en su opinión, eran la causa de los males de la sociedad occidental: el filisteísmo burgués, originado en el cultivo excesivo de la razón y en el alejamiento de las verdades supra-racionales. Su mirada crítica a este aspecto de la modernidad lo llevaba a preconizar un retorno a valores medievales. Es relevante notar que a pesar de las coincidencias, estas posiciones tienen desacuerdos importantes: los representantes de Esprit asumen una militancia religiosa que no interesa a Benda, defensor a ultranza de la razón; Frank, por su parte, aduce un antirracionalismo y una profunda identificación con la Edad Media, causa con la que no podía simpatizar el autor de La trahison des clercs $^{12}$, racionalista confeso y, aunque decepcionado, burgués por convicción ${ }^{13}$.

¿Por qué entonces, y de qué manera las tres posiciones adquieren un sugestivo "aire de familia"? Sin duda la comunidad de pensamiento se encuentra en la insistencia en predicar la equidistancia de los dos polos ideológicos que entraban en su más alto clima de conflicto en la Europa de finales de los años veinte. Con independencia de la mayor o menor verdad y rigor de las especulaciones reseñadas, las tres posiciones adolecen de un notorio carácter abstracto y utópico, de un desconocimiento de las circunstancias que las hacían inviables así como de un temor solapado al avance de los nuevos sujetos sociales -proletariado urbano- que desde medidos del siglo XIX estaban cambiando el escenario europeo. Por estas

12 Gran admirador del Siglo de las luces, sostiene que el mejoramiento del trato a los prisioneros de guerra "Son efectos de las enseñanzas del siglo XVIII, contra el cual se han rebelado, precisamente, los 'maestros del pensamiento moderno'".[Benda, 1974, 186] En este sentido Bobbio subraya: "de las batallas culturales que desencadenó y llevó a cabo en dispersos momentos y por diversas circunstancias, el motivo inspirador es idéntico: la defensa de la razón contra la pasión, de la inteligencia que domina y comprende la vida contra las pretensiones de la vida a la inteligencia". [Bobbio: 2001, 28-29]

${ }^{13} \mathrm{Al}$ respecto, Benda se lamenta que la deserción de la burguesía de sus propios principios lo obliguen en ocasiones a aliarse con la izquierda: "No es culpa mía si debo unir mis manos a las de hombres de los que rechazo la mayor parte de las ideas, desde el momento que la burguesía, a la que pertenezco por nacimiento, por educación y por mis gustos, muestra ahora, desde hace medio siglo, la más cínica de las traiciones respecto a los valores que debería defender". [Benda, 1949: 153. Citado por Bobbio, 1998: 38] 
razones, no debe extrañar que tales postulados hayan encontrado eco en zonas del campo intelectual aunque lejanas, afines.

El caso de Victoria Ocampo en Sur es esclarecedor y merece incorporarse a las observaciones. En su fundamental estudio sobre una de las más destacadas revistas culturales argentinas durante 50 años, John King indaga prolijamente sus afinidades ideológicas en los años treinta. De inmediato se puede observar que el ideario de Sur se nutre de los supuestos de los intelectuales mencionados con anterioridad. La distancia de los asuntos temporales inmediatos tiene un peso capital en la configuración del ideario intelectual de la publicación.

\begin{abstract}
Desde el principio, ciertos elementos definen Sur. Uno que ya hemos mencionado es el "ideal europeo". Esto debe verse en relación con otro concepto fundamental: que el escritor, cualesquiera que sean sus simpatías, no debe comprometerse con ninguna actividad política. André Gide y la Nouvelle Revue Française ofrecieron un modelo literario, y pensadores como Julien Benda y José Ortega y Gasset sistematizaron estas ideas. LA TRAHISON DES CLERCS (1927), DE BENDA, TEORIZÓ SOBRE LA NOCIÓN DE UNOS SABIOS COMPROMETIDOS CON LA BUSCA DE VALORES HUMANOS $Y$ DE INVESTIGACIÓN FILOSÓFICA, EN LUGAR DE PARTICIPAR EN LAS ESFERAS POLÍTICAS Y SOCIAL $^{14}$. [King: 1986, 63]
\end{abstract}

La dificultad de sostener tales postulados a medida que se enrarecía la convivencia en Europa se hace evidente en la década del $30^{15}$. No es fácil determinar si las terceras posiciones fracasan por inviables o porque recibían duras acusaciones por la ausencia de soluciones para los problemas sociales y políticos más acuciantes. Al menos, en el caso de España, donde la dictadura de Primo de Rivera languidecía junto al gastado sistema monárquico de la Restauración, el liberalismo era atacado desde la izquierda y la derecha.

Si se atiende al proceder de Benda, la prueba más elocuente del complicación del escenario es su participación en el II Congreso Internacional de Escritores Antifascistas celebrado en Valencia en 1937, durante la guerra civil española, encuentro que congregó a un alto número de intelectuales

\footnotetext{
${ }^{14}$ Subrayado mío.

${ }^{15} \mathrm{He}$ realizado un estudio detenido sobre el tratamiento de la guerra civil española en la revista Sur donde trato las relaciones ideológicas de Ocampo con distintos intelectuales europeos y americanos. [Macciuci, 2001]
} 
comprometidos con la defensa de la república española, entre los cuales se encontraban nombres de gran prestigio en la cultura contemporánea ${ }^{16}$. Es interesante examinar la intervención de Benda, quien afirma no haber modificado sus ideas y contesta especialmente a quienes lo acusan de contradecir las premisas de La trahison des clercs.

\begin{abstract}
Pues bien, yo digo que el intelectual está encuadrado perfectamente en su papel cuando sale de su torre de marfil para defender los derechos de la justicia contra la barbarie y que, si [sic] efectivamente no tiene nada que ver con las tareas bastante miserables, denominadas corrientemente "hacer política".

(...)

... entiendo que existe una doctrina que el intelectual tiene del derecho, "el deber", como tal intelectual, de suscribir: se trata de la doctrina republicana; la doctrina de la Revolución Francesa, porque ella proclama los derechos del hombre, es decir, los derechos del espíritu en suma, las libertades del espíritu, mientras los otros sistemas (el fascismo lo dice de una manera muy formal) tiene por esencia exigir que el espíritu esté al servicio de los jefes y que sea estrangulado si se niega a la obediencia. [Benda, 1937, Hora de España, 7 ag. 1937, pp. 21-24 (citado por Aznar Soler y Schneider: 1979, 18-19)]
\end{abstract}

Es notorio que su discurso ya no intenta transitar un justo medio y que a la dura condena del nacionalismo ya no se alza la equivalente diatriba contra el régimen comunista. A diferencia de otros clercs dirá que la verdad se defiende mejor estando a la izquierda, porque los hombres de izquierda declaran sus fines -la justicia social- y efectivamente, lo piensan, mientras los de derecha dicen querer salvar la patria, la civilización, la libertad, y piensan lo contrario defender sus propios intereses. Por otro lado, la justicia está de parte de los primeros, no de los segundos. En 1937 Benda eleva su voz afirmando los postulados sobre el papel de los intelectuales expuestos en su libro de diez años atrás, pero su discurso ya no es el mismo. La tendencia a la generalización universalizante deviene ahora denuncia y condena inflexibles de la neutralidad y pasividad culpable de las democracias occidentales para con la II República. Con la simple presencia en la provisoria capital española sus

\footnotetext{
${ }^{16}$ Menciono tan sólo algunos de ellos: José Bergamín, Malcom Cowley, Raúl González Tuñón, Cordova Iturburu, Corpus Barga, Nicolás Guillén, César Vallejo, André Malraux, Kurt Stern, Tristan Tzara, Antonio Machado, Louis Aragon, Bertolt Brecht, Ramón J. Sender, Miguel Hernández, Roman Roland, Bernad Shaw, Viriginia Woolf, Ernest Hemingway, Saint-Exupèry, llya Ehrenburg, George Orwell, Octavio Paz...
} 
palabras adquieren un grado de acercamiento a la realidad inmediata que no se percibe en su obra más célebre.

Debo añadir, por mi parte, que encuentro inconcebible el que algunos Estados, otros regímenes [que] tienen como resorte fundamental el respeto a estas libertades, no comprendan que la causa del Gobierno español republicano es la suya propia, que el enemigo de este último es su propio enemigo y que si se produjese la derrota de esta España, la derrota que ellos habrían consentido sería ciertamente seguida por una expiación tan terrible como merecida. [ld., id.]

Nuevamente un episodio registrado en la revista dirigida por Victoria Ocampo ilustra que el mismo grado de inviabilidad y creciente aislamiento de las terceras posiciones se registraban en ámbitos alejados del centro de los acontecimientos. Consecuentemente, la idea de compromiso sustentada por el pensamiento liberal no podía mantenerse en un escenario convulso y marcado por el antagonismo como era el de los años treinta. El historiador argentino José Luis Romero en el artículo "Sobre el espíritu de la facción" publicado en Sur observa que Occidente se encuentra sometido a la lucha de dos facciones de la que no permanece libre ningún aspecto de la realidad; el tratar de evitarlas buscando estar más allá o por encima de la política es un engañarse y condenarse a un aislamiento estéril.

\footnotetext{
Independientemente de que nos parezca bien o mal y de que deseemos que las cosas sean de otro modo, un mínimo de objetividad nos forzará a reconocer que la lucha de dos facciones constituye hoy en el mundo occidental el drama fundamental de la época, el proceso histórico vivo y creador. No hay reducto de la realidad que escape a esta determinación; y si el intelectual se siente humano, escapará a ella aún cuando decida sostener, como en el caso de Jacques Maritain, la posibilidad de crear, sobre supuestos teóricos, una tercera posibilidad de acción para el hombre contemporáneo. (Romero, 1937: 67).
}

Tanto Jules Romains como Jacques Maritain postulaban, según analiza el historiador argentino, la creación de un refugio, un espacio privado que les permita proteger la libertad imprescindible para la creación de la acometida de la efervescencia social, actitud que concluye al fin en una ataraxia, semejante al ideal escéptico o epicúreo. 
Aunque Romero no cuestiona la legitimidad de aquellos que desean mantener la independencia, absteniéndose de la lucha entre facciones, advierte sobre el peligro "de quedar fuera de la vida política y de no significar en ellas nada". El error no radica en defender la independencia del escritor -este es un principio irrenunciable- sino en pretender trasladar a la vida política y a las urgencias de la acción "irrealizables sueños de aislamiento, de soluciones utópicas o de concordias evangélicas." [Romero, 1937: 69 ]. Es oportuno recordar que Mounier, de manera similar a Benda, finalmente desempeñó un papel activo a favor de la república española y de los frentes populares.

\subsubsection{Benda y SARTRE}

Cuando se analiza la relación literatura y compromiso el nombre de Jean-Paul Sartre surge de inmediato. No será motivo especial de esta tesis el compromiso según Sartre por tratarse de un planteamiento que influyó especialmente en una época posterior a la aquí tratada. Sin embargo, interesa señalar que el filósofo francés pensó el problema de la función de la literatura desde una perspectiva que tiene numerosos puntos de contacto con las distintas hipótesis expuestas anteriormente, entre los que destaca de manera especial el debate con Julien Benda. Aunque en Sartre utiliza el término 'compromiso' en escasos momentos, es evidente que polemiza desde la primera instancia, bastante ásperamente ${ }^{17}$, con las nociones de compromiso, traición del intelectual/clérigo alentadas por Benda, a quien critica por su idealismo y abstracción.

En ¿Qué es la literatura? Sartre considera que el acto de escribir se halla ligado de forma indisoluble con la libertad, pero la libertad de escribir que el escritor necesita y reclama conlleva necesariamente la libertad del ciudadano, por tanto, sólo puede desenvolverse en el único régimen que la garantiza, el régimen democrático. Desde el momento en que el escritor se inicia en su oficio queda comprometido con esta causa, hasta el punto de que

\footnotetext{
${ }^{17}$ Las menciones a Benda suelen ir acompañadas de calificaciones muy duras, tales como las que desprenden del verbo 'chochear' o del adjetivo 'bufón'.
} 
si en un momento las palabras, la literatura, no bastan para defender la imprescindible libertad, se verá obligado a tomar las armas.

La pregunta que surge a continuación es de qué forma se lleva adelante el compromiso de defender la libertad, pues puede entenderse de diversas maneras. No queda lugar a dudas que Sartre tiene una concepción del intelectual opuesta a la de Benda, y que en su libro discute frontalmente con él.

\begin{abstract}
¿Se trata de constituirse en guardián de los valores ideales, como el "clérigo" de Benda antes de la traición, o es que hay que proteger la libertad concreta y cotidiana, tomando partido en las luchas políticas y sociales? [Sartre, 1950: 88]
\end{abstract}

La respuesta a este interrogante, que cierra el segundo capítulo de ¿Qué es la literatura, titulado "¿Por qué escribir?", se desarrolla con amplitud en el tercero, "¿Para quién se escribe?". Sendas menciones a Benda abren y cierran esta tercera parte. Sartre reprocha a su colega francés el hablar de una libertad eterna que se adecua tanto al nacional-socialismo, como al comunismo staliniano o a las democracias capitalistas y no perturba a nadie. A la eternidad de Benda el autor de Les mots opone la "situación", es decir, una circunstancia determinada, particular, no generalizable, que el escritor que lucha por la libertad comparte con el lector a través de la mediación del libro: "Cada libro propone una liberación concreta a partir de una enajenación particular" y cada libertad que se propone debe conquistarse a partir de una situación histórica. Así es como un escritor que aspira a conservar o a cambiar este mundo está hablando al mismo tiempo de unas ciertas instituciones y no de otras, de unas costumbres determinadas, no en abstracto: sin proponérselo, hará referencias a distintas formas de opresión, a la sensatez y la locura de cada día, a ciertas pasiones, a modos especiales de razonar que las ciencias han puesto de moda, incluyendo la percepción misma; todos elementos comunes al escritor y al lector.

Haga lo que haga, el escritor está metido en el asunto, marcado, comprometido, pero en muchas ocasiones, en la mayor parte de ellas, no tendrá conciencia porque se evade del compromiso. En este sentido, debe tenerse en cuenta que el escritor no es un hombre común para el resto de la sociedad, debe satisfacer cierta expectativa y tener conciencia de que se le atribuye una función 
social; cualquiera sea el papel que desee jugar, deberá partir de una determinada representación que un cuerpo social atribuye al literato, y por otra parte, ha de contar con un público que con sus costumbres y visión de mundo lo asedia y le exige. Si el escritor se hace eco del papel que de él se espera y por lo tanto se resiste a dedicarse a la contemplación de lo Verdadero, lo Bueno y lo Bello en medio de una situación de flagrante iniquidad -Sartre da el ejemplo de un escritor negro que vive en una sociedad racista- no será nunca un clérigo traidor, porque el clérigo sólo existe como parásito de las clases opresoras, no existe entre las oprimidas.

Sartre explica el conflicto y la tensión en que se debate el escritor a partir de la relación que este establece con el público. En los diferentes períodos de la historia, el escritor siempre ha contado con un público real, la clase dominante que puede compensarlo materialmente por su producción, y que por otra parte, es la clase capacitada para leer; y un público virtual, fuerzas progresistas aptas para asimilar y aprovechar las críticas que el literato hace del sistema al que sirve. La tensión varía según las épocas: en tiempos de los clérigos, en el siglo XII, prácticamente no existe el público progresista con posibilidades de reflexionar críticamente y el escritor se ve absorbido por el grupo del poder. El clérigo escribe para clérigos, sin cargo de conciencia debido a que existe un divorcio entre esfera espiritual y temporal. La sociedad medieval tiene al clérigo a su servicio, en calidad de especialista, y no concibe que sus servicios sean un derecho de todos los hombres. Las técnicas profesionales de los clérigos no sirven tan siquiera al desarrollo de las humanidades como lo harán en el futuro, sino solamente a la conservación y transmisión de la ideología cristiana. El escritor puede en este caso realizar el ideal de Julien Benda -demostrar la autonomía entregándose a la contemplación exclusiva de lo Eterno- porque se dan determinadas circunstancias: que la espiritualidad y la literatura estén enajenadas, que haya triunfado una ideología como la cristiana, que la estructura feudal haga posible el aislamiento de los clérigos, que la mayor parte de la población sea analfabeta y que el único público del escritor sea el colegio de los otros escritores. Sartre no acepta que "se pueda a la vez ejercer la libertad de pensar, escribir para un 
público que exceda de la colectividad restringida de los especialistas y limitarse a describir el contenido de valores eternos e ideas a priori". [Sartre, 1950: 103]

En los siguientes períodos los escritores desempeñarán de otras maneras la condición del clérigo. Sartre no se distancia de los especialistas como Bürger o Calinescu, que analizan el papel del literato y del artista en las etapas previas a la consecución de la autonomía en el marco de las transformaciones culturales de la modernidad; simplemente no le interesa tanto señalar la génesis histórica como reflexionar y propugnar, como intelectual él mismo, la función del escritor que considera más beneficiosa para lograr las transformaciones conducentes a un mundo más equilibrado y justo, habitado por individuos libres, no sustraídos por regímenes opresivos y enajenantes ${ }^{18}$.

Después del medioevo Sartre se detiene en el siglo XVII francés, esto es, en el proceso de laicización del escritor y del público gracias al desarrollo de la instrucción, del debilitamiento del dominio religioso y la aparición de nuevas ideologías; todo sumado a la convocatoria a la libertad que una obra del espíritu consuma. Sin embargo, el público continúa restringido a un sector de la nobleza, la alta burguesía y el clero. El lector es pues un hombre letrado, que domina el oficio del escritor y lo juzga en nombre de los valores que espera ver defendidos. Escritor y lector pertenecen a la clase alta, incluida la burguesía rica; poder religioso y poder temporal se asocian en la defensa de unos valores inmutables y anclados en el pasado: a los clérigos defensores del dogma se suman ahora poetas, historiadores, juristas y filósofos guardianes de lo temporal y de la ideología del absolutismo. Existe un tercer grupo verdaderamente laico, son escritores provenientes de la burguesía y pensionados por la nobleza, no defienden el sistema pero tampoco lo impugnan; aceptan la ideología religiosa y política pero sin sentir obligación de probarla y conservarla. Generalmente son dependientes del poder y para recordarles sus deudas y su origen corporativo y "clerical", se les congrega en las Academias. Desde allí halagan al poder constituido y alimentan, sin proponérselo y sin contradicciones, la idea de un orden inmutable, en que la monarquía se asienta mediante las mismas convicciones que el arte: confundiendo el presente con lo eterno, consideran valioso aquello que coincide con la tradición. La lectura -la relación del escritor

\footnotetext{
${ }^{18}$ Sartre no diferencia en este caso entre el orden capitalista y el comunismo stalinista.
} 
con el público- se convierte así en "una ceremonia de 'reconocimiento' análoga al saludo, es decir, la afirmación ceremoniosa de que el autor y el lector son del mismo mundo y tienen sobre todas las cosas las mismas opiniones". Por su parte, el lector "no se cansa de encontrar los mismos pensamientos en los libros más diversos, porque estos pensamientos son los suyos y no quiere adquirir otros, sino solamente que le presente con magnificencia los que tiene". [Sartre, 1950: 107-108]

En la centuria siguiente el escritor dejará de disfrutar de tan plácida existencia y brindará un ejemplo de lo que ocurre a la literatura cuando el hombre de letras se ve obligado a rechazar la ideología de la clase dominante. El poder ya no está tan confiado en su propia ideología y busca detener la circulación de las ideas nuevas, pero no logrará que su propia estrategia se le vuelva en contra. Comprueba que sus principios políticos y religiosos son su principal instrumento, pero por esta misma razón, los convierte en instrumentos; ya no cree en ellos pero los utiliza pragmáticamente en desmedro de la verdad revelada. Desaparecen los clérigos, la literatura de la iglesia es una pura apologética, apela al respeto y al temor, deja de ser un llamamiento a la libertad y, por lo tanto, deja de ser literatura.

El poder apela al escritor para que difunda sus dogmas pero con la conciencia de que ya no son válidos; el escritor, al dar su consentimiento, está demostrando que él tampoco los considera legítimos, y por lo tanto, al dejar de adherir voluntariamente a los principios que pregona, se enfrenta a su soledad y su libertad

Por otro lado, la burguesía, clase en ascenso, aspira a constituir su propia ideología en unas condiciones favorables de excepción: como se enfrenta a una clase en decadencia sólo sufre una opresión política, en lo restante, tiene riquezas y poder. Así el escritor se encuentra entre dos fuegos, el del estamento al que sirve -sus mecenas- y el de la clase ascendente, la propia, que constituye un público instruido y con medios económicos para comprar libros. El grupo en auge representa asimismo un bosquejo de un público de masas, en la medida que ya no constituye un público como el de la nobleza, que emulaba al escritor en 
formación y competencias, sino que espera pasivamente que el genio del escritor le proporcione todos los secretos del arte literario.

Para Sartre, el escritor del siglo XVIII será un prototipo del intelectual, "eternamente fuera de su medio": pudiendo haberse identificado con su clase, se mantiene apegado al estamento noble, del cual había asimilado estilos y costumbres, y está convencido de que la verdadera recompensa es ser leído por los anónimos burgueses de provincias. Pero nada es comparable a la verdadera consagración que logra cuando ingresa a los círculos más selectos y recibe el reconocimiento, casi feudal, del monarca y la corte. Vive con lujo pero continúa siendo pobre, y de vez en cuando se lo recuerdan con persecuciones, prisión o humillaciones que, paradójicamente, afirman al escritor en la independencia y rebeldía conquistadas con su pluma; por eso continúa escribiendo, para reivindicar su extrañamiento de clase que transforma en soledad: mira a los burgueses como un noble y a los nobles como un burgués y a la vez, los comprende desde adentro, como uno más de ambas clases.

\begin{abstract}
Con esto, la literatura, que no era hasta entonces más que una función conservadora y purificadora de una sociedad integrada, adquiere conciencia en él y por él de su autonomía colocada por una casualidad extrema, entre aspiraciones confusas y una ideología en ruinas, como el escritor entre la burguesía, la Iglesia y la Corte, la literatura declara repentinamente su independencia: ya no reflejará los lugares comunes de la colectividad y se identifica con el Espíritu, es decir, con la facultad permanente de formar y criticar las ideas. [Sartre, 1950: 116]
\end{abstract}

Se da en el siglo XVIII un fenómeno muy particular; el escritor rechaza toda solidaridad profunda con el medio del que procede -burguesía- y con el que lo acoge -nobleza- la literatura se confunde con la crítica, la negativa, la impugnación. La búsqueda de la verdad fuera del dogma, la aparición de una espiritualidad nueva, distinta de la osificada de la Iglesia, propician la búsqueda de caminos fuera de toda filosofía concreta y particular. De la misma manera, la adquisición de conciencia del escritor convierte los datos concretos en conceptos universales y en tanto hombre que toma la pluma se descubre una conciencia universal y libre y la literatura comienza a manifestarse como una función abstracta y liberadora, un ejercicio de la libertad. El escritor asume el 
papel peligroso de reivindicar el libre pensamiento en una zona que no es la de la burguesía ni la de la nobleza; a veces lo premian y otras lo castigan, lleva una vida de aventurero y se da cuenta de que una novela puede ser también un acto y como cree que ha roto lazos con las clases que lo condicionaban, piensa que su única motivación es la pura generosidad. Así sortea su condición parasitaria y adquiere conciencia de la libertad absoluta y la gratuidad de la creación literaria. Sin embargo, este encuentro con el hombre universal, con los valores abstractos de la naturaleza humana no lo iguala al clérigo de Benda pues va acompañado de una actitud crítica esencial por la cual siempre existe algo concreto que criticar: instituciones, tradiciones, actos del gobierno, etc. Al derrumbarse el pasado y la tradición que sostenían el antiguo régimen, el escritor descubre el Presente ${ }^{19}$ con sus problemas y se aboca a solucionarlos, logrando así evitar el idealismo: además de preocuparse por la Libertad o la Igualdad, interviene en la vida política, actúa para concretar esos valores en el aquí y ahora.

La siguiente etapa en las luchas sociales planteará un nuevo problema al escritor: si se han alcanzado los objetivos y la burguesía ya se ha hecho con el poder, los anteriores reclamos ya no tienen razón de ser y la literatura se convierte en un juego formal. Por otra parte, el literato ha perdido el lugar estratégico entre las dos clases, ahora unificadas. Dice Sartre que le llevará cien años resignarse a la desaparición de la clase que lo arropaba y protegía y las reglas de juego de los burgueses, que conciben la literatura no como un menester gratuito sino como un servicio pagado. La obra literaria debe entonces acceder a cumplir un fin, una utilidad, que no será otra que justificar los derechos de la nueva clase para ocupar el poder. Sartre, sin nombrarlo, considera al realismo como un arte poco ambicioso, que busca la facilidad y desconfía del talento. Frente al optimismo burgués, que confía en integrar el universo en un sistema de ideas, el escritor sabe que la belleza no se resuelve en ideas y que en las palabras hay una fuerza irracional que resiste.

El escritor se ve obligado a esconder su talento, renuncia a transmitir la opacidad y extrañeza del mundo y obedece a los requisitos de simpleza y utilitarismo del hombre burgués de manera que el público nunca sea

\footnotetext{
${ }^{19}$ Las mayúsculas mantienen el uso de Sartre.
} 
sorprendido. Algunos se rebelan y su resistencia afectará a la literatura durante medio siglo: desde 1848 a 1914 estos disconformes escriben contra todos sus lectores, aunque venden sus obras, desprecian a quienes las compran y se esmeran en decepcionarlos, rechazan el triunfo y la fama y, cuando es necesario, añaden a su libro un prefacio más duro aún que el mismo libro con las expectativas del público. Irrumpe así un fenómeno inédito en la historia literaria: sin designarlo con un nombre preciso, Sartre se esté refiriendo claramente al simbolismo-modernismo y a las vanguardias.

Pero surge al mismo tiempo otra circunstancia novedosa: la instrucción generalizada moldea un nuevo público, y el escritor se debate entre darle la espalda o intentar ser nuevamente el eslabón entre dos grupos sociales; sólo Víctor Hugo lo consigue. El proletariado ansía cambios materiales, no le preocupa la libertad en abstracto. Se anticipa a lo que Sartre considera el arte de escribir: el llamado histórico y concreto, singular y fechado que un hombre, aceptando "historizarse", hace a todos sus congéneres. La mayor parte de los escritores no rompe la distancia que lo separa del proletariado, abocado a las conquistas materiales y al fin de la explotación del hombre por el hombre y no por la libertade en abstracto, como entelequia (nueva alusión a Benda). La pregunta que surge ante esta realidad es si la literatura puede establecer una relación con los reclamos de las clases inferiores. Los literatos, es sabido, se amparan en su autonomía; la literatura se convierte en un objeto y su público, pese a las aparentes rupturas, sigue siendo la burguesía. Se niegan a reconocer para quién escriben realmente, se refugian en la soledad, a la vez que recuperan un público de especialistas pues el burgués separa lo temporal de lo espiritual. Vuelve a constituirse una especie de clerecía en tanto el arte se separa de la vida y retorna a lo sagrado. Es posible rastrear en quién está pensando el filósofo existencialista cuando realiza estas observaciones: "El público de Stendhal es Balzac, el de Baudelaire es Barbey d'Aurevilly y Baudelaire es a su vez público de Poe" [Sartre, 1950: 132]

Más adelante agrega:

La perfección en lo inútil, es sabido, constituye la belleza. Desde "el arte por el arte" hasta el simbolismo, pasando por el realismo y 
el Parnaso, todas las escuelas están de acuerdo en que el arte es la forma más elevada del consumo puro. No enseña nada, no refleja ninguna ideología y se resiste sobre todo a ser moralizador: mucho antes que Gide lo haya escrito, Flaubert, Gautier, los Goncourt, Renard y Maupassant han dicho a su modo que "es con los buenos sentimientos como se hace mala literatura". [Sartre, 1950: 135]

Y continúa con un inventario que va desde Flaubert, los realistas y naturalistas -"se trata de tranquilizar ante todo. Allí donde el realismo pasa no crece la hierba" [Sartre, 1950: 136] hasta el superrealismo. Mientras tanto la burguesía deja hacer, porque aunque rebeldes, no son revolucionarios; la obra gratuita es inofensiva, un entretenimiento. Como la literatura se ha convertido en una negación abstracta no ha de sorprender la frase descalificadora "no es más que literatura".

Pese al duro juicio que el arte de la modernidad merece a Sartre, no deja de reconocer el gran mérito artístico y finalmente, la eficacia de su esteticismo, pues consagró la gratuidad como una de las dimensiones infinitas de mundo y un posible objetivo de la actividad humana. $Y$ como se trata de artistas, algunos los más grandes, sus obras encierran un desesperado llamamiento a la libertad del lector al que simulan despreciar, invitándolo a salir del vacío por medio de la destrucción de todos los mitos y cuadros de valores. No obstante, considera el autor de El ser y la nada que el siglo XIX es una época de culpa y degeneración del escritor, el cual podría haber jugado otro papel si se hubiera acercado a la clase inferior y hubiera profundizado su arte hasta comprender que hay una relación entre elegir al hombre como tema y la democracia social. Lamenta Sartre que no hayan intentado despertar la conciencia obrera mostrando las injusticias de los burgueses. Pese a la riqueza de sus medios expresivos, traicionaron la literatura y más grave aún, son responsables de que el marxismo finalmente triunfante careciera de contradicciones y matices y se ahogara en su propia victoria.

Finalizando la tercera parte de ¿Qué es la literatura?, reconoce el autro la posible parcialidad de sus análisis, pero lo importante para él no es que el lector juzgue su mayor o menor discernimiento sino que su pensamiento sea 
contemplado como una reflexión sobre la obra de arte, la cual para el filósofo equivale siempre a un llamamiento libre e incondicionado a la libertad.

Para cerrar su idea acerca de la literatura reforzará el concepto de situación, que abarca tanto a la literatura como al escritor. Este es un hombre, que como los demás, está en situación, pero se diferencia en que su obra, a diferencia de la obra del zapatero o del herrero, precisa de la situación. En cada época la libertad del escritor se sitúa de diferente manera, y como en cada época la libertad -esencia de la literatura- ha sufrido diferentes formas de opresión, la literatura nunca ha podido ser vista en todo su alcance. La visión parcial encierra de todos modos una verdad, pero esta se convierte en error si no se supera.

A través del movimiento social pueden verse las fluctuaciones de la idea literaria. El desarrollo trazado por Sartre desde el siglo XII al XX intenta demostrar que la literatura pasó por distintos modelos de enajenación, es decir, de sometimiento a los poderes temporales o a la ideología. En este proceso el escritor puede tomar distintas actitudes, puede cumplir papeles diversos durante el curso de la literatura hacia la libertad absoluta, que es una utopía. Las diferentes actitudes están estrechamente vinculadas a la relación del literato con su público, pues este habrá de elegir dirigirse a un público virtual pero inexistente todavía, por falta de instrucción, o a un público real y reducido, minoría privilegiada que es tomada en representación de la totalidad. La elección del público reducido condiciona los temas de lo que resulta una preferencia sustantiva por la universalidad abstracta, a la que Sartre opone la universalidad concreta de la totalidad de los hombres vivos en una sociedad dada. La inclinación por la universalidad concreta permite al escritor definir su situación en el tiempo social.

En el tiempo en que el público real coincida con el público virtual, el escritor ya no correrá el riesgo de escribir sobre el hombre abstracto de todas las épocas sino sobre el hombre de su época y para sus contemporáneos y confundir los intereses y las preocupaciones del hombre con los del reducido público real que existe por el momento. En ese utópico día ningún celo aristocrático le impulsará a negar que está en situación, pues su situación sería 
universal, expresaría las esperanzas y la cólera de todos los hombres. Nada separará lo temporal de lo espiritual, no tendrá lugar el clérigo de Benda, que opone a las masas indiferencias un público de profesionales o de aficionados ilustrados. Para Sartre este clérigo, que se puede amparar en distintos lemas el Bien y la Perfección divina del medioevo, la Belleza o la Verdad en la actualidad- está siempre del lado del opresor y Benda es un claro exponente de esta tendencia, que aparta la vista del mundo para contemplar en el cielo valores establecidos. El escritor que alcance la plena conciencia de sí mismo aquí está su compromiso, aunque Sartre no lo diga expresamente- no adorará lo espiritual sino la espiritualización, esto es, la reanudación permanente de la espiritualización del mundo. Verdadero escritor será aquel que escriba para un público que tenga la libertad de cambiarlo todo, para esto no deberá actuar sobre las libertades del público sino llamar a sus libertades. La función del escritor es traducir con la mayor profundidad las exigencias colectivas y expresar lo universal concreto con la finalidad de llamar a la libertad de los hombres para que estos realicen y mantengan el reinado de la libertad humana.

Después de los ácidos juicios de Sartre sobre su colega y compatriota Benda, será iluminador introducir otra perspectiva, equidistante tanto del asentimiento total con las propuestas de La trahison des clercs como de la condena sin ambages del patriarca del existencialismo. Manuel Vázquez Montalbán se inscribe sin dudas en el tercer grupo de reflexión sobre el compromiso: escritor y militante confeso del PSUC (Partido Socialista Unificado de Cataluña $)^{20}$, en sus planteamientos convergen el manifiesto estético del escritor y la ética del intelectual.

Vázquez Montalbán considera a Benda una figura clave en el itinerario del pensamiento sobre la función del intelectual; uno de los pioneros en tratar el problema desde un punto de vista moderno y movilizar la discusión sobre el compromiso, paso imprescindible para abrir la discusión a la función social del arte y a las maneras de concretar el cambio deseado.

${ }^{20}$ Se trata de la rama catalana del PC. 
Y no era cuestión baladí el tema del compromiso de los sacerdotes de la cultura y que ese tema, INICIALMENTE INSCRITO EN LA PARCELA DE LA MORAL Y EL TALANTE, acabara llevando al de la función social de la creatividad. [Vázquez Montalbán, 1987, 1989: 19] ${ }^{21}$

Como Bobbio y Todorov aprueba la conducta de Benda pero en cambio, no recupera para el presente la independencia que este propugna; el autor de la Serie Carbalho representa al intelectual heredero del compromiso mítico de los años treinta y de los posteriores profetas de la rive gauche que hegemonizaron la cultura de izquierda hasta mayo del 68. Se atreve, en tiempos adversos a la función social de la literatura, a realizar una defensa del denostado realismo socialista, liberándolo de calificativos esquemáticos.

\begin{abstract}
Y sin embargo, desprovisto del reduccionismo temático y dirigido, la tesis del realismo socialista no era una bellaquería concebida en el cerebro de un burócrata. Respondía a una visión dialéctica y progresista del crecimiento continuo del espíritu, la misma que estaba presente detrás del optimismo histórico del marxismo y de otras culturas revolucionarias convencidas de la inmediata hegemonía de un nuevo sujeto histórico ascendente; la clase obrera. En el fondo de la tesis del realismo socialista subyace la afirmación de la literatura y el arte como reveladores de realidad (función tradicional de la que se había apropiado la burguesía) con la añadida de influir sobre la realidad para transformase en un sentido progresista. Balzac, Stendhal, Flaubert o Courbet, Renoir o Cézanne reproducen o revelan realidad, pero no tienen la intención histórica de cambiar a través de su medio de conocimiento y de acción la novela o la pintura, la realidad realmente existente. [Vázquez Montalbán, 1989: 20]
\end{abstract}

\title{
1.5. Síntesis sumaria de los PROBlemas en tORno al compromiso del artista
}

Como se puede apreciar, la categoría compromiso presenta un campo teórico menos homogéneo y por lo tanto, más difícil de sistematizar que el de la vanguardia. En principio se observan dos direcciones principales, cada una escindida por diferentes juicios y valoraciones: por una lado, aquella que se inscribe en el marco teórico de la modernidad estética; por otro, aquella en la cual prevalecen presupuestos morales y filosóficos.

${ }^{21}$ Subrayado mío 
En la primera instancia de reflexión -la modernidad estética- el compromiso vuelve a poner de manifiesto la separación que se produce en el siglo XIX entre la estética que propugnaba una profunda relación con la vida cotidiana y la realidad inmediata, y la que se orientó hacia la preocupación por los procedimientos y la constitución de un arte autónomo desvinculado del mundo cotidiano. El compromiso del escritor, ligado a formas representativas y "comunicables" de la literatura y el arte, queda excluido de la modernidad estética, junto con las tendencias realistas. El arte con función social adquiere reconocimiento y relevancia cuando a vanguardia "deshumanizada" es desplazada y sus principales representantes pierden el lugar hegemónico en el campo intelectual o abandonan los ismos modificando su praxis social.

Dentro de esta misma dirección, existe una visión conciliatoria que procura sortear la desavenencia entre la estética modernista-vanguardista con la estética del realismo social, estableciendo una línea de continuidad entre las vanguardias históricas o arte de vanguardia de la década del veinte con el arte de avanzada o arte de las vanguardias políticas de los años treinta. Esta dirección intenta al mismo tiempo atenuar los frecuentes desentendimientos entre vanguardias estéticas y vanguardias políticas haciendo confluir las paralelas del simbolismo-vanguardismo y la de los realismos de diferente escuela. El reciente y muy documentado libro de Haral Wentzlaff-Eggebert sienta este criterio en unos de los cinco prefacios que inauguran el estudio: "Se sabe, sin embargo, que [la literatura de vanguardia] se traviste en 1930 cambiando de apellido. En adelante se llamará 'Literatura de Avanzada'”. [Wentzlaff-Eggebert, 1999: xxx], afirmación que reenvía a los comienzos del problema, en el siglo XIX, cuando ambas vanguardias se acercaban o rechazaban, pero unidas a pesar de todo por un lema común, el de que la vida debía cambiar radicalmente ${ }^{22}$. Pogioli considera que el entendimiento de ambas vanguardias se reduce a los diez años que siguen a la experiencia de la Comuna, en 1871; Calinescu no lo considera un fenómeno tan acotado, pues, en la línea de pensamiento insinuada por WentzlaffEggebert, cree que

${ }^{22}$ El fuerte componente individualista del pensamiento político del fourierismo y del anarquismo propició, más que las alternativas socialistas, el entendimiento con la vanguardia política de artistas ligados a la bohemia y al arte por el arte. [Calinescu, 1991: 109-110] 
incluso lo que hoy consideramos 'vanguardia histórica' fue políticamente inspirada más de una vez, y aunque los movimientos así representados nunca lograron unirse totalmente a los movimientos más o menos paralelos en política, no sería exacto decir que las dos vanguardias están separadas por una brecha insalvable. [Calinescu, 1991, 116]

Esta no es sin embargo la posición dominante, y el mismo Calinescu registra, poco más adelante, que la izquierda marxista reservó celosamente el término 'vanguardia' para la vanguardia de la clase obrera y englobó en el adjetivo 'modernista' a las estéticas renovadoras, opuestas al realismo y desvalorizadas en la línea de Lukács.

En un rumbo antagónico, pero, como se ha visto, sustentado por los mismos presupuestos teóricos, Adorno reivindica un compromiso ligado a la experimentación formal de la vanguardia y de la estética modernista en general, invirtiendo de forma radical el concepto más arraigado y obligando a pensar y discutir la cuestión desde una perspectiva que aún se debate ${ }^{23}$.

En el mismo marco de la discusión, destacan los intentos de Brecht y de Benjamin dirigidos a salvar la incomunicación entre vanguardia y compromiso, pero sin abdicar de la exploración formal y del principio de la inorganicidad, esfuerzo teórico materializado en obras de prolongada descendencia durante todo el siglo XX. Sin embargo, tal esfuerzo especulativo, muy fructífero para el marco de la vanguardia, adolece de la misma parcialidad que ha mantenido en el ostracismo, fuera de la modernidad estética, la producción artística de cuño realista iniciada en el siglo XIX y vigente, aunque relegada hasta pocos años atrás, durante todo el siglo XX.

La posición de Joan Oleza, aunque no se focaliza sobre el tema del compromiso sino en el de la vinculación arte-vida cotidiana, dentro del cual la preocupación social es una parte, rompe con los preconceptos que la crítica y el canon acumularon sobre esta tendencia estética durante todo un siglo y se

\footnotetext{
${ }^{23}$ Téngase en cuenta al respecto el artículo "El artista como lugarteniente", en el cual Adorno argumenta a favor de la resistencia al orden administrado a partir de la obra de Valéry, "No atontarse, no dejarse engañar, no colaborar: tales son los moldes de comportamiento social que se decantan en la obra de Valéry, la obra que se niega a jugar el juego del falso humanismo, del acuerdo social con la degradación del hombre" [Adorno, 1984:218]
} 
constituye así en una invitación a analizar el problema a la luz de nuevos elementos teóricos.

La otra gran instancia de reflexión sobre el compromiso, en la cual se incluyen Benda, Sartre, Bobbio, Todorov, Vázquez Montalbán, no tiene la modernidad estética como eje y marco sino al intelectual en las distintas circunstancias y los diferentes nombres y perfiles que este adquirió desde la antigüedad hasta hoy. El centro del debate lo constituye aquí la autonomía del intelectual y la viabilidad de mantener su prescindencia de la polítíca y la defensa de valores abstractos y universales en toda circunstancia y momento. No se pronuncian estos pensadores desde el lugar del teórico o del investigador sino a partir del propósito de sentar posición como intelectuales; sus escritos tienen por tanto un componente perfomativo muy alto que se suma a la información y al propio debate. Los diversos enfoques y posiciones dejan a la luz que el problema no se resuelve linealmente. 


\section{Las vanguardias en España}

\section{Las VANGUARDIAS EN LA PERIFERIA}

Pensar el tema de la autonomía del arte y los movimientos vanguardistas en autores españoles, lleva necesariamente a recordar, junto con parte de la crítica, que en zonas preindustriales como España o América Latina, no se daban todas las condiciones para que tuviera lugar una crisis cultural profunda originada en el rechazo de la industrialización y el desarrollo tecnológico; tampoco se habían sentido los efectos devastadores de la primera guerra mundial que ocasionarían el descreimiento y la reacción generalizada en los países directamente afectados. Estas circunstancias diferentes a las de la Europa altamente industrializada han dado lugar a enfoques que analizan los movimientos vanguardistas en el mundo hispánico a partir de parámetros comunes a todos ellos. Las conclusiones tienen el hilo común de encontrarlos carentes del espíritu revulsivo y revolucionario que se verifican en los países donde se gestaron los ismos; sin embargo es preciso examinar matices y diferencias en las tesis resultantes $y$, por otra parte, tener presentes las divergencias de los fenómenos literarios y culturales entre América Latina y la vieja metrópoli.

El reputado especialista en las vanguardias latinomericanas, Jorge Schwartz, ha realizado un inteligente análisis del fenómeno en los países de Iberoamérica en el libro ya mencionado en el primer capítulo del presente estudio. Sus conclusiones pueden extenderse, en parte, al caso español, país que comparte algunos de los rasgos del nuevo continente -no pertenecer a los países centrales, sentirse particularmente sugestionados por los ismos parisienses- pero se diferencia de forma decisiva en no tener el sustrato común latinoamericano de un sentido de la condición colonial. Sin embargo, es válida también para España la advertencia que figura en el esencial prólogo de Alfredo Bosi al libro de Schwart, acerca del error de incurrir en una lectura estática de las vanguardias, pues estas

no tuvieron la naturaleza compacta de un cristal de roca, ni formaron un sistema coherente en el cual cada etapa refleja la estructura uniforme del conjunto. Las vanguardias se deben contemplar en el 
flujo del tiempo como el vector de una parábola que atraviesa puntos o momentos distintos. [Bosi, 1991: 15].

Sin precipitar una conclusión, es oportuno tener en cuenta que tanto el estudio introductorio de Bosi como el amplio marco de reflexión que propone Schwartz sugieren valiosos interrogantes para las vanguardias españolas: las oscilaciones y cambios de rumbo de los distintos artistas, ¿deben considerarse producto de la inconsistencia propia de las culturas periféricas?. El retorno a los clásicos y a la poesía folklórica, ¿se puede explicar con la manida fórmula renovación más tradición ${ }^{1}$ La doble dirección de la vanguardia iberoamericana, de búsqueda del otro y afirmación de la identidad ¿no constituye una valiosa herramienta para pensar el problema en España, afligida por un desconcierto de siglos en su relación con el resto del continente europeo? Las palabras de Carpentier citadas por Bosi, "Hay que tomar nuestras cosas, nuestros hombres y proyectarlos en los acontecimientos universales para que el escenario americano deje de ser una cosa exótica", ¿no proyectan su sombra sobre el neopopularismo de Alberti y en los romances y el teatro de García Lorca? ¿No representan también una literatura "marcada" por el fondo mítico -piénsese en el componente gitano y andaluzcomo lo son para Bosi el Perú quechua de Ciro Alegría y José María Arguedas - la Cuba negra de Nicolás Guillén, por citar sólo dos de los casos mencionados? $?^{2}$.

\footnotetext{
${ }^{1}$ Es de considerar la validez de la crítica a los esquemas rígidos sobre las vanguardias latinoamericanas para cierto discurso vigente en España. Textos programáticos y críticos: "A ese historiador le cabrá, finalmente, la adopción de un lenguaje resbaladizo de conjunciones copulativas que suman frases semánticamente disparatadas, aunque sintácticamente mezclables: 'el modernismo fue cosmopolita y nacionalista'; 'Las vanguardias buscaron inspiración en los ismos parisienses tanto como en los mitos indígenas y en los ritos afroantillanos; o también, 'el arte latinoamericano del 20 fue no sólo absolutamente puro, sino también radicalmente comprometido..."' (subrayado del autor). [Bosi, 1991: 14-15]

2 Es muy significativa la temprana mención a estas características del vanguardismo latinoamericano realizada por Guillermo de Torre en 1930 en su contestación a la encuesta de La Gaceta Literaria, 1 jun. 1930: En la América hispanoparlante -no puedo prescindir de mi actual punto de mira-, y además de los naturales reflejos y secuencias de algunos de esos "ismos", que en cada país y en cada literatura se colorean con un acento particular, todavía podríamos apuntar otros. Así aquellos que, empero su oriundez local y su ahínco terruñero, recibieron en lo formal, como razón extrínseca de su nacimiento, el soplo vivificante de los modelos antedichos. Tales. el nativismo, el criollismo, con brotes un poco esparcidos por todo el Atlántico; y el indigenismo, el indoamericanismo, visibles en la banda del Pacífico, aunque estos últimos se hallen más bien cargados de intenciones ideológicas y políticas que literarias". [Citado por Buckley y Crispin, 1973: 409]
} 
En el mismo rumbo, sirve para pensar la discutida vanguardia española la esclarecedora vinculación de las vanguardias latinoamericanas con investigaciones de carácter antropológico, las cuales acompañaron con sus hallazgos las exploraciones artísticas y literarias; así sucedió en Cuba, donde los estudios afroantillanos de Fernando Ortiz nutrieron la poesía de Nicolás Guillén y despertaron el interés por el pasado en Alejo Carpentier. Del mismo modo, las investigaciones incaicas y preincaicas de los peruanos Julio Tello y Castro Pozo fueron venero de José María Arguedas, José Carlos Maríátegui y José Sabogal. La lista que proporciona Bosi observa hechos paralelos en México y Brasil, pero no es necesario continuar con los ejemplos para señalar que en España existieron asociaciones muy similares que no pasaron inadvertidas a la crítica, desde la del magisterio de carácter más familiar de Don Antonio Machado y Álvarez, adelantado rastreador de las tradiciones andaluzas, en sus hijos Manuel y Antonio, hasta la muy consolidada Institución Libre de Enseñanza, partícipe aventajada de un proyecto cultural renovado. Como bien ha señalado Andrés Soria Olmedo, el interés de la Institución por lo popular, manifiesto de forma brillante en los estudios realizados por el Centro de Estudios Históricos, subyace en un importante núcleo de la renovación poética del 27. Las rigurosas investigaciones llevadas a cabo para la recuperación del material lírico tradicional proporciona claves para comprender el neopopularismo de Alberti y Lorca. Aunque retomaré esta decisiva cuestión, es de subrayar la presencia de la escuela de Menéndez Pidal en la reelaboración de los materiales primitivos en la poesía albertiana, una forma de ir "a la tradición desde la modernidad", camino que recorre el poeta gaditano "realizando la 'parte estética' de esta operación de rescate de la literatura antigua que efectuaba la filología hispánica según las modernas y rigurosas técnicas francesas y alemanas". [Soria Olmedo, 1990: 114]

Similar confluencia de la indagación científica y la renovación creadora puede observarse en el interés por los poemas mayores de Góngora, por un lado icono de poetas y prosistas del 27, arma arrojadiza contra prácticas anquilosadas $^{3}$ y académicos intransigentes, pero al mismo tiempo, objeto de

\footnotetext{
${ }^{3}$ Ricardo Gullón menciona entre los poetas considerados caducos a Gabriel y Galán, Marquina y el último Villaespesa. V. nota 3, cap. 4.2.[Gullón, 1969: 134]
} 
concienzudos estudios, como son los de Dámaso Alonso, referencia obligada aún hoy para adentrarse en la poesía del autor de las Soledades.

De igual manera, se podrían extender a España las múltiples maneras con que las vanguardias asimilan y recrean la fascinación y el desgarro que la urbe moderna provoca en el habitante de las provincianas ciudades del ochocientos; como también fueron múltiples las maneras de incorporar el cimbronazo estético y moral que significó el surrealismo. Por último, es válida también la observación que cierra el prólogo a la obra de Schwartz: las vanguardias representaron un puente desde la libertad más completa hacia las muy diversas opciones individuales. Hispanoamérica -y España- comparte rasgos de algunos países europeos como Italia o Rusia, que pese a no destacar por su desarrollo industrial y tecnológico igualmente ocuparon un lugar preeminente en el arte de vanguardia y experimentaron la crisis de la modernidad en igual grado que las sociedades más desarrolladas, pues "el deseo ardiente de lo nuevo sería más fuerte que las condiciones objetivas de la modernidad". Del mismo modo, cabe señalar que no faltaron igualmente, momentos en que "la vanguardia, en lugar de lanzar pasajes, se apropia de las formas nuevas y las exalta en sí mismas, abstractamente. En lugar de puentes constituye molinos de letras y castillos de cartas". [Bosi, 1991: 18 y 24]

Pero no todos los expertos en el tema encuentran tan productiva la peculiar situación de los países periféricos. Eduardo Subirats cree que la distancia cultural del mundo hispanoamericano con la Europa hegemónica tiene consecuencias más negativas que favorables a la hora de valorar la aclimatación de las nuevas estéticas. Cree que en nuestro orbe cultural las vanguardias carecieron del carácter subversivo que impulsaba a los futuristas italianos, los expresionistas alemanes o los neoplasticistas holandeses, ansiosos por cambiar un orden opresivo y falso y crear un mundo desde cero. Al difundirse los valores estéticos y sociales de las vanguardias en las áreas político-geográficas rezagadas, los mismos contenidos adoptaron valores diferentes. Faltó el espíritu revolucionario y sobró una actitud dogmática que 
incorporó el programa vanguardista sin la carga crítica radical de los valores del mundo moderno en crisis.

\begin{abstract}
Por el contrario, a través de los exponentes del racionalismo y el purismo, la utopía de la modernidad artística llegó a las zonas no industriales como el fenómeno acabado y definido a priori de la civilización tecnológica a secas y de una modernidad vacía de contenidos sociales. [Subirats, 1991: 47]
\end{abstract}

No es el momento de polemizar con el filósofo español ni de examinar el reduccionismo y la excesiva generalización que puede encerrar el adjetivo epigónicos y pre-modernos para referirse a los movimientos vanguardistas en España y Latinoamérica, aún cuando sus afirmaciones encierren una gran cuota de verdad para algunos casos puntuales. Interesa subrayar sus ideas como anticipo de los problemas que se plantean al estudiar los ismos en los países tardíamente modernizados, y como contrapeso de la visión más matizada de especialistas del ámbito latinoamericano. A las ya reseñadas posiciones de Bosi y Schwartz, merece sumarse la de Noé Jitrik, cercana a la de los dos catedráticos de Sao Paulo.

Jitrik rechaza de plano tanto las dicotomías entre la mirada artística y la mirada política sobre la vanguardia, como las que oscilan entre el imposible vanguardismo de los países periféricos debido a su sometimiento cultural a las metrópolis europeas y la concesión de una originalidad categórica liberada del riesgo mimético por el solo hecho de surgir en un ámbito distinto, el latinoamericano. Acerca de la primera cuestión, aboga por una ampliación de la idea de politicidad, que se manifiesta en la expresión y en el enunciado, en múltiples planos y de diversas formas. En cuanto al segundo problema, propone indagar en dos direcciones: en la búsqueda de lo específico americano y en la determinación, en cada caso específico, de las posibles marcas propias y originales.

Se diría, en conclusión, que aún aceptando que hubo un sistema de préstamos e intercambios dictado, tanto para la vanguardia como para otras iniciativas de escritura, de enorme fuerza, mediante el análisis particular de los textos se pueden advertir inflexiones y vibraciones que remiten a una necesidad textual latinoamericana; necesidad condicionada desde luego pero en pugna, buscando y encontrando el punto y la ocasión para formularse con su propia 
lógica o, mejor dicho, con su propio sistema de producción de escritura. Mencionemos, para no dejar esta idea en el aire, por los menos a Lezama Lima, a Macedonio Fernández, a Borges. [Jitrik, 1995: 69]

El parecer de José del Pino va por similares caminos. En su estudio demuestra que en la narrativa española de vanguardia no estuvieron ausentes las principales motivaciones iconoclastas y fuertemente cuestionadoras del mundo heredado que movían a los artistas de los principales países europeos. Sin desconocer que a menudo detrás de los vanguardistas españoles, de sus gritos y proclamas antipasatistas se ocultaban jóvenes burgueses bien situados que no tardaron en volver a sus trabajos rentados y provechosos, o a custodiar el orden establecido desde el lugar que le asignaba su origen social, es posible constatar que no fueron ajenos al sentimiento de crisis resultante de la pérdida de la fe en los planes totalizadores.

Sin negar la existencia de un vanguardismo que se caracterizaba como pose, y si restar importancia tampoco al papel jugado por la moda en la formación y desarrollo del movimiento, quiero considerar esta postura como el síntoma inevitable de un malestar más profundo que existía en la base de la sociedad y de la cultura urbana de los años de entreguerras. [del Pino, 1995:3]

Sobre la extracción social y el buen pasar económico de los vanguardistas españoles han insistido mucho los críticos, pero en este terreno la generalización es nuevamente nociva. Es preciso tener en cuenta datos aportados por distintas fuentes y no caer en determinaciones mecánicas. En este sentido informa Castañar que "entre estas fechas [1925-1930] los jóvenes viven la literatura con una entrega romántica", y añade a continuación

En toda España surgen revistas literarias que, aunque de vida efímera, al hojearlas hoy, nos permiten ver el espíritu que animaba a los jóvenes de entonces. Los escritores madrileños, o afincados en Madrid, van a colaborar en la mayoría de ellas sin preocuparse de la recompensa económica que pudiesen recibir y no es porque no la necesitasen, pues junto a los hijos de una burguesía solvente están otros cuyas familias se hallan en línea descendente -las de R. Alberti, $\mathrm{F}$. Ayala- y también algunos que se encuentran en apuros -caso Jarnés- o en una penuria ostensible como sucede con Salazar y Chapela. [Castañar, 1992: 14-15] 
Ricardo Gullón, con una mirada que no ignora el marco social de los fenómenos estéticos, pero a la cual le atraen con exclusividad los aspectos formales y distintivos de la literatura, juzga de manera similar el contrapunto de la faz meramente imitativa de los ismos y la de adelantada en el espacio del arte.

\begin{abstract}
En esta esfera la crisis se presenta como ruptura, como diversificación polémica del concepto de poesía: los ismos se multiplican y contradicen, testimoniando abundancia de corrientes. Esta proliferación es beneficiosa. Cunden extravagancias, manierismos y simulaciones, pero la incesante búsqueda, el estimulante ardor por los descubrimientos, ensancha y profundiza el mundo poético. Notas nuevas se incorporan a la lírica, y entre ellas formas inéditas o renovadoras. [Gullón, 1969: 138]
\end{abstract}

\title{
1. 1. Breves CONSideraciones historiográficas
}

Hasta tiempos muy recientes, cuya fecha límite puede situarse en los años setenta, las vanguardias en España habían sido parcialmente estudiadas. En esa década críticos de literatura y de arte llaman la atención sobre tan ostensible hueco en la historia española del siglo XX. Varios son los motivos que confluyeron en la omisión y en distintas ocasiones nos detendremos en ellos.

En primer lugar, es preciso hacer una breve alusión a la singularidad que presenta el tránsito del siglo XIX al XX en España. En este sentido, es insoslayable conocer la ruptura estética e ideológica que supone el entresiglos, que como bien ha señalado Agustín Sánchez Vidal, en España se llamó y debe llamarse "Crisis de fin de siglo", pues la rezagada modernización española ensombrecía el balance de los procesos que habían marcado la centuria.

\footnotetext{
...se añade "crisis" a ese concepto de "fin de siglo". ¿Por qué? Quizá porque otros países como Francia o Alemania compartían la sensación de culminar las siembras de la revolución industrial o del Romanticismo, mientras que en España la dudosa industrialización hacía ver lo moderno como "crisis" y conflicto. [Sánchez Vidal, 1999: 342]
} 
No es posible realizar aquí un examen estricto y pormenorizado del entresiglos hispánico y de su deslucida y cuestionada modernidad ${ }^{4}$. De la misma manera, deslindaré la célebre controversia autóctona entre Modernismo y 98, disputa que por otro lado ya ha sido analizada y superada tanto a través de conocidas polémicas como de enfoques teóricos debidamente actualizados $^{5}$. Finalmente, no es cometido de esta investigación, reiterar la conocida cronología de las vanguardias en España, para lo cual se remite a la copiosa bibliografía especializada ${ }^{6}$. Las distintas incursiones en problemas que atañen al fin de siglo o a la introducción y primeras manifestaciones vanguardistas estarán sujetas a la necesidad de conectarlos con los autores y período objeto de atención.

Es frecuente encontrar todavía hoy en los libros que el término vanguardia se utiliza con especial significación para dos movimientos exclusivamente literarios acotados en el tiempo, el Ultraísmo y el Creacionismo. En ocasiones, se encuentra también aplicado a la obra y trayectoria de Ramón Gómez de la Serna. Salvo excepciones, se podía observar también una general tendencia a parcelar el fenómeno por artes y disciplinas, con el

\footnotetext{
${ }^{4}$ Es interesante rescatar un comentario de Manuel Bonet cuando expone el segundo de los tres obstáculos con que topó para elaborar su diccionario: "La segunda [dificultad], lo difícil que es precisar el concepto de vanguardia, y más en un país como España, donde muchos que se acercaron a 'esa dama incierta y misteriosa que tiene por nombre modernidad', como la llamó Enrique Díez-Canedo, huyeron despavoridos a la primera de cambio" [Bonet, 1995: 13]

5 Destaco algunos autores que han intervenido en el célebre contencioso añadiendo perspectivas renovadas: Gullón, Ricardo, 1971; 1979; Ramos Gascón, Antonio, 1989, Tomás, 1998-2000, Ridao, 2000; Bozal, 2002.

${ }^{6}$ Los estudios especializados aceptan la siguiente cronología de la vanguardia literaria en España (se excluye la vanguardia en Cataluña por presentar un perfil propio y diferenciado): primera etapa: en 1909 Ramón Gómez de la Serna publica en su revista Prometeo (1908-1912) su "Concepto de la nueva literatura" y traduce el "Manifiesto futurista" de Marinetti. En 1910, también en Prometeo aparece la "Proclama futurista a los españoles". En 1914 Gómez de la Serna inaugura la tertulia del Pombo y de 1915 son sus primeras greguerías. Segunda etapa: en 1918 Vicente Huidobro publica en Madrid el manifiesto del Creacionismo Ultraísmo. En 1918 Rafael Cansinos-Assens funda el Ultraísmo, secundado por Guillermo de Torre. El movimiento se prolonga hasta 1925. Tercera etapa: Guillermo de Torre publica Literaturas europeas de vanguardia, José Ortega y Gasset La deshumanización del arte y Rafael Alberti y Gerardo Diego reciben el Premio Nacional de Literatura. En 1927 un grupo de poetas realiza un homenaje a Góngora en el trescientos aniversario de su muerte dando origen al nombre de una generación literaria. En 1929 el ímpetu del surrealismo y la creciente influencia de la literatura con función social provocan un giro al arte "deshumanizado" de la vanguardia. En $1930 \mathrm{El}$ nuevo romanticismo ("polémica de arte, política y literatura") de José Díaz Fernández y la encuesta aparecida en La Gaceta Literaria certifican el cambio de rumbo estético que se consolidará con el advenimiento de la II República en 1931. Cuarta etapa: desde 1931 a 1936 los ismos y el arte social se acercan y generan una nueva concepción de la vanguardia.
} 
subsiguiente velamiento de un fenómeno de amplio espectro y repercusión en todos los ámbitos de la cultura y, por otra parte, índice de un proceso modernizador que es preciso no dejar de lado y analizar desde diversas áreas. Hoy existen acercamientos renovados al problema y diferentes explicaciones para los insuficientes tratamientos anteriores.

El prólogo de Guillermo de Osma al Diccionario de las vanguardias en España: 1907-1936 da cuenta de la deuda que hasta hace pocos años tenían los estudios históricos y críticos con un período sin el cual no es posible comprender justamente el desarrollo del arte y de la literatura españoles del siglo $\mathrm{XX}$.

\begin{abstract}
La época que abarca este diccionario -los años de la vanguardia histórica- fue uno de los momentos más extraordinarios, brillantes e intensos de la cultura española. En todas las facetas de la vida artística hubo aportaciones relevantes e innovadoras: en la literatura, en la arquitectura, en el diseño, en la pintura, en la escultura, en la música y en el cine. La actividad que desarrollaron los creadores, poetas y críticos fue sorprendente y con una gran relación entre sí. [Osma, 1995:9]
\end{abstract}

Al hacer referencia al cambio decisivo del interés de la crítica por las vanguardias históricas en España, el especialista en arte esboza algunas causas del prolongado silenciamiento que merecen tenerse en cuenta, pero adolece su hipótesis de una velada condena a la politización de las posturas artísticas de los protagonistas, cuando desde la perspectiva que me interesa, el problema es cómo introducir la política sin reproducir los mismos antagonismos y parcelamientos de la crítica.

Sorprendentemente, nuestro conocimiento de este periodo es todavía
limitado y parcial. Creo que las razones más importantes para esta
injusta laguna radica, en primer lugar, en el proceso de politización de
las posturas artísticas de los propios protagonistas de esta época que
se inicia en los años inmediatos al estallido de la guerra civil,
radicalizándose inevitablemente durante el conflicto. La desaparición
violenta de muchos de los actores, en uno y otro campo, unido al
exilio forzoso de un bando y al silencio de la postguerra, han
resultado en un vacío importante de nuestra memoria histórica.
[Osma, 1995: 9]

Intentos similares de aislar los aspectos formales de los políticos de la vanguardia proliferan en numerosos artículos sobre la vanguardia, tendencia a 
compartimentar de fuerte raigambre en la crítica hispánica. En un estudio sobre Giménez Caballero, paradigma de figura de artista conflictivo por su explícito apoyo y activa militancia fascista, Miguel Corella demuestra el alto grado de voluntarismo teórico de los análisis basados en una supuesta pureza o asepsia de los postulados vanguardistas, que los harían refractarios a toda contaminación política, más aún si es de derechas. De esta manera, asistimos a un fenómeno inverso al que durante mucho tiempo mantuvo en el ostracismo al arte nuevo, pero igualmente pernicioso para un acercamiento no parcializado: la reparación del silencio de las historias del arte viene acompañada de una visión idealizada y teñida de torremarfilismo que ve en las vanguardias el modelo del arte reconcentrado sobre sí mismo, o, si prefieren una visión sociológica, identifican vanguardia con el pensamiento y la cultura de izquierdas.

\begin{abstract}
... Cabe preguntarse si existió algún movimiento de vanguardia que no intentara implantar subterráneamente cierta ideología política disfrazada de modernidad cultural. Frente a las interpretaciones formalistas de la vanguardia, que circunscriben el ámbito de sus intenciones al de las formas puras, cabe pensar que, incluso en sus expresiones más puristas como el cubismo o la abstracción lírica, y desde luego, en las versiones más abiertamente politizadas como el futurismo, hubo siempre una intencionalidad antiburguesa y antiliberal de claro sentido político. Pero, por otra parte, tampoco podemos compartir el supuesto (...) de que la vanguardia toda estuviera necesariamente unida al progresismo. Es un hecho que el espíritu revolucionario del arte nuevo fue compatible con un abierto conservadurismo político, como en el caso de buena parte de la poesía modernista angloamericana o en el fascismo italiano. Tampoco es cierta la tesis que identifica el autoritarismo político europeo de la primera mitad del siglo con las formas de legitimación cultural tradicionalista, pues, si existió un Rosemberg que legitimaba el régimen nazi en la tradición secular alemana, existió un Goebbels que quiso hacerlo compatible con la pintura expresionista o con la arquitectura funcionalista. [Corella, 2000: 128-129]
\end{abstract}

Otras razones del silencio crítico sobre las vanguardias se debieron a la intransigencia con que fueron tratadas por la historiografía literaria del régimen franquista, como bien señala Jaime Brihuega en sus dos fundamentales estudios. En la posguerra, sobre todo en la primera época, quienes dominaron el campo de la los estudios literarios y el de la historia del arte provenían de los

\footnotetext{
${ }^{7}$ En la misma línea de reflexión deben ubicarse las polémicas generadas por las nuevas aproximaciones a la figura de Leni Riefenstahl, la fotógrafa y cineasta alemana que en los años treinta revolucionó la estética cinematográfica a la vez que colaboraba en la sacralización mediática de la imagen de Hitler.
} 
sectores más reacios a la vanguardia y continuando con el desmantelamiento oficial de los fecundos procesos culturales de entreguerras, impusieron prácticas críticas asépticas y paradigmas deudores de un pasado cristalizado en las épocas doradas del imperio. En 1982, Brihuega responsabiliza a los voceros culturales del franquismo de ser causa del escandaloso desconocimiento de las vanguardias, pues

\begin{abstract}
..."lo moderno", aun en toda la imprecisión del concepto, quedó tan sistemáticamente marginado como lo fue (en algún sitio se ha dicho hace poco) Voltaire de nuestros bachilleratos. Esta razón simplista y casi panfletaria nos tienta porque, en el fondo, sabemos que toca de lleno el verdadero origen de una cadena de relaciones causa-efecto que han acabado por desembocar en la actual situación de pobreza historiográfica. [Brihuega, 1982: 13]
\end{abstract}

Un juicio más duro y punzante sostiene Domingo Ródenas de Moya, quien en su búsqueda de las razones del olvido en que se encontró durante mucho tiempo la narrativa de vanguardia, considera que el mismo grado de responsabilidad tienen los novelistas y críticos adeptos al régimen instaurado después de la guerra civil como los opositores que desaprobaban toda expresión alejada del camino trazado por el realismo testimonial.

\begin{abstract}
Unos y otros preconizaban un modelo narrativo realista, los primeros sacando a relucir la prosapia española del noble costumbrismo, los segundos enarbolando la bandera del engagement y el socialrealismo (...) Para los críticos orgánicos (o simplemente ronceros), la desviación estética de la genuina tradición española se veía agravada por la simpatía o el abierto compromiso republicano de los narradores nuevos (hechas excepciones con Ximénez de Sandoval, Giménez Caballero, Samuel Ros o Antonio de Obregón); para los críticos resistencialistas, los jóvenes escritores, sobre su falta de responsabilidad social por no testimoniar en sus obras la España problemática de la Dictadura y la República, cargaban con una falta mayor, la de representar una facción artística casquivana, pueril, eutrapélica y minoritaria frente a la facción lúcida, madura proletaria de los narradores sociales. El ostracismo de la novela española de vanguardia contiene, pues, en su decreto las firmas de tirios y troyanos; de ahí su letal eficacia. ${ }^{8}$ [Ródenas de Moya, 1998: 19]
\end{abstract}

También José del Pino hace referencia a la relectura y recuperación de autores poco estimados y a los nuevos enfoques críticos que permiten que la

${ }^{8}$ Todos los subrayados son del autor. 
narrativa de vanguardia haya ido adquiriendo un interés impensable en las décadas anteriores. [del Pino, 1995: xi]

En los años ochenta Gustav Siebenmann delineó una hipótesis sobre el perfil específico y diferenciador de la vanguardia en el campo de las literaturas hispánicas a partir de describir la suerte del vocablo en el ámbito señalado. Comienza haciendo un rastreo del término vanguardia, retrotrayéndose al siglo $\mathrm{XIX}$, y comprueba que no fue usado por los propios introductores de los ismos, como Gómez de la Serna por ejemplo. Registra la primera aparición del vocablo en un poema publicado en Grecia $^{9}$ en 1919; a partir de entones crece el uso de "vanguardia", sobre todo después que en 1920 Guillermo de Torre lo emplea en su "Manifiesto Vertical". Terminará imponiéndose definitivamente con la publicación, en 1925, de Literaturas europeas de vanguardia del mismo deTorre, pero siempre con la acepción de síntesis de los movimientos europeos. Desde entonces, se utiliza para designar a los ismos surgidos hacia 1920, y en especial al Ultraísmo y al Creacionismo.

El aspecto más problemático de la hipótesis de Siebenmann es la rígida diferenciación de las vanguardias del mundo hispanoamericano con respecto a las del resto de Europa, basada en el interés puramente estético de las vanguardias de España y Latinoamérica.

Como rasgo distintivo entre el mundo hispánico y las demás culturas, me parece que se puede afirmar que en aquél el término y los movimientos de vanguardia nunca han sido políticos sino más bien estéticos. [Siebenmann, 1984: (en Rico, 1995:181)]

La tesis adquiere una especial dimensión porque casi veinte años después de su primera publicación en 1984, el trabajo de Siebenmann abre el capítulo sobre la vanguardia en una historia literaria especialmente influyente como es la dirigida por Francisco Rico ${ }^{10}$. Tal recuperación antológica pone de

${ }^{9}$ Grecia (1918-1920), dirigida por Isaac del Vando Villar, fue una de las revistas sobresalientes de las llamadas vanguardistas. Se publicó en Sevilla hasta 1920 y luego en Madrid. Llegaron a salir cincuenta números. Fue la principal plataforma del ultraísmo y se abrió también a las novedades cubistas y dadaístas, a las letras francesas y, de la mano de Borges, al expresionismo alemán.

${ }^{10}$ Sobre la Historia y crítica de la literatura española Lia Schwartz ha dicho "El análisis de los tomos II y III de la ya citada HCLE, dirigida por Francisco Rico, por ejemplo, puede servir de modelo de lo que parece constituir el canon en estos momentos, un canon que no es temporal sino constitutivo de nuestra coyuntura histórica. "Siglos de Oro; cánones, repertorios, catálogos 
manifiesto que si bien se acepta que la literatura española no estuvo al margen de las corrientes del arte moderno del resto de Europa, se insiste en otorgarle un carácter decididamente atípico, con lo cual no se consigue valorar las señas particulares del fenómeno sino sólo reincidir en la búsqueda de la diferencia que hará perdurar la insularidad de España, o desde otro punto de vista, legitimar los lineamientos críticos que restringen su mirada a las cuestiones formales.

No obstante, al rayar el nuevo siglo, el campo de conocimiento sobre las vanguardias españolas se ha expandido de un forma notable, hasta el punto que el ingente material disponible sobre el tema vuelve más que justificados, imprescindibles, los diccionarios, las bibliografías sumarias y las compilaciones críticas como la publicada por Haral Wentzlaff-Eggebert,

Un breve repaso al estado de la cuestión nos informa igualmente que se han cubierto con creces los vacíos sobre la literatura y el arte de vanguardia y que el tema sigue concitando atracción y originando polémicas. Se puede constatar, por último, que se ha llegado a un nuevo punto de inflexión, en que, pasado el momento de eclipse e ignorancia de las vanguardias, comienzan a levantarse voces críticas. Se puede afirmar sin temor a errar que pese a las duras apreciaciones de Ródenas de Moya o las más tenues de Bonet, ya no tiene lugar la usual condena al esteticismo de la vanguardia que señalara Noé Jitrik:

\footnotetext{
Hay que admitir, también, que la polarización es usual y se presenta con frecuencia en términos valorativos: la opción "política" es enaltecida, la opción "artística" es escarnecida o retaceada. [Jitrik, 1995: 60]
}

Por el contrario, se puede observar el notorio descrédito de las opciones que llevaron a los vanguardistas a abrazar un arte más "situado" a finales de los añis veinte. En ocasiones, se atenúa la condena porque las obras resultantes del cambio de rumbo, como El blocao de Díaz Fernández, aún se benefician de los ecos y el virtuosismo vanguardistas que las vuelven más estimables. Curiosamente, pocas veces un crítico afirma lo contrario, que las obras de vanguardia se enriquecen con el aporte de siglos de tradición mimética y representativa. 
Frente a este juicio que goza de prestigio incontestable en el centro del sistema, algunas voces abogan por volver a integrar los aspectos políticos e ideológicos a menudo silenciados o rehusados en las aproximaciones vindicatorias de índole formal, que recortan el objeto de estudio dejando de lado un contexto histórico y social excepcional y de especial repercusión en los países de Occidente, como fue el que rodeó a la II República española y a la guerra civil de 1936-1939.

Como índice de la pervivencia del tema y de los debates que todavía suscita, es ilustrativa la visión de Francisco Caudet, quien si bien no se manifiesta contrario a ampliar los estudios existentes, es decididamente inflexible en su juicio acerca de la naturaleza pequeño burguesa de los ismos, de su manifiesta indiferencia hacia los problemas del pueblo español y del carácter elitista y minoritario de su proyecto creador. La tesis de Caudet ampliamente fundamentada con material bibliográfico y de archivo- parte del debate entre Lukács y Adorno y se afirma en la diferencia no sólo estética sino ideológica del realismo y el vanguardismo. El comienzo de Las cenizas del Fénix, su libro dedicado a la cultura española de los veinte y treinta, no deja dudas sobre su visión del arte nuevo.

Finalizada la primera guerra mundial se intensificó en Europa la proliferación de los movimientos de vanguardia. Los caracterizó un experimentalismo que pretendía imponer, rompiendo con las estéticas hasta entonces vigentes, una nueva sensibilidad. Grupúsculos de artistas y escritores, apiñados en torno a revistas de corta tirada y de exigua duración, lanzaron ininterrumpidamente manifiestos y proclamas que eran erigidos en efímeros cánones artísticos (...) España se sumó, de manera mimética, a la corriente vanguardista y tuvo su ultraísmo, su creacionismo, su dadaísmo, su futurismo, su surrealismo.

Esa moda, que sin duda respondía a menudo a unas auténticas exigencias de encontrar, agotados los viejos modelos, nuevas formas de expresión artística, partía de criterios minoritarios y elitistas. Su radio de acción estaba limitado a planteamientos que reducía el arte a la forma, y su público, a un estrecho círculo de iniciados. [Caudet, 1993: 17, 18]

Otras voces revisan el periodo poniendo el énfasis en la denominada dictadura estética de las vanguardias. Llaman la atención en que el arte moderno por excelencia estuvo invariablemente acompañado de la imposición de una única dirección estética y de la consecuente exclusión de otros rumbos, sea en el 
arte, la novela o la poesía. De esta índole son las objeciones ya expuestas de Oleza, a las que pueden añadirse las más puntuales y dirigidas de Facundo Tomás, quien al artista de vanguardia con el intelectual y con los hombres del 98, en tanto exponentes de un grupo social que a fines del siglo XIX se considera instalado en un lugar superior con respecto al pueblo, a quien explícita o veladamente, desdeñaba. Las críticas de Tomás ponen el acento en el alejamiento del arte moderno del gusto popular, en el sacrificio de los aspectos sentimentales de las obras, en la clausura de la comunicación subjetiva del receptor con el objeto artístico, el privilegio del componente intelectual en desmedro de lo sensorial ante los fenómenos estéticos; en resumidas cuentas, la fractura insalvable entre arte y vida.

\begin{abstract}
El siglo XX es la centuria de las vanguardias, que impondrán su punto de vista, hegemonizando al conjunto de la cultura. Nunca en la historia como en el siglo XX ciertos artistas y escritores llegaron a separarse tanto del resto de la sociedad, constituyendo un grupo aparte no sólo por su conciencia, sino también porque sus obras prescindieron del "gusto popular" desplazándose del "relato" hacia el "metarrelato", segregándose así del sentir cotidiano. La sustancia de radicalidad de las vanguardias las marginará absolutamente del gusto del gran público, como bien constató Ortega. [Tomás, 1998, Cátedra: $32,33]$
\end{abstract}

Se puede añadir que la dicotomía se volvió a instalar cuando se inició en España el levantamiento del interdicto sobre las vanguardias hacia finales de los años sesenta. La rehabilitación de los ismos coincide con el triunfo de la posvanguardia y la desvalorización terminante de la novela social de posguerra por los nuevos detentadores de la hegemonía en el campo, que convirtieron al realismo en "un cadáver sobre el que se cebaban todos aquellos interesados en sepultar bajo siente piedras lo que de crítico -léase compromiso socialhabía tenido aquel movimiento" según palabras de Constantino Bértolo [1989: 38-39] La sintonía entre crítica y creación, entre pensamiento y estética se puso de manifiesto una vez más a finales del siglo $X X$, cuando las perspectivas críticas sobre las vanguardias fue acompañada -¿o precedida?- por la revalorización de las estéticas que estas condenaron al ostracismo ${ }^{11}$.

\footnotetext{
${ }^{11}$ Sobre este punto, aunque no es posible describir el fenómeno en todas sus dimensiones, es preciso recordar que la recuperación de las vanguardias como objeto de estudio no está desvinculada de la imposición de un nuevo canon en la lírica y la narrativa de los años setenta, que optó por la exploración formal y la experimentación, dando la espalda, con agravio
} 
Desde diferente ángulo de la reflexión debe añadirse otras razones que inciden en la pervivencia del significado y en el reclamo del referente en la centuria dominada por la primacía de la forma. Desde la antigüedad las convenciones de la representación desempeñaron un papel decisivo lograr una explicación del mundo cercano. En el mismo sentido, son hoy numerosos los razonamientos teóricos sobre la función representativa del lenguaje -a la cual la literatura no es ajena- y entre esas funciones, una de las principales ha sido la representación de lo real inmediato ${ }^{12}$.

\subsection{LA BOHEMIA, VÍNCULO ENTRE dOS MUNDOS}

Ya hemos visto que no es fácil señalar con absoluto rigor el inicio de los debates acerca de la función de la literatura y el papel que debía jugar el escritor en su realidad inmediata. Sin duda existieron factores que despertaron las inquietudes de los escritores hacia fórmulas de mayor compromiso con la realidad social y un papel más activo en la esfera pública. En esta dirección, tuvieron especial incidencia las prédicas de Fourier y Saint-Simon que se comienzan a difundirse en España. Otro foco de reflexión y cambio de la

incluido-como es bien sabido, la novela social fue bautizada como "literatura de la berza"- a las tendencias ligadas al realismo y al testimonio que habían prevalecido durante las dos primeras décadas de la posguerra. Esa circunstancia anima a uno de los estudios pioneros: "Tal vez no sea demasiado aventurado -o profético- ver en la prosa de vanguardia paralelos con la literatura actual (...) Desde luego abundan las diferencias entre las dos épocas, pero es en cierto modo la creencia de que vivimos un momento estético y literario que recuerda y repite algunas de las experiencias de los años veinte lo que nos ha animado a componer la presente antología". [Buckley y Crispin, 1973: 14-15]

${ }^{12}$ Vale la pena introducir como un elemento más a considerar la hipótesis de Tom Wolfe sobre las causas de la aparición del género denominado no ficción y nuevo periodismo, pues presenta puntos comunes con los debates planteados en los años treinta: "El argumento [para desestimar el relato realista] consistía en que tales novelas eran un producto de la ascensión de la burguesía en el siglo XIX a la cumbre del capitalismo. Pero ahora la sociedad burguesa se estaba fragmentando, desintegrando. Un novelista ya no puede retratar una parte de esa sociedad en la confianza de captar el Zeitgeist; todo lo que le quedaría es una de las piezas rotas. (...) Todos aquellos escritores cobijados en los pubs literarios de Nueva York (...) se precipitaron a escribir novelas de todas las clases que quepa imaginar, con tal de que no fuese la llamada "gran novela" de costumbres y sociedad. Lo siguiente que se supo es que se metieron en novelas de ideas, novelas freudianas, novelas surrealistas ("comedia negra"), novelas kafkianas, y más recientemente, la novela catatónica o novela de la inmovilidad..." [Wolfe: 1988, 46-47] Semejante interés por dar cuenta de la intensa agitación social puede constatarse en los escritores a finales de la dictadura de Primo de Rivera, en 1930. 
función social del escritor surge con la irrupción de la literatura de folletín y las novelas por entregas, que bajo las intrigas sentimentales o aventureras introducen la defensa de las clases postergadas y difunden ideas revolucionarias o progresistas. Al mismo tiempo, la izquierda representada por el anarquismo y el comunismo se entrega a la discusión sobre la función del arte. Según sostiene Salaün [1998], como las cuestiones estéticas eran consideradas secundarias, no se realizó un intercambio de ideas riguroso desde un marco teórico inicial que facilite hoy reconstruir la génesis última del arte comprometido. Los escritores o artistas disponían de un vasto material no sistematizado, suministrado por un gran despliegue editorial y por las tertulias y ateneos, con singular peso y dinamismo en la España que va de entresiglos hasta la guerra civil. [Castañar, 1992, 107-122]

Otros antecedentes del resurgir de la novela social en la España de los años veinte se encuentran en las concepciones artísticas de los escritores opuestos a la burguesía, a la Academia y a las instituciones hegemónicas en el siglo XIX. Heredera directa de la bohemia francesa, surge en Madrid una poco estudiada atmósfera literaria bohemia ${ }^{13}$. La bohemia francesa en los años de la Comuna ya había dejado de ser la bohemia dorada que había nacido con los románticos rebeldes e individualistas y se había convertido en la denominada "bohemia negra", compuesta por un "proletariado intelectual", socialmente mucho más marginado, militante en política e ideológicamente jacobino. Se produce con este grupo un confrontación manifiesta con la burguesía, que ve en ellos a enemigos, irreductibles, agresivos y radicalizados, amenaza constante de sus valores y códigos morales.

He mencionado en páginas anteriores la esencial vinculación de los fenómenos antiburgueses de la época del Segundo Imperio con la aparición de la modernidad estética y las vanguardias. Interesa en el presente capítulo señalar que así como entre los grupos bohemios se robustece una actitud

\footnotetext{
${ }^{13}$ Aznar Soler proporciona una ajustada caracterización de bohemia francesa sobre la base del tratado de Murger, 1848?, Escenas de la vida bohemia. Encuentra su origen en el romanticismo rebelde e individualista que se siente distante de la burguesía. Murger establece los cuatro grupos: la bohemia dorada, de filiación romántica que surge entre 1820 y 1840 , junto a esta, la bohemia ignorada, reductos de artistas pobres, bien auténticos u oportunistas; bohemia de aficionados, compuesta por burgueses, transitoriamente atraídos por las formas de vida marginales, la bohemia oficial, integrada por los artistas que realmente triunfan. [Aznar Soler, 1980: 75-76.]
} 
esteticista, partidaria del arte por el arte y enemiga acérrima de la mercantilización del arte ${ }^{14}$; al mismo tiempo la bohemia marginal simpatizante del anarquismo alberga a grupos con una clara predilección por el realismo en arte y literatura.

En España la protesta bohemia se dirige contra la sociedad de la Restauración, contra el canovismo, la oligarquía, el caciquismo y la corrupción. sin embargo, existe disparidad a la hora de establecer las predilecciones estéticas; Aznar Soler no duda de que la mayoría defiende una concepción aristocrática, partidaria del arte por el arte

\begin{abstract}
Pero fundamentalmente el escritor bohemio eleva su protesta contra la sociedad burguesa a través de su rebeldía estética y de su decidida ruptura con la expresión realista que caracterizaba el gusto pequeñoburgués del filisteo decimonónico. Los escritores bohemios, aristócratas del arte, románticos rebeldes, individualistas anarquizantes, imponen el gusto "modernista" y la concepción del "arte por el arte". Despreciando tanto el gusto burgués como el proletario, atacan la valoración social del arte que defienden los críticos literarios anarquistas (Federico Urales) o socialistas (Verdes Montenegro). Para ellos bohemia es sinónimo de "modernismo" artístico, de simbolismo poético, de decadentismo literario. [Aznar Soler, 1980; 81]
\end{abstract}

Para Antonio Ramos Gascón en cambio, las fronteras entre las distintas concepciones del arte son más borrosas y lábiles. En primer lugar advierte sobre la necesidad de distinguir un segundo naturalismo en España, con un sustento ideológico muy diferente del que impusiera su primera y principal representante Emilia Pardo Bazán ${ }^{15}$ e impulsado por un grupo denominado "gente nueva", simpatizantes del anarquismo y admiradores de lbsen, el último Zola, Björnson y Hauptmann. Tanto en el género dramático como en el lírico, cultivan una literatura impregnada de moral antiburguesa y de preocupaciones

\footnotetext{
14 "La verdadera vida bohemia no es una forma de vida, forzosa en la mayoría y caracterizada por una extrema penuria, sino una manera de ser artista, una condición espiritual sellada por el aristocratismo de la inteligencia. La vida bohemia se asume porque para el artista bohemio no hay arte sin dolor, o como decía Baudelaire, arte equivale a malheur. La verdadera bohemia se vive, por tanto, como experiencia de libertad en el seno de una sociedad voluntariamente marginal, en donde el tiempo no es oro, sino ocio artístico, alcohol, búsqueda de paraísos artificiales, de alucinaciones mágicas, de belleza y "falso azul nocturno". [Aznar Soler, 1980; 78] ${ }^{15}$ El Naturalismo en España se combina con el ideario católico y conservador de su principal exponente, la Condesa Doña Emilia Pardo Bazán, dando lugar a la sorpresa del propio Émile Zola y originando numerosos debates aún abiertos. Para mayor información, v. Oleza, 1984 y Caudet, 1995.
} 
sociales que no estaban divorciadas de las tendencias estetizantes del modernismo; aún más, en numerosas ocasiones, un mismo poeta cultivaba ambas estéticas. La crítica posterior, imbuida de la dicotomía entre vanguardia y realismo testimonial, ha desconocido la intercomunicación entre las dos tendencias estéticas; mantener la tesis de su absoluta enemistad es tan erróneo como alimentar el litigio Modernismo y $98^{16}$. La poesía social de Juan Ramón Jiménez y de Ramiro de Maeztu, la inclusión de D' Annunzio en un semanario republicano sociológico como Germinal y en la propuesta cultural de conocidos socialistas son algunos de los ejemplos que demuestran el diálogo entre esteticismo y arte con función social.

Nosotros vemos en la coexistencia de ambas formas de expresión estética una manifestación más de la estrecha relación entre ellas, determinada por su común carácter innovador dentro de la literatura y su parecida significación social de índole rebelde. (...) Realismo crítico y vanguardismo literario no se presentaron como contradictorios para la "gente nueva", sino como doble actividad necesaria en la lucha por un cambio de la sociedad establecida, incluyendo sus valores y concepciones estéticas. [Ramos Gascón, 1975: 137]

Los estudios más recientes se inclinan por la segunda perspectiva, ya que demuestran que en el Madrid inclemente y hambriento del pasado entresiglos, la bohemia pura, defensora del arte por el arte y profundamente crítica con la sociedad burguesa de los filisteos, tiende un hilo conductor muy claro, tanto con los presupuestos estéticos e ideológicos que sustentan los modernistas como con los movimientos rebeldes detractores de la mediocridad política reinante.

\begin{abstract}
Era el proletariado intelectual. Era la lucha de unos jóvenes que intentaban, una vez más en la historia de España, propagar las ideas nuevas y terminar con la vieja España, ajustando sus cuentas con la Restauración de Cánovas, que por aquellas fechas se había convertido en una caricatura de sí mismo. Era, en fin, la guerra, la eterna guerra entre lo viejo y lo nuevo, que representaban dos revistas literarias en lucha a muerte: Gente Vieja, que agrupaba a los que defendían el viejo orden cultural, y Vida Nueva, que pretendía arrollar ese más bien desorden. [Esteban y Zahareas, 1988:10]
\end{abstract}

\footnotetext{
${ }^{16}$ Recuérdese que este crítico tiene una importante tesis sobre la construcción de la catergoría "generación del 98". [Ramos Gascón, 1989]
} 
Por otra parte, las inquietudes artísticas y antiburguesas se nutrían igualmente de difusos o meditados credos revolucionarios anarquistas, sin que faltaran vínculos con la acción directa y las ofensivas, no sólo simbólicas, contra el orden burgués.

\footnotetext{
Y es también cuando el anarquismo (bohemia=anarquismo, se ha escrito) hace sus estragos, y a él se suman el joven Azorín con su paraguas rojos y el joven Camba, apresado por su amistad con Mateo Morral, que ha arrojado una bomba a Alfonso XIII, y al que todos van a ver después de su suicidio y al que Ricardo Baroja hace una mascarilla hoy perdida. [Esteban y Zahareas, 1988:11]
}

De la vinculaciones entre artistas marginales y conspiradores, a las que se incorpora la evasión por vía contemplativa, surgen los muy citados aunque poco conocidos relatos místico religiosos sobre la lucha proletaria, en las que Cristo aparece retratado como trabajador socialista, amigo de obreros y bohemios perseguidos por el cruel capitalismo.

Entre los escritores que no pertenecían al anillo excluido de la bohemia, Valle Inclán representa la figura que mejor traza la mutua influencia entre los ámbitos políticos y artísticos, marginales y canonizados, que sin solución de continuidad, alimentarán cambios y transformaciones estéticas durante cuatro décadas. El conocimiento de esta abigarrada trama resulta al presente muy valiosa para explicar procesos que no se alimentaron solamente de los materiales de la alta cultura.

El autor de las Sonatas es un casi solitario nexo entre la bohemia inadaptada y maldita y las letras consagradas, erigiéndose él mismo en desafiante emisario, indigente y aristocrático, durante los años triunfales del modernismo. Para esta investigación, interesa subrayar especialmente la función modélica que el autor gallego juega a finales de los años veinte para los escritores que luchan por la conciliación de un arte exigente y innovador que al mismo tiempo no renuncie a ser partícipe de la conflictiva y cambiante realidad cotidiana. El esperpento es uno de los géneros que proporcionará un camino, aunque quisiera anticipar que la ruptura con el público minoritario es quizás más una expresión de deseos que una auténtica realidad. Los 
Esperpentos representan un renovación estética y un acercamiento a la realidad cotidiana, pero no dejan de constituir una literatura para pocos.

Los jóvenes que quieren dar una dimensión social a su creación novelesca encuentran en las palabras y en la obra de Valle-Inclán el camino a seguir. Sus esperpentos teatrales y, sobre todo, los narrativos convierten a Valle en un "caso clarísimo de auténtica vanguardia", en expresión de J. Zugazagoitia; aunque su denuncia se centra en los amenes del reinado isabelino era fácil encontrar concomitancias entre la sociedad que aparecía en sus novelas y los acontecimientos políticos que se vivían en aquellas fechas. En El ruedo ibérico había, por un lado, una crítica demoledora de la vieja aristocracia y, por otro, un arte novísimo tanto en la concepción como en la forma de expresar el contenido. [Castañar, 1992: 51] 
(Continúa el Cap. III)

\section{La vanguardia según Ortega}

\subsection{El CENTRO del CAMpo intelectual}

El nombre de José Ortega y Gasset es una cita obligada en todo estudio sobre la vanguardia española en particular y sobre la vanguardia en general. Con independencia de sus oportunas observaciones sobre la literatura y el arte de su tiempo, debe analizarse hasta qué punto su influyente pensamiento, prolongado durante todo el siglo con un alto grado de veneración en las historiografías más orgánicas, no convirtieron la obra y las reflexiones del filósofo en una sinécdoque de la vanguardia española; es decir, en qué medida aún hoy la evaluación y los alcances de los ismos se estiman según la mirada de Ortega, tanto para elogiarlos como para enjuiciarlos negativamente. También sería el responsable de la orientación formalista de los estudios de los ismos.

\footnotetext{
Prevalecen dos tradiciones críticas sobre la vanguardia. La primera (y la que ha predominado) entiende la vanguardia principalmente como una revolución lingüística y estilística. Arranca con La deshumanización del arte de Ortega. Su ensayo, descriptivo en un principio, se convirtió en seguida en codificación prescriptiva de la producción vanguardista. A partir de los postulados orteguianos se planteaba como valor positivo una radical separación entre arte y literatura, desterrando del arte toda preocupación extrapoética. (...) Renato Poggioli recoge, en su excelente Teoría de al vanguardia [sic], los mismos planteamientos ${ }^{1}$. [Geist, 1993: 54-55]
}

En sentido contrario al reconocimiento de su papel tutelar, es importante estar alerta ante el frecuente desmerecimiento de las reflexiones del filósofo sobre la vanguardia debido a impugnaciones de índole ideológica. Aspiro, de alguna manera, a ver la mutua interrelación de ambos aspectos.

Las razones de la simbiosis del pensamiento orteguiano y los estudios posteriores son altamente justificadas, pues el filósofo ocupó un lugar central y preeminente en el campo intelectual español durante la primera mitad del siglo $X X$, prolongándose incluso después de su controvertido exilio tras la guerra civil

\footnotetext{
${ }^{1}$ Subrayado del autor
} 
y a pesar del polémico regreso a España en $1945^{2}$. En el largo período en que su nombre connotaba prestigio cultural y reconocimiento científico ${ }^{3}$, el momento de mayor encumbramiento es sin duda desde la segunda década del siglo XX hasta finales de la siguiente; coincidente con su poderío mayor en el campo cultural de su país.

\begin{abstract}
Durante más de diez años reunió desde la cátedra y la libre disposición de un diario, de la mejor revista intelectual y de una casa de ediciones, el más formidable poder fáctico que un intelectual haya jamás concentrado en España ${ }^{4}$. [Tuñón de Lara, 1970 (citado por Castañar, 1992: 15)]
\end{abstract}

Si se acepta que las publicaciones culturales se asignan un lugar en el campo intelectual, estableciendo los límites entre su propia obra y otras tendencias, seguramente, el podio cultural de Ortega fue Revista de Occidente. Los debates acerca del verdadero espíritu renovador del autor de La rebelión de las masas se reactualizan permanentemente a la luz de nuevos enfoques Mainer utiliza la fórmula "escaparate cosmopolita" para introducir el tema en su La Edad de Plata.

Sin duda es más fácil hallar consenso cuando se trata de establecer el fundamental papel que Ortega, como representante conspicuo de la Generación de 1914, jugó a la hora de convocar a la modernización de España y a su integración con los demás países de Europa ${ }^{5}$. No es tan fácil sin embargo juzgar el cariz ideológico de sus preocupaciones por los males endémicos de su país.

Sostiene Mainer que pese al impulso renovador y al papel de activador de la intelectualidad de entreguerras, en Revista de Occidente pueden apreciarse las profundas contradicciones del pensamiento orteguiano:

La Revista de Occidente supuso la incorporación activa de la joven intelectualidad española a los rumbos del pensamiento internacional de entreguerras -en buena parte expresado a través de aquellas publicaciones-, pero también señaló las profundas contradicciones de ese

\footnotetext{
2 Sobre las repercusiones de su regreso puede consultarse "Ortega y Gasset: concepto de circunstancia y circunstancia propia", Lamana, 1971: 111-128.

3 Julián Marías sitúa en los años 1930 y 1931 la plenitud vital de su generación y el momento en que su obra comienza a proyectarse fuera de las fronteras. [Tusell, Queipo de Llano: 1990: 103]

${ }^{4}$ Se refiere a su cátedra de Metafísica en la Universidad de Madrid, el periódico El sol, la Revista de Occidente (1923-1936 y la editorial del mismo nombre), a los cuales deben añadirse los diarios Luz y Crisol (1931-1932), ambos efímeros desprendimientos de El Sol después de que Ortega y sus principales colaboradores fueron desplazados de su directorio.

${ }^{5}$ V. Cerezo Galán, 1994.
} 
mismo pensamiento: una vacilación entre el clasicismo y el orden, entre el nacionalismo y el cosmopolitismo, entre el optimismo y la convicción de una inminente catástrofe cultural. [Mainer, 1981:190]

Su sistema de pensamiento se apoyaba en una angustiada afirmación de las elites en el tiempo de las masas, patentizada en su pedido de auxilio a la cultura en tiempos de crisis para afirmar el "espíritu europeo" - que oportunamente recuerda el catedrático de Zaragoza, será uno de los reclamos de los fascismos de los años treinta.

Las relaciones de Ortega con la política es otro punto de interés reiterado por la crítica y clave para desarrollar el tema de esta investigación ${ }^{6}$. Con Revista de Occidente su director se aparta de su anterior etapa crítica de España ${ }^{7}$ y se proclama "de espaldas a toda política ya que la política no aspira nunca a entender las cosas"8. En 1925, mientras Araquistáin llamaba a los intelectuales a participar en la vida política, predica la abstención política y la dedicación plena a las actividades intelectuales, artísticas o científicas.

Pero Ortega no mantendrá este criterio por mucho tiempo: al hilo de la resistencia creciente de los intelectuales a la dictadura de Primo de Rivera, llega a convertirse en la principal voz del liberalismo contra el gobierno y a favor de la República. En 1929, después de surgido "el problema universitario" ${ }^{19}$, circuló una octavilla en Madrid -incorporada a las Obras completas de Ortega- mediante las cuales se invitaba a los intelectuales a abandonar su apoliticismo. Al final

\footnotetext{
${ }^{6}$ Considero innecesario extenderme en consideraciones acerca de las políticas que pueden encerrarse en la voluntad de no hacer política. Es oportuno recordar al respecto la semejanza con el ideario de Sur, la revista fundada por Victoria Ocampo en Argentina a instancias del filósofo en la década siguiente, sobre la cual hoy ya no se pueden hacer fáciles simplificaciones. V. mi trabajo "La guerra civil española en Sur". Macciuci, 2001.

${ }^{7}$ España (Madrid, 1915-1924): Semanario fundado y dirigido por Ortega y Gasset como órgano de su Liga de Educación Política, fundamental para la difusión de las ideas reformistas de la Generación del 14 y de la cultura moderna. En 1916 Ortega deja la publicación, y es reemplazado en la dirección por Luis Araquistáin hasta 1922, sucedido a su vez por Manuel Azaña hasta su cierre.

${ }^{8}$ Citado por Mainer, 1981: 191.

${ }^{9}$ En 1928 el gobierno primorriverista intentó realizar una reforma universitaria que incluía un artículo que equiparaba las universidades religiosas con las estatales. Fue aprobada aun con el rechazo de la comisión que debía analizar el punto polémico, pensando que la finalización del curso acallaría las protestas. El curso siguiente se inició sin embargo con recias campañas contra Primo de Rivera, apoyadas por Unamuno desde su destierro en Hendaya. Se llega a enfrentamientos con la policía y es detenido y confinado Sbert, presidente de la FUE (Federación Universitaria Escolar), muchos catedráticos renuncian a sus cátedras; varios son figuras muy prestigiosas -Sánchez Román, Jiménez de Asúa, Fernando de los Ríos, García Valdecasas, Ortega y Gasset. El dictador se vio obligado a derogar el decreto.
} 
aparecían las firmas de algunos de los jóvenes escritores más reconocidos, entre ellos varios discípulos dilectos, como Antonio Espina, Francisco Ayala, Benjamín Jarnés ${ }^{10}$. El 15 de noviembre del siguiente año el filósofo publica en El Sol el artículo "El error Berenguer" que finaliza con la célebre frase "Delenda est Monarchia"11.

Deslindar en compartimentos independientes el pensamiento estético del político en Ortega carece de fundamento; integrarlo en un único sistema es tarea ardua que sobrepasa el objetivo de este libro. Sin embargo, no caeré en la asepsia de aislar un sector como si se tratara de un ensayo de laboratorio, olvidando cuán profundamente políticas son muchas de las acotaciones introducidas en sus obras de asunto estético, breves apuntes a veces encerrados en inocentes preguntas parentéticas: (¿Quién sabe si los Estados de tipo moderno sólo son posibles en etapas
de gran torpeza psicológica por parte de los ciudadanos?). [ISN: 53]

Y además

Se acerca el tiempo en que la sociedad, desde la política al arte, volverá a organizarse, según es debido, en dos órdenes o rangos: el de los hombres egregios y el de los hombres vulgares [DA: 51]

En numerosas ocasiones el nombre de Ortega figura entre los teóricos y pensadores más ilustres que han reflexionado sobre la modernidad y el arte moderno. Por ejemplo, como señala Leo Geist, es evidente que el fundamental estudio de Poggioli -retomado por Ródenas de Moya- sobre la vanguardia se apoya en las tesis principales de Ortega. Asimismo Matei Calinescu estima la idea de la deshumanización como una de las más lúcidas caracterizaciones de la estética moderna, además de un nexo entre decadentismo y vanguardismo literarios y un preludio de las meditaciones sobre la desintegración del sujeto

\footnotetext{
${ }^{10}$ Entre los firmantes figuran también Federico García Lorca, Ramón Sender, Rivas Cherif. Para más datos ver Castañar, 1992: 27.

${ }^{11}$ El general Dámaso Berenguer recibió del rey el encargo de formar gobierno a la caída Primo de Rivera. Su breve período, desde enero a diciembre de 1930 se conoce como "dictablanda". En diciembre es reemplazado por el Almirante Aznar, que tiene la misión de volver a la normalidad constitucional, con un primer paso que fue la convocatoria de elecciones municipales, realizadas en el 12 de abril de 1931. El triunfo de los republicanos lleva a la proclamación de la II República el 14 de abril y a la partida del rey hacia Italia.
} 
contemporáneo. Por último, Calinescu lo nombra el más sagaz y aventajado intérprete de Nietzsche.

\begin{abstract}
Nietzsche fue uno de los primeros pensadores occidentales en señalar la deuda secreta con la cristiandad de la modernidad aparentemente anticristiana. La idea ganó aceptación y, medio siglo más tarde, Ortega y Gasset -quizá el más brillante seguidor de Nietzsche- pudo subrayar el impacto de la cristiandad sobre la modernidad casi como una cuestión de hecho. [Calinescu, 1991: 193]
\end{abstract}

En no pocas oportunidades, el filósofo es recordado por su parcial y conservadora mirada sobre la vanguardia y la modernidad. Ródenas de Moya [1998] sitúa a Ortega y T.S. Eliot en el "conservadurismo decoroso" frente a casos de palmario fascismo como los de Hamnsum, Marinetti, Ezra Pound o Giménez Caballero. El juicio de Marshal Berman, por el contrario, no deja lugar a atenuantes cuando lo sitúa entre los continuadores de Max Weber que acentuaron la desconfianza del pueblo sin conservar la fuerza crítica y el escepticismo de su predecesor.

En las ideas y gestos intelectuales de Ortega, Spengler, Maurras, T.S. Eliot y Allen Tate, vemos cómo la perspectiva neoolímpica de Weber ha sido usurpada, distorsionada y magnificada por los modernos mandarines y aspirantes a aristócratas de la derecha del siglo XX. ${ }^{12}$ [Berman, 1988: 17]

La innegable labor que Ortega desarrolló para impulsar la modernización de España, acompañada de un ingente esfuerzo por mantener el campo de la cultura actualizado y en diálogo con las tendencias europeas en el arte, la ciencia y la filosofía, impiden a menudo profundizar las razones de las ambigüedades y contradicciones de su pensamiento. Es sumamente esclarecedor en este sentido el juicio que el filósofo merecía a sus contemporáneos; valga como muestra la visión del destacado jurista Jiménez de Asúa, para quien Unamuno y Ortega, "las dos figuras más ingentes de las letras hispanas", representaban, en 1930, uno "el cogollo de la raza, la eternidad del

\footnotetext{
12 Un listado semejante, en donde falta Ortega, puede encontrarse en el teórico sobre la Posmodernidad, Ihab Hassan, según reseña de Calinescu. Los nombres de los considerado "criptofascistas" son Yeats, Lawrence, Pound, Eliot. [101: 143]
} 
españolismo"; "la antena vibrante a los aires de Europa, la modernidad entre nosotros", el otro. [citado por Tusell y Queipo de Llano, 1990: 25]

Entre las excepciones a los subterfugios intelectuales de los especialistas, se encuentra el análisis de Eduardo Subirats, a quien le interesa destacar refiriéndose al universo metafísico orteguiano- la tendencia de la "siempre tímida hispanística española a las ambivalencias y prevenciones frente a este problema"13. [Subirats, 1996: 52] Me referiré especialmente a los aspectos que tienen mayor relación con el tema que desarrollo.

Según Subirats, el conocido diagnóstico por el cual Ortega atribuye los males de su país a la ausencia de elites intelectuales en la España moderna, adolece de ingenuidad y se sustenta en una metodología errónea que realiza un sistemático escamoteo de los datos de la realidad social o cultural. El filósofo prefiere apelar a una teoría romántica de la cultura y a generalizaciones emblemáticas y retóricas. En lugar de realizar una rigurosa indagación de las razones históricas, retoma argumentaciones esencialistas para explicar el proverbial retraso hispánico y buscar posibles soluciones. Su concepto de elite es igualmente trascendente y heroico, basado en una premoderna función de estamento, casta o "raza", ajeno a la moderna función social del intelectual moderno.

La élite intelectual era en realidad para Ortega una casta de gobernantes
que definieron el papel hegemónico de Castilla, su función uniformadora,
su expansión religioso-militar y su universalismo colonial. Esta concepción
brutalmente jerarquizada, y violentamente unidireccional de una élite
configuradora, estructuradora de la sociedad, y la consiguiente
unilateralidad de una inteligencia ejemplar y autoritaria contrapuesta a una
masa humilde y obediente no sólo puede interpretarse como la estilización
totalitaria de un pensamiento moderno, ni tampoco constituye en realidad
el resultado de una reflexión sobre la maltratada tradición intelectual
española. Más bien nos encontramos con la extrapolación algo

${ }^{13}$ El filósofo catalán hace referencia explícitamente a Manuel Tuñón de Lara, respetable si los hay, historiador de izquierdas, que tras descubrir el componente fascista del pensamiento orteguiano se ve obligado a matizarlo y diluirlo. Más adelante Subirats reforzará su idea acerca del hispanismo: "El comentario elusivo de Dobson [acerca del fascismo de Ortega] es representativo de una hispanística que en las últimas décadas se ha impuesto como tarea o bien la concepción limitada de una historiografía simplemente descriptiva, mutilada de cualquier auténtica dimensión hermenéutica, o bien el objetivo de limar las deficiencias y puntos ciegos que llevaron la moderna cultura española del llamado 'desastre' de 1898 al verdadero desastre de las siguientes dictaduras". [Subirats, 1996: 55] 
simplificada de un sublimado pasado imperial español y sus agentes políticos. [Subirats, 1996, 51]

Consecuente con esta noción de aristocracia intelectual, aparece la idea de masa, grupo informe cuya máxima aspiración debe ser dejarse influir por la élite ilustrada para así aprender y perfeccionarse pero que, contrariamente a lo deseado, sólo actúa moviéndose, ocupando lugares, destruyendo tradiciones, desplazando todo lo calificado y egregio.

Las definiciones de elite y masa expuestas hasta aquí, del mismo modo que la interpretación con fisuras de la modernidad, tiene un correlato fundamental para este trabajo con las tesis y observaciones estéticas volcadas en La deshumanización del arte. Ya he anticipado el reconocimiento que las obras más acreditadas sobre el arte moderno hacen de la clarividencia del análisis orteguiano y en breve me dedicaré a ellas. Me interesa antes concluir con el parecer de Subirats, quien encuentra serios reparos a su visión de la vanguardia pues cree que Ortega no comprendió el arte moderno pues su perspectiva estaba anclada en lo supuestos de un verdadero arte, en la cultura griega y en un clasicismo dieciochesco prestado de Alemania. Su concepto de des-humanización no es suficiente para completar la abstracción necesaria para comprender el arte de vanguardia o "arte nuevo" como lo bautizó el mismo Ortega. Las categorías que establece, o son insuficientes, o son erradas -tal sucede con la intrascendencia- y revelan que no ha comprendido el motor esencial del arte de vanguardia:

\footnotetext{
Pero sobre todo el filósofo ignoraba, con gestos de castiza petulancia, el esfuerzo central que atravesaba a todo el arte de vanguardias: pensar las transformaciones de la sociedad industrial moderna y trazar al mismo tiempo un lenguaje nuevo y un proyecto civilizatorio. Ortega ignoraba la utopía social y lingüística de las vanguardias modernas. [Subirats, 1996: 52]
}

Las razones ocultas del análisis parcial de Ortega estarían en que el proyecto vanguardista vulneraba su propio concepto de regeneración de las masas a través de las elites selectas. Las masas sólo podían redimirse si se subordinaban a los ideales absolutos y de casta, a la superioridad de un grupo selecto afirmado en cualidades carismáticas y en un impreciso vitalismo; esto es, 
en un idealismo abstracto que precisamente rechazaban las vanguardias cuando se sublevaban contra la tradición y los valores jerárquicos que definían el ideal del artista clásico, bien se tratara del concepto de genio, bien del de obra maestra. La subversión de las vanguardias históricas equivalía a desterrar la jerarquía de unos valores ideales y un concepto cerrado de sociedad, aspectos innovadores que no se acomodaban a la filosofía orteguiana. Detrás de conceptos orteguianos de intrascendencia, ironía, juego, cree Subirats que se ocultaba el propósito de declarar la trascendencia del arte clásico frente al moderno.

Distintos momentos del discurso del renombrado pensador avalan el dictamen del filósofo catalán: en Ideas sobre la novela el arte nuevo es elogiado frente al ochocentista debido a la recuperación de tesituras que lo entroncan con el arte griego, medieval y con el clasicismo francés. Así sucede con el retorno al potenciamiento de la esencia frente a los actos y las funciones.

\footnotetext{
¿Por ventura tornamos hoy de las acciones a la persona, de la función a la sustancia? Esto equivaldría a un síntoma de clasicismo emergente.

Pero esto merece un poco más de comentario y nos invita a buscar una orientación en el confrontamiento del teatro clásico francés y el teatro español castizo. [ISN: 25]
}

La comparación resulta harto favorable al teatro francés, el cual, consecuentemente con la tesis principal, es más apto para los espíritus selectos $^{14}$.

2.2. Sobre UnA Sinonimia Equívoca: ARTE NUEVo, ARTE DESHUMANIZADo, VANGUARDIA

Si se acepta la tesis de Subirats en el sentido de que Ortega trató de desmerecer el arte nuevo, sin duda obtuvo el efecto inverso, pues sus observaciones se convirtieron en canon para un grupo de artistas no muy

\footnotetext{
${ }^{14}$ Introduce Ortega también otra de sus porfías más caras, la ejemplaridad de Francia frente al atraso y la estulticia españolas: "En suma, transparece en él [en el arte clásico francés] ese afán de selección, de mejoramiento reflexivo que ha permitido a Francia, generación tras generación, pulir su vida y su raza". [ISN: 27]
} 
numeroso pero influyente. Por otra parte, son abundantes los testimonios de su apoyo material y moral a los jóvenes escritores que transitaban la nueva estética $^{15}$. Sin embargo, las razones en que se apoya Subirats son verificables mediante la lectura La deshumanización del arte. Es indudable entonces que Ortega estaba rodeado de paradojas, paradojas que quizás se diluyan si se revisa la idea muy arraigada que asocia el discurso estético de Ortega con el de las vanguardias históricas. Es el momento también de rever algunas cronologías y caracterizaciones del arte moderno en España pues, a partir de las diferencias del artista de vanguardia con el arte precedente -modernismo o 98- se ha trazado una frontera tajante entre ambos movimientos, que en muchos casos fue solamente un disenso parcial con el arte moderno y una fuente de malentendidos.

Ya he adelantado, al tratar las vanguardias, los problemas que plantean las diversas acepciones y la extensión de los campos semánticos de las diferentes categorías utilizadas para tratar sobre el arte del último siglo. Se ha visto también que cualquiera sea la definición seguida, la vanguardia no puede separarse del extenso período de la modernidad estética. Igualmente, se hizo mención a las superposiciones y equívocos que se originan a partir de los conceptos y los nombres ${ }^{16}$. Es posible hallar numerosos ejemplos de tales confusiones; me limitaré a aquellas que son útiles para desarrollar mi propia visión del problema.

Un dilema digno de destacar surge de los diferentes períodos establecidos por Poggioli en su obra, cita inicial obligada de los estudios sobre las vanguardias. Quedan reseñadas las cuatro etapas propuestas por el profesor italiano, que permiten hablar de vanguardia y modernidad estética como conceptos comunes. Quizás es la base que lleva a Robert Langbaum a decir que avant-garde debe leerse como Modernismo, idea refutada por Calinescu quien, sin embargo, percibe claramente las dificultades derivadas del significado cercano de las dos categorías. Para evitar la confusión propone un criterio que se muestra entre los más operativos, junto al formulado por Peter Bürger acerca de la actitud de las vanguardias históricas ante la institución arte.

\footnotetext{
${ }^{15}$ V. Castañar, 1992 y del Pino, 1995.

${ }^{16} \mathrm{~V}$. cap. I.
} 
En Francia, Italia, España y otros países europeos la vanguardia, a pesar de sus diversas y a veces contradictorias pretensiones, tiende a ser considerada como la forma más extrema de negativismo artístico -siendo el propio arte la primera víctima-. En cuanto al modernismo, cualquiera sea su significado específico en lenguas diferentes y para diferentes autores, nunca transmite ese sentido de negación universal e histérica tan característica de la vanguardia. EL ANTITRADICIONALISMO DEL MODERNISMO ES, A MENUDO, SUTILMENTE TRADICIONAL. ESA ES LA RAZÓN POR LA CUAL ES TAN DIFÍCIL, DESDE un punto de vista europeo, concebir que autores como Proust, Joyce, Kafka, Thomas Mann, T.S. Eliot, o Ezra Pound sean representativos de la VANGUARDIA. ${ }^{17}$ [Calinescu, 1987: 141]

Continúa poniendo de relieve la dificultad de hallar lazos de unión entre estos autores y el dadaísmo, el futurismo o el surrealismo. La diferenciación es imprescindible cuando se aspira a operar con los distintos conceptos, sin olvidar, naturalmente, la primacía del primer movimiento moderno en inaugurar el gesto de la tradición contra sí misma que retomó la vanguardia; pero es también evidente que su radicalismo negativo y el antiesteticismo sistemático no daban lugar a la reconstrucción artística del mundo intentada por el arte finisecular. Para poder comprender mejor esta ambigua relación entre arte moderno y vanguardia, Calinescu dirá que esta es una parodia de la modernidad consciente y deliberada, con el grado de admiración y respeto, además de semejanza, que toda parodia debe tener con el objeto parodiado.

\footnotetext{
Para comprender la extraña relación entre modernismo y vanguardia (una relación tanto de dependencia como de exclusión), podemos pensar que la vanguardia es, entre otras cosas, una parodia de la modernidad ${ }^{18}$.

(...)

Vista como parodia de la modernidad, la vanguardia ilustra todas estas ambigüedades, $y$, aunque a menudo es grosera y tosca (como son la mayoría de las parodias actuales), a veces puede estar tan cerca de su modelo como para confundirla con él. [Calinescu, 1987: 141-142]
}

Ortega entrevé la actitud de veneración trasuntada en parodia -que desde mi punto de vista no es susceptible de ser generalizada- y, como se verá, la pone al servicio del merecimiento y superioridad del arte moderno cuando este puede diferenciarse de la vanguardia.

17 Subrayado mío. Se verá enseguida que esta dificultad se pone de manifiesto en La deshumanización del arte.

${ }^{18}$ Subrayado del autor. 
A la dificultad de establecer límites precisos entre movimientos que alcanza a gran parte de las expresiones de vanguardia, debe añadirse el particular problema español, fruto del profundo rechazo que la vanguardia expresó hacia el modernismo en su versión noventaiochista, cuyo molde estético y sobre todo, ideológico, motivaba la repulsa de los jóvenes artistas, hastiados del discurso patriótico y nacionalista. Vistas las complicaciones a la hora de dirimir el campo de los dos movimientos, cabe preguntarse hasta qué punto Ortega en La deshumanización del arte analiza la vanguardia; ¿qué significa para Ortega "arte nuevo?" ¿Puede reemplazarse por vanguardia?

En La deshumanización del arte Ortega describe el arte nuevo según determinadas características muy conocidas y que por tanto, mencionaré sintéticamente ${ }^{19}$ :

\section{Arte nuevo:}

- El arte nuevo conduce a una división inquebrantable entre el público que no entiende -la masa- y los egregios que entiende y logran la fruición estética. El arte nuevo es antipopular frente al ochocentista, popular, cuyo ejemplo manifiesto es el romanticismo.

- No permite la identificación sentimental del espectador con la obra mediante la eliminación de la ficción de realidades humanas; va en sentido opuesto al "arte viejo", el del siglo XIX, compendiado en las categorías romanticismo y naturalismo que "vistos desde la altura de hoy, se aproximan y descubren su común raíz realista"20.

\footnotetext{
${ }^{19}$ Ortega enumera los rasgos, pero luego no realiza un desarrollo ordenado de todos y cada uno de ellos. Son los siguientes: tendencias a 1: la deshumanización del arte, 2: evitar las formas vivas, 3: hacer que la obra de arte no sea sino obra de arte, 4: considerar el arte como juego, y nada más, 5; a una esencial ironía, 6: eludir toda falsedad, y por tanto, a una escrupulosa realización, 7: el arte, según los artistas jóvenes, es una cosa sin trascendencia alguna. [DA: 57]

20 Son conocidos los múltiples equívocos que surgen alrededor de la categoría realismo, especialmente cuando deja de referirse con exclusividad, como en este caso, al movimiento narrativo de la segunda mitad del XIX. Sin propósito de dirimir todos los problemas, considero enriquecedoras las observaciones de Valeriano Bozal, las cuales, por otra parte, son pronunciadas en torno a La deshumanización del arte. Acerca de la identificación del arte del siglo XIX con realismo y naturalismo, sostiene que "el arte del siglo pasado tiene una evolución y configuración suficientemente complejas como para que declaremos -cualquier historia del arte de ese siglo es terminante a ese respecto- nuestra insatisfacción por semejante identificación". En segundo lugar, cuestiona la supuesta popularidad del llamado arte realista, pues "no todo el arte de ese siglo, aunque sea realista, es igualmente popular o siquiera popular, ni tampoco todo
} 
- Es un arte deshumanizado, por su tendencia a ir contra la realidad, deformarla, romper su aspecto humano. El pintor produce objetos con los que no es posible dialogar humanamente. Las emociones que produce son de naturaleza exclusivamente estética. Para lograrlo con perfección la obra debe mantener un rasgo de "substantividad", es decir, un rastro del objeto "deshumanizado".

- El camino real del arte se llama voluntad de estilo. Estilizar es deformar lo real, desrealizar. Estilización implica deshumanización. Y no hay otra manera de deshumanizar que estilizar.

- De los tres rangos de lo humano, es decir, del repertorio de elementos que integran el mundo -personas, seres vivos, cosas inorgánicas- el arte rechaza con más energía el primer grupo. El arte no puede consistir en un contagio psíquico; el llanto y la risa son fraudes estéticos. El placer estético es un placer inteligente.

- Rechazo a la confusión del arte con la vida; el arte nuevo siente "asco" ${ }^{21}$ a lo humano. La vida es una cosa, la poesía otra.

- El poeta aumenta el mundo, añadiendo a lo real, que ya está ahí por sí mismo, un irreal continente.

- $\quad$ El procedimiento esencial para llegar a la deshumanización es la metáfora. La metáfora evita la realidad y ennoblece el objeto real.

- De todos los procedimientos, es el básico el cambio de la perspectiva habitual, invertir la jerarquía, destacar los mínimos sucesos de la vida, resaltar lo que de ordinario se desatiende.

- $\quad$ El arte nuevo tiende a la iconoclastia; manifiesta "asco" por las imágenes.

el arte popular es el realismo o el naturalismo del siglo XIX". Y añade que la literatura popular es la de los folletines, pero aun así, "es una popularidad relativa y restringida, pues alcanza fundamentalmente a la clase media y clase media baja, única que tiene suficientes conocimientos para leer periódicos y novelas. La gran masa no lee folletines -aunque pueden leérselos-, no lo hará hasta que los medios de comunicación de masas se desarrollen y se extienda la enseñanza básica, ahora sigue aferrada al romance, la aleluya y la narración corta". Para entender a qué hacé referencia Ortega cuando menciona la común raíz realista es preciso advertir que el elemento unificador de las estéticas decimonónicas en evidente declive en el novecientos, es la narratividad, que "produjo consecuencias diversas, altamente positivas en aquellas actividades artísticas que se sirven de la palabra y son expresamente narrativas, tal es el caso de la novela..." Bozal, 1993: 29, 30, 31]

21 'asco' es uno de los términos preferidos por Ortega para indicar rechazo o desapego y lo prodiga en numerosos momentos de su ensayo. 
- Rechaza la tradición y el pasado. Niega el arte viejo. Experimenta atracción por el arte de culturas exóticas o lejanas, carentes de tradición, y siente aversión a las reglas y la disciplina.

Su actitud es hastiada, desdeñosa. La nueva inspiración es indefectiblemente cómica. El arte nuevo se burla de sí mismo, ridiculiza al arte.

- El síntoma más agudo es la intrascendencia. El artista considera intrascendente su oficio y su obra. Rechaza la finalidad grave y solemne. Busca sentirse libre de toda empresa de salvación de la humanidad, de movimientos sociales o políticos, o de corrientes filosóficas o religiosas profundas.

- El arte nuevo adquiere grandeza cuando se interpreta su ligereza como intento de crear puerilidad en un mundo viejo. De ahí la nutrida presencia de motivos relacionados con el deporte, los juegos, el cuerpo, el cine.

- Como en toda Europa, el arte nuevo ha entrado en una época de infantilismo. Se ha desplazado del eje vital, en torno al cual giran las materias graves, hacia la periferia. Vaciado de patetismo, sin trascendencia, sólo aspira a ser arte.

- Hasta el momento de la edición de La deshumanización del arte el arte nuevo no había producido ninguna gran obra.

- La nueva situación del arte descripta ya no podía ser revertida.

Para lograr una noción más completa del pensamiento de Ortega que más influyó sobre las vanguardias españolas y por otra parte, que mayor eco ha obtenido entre la crítica especializada, es preciso conocer también los conceptos vertidos en Ideas sobre la novela ${ }^{22}$.

La redacción de ldeas sobre la novela obedeció al deseo de dar una respuesta a las opiniones de Pío Baroja sobre el género contenidas en su comentario a Las figuras de cera.

${ }^{22}$ Ortega escribe Ideas sobre la novela en respuesta a los comentarios, publicados por El Sol, que Baroja hiciera sobre su propia novela Las figuras de cera (1924). Luego el escritor vasco a su vez contesta al filósofo en "Prólogo doctrinario" a La nave de los locos. (1925). Ideas sobre la novela fue publicada primero en siete entregas en El Sol, entre diciembre de 1924 y enero de 1925. También apareció una parte en La Nación de Buenos Aires en marzo de 1925. 
De manera semejante a lo sucedido con sus opiniones de La deshumanización del arte, Ortega les resta toda intención de influir en el rumbo estético de su país.

\begin{abstract}
Estos son los pensamientos sobre la novela que una alusión de Baroja me ha incitado a formular. Repito que no pretendo con ello aleccionar a los que sepan de estas cosas más que yo. Es posible que cuanto he dicho sea un puro error. Nada importa si ha servido de incitación para que algunos jóvenes escritores, seriamente preocupados de su arte, se animen a explorar las posibilidades difíciles y subterráneas que aun quedan al viejo destino de la novela. [ISN, 1982: 56]
\end{abstract}

El eje que sostiene el ensayo es la idea de la decadencia de la novela; la línea de reflexión, la acentuación de la forma frente al contenido. Pese a las diferencias del sistema de pensamiento que los sustenta, la observación sobre el agotamiento del material tiene importantes puntos de contacto con los escritos de Benjamin sobre el empobrecimiento de la experiencia que serán retomados más adelante.

La preocupación por el momento formal de la producción artística y la denuncia de la ilusión mimética del relato realista se revela en diferentes enunciados:

- No basta el talento para escribir una buena novela.

- La novela es un género en decadencia porque se origina en una cantera de materiales finitos. Existe un número definido de temas posibles y es casi imposible hallar nuevos temas.

- Si la novela no está agotada, se halla en su período final. Padece una tal penuria de temas posibles que el escritor necesita compensarla con la calidad exquisita de los demás ingredientes. Afirma la imposibilidad práctica de inventar nuevos argumentos interesantes.

- Las mejores novelas son aquellas que evitan la narración y la descripción en favor de la presentación.

- La aventura y la trama deben ser sólo un pretexto, pero no pueden faltar.

- La narración atrapa al lector cuando se centra en los personajes y es capaz de transmitir un ambiente. Por eso debe ser un género moroso, 
esencialmente retardatario; todo lo contrario del cuento, el folletín y el melodrama.

- La tendencia de la literatura de principios del siglo XX a realzar la sustancia en menoscabo de la acción indica un retorno a valores y actitudes clásicas. El examen del teatro francés del siglo XVII frente al español constituye un inmejorable ejemplo de las virtudes del intelecto y de la reflexión frente a la acción y la intriga.

- Entre los escritores del siglo pasado, salva a Dostoievsky del general naufragio, y entre los contemporáneos, otorga el laurel a Proust, pero con restricciones, como se verá. En ambos de la morosidad de la prosa y la sencillez de la trama ponen de relieve la preeminencia de la forma sobre el contenido.

- La novela debe presentar un sutil equilibrio entre acción y contemplación, entre los elementos dramáticos y la atmósfera, entre escasos sucesos y abundantes detalles. La novela moderna se distingue por describir un ambiente, frente a la epopeya, el cuento, la novela de aventuras, el melodrama y el folletín, que prefieren la acción concreta, de línea y curso muy definidos.

- La novela, cualquiera sea su tema, debe aislar al receptor en un mundo cerrado. Para lograrlo es preciso angostar lo más posible el horizonte del lector. La táctica ha de ser aislarlo de su horizonte real y aprisionarlo en un pequeño horizonte hermético que es el ámbito interior de la novela. Sólo así el lector se interesará por lo que dentro de la novela pase.

- Ese interés del lector se logra gracias a la forma. El novelista debe olvidar la realidad ajena a su novela y conseguir hacérsela olvidar al lector. Una necesidad puramente estética impone a la novela el hermetismo, la obliga a ser un orbe obturado a toda realidad eficiente. Al novelista le interesa más su mundo mágico que cualquier otro mundo posible.

- Las novelas lastradas con intenciones trascendentales, sean políticas, ideológicas, simbólicas o satíricas nacen muertas. Por esta razón es inviable la novela histórica, que constantemente remite al horizonte de los sucesos del pasado. 
- El hermetismo es la forma que adopta el imperativo genérico del arte, la intrascendencia.

- La intrascendencia no impide que la novela suscite en el lector resonancias vitales.

- La novela es un género tupido, que incorpora la diversidad del universo.

- La situación de decadencia del género es propicia para que nuevas posibilidades sean exploradas por los espíritus selectos. Los avances en el conocimiento de la psicología deben ser aprovechados para crear caracteres, "psicologías" imaginarias, que no tienen que responder necesariamente a la de los seres del mundo real.

- La novela admite todas las disciplinas y discursos: filosofía, estética, arenga, ciencia, religión, sociología, pero no puede ser sociológica. Cualesquiera que sean su materiales, deben quedar envueltos en la atmósfera del relato.

Sería un propósito ímprobo rastrear todas los trabajos críticos que mencionan la influencia de Ortega, y de La deshumanización del arte en particular, en la producción vanguardista española, influencia que en múltiples ocasiones es aludida como el 'magisterio' que a todas luces ejerció tanto en la poesía como en la narrativa.

\footnotetext{
Mencionar la deshumanización forzosamente de inmediato trae a escena a Ortega y Gasset, ineludible en toda consideración de las vanguardias en España, particularmente de la generación del $27 .{ }^{23}$ [Morris, 1995: 164]
}

La vinculación de Ortega, y particularmente de La deshumanización del arte con la vanguardia, ha sido establecida alrededor de dos núcleos. En primer lugar se encuentra la idea de arte deshumanizado e intelectual, distanciado de las estéticas de cuño realista, que llevó a poetas y prosistas a intensificar los aspectos formales, y de manera especial, el cultivo de la metáfora preciosista hermética. Ligado a este primer aspecto, el elitismo y el alejamiento del gran

\footnotetext{
${ }^{23}$ Sólo en la colección dirigida por Francisco Rico, aluden este magisterio, entre otros, Jorge Guillén, Guillermo de Torre, Juan Manuel Rozas, Luis Cernuda, Anthony Leo Geist, Pedro Salinas, Gustav Siebenmann, José Luis Bernal. Especial énfasis en destacar su figura pone Ricardo Gullón, sobre todo respecto del "estilo de pensamiento y la pulcritud mental con que todos los problemas -y desde luego los de la creación- debían ser examinados". [Gullón,1969: 156-157].
} 
público devienen sus efectos lógicos. En segundo lugar, aparece la intrascendencia, la tendencia al juego y al humor y el rechazo de toda gravedad de pensamiento o propósito moralizante o aleccionador. Ambos factores sobran para justificar la asociación de los ensayos estéticos de Ortega con el arte de vanguardia.

Sin embargo, si se repasan sus observaciones podrá advertirse que muchos de sus embates y de sus ponderaciones no corresponden exactamente al arte de vanguardia, aun cuando se quiera explicar las posibles ambigüedades como contradicciones propias de un pensamiento que los estudiosos orteguianos se han ocupado de dilucidar ${ }^{24}$.

Decir que Ortega en La deshumanización del arte, o en Ideas sobre la novela, vuelca su análisis y diagnóstico sobre el arte de vanguardia circunscripto a la generación de poetas y prosistas del 27- es recortar sensiblemente el campo de su intervención ${ }^{25}$. Creo importante atender a esta cuestión pues ofrece otra entrada más al problema que se ha delineado en distintos momentos de este estudio: la dificultad de establecer lindes definitivas entre modernismo y vanguardia.

El tan mentado rasgo de impopularidad del arte nuevo, incluso el hermetismo, es un rasgo que se puede atribuir al arte moderno en general. Si bien el modernismo español -98 incluido- no es calificado hoy como arte minoritario, se puede constatar que muchos de los autores más representativos del grupo fueron poco entendidos en su tiempo y que ellos mismos alentaron un arte y un pathos refractario al lector masivo. Recuérdense las ya mencionadas polémicas y descalificaciones dirigidas contra un autor de indudable popularidad

24 Para Philip Silver la contradicción aparente del pensamiento del filósofo constituye un problema que puede esclarecerse. Es notorio, dice, "el simple hecho de que a menudo parece [Ortega] estar diciendo a la vez dos cosas que se oponen entre sí, haciéndose culpable de una frecuente duplicidad de argumentación. De ese modo Ortega nos invita a interpretarle mal. Pero lo que en concreto quisiera demostrar es que su duplicidad sólo es aparente, y que lo que parece justificar la crítica se debe, en primer lugar a que los ensayos de Ortega no se leen 'dentro' de la tradición de la fenomenología europea, y en segundo a que sus ensayos parecen haberse construido alrededor de una gesticulación retórica que a mi entender ha de atribuirse a una etapa orteguiana anterior a la penetración de los vectores idealista y existencial de la fenomenología de Husserl". (Subrayado del autor) [Silver, 1969: 34-35]

${ }^{25}$ En igual dirección apunta José del Pino: "Ortega está lejos de poder ser considerado un vanguardista. como hombre que cree profundamente en el papel liberador de la cultura, del arte y de la inteligencia en las sociedades modernas, las actitudes radicales de las vanguardias y sus ataques a la tradición no dejan de molestarle". [del Pino: 1995: 40] 
como Blasco Ibáñez, quien a su vez manifestaba su preocupación por no poner en sus novelas escollos formales que desorientaran al lector común.

Es oportuno aquí retomar el estudio de Facundo Tomás, quien no establece entre el arte de entresiglos, en su versión generación del 98, y la vanguardia, más que una diferencia de grado, la que separa al intelectual del artista volcado únicamente a su propia práctica. En tanto intelectuales, los representantes del primer grupo no se aislaron totalmente sino que se asignaron una misión de enlace entre la elite y el pueblo, mientras que los segundos cultivaron el arte en un ámbito mucho más autónomo; no obstante, de cualquier modo se igualan cuando conforman una nueva "clase" separada del resto de la sociedad.

La sustancia de radicalidad de las vanguardias las marginará absolutamente del gusto del gran público, como bien constató Ortega. El "intelectual" noventaiochista tiende a situarse en esa línea pero adopta una especie de "postura intermedia" que evita la total separación, y al contrario, le hace concebir un ideario jerárquico por el que a "los intelectuales" les corresponde "dirigir" a las masas e ir progresivamente "educándolas". También será Ortega quien con mayor claridad sintetice esta posición, que se encuentra diluida, aquí y allá -aunque no en germen, plenamente elaborada- en los escritos de Unamuno, Maeztu, Azorín, Baroja o Valle. [Tomás, 1998b: 35]

Igualmente se puede constatar que las novelas de los autores más relevantes del modernismo español, desde 1904, año clave para el "lanzamiento" del grupo, se encaminaron hacia un progresiva deshumanización, en tanto el argumento y la materia del relato se supeditaban al componente formal o incluso, a la reflexión metaliteraria, tendencia incluso verificable en Baroja, uno de los más "realistas" de entresiglos. Si bien muchas de estas obras han salido hoy del reducto de los iniciados, conservan todavía un alto grado de dificultad, bien porque producen "emociones exclusivamente estéticas", bien por apelar a la recepción inteligente. Así ocurre con La voluntad de Azorín, Camino de perfección de Baroja, Las Sonatas de Valle Inclán, Amor y pedagogía o Niebla de Unamuno.

Si el punto a tener en cuenta es la descalificación del arte realista, fueron tanto o más cáusticos con el ochocientos los escritores de entresiglos que los vanguardistas: recuérdense los agravios a Galdós, citado por su segundo apellido, Pérez, para condenarlo al anonimato, o el siempre recordado epíteto de 
Valle Inclán "don Benito, el Garbancero"26. No sorprende entonces que sea también el autor de Fortunata y Jacinta objeto de desaprobación en el célebre capítulo XIV de La voluntad por la artificiosidad de sus diálogos VER ${ }^{27}$, aunque las diatribas más rigurosas son para el autor de La barraca. Por otra parte, la conversación entre Antonio Azorín y el maestro Yuste, tiene tintes poderosamente orteguianos, en tanto gira alrededor de procedimientos literarios, representación de la realidad y emoción estética ${ }^{28}$.

En cuanto a la ofensiva del arte nuevo contra la tradición, se verifica tanto en la vanguardia como en el modernismo: son muy conocidas las ironías o invectivas de Valle Inclán, Baroja, Azorín contra lo más acendrado de la tradición literaria. Por otra parte, Ortega no deja lugar a dudas del amplio alcance de su concepto de antipasatismo cuando explica, en el capítulo "Influencia negativa del pasado" [DA: 81-85], que la burla y la agresividad contra la tradición es iniciada por el romanticismo.

Otro tópico siempre mencionado de La deshumanización del arte es el de la intrascendencia, término cuya ambigüedad semántica anticipa Ortega cuando refiere "una vez escrita esta frase me espanto de ella al advertir su innumerable irradiación de significados diferentes". [DA:88] En muchas ocasiones, se ha interpretado intrascendencia como futilidad, trivialidad, pero no es a mi juicio la única acertada, porque si bien afirma que el arte nuevo gusta del deporte, el cine, el culto al cuerpo -motivos esencialmente vanguardistas y de los veinte-, por otra parte Ortega identifica claramente intrascendencia con arte puro, "sólo arte, sin más pretensiones", enunciado que remite al arte autónomo, reconcentrado en sí mismo. Se podrá argumentar a favor de la equivalencia de

\footnotetext{
${ }^{26}$ La vanguardia no fue a la zaga; es bien conocida la desvalorización de Antonio Espina: "Galdós en literatura fue lo que Letamendi en Biología, Sagasta en política y Pradilla en pintura. Una 'enorme medianía' (...) Pertenece a aquel grupo que, con frase un poco plebeya, podríamos calificar de novelistas 'a ojo' y poetas 'a oído'". Y continúa: "Compendio y síntesis de aquella literatura es D. Benito Pérez Galdós, novelista de y para la clase media, que durante un cuarto de siglo ha devorado sus libros en la camilla familiar, al calor del brasero, después de la cena". [Citado por del Pino, 1995: 44-45]

${ }^{27}$ Los escritores modernistas buscaban con cierta alevosía los ejemplos, evitando detenerse en los aciertos y hallazgos más novedosos de los escritores realistas. Por otro lado, llama la atención la beligerancia prolongada muchos años después de los debates estéticos del modernismo: en su novela de 1930 Don Sandalio, jugador de ajedrez, Unamuno descalifica a Blasco Ibáñez, colega con el que además había compartido hasta su muerte, en 1928, el título de principal voz opositora en el exilio a la dictadura de Primo de Rivera. V. Macciuci, 2000: 732-742.
}

${ }^{28}$ Azorín, 1904. 
intrascendencia y futilidad que Ortega proporciona alusiones bastante transparentes:

Porque el hecho no es que al artista le interesen poco su obra y oficio, sino que le interesan precisamente porque no tienen importancia grave y en la medida que carecen de ella. No se entiende bien el caso si no se le mira en confrontación con lo que era el arte hace treinta años, y, en general, durante todo el siglo pasado. Poesía o música eran entonces actividades de enorme calibre: esperaba de ellas poco menos que la salvación de la especie humana sobre la ruina de las religiones y el relativismo inevitable de la ciencia. El arte era trascendente en un noble sentido. Lo era por su tema, que solía consistir en los más graves problemas de la humanidad, y lo era por sí mismo, como potencia humana que prestaba justificación y dignidad a la especie. Era de ver el solemne gesto que ante la masa adoptaba el gran poeta y el músico genial, gesto de profeta o fundador de religión, majestuosa apostura de estadista responsable de los destinos universales. [DA, 1993: 88]

El párrafo es extenso, pero se justifica su transcripción puesto que ilustra las mudanzas y la inestabilidad de las categorías que tratan de esclarecerse en esta tesis.

Que el arte del siglo XIX "en general" sea blanco de las críticas orteguianas es previsible, pero ¿a qué se refiere cuando habla de "treinta años atrás"? El artista grave, de gesto grandilocuente y con ambición de salvar a la humanidad es suficientemente impreciso como para atribuirle varios sujetos, pero indudablemente no incluiría nunca a los artistas "típicamente" modernistas Darío, Jiménez- pero sí a su versión hispánica más divulgada, es decir, los noventaiochistas. Ortega traza una línea divisoria que deja a un lado al escritor quizás mejor, las obras- de entresiglos atravesada por reflexiones sobre los problemas del hombre en general y de España en particular pero rescata a las que cultivan el arte puro. Si bien la aludida ambigüedad del filósofo una vez más pone a prueba una observación sobre su ensayo estético más conocido, la incorporación de Ideas sobre la novela al análisis puede abonar las hipótesis anticipadas $^{29}$. Aquí retoma la idea de la trascendencia, identificándola más claramente con la máxima autonomía artística:

Las artes se vengan de todo el que quiere ser con ellas más que artista, haciendo que su obra no llegue siquiera a ser artística. Igualmente la

\footnotetext{
${ }^{29}$ No desconozco a los críticos que han subrayado las contradicciones irresolubles de algunos afirmaciones de La deshumanización del arte con las de ldeas sobre la novela, sin embargo para mi estudio interesan más las continuidades. V. del Pino, 1995: 39.
} 
política del poeta se queda siempre en un ingenuo ademán inválido. [ISN, 1925 - 1982: 47]

Muchas de las dudas que plantea el pensamiento estético de Ortega y el alcance de sus conceptos se pueden reducir si se repasan los nombres -el corpus- con que apoya sus elucubraciones ${ }^{30}$. La comprobación más inmediata es que los aludidos no son artistas eminentemente de vanguardia, porque la gran obra vanguardista estaba aún por escribir.

En La deshumanización del arte la literatura estigmatizada tiene en Víctor Hugo uno de sus principales representantes, acompañado por Zurbarán, Lucas, Sorolla, Dickens, Galdós, Beethoven y Wagner. A Pirandello y Strawinsky les otorga el mérito de haber logrado recordar a la masa que sólo es masa para ser conducida -interesante lectura de Seis personajes en busca de un autor. El gran músico del arte nuevo es Debussy, y Mallarmé figura como el pionero de los cambios en poesía, concretados más tarde por los continuadores. A Baudelaire lo salva por su genio personal, que logra imponerse por sobre sus propósitos demasiado "humanos".

Cuando se trata de buscar los mejores exponentes de la superación del realismo -superación que Ortega bautiza como infra y suprarrealismo- mediante la intensificación y el cambio de perspectiva, los nombres que selecciona representantes insignes de la vanguardia ,Proust, Gómez de la Serna y Joyce, dejan un rastro de perplejidad ${ }^{31}$. Sin duda el canon posterior a 1925 no ha otorgado el mismo rango al autor de las Greguerías que al de la Recherche y al de Ulysses, pero no es esta la ocasión de analizar la operación de Ortega al proponer esta terna; interesa observar que una vez más, el concepto de vanguardia se aleja de la radicalidad de las expresiones más genuinas de los ismos para acercarse a una categoría de mayor extensión semántica y asimilable a la modernidad estética o, si se quiere, al Modernisme de la tradición anglosajona, categoría a la cual ya se ha dedicado más de una aclaración. A la

\footnotetext{
${ }^{30}$ Es claro que no se pretende investigar exhaustivamente las ideas estéticas de Ortega y Gasset, para lo cual sería preciso recorrer su vasta producción sobre arte y literatura. Se aspira a dar un justo lugar a dos ensayos que influyeron decisivamente en el campo cultural de su tiempo y en la historiografía sobre el tema.

${ }_{31}$ El dictamen de Ortega no debía de ser insólito en aquellos años. En 1926 Gómez de la Serna y Joyce integraron, con Georg Kaiser y Pierre Mac Orlan el equipo asesor de 900. Cahiers de I 'Italie et de l' Europe, publicación dirigida por Massimo Bontempelli y orientada por el grupo florentino La Voce. [Granjel, 1963:65]
} 
terna favorecida suma líneas más abajo a Jean Giradoux y Paul Morand ${ }^{32}$, nombres hoy de escasa repercusión en los estudios sobre la vanguardia, pero muy influyentes en calidad de narradores de la novela cosmopolita, según refiere José del Pino. El declive de estos autores en los años treinta es considerado un claro signo del triunfo de una estética de nuevo cuño, de contenido social y orientación realista.

En Ideas sobre la novela retornará sobre los autores que según su visión, mejor expresan el estado de la novela y las tendencias más marcadas. Vuelve a denostar a Balzac, se ríe de Emilia Pardo Bazán, elogia a Stendhal y dedica un apartado independiente a Dostoievsky y Proust. El ruso se exime de la general condena que merecen los realistas gracias a su capacidad de demorar el discurso, por su talento para concentrar la trama en tiempo y lugar, logrando una densidad comparable a la de la tragedia clásica -es de señalar la reiteración de elogios en función de un parecido con el arte clásico.

En cuanto a Proust, brinda un buen ejemplo de las limitaciones de Ortega a la hora de comprender el arte moderno. Si bien escoge a un autor faro de la renovación literaria, no se puede hoy inscribir en la vanguardia artística en su sentido más lato. Por otra parte, la ponderación queda muy atenuada, casi disuelta, por los reparos. Sostiene que el autor francés traspasó la medida de la lentitud necesaria. Algunas de las calificaciones que le otorga dan muestra de sus valoraciones con cortapisas: "falto de esqueleto", "nube informe", "plasma sin figura", "pulpa sin dintorno". Cree que el autor francés se excedió al debilitar excesivamente la trama, hasta el punto de eliminarla cuando esta debe conservar su función, no más mecánica que la del hilo en el collar.

Añade que Proust extremó hasta la exageración el carácter no dramático de la novela. Cree Ortega que un minimun de acción es imprescindible, requisito

\footnotetext{
${ }^{32}$ Los dos escritores franceses se citan con frecuencia en declaraciones y manifiestos de los años treinta como símbolos de la literatura que ha pasado al olvido. Morand diplomático y nómada, tuvo -según Mainer injustamente- fama de frívolo. Gómez de la Serna dijo de él en "Paul Morand (Retratos contemporáneos, 1945) "todas sus novelas tienen cuarto de baño y se puede estar seguro de que su automóvil nos llevará a ver espectáculos diferentes en los que su chauffeur ha adquirido palco). [Mainer: 2000, 22] . En 1931 Morand y Ramón dictaron sendas conferencias en Buenos Aires, que fueron reseñadas por Guillermo de Torre en Sur, 4, Primavera 1931, pp. 132-134.
} 
que tiene a Proust como contraejemplo, porque escribió una novela paralítica, sin movimiento.

Al finalizar Ideas sobre la novela en respuesta a Baroja es posible observar que se ha delineado un tipo de novela moderna en el cual ocupan un lugar sobresaliente Cervantes, Dostoievsky y Stendhal, y con reparos, Proust. En la otra acera, además de los denigrados narradores "realistas", quedan la epopeya, el cuento, la novela de aventuras, el melodrama y el folletín.

Aunque el propósito de este ensayo es distinto al perseguido con La deshumanización del arte, la vinculación entre sus ideas sobre la novela y sus ideas sobre el arte nuevo es evidente.

Acerca de la perspectiva del filósofo sobre el arte de vanguardia, he tratado de demostrar que se debe ser prudente en el momento de citarlo como su más lúcido observador. Tuvo el gran mérito de apreciar el arte moderno como un continuum, observando lazos de parentesco donde durante mucho tiempo sólo se vieron cismas y discordia. Su mirada panorámica le impidió discernir el radical rasgo distintivo la vanguardia, esto es, el cuestionamiento irreversible de un estado de cosas después del cual el arte, el hombre y la sociedad no podrían recuperar la inocencia ni sentirse exculpados.

Quizás a Ortega se le puede aplicar, invertido, su símil del cristal y el jardín ${ }^{33}$ : cuando enfocaba a la gente nueva, a "los jóvenes artistas", veía las tendencias del arte nuevo, pero sus hábitos estéticos y su utillaje mental le devolvían constantemente a la invisible barrera del vidrio, esto es, al arte moderno de filiación clásica, sólido refugio para la mentalidad de la aristocracia de talento, conservadora y temerosa ante los nuevos sujetos sociales y los fenómenos estéticos, políticos y sociales que los acompañaban.

\footnotetext{
${ }^{33}$ El símil es el siguiente: "Se trata de una cuestión óptica sumamente sencilla. Para ver un objeto tenemos que acomodar de una cierta manera nuestro aparato ocular. Si nuestra acomodación visual es inadecuada no veremos el objeto o lo veremos mal. Imagínese el lector que estamos mirando un jardín al través del vidrio de una ventana. Nuestros ojos se acomodarán de suerte que el rayo de la visión penetre el vidrio, sin detenerse en él, y vaya a prenderse en las flores y frondas. Como la meta de la visión es el jardín y hasta él va lanzado el rayo visual, no veremos el vidrio, pasará nuestra mirada a su través, sin percibirlo. Cuanto más puro sea el cristal menos lo veremos. Pero luego, haciendo un esfuerzo, podemos desentendernos del jardín $y$, retrayendo el rayo ocular, detenerlo en el vidrio. Entonces el jardín desaparece a nuestros ojos y de él solo vemos unas masas de color confusas que parecen pegadas al cristal. Por tanto, ver el jardín y ver el vidrio de la ventana son dos operaciones incompatibles: la una excluye a la otra y requieren acomodaciones oculares diferentes". [DA: 53-54]
} 


\subsection{Ortega y Benjamin}

Las lecturas más arraigadas de Ortega suelen detenerse en aspectos suficientemente conocidos, sobre todo en lo referente a sus preocupaciones formales. Sin embargo, la mirada aguda del filósofo supo advertir otros fenómenos que no se citan con frecuencia. Así sucede por ejemplo con la descripción de las transformaciones del sujeto lírico en la poesía nueva, con especial atención a Mallarmé, aportación que Walter Mignolo ha subrayado oportunamente en un célebre trabajo que retomaré en el capítulo dedicado a Alberti.

Otra acotación en la que Ortega demuestra su sensibilidad estética se refiere a la decadencia de la novela debido a la ausencia de materia prima para los relatos. Pese a las diferencias del sistema de pensamiento que los sustenta, la observación sobre el agotamiento del género tiene importantes puntos de contacto con los escritos de Benjamin sobre el empobrecimiento de la experiencia. El punto de partida de Ideas sobre la novela se apoya justamente en la verificación de la declinación del género novelesco, pero a diferencia de la hipótesis de Benjamin, que se funda en la dificultad del novelista -más que del narrador- en transmitir experiencias, Ortega lo atribuye al agotamiento del material novelable. Aunque no lo diga, pareciera que Ortega percibe otro de los fenómenos que preocupó a Benjamin, la consunción de la experiencia debido a las mediatizaciones varias entre el hombre y sus vivencias.

Seguiré en mis razonamientos el análisis de José Luis de Diego, quien a partir del "El narrador", realiza una proyección de los principales postulados de Benjamin en las teorías y prácticas estéticas de la segunda mitad del novecientos: Wim Wenders, Adorno, Grass, son el contrapunto contemporáneo de las conocidas anticipaciones benjaminianas sobre las imbricaciones artemedios masivos-experiencia.

La confluencia de las perspectivas del filósofo español y el alemán dan testimonio de la extrañeza que provocaban al hombre europe las novedades técnicas y sociales inauguradas con el siglo XX. Ortega registró tempranamente 
que el abandono de los viejos modos novelescos conduciría a un nuevo canon. Quizás no le extrañaría que después de un período en que renacería la novela clásica, el rechazo de la narración volvería a imponerse en los años 60, para retroceder otra vez a finales del último siglo.

\begin{abstract}
Los efectos de estas transformaciones [la pérdida de la experiencia y sus efectos sobre la narración] sobre la literatura han sido largamente reseñados: denegación de la totalidad social como objeto de la representación novelística, autorreferencialidad del discurso, fragmentación de la experiencia representada, experimentación formal, auge de los discursos paródicos, 'muerte del autor', etc. Estas características no solo fueron imperativos autoimpuestos por los escritores que se alejaban más y más del 'realismo ingenuo', sino también el fruto de una labor crítica que se ocupó de desmontar la supuesta NATURALIDAD del realismo decimonónico ('... ninguna escritura es más artificial que la que pretendió pintar a la Naturaleza más de cerca' decía Roland Barthes en 1953), y demostró un sostenido entusiasmo por las manifestaciones artísticas que se distanciaban ostensiblemente de este modelo". [de Diego, 2001: 250-251] ${ }^{34}$
\end{abstract}

Si se suprimiera la cita de Barthes podríamos pensar que el autor se está refiriendo a La deshumanización del arte y a la llamada novela deshumanizada o de vanguardia de los años veinte, en la que he de detenerme en un próximo capítulo. Indudablemente, el abandono de la novela que se sustenta fundamentalmente en la narración está ligado a otro de los rasgos más subrayados por Ortega y la crítica posterior, el hermetismo y la desvinculación con la vida, que a su vez, vuelve a remitir a la creciente imposibilidad del género de transmitir experiencias y de ocuparse de los grandes temas humanos.

Como consigna de Diego citando el guión de Wenders, los nuevos héroes "ya no son los guerreros y los reyes, sino las cosas de la paz, todas iguales entre sí. Las cebollas disecadas son tan valiosas como el tronco de una árbol atravesado en el pantano" [de Diego, 2001: 245]. ¿Qué otra cosa es la intrascendencia que la irrupción de las cebollas disecadas tras la desaparición de la épica?

$\mathrm{Si}$, como afirma de Diego a partir de Benjamin, el nacimiento de la novela moderna fue acompañado de un progresivo abandono de los elementos narrativos, se puede apreciar que lo que para Lukács era fruto de un momento histórico y de una conducta de clase -la "deserción" de los escritores burgueses, ${ }^{34}$ Subrayado del autor 
que abandonan la novela clásica, o sea, la narración- para el autor de Iluminaciones es el resultado de un más largo proceso.

Lo que me interesa destacar de la posición de Lukács es que la novela ha dejado de ser un MEDIo de comunicar la experiencia colectiva PORQUE ha abandonado la narración. [de Diego, 2001: 254]

Y añade líneas más abajo:

Lo novedoso de la hipótesis de Benjamin es que la novela no abandona la narración -según lo postula Lukács -durante un proceso fechable en la segunda mitad del siglo XIX, sino que la novela moderna nace contRA la narración; con el origen de la novela COMIENZA A DESAPARECER la narración como tantos otros, Benjamin menciona al Quijote como hito inicial de la novela moderna ${ }^{35}$. [de Diego, 2001: 255]

¿Qué sucede con la narración entonces? Las alternativas o estrategias de supervivencia de la narración una vez que ha sido desplazada de la novela es otra de las cuestiones que Ortega aborda, con lo que deja sentado un precedente para indagaciones posteriores ${ }^{36}$. Al finalizar el ensayo, ya se ha visto en páginas anteriores, que Ortega ha delineado un tipo de novela moderna en el cual ocupan un lugar sobresaliente Cervantes, Dostoievsky, Stendhal, y con reparos, Proust. En la otra acera, además de los denigrados narradores "realistas", quedan la epopeya, el cuento, la novela de aventuras, el melodrama y el folletín. A partir de la novela de Cervantes traza una demarcación que permite pensar que determinados géneros populares -“subgéneros"- se constituyen en la "reserva" de la narración o, dicho de otro modo, que la narracción, repudiada por la novela, se refugió en los "géneros menores". La hipótesis, como es sabido, goza de gran desarrollo en las actuales reflexiones sobre el arte en la posmodernidad.

\footnotetext{
Hace más de diez años que en las Meditaciones del Quijote atribuía yo a la novela moderna, como su misión esencial, describir una atmósfera a diferencia de otras formas épicas -la epopeya, el cuento, la novela de aventuras, el melodrama y el folletín- que prefieren una acción concreta, de línea y curso muy definidos. Frente a la acción concreta, que e un movimiento lo más rápido posible a una conclusión, lo atmosférico significa algo difuso y quieto. [IN: 36]
}

\footnotetext{
${ }^{35}$ En ambas citas, subrayado del autor.

${ }^{36}$ Cabe apuntar que Bozal advirtió también la necesaria diferencia entre narración y novela. V. nota 20 de este mismo capítulo.
} 
Poco más adelante, el filósofo describirá, sin proporcionar una explicación ideológica, la misma tendencia a describir que manifiestan los escritores naturalistas, frente a los realistas, que prefieren narrar; aunque en lugar de narrar y describir hablará de acción y contemplación. [Lukács, 1978]

La pura contemplación pretende ser una rigurosa imparcialidad de nuestra pupila, que se limita a reflejar el espectáculo de la realidad, sin permitirse el sujeto la menor intervención ni deformación de él. [IN: 38]

Pero inmediatamente pasará a desmitificar la pretendida objetividad abriendo el amplio campo de la investigación sobre la subjetividad y la enunciación, porque tras la imparcialidad de la pupila

\begin{abstract}
funciona el mecanismo de la atención que dirige la mirada desde dentro del sujeto y vierte sobre las cosas una perspectiva, un modelado y jerarquía, oriundos de su fondo personal. No se atiende a lo que se ve, sino al contrario, se ve bien sólo aquello a que se atiende. [IN: 39]
\end{abstract}

Los puntos de contacto de las reflexiones estéticas de Ortega con sus contemporáneos podrían ampliarse, pero mi propósito es esbozar la posibilidad una lectura de los ensayos estéticos no regida por los acercamientos previos, condicionados, bien por la condena de los aspectos más reaccionarios y elitistas de Ortega, bien por la veneración de sus empresa modernizadora -con restricciones-, bien por las lecturas reiterativas de sus aportaciones más divulgadas.

Pretendo demostrar también hasta qué punto la influencia contradictoria e incontestable en el campo político y cultural de su tiempo, unido a su discurso categórico y quizás, excesivamente didáctico -"es esto", que luego se convertirá en "no es esto"37- opacó la complejidad de un pensamiento que proporcionaba múltiples vías para la reflexión y que no se limitaban a una taxonomía de los recursos formales del arte nuevo. ${ }^{37}$ Su ruptura con el gobierno de la República se anunció con un célebre artículo titulado "No es
esto, no es esto". 


\section{(continúa Cap. III)}

Pretendo demostrar también hasta qué punto la influencia contradictoria e incontestable en el campo político y cultural de su tiempo, unido a su discurso categórico y quizás, excesivamente didáctico -"es esto", que luego se convertirá en "no es esto"1- opacó la complejidad de un pensamiento que proporcionaba múltiples vías para la reflexión y que no se limitaban a una taxonomía de los recursos formales del arte nuevo.

\section{Vanguardias en España: más que arte nuevo}

\subsection{Exordio del siglo XX. El umbral de las vanguardias}

A la hora de valorar las vanguardias españolas desde la perspectiva que se propone la presente tesis, esto es, abordar la cuestión sin parcelar los campos sino integrándolos a partir de las claves textuales y aceptando los interrogantes que cada autor y obra encierran, es necesario tener un panorama del complejo nudo de problemas que se presentan. Por este motivo, antes de detenerme en cada uno de los tres escritores señalados, pretendo describir el fenómeno de los ismos en su contexto estético, histórico y cultural a partir de las distintas contribuciones existentes las cuales, a pesar de su divergente juicio o perspectiva teórica, invitan a ser analizados en un universo común.

Al abocarme a esta tarea veo que reaparece una dicotomía ya expuesta: la lentitud de los procesos modernizadores en los países periféricos lleva a los críticos a depreciar y considerar secundarias y miméticas las expresiones vanguardistas allí surgidas, o por el contrario, a encontrar en la diferencia una fuente productiva y una ventaja para reforzar las marcas propias y originales. En esta línea me interesa seguir indagando.

Los puntos que considero esenciales para comprender el fenómeno exigen inscribir el período en un lapso temporal más vasto que el circunscripto a

${ }^{1}$ Su ruptura con el gobierno de la República se anunció con un célebre artículo titulado "No es esto, no es esto". 
las cuatro primeras décadas del siglo $\mathrm{XX}$ con su momento culminante en los años veinte y treinta.

El atraso de los procesos modernizadores de España, que comienza con las rémoras culturales, religiosas y políticas instauradas en el siglo XVII con varias felices excepciones, proyectará su sombra hasta bien entrado la pasada centuria: "El principio del fin del Antiguo Régimen (versión tardía, muy siglo XX) ocurrió en 1975", afirma Salvador Giner. Esta seña particular hispana es un axioma y punto de partida insoslayable para el investigador, hasta haberse convertido en una cita obligada y a veces, humorística.

\begin{abstract}
A lo mejor resulta que España es un enigma histórico. Ningún país europeo occidental comparable a ella por su tamaño y complejidad, así como por la envergadura de su civilización, consiguió lo que España logró: zafarse de la modernidad y hacer morder el polvo al Zeitgeist de la era industrial con tan insuperable brío y eficacia. [Giner, 1985 (En Rico, 1992: 51 y 46)]
\end{abstract}

La tensión entre fuerzas regresivas y fuerzas modernizadoras que Maravall señala como determinante del siglo barroco se reprodujo con distinto grado de virulencia en los siglos posteriores: pensemos en la reacción antiilustrada de Carlos IV, el oscurantismo de Fernando VII, las tres guerras carlistas del siglo XIX, el fracaso de la I República de 1868 y, por último, el del segundo intento republicano, seguido de la guerra civil de 1936 y la dictadura de cuarenta años de Francisco Franco.

Las recurrentes dificultades en la singladura modernizadora no autoriza sin embargo a invalidar los movimientos filosóficos, culturales, ideológicos, estéticos, que se introdujeron, generalmente a destiempo pero que, conjugados con el sustrato de la cultura y de la propia realidad españolas, adquirieron rasgos peculiares, bien se trate en el siglo XVIII de una llustración sin una clase burguesa sólida que la sustente, bien de un Romanticismo que careció del revulsivo de la marea racionalizadora de un auténtico Siglo de las Luces.

De la misma manera, a finales del ochocientos España si bien no experimenta un radiante Fin de Siglo, una dorada Belle Époque, no carece de los signos anticipadores de los grandes cambios del siglo XX, que sumen a la elite intelectual en actitudes dispares ante el reto modernizador. La crisis, así 
llamada por los historiadores, ha sido objeto de prolongada atención y de innúmeros trabajos, especialmente centrados en la fuerte tensión entre los partidarios del progreso y los defensores de la prosapia castiza y conservadora. La ambigua y divergente actitud de las clases dirigentes y de los intelectuales en este caso, los llamados "del 98"- ante fenómenos nuevos y desafiantes, impide el triunfo declarado de la opción modernizadora, con lo cual la idea de dos Españas cada vez más enfrentadas y separadas se profundiza preanunciando futuros conflictos.

Fin de siècle European anxieties about the decadence of western civilization were experienced in a particularly complex form in Spain; where intellectuals were divided as to whether or not Spain should follow the European modernizing model, and as to whether the problem in Spains's case was modernity or a lack of modernization. [Grahan- Labanyi, 1995:21]

La emergente sociedad industrial vino acompañada por la aparición de un público de masas y del fortalecimiento de las nuevas clases sociales organizadas en partidos y sindicatos. El enfermo sistema político de la Restauración y su inane y regresiva monarquía, si por una parte abonó las crisis y conflictos que estallarían en los años treinta, por otra, no pudo frenar los vientos modernizadores que se filtraban bajo múltiples formas.

En la esfera artística el modernismo hispánico es la expresión más descollante de la tendencia a la apertura y a la exploración de nuevos rumbos. Una de las consecuencias más evidentes es el desplazamiento de las poéticas de la representación del lugar central que habían ocupado en la segunda mitad del ochocientos, aunque permanecieron en las tendencias artísticas que proponían la vinculación entre arte y realidad cotidiana.

El aporte de recientes investigaciones abre en este sentido un dilatado panorama acerca del papel desempeñado por toda una literatura a menudo marginal y alejada de las tendencias estetizantes, a menudo colindante con ellas y en relaciones de buena vecindad, en la aparición de los nuevos fenómenos sociales y culturales como es el crecimiento del público lector y las políticas de las izquierdas dirigidas a la educación de los sectores populares. ${ }^{2}$

${ }^{2}$ Ramos Gascón otorga un importante papel en la gestación del arte moderno a las relaciones de escritores consagrados con publicaciones políticas de izquierda. Por su parte, Serge Salaün - 
Acompañando los programas políticos de la izquierda radical surgen las conocidas, aunque efímeras revistas Germinal, Vida Nueva, Alma Española y, representando a las organizaciones obreras más organizadas, las socialistas $\mathrm{La}$ Nueva Era y Revista Socialista en Madrid, y La Revista Blanca de filiación anarquista, en Barcelona. Basta acercarse a la imprescindible Edad de Plata de Mainer para tener una dimensión de la variada escena cultural española de entresiglos.

Con ese estado de cosas entran los españoles en el novecientos. En el escenario político, una intensificación de todos los fenómenos que rompían con el quietismo y las restricciones impuestas por la orientación conservadora de la restauración borbónica; en el campo artístico e intelectual, un sistema que comienza a abrir una brecha cada vez más profunda con la vida inmediata y con el resto de la sociedad acentuando la separación arte / vida que se agudizará en las obra de vanguardia.

Las tendencias estéticas modernizantes de finales del siglo XIX, aunque ocuparon el centro del campo cultural, no anularon las poéticas de la representación. La sistematización de las historias literarias frecuentemente hace olvidar no sólo poderosas firmas realistas como Blasco Ibáñez, sino también que Galdós murió recién en 1920 y que continuó escribiendo hasta 1912. Sólo una lectura muy condicionada por las categorías y los movimientos puede ignorar que el escritor canario realiza modificaciones de corte moderno en su poética realista y que, aún sus obras más "miméticas" -las llamadas novelas contemporáneas- demuestran la constante puesta al día de su universo novelesco a la luz de los cambios culturales. Sin abandonar la preocupación referencial introdujo cambios en su taller narrativo e incorporó el imaginario finisecular, el decadentismo y los debates sobre la relación arte y vida ${ }^{3}$.

indudablemente imbuido del imperativo categórico de la vanguardia- cree que fueron intentos fracasados, pues la mayor parte de los intentos anarquistas no elaboraron teoría estética alguna para encauzar sus aspiraciones sociales: "Los anarquistas españoles, por su rechazo de toda preocupación formal -considerada como burguesa y decadente-, por su concepción del lenguaje, no sólo no alcanzaron la soñada emancipación verbal y artística, sino que demostraron su absoluta dependencia del sistema educativo, escolar y estético de la burguesía dominante". [Salaün, 1998: 210]

${ }^{3}$ Como pequeña muestra de la incorporación de materiales propios del imaginario simbolistadecadentista, puede consultarse mi trabajo sobre Camino de perfección en el cual rastreo motivos 
De la misma manera, los hábitos impuestos por la sucesión cronológica de las historias literarias, y aún más, la compartimentación en períodos, siglos y volúmenes, oculta la contemporaneidad de fenómenos que sólo analizados conjuntamente expresan las múltiples tendencias y tensiones en un mismo momento histórico. Sólo sirva para pensar el problema que 1902 es considerado el año del lanzamiento de la nueva estética simbolista, con la publicación de Camino de perfección de Baroja, La voluntad de Azorín, Amor y pedagogía de Unamuno y Sonata de otoño, de Valle Inclán. Pero también a comienzos de siglo, en 1904, aparece el Manual de gramática histórica del español de Menéndez Pidal, piedra fundamental de una indagación científica sin la cual no se explican determinadas innovaciones poéticas del 27. Y a sólo seis años de la irrupción editorial de la narrativa modernista española y cuatro de uno de los puntales de la investigación filológica en España tiene lugar la traducción del Manifiesto Futurista de Marinetti por Gómez de la Serna en Prometeo, marcando la introducción de las vanguardias históricas en España.

Continuando con los hitos de la historiografía literaria, podemos preguntarnos qué obras representan mejor a Valle Inclán, ¿las decadentistas Sonatas de principios de siglo o los esperpentos de los años veinte? ¿Cuáles identifican mejor la modernidad estética? Si se acepta que el arte del siglo sería otro sin la fecundación de la vanguardia, ¿no vale la pregunta inversa?: ¿qué sería de la vanguardia y del arte moderno sin los aportes de la vigorosa tradición referencial, la narratividad y la cercanía con la realidad inmediata o lejana? Sin esa síntesis se entienden Martes de Carnaval o El ruedo ibérico, textos que muchos críticos consideran la culminación del arte de Valle Inclán, escritos entre 1920 y 1932, mientras las vanguardias eran hegemónicas y el modernismo era considerado caduco por los cultores del arte nuevo ${ }^{4}$. Pero el modernismo

finiseculares que ya aparecen en Tristana. [Macciuci, 2001]. Asimismo La novela en el tranvía es ya una rotunda muestra de la descomposición del patrón realista clásico.

${ }_{4}^{4}$ Gullón relativiza el antimodernismo de las vanguardias: "Respecto al 'anquilosamiento de la vieja generación' es necesario distinguir. Este grupo de poetas surge cuando los grandes de la promoción anterior se hallan en plenitud de vigencia. Unamuno y Juan Ramón produjeron en los años veinte algunos de sus mejores poemas. Entre ellos y la vanguardia no existió incomprensión. Al revés: el reconocimiento y alabanza de los nuevos valores fue practicado con generosidad por casi todos los hombres del 98: Azorín y Machado fueron los primeros en ayudarles y defenderles. Apenas se registran ataques de viejos a jóvenes, ni al contrario, y los 
denostado no era el del último Valle o el de arte puro de Juan Ramón Jiménez, sino el ornamental y tópico de los epígonos de Darío.

Casos similares tienen lugar si se analizan las letras de la segunda década novecentista: en 1917 Ramón Gómez de la Serna ya es un escritor reconocido y se consagra con la edición de su primer volumen de greguerías, su más fecundo hallazgo vanguardista, pero en 1912 Antonio Machado había publicado uno de sus poemarios fundamentales, Campos de Castilla y Unamuno Niebla en 1914.

En el campo político, por los mismos años -1912- surgía el Partido Reformista con el propósito de lograr "una España moderna, tolerante y democrática, con una legislación social avanzada y una enseñanza de vanguardia". No debe asombrar entonces que la obra de contenido más cívico de Antonio Machado, a sólo tres años de las greguerías y de la irrupción del Ultraísmo y el Creacionismo, coincida en el tiempo con la aparición de un grupo de destacados pensadores que de inmediato secundan al recién surgido partido en el proyecto de modernizar el país,

\begin{abstract}
Una clase intelectual, en el verdadero sentido del término, de amplitud nunca superada después, se adjudica la tarea de dar al liberalismo español consistencia ideológica e impulso ético. Son los Azaña, Ortega y Gasset, Fernando de los Ríos, Pablo de Azcárate y Américo Castro, que en 1913 convocaban un Liga de Educación Política ${ }^{5}$. [García de Cortázar y González Vesga, 1994:547-548]
\end{abstract}

Son igualmente signos de rigurosa modernidad el crecimiento de los movimientos de masas, ya iniciado en el siglo XIX, el protagonismo en auge de los sectores populares, la afirmación de partidos y sindicatos de izquierda, el triunfo electoral de las opciones progresistas, el enfrentamiento con el orden constituido 6 .

observables (por ejemplo los de Gerardo Diego contra Juan Ramón y Ortega, en Lola) no se deben a específica contradicción generacional sino a querellas de otro orden, como hubieran podido darse entre gentes de la misma edad. Los 'anquilosados' son los poetas de las tendencias abolidas: Gabriel y Galán, Marquina, el último Villespesa..." [1969: 134]

${ }^{5}$ Vale la pena consignar que el Partido Reformista nunca logró atraer más adeptos que los provenientes de una reducida minoría ilustrada y que, por otra parte, será el semillero de los líderes de diferentes grupos republicanos de 1931.

${ }^{6}$ Después de la revolución de 1868 surgen los primeros centros obreros en Madrid y Barcelona, en 1864 la I Internacional crea una sección española, en 1872 las Cortes la proscriben y disuelven todas las asociaciones obreras adheridas a ella; en 1874 se persigue 


\subsection{El contexto politico de las vanguardias: la Dictadura de Primo de Rivera}

A esta altura de la exposición quizás esté claro que la década que interesa especialmente a este estudio es heredera, desde el punto de vista estético, de las tendencias artísticas generales iniciadas en el último cuarto del ochocientos, sin cuya consideración todo acercamiento quedaría, a mi entender, trunco. Es entonces momento de conocer las singularidades de los años veinte, comenzando por el marco histórico en que tiene lugar la consolidación de los movimientos de vanguardia.

La denominación con que se designa al tercer decenio del siglo XX, "los felices veinte", es a todas luces paradójica si se piensa que desde 1923 a 1930 España vivió bajo la dictadura del General Miguel Primo de Rivera. Más paradójico aún es que el decenio siguiente se conozca como el de "los hoscos treinta", cuando en las elecciones en febrero de 1931 triunfa la opción renovadora y en abril del mismo año se instaura la II República, momento de convergencias y esperanzas generalizadas que concentra las miradas del mundo entero.

Difícil será en tan corto espacio trazar un panorama ecuánime del primer tercio del siglo XX en España, que desembocó en la mítica y durísima guerra civil de 1936, pero es preciso intentarlo porque quizás nunca como en los años veinte y treinta literatura, arte y acontecer histórico estuvieron por primera vez tan imbricados; nunca vanguardia y política tuvieron tanto que decir y decirse ${ }^{7}$. La desidia de la Restauración, su resistencia a llevar adelante los cambios estructurales, económicos, sociales el retraso del país requería, la respuesta

encarnizadamente a los cabecillas. En 1879 Pablo Iglesias funda el Partido Socialista Obrero Español (PSOE) y en 1888 la Unión General de Trabajadores (UGT), instituciones que se inscriben en la II Internacional Socialista de 1889. Entre 1991 y 1900 los anarquistas se organizaron en Federaciones Obreras y en 1911 fundan la Confederación Nacional del Trabajo (CNT).

7 "En resumen, [vanguardia política] es uno de los ingredientes esenciales de nuestra Historia contemporánea. Es más, detrás de este concepto complejo -no unívoco y reñido- emerge, a mi entender, la empresa intelectual y estética más efervescente, dinámica, decisiva, de los años treinta (y seguirá siéndolo en la década posterior, e incluso después) en el mundo 'occidental'". [Salaün, 1998: 209] 
violenta y regresiva que el orden daba a los reclamos populares, fueron el caldo de cultivo para el enfrentamiento de dos sectores que cada vez se distanciaban más: un país que marchaba hacia modelos de vida modernos, con los aspectos favorables y negativos que se han descripto en anteriores capítulos, frenado por estructuras premodernas tanto en el orden social, económico e institucional como en el plano de las mentalidades. Antagonismos diversos se agudizaron en la última etapa de la restauración: liberales frente a conservadores, movimientos obreros frente al sistema burgués capitalista, campesinado frente a estructuras agrarias semifeudales, republicanismo frente a monarquía, Iglesia frente a laicos, masones y ateos, anarquía frente a estado, centralismo frente a regionalismos. Desde fines del siglo XIX hasta comienzos de los años veinte España asistió al empuje del proletariado emergente y progresivamente organizado y a las fieras represalias del poder político y económico que se sentía amenazado por los nuevos sujetos sociales ${ }^{8}$.

Hacia 1920 el panorama es de profunda crispación en distintos frentes: en el plano económico, después de una breve mejoría derivada de la neutralidad española en la gran guerra, reaparecieron los males endémicos del país y las protestas por el encarecimiento de la vida.

Lo social viene signado por las innumerables protestas y movilizaciones obreras y campesinas, combinadas con la acción directa de los anarquistas y la institucionalización de la "ley de fugas". La izquierda socialista, por su parte, debe arrostrar la escisión de los más jóvenes, partidarios del modelo soviético y

${ }^{8}$ EI XIX se cierra con los juicios de Montjuich, famosos por la arbitrariedad y la falta de garantías jurídicas, hechos que pertenecen más al siglo que se inicia que al pasado, debido a la repercusión internacional y al efecto que produjo en los intelectuales. La primera de las grandes alteraciones sociales del siglo XX tuvo lugar en 1909 -semana trágica- cuando los obreros barceloneses se negaron a ser enviados como reservistas a la guerra de Africa y declararon la huelga general. El Gobierno los reprimió duramente y condenó a muerte al anarquista Francisco Ferrer y Guardia. La segunda, en 1917, cuando se declara una huelga general revolucionaria que fue rápidamente controlada. Por último en 1919, también en Barcelona, los anarquistas desencadenan numerosas huelgas, entre las que destaca la de La Canadiense, empresa de capital extranjero monopolizadora de la producción hidroeléctrica. La lucha obrera es neutralizada mediante lock-out empresarial, al cual siguen violentas acciones de los obreros y del gobierno barcelonés. El asesinato del presidente Eduardo Dato en 1921 se inscribe en los mismos episodios. 
de la participación en la III Internacional, que concluye con la creación del Partido Comunista (PC) en 1921.

En lo político y castrense la derrota -"el desastre"- de Annual en Marruecos, que causa doce mil bajas españolas, desmoraliza a civiles y militares, y genera pedidos de responsabilidades y alarma ante el temor de una reedición de la guerra de Cuba.

En estas circunstancias el General Miguel Primo de Rivera da el golpe de estado de 1923 invocando el mantenimiento del orden y la conservación de la paz laboral como primeros objetivos nacionales, con escasa resistencia de los distintos sectores sociales.

\begin{abstract}
Apenas si se oyó rechistar ante el cuartelazo de un ejército cada vez menos romántico y ya nada liberal. En realidad, buena parte de su éxito incruento se debió a la notable indiferencia del pueblo español y a la colaboración de la burguesía catalana, práctica donde las hubiere. Una mayoría de fuerzas sociales y políticas aceptaron, pasivas, el golpe y algunas, como la CNT, que podía haberse opuesto, estaban bastante caídas después de diez años de actividad frenética, luchas intensas y logros menguados. [García de Cortázar y González Vesga, 1994: 557]
\end{abstract}

La dictadura presenta dos caras opuestas que permiten explicar la expresión "felices veinte" y el florecimiento y auge del arte nuevo. En el plano político, la indiferencia inicial se transformará en un creciente descontento abonado por los ininterrumpidos fracasos de gran parte de las iniciativas e intervenciones políticas del dictador. En el campo económico y social, sin embargo, obtuvo importantes éxitos que acercaron al país a las cotas de modernidad esperable de un estado europeo. A la bonanza económica se sumó una relativa calma social, de la que fue partícipe el PSOE, que durante los primeros años acompañó la acción de gobierno, de carácter regresivo como es propio de una dictadura. Los huelguistas, que en 1921 llegaron a doscientos cuarenta mil, en 1926 eran menos de veinte mil; los atentados por causas político-sociales, que superaron los ochocientos en 1923, prácticamente dejaron de producirse. El cansancio de la clase obrera por el fracaso de los últimos levantamientos contra la monarquía y la inicial paz social lograda por Primo de Rivera consiguieron en los primeros años el apoyo de sectores populares. 
También los intelectuales manifestaron contento al comienzo de la dictadura primorriverista.

Entre los intelectuales españoles, al principio, se saludó con cierto optimismo la llegada de Primo de Rivera al poder; juzgamos esta actitud como una consecuencia de la ideología regeneracionista que había lamentado una y otra vez el fracaso español a partir de 1898 y que anhelaba una "mano de hierro", capaz de empuñar el país y llevarlo a nuevas singladuras. [Castañar,1992:23]

Al imaginario regeneracionista ${ }^{9}$, debe añadirse el éxito en el área de las obras públicas y la acción social del estado. Superados los fracasos africanos con un desembarco hispano-francés, el sector militar se apacigua y los esfuerzos económicos se vuelcan a la modernización y capitalización del estado: se amplían carreteras y caminos vecinales y se lanzan obras públicas con apoyo socialista que redundan en los sectores de la siderurgia y el cemento. Se inicia la electrificación rural, se crean las Confederaciones Hidrográficas y se reaniman los pequeños y medianos comercios con la demanda del Estado. Las grandes empresas y los cinco principales bancos se asocian para el apoyo financiero de obras públicas a empresas privadas con dificultades. Se incrementa notablemente la introducción de capital extranjero, sobre todo en sectores de punta: teléfonos, material eléctrico, alimentación, químicas y caucho, pero al mismo tiempo el Estado se hace fuerte con compañías monopólicas como CAMPSA (hidrocarburos) y Telefónica. Hacia 1929 el resultado es una inédita prosperidad económica y productiva en todos los órdenes y un aumento de la actividad industrial -muy dependiente del capital financiero y de las instituciones de crédito- que se refleja en el flujo migratorio de los trabajadores del campo a la ciudad con los fenómenos sociales y urbanísticos que le son propios. Consecuentemente, aumenta el consumo de forma notable y comienzan a

${ }^{9}$ Regeneracionismo: movimiento crítico surgido durante la Restauración liderado por Joaquín Costa (1846-1911). sus impulsores clamaron insistentemente por la regeneración de la patria, de ahí su nombre. Constituían un grupo heterogéneo: los más liberales, entre los que se encontraba Costa, no parecían oponerse a la iglesia católica sino que por lo general se hallaban más interesados en la reforma económica y política y en grado menor, en lo social. La meta de todos ellos era hacer que España alcanzara el nivel de progreso y modernidad de otras naciones europeas como Francia e Inglaterra. El gobierno respondía a su propia inseguridad con durísimos ataques contra sus críticos o con la censura y persecución de los disidentes. El regeneracionismo llegó a su punto más alto a la vuelta del siglo. Siguió existiendo, al menos hasta la década del veinte. 
integrarse las regiones apartadas sumidas hasta entonces en una acentuada pobreza $^{10}$.

Las ciudades crecieron, se construyeron nuevos edificios y se abordaron ensanches que consumaban la degradación de los antiguos barrios céntricos, se abrieron los primeros grandes almacenes y los primeros cafés con simplistas decoraciones art decó (...) Se construían cinematógrafos y rara fue la capital de provincia que no inauguró entre 1914 y 1920 su Gran Hotel como, poco más tarde, su servicio telefónico automático. Los pueblos se sintieron más integrados por obra de una impalpable revolución modernizante: el auge de las comunicaciones por carretera (líneas de autobuses, transporte por camión, aumento vertiginoso de coches particulares) se sumó a la generalización de la electrificación -ya iniciada a principios de siglo- y al descubrimiento del turismo (que se desarrolló grandemente bajo la Dictadura, momento en que se inauguraron los primeros paradores de Mérida, Benicarló, Aranda de Duero, etc.). [Mainer, 1981: 179]

El resultado es un cambio notable de las formas de vida, especialmente urbanas, que permiten hablar de una ruptura con la prolongada parálisis del siglo XIX y de un dinamismo cuya característica más sobresaliente era, pese a los signos de renovación, la pervivencia de fuertes contrastes con las zonas más atadas a la tradición.

Simultáneamente, el Estado comienza a asumir responsabilidades en la subvención de necesidades de la población: sanidad, educación, orden, vivienda. La relativa prosperidad permite el mantenimiento del régimen hasta que comienza un deterioro de la economía y recrudecen las protestas sociales, sobre todo las de los intelectuales y estudiantes universitarios.

Es clave para la comprensión de la caída de la dictadura registrar cómo los distintos sectores sociales pasaron de la indiferencia o del asentimiento tácito de los comienzos a la total disconformidad, hasta el punto que salvo contadas excepciones, no hubo colectivo o corporación que en 1930 no fuera enconadamente antidictatorial y antimonárquico. Igual distancia puede observarse entre la relativa tranquilidad social de los comienzos y el aumento de los conflictos y la movilización al final. En 1927 tiene lugar la trascendental fundación de la Federación Anarquista Ibérica ( $\mathrm{FAl})$, al tiempo que la Unión

\footnotetext{
${ }^{10}$ Naturalmente, corresponde a otra disciplina indagar la solidez o la precariedad de estos signos de prosperidad económica. A esta investigación le importa destacar la atmósfera de renovación que se extendía por vastos sectores de la sociedad española.
} 
General de los Trabajadores (UGT) aceptaba colaborar con la dictadura asesorándola en la redacción de las leyes laborales.

\subsection{Vanguardia, inTELeCtuAles Y Dictadura}

La oposición de los intelectuales a la dictadura, y por extensión a la monarquía, fue primordial para el advenimiento de la II República. En este caso, cuando se dice intelectual, se debe hacer extensivo a artistas y hombres de letras en general. Los historiadores coinciden en que sin su accionar no se puede entender el colapso del último monarca de la Restauración. Esta afirmación, en flagrante contradicción con el panorama que he esbozado en las páginas anteriores, debe precisarse temporalmente, pues la confluencia de fuerzas contra el régimen monárquico sólo tiene lugar en la última etapa, desde enero de 1930 hasta abril de 1931. Según el conocido estudio de Tussell y Queipo de Llano, aunque la oposición no surge de la nada, es importante recordar que "como el resto de la sociedad española, el mundo intelectual recibió el golpe de Primo de Rivera de una forma no totalmente negativa". [1990: 11]. Los nombres abiertamente críticos desde el comienzo fueron Unamuno, Valle Inclán, Azaña y Pérez de Ayala ${ }^{11}$. Muchos otros, la mayoría, bien por sus ideas conservadoras, bien por sentirse hastiados de la incompetencia de la Restauración, habían visto en Primo de Rivera la solución largamente esperada. El punto de flexión se produce en 1925, en que se comienza a perfilar el sector de los simpatizantes primorriveristas-Azorín, Maeztu, Fernández Flores, escriben contra el sistema democrático- mientras Araquistáin llama a los intelectuales a participar de la vida política. En ese momento Ortega buscaba convertirse, sin éxito, en inspirador de la obra política de la dictadura con el propósito de influir en Primo de Rivera para que no se dejara tentar por un retorno a los moldes del pasado. Acerca de la toma de posición del intelectual, el director de Revista de Occidente era partidario de que los escritores, artistas y

\footnotetext{
${ }^{11}$ Sin duda quien tuvo una trayectoria republicana más antigua y una posición más claramente antidictatorial fue Blasco lbáñez. La omisión o las referencias mínimas que suelen brindar los historiadores es un signo muy elocuente de una partición del campo intelectual en la cual el escritor valenciano era relegado a una zona secundaria.
} 
científicos no se apartasen de las tareas inherentes a su profesión, opinión que le hace romper con sus acompañantes de El Sol -Araquistáin y Gómez de Baquero. [Queipo de Llano, 1988: 16]

El dictador sin embargo no supo canalizar las simpatías que algunos le manifestaban. Continuó buscándose enemigos al cerrar el Ateneo y desterrar a Unamuno a Fuerteventura, aunque es en 1926, tras medidas muy desacertadas del dictador -persecución a Marañón, nombramiento de su propia persona como Doctor Honoris Causa por la Universidad de Salamanca, cierre del Ateneocuando se fragua una oposición compacta. No obstante, la misma ofensiva del gobierno provoca -según los mismos historiadores-, una reconcentración de los autores en sus obras, acentuándose así la poesía pura.

\begin{abstract}
Esta contraofensiva dictatorial tuvo como consecuencia un desvío del mundo intelectual respecto de la beligerancia política práctica, aunque, en última instancia, lo que sucediera fuera un alineamiento general contra el Dictador. En efecto, los años 1927 y 1928 transcurren en la antinomia entre pureza y politización de literatos e intelectuales. La "pureza" elusiva de cualquier compromiso político, fue el principal rasgo de la generación poética de 1927 , pero también es posible descubrir actitudes independientes entre la posición política y la creación literaria, incluso en escritores de inequívoca actitud opositora, como Azaña. [Tussell y Queipo de Llano, 1990: 12]
\end{abstract}

La interpretación es unilateral, pero igualmente merece tomarse nota de la proximidad, y no la oposición, entre arte puro y descontento en el campo político.

Otra hipótesis de los historiadores que conviene registrar es que los intelectuales solamente se volverán masivamente partidarios de la toma de posición política después de la caída del dictador, durante el año que transcurre entre el gobierno de Berenguer y la proclamación de la II República. Se puede decir que la disensión contra Primo de Rivera, gestada sobre todo con la movilización estudiantil a finales de 1929, que arrastró a un gran número de intelectuales, hizo eclosión cuando tras el alejamiento del dictador se suavizaron las condiciones de la censura ${ }^{12}$. Las tensiones subterráneas durante casi toda la

\footnotetext{
${ }^{12}$ Acerca del verdadero motor antidictatorial se ha dicho que al hundimiento de la Monarquía y a la proclamación de la Segunda República en gran medida "contribuyeron los jóvenes intelectuales y artistas de avanzada, aunque el crédito se lo terminara llevando la oficialidad atrincherada tras Ortega o Marañón" [Fuentes, 1998: 283]
} 
dictadura maduraron en el movimiento de la clase intelectual de mayor unanimidad que registra la historia de España.

De la misma manera, el sentimiento republicano aparece y se impone en ese mismo breve período caracterizado por una aceleración de los tiempos históricos y de los procesos de politización en todos los sectores, en fuerte contradicción con la lentitud de los reflejos del hombre que había sucedido a Primo de Rivera. Se registran además cambios notables en el pensamiento de los principales actores del campo intelectual, de modo que muchos incorporan ahora la temática política, ausente de manera explícita en su producción anterior. La urgencia por participar activamente como intelectuales y artistas en la vida pública se polarizó en las opciones de izquierda y de derecha. La izquierda encontró en la URSS el modelo de la nueva sociedad a construir, pero también atrajo a aquellos liberales que descubrieron la posibilidad de una alianza con el socialismo. En el otro extremo se encontraba la opción fascista, para la cual la Italia de Mussolini se convirtió en guía del futuro estado español. También existió una derecha moderada que alentó un monarquismo de corte retrógrado y anticonstitucional.

En este contexto tumultuoso, no deben extrañar los repentinos cambios de posición: Tussell y Queipo de Llano informan que difícilmente resulta idéntica la posición de un intelectual en enero de 1930 y en abril de 1931. En estos años se producen las grandes conversiones ideológicas, arrastrando tras sí las conversiones estéticas, entre las cuales sobresalen la adscripción de Rafael Alberti13 al Partido Comunista y la autoproclamación de Ernesto Giménez Caballero como representante del fascismo en la cultura ${ }^{14}$. Sin constituir casos tan renombrados, son incontables los hombres y mujeres de las artes y las letras que manifiestan públicamente el agotamiento de los modelos estetizantes y dan

${ }^{13}$ En verdad, en principio, Rafael Alberti manifiesta una rebeldía anarquizante contra el orden burgués, su adscripción al PC se produce más tarde, en 1932. "En 1931 emprendió un viaje, becado por la Junta de Ampliación de Estudios, a Francia, Alemania y la Unión Soviética. La carencia de definición ideológica resulta patente en las primeras crónicas que mandó, desde París, a El Sol..." [Caudet, 1993: 418]

${ }^{14}$ Es sabido que el director de la Gaceta Literaria colaboró estrechamente con el gobierno de Burgos durante la guerra civil, aunque nunca encontró la legitimación que buscaba como representante de la cultura en el régimen de Franco, quien no dudó en alejarlo cuando le fue posible, nombrándolo embajador del Paraguay, una de sus sedes diplomáticas más lejanas. 
a su proyecto creador un giro hacia la intervención en la esfera pública y el cultivo de temas de contenido social.

Junto al modelo estetizante, deshumanizado o vanguardista, los jóvenes entierran también al liberalismo democrático, que con todas sus contradicciones, encarnaba Ortega. Ya se ha mencionado que en los principales países de Europa y América las alternativas liberales, así como las llamadas terceras posiciones, pierden lugar frente al endurecimiento de la confrontación marxismo versus fascismo. Cabe recordar en esta instancia dos fenómenos que ilustran la complejidad del panorama político y social de finales del veinte: por un lado, que ante el avance de los movimientos de masas, la burguesía se refugió en múltiples ocasiones, en la alternativa fascista, tentación a la que Ortega no fue indiferente, como ya se ha visto. Se puede decir que comenzaba a tomar un perfil definido la idea que Ignacio Soldevila explica con pocas palabras:

Dictadura primo-riverista en el mundo de la política y orteguiana en las artes y el pensamiento no son sino dos aspectos de la reacción del individuo de élite, de la rebelión FRENTE A las masas ${ }^{15}$. [Soldevila, 1973: 22-23]

Por otro lado, el rechazo visceral a la dictadura implicaba el repudio conjunto de la España de la Restauración con todos sus tachas retardatarias, así como del imaginario liberal, russoniano, individualista y burgués del siglo XIX, que al decir de Ramiro Ledesma Ramos ${ }^{16}$, era un sentimiento existente por igual en la derecha y en la izquierda, sobre todo entre la juventud.

Hay dos Españas indudables en la pugna a las que sólo el confusionismo puede hoy unir en una pelea. A un lado la vieja España liberal, agotada... para quien las dificultades actuales se resuelven de plano en unas Cortes Constituyentes. Enfrente está la España joven, nacida ya en el siglo XX... Los jóvenes serán comunistas o fascistas, no lo sabemos, pero sí auténticamente hispanos y actuales... Unas Cortes Constituyentes significarían aquí la entrega de los destinos hispanos a las generaciones

\footnotetext{
${ }^{15}$ Subrayado del autor.

${ }^{16}$ Fundador del semanario La Conquista del Estado y en 1931 de la Juntas de Ofensiva Nacional Sindicalistas (JONS), cuyos símbolos fueron el yugo y las flechas. Estaban integradas por el mismo grupo de jóvenes que hacían la revista. En la revista se sientan los principios básicos del fascismo español: nacionalismo, antindividualismo, antiliberalismo, cooperación y no lucha de clases, unidad frente a separatismo, destrucción de la democracia burguesa, dictadura del Estado, acción de los poderes públicos para proporcionar cultura y acceso a la universidad a los hijos del pueblo. Años después la JONS se fusiona con Falange Española (FE), fundada en 1933 por Antonio Primo de Rivera.
} 
más viejas... Hay que impedir eso. [La Conquista del Estado, n 1, 14 marzo 1931. Citado por Tussell y Queipo de Llano, 1990: 89]

Llama la atención que a un mes de proclamarse la República, la polaridad ideológica no estaba constituida por las dos oposiciones que estallarían en los años siguientes; las derechas e izquierdas aún no habían llegado a su máxima confrontación. La consecuencia del estado de efervescencia y conflicto social fue la irrefrenable radicalización y común encono contra la democracia heredada de la Restauración por parte de los dos bandos que años más tarde se enfrentarían en las Cortes y en las trincheras, pero que a finales de la dictadura coincidieron en dos apotegmas básicos, el rechazo del purismo en el arte y del liberalismo en política.

La identidad de los jóvenes nacía de su ruptura con un mundo de liberalismo democrático que había sido y seguiría siendo el de Ortega. [Tussell y Queipo de Llano, 1990: 92]

La afirmación sin embargo debe complementarse a riesgo de equiparar dos ideologías opuestas. Por estos mismos años los grupos nacional sindicalistas no sólo vituperaron al sector que para ellos pecaba de liberal e individualista. En los jóvenes de La Conquista del Estado, por citar uno de los grupos de derechas más influyente, la prédica antiburguesa fue simultánea con la anatematización de todo lo extranjero, y principalmente, del marxismo, blanco de sus odios más intensos, que madurarían tiempo después en la plataforma de Falange Española (FE) ${ }^{17}$.

Hasta aquí se ha visto que en la década del veinte la dictadura primorriverista combinó, al principio con relativo éxito, la censura y la persecución de disidentes con una política modernizadora de la infraestructura del Estado e impulsora de la actividad industrial y financiera. Con ese encuadre político y económico, la esfera del arte desde el final de la gran guerra fue progresivamente dominada por "gente nueva" que continuó con muchos de los

\footnotetext{
17 "En vísperas de las elecciones generales de noviembre de ese año [1933], José Antonio Primo de Rivera funda Falange Española, contraria al liberalismo y el marxismo, declaradamente antirepublicana y empapada de un violento nacionalismo españolista". [García de Cortázar, González Vesga, 1994: 572]
} 
postulados esteticistas del modernismo pero renovados con las rupturas y propuestas formales de los ismos. Se puede afirmar que el rumbo dominante fue la profundización de la autonomía de la esfera artística, la exploración formal y el rechazo de las estéticas de la representación, premisas que produjeron el agotamiento y la repulsa generalizada al final de la década, del mismo modo que ocurría con las vanguardias en los países de Europa o América que las habían entronizado y convertido en modelos únicos e indiscutibles.

Pero el fracaso -provisorio- y las virulentas críticas recibidas de los partidarios de un arte con función social no debe impedir ver el componente político y revolucionario -no sólo en el plano del significante- del arte nuevo en España. La carga revulsiva y renovadora de las vanguardias se puede apreciar cuando se contrasta con las propuestas estéticas de las instituciones dominantes: los ismos no se enfrentaron tanto a los programas de recuperación del realismo y de la función social del artista como a instituciones anquilosadas y a las jerarquías que entronizaban el pasado y se ponían al servicio del inmovilismo en el arte ${ }^{18}$.

Del mismo modo que advierto sobre el error de no apreciar la carga de desobediencia y rebeldía que encerraban los gustos estéticos de la "gente nueva", deseo advertir la insuficiencia de un análisis que atribuya únicamente a una lógica interna de los propios ismos -por ejemplo, a la irrupción del surrealismo- la aparición de un gesto autocrítico y la recuperación del nexo entre el artista y su tiempo histórico. Significaría ignorar, como sucedió durante mucho tiempo, que los programas estéticos defensores de la vinculación del arte y la vida, o del arte entendido como instrumento válido para la modificación de la sociedad burguesa capitalista, o de la avenencia entre delectare y prodesse, todas concepciones alternativas al arte autónomo modernista o al arte hermético de las vanguardias, no desaparecieron en el útlimo cuarto del siglo XIX. Y significaría ignorar por tanto que tampoco desapareció el público que se inclinaba por las producciones más conectadas con la vida o el que elegía sin culpa el entretenimiento frente a la dificultad.

18 Sobre las disputas de las nuevas propuestas plásticas con las instituciones rectoras, ver Brihuega 1982a y 1982b. 
Pero sería igualmente erróneo restablecer la antinomia que enfrentara al arte gratuito de los modernos con el responsable y "situado" de los realistas. No sólo porque en la supuesta gratuidad existe una voluntad política antipasatista sobre la que me extenderé un poco más adelante, sino porque implicaría suponer que todos los escritores refractarios a la experimentación y la vanguardia practicaron una literatura testimonial, o suponer que todo el arte de cuño realista se puso al servicio de la transformación social. El problema es más complejo si se tiene en cuenta que hubo y hay otras polaridades, que hoy constituyen un importante foco de análisis, como es la oposición entre arte de masas y literatura. Hubo una literatura de entretenimiento que no cuajaba con la vanguardia pero tampoco con el arte con función social y que estuvo aún más arrumbada por la crítica. Con la aparición de estudios especializados que discuten e indagan estas categorías, se hace evidente que también el arte volcado a las inquietudes sociales formaba parte de una vanguardia que en este ocasión regentaba el campo de la "rehumanización".

La cuestión sobre la pertenencia a un grupo diferenciado del resto de la sociedad tiene una importancia crucial en los problemas que he venido desarrollando y por eso mismo me interesa subrayar. No se trata de una certidumbre que alentaba solamente a los artistas de la vanguardia y a los intelectuales de cuño orteguiano. Todos los sectores que se mostraban disconformes con el modelo burgués imperante y que apostaban al futuro, se sentían situados en un lugar "de avanzada", es decir, delante de la mayoría. Jorge Schwartz ha demostrado que las vanguardias artísticas prestan su discurso a las vanguardias políticas, las cuales, en ocasiones, llegan incluso a hacerse eco de sus matices elitistas y minoritarios. El convencimiento de pertenencia a un grupo reducido enlaza con dos cuestiones inmediatas: el público de las vanguardias en general y de las revistas en particular, y la supuesta conexión con el gran público de la vanguardia política frente al elitismo de la vanguardia artística. Sobre el primer punto, se observa que pese a tratarse, en los dos casos, de grupos minoritarios, poseían cualidades y medios como para operar transformaciones tanto en la esfera del arte como de la política. 
Sobre el segundo problema, no es pertinente establecer generalizaciones -no es igual la difusión de la poesía social en España a comienzos de los treinta que en plena guerra civil- pero sí se puede afirmar que vanguardia política y vanguardia artística compartían la idea de ser una minoría que se hallaba por encima o delante del resto de la sociedad, es decir, de ser "vanguardia".

\begin{abstract}
La metáfora de l'esprit nouveau, puesta en circulación en 1917 por Apollinaire, es retomada con fines estrictamente políticos. $Y$ a pesar de la orientación socialista del grupo Clarté, los autores dicen: "ESTAMOS SEGUROS DE QUE ESTE LLAMADO SERÁ OÍDO POR UNA MINORIA SELECTA Y CLARIVIDENTE".

Este llamado remite a la cuestión de los lectores de las revistas ¿Quiénes leían a la vanguardia estética? ¿Quiénes leían a la vanguardia política? En ambos casos parece que se trataba de una minoría letrada que, aunque no fuese significativa numéricamente, CONFORMABA UNA ÉLITE CAPAZ DE OPERAR CAMBIOS, TANTO EN EL CAMPO INTELECTUAL COMO EN EL CAMPO POLítICO. [Schwartz, 1991: $40]^{19}$
\end{abstract}

La poderosa aunque velada pugna del capital simbólico contra las leyes del público y del mercado afectaba incluso a las figuras más prestigiadas. Así ocurre con una parte de la poesía de Lorca, que aunque inserta en la vanguardia sobrelleva como un incómodo marbete el adjetivo de popular -y sin duda lo era, a pesar del propio poeta, al que le molestaba el calificativo, tanto como a Luis Buñuel le molestaba la poesía neopopular del granadino ${ }^{20}$. Se puede apreciar 19 Subrayado mío.

${ }^{20}$ Diferentes trabajos han indagado en las disputas estéticas del poeta con el cineasta y no quedan dudas de que el tradicionalismo lorquiano originó el fin de la amistad entre ambos [García de la Concha, 1984:358]. Por su parte, Jiménez Millán informa que "... dentro de la Residencia van a existir posturas más radicales, como las de Buñuel y Dalí (...) Buñuel, al igual que Dalí, no toleraba en absoluto las tendencias neopopularistas, reflejadas en el Romancero Gitano, ni los experimentos neogongorinos de Alberti y Gerardo Diego. A pesar del afecto que sentía por Lorca, Buñuel no tiene reparos en calificar el Romancero de tradicionalista, falsamente moderno y, a fin de cuentas, insoportable; de Alberti dice literalmente que 'está tocando los límites del absurdo lírico'; a Gerardo Diego le llama 'histrión' y, por último, afirma que hay que combatir toda la poesía tradicional, 'desde Homero hasta Goethe, pasando por Góngora, la bestia más inmunda que haya parido madre..."' [Jiménez Millán, 1999, 609-610]. Estos juicios deben inscribirse en los intentos de Buñuel y Dalí de convertir a Federico al Surrealismo. Similares opiniones envió el pintor al poeta desde Cadaqués después de publicado el Romancero: "He leido con calma tu libro, del que no puedo estarme de comentar algunas cosas. Naturalmente me es imposible coincidir en nada a la opinion de los grandes puercos putrefactos que lo han comentado. (...) Tu poesia actual cae de lleno dentro de la tradicional, en ella advierto la sustancia poetica más gorda que ha existido pero! ligada en absoluto a las normas de la poesia antigua, incapaz de emocionarnos ya ni de satisfacer nuestros deseos actuales. (...) Precisamente estoy convencido que el esfuerzo hoy en poesia solo tiene sentido en la evasion de las ideas que nuestra inteligencia a ido forjando artificialmente, asta dotar a estas de su exacto sentido real. (...) Tu te mueves dentro de las nociones aceptadas y antipoéticas... (...) El surrealismo es uno de los medios de Evasion. Es esa evasion lo importante". (subrayado del autor. Se ha respetado la ortografía original). [Dalí, 1928 (transcripta en Catálogo, 1995: 35-35)] 
que un tercero en discordia, la popularidad, se entrelaza en la polémica y crea un nuevo polo que no coincide con la literatura de vanguardia ni con la realista testimonial. Como contrapartida, confirma la existencia de una instancia superior que acotaría al arte elevado y "legítimo" -tanto vanguardista como "de avanzada"21 - equivalente, a intelectual y opuesto al arte de masa, y otro de raigambre más popular y ajeno al canon establecido ${ }^{22}$. A esta altura de la reflexión creo que insistir unilateralmente en la polémica arte deshumanizado arte con función social conlleva desconocer otras manifestaciones literarias que no respondían ni a una ni a otra.

\subsection{Hacia la Rehumanización de la literatura. Los nuevos temas de entreguerras}

La década del veinte verá aparecer numerosas editoriales que con mejor o menor suerte divulgan una literatura de izquierdas asentada en una concepción popular de la cultura. La crítica ha tratado esta vertiente como claramente diferenciada y distanciada de las vanguardias históricas.

Entre las tendencias que rechazaban la pureza en el arte tiene un capítulo aparte la traducción de literatura pacifista, resultado de las distintas experiencias bélicas europeas. Son obras de fuerte contenido autobiográfico que aspiran a difundir el horror de la guerra. Fueron primeros en alcanzar difusión los franceses -Henri Barbusse, Georges Duhamel, Romand Rolland-y hacia final de los veinte, los pacifistas alemanes. Todos gozan de gran éxito pero son acusados de ignorar la lucha de clases; se trataría de una proyección en la serie

${ }^{21}$ Recuérdese que a partir de El nuevo romanticismo (1930) de Díaz Fernández, literatura "de avanzada" designa a aquella que busca diferenciarse de la de vanguardia por su contenido social y "rehumanización".

${ }^{22} \mathrm{~V}$. Tomás, 1998b. Una llave muy interesante para romper los moldes de los estudios académicos tradicionales e incorporar zonas poco estudiadas del campo de la cultura en los años veinte y treinta la brinda Serge Salaün para el caso del teatro, término que propone reemplazar por la categoría espectáculo: "El concepto de placer, consubstancial del consumo teatral, espera sus teóricos. Este desfase entre teatro comercial, 'popular', o sencillamente de consumo masivo, y crítica universitaria explicará que, fuera de los 'grandes' de siempre o de los homenajeados por capricho del calendario, el resto de los dramaturgos de la época permanezca postergado u olvidado". [Salaün, 1995: 518] 
literaria de las críticas que las terceras posiciones recibían en el campo del pensamiento ${ }^{23}$.

Por los mismos años se daba a conocer la narrativa rusa y, con un impacto mucho menor, la norteamericana de principios de siglo, que denunciaba la quiebra de valores en su país. La rusa tuvo una inusitada repercusión, al hilo de las grandes esperanzas que despertó la revolución soviética, constituida en el anticipo inequívoco de los ansiados cambios radicales en las sociedades de occidente. Mucho se ha hablado de las ilusiones que la nueva dictadura del proletariado produjo en la cultura progresista, que por primera vez vio cercana la utopía de una humanidad libre de las injusticias del orden capitalista. Será también la época de los viajes y los relatos de las experiencias en la nueva Rusia agigantados por la mirada esperanzada del cronista.

Algunos críticos quisieron ver afinidades de naturaleza perenne entre el pueblo español y el ruso y entre sus dos literaturas. En 1927 el crítico E. Gómez de Baquero, Andrenio, desarrollaba su hipótesis -que rescata y amplía Fulgencio Castañar- acerca de la semejanza entre ambos pueblos, basada en el cultivo de un realismo similar, en un parecido ímpetu aventurero y errante encarnado en los pícaros, en un espiritualismo como los de Tolstoi y Dostoievski que se habían alimentado en fuentes hispánicas. [citado por Castañar, 1992: 39]

Sin embargo, el fenómeno no fue exclusivamente español y debe enmarcarse en la compenetración de las vanguardias políticas de occidente con la experiencia revolucionaria soviética. Al respecto, son extrapolables las experiencias que describe Beatriz Sarlo en la Argentina, donde a partir de 1918 se registran gestos públicos de adhesiones que terminarán cofigurando un nuevo sector en el campo intelectual. Se trata de una diferente manifestación del espíritu de "lo nuevo" -recuérdese que en España un grupo semejante invocará para sí el título de "nuevo romanticismo" y "literatura de avanzada".

La revolución rusa y los sóviets representaban, entonces, un principio de transformación radical, cuyo atractivo residía también en las proporciones épicas de sus actos, en la rapidez con que el cambio apreció realizarse, en la juventud de muchos de sus dirigentes, en el nuevo espíritu que anunciaba al mundo a la posibilidad de todas las transformaciones y el trastrocamiento

${ }^{23}$ Véase el cap. 2 de este libro. 
de todos los lugares sociales. La revolución rusa era una nueva cultura. [Sarlo, 1988: 122]

\title{
Entre las mutaciones felices que Rusia anunciaba tuvo especial
} recibimiento el nuevo estatuto del arte, porque en la sociedad sin clases artistas y escritores trabajaban para el pueblo sin necesidad de luchar con las leyes del mundo editorial. Reaparece, con rostro revolucionario, la vieja repulsa del arte moderno y de la vanguardia hacia las leyes del mercado. Por último, unos años después, Rusia representaría la esperanza de alzar una barrera al nazifascismo que avanzaba en todos los frentes; una alternativa a la que luego se la Revolución de Octubre de 1934 y la guerra de $1936^{24}$.

\begin{abstract}
Por estos mismos años en la esfera estética pueden encontrarse conversiones, coincidencias efímeras y replanteos similares a los que tenían lugar en el campo ideológico. Es evidente que la iconoclasia y la crítica los valores de la burguesía que las vanguardias habían llevado a cabo eran desplazadas por una nueva forma de entender la función del arte y el papel del artista en un sistema degradado e injusto. Para muchos críticos la ruptura fue tajante y definitiva, una divisoria de aguas que separó a los partidarios de un arte más cercano al hombre y sus problemas cotidianos, de los pocos indiferentes y superficiales que defendían el arte puro. Plantear la problemática de la literatura española de los años treinta supone abordar previamente las formas de liquidación de una vanguardia artística que se mostraba impotente para responder a la nueva sensibilidad de una década caracterizada por la fuerte politización de la literatura. [Aznar Soler, 1978: 13]
\end{abstract}

Existen sin duda razones de peso que justifican tales afirmaciones. Una de las argumentaciones más utilizada es la encuesta publicada en La Gaceta Literaria $^{25}$ el 1 de junio de 1930 sobre las tendencias en el arte ${ }^{26}$, cuyas

${ }^{24} \mathrm{~V}$. nota 33 VER del presente capítulo.

${ }^{25}$ Es la revista clave de la vanguardia española. Se publicó en Madrid desde 1927 a 1932. Fundada por Ernesto Giménez Caballero, fue su primer secretario Guillermo de Torre, reemplazado a finales del primer año por César Arconada, quien decidió abandonarla debido crecientea la inclinación al fascismo de su director a partir de 1929. Por este motivo, Giménez Caballero terminó haciendo la revista en solitario. Estos números individuales se titulaban El Robinsón Literario y alternaba con los primeros. Es imposible dar una lista breve de sus colaboradores, porque superan el centenar. Estuvo presente en La Gaceta Literaria la primera línea de la vanguardia española -con sus distintas regiones- la latinoamericana, la italiana, la portuguesa, y la de otras nacionalidades menos relevantes para el mundo hispano.

${ }^{26}$ La encuesta fue realizada por Miguel Pérez Ferrero y constaba de cuatro preguntas: 1) ¿Existe o ha existido la vanguardia?, 2) ¿Cómo la ha entendido usted?, 3) ¿A su juicio, qué postulados literarios presenta o presentó en su día?, 4) ¿Cómo la juzgó y la juzga ahora desde su punto de vista político?. Una selección de las distintas respuestas puede encontrarse en Buckley y Crispin, 1973: 394-412; y un registro de citas breves extraídas de la respuestas, en Brihuega, 1982: 20-22. 
respuestas confirman lo que ya se venía insinuando: el arte puro era rechazado por la gran mayoría de los artistas. Pero considero imprescindible realizar dos puntalizaciones: es metodológicamente riesgoso atribuir valor de verdad incontestable a los juicios de artistas y escritores que carecen de distanciamiento del fenómeno que protagonizan. Todos los consultados se hallaban muy influidos por el clima social de la época y por una reconfiguración del campo intelectual que desplazaba a las otrora incuestionables figuras del pensamiento y la nueva literatura -Ortega, Gómez de la Serna- y otorgaba el centro a otras voces. En segundo lugar, debemos los investigadores releer las fuentes tanto o más que los trabajos críticos resultantes de ellas, porque aún las tesis más sólidas pueden ser enriquecidas con revisiones actualizadas a la luz de nuevos marcos teóricos.

Asi se puede observar que estudios recientes matizan la impugnación de Díaz Fernández por la vanguardia, como bien ha señalado, entre otros, Jiménez Millán. Por una parte, el autor de El blocao rescata el futurismo por su "ruptura tajante con el modernismo y porque brindó los instrumentos para una alternativa renovadora:

\begin{abstract}
Sin embargo, la superación del formalismo vanguardista no implica, para Díaz Fernández, una regresión a los procedimientos realistas y naturalistas del XIX: se trataría, más bien, de incorporar todos aquellos elementos aportados por el tecnicismo de las vanguardias (muy especialmente las innovaciones de Mayakovsky), en orden a la construcción de una nueva literatura. Las líneas siguientes condensan una de las propuestas más importantes de El nuevo romanticismo: "La auténtica vanguardia será aquella que dé una obra construida con todos los elementos modernos síntesis, metáfora, antirretoricismo- y organice en producción artística el drama contemporáneo de la conciencia universal". [Jiménez Millán, 1999: 828]
\end{abstract}

Era previsible que José Díaz Fernández obtuviera la atención preferencial entre los encuestados habida cuenta de que su manifiesto "El Nuevo Romanticismo" fue la piedra fundamental de la recuperación del realismo. Por idénticos motivos también yo me ocuparé de él en varias oportunidades. No es objeto específico del estudio que realizo el análisis detenido de las proclamas y declaraciones estéticas de los años veinte, pero de hacerse seguramente seguirían replanteándose algunos veredictos. 
Entre sus afirmaciones, suelen citarse determinados párrafos:

Era pintoresco leer la literatura de esos señoritos satisfechos ${ }^{27}$ donde se mezclaban imágenes atléticas y palabras del tennis, del fútbol o del boxeo. Por lo general, estos muchachos no hacían otro deporte que el de ir el teatro con su familia en automóvil propio, o recorrer en bicicleta las carreteras lugareñas. Creían que los versos con muchos aviones y muchos "coocktails" era cifra y compendio de la moderna sensibilidad" [Díaz Fernández, 1930 (citado por Brihuega, 1982, 275)]

La cita precedente proporciona claves para inferir la condena de un arte de vanguardia muy particular, la narrativa de los "Nova novorum" tutelada por Ortega, pues alude a la tematización de las costumbres modernas propia de estas novelas así como a la extracción burguesa de sus autores. Se observa además que el manifiesto de Díaz Fernández menciona entre las razones principales del desprestigio de los ismos, la narrativa de vanguardia y, muy por encima en extensión y dureza, el futurismo de Marinetti, para entonces, aliado con el fascismo. Su crítica al vanguardismo español se asienta fundamentalmente en que lo encuentra perfilado por el futurismo fascistizante y por el tradicionalismo francés, aliado con la Iglesia ${ }^{28}$. Sin embargo, su opinión de las vanguardias como movimiento estético revolucionario es bastante más favorable de lo que suele darse a conocer; no sólo elogia y rescata, como se ha visto, aspectos formales de la vanguardia: el futurismo ruso de Maiakowski cantado por el pueblo ruso pero rechazado por Stalin- y la incorporación de los adelantos tecnológicos del futurismo italiano cuando estuvo en mano de los obreros. Los elementos formales no bastan si no se acompañan del espíritu rebelde y demoledor de la tradición y de la incorporación de nuevos temas y motivos representantes de los intereses del gran público. El contenido y la conexión con el público son, por lo tanto, inquietudes de primer rango.

El futurismo es la tendencia más seria y más fecunda de cuantas figuran en el índice de la nueva literatura. Le caracterizaba un ímpetu destructor, imprescindible en toda obra de avanzada artística. Daba entrada por primer

\footnotetext{
27 "Insuperable definición de Ortega y Gasset" (nota del autor)

${ }^{28}$ No es clara la alusión de Díaz Fernández "buscaron para sus metáforas el albergue tradicional del catolicismo", ¿se refiere al simbolismo-decadentismo?; ¿o al abate Henri Brémond, reputado partidario de la poesía pura? De cualquier modo, una prueba más de que las oposiciones no eran tan nítidas como luego quisieron verlas los críticos.
} 
vez en la lírica a elementos que habían estado hasta entonces desahuciados de la literatura y que respondía a exigencias de una nueva sensibilidad. Fue el futurismo el que creó las metáforas maquinistas, las imágenes simultáneas, el dinamismo lírico, y ese entusiasta desplazamiento del poeta hacia temas multitudinarios. [Díaz Fernández, 1930 (citado por Brihuega, 1982, 274)]

La condena de la vanguardia tiene como puede apreciarse, un recorte restringido, en el cual sobresale la descalificación del futurismo domesticado Marinetti ha pasado de iconoclasta a director de museo- $y$, en otro sitio del espectro ideológico, el arte deshumanizado, pero sobre todo, burgués e insensible a los problemas sociales, alentado por Ortega.

De la misma manera, si se continuaran analizando las restantes declaraciones, se podría comprobar que entre los consultados en la célebre encuesta de La Gaceta Literaria, hubo puntos de vista muy diversos: algunos tenían muy claro qué aspectos querían preservar del componente inquieto, osado, antipasatista del nuevo arte; otros consideraban cerrado un ciclo del que sin embargo les interesaba preservar el papel subversivo que había desempeñado la vanguardia. Con bastante frecuencia condenan la aclimatación disciplinada de los antiguos iconoclastas a las normas burguesas, y exaltan como fórmula de lealtad a la insurgencia originaria el tránsito de los rebeldes sobrevivientes al campo de la política. Varios de ellos reprochan el perfil de señorito incorregible del vanguardista tipo -reaparece nuevamente la velada alusión al grupo de Ortega. Por último, también aparece la impugnación virulenta de la vanguardia por quienes serían adalides del fascismo, como Ledesma Ramos, cuando aún no se había partido del todo el campo político e intelectual y la "dictablanda" de Berenguer favorecía la convivencia de todos los opositores a la monarquía.

Lo cierto es que a la luz de estas relecturas provisorias, cobra sentido la afirmación de Wentzlaff-Eggebert, para quien en los años treinta la literatura de vanguardia se travistió en literatura de avanzada. No hubo pues una linde infranqueable, es menos cierto aún que los ismos hayan sido universalmente repudiados ni que las acusaciones de snobismo y futilidad se pronunciaran de forma unánime y alcanzaran a todos por igual. Quizás las palabras más nocivas 
para el arte de vanguardia fueran las pronunciadas por Ramón Gómez de la Serna, consagrado como el vanguardista más conspicuo. El fundador de la tertulia de Pombo repara en que existía rechazo hacia el término y el concepto, pero se mantuvo ciego y sordo para percibir los nuevos derroteros de lo moderno, el cambio de sensibilidad, las nuevas inquietudes humanas y estéticas, así como la distancia real y simbólica que se había producido desde sus primeros pasos vanguardistas a comienzos de siglo hasta los agitados treinta. Su punto de vista, colmado de una subjetividad extrema, "la angustia me invade... No puedo más (...) tengo que dar un viva que me brota del corazón (...) ¡Viva la vanguardia! ¡Viva el vanguardismo!" [Buckley y Crispin, 1973: 401] contrasta con el talante más reflexivo y analítico de otros encuestados, antes vanguardistas reconocidos, como César Arconada, que después de ser redactorjefe de La Gaceta Literaria en los años treinta ingresó en el Partido Comunista y tuvo un relevante papel en Octubre ${ }^{29}$ y El Mono Azul ${ }^{30}$,.

\begin{abstract}
Los jóvenes de entonces cumplieron con su deber: abrieron fuego contra el enemigo. Hoy no nos damos cuenta, pero en aquel momento ser vanguardista era un heroísmo. La ruda hostilidad sólo podía sobrellevarse gracias a una juventud -una pasión- y a una táctica común -el grupo-. Como la mayor parte de aquellos jóvenes estaban adiestrados para la acción y no para la obra, para el grito y no para el rezo, para la lucha y no para el reposo, ellos murieron cuando se terminaron las finalidades de combate. Otros jóvenes cogieron la herencia, y en los campos pacificados empezaron a sembrar. Yo seré siempre el hombre que lleve una corona de agradecimiento a la tumba del vanguardista desconocido. [Buckley y Crispin, 1973: 397]
\end{abstract}

Las respuestas son sumamente iluminadoras, pero su análisis detallado constituiría una digresión muy extensa para este estudio. Me he limitado a citar

${ }^{29}$ Octubre apareció entre 1933 y 1934. Llegaron a salir seis números, siete si se incluye el número cero o Adelanto. Dirigida por Rafael Alberti y María Teresa León, llevaba el subtítulo "Escritores y artistas revolucionarios" y se consideraba el órgano del PCE. Contó con la colaboración de destacados escritores españoles y extranjeros, de los que sólo nombraré algunos: Cernuda, Arconada, Arderius, Garfias, Plá y Beltrán, Prados y los extranjeros Xavier Abril, Aragon, Barusse, Romain Rolland, Johanes Becher, Ehrenburg, Eisenstein, Gorki, Waldo Frank. Fueron ilustradores Alberto, Renau y Carreño, entre otros.

${ }^{30}$ Revista fundada por Rafael Alberti y María Teresa León, vinculada a La Alianza de Intelectuales Antifascistas para la Defensa de la Cultura. Salieron cuarenta y siete números entre 1936 y 1939. En ella colaboraron las firmas más prestigiosas del sector republicano, en un intento de continuar la cultura interrumpida por la guerra y llevarla a todos los sectores sociales, además de propagar el ideario político y social de la República. [V. García, 1977] 
varios párrafos que descubren una vez más el complejo cruce de vectores, no siempre opuestos, que tenía lugar a finales de los veinte, cruce que a menudo se resuelve como una oposición entre los defensores de la vanguardia -, Gómez de la Serna, Ernestina de Champourcin -habría que agregar a Guillermo de Torre, más reflexivo y teórico- y en la otra acera todos los demás, con el propio director de La Gaceta Literaria en primera fila. La eclosión de las tendencias que se forjaron durante toda la década del veinte muestra un punto especialmente sensible y destacado en la confluencia de arte y política, un momento en que no interesa tanto la adscripción ideológica como el rechazo visceral al apoliticismo y la independencia del intelectual. Desde mi punto de vista, es erróneo otorgar a ese breve pero crucial momento del final de la dictadura primorriverista la virulencia de los enfrentamientos ideológicos de los años previos a la guerra civil, definidos sobre todo después de la Revolución de Octubre ${ }^{31}$. Es desacertado asimismo extrapolar de una manera refleja la discusión política al ámbito estético, aunque para los dos campos vale la misma recomendación: las proclamas y diatribas fueron en un principio provocadoras y protestaban contra el estado de cosas, pero no se puede afirmar que las diferentes posiciones estuvieran definidas coherentemente. Todavía hoy los historiadores discuten sobre la veracidad de la amistad de García Lorca con José Antonio Primo de Rivera. No se enfrentaba, como ocurriría más adelante, izquierdas versus derechas, o legalidad constitucional versus sublevación fascista, sino izquierdas

\footnotetext{
${ }^{31}$ En Octubre de 1934, durante la República de derechas, los socialistas declaran la huelga general revolucionaria. En Cataluña Lluis Companys declara el Estado Catalán dentro de la República Federal española, pero el intento es rápidamente abortado. Sólo Asturias tiene una organización de base capaz de seguir adelante, la Alianza Obrera: se ocupan fábricas y minas y se pone en marcha una república utópica con núcleos de organización comunista. Francisco Franco dirige la ofensiva del ejército y domina la revolución con una extraordinaria dureza, seguida de represalias en toda España que dieron origen a una decisiva partición en dos sectores irreconciliables, "Los escritores, como el resto de la sociedad, se dividieron, y ni siquiera fue a partir de la proclamación de la República, en 1931. Fue algo más tarde. Desde luego, a partir de 1934. Los que no lo eran ya, se hicieron de izquierdas, otros de derechas y otros trataron denodadamente de no tomar partido por unos ni por otros, pero fueron desbordados por los acontecimientos..." El autor se desdice páginas después, en un movimiento propio del discurso ensayístico, efectista y no científico de su libro, el que pese a esos rasgos proporciona materiales y perspectivas personales muy útiles y estimulantes para evitar preconceptos muy afianzados sobre los años de la II República y de la guerra de España. "La primera guerra civil en España tuvo lugar, pues, en La Gaceta" [Trapiello, 1994: 22 y 32]. Caudet dirá que en 1934" tuvo lugar la Revolución de Octubre y su más directa consecuencia, la radicalización de la sociedad española" [1993: 31]
} 
y derechas contra liberalismo y monarquía. Retomando las observaciones, puede afirmarse que el rechazo de la vanguardia estaba asociada fundamentalmente a la concepción del arte nuevo primero descripta y luego convertida en norma por Ortega y Gasset -conjunción de esteticismo, deshumanización, distanciamiento El filósofo representaba un blanco de doble significación porque en él se asociaban un modo de entender el arte y un modo de encarar la política desde el ideario liberal.

También se repudiaba el divorcio programático con el público común, fruto de la autoconciencia vanguardista de pertenecer a una elite o a una especie rara y preciosa. El convencimiento de superioridad estaba presente no sólo en los artistas sino también en los intelectuales; no sólo en los clercs, asociados a un pensamiento liberal, sino en los intelectuales de izquierda, convencidos de su papel de guía de las masas sin conciencia. Al respecto, Cano Ballesta dirá refiriéndose a Alberti: "La doctrina orteguiana de las elites y la masa como base de aquéllas es algo que se respira en la atmósfera madrileña de la República. Alberti sabe que para mover a las masas revolucionarias se requiere UN GRUPO SELECTO ${ }^{32}$ que grite la orden de ataque". [Cano Ballesta, 1975: 225]

\subsection{VANGUARdia: Un PROYECTO totalizador}

El fenómeno vanguardista no se comprende en toda su magnitud $-\mathrm{y}$ España no es una excepción- si se mantienen las fronteras entre artes y disciplinas. En el capítulo I se ha desarrollado con detenimiento la noción de vanguardia como proyecto revolucionario y totalizador; reducir su estudio a un único ámbito sólo obedece a una exigencia metodológica, pero la perspectiva de conjunto no debe faltar.

Cuando se da el paso desde el campo de las letras al de la plástica, el cine y la arquitectura, los supuestos de que en los años treinta las vanguardias pasaron a mejor vida después de un breve e ilusorio reinado pierden aún más fundamento.

\footnotetext{
${ }^{32}$ Destacado mío.
} 
El aspecto esencial de la integración de las distintas artes ha sido tratado por Jaime Brihuega a partir de una cuidada selección de los manifiestos y las proclamas de las vanguardias en los años 20 y en los 30 , en dos libros ya clásicos para todo estudio sobre el tema ${ }^{33}$. Un simple repaso a los manifiestos y proclamas demuestra la amplitud del fenómeno y los riesgos de acotarlo a un único campo de expresión.

Retornando al decisivo año 1930, Brihuega registra la consolidación del Grupo de Arquitectos y Técnicos Españoles para el Progreso de la Arquitectura (GATEPAC), derivado del Grupo de Arquitectos y Técnicos Catalanes para el Progreso de la Arquitectura (GATCPAC), "que desde el campo específico de la arquitectura y el diseño se erigirá en el movimiento de mayor coherencia teóricopráctica y el único con una verdadera proyección internacional". [Brihuega: 1982:14]. El segundo libro del mismo autor dedicado a las vanguardias se cierra con una proclama del GATCPAC pronunciada en 1936 donde se declara a favor de la República y aboga "por el triunfo del racionalismo en nuestra profesión y para una depuración general y severa de la arquitectura de nuestros tiempos, convencidos de que ésta es la mejor forma de servir a la formación cultural del pueblo"34. [Briguega, 1982: 412].

En el libro anterior, el último de los textos doctrinales seleccionado por Brihuega para ilustrar el período 1910-1931 desemboca, una vez más, en José Díaz Fernández. Es muy singular que en el mismo año de la publicación de El nuevo romanticismo su autor utilice para llamar a modificar el rumbo estético un tono y un discurso a todas luces vanguardistas. La pregunta es entonces, hasta

${ }^{33}$ Es curioso que pese a la valiosa documentación que proporciona, Brihuega niega raigambre a las vanguardias españolas, consustanciado con las teorías de la reproducción mimética en los países periféricos.

${ }_{34}$ Uno de los principales impulsores GATCPAC (Grupo de Arquitectos y Técnicos Catalanes para la Arquitectura Contemporánea) y de su homónimo nacional, GATEPAC, (Grupo de Arquitectos y Técnicos Españoles para la Arquitectura Contemporánea) fue Josep Lluís Sert (1902-1983), arquitecto discípulo de Le Corbusier. Exiliado en Norteamérica después de la guerra civil, llegó a ser decano de la Universidad de Harvard. Recientemente su obra ha sido recordada por la Fundación Miró. El historiador y comisario de la muestra Josep Maria Rovira, abría la exposición dedicada al "aristócrata republicano" con unas palabras que revalidan el enfoque que propongo sobre las vanguardias: "Esta exposición no es un homenaje sino una reivindicación de la ética arquitectónica de Josep Lluís Sert, un intelectual al servicio de la ciudad y no de las multinacionales, como pasa ahora, que proponía una arquitectura antielitista que aunaba modernidad y tradición". [Serra, 24 feb. 2005] 
dónde los inspiradores de una nueva modalidad artística unida a un cambio de función social, ignoraron cuánto conservaba de la vanguardia el nuevo rumbo propuesto. El autor de La Venus mecánica no rechaza los motivos del progreso execrados por lo detractores del arte nuevo, al contrario, recurre a la imaginería del maquinismo para reforzar sus argumentos: "Acaso el hombre deba mirar al pasado por pura precaución: como el automovilista observa el camino que queda atrás por el espejito del parabrisas" [Briguega, 1982: 432]. $Y$ también: "aquí ya tendríamos que utilizar el espejito del parabrisas..." [Briguega, 1982: 432] ${ }^{35}$ Pero la impronta de la vanguardia no se reduce a signos formales, su propuesta de un nuevo arte necesita de la afirmación del presente como peldaño inmediato a un futuro por construir:

El hombre contemporáneo aprecia su misión vital por lo que tiene de actualidad y de presencia. Más que un depositario de la tradición, es un arquitecto de su propio impulso. [Briguega, 1982: 433]

La afirmación del futuro incluye el elogio de la máquina y la tecnología con el componente racionalizador y utópico al que me he referido en el capítulo I.

... puede decirse que nuestra época es de las más claras y definidas de cuantas ha vivido la humanidad. El maquinismo ha traído, acaso, esta simplificación, que es la cualidad que con más fruición disfrutamos. [Briguega, 1982: 433]

Pero es el planteo central del manifiesto, condensado en el mismo título, "Poder profético del arte", el más claramente vanguardista, animado por la búsqueda de una nueva praxis en la que el arte jugaría un papel primordial en el acercamiento a la vida y en la conformación de un mundo despojado de las penurias del presente. En este proyecto, como en la utopía moderna más genuina, cuyo intento de concreción más acabado fue llevado adelante por la vanguardia, el arte y el artista ocuparían la primera línea del frente. Para esa misión profética el artista dispone de capacidad visionaria para anticipar el porvenir ambicionado y de la herramienta esencial, el arte:

${ }^{35}$ Las referencias a José Díaz Fernández remiten a "Poder profético del arte", en Nueva España, Madrid, 11 de diciembre de 1930, reproducido por Brihuega, 1983a: 432-436. 
... será saludable fijarnos en que los artistas atisban antes que nadie las formas visuales del porvenir. Por algo los antiguos llamaron vate al artista más puro, al poeta lírico. Vate, es decir, adivino. La intuición es el atributo del genio, y genio, específicamente considerado, es el creador, el artista que por la gracia de su obra es semejante a un dios. Singulariza el arte la invención y si se trata del arte plástico revelará, mejor que ninguno, la expresión total de las futuras formas vivas. O, con más exactitud, trazará el diseño de la historia que está por escribir, de los movimientos inevitables que han de producirse. (:435)

Se puede observar una vez más la convalidación de una de las hipótesis que vengo desarrollando, el rechazo de los ismos tenía por una parte, motivos inmanentes a la obra de arte vanguardista, como es su carácter fragmentario y su desinterés por el poder referencial del lenguaje para representar la realidad cotidiana. Pero el rechazo mayor se dirige a la clase que, situada en el centro del campo intelectual, decidía el rumbo estético mientras intentaba consolidar la ideología liberal que a finales de los veinte sufría un franco menoscabo debido a sus errores, titubeos y omisiones ante la dictadura primorriverista. En el momento de crisis, en que el proyecto de la burguesía ponía en evidencia su incapacidad para dar respuestas a los reclamos más urgentes del hombre, el arte mostraba su capacidad de anticiparse a los acontecimientos. El mismo arte que se distraía en juegos desafiantes podía cumplir una misión esclarecedora y profética.

[en los años de la pre-guerra y de la post-guerra] el torrente de la conciencia histórica seguía, sin embargo, realizando su misión destructora y creadora a la veZ. ¿QUIÉN ADVIRTIÓ ENTRE AFIRMACIONES Y DESMANES, ENTRE CLAMORES, BABÉLICOS Y BÁRBARAS EXPLOSIONES, ESE RITMO GIGANTESCO Y CLARO? EL ARTE, Y PRINCIPALMENTE EL ARTE PLÁSTICO.

ERa el que estaba más alerta, a pesar de sus "ISmos" zigzagueantes, de sus CONTORSIONES PUERILES, DE SUS AUDACIAS TURBADORAS. Mientras el buen burgués vigilaba con los ojos desorbitados las cajas de caudales y los príncipes huían sin equipaje para convertirse en profesores de idiomas o en conductores de automóviles, LOS ARTISTAS PRENDÍAN EN SU LIENZO EL PAISAJE DEL PROVENIR. LA VIDA IBA A SER COMO PRESENTIAN SUS LÁPICES O SUS PINCELES ${ }^{36}$.[Brihuega,1982a: 436]

En un trabajo escrito a finales de los 90 [Macciuci, 1998b] reparé en un suceso que se constituía un símbolo de la convergencia de los cualidades más revolucionarias de las vanguardias y del acercamiento entre arte y vida que constituyó su utopía, símbolo además de la continuidad del impulso transformador que las inspiraba en un escenario histórico modificado abruptamente. Se trata de

${ }^{36}$ Subrayado mío. 
la construcción del Pabellón de España en la Exposición Internacional de París de 1937, en plena Guerra civil. El gobierno legal encargó el proyecto a una serie de artistas con el propósito de presentar al mundo un escaparate de la legitimidad republicana. Retomo las palabras del arquitecto Josep Lluis Sert, responsable de la obra junto con Luis Lacasa, cuarenta años después de la exposición:

-Fue una decisión de la República que España participara, a pesar de la guerra, en la Exposición Internacional de París (...) Hicimos el Proyecto del Pabellón Luis Lacasa y yo, con José Antonio Bonet (...) En la planta baja se eligió el lugar para que Picasso colocara el Guernica. A Picasso yo entonces le veía casi todas las noches en el café de Flore, con Miró y otros amigos, Juan Larrea, Max Aub, Paul Eluard, Aragon, Chagall, Calder y Braque.(...) tuvimos la suerte de contar en nuestro pabellón tan pequeño con los mejores artistas del momento. Picasso, Miró, Alberto, Julio González y Calder. [Vicent, 1984: 175-176] ${ }^{37}$

Los artistas convocados en el Pabellón de España dieron muestra entonces del giro que había experimentado el proyecto vanguardista, reorientándolo hacia una de las utopías de carácter colectivo que marcaron a fuego el último siglo. Josep Lluis Sert recuerda que

Allí todo el mundo trabajaba por la causa. Renau era director general de Bellas Artes y lo veías con un mono de mecánico dibujando carteles, dirigiendo los textos que luego los mejores literatos franceses, Aragon, Eluard, Tzara, rivalizaban en corregir. [Vicent, 1983: 177]

En el artículo mencionado, consigné que en los mismos días, otro importante sector de artistas e intelectuales de la intelligentsia republicana, se entregaba a la organización del "Congreso Internacional de Escritores Antifascistas", donde convergieron, como ya he comentado en el capítulo III, clercs, artistas de vanguardia y de avanzada. La efímera convivencia de 1930 de

\footnotetext{
37 "Josep Lluis Sert, en el voladizo de hormigón", en Vicent, 1984: 169-173. En su Inventario de otoño entrevista a diversas personalidades que tuvieron un papel destacado en los años veinte y treinta o en los inmediatos a la guerra. El libro ofrece un interesante testimonio de algunos de los protagonistas de la "Edad de Plata" recogido cincuenta años después la República. Son los entrevistados: Luis Calvo (periodista), Pedro Sainz Rodríguez (profesor), Dolores Ibárruri (política), Dámaso Alonso (filólogo), Cristino Mallo (escultor), Ernesto Giménez Caballero (escritor), Rafael Alberti (escritor), Domingo Ortega (torero), Juan Gil-Albert (escritor), Maruja Mallo (pintora), Luis Escobar (actor), Juana Mordó (galerista), Santiago Ontañón (escenógrafo), Josep Renau (cartelista), Concha Piquer (tonadillera), Faustino Cordón (científico), Josep Lluis Sert (arquitecto), Rosa Chacel (escritora), Federico Moreno Torroba (compositor), Gabriel Celaya (escritor), Laxeiro (pintor), Guillermo Marín (actor), Justino Azcárate (político), José Maldonado (político), Ramón Carande (historiador).
} 
izquierdas y derechas había concluido; por otra parte, los republicanos liberales más conspicuos -Ortega, Marañón, Pérez de Ayala- habían roto con la república. Francisco Ayala, representante irreprochable del último grupo no asistió al Congreso de Valencia por considerar que estaba controlado por el comunismo ${ }^{38}$. El más insigne partidario del arte por el arte, Ramón Gómez de la Serna se había refugiado en Buenos Aires y escribía artículos en que mezclaba la exaltación del torreburnismo con apelaciones al olvido y señales amistosas a los fascistas. Pero este será tema de próximos capítulos.

Mientras realizaba la redacción final de esta tesis encontré en la ya citada Bibliografía y Antología Crítica de Las Vanguardias Literarias en España de Wentzlaff-Eggebert, que un eximio conocedor del tema había reconsiderado sus postulados iniciales sobre la deshumanización y el compromiso como polos inconciliables, introduciendo preguntas que respaldaban mis planteamientos: el final de la vanguardia que parece desprenderse de opciones estéticas como el retorno al molde del romancero, a la poesía popular, al recitado en las trincheras, a la creación de un teatro de urgencia,

\begin{abstract}
Es solo cierto si aceptamos la definición de la vanguardia como revolución estética divorciada de un contexto histórico concreto. Efectivamente, sólo si entendemos por vanguardia un fenómeno formal y estilístico podemos aceptar la oposición vanguardia / compromiso. Pero por el contrario, si comprendemos que la experimentación formal es la expresión externa, superficial, de un impulso ideológico hacia la reinserción del arte en la praxis social, veremos que los romances, las letrillas, las canciones burlescas, El burro explosivo, etc., también son manifestaciones vanguardistas, manifestaciones que recuerdan precisamente el origen militar del término VANGUARDIA ${ }^{39}$. Es una suerte de punta de lanza, comprometida con la vida y contra el enemigo. [Geist, 1999: 440]
\end{abstract}

En el mismo libro se reproduce un trabajo de Sánchez Vidal que sigue idénticos derroteros, con expresa mención a la exposición de París, aunque el crítico parte de la evaluación acrisolada de la primera etapa de los ismos, es decir, que la primera etapa de las vanguardias españolas es meramente mimética y epigónica.

${ }^{38}$ Francisco Ayala me dio esta explicación cuando tuve oportunidad de conversar con él en su casa de la calle Marqués de Cubas de Madrid, en octubre de 1999.

${ }^{39}$ Destacado del autor. 
Si España había recibido de forma descafeinada y tardía las primeras vanguardias, se había implicado de forma acelerada en su evolución a partir del surrealismo, y ahora se veía urgida por razones históricas a plantearse antes que el resto de Europa la conversión en un arte de combate del ya nutrido arsenal experimental que había ido segregando (...) Tal madurez [de la intelectualidad de izquierdas] podrá ser apreciada en el exterior ese mismo año en el Pabellón Español de la Exposición de París. Obra del arquitecto Sert situada en los jardines del Trocadero, Calder aportó su Fuente de Mercurio, Picasso el Guernica, Miró El pagés Catalá: la revolució, Julio González su Montserrat y Alberto Sánchez El pueblo español tiene un camino que conduce a una estrella, estricto correlato escultórico de lo que suponía en poesía Viento del pueblo de Miguel Hernández. Un do de pecho difícilmente superable y que en modo alguno pudo compensar el bando "nacional". al mismo tiempo, filmes como The Spanish Earth de Joris Ivens y Sierra de Teruel ( $L$ 'Spoir) de Malraux difundían a los cuatro vientos la causa republicana. [Geist, 1999: 352-353]

Los rasgos más cuestionados del arte nuevo parecen haber quedado desterrados, sin embargo, la creencia en un futuro común que debía defenderse colectivamente, juntos los intelectuales, los políticos, los artistas y el pueblo pocas veces estuvo más granado. Las vanguardias, sin el adjetivo de políticas o artísticas, pocas veces estuvieron más en sintonía con su tiempo histórico, convencidos los actores de que la distancia entre experiencia y expectativa -según los conceptos de Reiner Koselleck- se acortaba cada vez más, acercándose el momento de la utopía [Koselleck, 1974: 9-31]

La mención de Viento del pueblo de la cita de Geist es más que oportuna para cerrar el capítulo con un nombre emblemático de la literatura si se habla de praxis vital, de vanguardia, o de compromiso. La pervivencia de uno de los postulados básicos de la vanguardia, la invocación al poeta demiurgo y figura predestinada a la construcción de un futuro despojado de barbarie aparece con fuerza en la poesía más combativa de los años treinta. Miguel Hernández, desde el título Viento del pueblo y la dedicatoria a Vicente Aleixandre pone de manifiesto una determinada concepción de la poesía y de la función del poeta que entronca con la utopía de la vanguardia.

Los poetas somos viento del pueblo: nacemos para pasar soplando a través de sus poros y conducir sus ojos y sus sentimientos hacia las cumbres más hermosas. (...) El pueblo espera a los poetas con la oreja y el alma tendidas al pie de cada siglo [VP: 304 ] 
La convicción de que el artista está llamado a cumplir una misión y que se debe a ella porque el pueblo lo aguarda es una, entre muchas, de las construcciones imaginarias del papel de las vanguardias. La guerra, paradójicamente, le ofreció al poeta la oportunidad de romper la esfera del arte y hermanarlo con la vida.

El 18 de julio de 1936, frente al movimiento de los militares traidores, entro yo, poeta, y conmigo mi poesía, en el trance más doloroso y trabajoso, pero más glorioso, al mismo tiempo, de mi vida. No había sido hasta ese día un poeta revolucionario en toda la extensión de la palabra y su alma. Había escrito versos y dramas de exaltación del trabajo y de condenación del burgués, pero el empujón definitivo que me arrastró a esgrimir mi poesía en forma de arma combativa me lo dieron los traidores, con su traición, aquel iluminado 18 de julio. [Miguel Hernández, Teatro en la guerra, 1937 (citado por Caudet, 1993: 49)]

En El hombre acecha, reaparece la idea del vate que, indiferenciado de los demás hombres, podrá cumplir su cometido, hipóstasis profana de bíblico mandato: ser la sal de la tierra, ser la sal del aire.

hablaremos unidos, comprendidos, sentados, de las cosas del mundo frente al hombre

y continuar con la misión integradora del mundo, Siempre fuimos nosotros sembradores de sangre

Siendo de esa familia, somos la sal del aire. [HA: "Llamo a los poetas": 386] 


\section{RAMÓN GOMEZ DE LA SERNA}

\section{Círculos concéntricos ramonianos}

De manera casi inevitable, los estudios críticos sobre Ramón Gómez de la Serna (1888-1963) comienzan con una referencia a la magnitud de su producción y a las grandes dificultades que durante décadas existieron para acercarse a su obra, actualmente un poco más cercana gracias a la cuidada edición de Galaxia Gutenberg preparada por lona Zlotescu. No obstante, resta aún por rescatar parte de los textos editados en prensa. Existe asimismo abundante documentación personal -cartas especialmente- que no ha salido de los archivos.

Suele continuar el especialista con una mención a la dificultad de encuadrar su figura original y solitaria en la serie literaria española. Sobre este punto, debo anticipar las enormes divergencias existentes entre los especialistas a la hora de juzgar su obra, muchas veces contaminada del enjuiciamiento de las relaciones confusas y oscilantes con los distintos regímenes políticos por los que pasó durante su larga vida y, en particular, con el régimen franquista. Andrés Trapiello transcribe párrafos sumamente esclarecedores de una de las distintas epístolas enviadas por Ramón a Ernesto Giménez Caballero, quizás el más conocido representante de los vencedores a quien ofreció su colaboración, pero no el único. En una carta de noviembre de 1939 , -la guerra civil había terminado el $1^{\circ}$ de abril del mismo año- generosa en parabienes a los vencedores y en acusaciones a los vencidos, encabezada por un "¡Arriba España!" y el dibujo de una banderita pintada por él mismo, Ramón escribió:

Sigo la vida de España en una perspectiva de adorador ferviente. Todas las torres están más en pie que nunca. ¡Feliz paisaje! Nuestro Madrid sé que ha vuelto a ser el que queríamos, el que nos habían deformado y que sentíamos esa deformación dolorosa e íntima, como si nos hubiese dado una parálisis infantil retrospectiva, algo así de incongruente y grave (...) Tiene usted mi aquiescencia para reunir como quiera las páginas nacionales de mi obra literaria. Nada me enorgullecerá ni me emocionará más. Con Sánchez Mazas, con José María Alfaro, con Manuel Aznar estoy gestionando hace meses un puesto en el periodismo madrileño. Lo necesito con urgencia, porque soy el más náufrago de todos, ya que aquí sólo viven los que se unieron a lo otro, a lo nefasto, para que su vida resultase fácil. De no llegar eso me ahogaré el primero de año. [Trapiello, 1994: 14-15] 
El indigno ofrecimiento no es un gesto aislado, se suma a una cadena de actos que habían generado ya la irreversible enemistad de los exiliados republicanos en Buenos Aires, a donde se dirigió precipitadamente en 1936. Aunque Trapiello es poco riguroso (o generoso) a la hora de proporcionar fuentes, otros testimonios bien documentados dan verosimilitud a la cita anterior: María Teresa Pochat ha dado a conocer textos inéditos que demuestran el malestar que las declaraciones pro-fascistas del famoso escritor producía entre los partidarios de la República Española en Buenos Aires. Destaca entre el material de archivo la dura reconvención de su amigo José Venegas tras declaraciones vertidas en distintos medios internacionales, que luego el inventor de las greguerías intentó ocultar o atenuar.

...la interviú no es un hecho aislado. Empleo todas mis horas en leer lo que se escribe sobre España o en escribir sobre España. Me llega marcado lo que usted escribe aquí, en Santiago y en Lima. Bastaba con esta frase "gracias al amor y a la poesía nos salvaremos del comunismo".

Es demasiado identificar a Hitler y a Mussolini con el amor y la poesía. $Y$ es imposible aceptarlo en un español.

(...)

Lo peor de su conducta es que se traiciona usted a sí mismo. En la España de Franco estaría usted fusilado (...) A usted no le han leído ni le han hecho caso más que los españoles inteligentes, que eran antifascistas. $Y$ en la Argentina, los argentinos antifascistas. Qué lamentables sus ataques y qué injustos a esos argentinos, amigos de España. [Pochat, 1995: 474]

Ya antes de la proclamación de la República y del inicio la Guerra civil, las anécdotas y curiosidades biográficas de Ramón se superponían a su obra: conferencias en un circo, sentado en un trapecio o en el lomo de un elefante; célebres apariciones con una valija repleta de objetos curiosos, su propia indumentaria, hacían de él un escritor que no pasaba inadvertido. El afán de protagonismo parece haber sido un designio muy importante en su vida, no ajeno naturalmente a la imagen de autor que construyó. La salida ingeniosa, el propósito

\footnotetext{
${ }^{1}$ Dio un conferencia sentado en el trapecio del Gran Circo Americano de Madrid y montado en el lomo de un elefante en el Circo de Invierno en París con motivo de la traducción al francés de su libro El circo. Solía presentarse a dar sus charlas con una maleta, de la cual sacaba un objeto comprado en el Rastro y comenzaba a decir greguerías sobre él.
} 
de romper con el atildamiento, podían apelar a los más insospechados recursos, a veces rayanos en la impiedad ${ }^{2}$.

Alrededor de figura y obra tan controvertidas, hay, sin embargo, algunos acuerdos básicos: Gómez de la Serna introdujo y anticipó las vanguardias en su país ${ }^{3}$ pero su figura se presenta solitaria en el campo literario; sus convocantes reuniones en Pombo no aglutinaron a un grupo de cierta homogeneidad estética como ocurrió con la Residencia de Estudiantes

\begin{abstract}
...se le reconoció como auténtico precursor (e introductor) de las vanguardias en España; se admiró su singularísima personalidad -por primera vez aparecía en el panorama literario español una voz radicalmente distinta a las otras de su tiempo-; su contribución a la liquidación de los viejos esquemas, pero pronto se vio la imposibilidad de secundar su camino. Ese particular fenómeno literario que luego dio en llamarse "ramonismo" empezaba y terminaba en Ramón. [Rodríguez Fischer, 1999: 351-352]
\end{abstract}

A la dificultad ya reseñada de dar un estatuto definitivo a los ismos en España sin aislarlos del contexto europeo pero, al mismo tiempo, otorgándoles sus perfiles propios, se suma el hecho de que en un país que no sigue el fenómeno vanguardista al pie de la letra, aparecen, sin embargo, muy tempranas

\footnotetext{
${ }^{2}$ Francisco Ayala cuenta en sus memorias el siguiente episodio: "Una noche, alguien me llevó a la tertulia de Pombo. Ya por entonces había leído yo a Gómez de la Serna, y hasta le había visto actuar en la memorable función del circo Price donde, trepado al trapecio, leyó un rollo que se desplegaba desde su altura hasta el suelo. El tono de la tertulia famosa era eutrapélico también y, a veces, muy forzadamente eutrapélico. Ramón se desgañitaba para mantenerlo a todo trance, y con este empeño las bromas podían llegar a ser muy crueles. Por desdicha, el día que yo acudí, el único que fui a la tertulia de Pombo, esa crueldad reventó en forma casi insufrible. Entre los infelices o tontos que servía de ordinario pasto a las facecias ramonianas, figuraba una especie de mendigo apodado Pirandello, quien, a cambio de un café con media tostada pagado a última hora, se avenía a hacer de bufón hasta haberse ganado tan magro refrigerio. Según parece, el sábado anterior (la tertulia era sabatina) Pirandello no había comparecido, y al pedírsele cuentas de su ausencia dijo que había estado hospitalizado. ¿De qué padecía? Insuficiencia mitral. "Pirandello padece de insuficiencia mental" vociferó Ramón, temeroso de que el asunto derivase hacia lo serio. Pero aquel pobre diablo estaba de veras muy malo, pues ahí mismo le vino un vómito de sangre. Ramón, pálido como un muerto, empezó a gritar: "Las mulillas!, ique traigan las mulillas!", aludiendo a las que en la corrida arrastran al toro. Pero nadie se reía; no era caso de broma. A mí la escena me desagradó tanto que resolví no volver más a Pombo. [RO1, 1984: 86]. Existen otras interpretaciones del caso: "Para Ayala éste parece ser el epítome de la crueldad de Ramón con los demás, una actitud pueril, irresponsable, de la que iba a dar buena muestra, huido de la guerra civil, al saludar con el puño en alto a su desembarco en Buenos Aires, para a continuación, en la primera oportunidad, alzar el brazo fascista en actitud contraria. Es obvio que Ramón era incapaz de renunciar a su mofa, cuando en realidad lo que le convenía era el silencio. En fin, no deja de ser propio de su proverbial actitud de escándalo". [Pereira, 1993: 60]

3 V. Yhani, 1995: 591-593. Rodríguez Fischer brinda un repertorio de citas de escritores contemporáneos de Gómez de la Serna que manifiestan su deuda con él. [1999: 351-354]
} 
manifestaciones adscribibles en esa tendencia. En la revista Prometeo ${ }^{4}$, nominalmente dirigida por su padre, Ramón tendrá oportunidad de escribir artículos que anuncian sus futuras posiciones, tales como "El concepto de nueva literatura" (Memoria para el Ateneo - 1909) o "El libro mudo- Secretos", de 1911. Como ya se ha señalado en distintas ocasiones, en esta temprana publicación se conoció en España el Manifiesto futurista de Marinetti el año de su proclama, en 1909, y al año siguiente, una inédita Proclama futurista a los españoles, del mismo vanguardista italiano.

Crecen los interrogantes acerca de continuar considerando su figura como un astro aislado en el campo literario español o integrarlo en otras corrientes y grupos. Cada vez son más los estudios incuestionables que demuestran que Ramón tuvo una relación decisiva con Ortega $Y$ Gasset $^{5}$, lo cual le ayudó a situarse en un lugar clave del campo intelectual español. Hoy se sabe que no fue inmune a influencias estéticas diversas, como tampoco fue refractario a ejercerlas sobre sus contemporáneos. Para observar sus huellas en los escritores, dentro y fuera de España, no es necesario aguardar a la década del veinte; sin embargo, es en estos años cuando comienza a ser celebrado internacionalmente: en Argentina fue una figura mimada, con algunas calificadas reservas, por el grupo de Florida y luego por Victoria Ocampo, la influyente directora de Sur. En 1923 ingresa triunfalmente en Francia de la mano de Paul Larbaud, y en 1925 y 1926 recibe distintos reconocimientos en Italia, coincidiendo con su estancia en Nápoles ${ }^{6}$.

Es preciso profundizar sobre su preparación intelectual. ¿Fue un gran improvisador, que hacía surgir de la nada, o de una capacidad innata, sus originalísimas creaciones? ¿O recibió en su juventud una enseñanza, aunque no sistemática, nada despreciable? El profesor Soldevila Durante ha demostrado suficientemente que en sus años de aprendizaje y de formación,

\footnotetext{
${ }^{4}$ Prometeo apareció entre 1908 y 1912. Ramón Gómez de la Serna firmó a menudo con el seudónimo "Tristán" sus primeras greguerías y material diverso de sus primeros libros. La mayor parte de sus colaboradores fueron modernistas o postmodernistas.

${ }^{5}$ V. Vega Díaz, 1984.

${ }^{6}$ V. Granjel, 1963: 64-68.
} 
tan cuidadosamente ocultada por su protagonista, Gómez de la Serna es, en primer lugar, un ensayista, y el objeto primordial de sus preocupaciones no es la literatura, sino la política, la ética, las estructuras sociales, el origen, la realidad y el lugar del hombre en el cosmos. [Soldevila Durante, 1988]

La respuesta afirmativa trae aparejada una nueva pregunta: ¿qué interés pudo haber tenido el propio Gómez de la Serna en tributar a la concepción del creador como genio, como prodigio de la naturaleza, tan opuesta a la idea de autor como agente de transformación que propone Benjamin en su conocido escrito "El autor como productor"? Tomo las reflexiones de Beatriz Sarlo, quien afirma que es de interés para analizar las relaciones literatura - historia la cuestión del sujeto, no solo como figura textual sino como figura cuya definición es colectiva, cuyo lugar en la vida social cambia, cuyas relaciones con el poder son variables, cuya autonomía respecto del mercado o del patronazgo es también una construcción histórica.

En esta perspectiva, una historia podría ordenar los lugares que el autor ha tomado en diferentes momentos de una sociedad: el profeta, el apóstol, el visionario, el marginal, el dandy, el bohemio, el profesional. Estos lugares son producto de un reconocimiento social y de la adjudicación de responsabilidades y derechos a los escritores, que, al mismo tiempo, no puede dejar de relacionarse con transformaciones textuales". [Sarlo, 1991: 28]

La imagen tópica de Ramón, "patillas y pipa", el aura de criatura imprevisible y genial, incluso hasta la irresponsabilidad y la deslealtad, muy atento al personaje que forjaba, se originan en innumerables anécdotas pintorescas y boutades, y llegan a ocultar su obra literaria. En sentido contrario, es justo mencionar que tras su facundia y humor desbordante asoma una melancolía y un desamparo propio de un espíritu frágil, aniñado para algunos ${ }^{7}$. A partir de los críticos que más han condenado la improcedencia de los estudios apoyados en la biografía -merece un lugar privilegiado Soldevilla Durante-, consideramos que ambos aspectos deben reunirse en un rumbo que presenta ejemplos muy acabados, como es el estudio de la Profesora Martínez-Collado, de la Universidad de Castilla-La Mancha ${ }^{8}$. En este dirección, creo que aportan nuevos sentidos e iluminan la obra, no sólo en cuanto a la materia propiamente textual sino también

${ }^{7}$ Sobre imagen de autor, v. Gramuglio, 1992.

${ }^{8}$ Martínez-Collado: 1996. 
acerca de las circunstancias que rodean al escritor y contribuyen a darle un lugar dentro del campo intelectual e intervienen en los procesos de canonización. El estereotipo acuñado en torno a Gómez de la Serna obedece en parte a la voluntaria construcción de una imagen, y se enlaza con una concepción del arte, del escritor y de la función de la literatura. Este último aspecto es esencial en un hombre de letras que ha dejado más de una autobiografía y ha transitado otros géneros cercanos a la escritura del yo ${ }^{9}$.

Algunos de los interrogantes a los que se enfrentan los críticos dedicados a la obra de Ramón, que subsisten aún después de las numerosas aportaciones recientes, podrían obtener una respuesta desde el marco teórico propuesto en esta investigación. El encuadre de la vanguardia en el contexto de los procesos modernizadores y de la conformación de un subsistema social artístico autónomo echa luz sobre las proverbiales oscilaciones y contradicciones del prolífico escritor. La noción de vanguardias históricas como parte de un proceso estético y cultural más amplio, que se enraíza inextricablemente con el arte moderno y que presenta una marcha discontinua y plural, lejos de toda homogeneidad ideal que se rija por los modelos dominantes, permite acceder a la obra ramoniana sin hacer rodeos ante sus gestos humanamente reprochables o ante un supuesto apoliticismo que derivó en aplausos a la dictadura y en una recepción en el Palacio del Pardo ${ }^{10}$. El último giro ideológico de Ramón, que no fue un simple capricho pues duró varios años, no pudo ser asimilado, naturalmente, por el exilio republicano que lo arropó en los primeros meses de su refugio en Buenos Aires. José Ignacio Ramos, consejero de información de la Embajada de España en Argentina y amigo personal de Ramón, justifica sus posiciones en el libro que le dedicara. La afección al régimen parece motivada en razones personales y endebles, no se

\footnotetext{
${ }^{9}$ La crítica no deja de subrayar el importante peso que el autobiografismo tiene en Ramón, rasgo que conformaría una entrada convergente del análisis que me interesa sobre su forma de asumir el arte y su cometido social. Los trabajos recientes en esta dirección son numerosos y coinciden en el hallazgo de una fuerte presencia narcisista que anula las fronteras entre los géneros y explica su tendencia al solipsismo, además de constituir un objeto de estudio excepcional en la tradición española. Artículos como "Sobre la torre de marfil" y "Más sobre la torre de marfil" que se comentarán más adelante, pueden integrar el género autobiográfico.

${ }^{10}$ Después de múltiples demostraciones epistolares de afección al orden imperante, Gómez de la Serna viajó a España en 1949. Fue homenajeado por el alcalde de Madrid y Franco lo invitó a su residencia.
} 
aprecia una ideología clara, y aunque solicitaba ayuda material con frecuencia, no obtuvo importantes dádivas. Murió en la pobreza.

\begin{abstract}
Ramón no era político. Defendía su apoliticismo con uñas y dientes. Le dolía profundamente la guerra civil española y ansiaba que la paz se restableciese pronto. Por poner orden en el desorden, simpatizaba profundamente con el general Franco. [Ramos:1980:29]
\end{abstract}

En dirección opuesta, las exégesis más ponderativas minimizan estos hechos y no los integran en el conjunto de las operaciones críticas, como sucede con el análisis realizado por César Nicolás, que se limita a comentar que "tuvo en Buenos Aires problemas para sobrevivir; muere un tanto delgadiño; nuestro fascismo le reza el responso". [Nicolás, 1999, 385]

En otras ocasiones, se inscriben sus devaneos y claudicaciones con el régimen franquista como parte de la perpetua incomprensión que sufren los poetas en el mundo profano.

\begin{abstract}
Únicamente cabe decir que a una justificación moral-social para el compromiso intelectual, oponía Ramón su propia causa moral-individual para rechazarlo: el deber ascético del escritor para con su trabajo; su modelo vital desinteresado e independiente; el estoicismo que rehuye todo sectarismo político, todo afán de poder, su arbitrarismo libertario... [Pereira, 1993: 61]
\end{abstract}

Reaparece la actitud de la crítica que he desaprobado desde las primeras páginas de este libro: la distancia que hoy separa a los críticos de la tragedia de la guerra civil española y de sus inmediatas consecuencias favorece el estudio distanciado de autores altamente afectados por las posiciones ideológicas que asumieron -Gómez de la Serna, Rafael Alberti. Sin embargo, en no pocas ocasiones la distancia se transforma en una especie de celebración por el retorno a unos supuestos fueros del arte, esto es, a la refracción de los aspectos sociales o ideológicos, cuando según mi perspectiva, el reto es cómo incluirlos sin caer en fáciles reduccionismos -salvo, es claro, si el crítico suscribe a un modelo teórico formalista o heredero de la estilística .

El caso de Gómez de la Serna es quizás uno de los más difíciles por la gran seducción que provoca en los partidarios del arte intrascendente, quienes parecen 
reproducir de manera especular su visión del arte en el modelo crítico y en la metodología; cuando no va acompañada esta posición de un varapalo colateral a aquellos escritores que concibieron el arte con proyección social. No se trata de reproducir "las superficialidades y la insuficiencia de los que subordinan lo analítico y crítico a lo anecdótico y personal" [Morris, 1995: 134] sino de indagar cómo se articulan este y otros episodios en la obra ramoniana, pues, como he razonado en anterior ocasión, "el ostracismo al que lo llevó la condena de sus contemporáneos no debe ser una barrera para la investigación literaria, pero tampoco debe ser esta una circunstancia ajena al estudio de su obra, a riesgo de caer en un ramonismo de la crítica". [Macciuci, 1995: 398]

No es mi propósito desandar el vastísimo universo de la producción de Gómez de la Serna, vastísimo por su larga vida literaria, desde 1904 hasta prácticamente el momento de su muerte, en 1963, y por su inagotable energía creadora -era reconocida su capacidad para llenar cuartillas con larga series de greguerías. Tampoco voy a reiterar información harto conocida sobre el innegable papel que jugó en la renovación del discurso literario, que las vanguardias supieron aprovechar y continuar. Remito a la extensa bibliografía existente, con autorizadas descripciones de su influjo en el campo cultural de principios del siglo $X X$, y de la lengua poética, en particular, alrededor de la naturaleza y procedimientos de la greguería, su hallazgo más fecundo. Mi mirada se centrará en cambio, en el estudio de la narrativa escrita en la década del veinte, es decir, en el momento culminante de las vanguardias históricas. Considero que esta parte de su producción, la menos conocida por los lectores y sólo recientemente abordada por la crítica, surgida precisamente en los años en que el arte nuevo se consolida como tendencia hegemónica, encierra claves que enriquecen lo ya conocido sobre su entrega al arte y a la estética vanguardista. Vale la pena recordar aquí la hipótesis sostenida por Corella Lacasa ${ }^{11}$ en su trabajo sobre Giménez Caballero, opuesta a aceptar que un giro inusitado convierte de pronto a un vanguardista de primer orden en un fascista confeso. Por el contrario, existirían formas de abordar la materia poética que anticipan o explican la evolución

\footnotetext{
${ }^{11}$ V. cap. III.
} 
ideológica. De la misma manera sostengo que las llamadas "novelas grandes" y los relatos breves -cuentos, nouvelles- de Ramón proporcionan materiales que enriquecen lo más conocido y estudiado de su obra, las greguerías, y, al mismo tiempo, arrojan nueva luz sobre sus relaciones -encuentros y desencuentros- con los hombres y la sociedad de su época ${ }^{12}$. Se trata de encontrar respuestas a la justa observación de Mainer, "Hasta hace bien poco, Ramón ha sido una víctima del naufragio de aquel nuevo Titanic, nave de los locos universal, que fue la Europa de entreguerras. Pero esa es otra historia..." [Mainer, 1996: 7] Se trata, pues, de seguir la historia.

\section{LAS NOVELAS de LOS AÑos Veinte}

Durante mucho tiempo, las novelas de Ramón habían naufragado para la critica. Sólo en los últimos años comenzó a reeditarse su obra narrativa acompañada de estudios críticos.

Entre 1921 y 1936, año en que abandona España, publicó una serie de narraciones mediante las que se adentra en el relato largo y la novela; no obstante, la mayor producción se concentra en los veinte.

Es conveniente subrayar que en la década del veinte, Ramón es un escritor consagrado, reconocido como iniciador y representante indiscutible de la vanguardia española. Se ha hecho ya mención a que en ldeas sobre la novela (1925) Ortega y Gasset lo considera, junto a Proust y Joyce, uno de los grandes renovadores de la prosa e insigne representante del arte nuevo en su país. El mismo año, en Argentina, Oliverio Girondo le había dedicado uno de los textos de Calcomanías, "Calle de la Sierpes", y en 1925 el grupo de la revista Martín Fierro esperaba la llegada del escritor madrileño al puerto Buenos Aires con un magno homenaje -que no llegó a producirse porque el creador de las greguerías suspendió el viaje. El reconocimiento internacional alcanzado en esta década se verifica en las distintas traducciones de su obra al francés y en sus largas temporadas en París.

${ }^{12}$ El ya mencionado trabajo de Nicolás descubre nuevos aspectos del intercambio de Gómez de la Serna con su tiempo, algunos de los cuales tienen puntos comunes con mis planteamientos, aunque con visiones diferentes, por lo tanto, en varias ocasiones habré de referirme a su análisis. 
Continuando con la prevención contra las taxonomías y periodizaciones estrictas, me interesa aclarar que no suscribo la crítica que desmerece la narrativa de Ramón simplemente porque no responde a las expectativas de la novela clásica decimonónica, que aunque fue muy atacada a principios de siglo, continúa siendo el parámetro con que se juzga el género ${ }^{13}$. En un período caracterizado por el afán de ruptura y las exploraciones formales, en que surgieron decisivas transformaciones como las nivolas, los esperpentos, la novela lírica, poemática, intelectual, vanguardista... sorprenden los dictámenes que desconocen las mudanzas del género, aún en declarados admiradores de, en este caso, Gómez de la Serna.

Escritor sin género, veamos cómo Ramón va fingiendo novelas, comedias, biografías. Sus novelas son novelas fingidas, ya de entrada, porque no nacen de una idea novelesca, sino de una idea poética. Idea poética que él va tratando de novelizar a lo largo de páginas y páginas. Esa es la clave de la novelística ramoniana, clave que nadie ha visto quizá porque esa novelística interesa poco (y en buena medida, con razón) [Umbral, 1978: 80]

Por otra parte, a finales de los veinte tiene lugar la aparición de la colección Nova novorum, impulsada por Ortega, proyecto editor dirigido a difundir la novela de vanguardia, de efímera existencia, duro enjuiciamiento ${ }^{14}$ y prolongado olvido, que comenzó a revertise hace aproximadamente dos décadas ${ }^{15}$. Si se acepta que este grupo de relatos es el ejemplo más acabado de la narrativa deshumanizada, la mayor parte de las novelas de Ramón no se ajustarían a las tendencias del género, aunque deje su impronta en la mayoría de los autores. Sus greguerías y

${ }^{13}$ Quizás sería aconsejable que el término 'novela' se pusiera "en cuarentena" pues se evitarían bizantinas discusiones sobre si un texto es o no es inscribible en el género. O bien podría acordarse que novela es el tipo de narración larga que floreció en la segunda mitad del ochocientos, o bien, acordar que puede haber novela aunque no responda al canon decimonónico.

${ }^{14}$ Es citada frecuentemente la calificación "cagarrita literaria" de Max Aub, que fue escritor de vanguardia, para referise a este conjunto de relatos.

${ }^{15}$ Pérez Firmat tipifica una novela de vanguardia que se cultivó entre 1926 y 1934. Distingue tres períodos: "Three of them arise from editorial ventures: the first moment corresponds to the founding of the series "Nova Novorum" of the Revista de Occidente (...) The second moment belongs to the "Contemporáneos", a group of young Mexican writers who collaborated in the magazine of the same name and wrote several novels that were classed with those of the "Nova novorum" as manifestations of the same revisionary impulse. The third moment comprehends those works published by de Colección Valores Actuales of the Ediciones Ulises". [1982:7-8] . Algunos de los escritores que cultivaron este género son Francisco Ayala, Antonio Espina, Benjamín Jarnés, Pedro Salinas. 
su re-alumbramiento de las cosas, contempladas tras un nuevo prisma, se diseminan en distintos relatos de los escritores jóvenes:

Le encomendaron después la tarea de dibujar un mapa del cielo. Comenzó por trazar sobre el papel una CUADRÍCULA DE MERIDIANOS Y PARALELOS, LAS REJAS DE LA CÁRCEL CELESTE. El CIELO, EN EFECTO, ES UNA VASTA CÁRCEL. Aun esos astros que suponemos vagan libres por el univerSO, LOS ASTRÓNOMOS LOS SIGUEN EN SUS MOVIMIENTOS A TRAVÉS DE LOS BARROTES DE LA REJA. Y desgraciado si algún cometa desconocido aparece un día en el cielo pasándose ufano de su cola y de su órbita libre y arbitraria; DESDE TODOS LOS OBSERVATORIOS DEL GLOBO LE APUNTARÁN CON SUS ARMAS DE POLICIAS CELESTES ESTOS HOMBRES TERRIBLES, HASTA REDUCIRLO AL CERCO QUE YA NO PODRÁ ABANDONAR MÁS. ${ }^{16}$ [Valentín Andrés Alvarez, "Telarañas en el cielo", 133-134]

Pero el propósito de mi indagación no es la narrativa de vanguardia ni la colección Nova novorum ${ }^{17}$, aunque sea útil como punto de contraste con las de Ramón, tanto como lo es la novela realista. Por otra parte, la obra de Francisco Ayala obligará a tener en consideración los aspectos peculiares del arte nuevo en su prosa más representativa.

\subsection{Ecos DE ENTRESIGLOS}

Dos reconocidos estudiosos de los ismos en España han señalado la impronta finisecular del primer Gómez de la Serna. José Carlos Mainer observa que

Ramón reconocía unos orígenes menos selectos [que los de Juan Ramón Jiménez]: todo el confuso mundo nietzscheano y decadentista que, con

\footnotetext{
${ }^{16}$ Subrayado mío. La composición greguerística es evidente.

17 En su libro varias veces citado en el presente estudio, José del Pino establece dos rasgos específicos de la novela vanguardista: la afirmación de un concepto de novela centrado en la fragmentación formal como resultado de un impulso de renovación y de la conciencia de la imposibilidad de crear la novela como totalidad según la entendía el realismo; y la tematización del cosmopolitismo urbano y de las distintas manifestaciones textuales de los avances científicos y tecnológicos de principios de siglo. He tenido en cuenta sus hipótesis pero sin ceñirme al corpus específico que él propone y sin adscribir totalmente a la separación entre auténticas y supuestas novelas de vanguardia, pues significa dar por aprobado que la estética de vanguardia siempre adhirió a un proyecto ideológicamente moderno y progresivo.
} 
algunas notas de vanguardismo destemplado, dio su primeriza revista Prometeo (1910). [Mainer, 1981: 205]

En su diccionario, Manuel Bonet refuerza la hipótesis:

\begin{abstract}
Aunque fue en Prometeo donde se publicaron la versión castellana del "Manifiesto futurista" de Marinetti, y su "Proclama futurista a los españoles", la mayor parte de los textos traducidos en ella fueron de escritores simbolistas, muy en la línea del Mercure de France, que evidencia las raíces finiseculares del vanguardismo de Ramón. [Bonet, 1995: 501]
\end{abstract}

Considero entonces necesario ir más allá de los primeros años de la carrera literaria de Gómez de la Serna en la búsqueda de su lazos con el anterior entresiglos. La pervivencia de un imaginario anclado en el paso entre las dos centurias impregna de distinta manera la obra de Gómez de la Serna hasta bien avanzado el siglo XX y propician una forma particular -muy personal- de comprender la vanguardia.

Me propongo demostrar que las actitudes públicas de Ramón, para muchos desconcertantes, irritantes o deshonrosas, guardan coherencia con su concepción del arte y de la función del escritor, anclada en el entresiglos, lo cual le significó una enorme dificultad para comprender la radical interpelación que el arte del siglo XX realizaba a la civilización occidental. Pese a lo signos de renovación formal de sus novelas, sobre todo si se cotejan con las galdosianas, existe un imaginario, un universo e, inclusive, un discurso narrativo, más que propiamente de vanguardia, con fuertes reminiscencias decandentistas.

Con este fin he tomado un corpus representativo de las llamadas "novelas grandes" ${ }^{18}$ y de los cuentos, novelas cortas y nouvelles, susceptible de dividirse en dos subconjuntos. El primero está constituido por relatos cuya acción, situada o no en el siglo, se impregna de una atmósfera y de un tiempo pretérito o incierto. El segundo grupo está integrado por narraciones localizadas en una rigurosa modernidad.

Las huellas finiseculares que persisten en la obra de Gómez de la Serna en la época más plenamente vanguardista ratifican la hipótesis acerca del carácter

${ }^{18}$ Así llama Ramón a sus relatos más o menos extensos, opuestos a las novelas cortas, cuentos y nouvelles. 
heterogéneo del fenómeno de los ismos en los países periféricos, y con ello la exigencia de no ceñirse al canon vanguardista de las culturas dominantes. Con respecto a las categorías más apropiadas para designar las estéticas y mentalidades que caracterizan el fin de siglo, tomo la idea hoy más aceptada por los especialistas de que el decadentismo resume la atmósfera y la mentalidad fin de siglo, englobando a los distintos movimientos que lo habitaron: simbolismo, modernismo, esteticismo, arte por el arte, y presentando un panorama europeo muy diverso. [Hinterhäuser, 1987: 9-13] Si aceptamos con Mario Praz (1999) que uno de los aspectos más característicos de la estética decadentista es la sensibilidad erótica, se vuelve posible y hasta recomendable analizar el primer subgrupo a la luz del imaginario decadente. Igualmente, los rasgos decadentistas reseñados por Ana Balakian constituyen también una entrada crítica muy sugerente. Balakian habla de la obsesión por el abismo, la desviación de lo normal, el narcisismo, el miedo al amor y a la sexualidad, el tedio de la existencia, el acuciante sentido de la temporalidad y por lo tanto de la muerte. El héroe decadentista manifiesta una sensibilidad agudizada, intenta reducir la vida a la inacción y al sueño, y muestra inclinación por los fenómenos nerviosos excepcionales. Por otro lado, el decadentismo se alimenta de corrientes filosóficas pesimistas entre las que figuran pensadores desde hace tiempo asociados a la mentalidad finisecular, como Schopenhauer, de quien provendría también un marcado antifeminismo. No puede evitarse una mención a la mujer, con sus dos rostros, el de la mujer fatal, devoradora de hombres, proveniente con la bíblica Salomé y la Salambó de Flaubert como paradigmas; y la donna angelicatta de la escuela prerrafaelista inglesa, con su retorno a la ingenuidad, la sencillez y el arcaísmo. Opuesta a las dos anteriores, se acompaña de un erotismo espiritual y refinado, acorde a su condición de virgen etérea. Pocas de estas características están ausentes en las novelas que propongo analizar en primer término.

Mi visión del problema, que he adelantado en anteriores trabajos ${ }^{19}$, quedará ejemplificada fundamentalmente con La Quinta de Palmyra, por tratarse de una de las novelas más difundida de Ramón y, según diversos críticos, la mejor y más

${ }^{19}$ V. Macciuci: $1998 b$. 
elaborada. Además, marca una fecha emblemática ya que fue publicada en 1923, el mismo año de la creación de Revista de Occidente. Para escritores contemporáneos, como Benjamín Jarnés, representa la nueva forma de novelar:

\begin{abstract}
... Benjamín Jarnés points out that La Quinta is an example of the "new novel", form of fiction that differs sharply from the nineteenth-century novel. Unlike the "old novel", the new novel is "spontaneous, free and coherent". [citado por Pérez Firmat, 1983: 18-19]
\end{abstract}

El título, La Quinta de Palmyra, concede un papel privilegiado al espacio ${ }^{20}$, una quinta, espacio más rural que urbano, para Carolyn Richmond, el verdadero protagonistaNOTA. Se trata en realidad de un palacete rodeado de un espacioso parque en una zona boscosa cercana al mar, no muy lejos de Lisboa. Es frecuente que se enfatice el componente autobiográfico que subyace en la historia de esta residencia. Entre los años 1916 y 1917 Gómez de la Serna se hizo construir una finca cercana a Estoril a la que llamó "El Ventanal", donde residió con Carmen de Burgos en un más proclamado que real apartamiento buscando un sosiego que no encontró, atribulado por las deudas adquiridas para concretar su sueño de aislarse para escribir ${ }^{21}$.

Sin negar la huella autobiográfica en La Quinta de Palmyra, no se deben olvidar las connotaciones que Portugal tuvo durante mucho tiempo para el resto de la Península Ibérica. La imagen lusa en España corresponde a la de un país que pese a ser vecino, es desconocido o, mejor, mal conocido a través de una serie de tópicos: situado en el extremo del continente, fue desde la época del imperio romano un sitio remoto, y por esa misma razón, reserva de costumbres del pasado. Portugal es una nación relegada del concierto europeo aun para un país tardíamente modernizado como España. El portugués es por otra parte un pueblo asociado a la melancolía y a las expansiones líricas; es también un cultura en la cual la figura femenina tiene un fuerte protagonismo.

${ }^{20}$ Las diferentes reflexiones teóricas sobre las relaciones del espacio con el hecho literario han contribuido a enriquecer el análisis de la producción ramoniana, muy determinada por el singular peso de este elemento en su universo textual, cualquiera sea el género. [Gutiérrez Carbajo,1997: 24 y ss.]

$21 \quad$ V. más datos en Richmond,1983. 
Es interesante observar en el principal libro de memorias de Gómez de la Serna, Automoribundia, escrito casi veinticinco años después de La Quinta de Palmyra, la pervivencia de la imagen exótica y arcaica de Portugal. Recuerda el autor "aquel Portugal, ilusionado aún por sueños antiguos", que le "hizo volver al pasado", "aquel ambiente absolutamente siglo XIX"22.

Nos encontramos entonces con la novela de un artista "de vanguardia" que transcurre en un espacio alejado de las grandes urbes industrializadas, en un palacio apartado de la capital de un país exótico, cuando es bien conocido que tanto la prosa como otros registros de vanguardia, que exceden el campo de la producción literaria, manifiestan una abierta predilección por los ambientes urbanos; la vanguardia sin la urbe moderna perdería un rasgo esencial, hasta cierto punto, constitutivo.

Desde ese refugio los signos de la modernidad aparecen fugazmente; la residencia opera como un baluarte que preserva una forma de vida aristocrática y reposada. La tecnología se insinúa pero se rechaza, queda afuera: automóviles, turistas, taxis, buques, telégrafo, no traspasan nunca los límites de la quinta.

\begin{abstract}
Después de la riña con Fausto, una de las cosas que más emocionaban su vida de soledad, lo que la llevaba hacia el mundo, lo que la ${ }^{23}$ daba la palpitación máxima del corazón era ver los automóviles que unidos a los transatlánticos que hacían escala en Lisboa, transportaban a los viajeros más inquietos para que viesen aquellos parajes de la costa y el faro estratégico. [QP:229]
\end{abstract}

Cuando los modernos inventos aparecen, operan negativamente sobre el espacio preservado: el telégrafo sirve para que el primero y más amado de los amantes de Palmyra, Armando Vivar, idee un ardid para abandonarla. Se verá más adelante que de forma recurrente la técnica cumple una función desestabilizadora en la narrativa ramoniana.

El cosmopolitismo, las grandes capitales del mundo, toman contacto efímero con Palmyra a través de los amantes que no logran inmutar el ambiente, por el contrario, el ambiente se defiende y finalmente los rechaza: un español, dos

${ }^{22}$ Citado por Carolyn Richmond, 1982: 54.

${ }^{23}$ La crítica ha señalado la utilización de 'la' con valor de objeto indirecto -laísmo- por Gómez de la Serna. De ahora en más no haré nuevas referencias a este uso bastante frecuente en algunas zonas de España, especialmente en el Madrid castizo. Ramón advierte en las páginas preliminares de Senos "Yo soy partidario de la en vez de le" [ Nicolás (ed.), 1998: 531] 
portugueses, un judío norteamericano, un navegante sin nacionalidad manifiesta, pasan infructuosamente por la residencia.

Por un camino opuesto, otros narradores vanguardistas incorporan en la representación de la metrópolis los avances tecnológicos como índices de la utopía urbana y cosmopolita que caracteriza el universo de los ismos. La quinta, en cambio, no se deslumbra ante la técnica, sino que por el contrario, el texto acentúa el contraste con la presentación de antiguos objetos de abolengo entre los que sobresalen los coches de tiro y los caballos utilizados por Palmyra para pasear por los alrededores del palacio.

\footnotetext{
Después se entraban en la Quinta que tenía calor propio, olor a maderas finas y el último perfume a flor de los bosques antiguos. Otros días llovía y no salía. Gozaban de la lluvia que en una definición hecha de los placeres del castillo por el señor castellano, ocupa su número de orden entre los placeres: "Ver llover". [QP:285]
}

Uno de los elementos más recurrentes en el arte nuevo es la tematización del dinamismo temporal propio del siglo y sus grandes inventos, reforzada en ocasiones en el plano del significante por medio de la fragmentación, la aceleración de la frase o del ritmo narrativo. En la novela de Gómez de la Serna, en cambio, el narrador se recrea en la descripción de objetos refinados y exclusivos, piezas preciosistas, a medio camino entre aristocráticas antigüedades y finisecular art decó, tiñendo de atemporalidad y clausura el espacio de la quinta.

Los muebles estaban pasando una temporada de primavera eterna, y por eso se les veía plácidos, como dedicados a la lectura y a la conversación. Numerosos veladorcitos con ceniceros, libros y cajitas revestidas de conchas se acercaban a los grupos de asientos en actitud servicial. (QP:163)

Desde los dos primeros capítulos, titulados significativamente "Descripción de la finca" e "Interior de la quinta", el espacio es clave en el desarrollo de la novela, complemento necesario de un tiempo igualmente decisivo a la hora de brindar una atmósfera adormecida, con ritmo propio, ajena al más actualizado mundo exterior. La reticencia de datos que permitan precisar las coordenadas temporales de la acción es otro rasgo reiterado, lo cual contribuye a realzar el plano espacial, que en este caso, se duplica con objetos alusivos. 
Unos cuantos mapas mundis y varias esferas armilares había repartidos por la casa y la daban una especie de trascendencia ultramarina y ultraterrestre. [QP:164]

En La Quinta de Palmyra se observa una morosidad, casi estancamiento narrativo, con una acentuación de la inmutabilidad del personaje principal ante el transcurrir temporal. La defensa de un tiempo pretérito se afirma en la casi imperturbable asistencia de Palmyra al paso dinámico y seriado de los sucesivos amantes.

El sentimiento de aristocrática melancolía ante las pérdidas que la vida moderna ocasiona a las costumbres hidalgas y reposadas remite a la mentalidad decadentista: el aislamiento, el retiro contemplativo, la construcción de un espacio de resistencia que se basta a sí mismo y da la espalda al mundo contemporáneo, demorándose, en una actitud típicamente finisecular, en el goce del mundo próximo a extinguirse. El simbólico país lusitano proporciona el exotismo necesario.

Se volvió a sentir Palmyra en las playas últimas de Europa... Se acordaba de lo que decía Armando con cierta tristeza: "Aquí se ve el último momento del ocaso que ve toda Europa... Nosotros lo despedimos en el último puerto, cuando ya se va decididamente al otro mundo. [QP:215]

Palmyra y sus amantes, en tanto permanecen juntos, observan pasivamente los indicios de la sociedad que existe fuera; a veces, excepcionalmente, perciben las miradas de los otros, que marchan en dirección opuesta. La aparición del proletariado y otras alusiones a la era de la industrialización y la lucha de clases suelen reducirse en las novelas de Ramón a rápidos pantallazos.

Volvían hacia la casa. Contra corriente tornaban también los trabajadores, que miraban cínicamente a los coches. [QP:193[

\subsubsection{Erotismo y mujeres}

Tanto para atacarlo como para elogiarlo, la crítica ha prodigado comentarios sobre el tratamiento de la sexualidad y el erotismo en toda la producción de Gómez de la Serna ${ }^{24}$. Es un aspecto clave de la obra ramoniana que ha merecido

${ }^{24}$ Es llamativo que la crítica contemporánea a La Quinta de Palmyra no se haya detenido en el erotismo, en cambio, sí lo hizo para condenarlo ásperamente la aparecida en los años 60: "no es sino la crónica de unas fáciles seducciones en las cuales la peculiar situación de quienes las 
estudios pormenorizados e indudablemente aún presenta interesantes zonas por indagar ${ }^{25}$. Desde el punto de vista que propongo, me interesa el erotismo como un anclaje en un mundo que no es el vanguardista de los "felices veinte": por el contrario, responde más a un imaginario simbolista-decadentista -con ascendencia valleinclanesca- que a una auténtica revolución como podría ser el tratamiento del sexo y del amor en la vanguardia, y más liberador todavía, en el surrealismo. La cuestión es compleja, porque sin duda Gómez de la Serna tiene en el erotismo uno de sus sellos más notables. Puede comprobarse que la sexualidad de sus personajes es el eje de muchos de sus relatos, además de contar con la singular creación de un libro como Senos, de 1917. Pero pesan en sus repetidas exploraciones del amor anómalo, más que un gesto rupturista, la atracción finisecular por las patologías y las perversiones sexuales; más un eros de la provocación que de la emancipación que acompañó a las demás conquistas del hombre de la modernidad de los años veinte. El atractivo de las mujer rodeada de misterio y de crimen, la aproximación del amor y la muerte, constituyen en cambio, motivos indudablemente decadentistas.

\begin{abstract}
Armando encontró en Palmyra, puesto a encontrar encantos, el encanto de la que había escapado al veneno, y la encontró más apetitosa, más necesitada de protección y con mayor deseo de retenerla, la besó con afán en la mejilla y en la boca, que era como le gustaba besar, mientras apretaba sus manos como si la consolase de la orfandad de aquel abuelo envenenado. [QP: 203]
\end{abstract}

En las novelas que del Pino considera más representativas de la novela de vanguardia, la mujer está ligada al conocimiento y a la conquista del espacio urbano; la conquista de nuevos territorios del erotismo acompaña a la posesión de la ciudad en un impulso en principio jubiloso y confiado. La dueña de la quinta

protagonizan, la ausencia en todos de represiones éticas o frenos sociales, priva a los sucesos de dramatismo y hasta de anécdota", haciendo referencia además a "la relación entre los sexos, reduciéndola a mera satisfacción mutua de apetencias carnales" y a que en los personajes "su individualidad biológica aparece reducida al funcionalismo, hipertrofiado desde luego, de unas glándulas". [Granjel, Luis, citado por Richmond, 1982:32]. La acritud del comentario es un índice del retroceso impuesto por la dictadura franquista, en cuyo contexto Ramón sin duda quebrantaba los códigos morales de la literatura bienpensante.

${ }^{25}$ V. López Criado, 1988. Por su parte, Octavio Paz piensa que "Gómez de la Serna es uno de los pocos escritores modernos que trató del erotismo con calidad literaria" [1973. Sólo a dos voces, Entrevista con Julián Ríos, Barcelona: Lumen. (Citado por Richmond, 1986: 47)]. Un detallado análisis del erotismo en las 6 falsas novelas se encuentra en Zlotescu, 1989. 
ramoniana ejerce, por el contrario, un erotismo "meduseo" con la finalidad de retener a sus amantes, apartarlos del llamado de la urbe y alimentar el gusto por el pasado y el apartamiento.

Sensual y generosa con los amantes, Palmyra Talares encarna un tipo particular de mujer de fin de siglo; reúne cualidades maternales y perversas, se muestra insaciable y enfermiza, incomprendida y melancólica. Su cuerpo se une a la seducción del palacete y a su ocio indolente y aburguesado para cautivar a los viajeros, quienes no tardan en sentir la asfixia de la mujer y del medio. Palmyra es la antítesis de la mujer que entroniza la vanguardia, generalmente activa, deportista, ávida de conquistar el mundo nuevo que las convenciones le han negado. Tampoco encarna el objeto amoroso en donde culmina la paradójica síntesis de libertad y destino, libertad y necesidad, con su carácter exclusivo e intransferible y liberador ${ }^{26}$.

El sexo, la afinidad de los sentidos y el sometimiento del otro, más que el amor entendido como entrega plena del sujeto, es arma imprescindible para mantener el encierro. Sin embargo, la transgresión de Palmyra -cinco amantes, definición lesbiana al final- no es más audaz ni provocadora que el incesto, la homosexualidad y los ultrajes a la religión en Valle Inclán. Aunque va más allá que el escritor gallego en la representación de la sexualidad, los personajes de Ramón no tienen la voluntad de transgresión y la conciencia de traspasar límites como sucede con el Marqués de Bradomín, más aristocrático, subversivo y blasfemo sin culpa, aunque se trate de un amor incestuoso e involuntariamente criminal, como el que despierta el viejo seductor de Sonata de Invierno en la inocente novicia e hija ignorada.

Por guardar eternamente un secreto, que yo temblaba de adivinar, buscó la muerte aquella niña a quien lloraré todos los días de mi vejez. ¡Ya habían blanqueado mis cabellos cuando inspiré amor tan funesto! (SI: 86)

Dos décadas después de las Sonatas, La Quinta de Palmyra recrea gran parte de los tópicos decadentistas sin la carga revulsiva de Valle Inclán, teñidos de un recato contradictorio que hace pensar la vigencia de los rasgos de

\footnotetext{
${ }^{26}$ V. Paz, Octavio, en Víctor García de la Concha, 1982: 36-49.
} 
"moderación" que la crítica especializada observa en el decadentismo latinoamericano.

Angel Rama va a hablar de los "Límites de la capacidad asimiladora" en este proceso de adopción de modelos europeos, y trae a mención la mentalidad aldeana de muchos modernistas. Los valores tradicionales, como una corriente interna, prevalecieron frente a las propuestas que, como el decadentismo, implicaban un enfrentamiento demasiado virulento con estas convicciones. [Colombi; s/a: 4]

El autor de Tirano Banderas incursionó con osadía en múltiples variantes del amor contrario a las normas de la moral burguesa, de las cuales el discurso erótico de Ramón parece una prolongación exuberante -como lo es toda su producción, morosa y descriptiva- pero ambiguamente censora dentro de su permisividad.

Ana Balakian señala como un rasgo típicamente modernista la hiperestesia, disposición ideal para captar las armonías ocultas del universo. La búsqueda del afinamiento de las sensaciones se ayudaba con los estimulantes. En Francia, favorecidos por sus relaciones con el Este asiático, fue alto el consumo de opio, llave irremplazable para alcanzar los anhelados paraísos artificiales, y el descubrimiento de nuevos estados de conciencia, estableciéndose un antecedente que con los surrealistas se convertirá en un valor programático.

Attrait pour la modernité, contemplation d'un paysage urbain métamorphosé par la nuit ou la brume, et bigné d'imaginaire, recours à la drogue ou abandone au rêve, il s'agit toujours pour ces écrivins de trouver un univers compensatoire qui permette de supporter les alideurs de l'univers réel. [Pierrot: 1977: 235]

Palmyra Talares tiene un sensibilidad ultra desarrollada, pero Gómez de la Serna previene, no obstante, sobre la inconveniencia del consumo de estupefacientes.

Ya en el atardecer, vieron cómo en el marco de una lejana puerta se encendía la primera fogata de las cocinas.

-Siempre creo que son un incendio que nace esos fuegos de las cocinas... tienen un color tal de gasa de fuego las llamas a esta hora, que me sobresaltan el ánimo.

--Eres una hiperestésica... En Portugal, todas sois hiperestésicas. 
- Si no se es hiperestésico, no vale vivir... Comprendo que no se debe tomar ninguna droga para fomentar la hiperestesia, pero si se es lealmente no hay por qué dejarlo de $\operatorname{ser}^{27}$. (QP: 272)

¿Dónde concluye la voz del personaje y se escucha la del autor?. La aclaración de Palmyra es inmotivada, no responde a ningún requerimiento interno del texto ${ }^{28}$. Distintos críticos han tratado la dualidad de Ramón, que se inclina hacia lo prohibido y, al mismo tiempo, adopta un tono moralizador y decoroso, sea alrededor de motivos sexuales o, como en este caso, de los paraísos artificiales: así en La Nardo, Mainer [2000: 41] señala una pugna entre "la moralización trágica y la exaltación de la suprema libertad" que considero no es privativo de esta novela ni del motivo amoroso.

El erotismo de Gómez de la Serna se atreve a incursionar en las zonas de la morbidez y el deseo femenino; su audacia mereció la reprobación de críticos que no pudieron leer más allá de lo obsceno. También va lejos cuando incursiona en el herético entrecruzamiento de sexualidad y fervor religioso, aunque cuando están en juego los valores más arraigados, no faltan los comentarios de orden moral, como ocurre con el rechazo de los estupefacientes. La herética fusión de erotismo y arrobamiento piadoso, tan cara al decadentismo -y a Valle Inclán-, reaparece en La Quinta de Palmyra.

Velos invisibles cubrían las cosas, las adormecían, las daban carácter de Semana Santa, cuando toda imagen se envuelve en un paño morado. [QP: 164]

Las citas bíblicas, metonimia de la atracción erótica, no faltan a lo largo de la novela. Durante la espera de Lucinda, su última conquista, Palmyra Talares es

${ }^{27}$ Las drogas, psicoactivas o no, comienzan a ser severamente penalizadas a partir de 1920. Los años en que escribe estas obras coincide por lo tanto, con un aumento del control y de la criminalización del consumo por parte del estado, que no obstante no logra reducir su circulación. La prevención de Palmyra no ilustra el consumo carente de culpa propio del siglo XIX, como puede encontrarse en innumerables artistas y escritores franceses -Hugo, Gautier, Rimbaud, Baudelaire..- y en, España, un poco más atrás, en Goya. El consumo de estimulantes y narcóticos reaparece en diferentes novelas de Ramón: Cinelandia, El Chalet de las Rosas, La Nardo. En esta última llega a determinar el destino de los protagonistas. El autor parece inclinarse por la tematización de los aspectos más punibles del consumo. [Escohotado, 1994 y 1989]

${ }^{28} \mathrm{La}$ acotación guarda un significativo paralelismo con una mención a Gide del mismo Gómez de la Serna. Elogiando la figura del autor francés cree necesario aclarar "en sus mejores cosas no en las pervertidoras". "Sobre la torre de marfil", Sur, VII, 29, feb. 1937, p. 66. 
comparada con la virgen doliente en un cuadro típicamente cuaresmal, combinado con una ansiedad ingobernable lindante con el éxtasis místico:

La tarde pasaba y Lucinda no llegaba.

Asomada al balcón, no podía retener una idea ni casi retenerse a sí misma.

Las nubes, rápidas, la daban una melancolía de desangramiento. Palmyra las miraba con gesto de dolorosa. [QP: 305]

Nuevamente el contraste con Valle Inclán proporciona elementos iluminadores sobre la naturaleza de las rupturas -si así pueden llamarse- de Gómez de la Serna. Mujeres lánguidas, temibles tras los arrobos inocentes y angelicales, a veces víctimas, a veces victimarias, tanto más seductoras cuanto más encarnan una conjunción sacrílega de ángel y demonio, de ofrenda y sacrificio. Las Sonatas del autor gallego son generosas en situaciones en que la mujer ejerce un peligroso magnetismo a partir de la fusión ángel demonio.

Divina María Antonieta, era muy apasionada y a las mujeres apasionadas se las engaña siempre. Dios que todo lo sabe, sabe que no son éstas las temibles, sino aquellas lánguidas, suspirantes, más celosas de hacer sentir al amante, que de sentir ellas. María Antonieta era cándida y egoísta como una niña, y en todos sus tránsitos se olvidaba de mí: En tales momentos, con los senos palpitantes como dos palomas blancas, con los ojos nublados, con la boca entreabierta mostrando la fresca blancura de los dientes entre las rosas encendidas de los labios, era de una incomparable belleza sensual y fecunda. [SI: 118]

Las referencias religiosas exasperan el erotismo y dan un mismo aire de familia a las novelas del artífice de Pombo y a las del autor de las Comedias bárbaras.

Armando luchaba por alcanzar aquel ¡Ay Jesú! sin la ese final, y sin la ceda andaluza, que daba singular aire de martirio y derretimiento al amor. También cuando le salía un "¡Ay mía mãe!" encontraba en ella toda la dulzura portuguesa.

Aquella noche brotó el "¡Ay Jesú!" suave, inusitado, con blandura suprema. [QP: 205]

Pero acuerdo con Carolyn Richmond que en Gómez de la Serna estas asociaciones tienen una carga de sanción moral o de contención extraña al mundo decadentista ${ }^{29}$. Cuando la voz del narrador se manifiesta más claramente revela

${ }^{29}$ En el prólogo a La Quinta de Palmyra, Richmond cita la reprobación que las tendencias lesbianas de Palmyra merecen al narrador: "Entonces sí que se podría decir que había comenzado a ser una mala mujer". [Richmond, 1982: 135] 
otra vez sus escrúpulos al referirse a las preferencias sexuales de Lucinda, dice "tenía mucha fama de eso" 30 y acompaña la descripción con distintos tópicos de la mujer fatal

„,,tenía los ojos unidos de las serpientes con las pupilas muy abiertas de quien ha querido ver mucho las cosas que absorbió, las víctimas desangradas. Tenía también el gesto sospechoso de la serpiente que muerde en lo bajo y mira hacia lo alto para ver encima de ella el gesto de la mujer mordida. [QP: 304]

El discurso más blasfemo y transgresor se apoya en un discurso prestado, en un poema y versos de la poeta homosexual Renée Vivien

"Yo la tenía sobre mi amor como una crucificada." Y como era una mujer la que hablaba a otra, la cruz era suave y sin tormentos y la crucifixión estaba llena de blanduras.

"Yo me acuerdo de las tardes rojas en que nos devorábamos, insaciablemente hambrientas, y nuestros besos se volvían asesinatos, y nuestras bocas entreabiertas, como heridas, tenían un gusto a sangre". [QP: 307]

La homosexualidad constituye un motivo de transgresión de la moral tradicional cara al decadentismo. Si se trata de provocar, una vez más Valle exhibe un desacato más desenfadado y triunfante que el autor de Senos.

Viendo a los dos prisioneros, lamenté más que nunca no poder gustar del bello pecado, regalo de los dioses y tentación de los poetas. En aquella ocasión hubiera sido mi botín de guerra y una hermosa venganza, porque era el compañero del gigante el más admirable de los efebos. Considerando la triste aridez de mi destino, suspiré resignado. El efebo me habló en latín, y en sus labios el divino idioma evocaba el tiempo feliz en que otros efebos sus hermanos, eran ungidos y coronados de rosas por los emperadores:

(...)

al verlos partir recordé a la niña de los ojos aterciopelados y tristes, y lamenté con un suspiro, que no tuviese las formas gráciles de aquel efebo. [SI: 150-151]

\subsubsection{Novela y ARTIFICIO}

El peso del espacio natural en La Quinta de Palmyra -el mar, los bosques, las variaciones del tiempo- no deben confundir al lector acerca de una posible relación mimética. Entre la naturaleza y su representación se introduce la conciencia del artificio, la voluntad de embellecer y estilizar. Palmyra es obsesiva

\footnotetext{
${ }^{30}$ Subrayado del autor.
} 
con el lenguaje, porque es uno de los secretos, quizás el primero, de la armonía buscada.

Para el decadentismo el mundo del arte y la cultura es el principal referente, la naturaleza es sinónimo de rusticidad y prosaísmo grosero. En la novela portuguesa de Ramón no se llega al límite de preferir las flores artificiales a las naturales, pero queda al lenguaje cumplir la misión distanciadora, poniendo en práctica el célebre aforismo de Paul Bourget, considerado el primer teórico de la decadencia: "... I' unité du livre se décompose pour laisser la place a l' independence de la page, ou la page se décompose pour laisser la place a l' independence de la phrase, et la phrase pour laisser la place a l' independence du mot...". ¿No podría constituir la frase un manifiesto de la estética ramoniana? La exquisita sensibilidad de Palmyra para captar la naturaleza de su alrededor no serviría de nada si su percepción de la realidad no estuviera tamizada por una exigente reflexión sobre los vocablos: el lenguaje es un instrumento tan suntuario y delicado como los muebles, la indumentaria o la buena mesa, y a través de él define la relación con el mundo: no compartir el código preciosista de la mujer significa no ingresar en su ámbito. Un exabrupto en boca de su segundo amante ocasiona la ruptura.

-No puede ser -dijo ella-, has vuelto a ser el extraño, como si aquel señor que recogí en el Casino me hubiera dicho una grosería entonces, en vez de ser galante y apasionado... Jamás se oyó en la quinta esa palabra... No la podré olvidar... Luego, al atardecer, tomas tus cosas y te vas. [QP: 228]

La estrecha simbiosis entre personaje y espacio, sostén de la tenue acción de la novela, se funda en la "traducción" que Palmyra realiza del paisaje, el cual a través de una sensibilidad exacerbada lindante con lo patológico, se convierte en la prolongación de su estado voluptuoso e hiperestésico.

Ponían nombres solemnes a las cosas (...) y el opinaba, señalando esas ruinas o esas montañas que parecen castillos, que: "La naturaleza es muy novelera, y quiere que se la dote de castillos con fosos y almenas". [QP: 192-193]

"La Quinta" propone una ruptura con la narrativa realista decimonónica que ha llevado a muchos críticos a negarle el estatuto de novela. El adelgazamiento de 
los personajes, la escasa profundidad psicológica, la reducción del peso relativo del argumento y la intriga, el cultivo extremo de la metáfora, recuerdan las observaciones de Ortega sobre el arte nuevo. No obstante, la novela presenta un desarrollo lineal, sin oquedades que requieran un lector activo y altamente competente como ocurre con los textos de vanguardia. El argumento se encamina a un desenlace a través de episodios, que pese a ser intercambiables, encierran una progresión impresionista asimilable a renovaciones modernistas transitadas por Valle Inclán o Azorín. Sólo un episodio es mencionado mediante una elipsis, el viaje de Palmyra a Lisboa, donde aparece la novedad de la introducción de la voz del narrador en un atisbo metaficcional ${ }^{31}$. Más inusitada resulta la reaparición de una voz autoral cargada de escrúpulos, muy lejos de la deleitación decadentista - "la fruta a punto de perderse es la más exquisita", sostenían- o de la emancipación jubilosa de la vanguardia.

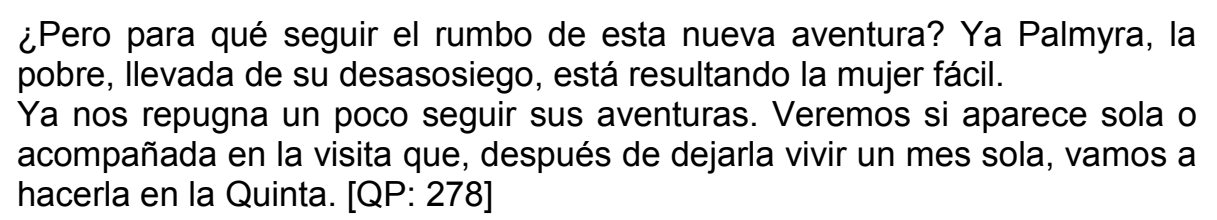

Sin embargo, el paréntesis en el viaje de Palmyra a la capital a "buscar café" -un imperativo aristocrático por su exquisita futilidad-cumple una función estructural básica. Algunos críticos ponen el enfásis en la autocontención del narrador en el momento en que la protagonista se entrega a aventuras demasiado promiscuas en la capital. Creo que la omisión de la andanza lisboeta, desde donde regresa con su último amante, refuerza el aislamiento espacial, la atmósfera anacrónica del palacio, la atemporalidad subrayada fugazmente por los vestigios de la ciudad cosmopolita en la periferia. La homogeneidad del espacio de la novela se hubiera alterado si el autor desarrollaba una secuencia semejante a las anteriores en un espacio urbano.

Otros denominadores comunes al decadentismo aparecen compendiados por Jean Pierrot en L' imaginaire décadent (1997), entre ellos, el mito de la decadencia de occidente, y la convicción de estar viviendo un momento de

${ }^{31}$ Ramón fue un gran experimentador con los recursos metaficcionales. Su máximo logro es, a mi entender, El novelista (1923). 
desequilibrio continuo. En un mundo carente de poesía el artista está destinado a poseer un exceso de sensibilidad y de inteligencia crítica en abierta oposición a la falta de voluntad. A la vez, el conocimiento de otras culturas lleva al escepticismo religioso, al relativismo y al cosmopolitismo, que hacen del artista un ser desarraigado.

Las circunstancias y la atmósfera reseñadas producen un estereotipo de héroe decadente, caracterizado por el tedio, la pasividad, la apatía. Se trata de personajes abúlicos, dubitativos, seres aislados de la sociedad que condenan de forma absoluta la existencia.

De a la religión, el decadente tomará sus aspectos estéticos y se sentirá atraído por lo sobrenatural, pero evitando el dogma y la filosofía. Misticismo y voluptuosidad, piedad y atractivo carnal, convivirán de manera pecaminosa, sirviendo de estímulo al erotismo y la sexualidad. Conectar con el texto

\subsubsection{Paseante de los suburbios}

Distintos analistas de las novelas de Ramón [Umbral, 1978; Rey Briones, 1998; Nicolás, 1999] han hecho hincapié en su cosmopolitismo de vanguardia debido, entre otras razones, a las diversas localizaciones de sus relatos: París, Roma, Nápoles, Madrid, Lisboa, Berna... En el caso de Rey Briones, según mi opinión, su artículo se basa en un corpus poco representativo, que proporciona un acercamiento parcial al problema. En cuanto a los argumentos de Umbral y Nicolás, creo que deben sopesarse con otras razones, algunas de ellas ya anticipadas en el análisis de La Quinta de Palmyra: se ha visto que en la novela portuguesa el espacio opera como un tipo de reserva a la que difícilmente llegan los ecos del mundo moderno. En otros relatos ramonianos transcurren en grandes ciudades, incluso con mención expresa de las novedades de la modernización urbana y de innumerables fetiches del progreso tecnológico; sin embargo, estos motivos no bastan para considerarlos un factor innegable de vanguardismo. En relatos como El Chalet de las Rosas, o La mujer de ámbar, el espacio de la intriga se repliega, buscando un encapsulamiento para apartarse del la polis, de su ritmo y sus exigencias al nuevo homo urbano. En otros casos, el centro de la acción se 
sitúa en zonas alejadas, que mantienen la atmósfera de ciudades tradicionales, cuando no detenidas en el tiempo. El rasgo, que por sí solo sería escasamente relevante, se conjuga con otros elementos compositivos que refuerzan la atracción por el pasado y el gesto remiso a la seducción del progreso. Así ocurre en el Chalet de las rosas, novela ambientada en Madrid pero cuya localización principal se sitúa en el extrarradio, en Ciudad Lineal. Barrio diseñado a finales del siglo XIX a partir de concepciones urbanísticas muy novedosas, fue comenzado a construir en $1894^{32}$. De forma similar a la Quinta de Palmyra Talares, el "hotelito" ${ }^{33}$ funciona al servicio del aislamiento los personajes. Un hombre, Don Roberto Gascón, atrae con engaños a sucesivas mujeres, todas ellas solitarias y sin vínculos fuertes con el tejido social, circunstancias que le permiten asesinarlas y enterrarlas en el jardín de su chalet. Las primeras líneas de la novela sitúan al lector en la atmósfera sombría adecuada para esta clase de asesinatos.

La tristeza de la Ciudad Lineal era la tristeza de una de esas ruinas nuevas, es decir, ruinas de una casa que no se pudo acabar en un paisaje suburbano y deshabitado. [ChR: 63]

El protagonista y su última mujer huyen a Francia. Ella no es asesinada porque el criminal la necesita para cobrar la herencia de su última víctima. Aun cuando la acción se traslada a París, vuelven a ser decisivos los espacios interiores, el encierro, los suburbios. La soledad de los personajes llega al extremo cuando se relacionan con un judío polaco -inequívoco símbolo de desarraigo- que desde los cinco años ha mantenido secuestrada y encerrada en un inmenso edificio deshabitado a una mujer que en el momento de los acontecimientos tiene treinta. Los turbios personajes viven apartados, pocas veces se asoman a la ciudad bulliciosa; los momentos en que el narrador se interna en la agitación ciudadana son excepcionales

32 Gutiérrez Carbajo [1997] proporciona datos interesantes sobre Ciudad Lineal y señala oportunamente que en El Chalet de las Rosas el autor teñirá al nuevo barrio madrileño de cualidades sombrías funcionales a la materia del relato, que no se correspondían con el proyecto del arquitecto Arturo Soria de crear una zona de integración entre la ciudad y el campo.

${ }^{33}$ En Ramón y en otros narradores de principios del siglo XX 'hotel' se emplea frecuentemente como equivalente a chalet, correspondiendo a la segunda acepción del diccionario: "Casa aislada de las colindantes y habitada por una sola familia". 
Otros días tomaban un auto y hacían excursiones larguísimas. Esa intimidad del automóvil público que no compromete y que se paga llegaría al fin del mundo sin poner inconveniente.

$(\ldots)$

Cuando todos los automóviles se paraban, en interminable hilera se sentían, si bien ocultos por la larga fila, detenidos, como si alguien que les había dado el 'jalto!' les fuese a registrar.

En esa parada del mundo, que es una de estas paradas de la circulación, don Roberto y Amanda se miraban en los escaparates con cierto temor de ver sus siluetas tan quietas y oscuras.

En una cuneta, la bicicleta desmayada era difícilmente reanimada por su dueño. [ChR: 142-143]

Pero los espacios que los personajes habitan y por los cuales se desplazan carecen de indicios de modernidad; es más, el aire envejecido y el ritmo entre desganado y autónomo refuerzan la naturaleza anómala y enfermiza de los personajes. Así sucede con la residencia del judío polaco Kroztia.

-Toda la casa está deshabitada y no abre nunca sus persianas... Esto en París ni se nota. El patio hacia donde da su habitación está rodeado de otras casas deshabitadas que también son mías. Ningún grito suyo [de la secuestrada] puede encontrar eco. [ChR: 162]

Si a la atmósfera clausurada se suma el carácter anómalo de los personajes, las pasiones enfermizas y el motivo del crimen serial, la distancia de la vanguardia se concreta aún más, desplazada por el carácter típicamente decadentista de los motivos.

Mucho se ha hablado del gusto de Ramón por el callejeo, propio o de sus personajes. Apasionado por su ciudad natal, sus costumbres han sido definidas como las de un flàneur madrileño. En principio, me detendré en sus vagabundeos figurados. Se puede ver en Ramón un paseante que encamina sus pasos hacia los lugares simbólicos de la literatura y atraviesa barrios altos y bajos, deteniéndose libremente en las zonas más diversas, acopiando y reelaborando materiales múltiples y variados. Como de los objetos del Rastro que tanto le subyugaban, se apropia de los distintos géneros, a veces nuevos y cotizados, otras en desuso o desprestigiados y los devuelve, luego de tratarlo en su taller, con una nueva fisonomía.

El excelente estudio de César Nicolás toma nota de la personal manera de Ramón de integrar sin reparos materias primas de muy diversa procedencia, 
ajenas a los gustos configuradores del arte nuevo. El crítico procura hallar explicaciones que considero valioso atender y en parte, reconsiderar.

Nicolás acuña la expresión "flâneur vanguardista" para definir a Gómez de la Serna, expresión que remite a la condición de perenne paseante y contumaz observador. El título mismo de su trabajo, "Las paradojas del paseante", anticipan la singularidad ante las que se enfrenta el crítico español.

Buscando otro tipo de lectores, nuestro primer vanguardista acompañó su ruptura con una poética personal. Para comprenderla, hemos de remontarnos al siglo anterior, y pasear con Ramón al hilo de Baudelaire y los 'raros'. [Nicolás: 1999, 355]

El llamado de atención que hace Nicolás sobre la gravitación de una actitud itinerante con fuertes amarras en el siglo XIX enlaza en parte con la hipótesis que he venido desarrollando en este y anteriores trabajos acerca de las raíces ochocentistas de Ramón, pero diverge en la interpretación final, quizás, en parte, por no compartir el juicio que aclama la vanguardia y estigmatiza las tendencias que le precedieron, en un juego opositivo que sin duda funcionaba justificadamente en muchos artistas de entresiglos, pero cuya estela no debe envolver a los especialistas cien años después ${ }^{34}$.

Con el estilo encomiástico que en él despierta el inventor de las greguerías y haciendo gala de un discurso metafórico en el que subyace abundante material teórico, el profesor de la Universidad de Extremadura observa oportunamente la pervivencia de improntas decimonónicas en la obra rupturista de Ramón, síntesis

\footnotetext{
${ }^{34}$ En distintos momentos de su estudio Nicolás muestra compartir criterios literarios que animaban a muchos de los escritores de principios de siglo: "parasitando y cuarteando el texto realista (garbancero, asfixiante y espeso), atomizando con cariño el modernista (ese corsé lírico y sensitivo que propende a lo cursi) Gómez de la Serna nos propone un texto ligero y agujereado, cuyo significado, al tiempo que ronda lo 'indecible', se torna perverso e intertextual"(1999: 364). Por otra parte, se hace hoy difícil sostener a riesgo de realizar lecturas sumamente pobres, el aserto que durante años condenó a la novela realista: "El narrador omnisciente del realismo manipulaba la realidad; observaba todo desde una perspectiva central o privilegiada -distante, que era a la postre fija, unilateral, engañosamente 'objetiva': todo estaba predeterminado de antemano" (368). Por último, es significativa la reaparición de Blasco lbáñez como nombre que concentra el mal de la novela burguesa con el inri más denostado/ambicionado de un público fiel, algo que no está mal si se logra atraer con frutos más selectos -Nicolás refuerza las paradojas, al mantener incólume el elitismo tutelar de la vanguardia pero con ansias de popularidad: "Y es que Ramón, que ama la desintegración, adopta también esas lentes del naturalismo que (incluso antes del XIX, en un Quevedo) miran a lo 'bajo', haciendo puntillismo (y que tienen en la pesada novela burguesa, y más en la de Blasco, un público apetecible, potencialmente tránsfuga, si se le sabe dar lo descriptivo desde una óptica vanguardista, incongruente, lírica, atomizada)". (384-385) Subrayado mío.
} 
y origen de su costado más novedoso y único, de su batería más revolucionaria y, paradójicamente, vanguardista. La visión de Nicolás representa un acercamiento original a la complejidad del autor que se analiza, valiosa tanto más porque no se somete a las cronologías, los movimientos y las teorías dependientes de los modelos centrales.

\begin{abstract}
¿Cabrá proponer a Ramón como trapero y flâneur de nuestro siglo? Multifacético, frecuenta los derribos. Es allí donde recoge retazos y cascotes de greguerías, que contienen y sobrepasan todas las realidades e incongruencias encontradas en su deambular infinito. Más tarde vende también ropa usada, pero tijereteada y enjaretada por lo nuevo. Payasea, voceando sus ofertas a los transeúntes. [Nicolás, 1991:16]
\end{abstract}

La contraparte de la deuda finisecular de Ramón, en la que Nicolás no se detiene, es un modo de entender el arte y el lugar de artista anclado en una Belle Époque que hubiera deseado perpetua y en la que perseveró porfiadamente, ciego y sordo al paso del tiempo y de la historia. Hoy quizás el giro de los tiempos levante elogios a su fidelidad al arte, pero mi análisisintenta justamente lo contrario: distanciarse tanto de las lecturas excesivamente marcadas por la contemporaneidad con el objeto analizado como de la descontextualización y las lecturas ex - temporáneas. La cuestión continuará desgranándose en las siguientes páginas, previo retorno a sus criaturas de ficción.

Ramón se siente atraído, como el paseante benjaminiano, por los lugares de la ciudad intermedia entre el pasado y el moderno diseño, que le permiten experimentar el atractivo de lo nuevo y cambiante en un ambiente resguardado; lugares materializados en los pasajes y, en su versión más adocenada y dominada por la mercancía, los bazares. Las localizaciones de muchas novelas y relatos de los años veinte revelan recurrentemente ese arraigo en el siglo XIX, pero los tiempos ya no son los mismos. Como señala Nicolás, "Esos bulliciosos pasajes comerciales, que tanto sedujeron a Baudelaire y los modernistas, son vistos ahora como desangelados y sombríos" [Nicolás, 1999: 380-381] y operan a modo de barreras que lo alejan de la urbe cosmopolita. Sin embargo, su imaginería permanece fiel al mundo de entresiglos -más literario que real, porque en Ramón, la literatura era el primer engranaje. No se trata sólo de motivos arquitectónicos, el 
imaginario se nutre de fenómenos, que asombraron a los habitantes que vieron modificar el pulso de la ciudad al ritmo del crecimiento industrial y la aparición de la muchedumbre. Las novedades, convertidas en motivos librescos, literatura de género o sitios de la nostalgia, reaparecen en las novelas grandes: el anonimato de la ciudad junto al prófugo y al detective, las ocupaciones que se alimentan del detritus industrial, la mujer misteriosa e inaccesible, la prostituta, los paseantes ociosos, todos propensos a cultivar perversiones varias.

\begin{abstract}
Pasados los primeros meses de aclimatación, se atrevieron a más y alquilaron la casita en el pasaje de los Pasos Perdidos, entre aquellos chamarileros y aquellos tapiceros, cuyos muebles desnudos daban inapetencia al pasadizo.

Las habitaciones de su intimidad daban a aquel desfiladero secreto de la ciudad, por el que sólo cruzaban los que tienen un fuerte instinto de ocultación y que si pudiesen buscarían siempre calles subterráneas.

Los aburridos supremos del mundo mataban -asesinaban- su tiempo en el pasaje asomándose a los escaparates turbios de los anticuarios-prenderos, llenos de relojes descorazonados.

Toda la miseria y la tristeza de París pasaba por aquel pasaje, y hasta las niñas de piernas blancas y melenas sueltas y desmelenadas de mujer parecían ir a aprender la prostitución. [ChR: 139]
\end{abstract}

Similares paseos a los del El Chalet de las Rosas tienen lugar en La Nardo. El narrador se aparta de la Gran Vía madrileña y se introduce en el Rastro y en las zonas populares de Madrid para trazar la historia de una bella castiza seducida y echada a perder por un chulo que la hace prostituir con hombres de fortuna diversa. Al final, enamorada sinceramente de uno de ellos, deciden, la mujer y su amante, darse muerte por sobredosis, desesperanzados de encontrar otra salida ${ }^{35}$. El secreto del Acueducto es quizás la novela con menos rastros de modernidad: Segovia, ciudad provinciana y paupérrima proporciona el ambiente, entre recatado y místico, a una relación que superficialmente puede parecer una patética historia de amor entre un maduro hidalgo de pueblo y cronista oficial, Don Pablo, que casa con Rosario, su criada y sobrina. La relación se complica aún más cuando después de la boda se suma a la desigual pareja Don Antonio un

\footnotetext{
${ }^{35}$ Mainer [2000] compara el tratamiento, estilizado e intelectual, de la temática castiza en Ramón con la operación que Borges realiza con el arrabal y Toulouse-Lautrec con la variopinta humanidad de Montmartre. La observación es sugestiva y merecería ser desarrollada. En El torero Caracho Ramón también incursiona en un tema castizo y costumbrista, con un interesante distanciamiento de la fiesta de los toros.
} 
sacerdote y huésped del primero. El religioso desplaza al marido, quien sin embargo no se aleja del todo porque participa como un voyeur auditivo, escuchando los encuentros nocturnos de los amantes a través de la pared. La historia, un poco sórdida, poco aplaudida por la crítica o simplemente denostada, adquiere otro cariz si se aprecia cómo Ramón combina ingredientes decadentistas para acentuar la morbidez, aunque al mismo tiempo, como es habitual, ejerza de censor y moralista: la locura es el castigo de la "lujuria senil" -otra vez, cuán lejos lo sentimos del orgulloso Marqués.

Una lectura decadentista permite ver no sólo que se trata de un amor desigual, incestuoso -nunca se aclara si el parentesco de Rosario y Don Pablo es sanguíneo, lo que a mi entender corrobora la sospecha-, sino que la ciudad, sobre la que se acentúa el perfil monacal y recoleto, guarda en el convento de las Descalzas a Mónica, monja e hija del cronista. El silencio y encono de la joven hacia su progenitor y prima/madrastra oculta un secreto que aumenta la morbosidad cuando se describe con tropos conventuales el asedio del cronista a la criada que le recuerda a su hija, como bien ha señalado Carolyn Richmond en su edición de la novela. A su vez, Mónica, inmaculada y penitente, esconde una maldad que retrotrae a las femmes fatales, mezcla de mártir y victimaria del poder patriarcal.

"Si ella ha usado toda la crueldad que se puede usar en la vida -pensaba-, yo puedo usar toda la indiferencia"

No había querido entrar nunca ni en la iglesia del convento para no ver ese enrejado que defendía a la hija contra el castigo del padre que la habría cogido de los pelos y la habría arrastrado. [SA: 123]

Por último, el acueducto refuerza la gravitación del erotismo y de la preocupación fálica del maduro protagonista, cuya fascinación por el monumento romano corre pareja con la preocupación por su virilidad.

Despedía esa boda la fuerte sensualidad de las bodas del tutor con la pupila, y tenía algo del fuerte pimiento de los incestos.

-iPero Don Pablo!

-Soy tan fuerte como el Acueducto, y aún espero casarme alguna vez más.

[SA: 170] 
Ambas inquietudes, genital y arquitectónica, desembocan al final en la derrota sacrílega para más depravación- frente al rival con sotana, y en la demencia, que lo convierte en el loco del acueducto y del pueblo.

Lucía, La mujer de ámbar, se desarrolla nuevamente en un espacio altamente marcado por motivos tradicionales y de ascendencia libresca. Como $\mathrm{La}$ Quinta de Palmyra, esta novela grande es el resultado de una experiencia autobiográfica, originada en los años en que decide instalarse "definitivamente" en Nápoles. La mujer ambarina retoma tópicos de la mujer decadentista, que envuelta en un aura irresistible e inmaculada, provoca una atracción irresistible en el protagonista masculino. Pero la relación se ve amenazada por una vieja saga familiar, en la que unos tatarabuelos de la bella napolitana fueron condenados a muerte por un invasor español. Los ingredientes que arman la intriga se sirven, como en la novela portuguesa, de una percepción del otro desconocido muy arraigada en tópicos y prototipos convencionales, a la manera del cuadro costumbrista: familias emblemáticas con espíritu de clan donde no faltan un cura, un presidiario y un bizarro; odios transmitidos de generación en generación, hombres que velan por el cumplimiento del mandato familiar. La pervivencia del pasado impone un final cíclico, que renueva la sed de reparación: el suidicio de la mujer de ámbar el día de su boda debido a que no halla otra fórmula para huir de la historia funesta de sus antepasados y de un prometido que no está a la altura de las circunstancias ${ }^{36}$.

El espacio napolitano, imprescindible para la maduración del conflicto, vuelve a preferir la ciudad del pasado, las callejuelas y los ambientes cargados de referencias culturales, así como de vivencias personales que revelan la atracción por el lugar excéntrico e históricamente marcado. Al comienzo de la acción, cuando el extranjero Lorenzo reconoce la ciudad, abundan lo signos que remiten a la inmediata contemporaneidad y al ritmo moderno, con menciones al tránsito de

\footnotetext{
${ }^{36}$ Distintos críticos han analizado el posible feminismo de Gómez de la Serna a partir de la compleja naturaleza de sus personajes femeninos, cuya importancia se evidencia sólo con analizar los numerosos títulos que aluden a una mujer. La cuestión no es tema de esta tesis, sólo me interesa señalar que si bien observo cierta autonomía y voluntad en sus heroínas, estas no dejan de responder a los moldes del prototipo que llamaría prevanguardista, definidos por el sometimiento a las funciones y conductas de género patriarcales clásicas: dependencia del hombre, a menudo con el suicidio como única salida.
} 
tranvías y automóviles, al bullicio de la muchedumbre y a la elegancia y lujo de hoteles y restaurantes; pero ni bien el personaje comienza a arraigarse, el vagabundeo lo llevará al Nápoles oculto, atávico, atravesado por citas paganas y cristianas que dibuja un aura intransferible.

Un napolitano se puede reír del mundo advenedizo de otros lados. El peñón de atardecer que allí cae y la antracita respirable de la noche napolitana son únicos en Nápoles. (MA: 58)

Reaparece el decadentismo en otros motivos compendiados por Jean Pierrot: el cosmopolitismo no es en el fin de siglo un motivo de júbilo, pues va unido al escepticismo religioso y al relativismo, resultado del conocimiento de otras culturas, lo que produce una profunda sensación de desarraigo. Veremos que en Ramón la aparente fascinación por el viaje y las ciudades dejan un poso de pesimismo. Es la melancolía que produce el mito de la decadencia de occidente, junto a la convicción de estar viviendo un momento de desequilibrio continuo que en Gómez de la Serna se contrarresta con la satisfacción de pertenecer al escogido grupo de los creadores, pues en el mundo falto de poesía, el artista solitario está destinado a poseer un exceso de sensibilidad que hará más tolerable la cotidiana existencia.

\footnotetext{
En la Torre de Marfil no se prepara el mal de nadie ni se traiciona a los demás. Además de que son muy pocas las torres de esa clase, sus moradores piensan con amor en la humanidad y tratan de dilucidar sin error lo que se tergiversa en la calle.

$(\ldots)$

El de la Torre de Marfil vive, pero se asoma a las posadas, sin contagiarse por eso con las doctrinas que desvirtúan al hombre enrolándole en la gritería del bajo carnaval.

(...)

En la Torre de Marfil no se cree más que en los seres que han llegado a cierta superioridad, y no porque ellos se lo crean, sino porque es verdad en la competencia libre en que puede destacarse el hijo del obrero o del prócer. Única competencia del azar que se justifica. [MPL: 90-93]
}

\subsection{La inQUietANTE, Difícil MOdernidad}

Los itinerarios de Ramón no son únicamente espaciales, se ha visto que su atracción por el fin de siglo se revela también en un flâneurismo simbólico a través 
de los géneros narrativos, la estética y el imaginario propiamente decadentistas. Hasta qué punto hay renovación, parodia y ruptura, es un tema no muy fácil de dilucidar. Está claro que un estilo no se reproduce fuera de su contexto histórico y cultural sin consecuencias pues no puede ser ya la misma escritura ni es igual el utillaje mental del novecientos al del siglo anterior. El problema no ha pasado inadvertido para los críticos, a los que he de referirme más adelante para tratar de comprender la recuperación ramoniana del imaginario finisecular previo análisis de las restantes novelas.

En 1927 publica 6 falsas novelas. Bajo el título de cada uno de estos relatos, algunos de los cuales han sido catalogados de nouvelles, se añade entre paréntesis Falsa novela, seguida de un gentilicio: María Yarsilovna (Falsa novela rusa), Los dos marineros (Falsa novela china), La fúnebre (Falsa novela tártara), La virgen pintada de rojo (Falsa novela negra), La mujer vestida de hombre (Falsa novela alemana), El hijo del millonario (Falsa novela norteamericana). Es de interés precisar que las seis novelas habían sido publicadas con anterioridad de forma independiente en distintas colecciones ${ }^{37}$.

Tras los enunciados parentéticos aparece una intención paródica de un grupo de géneros que desde el siglo XIX se habían dado a conocer por su procedencia: la novela rusa, alemana, norteamericana o pacifista y, en los casos que no remiten a un origen concreto, se pueden adivinar las distintas variantes del exotismo y el orientalismo: así ocurre con las novelas china, negra o tártara. De ninguna manera, los géneros se igualan a través de similar determinación gentilicia; se trata de modalidades diversas y a veces, distantes: la novela rusa aparece en el siglo XIX y está ligada a las múltiples expresiones decadentistas. También el erotismo desgarrado y tormentoso de Dostoievski sobrevuela la narrativa europea finisecular.

${ }^{37}$ María Yarsilovna en Revista de Occidente, t. 1, 1923; Los dos marineros y La fúnebre, en La novela corta Madrid, $n^{\circ} 458$ (1924) y $n^{\circ} 484$ (1925); La virgen pintada de rojo y La mujer vestida de hombre, en La novela pasional, Madrid, nos. 31 (1925) y 70 (1926); El hijo del millonario en La novela mundial, Madrid, n 46 (1927). En 1907 había surgido la colección El Cuento Semanal, dando origen a un fenómeno inusitado de literatura de masas que se rápidamente se multiplicó en otras series tanto en España como en América Latina. V. Pierini, 2004. 
Puede confluir un segundo alcance, más difundido, de novela rusa referida a la narrativa de esa procedencia que se volvió especialmente influyente en Europa después de la revolución de 1917 e incluía tanto la novela soviética de orientación proletaria como la de los grandes narradores del siglo anterior. Novela rusa, alemana y norteamericana constituyeron un venero decisivo para las llamadas novelas con función social y las del "nuevo romanticismo" de la década del veinte.

A excepción de La falsa novela norteamericana, los seis relatos se desarrollan en torno a las relaciones entre los dos sexos. Todas las situaciones están determinadas por alguno de los tópicos del amor anómalo que atraía al decadentista, o por algún complemento que procura un atractivo especial al erotismo.

El riguroso y sutil análisis de loana Zlotescu informa del auge en Europa de influencias exóticas -arte negro, arte oriental- muy visible a comienzos del siglo $\mathrm{XX}$, tendencia en la cual incluye las 6 falsas novelas, todo un signo de la notable capacidad de asimilación ramoniana.

Más acá o más allá de una realidad o de un recuerdo, las Falsas novelas respiran con el autor el aire del tiempo y constituyen una valiosa aportación española a la literatura ecléctica y cosmopolita de los años veinte. [Zlotescu, $1989,20]$

Considera por otra parte la notable especialista polaca que este volumen de relatos presenta características muy peculiares que invitan a analizarlo separadamente de las novelas grandes. Desde mi perspectiva, la desconstrucción que el autor realiza de la tradición no anula, sus fuertes lazos con el mundo simbolista, por el contrario, fortalecen la idea enunciada en los capítulos iniciales de mi estudio, en el sentido de que vanguardia y simbolismo-decadentismo presentan intrincadas líneas de ruptura y también de continuidad.

Según mi lectura, las falsas novelas, pese a sus rasgos distintivos -a los que no son ajenas las condiciones editoriales en que vieron la luz- se enlazan significativamente con el imaginario que habita los cuentos y novelas del mismo 
período; descubrir la homogeneidad y las continuidades de ese mundo ampliará un poco más el conocimiento de los múltiples entresijos ramonianos.

La novela rusa está precedida de un breve prólogo del autor en el cual advierte que no se trata de una parodia, sino de un homenaje a las grandes obras del género, con "príncipes, condes, avaros y toda aquella anquilosada y extraña vida de antaño" [FNR:11]. María Marsilovna se vale del plus de la atracción erótica, trasuntada en fervor piadoso que deviene del trato sacrílego entre una mujer y un príncipe sacerdote. La pasión se consuma bajo la apariencia de un rito de purificación, tras el cual María reaparece con "una repugnante sonrisa deshelada, casamentera y deliciosa". [FNR: 26]

La Falsa novela china es la historia de una joven oriental que se debate entre el amor del hombre del mar y el hombre de río. La competencia entre los dos rivales se resuelve con un crimen y la muerte del más débil, en este caso, el marinero de agua salada. Ambientada en un clima exótico, la naturaleza es exuberante y paradisíaca. Las gentes viven en un estado de absoluta libertad, sin ataduras a convenciones morales, utopía que remite al lluminismo francés y a la construcción del mito edénico de Tahití, que al mismo tiempo fue el germen del argumento favorable a las perversiones sexuales que desde Sade en adelante fructificarán en la literatura y el arte, y, con especial éxito, en el decadentismo.

En verdad Diderot es uno de los mayores heraldos de aquel Système de la Nature, que llevando a sus consecuencias lógicas el materialismo, y proclamando el derecho supremo del individuo a la felicidad y al placer contra el despotismo de la moral y de la religión, prepara el camino de la justificación, en nombre de la naturaleza, de las perversiones sexuales. [Praz, 1999: 179]

La Falsa novela tártara se construye en torno al tópico de la mujer fatal poderosa y asesina, enriquecido con el exotismo de un pueblo bárbaro y riguroso. La protagonista es "La Fúnebre", llamada así porque ha logrado la muerte de siete maridos sin más evidencias que su propia viudez. El octavo cónyuge, que vive martirizado por la amenaza, resuelve el conflicto apuñalándola durante el sueño.

En la Falsa novela negra la atracción por el mito de la mujer de ébano de belleza virginal e irresistible, ambientado en un escenario natural privilegiado se 
combina con un igualmente exótico rito de la lucha por la hembra, en el que los hombres jóvenes se disputan la doncellez más deseada en una larga jornada de caza, en la cual la presa es la hermosa núbil, desnuda y ritualmente pintada de rojo. La cacería concluye cuando el más astuto y ágil somete a la virgen, que sucumbe al varón en una danza animal, entre erótica y guerrera.

La Falsa novela alemana deja los ambientes exóticos para situarse en la cultura contemporánea, pero a partir del motivo de la ambigüedad sexual que atrajo tanto a los decadentistas y que las vanguardias retomaron bajo el signo de la emancipación femenina.

\footnotetext{
Una parte del séptimo tratado del Amphithéâtre des sciences mortes de Pladan expone la teoría del andrógino bajo el título de Érotologie de Platon. Allí la mujer andrógina se define como Marta y María en una sola persona, como una manera de combinar las facultades activas con las contemplativas, perfecta fusión de inteligencia y de voluptuosidad. [Praz,1999: 601]
}

Marien, joven germana, comienza a experimentar las ventajas de travestirse y desafiar al otro sexo con armas semejantes sin perder las distintivas del propio género. El narrador se adentra en el mundo de la ambigüedad sexual pero sin traspasar el límite tolerado -Marien se limita a provocar desconcierto y embarazo en los hombres. Su paulatina masculinización no le resta el atractivo femenino, al contrario, le confiere doble encanto. Pero finalmente su nuevo estado le demuestra que no podrá hallar nunca ningún varón que acepte el desafío de permanecer a su lado y opta por aislarse en el mundo de la producción cinematográfica, que le ofrece un papel y un refugio permanente, alejada del mundo.

La última novela, como he anunciado, no guarda una estrecha relación con el conjunto; representa en cambio un eslabón provechoso para entrar en otro apartado de la narrativa de Gómez de la Serna. La Falsa novela norteamericana está protagonizada por el joven David Karvaler, quien, como el título adelanta, es hijo de un millonario norteamericano. La combinación de riqueza, ocio y tecnología a su entero arbitrio convierten al joven en un asesino que experimenta con el crimen, y la muerte por simple entretenimiento. Surgen elementos de crueldad 
gratuita que conectan con la tradición iniciada por el Marqués de Sade, fuente de voluptuosidad y placer: la serie de violencias que comete empieza con el atropello deliberado de transeúntes, sigue con la contemplación de una harakiri por encargo -la familia del voluntario se beneficiará con veinte mil dólares- en un fumadero de opio, previa coerción a una de sus amantes para que contemple el espectáculo. El próximo paso es la instrumentación de una antena que interfiere todas las emisoras radiotelefónicas hasta que la amenaza de la ley le obliga a destruirla. Continúa la serie de actos criminales con uno de carácter morboso: el cercenamiento y posterior conservación en cloroformo de las orejas de cincuenta y dos mujeres y guardarlas en cloroformo. Seguidamente siembra el pánico en lugares de reunión de negros y llega a provocar entre dos de ellos una riña seguida de un asesinato.

Por último, ya aburrido de sus crímenes individuales, planea un asesinato en masa, sirviéndose de los avances de la tecnología. La civilización industrial proporciona una posibilidad desmesurada que multiplica la ferocidad del mal: el hijo del millonario diseña su propia fábrica con un dispositivo que le permite destruirla con los dos mil obreros trabajabando en su interior hecho que concreta sin culpa alguna. Finalmente, tras ser descubierto, David Karveler es juzgado, condenado y ejecutado en la silla eléctrica.

En la serie de novelas cortas analizadas, merece un excurso especial $\mathrm{La}$ hiperestésica, pues aunque que no pertenece al volumen de "las seis" que guarda numerosos paralelismos con ellas y, como El hijo del millonario, puede funcionar de unión entre los dos grupos previamente formulados. Elvira, la protagonista de La hiperestésica, posee una sensibilidad agudizada que roza la hipocondría, la crueldad, la locura y el satanismo ${ }^{38}$. Su estado patológico se exacerba a causa de la civilización moderna.

Viajera de numerosos viajes, junto a sus padres; entregada siempre a la velocidad; enterada de las noticias de todos lados; suscrita a una enorme

\footnotetext{
${ }^{38}$ Las resonancias de des Esseintes, el héroe de $\dot{A}$ rebours, son sugestivas. Como es sabido la novela de Joris-Karl Huysmans, publicada en 1884, es considerada el decálogo de la literatura decadente y una metáfora del arte por el arte. En ella el héroe se aísla en una vivienda de los alrededores de París y lleva adelante un proyecto de ruptura con el mundo, rodeándose de objetos suntuarios que mediatizan su relación con la realidad.
} 
variedad de revistas; rodeada de diversiones, amigas y luces, era víctima del progreso, que aceleraba el ritmo de su alma débil y pusilánime.

Antes de dormirse en todos sus sueños se remetía la camisa entre las piernas para evitar la posible violación del diablo. [LH: 136]

Finalmente, muere a causa de una hemorragia después de su primer parto, pero antes da muerte a su hija recién nacida.

En el conjunto de las novelas grandes de Gómez de la Serna del período estudiado, se distingue un grupo que comparte con los dos últimos relatos analizados un común ambiente moderno y cosmopolita. lo, distintas de las que he señalado en primer lugar. Podrían ser denominadas narraciones de ambiente próspero y moderno. Como en El hijo del millonario el autor desarrolla un fresco cosmopolita donde capta, a partir de una acción vertiginosa y reiterativa, la parafernalia urbana del progreso. Pertenecen a esta clase El caballero del hongo gris, El gran hotel, Cinelandia, Policéfalo y señora, de alguna manera, también El dueño del átomo.

Leonardo, "el caballero del hongo gris", descubre que una buena presencia -la que le otorga un sombrero elegante- le da prestigio y le abre las puertas de los magnates, permitiéndole hacer pingües negocios fraudulentos con banqueros, empresarios y agentes de bolsa, a la vez que le facilita seducir a toda clase de mujeres. En su itinerario marcado por las estafas y la huida, mientras acrecienta su fortuna recorre grandes ciudades europeas - de Madrid pasa a Barcelona, Lisboa, Londres, nuevamente Lisboa, París, Marsella, Génova y Roma. El contacto con las fortunas más grandes de la época da pie al narrador para incursionar en el mundo rutilante del los felices veinte: viajes, aviones, banca, bolsa de valores, inversiones en turismo, jazz band, hoteles de lujo, teléfonos.

Cinelandia es un magno lienzo de la industria cinematográfica que deslumbró a la sociedad de comienzos de siglo, modificó costumbres y dejó su huella indeleble en el arte y la cultura. Una vertiginosa y fantástica representación de una ciudad remedo de Holly.wood, concebida desde y para el cine, da cuenta de la moderna fascinación del star system, factor de cambio de la vida y la mentalidad de las grandes ciudades ${ }^{39}$. Trazados con certeros rasgos, desfilan los

${ }^{39}$ Uno de los estudios más exhaustivos sobre la influencia del cine en los artistas de la vanguardia es el de Román Gubern. De Cinelandia dice que "propone una descripción pseudodocumental, 
nuevos estereotipos que darán sus señas particulares al séptimo arte: la diva, los malos, el niño perverso, los japoneses, los gordos, los borrachos, los facinerosos.

Entre el público de la ciudad cinéflua figuran unos hombres que no tienen tipo de malvados, ni son achinados, ni se muerden la comisura de la expresión.

Los tenebrosos son hombres con grandes facultades sombrías. Oscurecen la habitación en que entran. Sentados en un rincón de la taberna del cinedrama la dan un aspecto imponente y un alcance que sin ellos no tendría.

Quizás no hablan una palabra, no se corresponden con nadie, se distraen en fumar su pipa únicamente, pero crean el ambiente, lo sitúan como esas lámparas que son como grandes moscardones de luz, que salen danzando en la hora de los silletazos, dedicándose a columpiarse con la pamela de la tulipa torcida.[C: 71$]$

La percepción proverbial de Ramón, tantas veces elogiada, indaga en el arte del celuloide con anticipaciones certeras, oportunamente señaladas por distintos críticos:

Aborda ya el debatido problema de las adaptaciones y en el capítulo dedicado a las "Películas de ensayo", habla de filmes sorprendentes en los que, a veces, los únicos protagonistas son dos ojos que se mueven en la oscuridad.

Se analizan aquí diversas clases de películas. Al tratar de la modalidad "poética", se afirma sabiamente que toda película está regida por el verso, universo que no se proyecta ni se transcribe en la pantalla, pero que da el ritmo inimitable de la creación cinematográfica. Se estudian los resortes secretos del cine y se anuncia lo que será en el futuro. [Gutiérrez Carbajo, 1995: 27]

Es indudable que en las tres obras que se sumergen en su actualidad más cercana, Gómez de la Serna logra, mediante el tropo acumulativo e hiperbólico, una instantánea de su tiempo desbordado por las transformaciones provocadas por la innovaciones técnicas, los nuevos imaginarios sociales y la reformulación del proyecto burgués en un etapa de floreciente expansión económica. Podría entenderse que tanto el El hijo del millonario, como El caballero del hongo gris y Cinelandia constituyen una gran alegoría de la era de la tecnología moderna en sus consecuencias más funestas y en sus defectos más ostensibles: la frivolidad,

fantasiosa, irónica, fragmentada, descoyuntada y caleidoscópica de la capital norteamericana del cine y de sus ritos, costumbres y de algunos de sus arquetipos estelares, que en la novela viven unos lances amorosos". Considera que la novela, publicada 1923, "se adelantó a otros relatos, más o menos satíricos, que tomarían como referente el universo cinematográfico de Hollywood". [1999: 18 y 21$]$ 
el hastío, la omnipotencia del dinero, el triunfo de la apariencia. Se reitera en Ramón un límite difuso entre la crítica y el mero juego, pero aún aceptando un sentido último detractor de los valores impuestos por la civilización tecnológica, exhibe ciertos mecanismos que diferencian su cuestionamiento de llevado adelante por los escritores que se tratarán en próximos capítulos.

\section{Miedo al Siglo. Un VANGUARDismo finisecular}

En ninguna de estas novelas de tema cosmopolita los iconos vanguardistas representados trasuntan el júbilo utópico que anuncia un tiempo nuevo, como tampoco el escepticismo parte de un replanteamiento de los ideales o de la soledad ante el abismo del hombre moderno agobiado por el vacío, umbral imprescindible para futuras búsquedas. Gómez de la Serna sólo ha creído en las vanguardias como campo de reafirmación de la autonomía del arte, quizás nadie como él llevó a los límites más extremos la noción de arte por el arte y el ideal del artista soberano, única autoridad en su universo estético. La parábola discontinua y fragmentada de la modernidad permite que convivan en Ramón la inquietud por incorporar los hallazgos estéticos de las culturas faro de Europa y por explorar nuevos procedimientos formales realizando una incesante desconstrucción de los moldes heredados sin renegar de la concepción de la literatura y del escritor característica del arte finisecular. La tensión es alimentada, en este particularísimo caso, por una naturaleza egocéntrica -muchas veces se le atribuye un costado infantil- que le hacía subordinar la percepción de realidad a las reglas de su extravagante mundo. Egocentrismo ramoniano que Francisco Umbral ha sintetizado en esclarecedora imagen:

... escritor encerrado en su circunferencia, que jamás ha salido ni saldrá de ella. Ramón es él y su circunferencia, y por eso le saldrán siempre los géneros fingidos, porque no ha nacido jamás a la vida. Lo suyo es andar y andar la circunferencia, recorrerla y contárnosla. Ahí está su genialidad circular y, por lo tanto, limitada; y, por lo tanto, infinita. [Umbral, 1978: 84] 
Si es útil hallar un apelativo que sintetice la peculiar forma de asumir la vanguardia en Gómez de la Serna, antes que flanêur vanguardista acuñado por César Nicolás, prefiero invertir los conceptos y hablar de vanguardista finisecular, remarcando el componente nostálgico de su proyecto creador. Ramón sin duda se sintió atraído por la interpretación de la vanguardia que ponía el énfasis en la revolución formal, en el cuestionamiento al canon literario existente y en la informalidad desenfadada, actitudes en la que no estuvo solo, pues este impulso fue el motor de los primeros ismos, sostenidos por el inestimable mecenazgo material y simbólico de Ortega, como ya se ha visto.

Pero -también se ha insistido en ello- tras la aparente despreocupación y juego de los jóvenes artistas, existía una inquietud que rebasaba la esfera del arte y que con el tiempo fue reorientándose hacia otras metas. Ramón destacó por insistir en su devoción por la vanguardia entendida como "arte que no desea más que ser arte". Tan anacrónico fue su gesto después de los años treinta que llegó a pactar con el demonio, alentando la paradoja de que renunciando a su tan proclamada autonomía le permitiría salvaguardar su condición de artista no contaminado por el mundo profano. Es difícil comprender qué circunstancia pudo llevar a un autor que proclamaba el ascetismo del arte puro, a degradarlo ofrendándolo a la dictadura franquista en un doble gesto mediante el cual accedía a mutilar su obra y al mismo tiempo obsequiaba una crítica grata a la censura.

Dice de su Pombo en una carta a Giménez Caballero: "libro ortodoxo, cuidado en sus partes escabrosas, corregidas y suprimidas muchas figuras, conducido desde el prólogo hasta las últimas palabras hacia una moraleja de orden". [Trapiello, 1994: 361] Es igualmente inconcebible que rinda al nacional catolicismo su celosamente guardada independencia de artista.

Políticamente soy un bueno y (...) me someto gustoso a que me dirijan los mejores, los más patriotas, los que no quieren deshacer ni desintegrar mi mundo de alrededor. [carta de 1946 dirigida a Pérez Ferrero. Citada por Trapiello, 1994: 361 $]^{40}$

40 Pese a la falta de datos fidedignos - no aportados por Trapiello- la actitud y el tono se corresponden con la imagen proporcionada por Francisco Ayala y con la letra de documentos debidamente probados. Sobre ambas fuentes ya he hecho mención en páginas anteriores. 
En lo personal, parece adolecer de capacidad de reparar en todo aquello ajeno a sus motivaciones más cercanas. Sentía un miedo proverbial a las alteraciones y cambios, proyectado quizás en las opciones éticas de sus creaturas, siempre sujetas a veladas admoniciones y conducidas casi invariablemente al fracaso y la muerte. Diferentes críticos se han detenido en este rasgo entre inmaduro y conservador: Percival lo define como inestabilidad moral propio de una personalidad literaria narcisista; Morris advierte que Cinelandia, junto a una exacta descripción del mundo que rodea al séptimo arte convive una denuncia de Hollywood llena de prejuicios ${ }^{41}$. Mueren la hiperestésica y el torero Caracho, se suicidan la mujer de ámbar, la Nardo y su amante, es asesinada la tártara y condenado a muerte el asesino del chalet, enloquece el hidalgo segoviano... Pero si en el universo narrativo decadentista la muerte encuentra justificada su aparición, es disonante en sus novelas cosmopolitas. El ajusticiamiento del joven Karveler, la reclusión de la alemana que no puede encauzar en el "tiempo" su triunfadora personalidad andrógina recién adquirida, la destrucción final de la fabulosa Cinelandia, la muerte en duelo -el ritual antiguo es altamente significante- del caballero del hongo gris, funcionan como la cláusula que desmorona la ilusión modernizadora y justifican su permanencia en el aureolado apartamiento.

Recuerdan estos finales que retrotraen a una situación peor de la que surgen, aboliendo toda posible superación, la lectura que Mauricio Molho hace de El Buscón de Quevedo, escritor que la crítica ha emparentado reiteradas veces con Gómez de la Serna.

La hipótesis sobre don Pablos se afirma en que, a diferencia de sus antecedentes genéricos, el de Quevedo es un pícaro que no logra ascender socialmente. En una época en que el sistema estamental se resquebraja por la acometida de una capa ascendente, Quevedo rechaza la movilidad social condenando a su personaje a un lugar más bajo del que se encontraba antes de

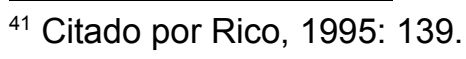


intentar elevarse por encima de su condición, recibiendo un merecido castigo por su osadía.

Los infortunios de Pablos de Segovia no son sino el sueño triunfalista de una sociedad estamental que, sintiéndose en crisis y, por la crisis, en peligro de desestructuración, se petrifica, vedando todo paso promocional de un estamento al otro. [Molho, 1977: 103].

El paralelo que establezco no pretende sostener que hay en Ramón un conservadurismo equivalente al de Quevedo, pero considero que su operación tiene algún parecido: al desprestigiar la nueva realidad social y cultural derivada de la modernidad tecnológica, en la cual no ve otros aspectos que el poderío de la técnica y la moneda, refuerza los argumentos para sostener que ante esa realidad el arte es la única arma y refugio. Emblema de la fatuidad de ese mundo es el señor Leonardo, quien sin siquiera tener apellido, sólo un sombrero gris, disputa poder y fortuna a otros acaudalados con indicios de ser tan tramposos y volátiles como él. La realidad emergente del novecientos que Ramón pinta en El caballero del hongo gris se parece a la que intranquilizaba a Quevedo, por la falta de orden y alternativas.

La Vida del Buscón llamado don Pablos se ha escrito para decir ese desierto, ese universo vacío de esperanza y rectitud, donde entre los caballeros arruinados y chirles y los judíos advenedizos, no hay lugar sino para los pícaros que en su tentativa ascensional no se tropiezan con más adversarios que otros pícaros que les precedieron en el camino del ennoblecimiento. [Molho, 1977: 114]

Como se ha dicho repetidamente del señor de la Torre de Juan Abad, Ramón también está atravesado por contradicciones, pregona detestar la mercantilización del arte, pero le seduce el gran mundo, los viajes, los halagos, el reconocimiento. Si la medianía burguesa y la supremacía del dinero lo fastidia, no le queda otra salida que el torremarfilismo. No es capaz de ver que en la moderna sociedad industrial se gestan cambios tumultuosos que afectarán también al campo del arte. A veces asoma en su textos un tenue reflejo, la contracara pasiva: los dos mil obreros que mueren incendiados en una fábrica. Seres fugaces e incomprensibles que se asoman entre artistas, viajeros, chulos, magnates, horteras, toreros y mujeres mórbidas. 
Cinelandia palpitaba de necesarias películas. El mundo demandaba cada vez más. Los proletariados tristes necesitaban llenar de sombra sus largos asuetos. [C: 178]

La cita no fue elegida al azar, aparece en ella el proletariado unido al entretenimiento y los largos asuetos. Ramón no vio la gran masa de hombres que por primera vez en la historia elevaban su voz, pero tuvo un fino sentido para percibir un nuevo público. Fue otra de sus paradojas y frustraciones, de su forma personal de entender los ismos. Nicolás ha advertido que en su flâneurismo por las canteras literarias disponibles, bebió en las fuentes de la literatura popular y experimentó, estilizándolos, con los viejos géneros. La cuestión excede el campo de mi estudio, pero si se han de señalar las desiguales singladuras vanguardistas, debe quedar abierto para ulteriores estudios esta última paradoja: el defensor de la autonomía realiza ensayos con la literatura de masas: muchos de sus relatos cortos se editaron en "La novela semanal" o en colecciones similares; esto es: dignificaba los géneros populares y a un tiempo intentaba sacar el arte de vanguardia de su selecto aislamiento, pero la operación no podía ser comprendida por los defensores del arte. La elite del arte nuevo disfrutaba con sus rarezas y se nutría de sus hallazgos, pero sus comentarios dejan la impresión de que prevaleció entre los escritores más preeminentes la idea que asociaba a Ramón a un "acordeón tocado por un ángel", o al "humorismo de obeso cachazudo", o "al botijo que pare inesperadamente porcelanas de Sèvres" NOtas. Ramón recorrió campos distintos de los que exploraron, siguiendo su ejemplo, la generación del 27, quizás por ello deja la impresión de no haber pertenecido del todo, de no haber sido admitido simbólicamente en el grupo selecto. Como maestro no tuvo el prestigio irreprochable de Juan Ramón Jiménez.

Tendrá que concluir el siglo XX para que su peculiar obra se beneficie de distintas circunstancias: la desmitificación y revisión del arte de vanguardia proporciona nuevas herramientas para estudiar una literatura que asombró, desconcertó, pero no fue comprendida en toda su magnitud.

Por otro lado, el tiempo transcurrido desde la guerra civil hace posible acercarse a las conflictivas relaciones que entabló con su tiempo histórico sin el apasionamiento que condenaba toda su obra al Index de los proscriptos. 
Por último, quizás resultado de vivir tiempos de herejías eclécticas y carentes de grandes epopeyas, su forma adánica de ver el mundo tiene un sitio señalado en la literatura española -y también allende fronteras- sin que carguen con culpa los amantes de un arte despreocupado de las grandes experiencias humanas y de la totalidad de lo social.

Se beneficia igualmente Ramón de que en un tiempo como el presente, en que el arte ha salido de la hornacina, es posible valorar en su justa dimensión lo que hizo por desembarazar la literatura de solemnidad y academicismo.

La aportación más considerable y duradera, aparte su labor de erudición y de crónica, es la actitud sincorbatismo ante el lenguaje que buena parte de la literatura posterior adoptará felizmente frente al engolado normativismo de respeto por "la legítima". Su lección y su labor de zapa, mina y desmenuzamiento de los monumentos ha permitido que en literatura los materiales fueran de nuevo aptos para su uso y no monolíticas piezas de museo. [Soldevila,19890: 31]

El riesgo del justo reconocimiento actual, en que se le brindan homenajes donde se reproduce su trapecio, pero con el circo trastocado en museo, es reproducir su juego escamoteador de la realidad, pero sin su inocencia. 


\section{FRANCISCO AYALA}

\section{ReVISTA de Occidente o el vanguardismo modernizador}

Con poco que se conozca la vida y el proyecto creador de Ramón Gómez de la Serna y de Francisco Ayala se comprende que ambos escritores no hayan congeniado en las distintas ocasiones en que la suerte los puso en contacto. Se ha citado en el capítulo anterior el juicio del granadino sobre el madrileño, al que podrían añadirse otros comentarios igualmente severos. En sus Memorias $^{1}$, por ejemplo, sin dejar de confesar admiración por la obra de Ramón, rememora: "en Buenos Aires, quizá en un par de ocasiones me lo he cruzado en la calle, pero ambos nos hicimos los distraídos evitando el saludarnos. Pocos deseos tenía yo de hablar con él en esa época". [RO1: 87] La vanguardia no los acercó antes ni después de la guerra civil, su concepción del arte y de la literatura fue muy distinta; la circunstancias vitales también. El episodio recogido trasciende el dato meramente anecdótico o biográfico, para engarzarse con cuestiones centrales de esta investigación.

Los estudios críticos más recientes sobre la obra de Francisco Ayala se inician normalmente con el análisis del conjunto de relatos vanguardistas, escritos entre 1929 y 1930. De la producción anterior se mencionan, sólo en calidad de experiencia inicial, las dos novelas de juventud, Tragicomedia de un hombre sin espíritu (1925) e Historia de un amanecer (1926). Este trabajo no romperá con la costumbre de empezar por las vanguardias, si bien en posterior momento se ocupará de los primeros textos, por considerar que inauguran un rumbo que, con matices, no se interrumpirá.

Ha sido sobradamente superado el tiempo en que la producción vanguardista de Ayala, como la de los prosistas "del 27" en general, se relegaba al olvido o era resumida en breves líneas ${ }^{2}$. En capítulos anteriores he comentado el eclipse que

${ }^{1}$ Las memorias de Ayala se publicaron en tres partes bajo los títulos Recuerdos y olvidos 1. Del paraíso al destierro. (1982); Recuerdos y olvidos 2. El exilio /1983); Recuerdos y olvidos 1. Del paraíso al destierro. 2. Recuerdos y olvidos. El exilio 3. Recuerdos y olvidos. El retorno.(1988).

${ }^{2}$ Vale la pena comparar en este sentido la bibliografía reciente con el libro pionero de Keith Ellis [1964] que se ocupa de la prosa de vanguardia en un capítulo, "II: Obra novelesca de 1925 a 1930" 
desde la década del treinta hasta los años setenta sufrió el arte nuevo y, de forma especial, la novela y géneros cercanos. Del mismo modo, se indicó que los propios autores fueron partícipes del descrédito de su creación de vanguardia, en la medida que no pudieron sustraerse a la corriente crítica adversa cuando los modelos estéticos cambiaron de signo y la realidad histórica y cultural llevó por otros derroteros. No volveré sobre la cuestión, salvo para recordar el dictamen del mismo Ayala -citado con suma frecuencia- sobre su prosa de vanguardia, veinte años después de haberla publicado. Se trata de las palabras iniciales del proemio a La cabeza del cordero, volumen de relatos editado en Buenos Aires en 1949:

A los veinte años, uno escribe porque le divierte, y ¿para qué más justificación? A los cuarenta, ya es otra cosa: hay que pensarlo... [CC: 177]

Pocas líneas más adelante refuerza la idea de irresponsabilidad y juego que atribuía a aquella estética.

\begin{abstract}
¿Quién no recuerda la tónica de aquellos años, aquel impávido afirmar y negar, hacer tabla rasa de todo, con el propósito de construir -en dos patadas, digamos- un mundo nuevo, dinámico y brillante Se había roto con el pasado, en la literatura como en todo lo demás; los jóvenes teníamos la palabra: se nos sugería que la juventud, en sí y por sí, era ya un mérito, una gloria; se nos invitaba a la insolencia, al disparate gratuito; se tomaban en serio nuestras bromas, se nos quería imitar... El balbuceo, la imagen fresca, o bien el jugueteo irresponsable, los ejercicios de agilidad, la eutrapelia, la ocurrencia libre, eran así los valores literarios de más alta cotización. [CC:
\end{abstract} 178]

En otro lugar he aludido a la modificación de los juicios más severos sobre la la vanguardia, resultado de la visión mejor dispuesta de finales del siglo XX. Ayala también mitiga su mirada en su memorias, publicadas en 1982.

\begin{abstract}
Sentía que la vanguardia, a cuyos movimientos extranjeros y no sólo españoles me asomé con ávida curiosidad, era la actitud idónea para dar expresión literaria a la época en que estábamos viviendo. Me apliqué desde luego a probar mi mano en las estilizaciones vanguardistas y ensayando sus técnicas produje una serie de ficciones breves que (...) marcan un período bien definido de mi evolución literaria. Si, como más de un crítico ha señalado, bajo lo que en tales escritos hay de voluntaria adscripción a una
\end{abstract}

que comparte el breve espacio con las dos novelas de iniciación, Tragicomedia de un hombre sin espíritu e Historia de un amanecer . 
corriente de los tiempos -o bajo una ropaje de moda- se descubre el estilo personal profundo -o el cuerpo vivo- de quien los escribió, alguna perduración podrá acaso prestarles esa virtud. [RO1:92]

Vale la pena reiterar la advertencia, sobre todo si se trata de la vanguardia, acerca de las opiniones cambiantes, resultado de los vaivenes del canon y de las distintas autoridades que lo sancionan. En el caso de Francisco Ayala la recomendación es doblemente necesaria, pues se trata de un escritor que ha desarrollado una labor crítica constante sobre sus propios textos y, en no pocas ocasiones que trataré más adelante, ha terminado convirtiéndose en el primer punto de referencia y a menudo inmutable, aun cuando tanto se ha teorizado sobre los problemas de la figura y la voz del autor ${ }^{3}$.

De los tres autores estudiados, Ayala es el que presenta un paso por el vanguardismo más acorde con el paradigma asociado al magisterio de Ortega y Gasset y Revista de Occidente. Es también quien cultiva con mayor aplicación los rasgos definidores de la prosa "moderna" tal como su autor lo había expuesto en $\mathrm{La}$ deshumanización del arte y en Ideas sobre la novela. Gracias a la mediación de Melchor Fernández Almagro ${ }^{4}$, Ayala integró tempranamente el grupo de Ortega, del que formaban parte, entre otros, Rosa Chacel, Benjamín Jarnés, Antonio Espina, Juan Chabás, Ernestina de Champourcin. Acerca del impulso que Revista de Occidente concedió a las letras españolas y de su papel vertebrador de las innovaciones estéticas, tanto en la narrativa como en la lírica existe abundante bibliografía citada en distintos capítulos de este trabajo. Merece agregarse el primer volumen de las memorias de Ayala mencionado líneas arriba, y la conversación de Luis García Montero con el mismo escritor de Granada más José (Pepín) Bello,

\footnotetext{
${ }^{3}$ Otra matización sobre sus propios juicios se puede hallar en un trabajo de 1977 -nuevamente la fecha coincide con la rehabilitación de la literatura experimental-: "cuando escribí el proemio al libro La cabeza del cordero, quise marcar la novedad de la posición literaria adoptada en él, tirando un poco contra las obras de vanguardia. Pero la gente tomó mis frases demasiado literalmente, exageró su intención, se me creyó demasiado al pie de la letra lo que decía. Yo no pienso que esa etapa mía fuera un jugueteo frívolo, sino que tenía una sentido muy real, y ese sentido real sigue estando ahí presente, por debajo, y puede manifestarse y se manifiesta de alguna manera en la obra ulterior". ["Intervención de Francisco Ayala", en VV.AA., 1977. Novela española actual, Madrid: Cátedra. (Citado por Barroso Villar, 1998:94)]

4 Más información sobre estos aspectos en Esteban, José. "La narrativa de la generación del 27" en Cuadernos Hispanoamericanos, 514-515, 1993, pp. 81-92.
} 
Rosa Chacel y Rafael Alberti ${ }^{5}$, de gran interés por el componente autobiográfico y porque los propios protagonistas contemplan el pasado desde el horizonte de finales del siglo XX.

\subsection{Cazador en el alba y otros relatos de vanguardia}

La prosa narrativa de Ayala se concentra en el breve lapso de dos años, 1929 y 1930, en que publica El boxeador y un ángel, en Madrid, editorial Cuadernos Literarios, y Cazador en el alba, también en Madrid, editorial Ulises. El primero reúne seis relatos muy breves, el que da título al volumen más "Hora muerta", "Polar estrella", "Susana saliendo del baño", "El gallo de la pasión'" y "Medusa artificial". El segundo consta de dos relatos largos, considerados novelas, Cazador en el alba y Erika ante el invierno ${ }^{7}$. Estas dos últimas obras son las que más han atraído la atención de la crítica.

El análisis ya mencionado de José del Pino ${ }^{8}$ constituye una entrada pertinente a la narrativa vanguardista de Ayala por sus puntos de contacto con la perspectiva del presente trabajo. Confluyen muy claramente en la novela dos aspectos considerados identificadores de la prosa vanguardista: las novedades formales y la tematización de la relación del hombre con la urbe moderna, erigiéndose "como la obra vanguardista donde el principio de la deshumanización por medio de la transformación metafórica alcanza sus máximas cotas". [del Pino, 1995: 155]

Diferentes lecturas coinciden en que Madrid, espacio no mencionado pero reconocible de la acción de Cazador en el alba, simboliza las expectativas que la ciudad moderna generó en el hombre de principios de siglo, mientras que Berlín, lugar de los acontecimientos de Erika ante el invierno, representa el vacío y la

${ }^{5}$ García Montero, 1993:11-24.

${ }^{6}$ Este relato fue escrito a pedido de Federico García Lorca para la revista Gallo. Revista de Granada. Nominalmente dirigida por Francisco García Lorca, salieron dos números en 1928. "Hora muerta" apareció en Revista de Occidente. XVI, abril 1927, y "Medusa artificial" en la misma publicación, número XIX, diciembre de 1928.

7 Cazador en el alba fue publicado en Revista de Occidente en 1929, seguido de Erika ante el invierno, en 1930. A finales de 1930, como se ha dejado dicho, aparecieron de manera independiente en un único volumen.

${ }^{8}$ Pino, José de, 1995. "Entrada y salida de Metrópolis: la ciudad metafórica en Cazador en el alba": 155-177. 
soledad a que son condenados los seres anónimos en la metrópolis. Más adelante matizaré esta aseveración, pero en principio es válida para abordar el primer texto. La fascinación por la ciudad, los estímulos que acomenten al habitante de las grandes ciudades, se condensan en una sobreabundancia de imágenes embebidas de novedades tecnológicas que internan al lector en una atmósfera de extrañamiento y hermetismo.

Un cielo de lana de los Pirineos amortiguaba las miradas, enguataba las voces. (Un cielo blando, como el fondo de ese cajón del que ya han desembalado los regalos de fin de año).

... inhumana especie recién salida de los huevos eléctricos que las grandes avenidas incuban. [CA:69]

Solicitaba apertura de un paraíso incógnito, lleno de manzanas luminosas y de mujeres artificiales, que hacían señas desde lejos a su alma rústica, de Hércules, donde pastaban las lentas ovejas de su pensamiento. [CA: 70]

Grandes rebaños de maletas se orientaban hacia prados recién florecidos de ventiladores. [CA: 89].

Del Pino ha observado la rigurosa funcionalidad del juego metafórico de Cazador en el alba: la cadena semántica relativa al ámbito rural se combina con otra propia del ámbito urbano, de manera que el posible enfrentamiento campo y ciudad se disuelve en una síntesis no conflictiva. No existe por lo tanto una oposición irreconciliable entre los dos espacios, por el contrario, ambos se integran mediante enunciados que revelan la percepción de la ciudad por un campesino recién llegado. El protagonista, el soldado Antonio Arenas, conservará mientras le sea necesario el marco de referencias rurales y se servirá de él para traducir las sensaciones y la aprehensión de lo nuevo y desconocido, hasta conformar, no un mundo extraño sino una segunda naturaleza, tan válida como la primera que ha abandonado: Numerosas imágenes diseminadas a lo largo del texto permiten ilustrar el procedimiento: "las raicillas más delgadas del mundo industrial", "el rastro precario del automóvil en el polvo: todos estos signos huyen por el campo como liebres", "junto a él se apacientan los oscuros rebaños de vagonetas". [CA 67-69]. La síntesis de los dos mundos transmite, con algunas reservas, la confianza de la primera 
vanguardia en que la ciencia y la tecnología habrían de contribuir a mejorar las condiciones de vida de la humanidad.

Por otra parte, la profusión metafórica no sólo destruye todo intento de representación mimética e ilusión referencial sino que contribuye a renovar las formas narrativas mediante el desvanecimiento del personaje clásico y el debilitamiento de la trama y el argumento.

Al respecto, Rosa Navarro Durán ha señalado la naturaleza propiamente esteticista del recurso, así como las resonancias gongorinas, vigentes aún a dos años de la célebre conmemoración del tricentenario de la muerte del poeta barroco.

Los escritores vanguardistas utilizan su mismo instrumento, la imagen, pero la crean a cada instante. La semejanza puede ser insospechada, depende del ingenio del escritor y de la capacidad del lector de advertir el nexo entre la realidad y el lenguaje. [Durán, 1988: 24]

Nuevamente nos encontramos ante un fenómeno vanguardista no fácilmente disociable del preciosismo de arte por el arte, tal como se ha subrayado insistentemente en los capítulos precedentes.

El nuevo tipo de receptor activo, derivado de la dificultad propia de la obra inorgánica se pone de manifiesto en la competencia que la metáfora de Ayala exige para ser descifrar. La metáfora eutrapélica o preciosista se convierte en un recurso que distancia al lector de todo compromiso sentimental o identificación psicologista, de la misma manera que el campesino, obligado migrante a la urbe en cumplimiento del servicio militar, contempla impasible la nueva realidad a la que se enfrenta. Vedadas las introspecciones de la novela psicológica, el protagonista es dado a conocer a través de conductas e indicios externos. Las primeras impresiones urbanas experiencias se narran mediante tropos que remiten a un mundo moderno y mecanizado; se podría establecer un paralelo entre el personaje y el lector, ambos tienen que pasar de un medio conocido -el campo, la novela clásica- a un territorio urbano y a un discurso narrativos desconocidos.

Una tiza luminosa dibujaba en el encerado de la noche sus figurasesquema, tan pronto conclusas como borradas: la estilográfica enorme o el 
pez aeronauta. Trazos azules, rojos, aparecían y desaparecían con un parpadeo capaz de fingir la pulsación normal de las paredes... [CA: 69]

La acción, débil, fragmentada y velada por el discurso metafórico, da cuenta de la aclimatación de un joven que llega de un lugar indeterminado del campo a un ciudad identificable con la capital española ${ }^{9}$. En contraste con los personajes realistas, de los que se conoce el árbol genealógico y múltiples enclaves espaciotemporales, el personaje principal no tiene pasado, ni un origen o genealogía; es apenas un nombre cuyo un apellido, Arenas, se asocia a al disolución, la inconsistencia y la fugacidad. El anonimato se acentúa cuando, tras ingresar al ejército, la filiación es reemplazada por un número pronto será cambiado por un número. La fragilidad se pone de relieve cuando voces no identificadas en el relato revelan los rasgos físicos del recién ingresado recluta -secuencia no exenta del humor propio de la vanguardia. A las señas de hombre corriente suma una complexión menuda y endeble, dibujándose así un héroe opuesto a las redondas criaturas galdosianas y a los nietzschianos protagonistas de Baroja -Zalacaín, Avinareta, aventureros y conspiradores refrendados por rotundos y sonoros significantes.

\footnotetext{
Y desde entonces tuvo la noción clara, numérica, de su recién adquirida personalidad.

Soldado Antonio Arenas, primer regimiento de Cazadores, primera compañía. Perímetro, 96; peso, 62; talla, 1,55. [CA: 67].
}

\footnotetext{
${ }^{9}$ El hermetismo del relato lleva a los críticos a realizar distintas interpretaciones argumentales. Para Carolyn Richmond [1998a] y para Elena Barroso Villar [1998] todo el relato es producto del delirio del soldado mientras se recupera en la enfermería del cuartel después de sufrir la agresión de un caballo. José del Pino es de otra opinión: el relato comenzaría "con la recuperación del soldado tras su accidente. En medio de la duermevela febril había evocado el viaje en tren que lo conducía a la ciudad, así como las primeras impresiones que ello causaba en él. Ayala abandona este recurso inicial de flash-back, para continuar con las siguientes etapas de la vida del protagonista, sin mencionar ya para nada el estado de convalecencia. Esto sugiere que el autor, una vez establecido un marco distanciador que favorece y justifica su subversión formal, quiere dirigir la atención al desarrollo de las aventuras urbanas" [del Pino, 1995: 158]. Ambas lecturas son posibles, no existe un clave textual que permita establecer la referencia temporal del último párrafo, "Entonces despertó Antonio" [CA: 94]. Hora y situación coinciden con dos posibles circunstancias: el amanecer en su cama de la enfermería o en la sidrería donde se quedó dormido después de beber. Es claro que la ambigüedad refuerza la fragmentación y la inorganicidad típicas de la obra de vanguardia.
} 
Del Pino otorga una función central y vertebradora al proceso de integración del soldado en la capital. La ciudad como palimpsesto, como suma y acumulación de la memoria y del pasado cultural, se va revelando en el relato al mismo tiempo que la descubre Arenas en su deambular por Madrid, pasando sucesivamente por la edad olímpica, definida por fuentes y estatuas mitológicas; por la de bronce, poblada de imágenes ecuestres, y arribando por último a la nueva, dominada por los objetos de la sociedad industrial donde campea el popular reclamo publicitario del nemático Michelin.

No menos importante, pero demócrata, la siguiente generación -planiforme, impresa en bi o tricolor- proliferaba por las vallas y las esquinas. Sus más caracterizados representantes: la estival patrona de la Foto y el dios de las Autopistas, gordo, neumático padre de familia, venerado en todos los garajes. [CA: 69]

El presente, mediante su arraigo en el pasado, adquiere en la ciudad -lugar moderno por excelencia- el prestigio de lo histórico. La ciudad aún es el lugar antropológico de la cultura donde pasado y presente se integran y alimentan; es el lugar del anonimato pero sin perder todavía el abrigo del pasado y la tradición. Antonio Arenas no se sume en la angustia porque puede encontrar coordenadas espacio-temporales que le devuelven a lo conocido y familiar.

El salón de baile era un prado. Un hermoso y lírico prado, donde la pianola -vaca próvida en armonías- rumiaba, paciente, un rollo de verdes y jugosas notas. ¡Infelice vaca de idilio, rodeada de tábanos vibrantes"!. [CA: 72]

Es momento de retomar ideas anticipadas en páginas anteriores: contrasta esta ciudad y la elección del personaje, que se sumerge sin dudarlo en la metrópolis actual, con las huidas hacia la periferia y el pasado de las creaturas ramonianas, siempre espectadoras de la agitación urbana, pero rara vez asimiladas a ella. Cuando se licencia del servicio militar, Antonio Arenas no duda cuál será su habitat , "... iba solo. Borracho de aire. Para él, las calles estaban renovadas, tenían una dimensión ociosa y festiva" [CA: 89]. La ciudad encierra su cuota de amenaza y agresión pero no llega a volverse ajena, alienante, porque la va conociendo sin romper vínculos con su mundo anterior; la vive como una segunda naturaleza. 
Experimenta el momento utópico en que aún no se ha producido el desencuentro entre naturaleza y cultura iniciado con el mismo proceso modernizador ni la posmoderna fractura entre lugares y no lugares. La simbiosis aún armómica se traduce en Cazador en el alba en cadenas metafóricas que remiten al orden natural, necesaria contrapartida:

(Existen, sin duda, una fauna y una flora musicales, y no es difícil comprobar en ellas la enorme diversidad de la naturaleza, inagotable en recursos: especies alpestres, lacustres y submarinas, llaman la atención junto a otras más vulgares. Sus catálogos ofrecen: desde ese gigantesco insecto de níquel -familia saxófono- que chupa la sangre con desesperante lloriqueo a un pobre negro convulso, hasta las guitarras -en general, bastante lascivas- cuyas variedades trasatlánticas tienen la voz velada de las alcobas. Desde las altas corolas, cuyos pistilos filarmónicos fecunda el viento, hasta los volubles juncos de los violines...). [CA: 72]

No es de extrañar entonces que la concurrencia sin conflicto de los dos espacios favorezca una integración paulatina y serena del soldado a la urbe, hasta renacer "en el centro del trajín urbano" ${ }^{10}$.

El proceso de urbanización del protagonista se confirmará al lector fundamentalmente a través de dos vías, la acción, tenue y elemental, y la transformación operada en el personaje, que cambia su estatuto de campesino por el de habitante de la civitas.

La acción se desenvuelve a partir de un motivo propio de la narrativa de vanguardia: la búsqueda y encuentro con la mujer y la experiencia erótica, que luego dará lugar a la búsqueda e inserción en un peculiar "mercado laboral". Me limitaré a mencionar los pasos principales del itinerario amoroso del soldado ${ }^{11}$.

10

Citado por del Pino [1995: 160] Es preciso añadir que queda pendiente el análisis de la función del narrador como intérprete-traductor de la mirada y las experiencias del personaje, un rústico y simple campesino, al lenguaje culto y altamente sofisticado del relato, en el cual, además del discurso narrativo en tercera persona, se introducen con frecuencia largos párrafos parentéticos que revelan otra voz y otra mirada, quizás un desdoblamiento del narrador en un más activo, reflexivo y aún culto observador. Esta clase de intervenciones queda claramente ilustrada con la cita que precede esta nota, y con variantes, en el párrafo siguiente: "Antonio vio entonces lo nunca visto: lo divino. (Su centro de gravedad emigró, como un globo al que cortan las amarras.) La vio a ella. Es decir, vio a una. A una que era ella". [CA: 73]

${ }^{11}$ Las vivencias eróticas de Arenas abren las puertas al estudio de la relación mujer-ciudad y su elaboración simbólica en los textos vanguardistas, así como a la visión desde la perspectiva de las heroínas del cine. [Gubern, 1999] 
Arenas construye sus vivencias con el sexo opuesto mediante encuentros con distintas mujeres, quienes desde el comienzo aparecen marcadas por el artificio. La mujer-maniquí de los escaparates y la mujer-prostituta del burdel se resolverán finalmente en la mujer urbana que reúne, igual que la ciudad, lo natural y lo civilizado, lo nuevo y lo perenne -"castiza"- en una síntesis perfecta, cuyo nombre, Aurora, simboliza la nueva realidad a la que está naciendo el soldado Arenas.

\begin{abstract}
Ella había quedado en medio de la sala, luciendo sin pudor sus dientes desnudos. Sola entre tanta gente. Las demás muchachas, ágiles y exactas como compases -telefonistas, mecanógrafas-, no sabían acercarse a ella, que tenía algo de presidenta de una corrida de toros. Era la mujer ibérica (y bastante romana), barroca, vegetal rizada y curva. Una castiza.

(...) A su lado las otras muchachas, de tipo elástico y sucinto, eran Gracias menores. Aurora inspiraba un culto especial, impresionante, como si todos la identificasen con la deidad que siempre habían visto representar a la Patria en las alegorías, entre emblemas de las artes y las ciencias. [CA: 74]
\end{abstract}

Como en el retrato del protagonista, se superpone en esta descripción un sutil discurso humorístico: la mujer-diosa no sólo contrasta con el perfil esmirriado de Antonio Arenas, sino que es lo opuesto a la fémina exaltada por la vanguardia: acicalada, deportista, dinámica, activa; trabajadora o profesional; burguesa y mundana. De Aurora sabrá poco el lector: los antecedentes apenas esbozados están regidos por el ocio y la inactividad; de cualquier modo, representa un síntesis, una transición de la mujer rural a la moderna.

El cambio de campesino a ciudadano se deja advertir además por alteraciones de signos externos que operan como indicios. De singular trascendencia es el paso de soldado a hombre de ciudad a partir de un simbólico cambio de indumentaria que acompañará la adecuación progresiva de sus modales a los de la urbe. Con la nueva vestimenta adquiere también el gusto por el ocio, por el deambular gratuito, sin que participe de la angustia del habitante de la ciudad industrial -berlinés o británico- descripto por Benjamin, ni del afán de huida o búsqueda de refugios -pasajes- del flâneur parisino. Arenas es un recién llegado, un rústico sin melancolía ni spleen, que se complace en abandonar la dimensión rural de donde proviene - probable proyección del deseo de formar parte de la Europa civilizada y moderna expresado por Ortega. No se debe olvidar, por otra parte, que 
Arenas acaba de dejar la milicia, tiene por lo tanto un ansia añadida de libertad y autonomía.

\footnotetext{
Entró, por un movimiento en gran parte instintivo. Sentía la necesidad confusamente- de completar su transformación. Se alejó entre los parapetos de los mostradores, y cuando, un rato más tarde, volvió a trasponer la puerta, los maniquíes-centinelas no le reconocieron: era otro.

(...) El era el desocupado que se para ante los rascacielos, viendo cómo chorrea el sol por sus aristas hasta regar las anchas avenidas; que se detiene a contemplar la agitación de talleres y estaciones.[CA: 90-91]
}

Por el momento, el recién llegado no toma conciencia de la marginalidad que deviene de su estatuto social, no se integra a la urbe como uno de su clase -no pasa de labriego a obrero industrial. Pese a que la vanguardia problematizó en ocasiones los fenómenos sociales anejos al desarrollo económico de la burguesía, en este caso no se plantea un conflicto. El antiguo soldado se iniciará en la carrera deportiva a través de la única entrada disponible para un hombre del pueblo, el boxeo. El camino del cuadrilátero es signo más del imaginario moderno en tanto reemplaza al toreo como forma de ascenso social rápido y exitoso, otra forma simbólica de tomar distancia de la España castiza e inmemorial que agobiaba al grupo de Revista de Occidente ${ }^{12}$.

\subsection{Discursividades VANGUARDistas}

Como se ha de reiterar en distintos momentos de este libro, para los vanguardistas españoles más influyentes la modernidad estuvo ligada, no sólo a la sincronización de los programas estéticos peninsulares con los del resto de Europa, sino también al propósito de modernización de las estructuras culturales,

12 "La Fiesta Nacional" ha sido siempre en España un duro escollo para las corrientes modernizadoras. Circula un dicho -que no he podido documentar-atribuido a un miembro de la generación de Ortega: "Si yo fuera Ministro de Cultura prohibiría la fiesta, pero como no lo soy, esta tarde iré a los toros". 
sociales, políticas y económicas, que para Ortega se lograría si se superaba el atraso cultural en términos estrictamente culturales

... el mal de España es la falta de la cultura sustantiva, científica, que determina la edad moderna de Europa. Todos los males -la incompetencia, la insolvencia, la falta de tradición liberal y democrática, la invertebración social del país...- se reducían para Ortega al radical de la cultura. España no había tenido llustración. [Cerezo Galán, 1994: 21-22]

A la hora de relacionar la meta europea con la estética de vanguardia es productiva la descripción que traza Jorge Schwartz, partiendo del criterio establecido por Beatriz Sarlo, de las revistas de tendencia modernizadora, en cuyo módulo se inscribe sin duda Revista de Occidente.

[Frente a las revistas de vanguardia] las revistas de tendencia modernizante también se empeñan en la renovación del panorama local artístico, aunque no se propongan transgredir las normas del establishment literario del lugar. Nada que pueda épater le bourgeois. Lo moderno en dosis moderadas, de buen comportamiento, lejos de la risa y del escándalo. Desprovistas del carácter agresivo de las publicaciones de vanguardia, esto les garantiza una mayor estabilidad y continuidad. [Schwartz,1991: 37]

Indudablemente, el proyecto vanguardista del grupo liderado por Ortega tuvo, junto al gran interés por la renovación formal de la lengua literaria, un definido ánimo civilizador, acorde con la función que el filósofo atribuía al intelectual, hombre dotado de cualidades superiores y, por lo tanto, destinado a cumplir una función "regeneradora". Ayala será uno de los discípulos que mejor integre la misión artístico-literaria con la modernizadora tanto en su obra como en su trayectoria intelectual.

Desde esta perspectiva, la representación urbana de Cazador en el alba, en un país con enormes atrasos estructurales, otorga un voto de confianza a las ventajas de la vida ciudadana y a los modos de existencia derivados de los avances científicos y tecnológicos de comienzos de siglo.

Pero no sólo importa el contenido más explícito para verificar el alcance de la utopía del arte moderno y la puesta en práctica del programa del arte nuevo en la obra de Francisco Ayala. Es posible descubrir otros elementos que revelan la 
manera de entender el proyecto vanguardista en el marco de Revista de Occidente.

Se afirma reiteradamente que los ocho relatos publicados entre 1929 y 1930 representan el ejemplo más coherente y el grado de máxima elaboración de la narrativa de vanguardia ${ }^{13}$. Cito sólo el parecer de Carolyn Richmond, al que podrían sumarse otros de similar temperamento:

\begin{abstract}
Seguro de su pluma, Ayala se embarca en una aventura estética única cuyo resultado -ocho piezas escritas en una prosa de una originalidad y asombrosa calidad lírica-constituye, a juicio mío, la más valiosa joya de la prosa española de la época vanguardista. [Richmond, 1998a: 20]
\end{abstract}

Es siempre enojoso establecer un orden de méritos cuando se trata de producciones artísticas. Hoy es objeto de debate la idea de que mayor elaboración formal implica mayor logro estético; es en cambio demostrable que Ayala concentra en sus relatos una gama muy amplia de procedimientos de la vanguardia, lo que pondría de manifiesto una asimilación privilegiada de las principales direcciones de los ismos, sin que esto deba traducirse en la adscripción a ninguno de ellos. Delinearé un repertorio de las huellas vanguardistas en la prosa ayaliana

a. El surrealismo. Cazador en el alba fue publicado en 1930. En 1925 el surrealismo había sido introducido en España con inmediata aceptación y resonancia. El relato de Ayala está cruzado por motivos que delatan la presencia de lo surreal que impregnó la atmósfera cultural europea a mediados de la década del veinte, sin que el interés por los hallazgos de Breton y sus discípulos signifique una adscripción a su escuela. En principio, las condiciones físicas del soldado, herido por un caballo cuando estaba pronto a dejar el servicio militar, derivan en un estado delirante muy apto para dar entrada al mundo del inconsciente y de las visiones oníricas.

Con la cabeza despavorida, inflamada, pueden atarse los vientos tránsfugas, las imágenes rotas, las ideas sueltas. Y su cabeza pendía de una garganta reseca, tan reseca como una caña tronchada: pensamientos

${ }^{13}$ Añadir títulos cuentos 
sin bridas ni freno arrastraban su cuerpo, estribado, por la tierra amarilla, negra, ocre. [CA: 63]

Las descripciones recuerdan a la plástica surrealista, en especial a aquellas representaciones del cuerpo mutilado y dislocado; imágenes hiperbólicas que caracterizan, por ejemplo, la pintura de Salvador Dalí.

(...) El soldado Antonio Arenas notaba que sus brazos y sus piernas, licuados, huían como huye el agua por una tubería rota. Su cuerpo se dispersaba, gavilla desatada en un ribazo, e invisibles gallinas mecanográficas picoteaban sus sienes.[CA: 63]

Pero quizás la huella surrealista más visible se encuentre en el tratamiento de la mujer y el lugar que Eros ocupa en la peripecia del protagonista. La función que el surrealismo reserva al amor en tanto impulso liberador y supremo ha sido explicada en un célebre artículo de Octavio Paz. El amor, necesario y fortuito, conjunción de la doble soberanía de libertad y destino es la llave para el retorno a la inocencia perdida. [Paz, 1954] Aurora guía a Antonio por la metrópolis desconocida y completa su aprendizaje citadino con una iniciación erótica plena, radicalmente diferenciada del fugaz paso por el burdel. El tropo desmesurado al comparar el cuerpo femenino con accidentes geográficos, enfatiza al mismo tiempo la ya mencionada armonía de naturaleza y civilización así como la función liberadora de la experiencia amorosa.

Entre las sábanas de su cama, Aurora parecía una deidad marina. Su cabeza, desmelenada de rubias algas, reposaba sobre la almohada de sus brazos paralelos. El alba dual de su pecho -presencia de una fuga- se evadía en la indecisión. Surgente, insurgente. [CA: 85]

De la mano del hermano de Aurora llega la incorporación al "mercado" de trabajo. Se ha visto que Antonio no se integra a la urbe a través de los mecanismos propios de la clase asalariada, sino que, trasunto humilde de los jóvenes burgueses representados en las novelas de los Nova novorum y otras del género, se incorporará al mundo a través de un deporte típicamente vanguardista, el boxeo.

La mujer, lejos de estar recluida, secuestrada o apartada como los personajes femeninos de algunas notables novelas de Gómez de la Serna, es una metáfora del futuro y una proyección simbólica de la ciudad que se ha de conquistar. Reúne los 
atributos de la hembra libre de ataduras morales y religiosas y desconoce los conflictos e inhibiciones de las protagonistas de la novela decimonónica ${ }^{14}$.

\begin{abstract}
Aurora interrogaba con todos los rizos de su pelo. Antonio mostraba frente a su frente el gesto alucinado que sobreviene al final de una marcha, tras una fuga áspera y nocturna.

Seguros ambos de su amistad venidera, de su amor sin explicaciones, se sentaron juntos, en un rincón (...) Sólo contaban con su efectiva presencia: no tenían pasado y el porvenir estaba en sus manos, sumiso. [CA: 73]
\end{abstract}

b. Variaciones sobre metrópolis. La lectura de Cazador en el alba que podría llamarse esperanzada no es aceptada unánimente por la crítica. Tampoco la que entiende la relación entre Antonio Arenas y Aurora como una nueva conquista de libertad en un espacio desembarazado de los códigos morales de la burguesía. Sobre esta última cuestión, me resulta muy difícil coincidir con la visión de Barroso Villar quien descubre en Aurora una síntesis de mujer fatal y diosa clásica, de ser dominante e inferior -acéfalo- objeto de la misoginia vanguardista (con especial referencia al futurismo). La lectura de Barroso Villar se funda en la ambigüedad argumental irresuelta ya mencionada, que ve en Aurora, gacela que finalmente huye, una mujer que se le escurre a Arenas de las manos cuando sale del sopor, producido bien por la fiebre, bien por el alcohol.

La visión frustrada y frustrante de la presencia femenina reforzaría, para la misma especialista, lo que evalúa como una experiencia negativa de la incorporación del campesino a la metrópoli. Si bien es aceptable, como señala Rafael de Cózar, que Ayala no puede parangonarse con los escritores que exhibieron "un acento meramente lúdico, desenfadado y optimista" [1998], ya que su proyecto creador, aun en esta etapa "eutrapélica", evidencia una gravedad y un propósito edificante que emergen tras la prosa distanciada. Pero rechazar la lectura simplificadora no conlleva negar que pese a las reservas y hasta la advertencia sobre la dureza de la civilización moderna, prevalece la mirada positiva. Un signo de especial relevancia en este sentido es el título de la obra. Cualquiera sea la interpretación sobre el desenlace dual, la actitud alerta y dispuesta al asalto del cazador -el campesino- sobre la presa, al alba -hora

${ }^{14}$ Se podría establecer un correlato similar entre el tipo de relaciones que surgieron alrededor de Gala, la musa de Dalí y de Luisa Sofovich, la mujer de Gómez de la Serna. 
símbólica de futuro y promesa- constituye una alegoría de la conquista de la mujer-ciudad y de la confianza en el triunfo.

Es verdad que la novela también incursiona en el lado sombrío de la gran ciudad, en la soledad del hombre anónimo, en la violencia agazapada. Pero si se alude a los niveles de complejidad de la prosa del escritor granadino, conviene buscar otras interpretaciones además de las muy pertinentes lecturas benjaminianas. La entrada y salida de la ciudad son motivos ayalianos anteriores a la prosa vanguardista: en su primera novela, Tragicomedia de un hombre sin espiritu el héroe realiza un camino inverso: huye de la ciudad buscando un refugio para su pobre naturaleza enfermiza y contrahecha, piensa que el campo será más humano con su cuerpo desvalido objeto de burlas despiadadas.

En Erika ante el invierno el mundo rural reaparece con el valor mítico de refugio y salvación. Se ha analizado esta novela como el reverso de Cazador en el alba. Aquí la ciudad ejerce de imán para el recluta; en cambio se torna hostil para la joven Erika, que regresa nostálgica al campo, donde un accidente aciago le causa la muerte. El mismo Ayala sentó los precedentes de esta lectura y también legitimó el análisis del conocido crítico Walter Pabst quien vio una premonición de la barbarie nazi -el relato transcurre en Berlín. Pero quizás ni todo en Cazador en el alba es tan halagüeño ni Erika plantea solamente el drama del hombre moderno y la amenaza del nazismo: entiendo que deberían analizarse otros motivos igualmente relevantes en el entramado textual: la infancia perdida, el dolor del crecimiento, el choque con el mundo adulto y violento, el azar.

c. La vida moderna. Uno de los flancos más atacados por los adversarios de la vanguardia fue la inclinación, casi obligada, por los tópicos de la vida moderna -aviones, hoteles, jazz, cine, deportes ${ }^{15}$-, débito contenidista que,

${ }^{15}$ Las estancias juveniles de los hijos de la burguesía catalana, vasca, andaluza o mediterránea en las universidades británicas les hizo gustar de los deportes. Al regresar mostraban las emociones del fútbol, del lawn tennis, la estética de la gimnasia colectiva, el esfuerzo del ciclismo y del patinaje sobre ruedas. [Samarach, 1994: 834] 
contemplados desde el presente lastra de ignenuas leyes de verosimilitud el discurso vanguardista. Pero entonces, "no construir imágenes con esos referentes podía indicar una peligrosa marginalidad respecto de la verdad ${ }^{16 "}$. [Jitrik, 1995: 73]. Sin embargo, puede extenderse a la inclusión de las imágenes de tópicas del progreso el mismo criterio contrario a las generalizaciones dogmáticas con que se juzga las vanguardias. Las imágenes de la actualidad urbana no siempre son gestos meramente miméticos, su presencia parecerá más o menos motivada según sea el grado de integración en la arquitectura de la obra.

Es más, podría pensarse que la sensación de caducidad que se imputa hoy a los motivos modernos deviene de la cercanía temporal del crítico con la realidad representada, que le lleva a ver en ellos únicamente lugares comunes exigidos por los códigos de la vanguardia. Sin embargo, así como las imágenes urbanas de Galdós constituyen hoy una entrada a la historia del siglo XIX sin peso de anacronismo y obsolescencia, los motivos ciudadanos en la prosa o la poesía de vanguardia remiten a una metrópolis en vías de transformación y revelan la agitación urbana de los "felices veinte". Así ocurre, por ejemplo, con el Madrid de Cazador en el alba.

\footnotetext{
El nombre de las playas de moda se repetía en las esquinas, en los periódicos. Fotografías de chalés, reclamos de los balnearios, anuncios policromos de las ciudades y las sierras.

Grandes rebaños de maletas se orientaban hacia prados recién florecidos de ventiladores. La resaca del tiempo había amontonado en los escaparates de los grandes almacenes sombreros blancos y zapatillas de paja, leves ya como el paso de las bañistas; canoas, vaporcillos, aviones con olor soleado a pintura fresca; lánguidos maillots, esponjas rubias como una estrella de cine, jerseys ligeros fruncidos por los dedos del aire... [CA: 89]
}

Aunque en la serie de motivos urbanos que se suceden en la novela subyace el germen de la melancolía -las mujeres son como maniquíes, en Navidad las calles se adornan de cadáveres de animales- Antonio Arenas abandona complacido su vieja identidad campesina. Es de insistir que la vida moderna se presenta halagüeña y el futuro, alentador. Mainer [1981] recuerda

${ }^{16}$ Subrayado del autor 
que pocos años después, en 1933, García Lorca brindaba una visión dura y trágica de la "otra España" en Bodas de sangre, la primera entrega de su célebre trilogía dramática. VER

d. El álgebra superior de las metáforas. Ya se ha mencionado que en los relatos de vanguardia la estructura narrativa tradicional se adelgaza hasta casi desaparecer, alejando a los personajes y el universo orgánico de la obra realista. Para lograr este cometido, Ayala se vale fundamentalmente de la metáfora, lo cual significa llevar adelante las pautas que Ortega promoviera en sus ensayos estéticos. Si se analizan los tropos e imágenes ayalianos, en gran medida asépticos como suelen serlo en la primera poesía del 27 , se verá que intensifican el distanciamiento con la frecuente apelación a la geometría. Las imágenes, cuando son de naturaleza plástica, describen un campo visual perfilado por rectas y planos, nítido y luminoso pero a la vez escuálido, que recuerda la afición por el cristal y la línea pura apuntados por Eduardo Subirats como índice del rigor racionalista y cartesiano de un sector de la vanguardia. En ellas se cruzan la pureza gongorina con el intelectualismo cubista y la adustez de un de Chirico.

Tras el muro, el campo se agrietaba, crujía; los árboles, escasos, levantaban sus brazos delgadísimos de morabito...

Abrir una ventana hubiera sido echar en la sala, entre dos camas, un metro cúbico de luz compacta. Las ventanas cerradas sólo consentían el ingreso de superficies blancas como pliegos de papel. [CA: 63]

El distanciamiento y la extrañeza se refuerzan con metáforas de naturaleza "polipétala" provenientes del creacionismo y del ultraísmo, dos movimientos amantes de los símiles despojados e intelectuales. ${ }^{17}$

El sol asediaba la sala, perro sediento de su oscuridad. Lanzaba dardos, introducía espadas por las rendijas, hacía impactos en la pared frontera.

\footnotetext{
${ }^{17}$ Según Gloria Vileda. La imagen polipétala o múltiple "se logra resumiendo en una imagen dos o más analogías. Cuando Borges dice: "El sol con sus espuelas desgarra los espejos', sintetiza varios paralelos: 'Los charcos de agua helados al amanecer son como espejos. El sol naciente los hiere (los derrite). Sus rayos tibios, por tener el poder de desgarrar, son como espuelas'" [Videla, 1963: 110]. Es significativa la semejanza de la metáfora citada con algunas que utiliza Ayala.
} 
La imagen encierra la idea de luz, calor y acechanza del exterior a la umbría y silenciosa sala de hospital.

Los aspectos técnicos y retóricos del lenguaje vanguardista de Ayala han sido tratados con escrupulosidad por distintos especialistas, como Vázquez Medel [1998c] y Miguel Nieto Nuño [1998], quienes demuestran sobradamente que la crítica no se equivoca al ponderar el talento del autor para construir un exquisito discurso deshumanizado. Si técnicamente constituye un ejemplo de difícil superación, la sagacidad del artista para captar la nueva sensibilidad estética le confiere aún mayor complejidad y perfección. Rafael de Cózar ha observado oportunamente que Ayala construye la prosa con desechos o materiales considerados plebeyos para el arte clásico, a semejanza de los collages cubistas y dadaístas, elaborados con cerillas y billetes de metro.

\footnotetext{
...parece además sorprendente esa capacidad para integrar multitud de objetos que entonces tal vez no entrarían de lleno en el concepto generalizado de la belleza, del mismo modo que hoy podría sorprender la presencia en un poema de un mando a distancia, un chip y un programa de ordenador... [ de Cózar, 1998: 42]
}

e. La cita culta. La capacidad de Ayala para subvertir el estatuto de los objetos vulgares e incorporarlos a la materia estética -gesto que desde su inauguración por Baudelaire no cesó de dar frutos sorprendentes- se pone en evidencia en los relatos que se analizan. El procedimiento, revelador de una nueva concepción del arte, va más allá del mundo representado para abarcar también el plano metafórico, lo que es más innovador aún. Ya se ha hablado de la función que cumple la cadena semántica perteneciente al ámbito rural en metáforas como "Grandes setas de mármol florecían a la orilla de la multitud danzante" [CA: 72]. A ella deben agregarse símiles inusitados del tipo "la carne rosa de las auroras boreales -tan parecida al jamón de Chicago" [CA: 61] que contribuyen a quebrar el sentimentalismo del lector, pues la discontinuidad del mundo de referencia carne, jamón de chicago, aurora boreal- realza la ostranenie y aumenta el efecto distanciador. Constituye una variante la ruptura del pensamiento racional mediante la introducción de un absurdo que reenvía nuevamente a la imagen surrealista: 
"Todos sabemos que es peligroso, en los días de nieve, acercarse demasiado al oso hambriento de la peletería"18. [CA: 61]

En este sentido actúa también otra importante procedimiento: paralelamente a la serie metafórica que remite al mundo rural, se incluye otra que opera de forma antitética a la primera, mediante la vinculación de los objetos de la serie "real" con el mundo de la cultura y de los saberes elevados: [el caballo] "tenía el cuello amplio; la crin, corta; la mirada, cuando no turbia, de Apocalipsis, era una mirada de égloga" [CA: 65] y las calles eran "grises danubios de asfalto" ${ }^{19}$. [CA: 83]

f. El séptimo arte. Continuando con el rastreo de coordenadas vanguardistas de los relatos breves de Ayala, se encuentra la fuerte presencia del cine, que tanto fascinó a los artistas y hombres de la cultura de las primeras décadas del siglo XX, venero de fecundo intercambios de motivos y técnicas. Ayala, en Indagación del cinema (1929), deja registrado tempranamente el imán que ejercía el nuevo arte en los artistas jóvenes ${ }^{20}$. Señal de tal influjo es la incorporación de recursos propiamente cinematográficos en sus prosas, que ponen de manifiesto una nueva forma de mirar, semejante a la introducida por la cámara filmadora. Se sabe, por otra parte, que los rasgos formales de la obra inorgánica coinciden con el cine en la utilización del montaje como procedimiento básico, aunque en la literatura este no es sustantivo como en el cine. El nuevo lenguaje ofreció un campo de experimentación inapreciable para los deseos de innovación de la vanguardia que sigue concitando la atención de los especialistas:

...el arte nuevo del novecientos, el cinematógrafo, ofrece una manera inédita de mirar la realidad, proponiendo una repristinación de los objetos y del gesto, una manera para la que las nociones tradicionales de espacio y

\footnotetext{
${ }^{18}$ En Cal y canto de Rafael Alberti se encuentra un precedente de esta imagen: "Autorizadas, las peleterías/ abren las jaulas del escaparate /y el oso blanco abriga los tranvías"/. [CC, "Invierno postal": 92]

${ }^{19}$ Subrayado mío.

${ }^{20}$ Sería interesante contrastar el discurso ensayístico de los primeros trabajos de Ayala con los del exilio, pues también la prosa no ficcional se impregna de las estéticas vigentes. El lenguaje de Indagación del cinema es más ágil y espontáneo que el de El escritor en su siglo, por ejemplo.
} 
tiempo han envejecido por obra del plano, el montaje y el découpage. [Ródenas de Moya, 1998, 150]

Ayala estuvo muy atento a estas novedades. Así encontramos que la llegada de una locomotora a la estación es una película interrumpida: "... De pronto, todo quedó inmóvil, parado. (Un film que se corta.)"21 [CA:68]. El contrapunto entre los dos planos de la historia de Antonio Arenas -ya se trate de un vagabundeo real o virtual por la urbe- es considerado un montaje por Carolyn Richmond

Pero el presente se componía de dos planos cinematográficos: un gran plano con el rostro de Aurora $\mathrm{y}$, a través de él, todo el paisaje en movimiento. [CA: 93]

Incluso la misma especialista encuentra que una secuencia de "Medusa artificial" anticipa el uso del primer plano en la célebre escena del ojo cortado por una cuchilla de afeitar en Un chien andalou de Buñuel y Dalí.

Al retraer la mirada hasta la superficie del cristal encontró Tere el reflejo de la calle, y sobre las direcciones encontradas, su rostro en gran plano. [MA, 1928: 151]

No se trata sólo de procedimientos, el nuevo arte aparece especialmente tematizado en "Polar estrella", en el cual un espectador anónimo se enamora de una actriz y finalmente se suicida arrojándose al río desde un puente. El antisentimentalismo del arte nuevo se consuma en alto grado mediante un lenguaje riguroso, impersonal y fragmentado por procedimientos que le restan dramaticidad, fusionando el episodio con una visión entre onírica, surrealista y fantástica, en una palabra, cinematográfica.

${ }^{21}$ Gubern realiza una detenida y brillante lectura de Cazador en el alba en clave cinematográfica y proporciona un minucioso registro de los procedimientos de la novela que se corresponden con el lenguaje y la técnica de la imagen: los diversos planos narrativos se estructuran "cual emplazamientos de cámara distintos, propios de un découpage cinematográfico"; "Ayala dinamiza en varios lugares la acción con efectos de travelling", etc. Sostiene que la novela está diseñada "como la transcripción literaria de un film visto en la pantalla o imaginado en la mente". [1999: 130-131] 
Pero enseguida se sintió flotando en sorpresa. El aire le había recogido en su seno. El dios del cinema tenía dispuesta su caída au relenti.

Descendía blandamente, con suavidad viscosa, desenlazándose en una danza sin música de miembros interminables y ritmo submarino.

Horizontal. Vertical. Inclinado. Los pies divergentes. Atrás, los brazos, de nadador...

A llegar al suelo se quebró como si hubiera sido de porcelana. Su último pensamiento y su última mirada fueron dirigidos a Polar. Le hablaba. La sentía presente, ángel ipor fin! apiadado. Maniquí de cera, para los demás, invisible. [PE: 143]

En el relato por otra parte aparecen cifradas referencias de estrellas del celuloide: Polar estrella es una síntesis de Greta Garbo, nórdica y glacial, y de Pola Negri, artista polaco-nortemaricana. Pero más interesante es la desarticulación de la ilusión cinematográfica mediante la descripción del montaje y la interrupción del film a causa de un desperfecto técnico

...además de patentizar la manipuladora intencionalidad del montaje (el cambio de plano que impide el goce erótico del espectador), llegaba Ayala a desvelar el artificio de la proyección cinematográfica cuando, antes de la escena del baño y su frustrante cambio de plano final, una avería del proyector hacía que la figura de la estrella quedase quebrada en la pantalla, con la parte superior de su cuerpo abajo y su parte inferior arriba. [Gubern1999: 91]

g. La autorrepresentación. El ejercicio analítico del artificio se conecta con uno de los más visibles rasgos de modernidad estética, el recurso metaliterario que hace mención a los mecanismos constructivos. En este sentido, Ródenas de Moya ha demostrado escrupulosamente que "la ficción autorreferencial aparece (...) como una réplica al apartamiento que había sufrido el arte respecto al mundo de la vida a lo largo del proceso de sectorialización de la sociedad industrial". [1998: 101]. Cuando la protagonista de "Medusa artificial", Mari-Tere está en manos de un peluquero que no casualmente lleva el nombre del ángel mesajero en un capítulo titulado "La anunciación", se desarrolla el siguiente diálogo:

Gabriel sentenció con un dedo en alto: ${ }^{22}$

\footnotetext{
${ }^{22}$ Nótese que el gesto inconográfico del arcángel remite a tradición litúrgica cristiana.
} 
-No exagero; cualquier hombre que la mire se quedará de piedra. Mi ondulación es permanente.

- ¡ESO ES UN MITO!- exclamó con rapidez.

(...)

-UN MITO, si usted quiere -replicó Gabriel-, pero MI ONDULACIÓN ES GARANTIZADA $^{23}$. [MA, 1928: 153]

Bajo la trivialidad de la conversación, subyace otro nivel discursivo que recuerda al lector avisado que el relato se construye mediante la reescritura de diferentes mitos paganos y cristianos. Si se extrema la intencionalidad del recurso, incluso se puede entender que la doble ondulación garantizada hace referencia a la ida y vuelta de una lectura de superficie a una segunda más intelectual, que dilucida las claves compositivas.

Una modalidad distinta de ejercicio aurorreferencial es la que se funde con la mención al acto de escritura, que según demuestra Richmod [1998b], se verifica en la prosa de vanguardia de Ayala y mantiene una notoria presencia en toda su obra posterior. Destaco el momento escriturario descripto en "Hora muerta", donde el narrador mediante el desdoblamiento de la narración y el acto de escribir incursiona en el mecanismo de la escritura automática, que bien puede tratarse del momento previo a la redacción elaborada; a la manera de apuntes, notas, impresiones personales. Richmond piensa en el borrador de un guión de cine.

Boxeador. -Dientes blancos. Frente angosta.

Un ring en cada meridiano. Sonrisas inexpresivas. Apretones de manos, también inexpresivos...

No recuerda. No recuerda. Pero ... ja su lado va el manager!.

Negro. -Sonrisas grandotas. Plebeyez -democracia multitudinaria- de sombrero hongo -muy metido- y cartera en la mano. (En la otra mano, un junco. $Y$ en las dos, guantes amarillos.) [HM: 121]

h. Los saberes mitológicos. A la concentración de recursos propios de una lenguaje literario que va contra la representación, en el caso de Ayala se añade un conjunto de referencias cultas y librescas que intensifican el hermetismo, la dificultad. Este plus se basa, en importante grado, en la recreación de un saber

${ }^{23}$ Subrayado mío. 
mitológico, de origen profano o religioso, que no se rige por la "enciclopedia" más difundidas, por el contrario, con frecuencia recurre a relatos clásicos que exigen un lector entendido, expresados, por otra parte, "mediante un vocabulario muy culto otra característica de la prosa de Ayala", según Carolyn Richmond [1998a: 17]. Las alusiones mitológicas se complementan con una tradición pictórica que refuerza la cita erudita, como ocurre con la saga plástica de Susana y los viejos y de Salomé en "Susana saliendo del baño". Por lo tanto, el lector-decodificador, además de aceptar el reto formal propio de la obra inorgánica, destinada a un público egregio, como quería Ortega, debe contar con una instrucción elevada.

Para seguir sucintamente las huellas de la mitología en la prosa ayaliana de los años treinta es menester nuevamente citar a la profesora de la City University of New York, quien ha realizado un fino análisis que abarca desde la primera producción hasta la narrativa más reciente, pasando por Indagación del cinema. En primer lugar rastrea la historia bíblica de Susana y los viejos (Daniel. XIII), antecedente del cuento en el cual Ayala ha trastocado los viejos en objetos, dos grifos de níquel ${ }^{24}$. No falta aquí un cruce con el mito clásico de la medusa, que reaparecerá con mayor protagonismo en "Medusa artificial". En este relato la aventura de Perseo y la Gorgona une la bíblica contraposición de Eva y María, representadas en la mujer virtuosa y hogareña -modista- y la provocativa e independiente -taquimecanógrafa (toda una desconstrucción de la heroína de la novela realista y del folletín). Las alusiones mitológicas continúan en el personaje del padre, a medias incestuoso, a medias guardián de la honra, y en el de Salomé, el mito preferido por los decadentistas, síntesis de castidad, perversión y refinada crueldad $^{25}$.

Y si, por asociación, la imagen de una cabeza "sobre una bandeja de cristal" de aquella pieza trae a la mente la del Bautista en la historia de Salomé

${ }^{24}$ Encuentro un antecedente de la metamorfosis de los viejos en grifos a la hora del baño en el soneto "Romeo y Julieta, I (Baño)" de Cal y canto, de Rafael Alberti: "Llaves áureas, los grifos templadores/, que igualaron su sangre con tu cuerpo/. sin habla ya, sobre tu frente y muslos/". [CC: 92-93]

25

Los motivos finiseculares tienen una funcionalidad diferente a la observada en Gómez de la Serna, pues en Ayala operan como elementos distanciadores que contribuyen al hermetismo y a la complejidad del sentido. 
(tema -recuérdese- desarrollado por Oscar Wilde), también en la actitud asumida por Godofredo hacia su hija podríamos encontrar quizás un eco de la perversa atracción ejercida sobre su padrastro por la bíblica tentadora.

[Richmond, 1998a: 22]

.En Cazador en el alba Richmond recupera fuentes mitológicas en el proceso de adaptación de Antonio Arenas a la ciudad. Como a Ulises, la fiebre y el delirio lo hacen descender a los infiernos, y como en la antigüedad pagana, las mujeres son, o deidades inaccesibles del Olimpo, o tres gracias entre las que debe escoger. La elegida finalmente no es ninguna de la terna sino Aurora, de rosados dedos, con algo de Cibeles, diosa agraria. Ella le tenderá un hilo de Ariadna en el laberinto de parejas en el baile, y será más tarde deidad marina en la cama. Los ejemplos podrían continuar: el gallo de la pasión alude naturalmente, a la madrugada en que Pedro traiciona a Jesucristo; el boxeador y el angel se insertan en la angeleología de prolongada estirpe en la tradición occidental y se constituyen en un contramodelo de la lucha ciega de Jacob, pues el boxeador recibe auxilio celestial para vencer a su contrincante.

1.3. La presencia de Ortega. Si se procede a revisar las premisas del arte nuevo enunciadas por Ortega, veríamos que pocas son las ausentes en la prosa vanguardista de Ayala. Reseñaré sucintamente los rasgos sobresalientes: recepción minoritaria, rechazo de las emociones, realce y complicación de la forma, con especial incidencia de la metáfora y la perspectiva inusitada; desprecio de la intriga y la acción en beneficio de la reflexión y el intelecto; todas características ya tratadas en el capítulo III.

Puede verse también que Ayala no acuerda con algunas de las características más divulgadas de los ismos, rasgos que sin embargo, figuran entre los más atendidos por la crítica y los artistas: rechazo de la tradición y el pasado, aversión a las reglas y la disciplina. No suscribe la actitud desdeñosa del artista y la inspiración cómica, ni admite la intrascendencia del oficio y la obra, pues no se puede afirmar que los textos analizados rechacen toda finalidad grave y solemne y persigan la puerilidad y la simpleza. 
El quiebre mayor con la doctrina del arte nuevo tiene lugar frente a la compleja categoría de la intrascendencia, aunque ya se ha visto que Ortega en Ideas sobre la novela desalienta las interpretaciones lineales sobre este concepto cuando agrega que la intrascendencia puede acompañarse de resonancias vitales en el lector y que no está reñida con la incorporación de elementos perteneciente a ámbitos ajenos al arte, como la filosofía, la estética, la ciencia, la religión, la sociología.

Se puede reafirmar a esta altura de la exposición aquello que la crítica ha probado con rigor: la narrativa vanguardista de Francisco Ayala no es mero juego iconoclasta, ya que detrás del humor, del gesto paródico, de la simplicidad de los héroes y de la realidad representada palpita una constante actitud crítica y reflexiva sobre el mundo y la existencia, fortalecida por una densa red de referencias culturales y acumulación de sentidos.

\section{INTERRUPCIÓN Y CONTINUIDAD DEL PROYECTO CREADOR}

El análisis de la narrativa de vanguardia de Francisco Ayala hasta aquí realizado se propone demostrar que la gravedad y circunspección que gravitan en la prosa ayaliana con una fuerza superior a la de otros narradores se explican por la filiación orteguiana del escritor granadino, sin que ello signifique reproducción fiel del rumbo del maestro. Tampoco quiere decir consustanciación absoluta entre la estética de uno y otro, sino identidad de un proyecto y una forma de entender la cultura.

Para el autor de La rebelión de las masas, el intelectual y el artista tenían la misión de contribuir al mejoramiento del hombre transmitiendo el acervo cultural de la humanidad. Si en la etapa vanguardista de Ayala estos preceptos no son explícitos en demasía, a partir de 1939, las manifestaciones 
en este sentido serán elocuentes, reforzadas sin duda por las especiales condiciones del exilio.

Si se aceptara el aparente contrasentido de la expresión "vanguardia ilustrada", el apelativo podría definir las prácticas artísticas de Francisco Ayala en los años en que formó parte del selecto grupo de Revista de Occidente. Así como hubo un grupo de artistas de vanguardia que no pudo desprenderse de las connotaciones de señoritos burgueses acomodados, a otros no los abandonará un aura de elite intelectual egregia, confiada en poseer los resortes culturales y morales de la modernización de España.

Apoyan la hipótesis sobre este proyecto creador un tanto contradictorio con el componente de radicalidad que supone la vanguardia, algunas circunstancias biográficas del escritor granadino en que los estudiosos no suelen recalar: la publicación de Cazador en el alba en 1930 se halla inscripta en una serie de hechos decisivos para la vida académica de su autor: la obtención de la Licenciatura en Derecho en 1929 y su inmediata incorporación como ayudante a la cátedra de Derecho Político, la estancia en Berlín durante 1930, después de ganar una beca de la Junta para la Ampliación de Estudios; la defensa de la tesis doctoral en 1931, tras su regreso. En ese mismo año se desempeña como Profesor Auxiliar de Derecho político y Secretario de la Facultad y gana una oposición para el Cuerpo de Oficiales Letrados del Congreso. En 1932 publica El derecho social en la constitución de la República y en 1933 obtiene por concurso la titularidad de la cátedra de Derecho Político en la Universidad de La Laguna, en las Islas Canarias, cargo en el que pide la excedencia ya que nunca había pensado en trasladarse al archipiélago. Durante el mismo período completa su formación y sus antecedentes académicos realizando traducciones del alemán de obras jurídicas y sociológicas. ${ }^{26}$

${ }^{26}$ Reconstruyo la trayectoria de estos años a partir de las memorias de Ayala [1984: 129-196] y del Cuadro cronológico incluido en Navarro Durán y García Galiano, 1996: 71-73]. 
Según palabras del propio Ayala, ${ }^{27}$ eligió la carrera académica frente a una alternativa más rentable y desahogada de funcionario estatal en Tabacalera porque pensó que este cargo terminaría apartándolo del ejercicio literario, su auténtica vocación. Optó así por su proyecto más sentido:

Pero no quise engañarme; y por fin, sin haberlo consultado con nadie, le di mi respuesta negativa a don Nicolás Pérez Serrano; lo que yo deseaba era ampliar mis estudios en el extranjero, y ser catedrático. [Ayala, 1984: 131]

Es significativo que la vocación literaria vaya unida a un objetivo tan concreto y de tan alta responsabilidad, ser catedrático, no en la Facultad de Filología sino en la de Derecho, con todo lo que ello implica. Opción muy distinta de la de aquellos escritores que se amparaban en un cargo de escasa exposición pública y profesional para poder así escribir sin distracciones ni apuros materiales. Diferente también de la alternativa que tomaron quienes vieron posible unir profesión y vocación, como Pedro Salinas. Pero en el caso que analizo, priva un ideal de hombre de letras asociado a hombre de la cultura, que integra en una misma persona al creador y al intelectual, al sabio y al ciudadano influyente -Ayala estuvo a cargo de los editoriales de El Sol, Luz y Claridad-comprometido con las instituciones públicas y el progreso de la humanidad como aspiración general.

Otro dato relacionado con su proyecto creador que interesa rescatar de las memorias, escritas con posterioridad de medio siglo respecto de los acontecimientos narrados, es la reflexión sobre la independencia para escribir a su antojo que obtendría de su labor académica, en contraste con una tercera alternativa, la profesionalización como escritor.

Y si hubiera resuelto, acaso, vivir de la pluma, ¿no me hubiera ello obligado también a comprometerme con el periodismo, con la industria editorial, con las demandas del público, forzándome a escribir con la vista puesta en consideraciones ajenas a mi propio gusto y gana? [Ayala, 1984: 131]

${ }^{27}$ Considero necesario aclarar que no doy valor inapelable a la "razón" autobiográfica por motivos que el actual estado de la teoría sobre las escrituras del yo me exime de desarrollar. Las fuentes de esta naturaleza adquieren valor en tanto se contrapesan y evalúan en el conjunto de las fuentes utilizadas. 


\title{
2.1. El SILENCIO de LOS AÑos tREINTA
}

Lo cierto es que llama la atención que en proyecto tan meditado, según lo reconstruye el escritor a la distancia, exista un hiato tan extenso entre su último relato - de vanguardia- y el cuento que abre la segunda etapa, "Diálogo de los muertos", publicado en la revista Sur $^{28}$. El paréntesis abarca además al género ensayístico: después de Indagación del cinema retomará esta práctica en 1944 con Histrionismo y representación ${ }^{29}$. Los últimos artículos en Revista de Occidente $^{30}$ y los de La Gaceta Literaria ${ }^{31}$ son de 1931. También depone su colaboración sistemática en medios de prensa hasta pasados casi diez años, en que reaparece su firma en La Nación de Buenos Aires. Las memorias ofrecen la explicación del autor sobre este prolongado silencio.

\begin{abstract}
Así, en los años que van desde mi regreso de Alemania hasta el exilio en Buenos Aires, mi actividad literaria como autor de obras de imaginación quedó en suspenso (...) Retrospectivamente he podido interpretar esa larga pausa creativa como resultado del brutal cambio que se estaba produciendo en la atmósfera espiritual del mundo; y sin duda ésta fue la razón profunda de mi silencio: falta de una disposición interior acordada a los estímulos externos, que es condicionante para la creación artística. Pero esto no podía percibirlo con claridad en su momento de modo que a mis ojos la postergación de aquella actividad a la que me sentía vocado era un mero aplazamiento que me imponía a mí mismo hasta tanto hubiera consolidado mi posición social, para cuyo efecto estaba ocupado con los trabajos preparatorios de unas oposiciones a cátedra. (...) La verdad es que si hubiese sentido el apremio de expresar poéticamente tal o cual intuición, tiempo no me hubiera faltado... [Ayala, 1984, 166]
\end{abstract}

La justificación es plausible, pero deja algunos resquicios, ya que pocas líneas más abajo recuerda el advenimiento de la República -coincidente con el inicio de su alejamiento pasajero de la actividad literaria- como un momento promisorio, ajeno a las dificultades que el contexto internacional anunciaba.

... es lo cierto que la tónica optimista del proceso interno de España, tan a destiempo del ritmo mundial, le impedía a uno percibir que, al fin y al cabo,

\footnotetext{
${ }^{28}$ Sur, Buenos Aires, 63, (dic. 1939), 35-42.

${ }^{29}$ Buenos Aires: Sudamericana, 1944.

30 "Berlín-Norte", Revista de Occidente, XXXII, 94 (abr. 1931), 117-120.

31 "Anotación en el margen del calendario", La Gaceta Literaria ,III, 105 (1 mayo 1931), 136 (16).
} 
nuestro país estaba dentro del mundo y no podía escapar al terrible temporal en ciernes. [Ayala, 1984: 165]

Queda visto en el capítulo correspondiente que la Revolución de Asturias, en 1934, fue el episodio que dividió aguas polarizando definitivamente a la sociedad española en los dos bandos que se enfrentarán en 1936. Ayala también se sintió sacudido por los hechos, aunque su ideología liberal y su disposición a la ecuanimidad lo lleve tanto a rechazar las motivaciones y la estrategia de los revolucionarios como a condenar la bárbara represión llevada a cabo por el ejército.

No, no escasearon las insensateces. Venían encadenadas en series dialécticas, y una de las mayores fue, sin duda, aquella malhadada revolución de octubre de 1934. [Ayala, 1984: 179-180]

¿Es suficiente entonces la explicación del autor sobre su peréntesis en el quehacer literario? Las citas precedentes tratan de mostrar que otras hipótesis, pueden añadirse a las esbozadas por el escritor. Como anuncié en su momento, se observa en Ayala una concepción del arte y una estética que no se rigen por el credo vanguardista más al uso sino que se conectan con la visión más global de Ortega, en la cual ismos y arte moderno son todo uno, y como fenómeno único, adquieren su relevancia en el campo de la cultura. Esta visión va acompañada de un espíritu didáctico y de un fin civilizador que de manera más o menos evidente acompaña a la obra ayaliana ${ }^{32}$; una prueba de ello es "La carta a los editores" que precede la primera edición de Cazador en el alba, guía y programa de lectura impropios de la obra abierta e inorgánica. El preludio responde mejor a la figura tutelar de un autor/auctoritas, imbuido de una misión que va más allá de la creación literaria. Veremos, por otra parte, que Ayala no abandona este hábito, que antes bien, se intensificará en la etapa siguiente, ya se trate de autocrítica abierta, ya del artificio de la crítica apócrifa, como queda señalado en el ya clásico libro de Estelle Irizarry ${ }^{33}$. La voz del crítico, que encierra la del académico y la del

\footnotetext{
${ }^{32}$ Mainer al intentar situar generacionalmente a Ayala menciona "su tono profesional (como catedrático, politólogo)" y a "su vinculación funcionaril y académica..." [1998: 48]

${ }^{33}$ V. Irizarry, 1971: Cap. I. "Del estrecho entronque entre la actitud crítica y la imaginativa".
} 
sociólogo, adquiere tal relevancia que es difícil que no se convierta en la primera autoridad frente a sus propios textos. A pesar de que las vanguardias fueron adictas a las proclamas, manifiestos y toda especie afín a la definición programática, encuentro en este párrafo una actitud y un discurso más acordes con el magisterio del escritor que con el furor iconoclasta y antipasatista o con la tendencia a la autorrepresentación que señala Ródenas de Moya como "dominante" ${ }^{34}$ del arte moderno.

\begin{abstract}
Ahí están esas dos pequeñas novelas. Cazador en el alba contiene una visión clara, ilusionada y frutal del mundo. Erika ante el invierno tiene asimismo un corazón frutal, sí; pero madurado. Nubes bajas han puesto de repente seria la faz del cielo. La técnica es similar en ambos opúsculos; pero la postura espiritual ha cambiado casi imperceptible, por lo mismo que radicalmente $^{35}$. [Citado por del Pino, 1995: 167]
\end{abstract}

Profundamente liberal en las ideas y quizás el más constante integrante del grupo de Ortega que alentó una vanguardia reformista, Ayala mantendrá invariable su posición sobre las relaciones del arte y la política. Esta postura guarda una coherente afinidad con la idea de la independencia del intelectual y del compromiso entendido como un deber de orden moral y universal que propugnara por Julien Benda en La trahison des clercs. José Carlos Mainer ha rescatado las respuestas del autor de El jardín de las delicias a un cuestionario realizado por $\mathrm{La}$ gaceta literaria en $1927^{36}$. Los conceptos vertidos por Ayala son taxativos: si la literatura hace política, se convierte en una "mixtificación insoportable, que es la últimamente realizada por la generación del 98", comportamiento que la nueva generación "más fina de espíritu", ha rectificado. En otra de las respuestas reclama un "urgente internacionalismo" y "una injerencia absoluta de las entidades

\footnotetext{
${ }^{34}$ Dominante en el sentido de categoría que determina el eje que gobierna, determina y transforma los elementos de una obra, período, movimiento: la dominante del Renacimiento son las artes visuales, hacia las que se orientan todas las demás artes, la del Romanticismo sería la música, la del Realismo el arte verbal, la del siglo XX la autorrepresentación.

${ }^{35}$ Es de notar que la breve apreciación sobre su propia obra creó un precedente del que parte casi invariablemente la crítica, fenómeno que se repetirá con relatos posteriores, como Los usurpadores.

${ }^{36}$ El número 22 del 15 de noviembre de 1927 convocó a distintos escritores con una encuesta sobre "Política y literatura" que constaba de tres preguntas: "¿Debe intervenir la política en la literatura?", "¿Siente $\mathrm{Vd}$. la política?" y "¿Qué ideas considera fundamentales para el provenir del estado español?". [Citado por Mainer, 1991: 42]
} 
públicas en la vida social para la realización de servicios cada vez más complicados y costosos". [Citado por Mainer, 1991: 42-43]

Es claro que Ayala se distancia de los escritores y artistas que, volcados a la palestra pública, se replantean las relaciones de la literatura y la política en franco favor de integrar ambas prácticas. Basta recordar los ejemplos recogidos en el capítulo II. Considero entonces que la explicación brindada por Ayala sobre el silencio creativo de los años treinta puede ampliarse con razones originadas en el estado del campo literario e ideológico que no daba lugar a posiciones como las suyas. En el mismo contexto, se ha hecho mención del creciente descrédito de Ortega y sus doctrinas, así como de la inviabilidad de las terceras posiciones o de los discursos humanitarios basados en categorías abstractas de alcance universal. Se ha visto también que incluso intelectuales como Benda, sin abjurar de sus ideas, las modifican según las nuevas circunstancias históricas y sociales de Europa, y de España en particular, y se aviene a participar del Congreso de Intelectuales Antifascistas celebrado en Valencia, reunión altamente convocante a la que el autor de Cazador en el alba se no asiste debido al alto protagonismo de Partido Comunista ${ }^{37}$.

Ayala, en su condición de hombre público partidario de la República, nunca renunciará al compromiso con las instituciones democráticas; al contrario, lo acentuará en las situaciones adversas. Cuando estalló la guerra civil se hallaba con su esposa e hija en Argentina, invitado por la Institución Cultural Española (ICE) para el dictado de una serie de conferencias. Toma el camino contrario al de Gómez de la Serna, pues se apresura a regresar a España, no sin pasar momentos de riesgo e incertidumbre durante el largo trayecto en barco. Hasta el final de la contienda se desempeña como funcionario de la República, primero en

\footnotetext{
${ }^{37}$ Manuel Aznar ofrece una meditación compleja y justamente contextualizada de las grandezas y estrecheces del II Congreso Internacional de Escritores Antifascistas, en el cual convergieron la actitud solidaria y el compromiso con la causa republicana y la indudable preeminencia del Partido Comunista. Este protagonismo era conflictivo para muchos, pues el partido que en ese mismo momento realizaba una feroz purga de los disidentes, dentro y fuera de la URSS, representaba al único país que ayudaba a los leales. Silenciamientos e interdictos de cariz stalinista no impiden que en el Congreso celebrado en Valencia haya prevalecido el "propósito prioritario de demostrar ante el mundo, a través de la voz cualificada de la inteligencia, una solidaridad internacional con la causa republicana, convirtiéndose así el Segundo Congreso en el acto de propaganda más espectacular realizado en la España republicana durante la Guerra civil". [Aznar, 1978: 148]
} 
Praga y luego en España, de donde parte en 1939. Las fuerzas franquistas habían fusilado -a su padre y a uno de sus hermanos, que habían quedado en Burgos. $\mathrm{Ni}$ el contexto contrario a su idea sobre el arte ni las penosas circunstancie personales le indujeron a modificar la convicción acerca de la función de la literatura ${ }^{38}$.

Pero ¿qué hubiera podido escribir Ayala en esa década? Ya no arte de vanguardia. ¿Una novela que testimoniara la irracionalidad de izquierdas y derechas?. De alguna manera esa obra ya estaba escrita y las circunstancias no permitían volverla a escribir porque podría ayudar al fascismo y Ayala no era de esa clase de liberales.

El libro que considero ya escrito es Historia de una amanecer (1926), anticipo de la posición ideológica que mantendrá en los años conflictivos de la década siguiente, sobre todo ante la Revolución de Octubre. La segunda novela de Ayala cuenta la historia de una célula clandestina revolucionaria, en la cual varios personajes discuten la estrategia a seguir. El futuro de la organización, dirigida por un viejo maestro, se definirá entre dos jóvenes discípulos, Abelardo, intelectual y pacífico, y Crisanto, activista y violento. Abelardo al final es vencido y acepta morir envenenado -como Sócrates- para delegar su más autorizado liderazgo en su camarada Crisanto, aventurero y radical en sus ideas. El líder

\footnotetext{
38 Los más representativos artistas de vanguardia tomaron distintos caminos. Algunos, como Antonio Espina y César Arconada, se identificaron con las posiciones de izquierda. La opción elegida por Ayala fue, con matices, la adoptada por quienes seguirían más fieles a un ideario orteguiano, aunque no hubieran pertenecido al núcleo más cercano al filósofo. Recuérdense las reflexiones de Guillermo de Torre, acerca de que el artista en los tiempos dramáticos que se vivían en 1936 debía tomar partido, pero sin someter al arte a consignas políticas o enrolamientos partidarios. Sobre este problema llevó adelante una célebre polémica con Sánchez Barbudo, director de Hora de España. Merecen destacarse algunos de sus conceptos, muy cercanos a las tesis de Adorno en su disputa con Lukács. "Si antes se pudo objetar -por algunos casos aislados, pero no en su tónica general- que el avanzadismo estético iba acompañado de un reaccionarismo ideológico, en el plano social y político, hoy cabe hacer la comprobación inversa, de radio más general y de alcance mucho más grave: el revolucionarismo social se alía con las formas del peor academicismo". Y más adelante: "'Todo aquello -leemos en The Seven Soviet Arts- que nosotros, miembros de la cultura occidental llamamos 'arte moderno' es hoy día rigurosamente proscripto en la U.R.S.S. Y, por el contrario, todo aquello que nosotros miramos como obsoleto y anticuado, aun más, como reaccionario, resulta allí digno de estímulo". Y añade: "Recordando lo que fue el arte soviético en los primeros años de ese régimen, el magnífico impulso transformador que prevaleció en todas las expresiones artísticas y literarias, apenas puede uno creer que hoy haya venido a dominar el espíritu diametralmente opuesto". [de Torre, 1937:58 y 50] No debe extrañar que en el exilio, de Torre y Ayala se hayan incorporado al plantel de Sur, publicación que debía mucho a Revista de Occidente.
} 
triunfante es la contracara del reflexivo y moderado Abelardo - ¿sacrificado o pusilánime?, ¿generoso o ingenuo? Crisanto, ambicioso y temerario, aspira a mandar sin importarle sacrificar la vida de los suyos. La escena final es elocuente ${ }^{39}$.

Crisanto dio la orden de marcha: la multitud comenzó a moverse con una fuerza lenta y enorme; sonaron las primeras cargas de fusilería... [HA: 108]

Cuando se deshace de su oponente, Crisanto lo convierte en mártir. Despejado el camino de la acción, guía a los sumisos integrantes a una lucha desigual, mientras se insinúan nuevas peleas intestinas en el grupo revolucionario, donde de inmediato surge un plan para suplantar al flamante jefe.

La novela, con sus tipos bien definidos, parecería haberse guiado por los preceptos lukacsianos si no fuera por el peso excesivo de la tesis. Historia de un amanecer es la historia de los primeros pasos de un escritor, que en pleno auge de los ismos estuvieron más cerca de la novela realista de propósito formativo que de la vanguardia de estetizante Ortega; y más próxima a la función de literatura que inspiró su obra del exilio. ${ }^{40}$

En los años treinta no hay lugar para el arte nuevo como lo practicaron los jóvenes artistas ansiosos de modernidad e irreverencia, pero tampoco para expresarse desde la utopía del liberalismo político.

\subsection{LA MISIÓN DEL INTELECTUAL}

\footnotetext{
${ }^{39}$ No comparto la lectura de Ellis, [1964: 37-38] quien encuentra una igual valoración positiva hacia los distintos personajes: "Desde el punto de vista del autor, todos los personajes principales, Abelardo, Darío, Nazaro, Crisanto, son buenos, admirables. Tampoco considero que "Crisanto parece destinado a llevar a su pueblo a una batalla victoriosa y a un glorioso futuro" ya que el narrador sobrepone al discurso del revolucionario su reprobación y escepticismo y, aunque condena la debilidad en uno y el autoritarismo en el otro, el peso recae sobre el activista partidario de la acción violenta. Me inclino por la interpretación de Irizarry [1971: 83-84], quien cree que Abelardo encarna al intelectual que no desea mezclarse en las impurezas de los hechos y cuya muerte dejan al lector un interrogante sobre el destino de la intelectualidad. La conducta del activista, más que interrogantes, deja la convicción sobre su errado proceder.

${ }^{40}$ Es de destacar que en el discurso pronunciado en ocasión de recibir el Premio Cervantes 1991, Ayala enfatiza que en la guerra civil actuó "como ciudadano (pero no por cierto como escritor) al lado de la República". Ayala, 1997, 282.
} 
Cuando pasados diez años Ayala vuelve al ejercicio de la literatura al mismo tiempo que desarrolla en una importante labor ensayística, reaparece una función, más moral que política, ya en germen en Historia de un amanecer y decididamente alejada de la intrascendencia del arte nuevo. La idea que ahora defiende con claridad es que la literatura debe cumplir una función ejemplar y formativa, y ésta sólo puede concretarse mediante una escritura elaborada y densa de contenidos morales.

Diferentes ensayos reforzarán su idea sobre el arte. En "El escritor en lengua española", de 1952, recogido en La estructura narrativa y otras experiencias literarias, afirma que la misión del literato es mejorar al vulgo mediante una obra cuyo desentrañamiento contribuya a la elevación espiritual. El artista ha de evitar caer en la engañosa premisa de degradar el arte para hacerlo más accesible a la masa. En esta línea de pensamiento, es partidario del intelectual sacerdote -estatuto que entronca con el clerc de Benda ${ }^{41}$ - y del escritor asceta, nunca profesionalizado, reacio tanto a la popularidad "fácil" como a las pingües ganancias. El adjetivo entrecomillado es de suma importancia, porque marca la diferencia con las obras para él más valiosas, las de Cervantes o Shakespeare, populares pero no "fáciles".

la obra literaria realmente grande combinará y escalonará en sí, siempre, los puntos de abordaje y vías de acceso de modo tal que atraiga a la multitud con una aparente sencillez, induciendo a cada uno para que avance, según las fuerzas de su alma, hacia el reducto del castillo espiritual, hacia su núcleo significativo. [EEE: 210]

Pero a falta de esta genialidad excepcional, "el escritor digno de su sacerdocio gobierna sectas, oficia en capillas, se dirige a los pocos elegidos, indiferente al despecho, a los denuestos, a la burla..." [EEE: 211]

Reivindica, por lo tanto, el capital simbólico, que convierte al hombre de letras en un ser socialmente prestigioso e influyente. Ha pasado la época gloriosa del arte nuevo, pero defiende aún uno de los rasgos por los que se caracterizó, y

${ }^{41}$ Al final de ensayo marcará un disenso que no modifica mi razonamiento: "...a diferencia de los orondos clercs de épocas culturalmente bonancibles", al escritor de hoy le toca "el destino ingrato de los profetas: pedradas, rechiflas, o una también pétrea sordera ante nuestros clamores y prédicas en el desierto". 
que redundó en mayores críticas: el sentimiento de pertenencia a un estamento superior, revestido ahora de una misión específica. Expresado con palabras de Estelle Irizarry,

\begin{abstract}
Ayala ve al intelectual contemporáneo en estado de crisis también, contagiado del desamparo general y a la vez denostado por su incapacidad en la crisis de nuestro mundo. La hostilidad de las masas contra las jerarquías de la inteligencia se debe a considerar los portadores de la espiritualidad como minoría parasitaria y voluntariamente sustraída de las circunstancias concretas... [1971: 82]
\end{abstract}

La impronta orteguiana sobrevive en la idea de una aristocracia de talento, aunque volcada ahora, no a la renovación del arte sino al mejoramiento del hombre, en una nueva versión de delectare y prodesse.

\begin{abstract}
Sacerdocio significa comunicación y mediación con una esfera trascendente, con el orden de lo espiritual; y el escritor tiene por misión, en efecto, captar los valores del espíritu en fórmulas que los hagan aptos para la comunión popular. Le importa, por lo tanto, y debe importarle, que el acto de comunicación se cumpla a través de su obra, sin lo cual ésta carecería de sentido, quedando frustrada; pero, al mismo tiempo, deber reconocer y no perder nunca de vista que el valor no radica en el acto de la comunicación, sino en la esfera transcendente donde su obra se inspira, y cuyo acceso es siempre escarpado, arriesgado, inseguro, de manera que una popularidad fácil vale, en verdad, como indicio de bastardía o impureza, de calidad inferior en la obra producida; sugiere rebajamiento al nivel del vulgo en lugar de un esfuerzo por elevarlo al grado de una humanidad superior. [EEE: 210]
\end{abstract}

Las consecuencias que recaen en el escritor que se mantiene fiel a estos principios en un mundo materialista y masificado se miden, según Ayala, en incomprensión, permanente soledad, exilio.

El régimen social de las masas que, en lugar de extraer, cultivar y fomentar lo valioso y digno de la humanidad, liberándolo de la opresión, ha desencadenado, por el contrario, y erigido en paradigma lo común, ordinario y vulgar, lo negativo de toda humanidad, convierte al escritor en exiliado nato, le expulsa, en medio de la multitud, al desierto. [EEE, 1952: 211]

El temor y la incomprensión de los fenómenos masivos -rasgos característicos del grupo Sur, según John King, reaparecen, reelaborados, en Francisco Ayala ${ }^{42}$. Las redes del campo intelectual excedían para este conjunto de

${ }^{42}$ El fenómeno del Peronismo es una verdadera prueba para intelectuales exiliados republicanos como Ayala. Valga como ilustración el siguiente ejemplo: en ocasión de presenciar "la multitud de siempre, desbordada y gritona" en un acto convocado por Perón en la Playa de Mayo citará el comentario de un funcionario de Franco sobre la multitud peronista, "'Pues en España, nosotros 
notables, los límites de las literaturas nacionales. Es sabido que el escritor granadino encontró en sus primeros años de destierro el seguro amparo de Victoria Ocampo, cuyo círculo tenía tanta fama de cerrado como el de Revista de Occidente $^{43}$.

Interesa a esta altura de la exposición examinar cómo se traducen en la materia textual de la segunda época las continuidades y los cambios mencionados. En principio, creo pertinente hablar de dos etapas, sobre todo habiendo un período de casi diez años sin actividad literaria entre una y otra descartando la idea de dos bloques dispares ${ }^{44}$.

En 1949 Ayala publica las primeras obras independientes -dos volúmenes de cuentos- después de la narrativa de vanguardia. Pese a la simultaneidad de la aparición, no las considero "gemelas", ya que varios de los relatos de Los usurpadores habían aparecido con anterioridad, uno de ellos, "Diálogo de los muertos", en 1939 como ya se ha apuntado ${ }^{45}$. No sucede lo mismo con La cabeza del cordero, libro del que sólo he podido registrar un cuento publicado de forma autónoma ${ }^{46}$.

Los cuentos de Los usurpadores se sitúan en el pasado y recrean hechos sobresalientes de la historia de España: la lucha fratricida entre Pedro I y Enrique de Trastamara, la lenta decadencia de la dinastía de los Austria, encarnada en la figura de Carlos II; la derrota de Alcazarquivir y la leyenda del rey don Sebastián de Portugal, son algunos de los episodios que recrea. Constituyen dos excepciones el primer cuento, "San Juan de Dios", cercano al relato hagiográfico con elementos de parábola evangélica, y el último, "Diálogo de los muertos", coloquio de fuerte valor simbólico entre dos víctimas de la guerra civil. La lectura de Los usurpadores, si bien no se vuelve hermética para un lector no familiarizado con la historia de

nos levantamos para impedir que esa gente salga a la calle' para luego añadir: "Confundía gente con gentuza, pueblo con populacho; pero en el fondo tenía razón". [Ayala, RO/2:124]

${ }^{43}$ La semblanza que traza Ayala de Ocampo encierra un dejo de crítica e ironía detrás de una declaración de respecto y amistad. Una de sus apreciaciones señala que a sus ojos era "el monumento que de ella había hecho Ortega y Gasset". [RO/2: 58-59]

${ }^{44}$ Parte de las hipótesis que siguen se recogen en Macciuci, 1997.

45 Sólo "El Inquisidor" es un relato posterior a los que integraron la primera edición de Los usurpadores. Fue publicado en Cuadernos Hispanoamericanos en 1950 y a partir de las Obras narrativas completas de 1969 pasó a formar parte del volumen.

${ }^{46}$ Se trata de "El mensaje", aparecido en Sur, 170, dic. 1948, 19-53. 
España, presupone una "enciclopedia" muy específica para actualizar los contenidos.

La dificultad no se agota en la especificidad de las referencias históricas. Si bien el discurso está a gran distancia, temática y formalmente, de la prosa de vanguardia, constituyen el principal desafío para el lector, pues el estilo -tomo las observaciones de Andrés Amorós- "remite a la complejidad y artificio de la prosa clásica, con sus "frases muy largas, de hasta catorce líneas, pero hábilmente repartidas y contrapesadas", "los adjetivos, las exclamaciones retóricas, los diálogos con lo inanimado, los esquemas triples, el ritmo bimembre, la simetría paralelística, las fórmulas contrapuestas, los sintagmas no progresivos, etc." [Amorós, 1978: 13]. La extensión de la siguiente cita es inevitable.

\begin{abstract}
En el ardor de las deliberaciones llegaron a olvidarse por completo del testamento, y hasta del propio rey Alfonso, tendido ahí, crecido, imponente bajo sus armas: la ancha espada rígida a su costado; entrelazados los cortos dedos peludos de sus manos, que salían como revoltijo de enormes gusanos por entre las mallas de los guanteletes hundidos y borrados los ojos que fueron lo terrible en su cara, y destacada en cambio la desvaída barba, rubia canosa, en cuyo desorden se medio perdía la famosa cicatriz por la que era reconocido de las gentes y que, desde la oreja, perpetuaba en la carne de la mejilla izquierda el veloz trazado del tajo que la abriera, hasta caer sobre el ángulo mismo de esa boca, ahora negra, de la que un paje oxeaba a las moscas contumaces [LU, "La campana de Huesca": 82).
\end{abstract}

El género de Los usurpadores - ¿relato histórico, hagiografía, apólogo moral, leyenda?- es otro factor que ha concitado la atención de los especialistas y evidencia que la recepción de la obra exige un lector activo, dispuesto a sortear, como ocurre con la obra de vanguardia, las exigencias de un texto altamente codificado; problema que ha analizado acertadamente Emilia de Zuleta:

No puede hablarse en este caso, simplemente, de narrativa histórica, y ello ha sido advertido por los críticos. Esa reducción de los elementos históricos a lo sustancial, su ordenamiento según la intención plasmada en un tema unificador, tienen su correlato en una organización estética concebida de modo tal que los motivos y las imágenes cobran tanta importancia como la acción y los personajes en la articulación de la estructura. [Zuleta, 1997: 94]

De las citas anteriores se desprende que el lector de Los usurpadores debe ser culto, avezado en lecturas de textos áureos, más deseoso de deleitarse con la 
morosidad y reminiscencias clásicas del estilo que de ser atrapado por un argumento o unos personajes aptos para las redes de la intriga. Si bien gran parte de los relatos permite una lectura guiada por un misterio a desvelar, la competencia del receptor avisado en resonantes episodios de la historia de España lleva a fijar la atención en otros aspectos, como por ejemplo el sondeo de los resortes de las conductas humanas cuando se hallan condicionadas por el agobio y la soledad del poder.

Es así como los retos de la recepción artística permanecen en algo grado, aunque hayan desaparecido los motivos básicos de la vanguardia cosmopolita. El lector implícito continúa revelándose como el individuo dueño de competencias altamente cualificadas; la gravedad se ha intensificado gracias a una mayor voluntad de transmitir preocupaciones morales, filosóficas o sociológicas.

La idea del arte con función edificante y aleccionadora, capaz de llamar a la reflexión, aparece en primer plano, ligada estrechamente a un sentimiento de superioridad moral e intelectual del que hace partícipe a los lectores que se congratulan de pertenecer a un grupo selecto frente al gran público adocenado. En este sentido, son harto esclarecedores y no necesitan comentario, los conceptos vertidos en la contratapa de una compilación crítica sobre la obra ayaliana -y se sabe que las contratapas son un guiño para el lector deseado. Reaparece, con un discurso adaptado a la realidad cultural de finales del siglo XX, la distancia, el aristocratismo de la elite ilustrada; el intento de perduración de una idea del arte y la cultura que desde las vanguardias mismas comenzó a resquebrajarse.

Francisco Ayala no es escritor-estrella fugaz que deslumbrara intensamente y luego desapareciera del firmamento literario; ni escritor-satélite que reciba su luz prestada y que, aunque brille con intensidad -incluso mayor que la de las estrellas- luego desaparezca. Ayala es un astro vivo del firmamento de la experiencia literaria (y por ello, humana). Pero su distancia ética y estética (gestada desde la entraña misma de su experiencia histórica), en relación con la mediocridad circundante, es tal, que ha precisado años para que su luz llegue con fuerza y con vida propia a los lectores de miras elevadas (lamentablemente, aquellos que siguen contemplando rastreramente el suelo apenas podrán percibir indirectamente la luz de don Francisco). [Vázquez Medel, 1998a, contratapa] 
Seguramente el elogio le parecerá a Ayala desmesurado, con un accesorio innecesario de altivez que no se condice con la sobriedad que lo caracteriza, pero interesa igualmente porque revela el halo que de él emana.

Es visible que la confianza en las doctrinas del liberalismo político y en la capacidad de la cultura como instrumento reformador, concatenadas con ideas morales de alcance universal, se volvió más explícita en sus textos-y también más escéptica- después de la guerra civil. Sin embargo, existe una constante que conecta con la vanguardia tal como la entendió y llevó a la práctica el escritor granadino. Incluso se puede afirmar que a partir de Tragicomedia de un hombre sin espíritu el proyecto creador es uno, pese a que haya adquirido distintos rostros en el siglo. 


\section{RAFAEL ALBERTI}

\section{1. el síntoma de alumno externo}

El nombre de Rafael Alberti (1902-1999) hizo circular una versión que más allá de su veracidad, se ha transformado en una imagen de un valor simbólico insoslayable: tres poetas, cuatro, de la llamada generación del 27 , orinando contra los muros de la Real Academia Española1. Las vanguardias versus. la institución literaria; no la institución arte en todo su alcance, pero tampoco cualquier institución. Se trataba del emblema supremo de las letras hispanas.

El autor de Marinero en tierra figura en los primeros planos de las historias de las letras españolas de este siglo, bien como poeta de la tradición neopopularista, bien como virtuoso compositor de poemas gongorinos, ya convertido en vanguardista irreverente frente a los muros de la RAE o en el Lyceum Club Femenino, cuando en plena rebelión surrealista pronunció una conferencia que escandalizó a una parte de las asistentes y arrancó aplausos y risas a la otra. ${ }^{2} \mathrm{El}$ interesado en su biografía literaria lo encontrará después como el autor del poemario surrealista más destacado de la literatura española, y a continuación, ya en los años treinta, lo verá convertido en paradigma del escritor comprometido. Derrotado el bando republicano, será después de 1939, la voz lírica del exilio; no el único pero sí uno de los símbolos sobresalientes de la España peregrina. Incansable en su

\footnotetext{
1 "-Le he dicho a Dámaso Alonso: 'Mira, no quiero ser académico porque no tengo ni siquiera el bachillerato y además un día me meé en aquellas paredes. ¿Qué iba yo a hacer ahí adentro?"'.

Cfr. -"Yo [Dámaso Alonso] no fui. Quiero decir que no lo recuerdo. No niego que pude haber estado allí; sólo digo que no lo recuerdo, y si no lo recuerdo es porque no estuve, de lo contrario me acordaría. Ya sé que Alberti lo va contando por allí (...) Nosotros nunca quemamos libros antigongorinos, ni nos orinamos contra nada-'. [Vicent, "Rafael Alberti, con los bolsillo llenos de sal marina" y "Dámaso Alonso: en el jardín de la filología", 1984: 43 y 77].

${ }^{2}$ El episodio ha sido recordado por distintos testigos: Alberti refiere en sus memorias que fue invitado a dar una conferencia el 10 de noviembre de 1928 en el Lyceum Club, círculo femenino. El titulo propuesto fue "Palomita y Galápago (¡No más artríticos!)", también anunciado "Divertimiento sobre la poesía cómica española", y se presentó a dictarla acompañado de sendos animales y vestido con un atuendo funambulesco. La conferencia se burlaba de los nombres más prestigiosos de la literatura consagrada: Juan Ramón Jiménez, Pérez de Ayala, Ortega, D'Ors, Canedo, Valle Inclán. El acto terminó en escándalo y se dice que una dama lo abofeteó a la salida. EI protagonista inscribe el suceso en la agitación espiritual de esos años clave en su vida: "Yo era un tonto y lo que había visto y continuaba viendo me habían convertido en dos tontos. Quiero decir que estaba ya dispuesto a vengarme de todo, a poner bombas de verdad, o casi de verdad, como aquella que entre burlas y veras coloqué una tarde en aquel Lyceum femenino" [AP I: 282]
} 
denuncia de la dictadura, retornorá por fin a su patria, no para descansar sino para sumarse a otro tipo de combate, esta vez desde su cargo como diputado del PCE, electo por Cádiz en las Cortes Constituyentes de junio de 1976, las primeras de la reinstauración democrática.

De él ha escrito el prestigioso crítico Ricardo Gullón:

Leer la obra de Alberti, desde 1924 a 1962, es estudiar en vivo la evolución de la poesía contemporánea. Sin ceder a la pedante tentación sistematizadora que cree descubrir en la clasificación el secreto de lo escrito, y aun de lo vivido, es posible señalar en este poeta cinco tendencias coincidentes con otros tantos avatares de la lírica de nuestro tiempo. [Gullón: 1975: 65]

De forma parecida juzga la trayectoria albertiana Luis García Montero, eximio especialista y editor de su Poesía:

\begin{abstract}
Rafael Alberti es un caso ejemplar. Alberti cambia, se define en sus propios cambios y define a la vez el desarrollo de la lírica española más característica. Ocupa el lugar de la metáfora viva. Desde sus inicios asume la carencia, la palabra de la civilización que vive en la pérdida y que sólo puede instalar sus paraísos en un espacio distanciado de la realidad, en una metáfora móvil. La inquietud y la búsqueda son las peculiaridades más llamativas de su estilo. [García Montero, 1988, xxxii]
\end{abstract}

En las siguientes páginas procuraré describir la trama que une la trayectoria estética de Alberti, la forma de situarse en el tiempo histórico y su particular actuación como escritor y hombre público en el período analizado en este libro.

En el capítulo anterior he analizado cómo Ayala, adepto tardío al arte nuevo, concentra en los breves relatos escritos en un lapso temporal muy acotado -poco más de un año-, una densa enciclopedia vanguardista, visible en motivos, procedimientos e imaginarios culturales y estéticos. La relación de Alberti con la vanguardia tiene rasgos opuestos: desplegada en el tiempo, los distintos ismos quedan registrados en una suerte de sucesión lógica en distintos poemarios publicados durante más de una década, desde comienzos de los años veinte hasta el final de la guerra civil.

Es bien conocida la forma súbita en que el poeta gaditano irrumpe en el campo de las letras con la obtención del Premio Nacional de Poesía en 1924, 
concedido por un exigente jurado compuesto por Ramón Menéndez Pidal, Gabriel Maura Gamazo, Carlos Arniches, Antonio Machado y José Moreno Villa, los dos últimos por poesía. El poemario, originalmente titulado Mar y tierra, será publicado con el título de Marinero en tierra en 1925 y servirá para que, ya desplazados los primeros ismos -ultraísmo y creacionismo-, se instale un nuevo patrón de poesía vanguardista española. Al mismo tiempo comienzan a forjarse los intentos de sintetizar la poesía más innovadora e internacional del primer cuarto de siglo en dos sellos de larga vida: la fórmula "tradición más vanguardia" y el rótulo " generación del 27". Es momento de volver a las ideas que anticipé en el capítulo correspondiente a las vanguardias en la periferia para ir más allá de los mencionados marbetes, no porque los considere falsos sino porque a todas luces, resultan empobrecedores de un fenómeno más extendido y complejo.

En primer lugar se debe atender al cambio, lento pero ininterrumpido, por el cual desde fin de siglo España buscaba adecuarse al ritmo de los países modernos. Las manifestaciones de este anhelo comprendían todas las esferas de lo social. Para el seguimiento del proceso en el campo de las artes y la cultura. José Carlos Mainer ha reseñado los modos en que esas energías hallaron distintos cauces institucionales entre 1920 y 1936: periódicos, revistas, exposiciones, auge editorial, expansión cultural desde la capital a las provincias, divulgación de la cultura mediante ediciones populares. En un lugar preeminente se sitúa la creación de la Junta para la Ampliación de Estudios -piedra sillar del actual Consejo Superior de Investigaciones Científicas (CSIC)- y de la Residencia de Estudiantes, secundados los dos organismos por un notorio mejoramiento de la enseñanza universitaria. En la formación del campo intelectual es de destacar la incorporación de jóvenes procedentes, en gran parte, de la burguesía bien situada $^{3}$, con medios y vocación para que sus hijos se subieran al tren del progreso. El resultado se ha anticipado en capítulos anteriores: al final de la dictadura de Primo de Rivera España se hallaba más integrada, no sólo a Europa sino también entre sí,

${ }^{3}$ Se han mencionado las distintas visiones sobre esta cuestión: había un no desdeñable grupo de clase media que pasaba apuros; los casos de Ayala y Alberti son siempre citados como ejemplos de burguesía venida a menos obligada a emigrar a la capital y afrontar dificultades económicas. 
la radiodifusión, el automóvil, el cinematógrafo y aquella cultura de quiosco a la que aludía más arriba borrarían muchas distancias y supondrán un paso gigantesco en la integración moral y política del país, en la conquista de una "vida nacional" irrigada por idéntico fluido histórico. [Mainer, 1990: 76]

Cuando Alberti llega a Madrid proveniente del Puerto de Santa María se integrará sesgadamente al mundo selecto de los jóvenes artistas. Desde los comienzos de su trayectoria conviven conflictivamente en él la doble vertiente del rebelde, marginal a los círculos de los señoritos habitantes de la Residencia, bien instalados en la vida académica, y la del estudioso que se unía al proyecto modernizador por vías institucionales. En principio, no vivía en la "Colina de los chopos"; sus biógrafos han detallado sus penurias económicas, que el propio Alberti relata en La arboleda perdida ${ }^{4}$. No interesa tanto el grado de necesidad del poeta de Cádiz, porque quizás hubo quienes sufrían mayores estrecheces; es muy relevante en cambio la imagen de escritor que Alberti va a construir y la que los otros elaborarán de él, cifrada en la no pertenencia al grupo, en la condición social diversa. La figura construida no es inopinada: comienza en su infancia de estudiante en un colegio jesuita, donde sufría la discriminación propia de los alumnos externos, más pobres frente a los internos y pudientes.

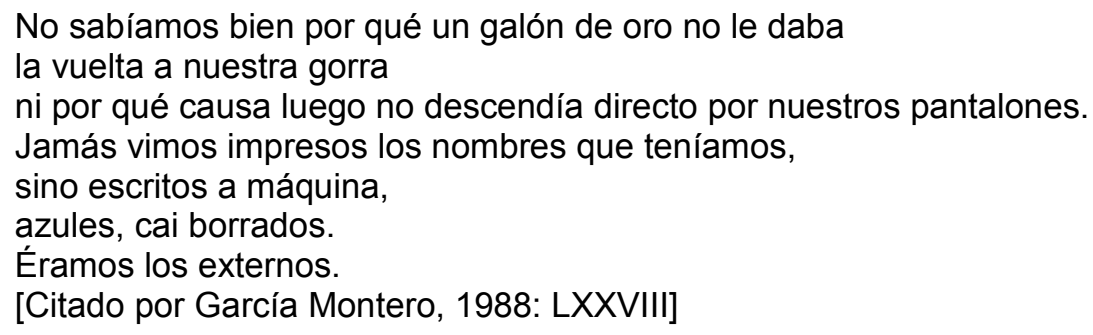

\subsection{La poesía nUeva. Un diálogo privilegiado con las vanguardias}

Hemos visto que en la larga parábola del arte moderno pueden conciliarse la estética simbolista y el espíritu del arte nuevo, la poesía pura con la aparente intrascendencia; el amor por lo nuevo y la recuperación de la poesía tradicional y

\footnotetext{
${ }^{4}$ Alberti escribió tres volúmenes de memorias, aparecidas como La arboleda perdida. Libros I y II (1959), La arboleda perdida (Segunda parte) (1987) y La arboleda perdida (Tercera parte), (1989). De la primera parte existe una edición independiente publicada en 1942 como La arboleda perdida (Libro primero de memorias y otras prosas), México: Séneca.
} 
del siglo XVI. Marinero en tierra es un ejemplo privilegiado de tales convergencias: cuando la línea más pura de la lírica juanrramoniana se une a la sencillez del cancionero y la lírica primitiva surge el neopopularismo.

Pero los versos premiados venían con recomendaciones y reticencias que vale la pena conocer en tanto iluminan la clase de pugna que se daba en el campo estético y cultural. Maura Gamazo quería premiar a Julián Sánchez Prieto, cuyos poemas presentados al concurso no he podido recuperar, pero sí un breve fragmento que da el tenor de su lírica:

Generosa tierra mía, la que se viste de flores para recibir al hijo que vuelve de la campaña, la de los rojos claveles y los frutos como el oro ¡La que tiene los colores de la bandera de España! ${ }^{5}$

[Citado por Soria Olmedo, 1990: 111]

Si el fragmento transcripto diera lugar a objeciones metodológicas, dadas la procedencia y la distancia de los hechos que se juzgan, creo quedarán disipadas al complementarse con juicios aparecidos años después del otorgamiento del premio mayor de poesía de España.

Alberti, el autor de Marinero en tierra, premio Nacional, se le /sic/ debió quizás a un jurado asaz connivente; pero sin el bagaje cuasiclásico, de seguro que el jurado no se hubiera atrevido a nacionalizar aquellas poesías.

Aceptada con reticencias la decisión del jurado, se permite el crítico añadir su recomendación -y admonición- final:

sic] y estos son, sin embargo, merced a su talento, esperamos que, sin tardar, vuelvan a sus lares patrios y a los penates clásicos"6. [citado por Soria Olmedo, 1991: 112]

Según las observaciones de Mainer antes aludidas, y las propias del investigador que rescató los comentarios anteriores, a la par de la batalla estética entre academicismo y vanguardia, se libraba una batalla por una nueva cultura

${ }^{5}$ Corresponde a un fragmento de la zarzuela El ruiseñor de la huerta (1929). Otro ejemplo: "Es artista y cordobesa,/ con andares de gitana;/ mira como una sultana/ y habla como una princesa". ("Canto a la mujer cordobesa)".

${ }^{6}$ Corresponde a C. Eguía Ruiz S.J. "Del creacionismo y ultraísmo al vanguardismo en España. Un decenio de incongruencias". Razón y fe, 85, oct. dic. 1928, p. 518. (Se trata de una publicación de la Compañía de Jesús). 
que debía desplazar al viejo y obsoleto modelo de la Restauración, ofreciendo una moral rejuvenecida y una manera acorde a los tiempos de sentir y ver la realidad. Los ejecutores del ambicioso proyecto que miraba hacia Europa tendrán dos figuras rectoras; Ortega en el campo del pensamiento y el médico Gregorio Marañón en el de la ciencia.

\begin{abstract}
La revisión de estas primeras reacciones de lectura nos permiten enfocar el fenómeno de Marinero en tierra a la luz paradójica de una cierta militancia artística, como libro al servicio de una estética y una ideología, dentro de una vasta corriente que pretende establecer su hegemonía, en el sentido gramsciano del término, sobre el conjunto del país en el terreno cultural y en el terreno estético; dentro de él, en el terreno poético. Desde ese punto de vista, la práctica de Alberti forma parte de un bloque intelectual de la burguesía, en proceso de gestación, que pretende hallar nuevos medios de expresión, más acordes en el terreno cultural con la hegemonía que está adquiriendo en el terreno político y que culminará con la toma del poder al instaurar la Segunda República..." [Soria Olmedo, 1991: 112]
\end{abstract}

Antes de continuar, considero necesario hacer una advertencia: de la misma manera que en los anteriores capítulos no me he detenido en la abrumadora capacidad de invención y en los múltiples caminos que la imaginación de Gómez de la Serna abrió a la palabra poética; ni me fue posible profundizar en el complejo e intelectual universo narrativo de Francisco Ayala, en esta ocasión habré de resignar explayarme en el talento poético de Alberti, cuya capacidad para cultivar registros diversos ha generado minuciosos trabajos especializados ${ }^{7}$. Aspiro, no obstante, a que su discurso poético no quede en sombras porque mi análisis no prescinde del hecho literario, sino que lo introduce en una trama más amplia.

Los conocedores de la obra albertiana destacan la veloz y rotunda integración de Alberti al campo de los poetas consagrados desde su primer libro de versos, que daba ya muestras de una inusitada madurez.

Es verdad que hubo un período previo que se inició en Sí, revista dirigida por Juan Ramón Jiménez, y continuó bajo las premisas del ultraísmo ${ }^{8}$, visibles en

7 Para aspectos temáticos y procedimientos estilísticos, técnicos y retóricos, $\mathrm{V}$. los clásicos estudios de Salinas de Marichal [1968] , Zuleta [1971], Zardoya, [1974] y Tejada [1977].

${ }^{8} \mathrm{Si}$ hemos de guiarnos por la "Carta de Juan Ramón Jiménez" que precede Marinero en tierra, Alberti había anticipado algunos de los versos de su primer libro: "Las poesías de este libro -que yo había visto ya, el año pasado, en La Verdad de nuestro fervoroso Juan Guerrero y en las copias que usted tuvo la bondad de enviarme para el primer Sí..." [MT, 1977: 11] 
tres poemas en Ultra ${ }^{9}$ aparecidos en mayo de 1924 con el título de "Balcones"; Hoy, gracias a una sobrina del poeta, se han reunido hasta cuarenta y ocho composiciones anteriores a su primer libro. Los poemas dispersos en las distintas revistas no disminuyen el carácter excepcional de Marinero en tierra y, por otra parte, afirman mi hipótesis sobre la peculiar capacidad de Alberti para seguir el pulso de la estética vanguardista en sus diversas modalidades. Serían los años previos a Marinero un tiempo de búsqueda y tanteos para el poeta, quien posteriormente, en su La arboleda perdida, prefirió explicar su inicio en la poesía como resultado de la conmoción sufrida por la muerte de su padre, ocurrida en 1920; momento en que decide cambiar la pintura, su primera vocación, por la poesía. Este poema considerado fundante por el autor, en sus ecos de León Felipe, en especial de sus versos contrarios al ultraísmo, encierran una ruptura con sus experiencias primerizas.

Bien aprovechados, sus ensayos iniciales maduran plenamente en Marinero en tierra. En los versos despojados, musicales y luminosos de su primer libro de poesías, Alberti logrará una síntesis feliz de los gustos estéticos que terminarían imponiéndose. Debe recordarse que por entonces, Menéndez Pidal y su Centro de Estudios Históricos establecían las bases científicas de la recuperación de la lírica tradicional, inscripta a su vez en la tendencia más amplia de la búsqueda de lo popular. El proyecto aparece así secundado por un planteamiento estético; erudición y poesía retornan avenidos a las mismas raíces. Al mismo tiempo, converge con la recuperación del fondo tradicional y con la tendencia al clasicismo y a la depuración retórica de la modernidad estética. En el recurso de la fragmentación y la abreviación subyace una poesía cuyos modelos eran Baudelaire, Mallarme, Valéry. La vanguardia post-ultraísta tampoco fue indiferente al clasicismo propugnado por Jules Romains y André Gide, pero con un alerta ante el riesgo de que en la Península, clasicismo se tradujera como casticismo ${ }^{10}$. Vale

${ }^{9}$ Ultra apareció en Madrid en 1921 y 1922, salieron veinticuatro números. Fue la gran publicación del movimiento ultraísta. Tenía formato de tríptico y fueron notables sus cubiertas xilográficas, algunas en colores. Entre sus numerosos colaboradores destacan José Rivas Panedas, Guillermo de Torre, Gerardo Diego, Rosa Chacel, Ramón Gómez de la Serna, Manuel Garfias, Luis Buñuel, Jorge Luis Borges, Norah Borges.

${ }^{10}$ Soria Olmedo cita palabras de José Bergamín: En España el regreso al clasicismo debe andar con cuidado, "pues el blanco cordero correría el riesgo de ser guisado por aquellos para quienes clásico quiere decir: guisote grasiento, garbanzo, olla podrida, etcétera". (subrayado de Bergamín) 
la pena insistir en que la vanguardia sintió un rechazo intenso por todo aquello que pudiera interpretarse como exaltación de valores telúricos o invocación a las esencias nacionales ${ }^{11}$.

Para percibir las señas eminentemente modernas de la poesía albertiana, a lo ya dicho se puede añadir la observación de Soria Olmedo sobre la conformación de un sujeto errante, en búsqueda perpetua de su centro, sometido a fuerzas opuestas, simbolizadas en el mar y la tierra, motivos que se reiteran en toda su biografía poética, y se anuncian precozmente en el título mismo del libro y en las dramáticas interpelaciones de la primera página: "¿Por qué me trajiste, padre,/a la ciudad?/ ¿Por qué me desenterraste/ del mar?". El sujeto atravesado por vectores opuestos, será una constante de la lírica albertiana que se corresponde especularmente en su primera imagen de autor, a mitad de camino entre la displicencia belicosa y la circunspección profesional; una anécdota varias veces relatada sintetiza el conflicto: gastó el dinero obtenido por el Premio Nacional de Poesía en comprar helados y las obras de Gil Vicente.

En sintonía con los esfuerzos por perfeccionar su poesía, en la primera época se observa una consciente y rigurosa labor de depuración y construcción de una lengua poética, en la cual la pureza y desnudez de lenguaje poético vanguardista se traduce, continuando con el criterioso estudio de Soria Olmedo, en un "enfriamiento" del color local. El trabajo de estilización es notorio en la recuperación del fondo tradicional andaluz despojado de referencias geográficas, nombres propios o tópicos regionalistas. Alberti profundiza la depuración mediante el buceo en el cancionero Gil Vicente, sobre todo- evitando de esta manera el "acarreo fácil", operación que mereció el elogio de Juan Ramón en la famosa carta introductoria al tercer apartado. De esta manera, encareciendo las raíces, universaliza el discurso poético a partir de

[1990: 110]

${ }^{11}$ Mainer considera que pese a las diferencias, existía una comunidad de objetivos entre el 98 y la generación más europeísta nucleada por Ortega, ya que ambas sentían la misma vocación modernizadora; el auténtico enemigo de esta meta lo encarnaría la burguesía pacata amante de un arte adocenado y ramplón. En cierto modo, los grandes maestros - Juan Ramón, Antonio Machado, Unamuno- nunca sufrieron el escarnio de un Galdós, por ejemplo, aunque el mismo catedrático de Zaragoza reproduce palabras de Bergamín que reflejan un sentimiento, al menos, ambiguo: "dijo noventayocho y al decirlo, su voz doblaba a muerto, lánguidamente, como una campana" [Gaceta Literaria, $\mathrm{N}^{\circ}$ 3, 1927, citado por Mainer, 1991: 70]. Y sobran ejemplos de que la llamada Generación del 98 fue poco consecuente con la empresa modenizadora que sus hijos emprenderían más animosamente. 
una operación de ida y vuelta que recuerda a la definida por Alfredo Bosi para explicar la vanguardia latinoamericana. La lengua poética es el resultado de filtrar la retórica superficial y redundante, pero manteniendo un nota de sentimiento; Alberti nunca toma la distancia aséptica de algunos poemas ultraístas o del gozoso intelectualismo de Jorge Guillén. El sujeto poético deja entrever, al menos hasta la experiencia de Cal y canto, una sombra de melancolía y de vitalidad

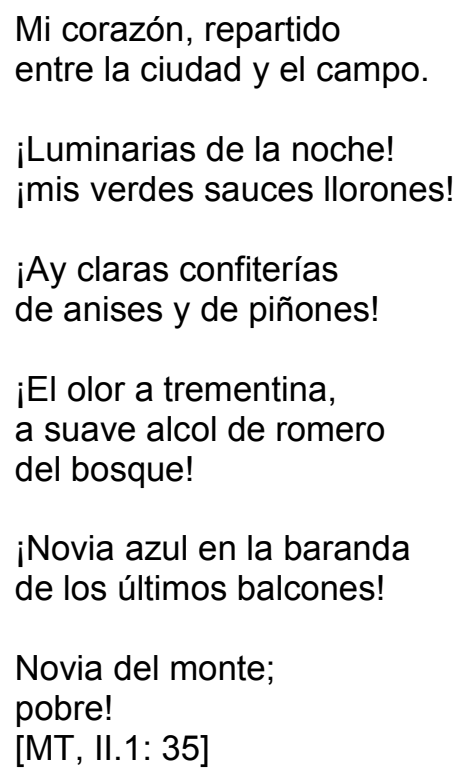

El neopopularismo de la primera época reaparecerá con nuevos rasgos en un segundo momento, después de la revolución de octubre de 1934, cuando otras son las circunstancias y la recepción de la literatura. En su poesía de denuncia y de combate, Alberti se hace eco del renacimiento del romancero, recuperado con más fuerza en la zona republicana debido a la mayor cercanía a los sectores populares. Volveré sobre este registro poético que recobra otros elementos de la tradición, entre los que destaca la oralidad y la vertiente satírica. El no reconocimiento de estos materiales deriva en desaprobaciones fundadas en perspectivas estetizantes, que no son pertinentes para un hecho literario que en los años 30 responde a una concepción del arte muy diferente de las que habían impulsado el neopopularismo inicial.

Volviendo a la primera época, es oportuno registrar la advertencia de Pere Gimferrer acerca de la preeminencia que se ha otorgado a la tercera parte de Marinero en tierra, encabezada con idéntico título, y realzada por la elogiosa carta 
de Juan Ramón Jiménez ${ }^{12}$. Con el eclipse de las partes primera y segunda se desdibuja el importante influjo de otros poetas que serán objeto de posteriores evocaciones en Alberti: Quevedo, Góngora y Lope de Vega. Asimismo, la focalización en el libro III obtura el amplio espectro al que se abría la poesía albertiana, germen de posteriores profundizaciones en otros registros.

Cuantos-y fueron todos- admiraron desde un principio Marinero en tierra, difícilmente se hallaban en situación de percibir hasta qué punto aquel libro anunciaba la abarcadora diversidad con la que Alberti (...) configuraría una de las obras más cargadas de poder indagatorio de la poesía castellana contemporánea. [Gimferrer, 1998: 7]

En los poemarios siguientes Alberti continuará experimentando con el neopopularismo. En La amante (1925) traslada el espacio poético a tierras de Castilla, en un itinerario viajero y espiritual a la vez. El módulo predominante continúa siendo el de la poesía tradicional, con alta presencia de la construcción paralelística, acompañada de motivos igualmente tomados del cancionero y de la lírica popular. Alberti reitera el gusto por el misterio y los interrogantes sin respuesta, germen de breves episodios dramáticos.

\author{
Zarza florida. \\ Rosal sin vida. \\ Salí de mi casa, amante, \\ por ir al campo a buscarte. \\ Y en una zarza florida \\ hallé la cinta prendida, \\ de tu delantal, mi vida. \\ Hallé tu cinta prendida, \\ y más allá, mi querida, \\ te encontré muy mal herida \\ bajo del rosal, mi vida. \\ Zarza florida. \\ Rosal sin vida. \\ Bajo del rosal sin vida \\ [LA, 3. "San Rafael (sierra de Guadarrama)": 42
}

\footnotetext{
${ }^{12}$ El poemario se organiza en la carta de Juan Ramón Jiménez, seguida de un prólogo, compuesto de un poesía en tercetos titulado "Sueño del marinero". Continúa el cuerpo del libroo, dividido en tres partes, primera y segunda introducidas solamente por los números I y II y una tercera titulada "Marinero en tierra". Aunque es sobradamente conocido, merece citarse el principal pasaje de la carta del poeta de Moguer: "Poesía 'popular', pero sin acarreo fácil: personalísima; de tradición española, pero sin retorno innecesario: nueva; fresca y acabada a la vez; rendida, ájil, graciosa, parpadeante: andalucísima". [MT. "Carta de Juan Ramón Jiménez", 1977: 12]
} 
El alba del alhelí (1925-1926), respondiendo a la eufonía y aliteración presentes en el título, representa una intensificación de los aspectos sonoros, lumínicos y plásticos, recursos en que se destaca con singular maestría el poeta gaditano. Versos como "iAy mis alfanjes guerreros,/tintos de moras moradas!/¡Picas mías, coronadas/de limonares luneros!/" [EAA: 54] o " $E$ El amarillo lucero,/ cogido a la verde rama/ del celeste duraznero!" [EAA: 60] ilustran la dirección predominante en el poemario. El juego con el significante, a menudo cercano a la jitanjáfora, recuerda el gusto de la vanguardia por los estados de inocencia y puerilidad, en vecindad, por otra parte, al mundo del inconsciente y del sinsentido, como lo había introducido el movimiento Dadá y lo registrara Ortega en La deshumanización del arte.

\author{
¡Vente rondaflor, al puente \\ de la golondrina, amor! \\ - ¡Buenos días, hiladora \\ del agua-rosa-naciente! \\ -¡Buenos días, rondaflor! ... [EAA: 59]
}

Cal y canto (1926-192) coincide con la exaltación de Góngora por el grupo de poetas vanguardistas. Se aleja Alberti de las formas estróficas breves de la lírica tradicional y muestra su virtuosismo en el cultivo del verso clásico en arte mayo, en las cuales sobresale el homenaje a Góngora a través de sonetos, silvas, romances y una Soledad Tercera. La realidad-otra, estilizada y extrañada, que caracteriza los más exquisitos poemas barrocos se recuperan en $\mathrm{Cal}$ y canto a través del tratamiento del mito, con transfiguraciones que dejan ver el salto al irracionalismo del arte moderno ${ }^{13}$. La cita intelectual y culta del barroco, que requiere un lector catecúmeno, reaparece en $\mathrm{Cal}$ y canto con una exigencia mayor, porque pide además un elevado grado de abstracción. A la dificultad del código poético de Góngora debe añadirse la ruptura de la obra orgánica: la lengua y las referencias cultas se entrelazan con símbolos de enigmático significado, como el toro, que tendrá larga permanencia en su poesía posterior.

${ }^{13}$ Carlos Bousoño, en su clásico libro Teoría de la expresión poética, [Gredos, 1952] ha señalado como un rasgo clave para diferenciar la imagen clásica de la moderna la ausencia de una conexión lógica, racional, por oscura que sea, entre la serie real y la metafórica. 
Herida, sobre un toro desmandado, salta la noche que la mar cimbrea ¿Por dónde tú, si ardiendo en la marea va, vengador, mi can decapitado?

Rompe la aurora en el acantilado su frente y por el viento marinea. ¿Por dónde tú, si el pabellón ondea, de luto, al alba, el toro desanclado?

[CC, "Busca" (fragm.): 78]

Mucho se ha hablado de la reivindicación del autor de Fábula de Polifemo y Galatea por los poetas del 27. Considero arriesgado establecer un denominador común en las distintas lecturas de Góngora por los escritores jóvenes, pero es indudable que la concepción moderna de la lengua literaria confluía con la vanguardia devota de la perfección formal de los grandes poetas simbolistas y parnasianos: Mallarmé, Valery en Francia, Juan Ramón Jiménez en España. Pureza, elaboración, distanciamiento del sujeto lírico, constituyen quizás la forma de entender la vanguardia más cercana a los postulados de Ortega, aunque el mundo de la poesía no haya sido el centro de sus ensayos estéticos. Es muy conocido el artículo de Walter Mignolo en el cual desarrolla la hipótesis de que la lírica moderna favorece una imagen del poeta identificable con la figura autoral, en tanto "la lírica de vanguardia se construye sobrepasando los límites de lo humano", y es, por ello, que "paulatinamente se evapora" para dejar en su lugar "la presencia de una voz" [Mignolo, 1984: 63]. Es significativo que uno de los antecedentes que invoca en su razonada tesis sea un pasaje de $\mathrm{La}$ deshumanización del arte, en el cual Ortega, refiriéndose a Mallarmé, subraya el borramiento del sujeto lírico tradicional. La formalización de esta nueva posición enunciativa autoral presenta en $\mathrm{Cal}$ y canto una manera muy diferente a la que adoptará en Sobre los ángeles.

Al poemario más gongorino y deshumanizado de Alberti se le pueden aplicar las observaciones que Ortega hace sobre el poeta francés:

A fuerza de negaciones, el verso de Mallarmé anula toda resonancia vital y nos presenta figuras tan extraterrestres que el mero contemplarlas es ya sumo placer. ¿Qué puede hacer entre estas fisonomías el pobre rostro del hombre que oficia de poeta? SOLO UNA COSA: DESAPARECER, VOLATILIZARSE Y QUEDAR 
CONVERTIDO EN UNA PURA VOZ ANÓNIMA QUE SOSTIENE EN EL AIRE LAS PLAGARES, VERDADERAS PROTAGONISTAS DE LA EMPRESA LÍRICA. Esa pura vOz anónima, mero subtrato acústico del verso, es la voz del poeta, que sabe aislarse de su hombre circundante. [DA (cita y subrayado de Mignolo, 1984: 65]

Si consideramos los distintos momentos de la poesía de Alberti como índices privilegiados de la larga parábola del arte moderno, es claro que Cal y canto representa, a partir del mismo título, el momento de mayor hermetismo y deshumanización, en que el arte nuevo se concentra en el material y en la forma, indiferente a la recepción de otro público que no fuera el de los iniciados. Es la época en que las revistas de vanguardia decidían el futuro de un poeta; las memorias de Alberti revelan la desazón que le producía la espera del veredicto de los críticos o de los poetas ya consagrados.

Después de Cal y canto, cumbre del arte puro, sobrevendrá un cambio de rumbo. Al hablar del escritor gaditano, es preciso volver a precisar que pese a los importantes puntos de encuentro entre el arte moderno y los ismos -y Cal y canto es una claro ejemplo de aproximación- la vanguardia se diferenciará por el dinamismo, por la búsqueda incesante, al contrario del poeta torremarfileño, que se sentirá complacido en un ámbito exclusivo para el ennoblecimiento de su arte. El poeta del Puerto de Santa María es, por el contrario, el máximo representante de la celeridad y el afán de búsqueda y transformación que caracteriza a las letras de la tercera década del siglo XX.

\footnotetext{
Rafael Alberti es el poeta español contemporáneo que mejor cumple este destino de vitalismo literario y moral estética. Más que la elaboración profunda de un mundo estético propio, su poesía quiso definirse en el movimiento, en la búsqueda, en la maestría danzante, en el paso de un estilo a otro. Neopopularismo, gongorismo, surrealismo, poesía de compromiso, verso meditativo, la obra de Rafael Alberti encara el impulso de la insatisfacción, la llama viva de un deseo que tiende a dudar del presente a favor de la elegía o del himno, del paraíso perdido o del futuro por conquistar. Su poesía esgrime la misma condena de nomadismo que su propia vida, el mismo impulso del deseo insatisfecho. [García Montero, 1999: 52]
}

El clasicismo y la ruptura -los libros canónicos y los helados- pugnan en Cal y canto, pese a la impronta hermética y deshumanizada. Junto al clasicismo de los sonetos, las silvas y la "Soledad Tercera", el libro sorprende con la 
incorporación de los motivos del progreso y la vida ciudadana, encarnados en dioses urbanos, medios de transporte y otras novedades tecnológicas: Venus sube en ascensor y Narciso trabaja en una camisería. La dignificación de materiales espurios, envueltos en el ropaje noble de las formas canónicas y del discurso lírico altamente elaborado, recuerdan el collage cubista o la provocación dadaísta y anticipa operaciones similares a las halladas en la prosa de Francisco Ayala. Si el arte ha sido reificado, los oficios sin abolengo -una nadadora, un arquero de fútbol Platko,- y nuevas cosas vulgares -no ya las de Azorín- pueden convertise en temas poéticos: un billete de tranvía origina un madrigal, un telegrama un poema breve.

\section{Angel terrenal}

En 1929 aparece Sobre los ángeles, una obra decisiva en la producción albertiana, para muchos, su cima poética ${ }^{14}$. Dejando de lado juicios que, ya se ha visto, están muy imbricados con los intereses y actitudes del receptor -no es casualidad que Pere Gimferrer, crítico sutil pero también narrador y poeta, claro heredero de las vanguardias e incondicional del surrealismo, aprecie Sobre los ángeles y Sermones y moradas por sobre los precedentes libros de Alberti ${ }^{15}$.

Cualesquiera sean las predilecciones de los críticos, debe reconocerse que ambos poemarios tienen un sello particular, y cumplen una función clave en la trayectoria del poeta.

${ }_{14}$ Transcribo distintos juicios: "El alcance poético de Alberti en Sobre los ángeles es, en cierto sentido, único en la poesía moderna post-baudelaireana e incluso post-rimbaudiana". [Krysinski, 1996: 23]. Azorín consideró que con el poemario Alberti había llegado "a las más altas cumbres de la poesía lírica" [AP I: 276].

15 "Sermones y moradas, (que) lleva la exploración abierta en Sobre los ángeles a sus últimas consecuencias y contiene acaso los más importantes poemas de toda la obra de Alberti anterior a la guerra civil". [Gimferrer, 2000: 241] 
En torno a Sobre los ángeles se han establecido dos controversias principales. Una de ellas es acerca de la impronta autobiográfica -relacionada con una profunda crisis, sentimental y vital que sufrió Alberti en el tiempo de la redacción. Esta cuestión enlaza con la lectura que puede hacerse del motivo angélico. El asunto enviste gran complejidad pues confluyen múltiples referencias de la tradición occidental, pero sobre todo, bíblica, como el mismo título lo anticipa.

En muchos casos el crítico ha tendido a trasladar de un modo reflejo la información biográfica, los testimonios de amigos y las confesiones del propio Alberti en La arboleda perdida, libro escrito con una posteridad de casi tres décadas. Reitero pues las mismas advertencias que realicé ante otros textos autobiográficos tratados en este mismo libro.

Entre quienes se han ocupado de este poemario, Luis Felipe Vivanco encuentra en la crisis amorosa y existencial su motor primero, agudizada por el fin de la etapa juvenil y la pérdida de la fe religiosa.

\begin{abstract}
Antes de seguir adelante, debemos tener en cuenta que en los primeros poemas del libro hay una gran tragedia amorosa. Yo he conocido personalmente a Alberti, le he acompañado por las calles de Cercedilla, y he llegado a ser amigo suyo cuando le dolía esta tragedia, cuando sufría de veras -y no sólo romántica o literariamente- por ella". [Vivanco, 1975: 192]
\end{abstract}

Las circunstancias personales del poeta gaditano llevan a Vivanco a negar la presencia de determinaciones relacionadas con la esfera del arte, y en particular, con el movimiento surrealista, que constituye el núcleo del otro importante debate al que aludía más arriba.

\begin{abstract}
Hoy día sabemos que Bécquer, junto con Poe y Baudelaire, forma la trilogía de grandes poetas post-románticos, super-lúcidos y super-conscientes. En este sentido, debemos situarlos en el extremo opuesto de todo surrealismo, con sus imágenes, no sólo autónomas como las creacionistas, sino automáticas. Y también Alberti, a pesar de sus posibles conatos de contagio. Por eso he dicho antes que llegaba a utilizar imágenes aparentemente resueltas, sin el control de la conciencia. Pero, aparentemente, nada más. Por otra parte, la culpa del peculiar surrealismo de Alberti no la tienen ni Bécquer ni Baudelaire, sino el profeta Isaías. [Vivanco, 1975: 199]
\end{abstract}

Ya he manifestado mi escepticismo ante las lecturas biográficas, aun cuando se trate de poesía, género propicio para la identificación del sujeto lírico 
con el sujeto de enunciación ${ }^{16}$. Esta identificación es más problemática cuando la poesía que se analiza es de vanguardia pues, como se ha aludido, el sujeto lírico de la lírica tradicional sufre importantes innovaciones.

En el caso del poeta gaditano, me desanima a hacer una lectura biográfica lineal el simple hecho, quizás tan reductor como la anterior deducción, que al mismo tiempo que escribía este poemario de tono atormentando, disolvente y sombrío, publicaba en La Gaceta Literaria las poesías que serían recogidas en Yo era un tonto y lo que he visto me ha hecho dos tontos, de tono risueño aunque no exento de melancolía. Si no fueron simultáneas, fueron inmediatas, de cualquier modo, intermedias entre Sobre los ángeles y Sermones y moradas, libro que también transmite, y aun acentúa, el estado de crisis y angustia.

Para la cuestión del componente autobiográfico me parecen atinadas las perspectivas de Emilia de Zuleta y de Vladimir Krysinski. La primera define el poemario "autobiografía espiritual"; el segundo prefiere hablar de autobiografía poética ${ }^{17}$, categoría que le provee además de una respuesta para los también controvertidos contenidos religiosos del texto. Alberti realiza una operación semiótica sobre la tradición angelológica que desde la Biblia llega hasta el siglo $X X$, pasando por los ilustres nombres de Dante, Rainer Maria Rilke y Paul Valéry entre otros. El resultado es la desconstrucción del símbolo fuertemente ideológico y religioso en un símbolo propio, terrestre y poético, a través del cual se reconoce como sujeto. Los ángeles se convierten en operadores simbólicos personales negativos, que contienen una dialéctica de la superación del simbolismo religioso.

Los ángeles quedan así convertidos en los actantes indeterminados de un psicodrama y de un proceso dirigido contra el cielo por el sujeto. A "estos ángeles" ya no les es posible volver al cielo. [Krysinski, 1996: 30]

\subsection{El ángel deshabitado}

\footnotetext{
${ }^{16}$ Un criterioso trabajo sobre la cuestión autobiográfica centrado en el cotejo de las memorias de Alberti y María Teresa León pueden encontrarse en Pope, 1991.

17 "...diálogo interior e interrogación definen el tono de Sobre los ángeles; su contenido es una biografía espiritual, el itinerario del propio conocimiento, dentro de la tradición moderna, desde Rimbaud, al postsimbolismo; su sentimiento, la conciencia de la pérdida del paraíso y el consiguiente drama interior de nostalgia y angustia". [Zuleta, 1971: 324]
} 
La segunda gran cuestión en Sobre los ángeles es su deuda con el surrealismo. Ningún crítico soslaya hoy este hecho estético y cultural decisivo para la historia de la vanguardia española: la introducción del surrealismo y su pronta coronación entre los ismos en boga. Es momento entonces de prestar atención a uno de los ismos más influyentes, no sólo por la difusión lograda sino por la profunda huella que dejará en todo el siglo XX. Creo necesario hacer sólo una breve mención a un debate que en su momento hizo correr mucha tinta: me refiero a la discusión acerca de pertinencia de hablar de surrealismo en España, cuando no existió una escuela surrealista sujeta a unas reglas estrictas como lo fue la liderada por André Bretón. (Dejo al margen la discusión lexicográfica en torno a lo que, para muchos, constituía flagrante e intolerable galicismo).

La primera parte de la polémica -sobre la presencia surrealista en Españafue superada al mismo tiempo que se revertía la idea de la imposibilidad de la vanguardia en un país periférico con una revolución industrial tardía, juicio asociado a una expectativa de la vanguardia como reproducción fiel de los patrones dominantes. Acerca de la segunda controversia, basta consultar la imprescindible compilación de García de la Concha para comprobar que hasta los más conspicuos impugnadores del surrealismo en España, como Ricardo Gullón, hacen mención a la presencia de ciertos rasgos:

...no hubo en España surrealistas de estricta observancia; sí cabe hablar de obras con rasgos de este tipo. En general, y con la excepción del grupo canario, no hay más: ni escuela, ni actividad surrealista ${ }^{18}$. [Gullón, 1982: 81]

En dirección contraria, autorizados especialistas consideran que a pesar de no seguir el dogma al pie de la letra, ni formar grupos o capillas -excepto el de las

\footnotetext{
${ }^{18}$ Respecto de Sobre los ángeles el mismo crítico sostiene: "Probablemente Alberti ignoraba las teorías del surrealismo francés, o le tenían sin cuidado. Supongo que habría leído poemas de Robert Desnos y algún otro miembro de la secta, pero su vinculación con los ángeles oscuros es independiente y arranca de una crisis personal. Del surrealismo contemporáneo recibió un efluvio, un susurro, y lo interpretó a su manera, poniéndolo al servicio de lo que necesitaba expresar entonces. [Gullón1975: 70] Similar posición sostiene Octavio Paz: "Muchos poetas de ese período adoptaron el onirismo y otros procedimientos surrealistas, pero no puede decirse que Neruda, Alberti o Aleixandre hayan sido surrealistas, a pesar de que, en algunos momentos de su obra, sus búsquedas y hallazgos hayan coincidido con los de los surrealistas". [Paz, 1981: 206]
} 
Islas Canarias- el movimiento tuvo una presencia destacada y muy extendida en España ${ }^{19}$, aunque atenúen el término con especificaciones diversas: estímulo, modalidad, surrealismo sin apoyo teórico e ideológico ${ }^{20}$.

Resulta ya un tanto trasnochado a estas alturas entrar en las polémicas sobre las relaciones del surrealismo español con el francés. Únicamente queremos insistir en que el surrealismo francés sí fue bien conocido en España, de primera mano, y que su verdadero influjo no fue sólo técnico: la escritura automática no es el dogma central del surrealismo, como algunos pretenden, es una de sus posibles técnicas. Lo esencial fue la nueva actitud moral que introdujo, y aquí el papel de Luis Buñuel fue clave. [Rico, 1984: 670]

La oposición contraria no cuenta hoy con muchos adeptos, pero es conveniente estar alerta a las resistencias que, según estudios muy recientes, el concepto surrealismo sigue suscitando, semejante a los que todavía reaparecen en torno a la vanguardia. Es esclarecedor en este sentido el estudio de Lucie Personneaux, quien demuestra que hasta finales de los sesenta la crítica negó toda posible huella del surrealismo en España. Por ese entonces José Albi y Joan Fuster, desde las página de una revista de Alicante, se enfrentan a la opinión generalizada, aunque sin el justo eco que hubieran merecido. Ya iniciados los setenta, Vittorio Bodini y Paul llie dan uno paso que será definitivo para la rehabilitación del movimiento liderado por Breton. Situado por fin en el lugar que le corresponde en el arte español del Siglo XX, conviene tener presentes las cuatro hipótesis que sustenta la especialista francesa sobre las causas del rechazo que sufrió durante tanto tiempo:

. Ser surrealista es ser de izquierda; "confesarse surrealista podía ser peligroso y dar lugar a ser acusado de comunista o al menos de poco entusiasta de los ideales nacionales e imperiales del momento" dice José Luis Cano.

19 No considero aceptables las hipótesis que sostienen que en España el surrealismo existía
previamente como tendencia, visible en autores como Góngora, Quevedo, Goya, Solana, Machado
y Valle Inclán, a los cuales debe añadirse la inclinación de la lírica tradicional a la imagen
incongruente y al irracionalismo. Creo que el surrealismo se fundamenta en un marco científico -el
psicoanálisis- y en un contexto cultural y tecnológico eminentemente moderno, de principios del
siglo XX para más exactitud, y que las coincidencias formales o temáticas no hubieran sido
suficientes para crear el movimiento. Nuevamente vemos que el proceso es inverso: ciertos textos
pueden leerse a posteriori como surrealistas gracias a que surgió ese ismo. Sí podría aceptarse la
hipótesis sobre la proclividad española a las imágenes incoherentes e ilógicas. ${ }^{20}$ V. Guillén, [1982], Ilie, [1982], Bodini, [1982]. 
. Ser surrealista, también, es no tener seriedad. Las actividades algo extrañas que caracterizan las reuniones de los surrealistas franceses chocan profundamente a muchos españoles que van a emplear el adjetivo "patológico" respecto a ellos. La personalidad de Salvador Dalí no es extranjera a este sentimiento de los españoles...

. Ser surrealista, aún, es ser anticlerical, lo que no está aconsejado en la España oficialmente muy católica. Así es como reciben los surrealistas los calificativos que se atribuirán más tarde a sus descendientes postistas: "revolucionarios, rojos, inmorales, masones, corruptores de la juventud".

. Ser poeta surrealista, por fin, es renunciar a su dignidad de poeta. En efecto, casi todos los críticos y poetas españoles asimilan en esta época, el movimiento surrealista al dictado automático. (...) ¿Qué mérito puede tener un poeta si toda conciencia crítica o artística está ausente? Ello nos explica la reserva de muchos poetas... ${ }^{21}$ [Personneaux, 1999: 460-461]

Interesa añadir, por último, que una cultura que experimenta los fenómenos de la modernidad, de los cambios tecnológicos, de la atracción y la repulsión de las renovadas formas de existencia y, por último, que sufre las imposiciones de la ideología burguesa sobre el individuo, difícilmente podía ser indiferente a la radical rebeldía del surrealismo. Tampoco debe olvidarse que este movimiento fue también resultado de una atmósfera, afectada de los dos duros golpes acestados al hombre moderno, dueño de sí mismo y del universo: el psicoanálisis de Freud y la teoría de la relatividad de Einstein.

Las consecuencias inmediatas de todo esto son auténticamente catastróficas para el yo: las barreras que había ido levantando para preservar su domino de la situación han caído: no está en el centro del cosmos, no es ya "rey de la creación" (distinto de los animales en un grado radical) y ni siquiera constituye un ser gobernado por una razón que ponga una barrera infranqueable entre el sujeto que conoce y el objeto pasivo y sumiso. Es más, uno y otro no se diferencian demasiado, y Freud indicó sin contemplaciones que el precioso "sujeto" podía ser, a su vez, "objeto" de estudio. [Sánchez Vidal, 1982: 54]

Esta hipótesis sobre la existencia de un clima favorable al surrealismo no se debe entender solidaria de quienes niegan la influencia francesa, por el contrario, intenta reforzar las indagaciones que han demostrado que la conexión parisina funcionó de una manera voluntaria y consciente en un grupo de relevantes

${ }^{21}$ Las transcripciones entrecomilladas en la cita de Lucie Personneaux van acompañadas, en el texto original, de las correspondientes referencias a las fuentes, y son, por otra parte, más extensas y variadas. Remito para su completo conocimiento a dicho material bibliográfico. 
artistas: José María de Hinojosa, Luis Buñuel, Emilio Prados, Luis Cernuda, Vicente Aleixandre, Rafael Alberti, Federico García Lorca.

... [el vínculo de los siete poetas nombrados] con el surrealismo fue una relación consciente y los testimonios muchas veces aducidos para probar lo contrario son, con frecuencia, desmentidos por los hechos. En otras ocasiones las razones expuestas no son motivo de exclusión por sí mismas. Pienso en la noutilización [sic] de la escritura automática aportada como prueba de su nopertenencia [sic] al surrealismo por algunos poetas y críticos. Si esta medida fuese tomada rigurosamente no podrían ser llamados surrealistas los poetas franceses cuya ortodoxia a los principios, sin embargo, no es cuestionable. [Pariente, 1999: 475]

Volviendo a la obra que motiva estas disquisiciones, acepto, con gran parte de los especialistas, que Sobre los ángeles se resiste a las clasificaciones. Se trata de un texto de alta densidad poética, con registros y referencias tan vastos, que la lectura desde un solo sitio resultaría empobrecedora. Sin embargo, creo también que no otorgar la debida atención al surrealismo como base estética y sobre todo moral, significaría el silenciamiento de un elemento básico en la producción de significado y una rémora para la justa comprensión del lugar que ocupa tanto en la producción albertiana como en la poesía española de vanguardia. Por otra parte, el contacto de Alberti con el surrealismo es un jalón ineludible para el cometido de mi estudio desde la hipótesis de que este movimiento fue funcional al cambio de rumbo poético de los años treinta -hecho que en la actualidad prácticamente no se discute. Por otra parte, iluminará la manera en que el escritor de Cádiz comprendió y asumió la vanguardia e, inversamente, el modo en que la vanguardia enlaza con su proyecto creador.

Constituye un lugar común en los estudios atribuir al surrealismo un influjo rehumanizador en la estética distanciada e impersonal de los ismos. Creo que la consideración puede dar lugar a equívocos, pues llevaría a pensar que la vanguardia fue "deshumanizada" -reaparece una vez más el gran influjo de las ideas de Ortega y la poco feliz imposición del adjetivo- cuando es más apropiado hablar de un antisentimentalismo y un antipatetismo. Igualmente lesivas son las generalizaciones sobre la vanguardia que derivan en una homogeneización impropia, pues si los ultraístas y algunos prosistas -Gerardo Diego, el Alberti de Cal y canto, Ayala- 
fueron en verdad muy "asépticos", no se puede decir lo mismo de autores como Jarnés, García Lorca o Salinas.

Otro riesgo es que el trajinado término rehumanización lleve a pensar que en el Alberti de Sobre los ángeles se verifica una mayor presencia del yo poético y del sentimiento, cuando en verdad, estos están mucho más ausentes. En versos como

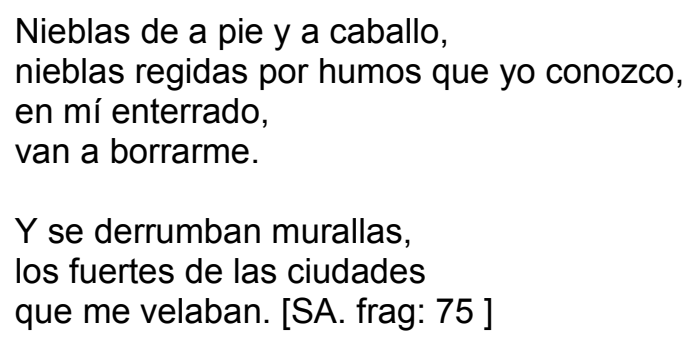

la subjetividad es menor que en numerosos poemas de la primera época como el que se transcribe a continuación, aunque ambos discursos se enuncien en primera persona $^{22}$.

Yo te hablaba con banderas,

hija de la panadera,

la que siempre eras de pan

entre la grey marinera.

Me perdí en la tierra,

fuera de la mar.

Yo te hablaba, a los luceros, con la luna del espejo

de una estrella volandera.

Fuera de la mar,

me perdí en la tierra. [MT, 3, 20: 95]

Vivanco ha visto con acierto que "en algunos poemas de Sobre los ángeles no tiene más remedio que hablarnos en primera persona. Y sin embargo, su libro

${ }^{22}$ Es de atender la carga subjetiva que encierra la tercerilla que introduce el libro tercero de Marinero en tierra.

Entraña de estos cantares:

¡sangre de mi corazón

tarumba por ver los mares! [MT, III: 73] 
va a ser el que menos presencia personal subjetiva contiene de toda nuestra poesía contemporánea". [Vivanco, 1975: 191]. Es preciso retomar la idea del sujeto en la lírica de vanguardia de Walter Mignolo. En Sobre los ángeles, más que una voz, como en $\mathrm{Cal}$ y canto, se observa una desarticulación del sujeto poético. El "personaje" que se adivina junto al sujeto lírico tradicional, ahora se desvanece, se fragmenta, adquiere dimensiones desmesuradas, pierde el control de sí mismo a manos de fuerzas que el hombre -poeta corriente- no controla. No obstante, la "voz" es una voz más terrena y humana que la de Cal y canto; no en vano dirán los críticos que con el surrealismo comienza la "rehumanización" del arte.

Con independencia de la crisis espiritual, amorosa, religiosa o estética de índole individual que pudo embargarlo, Sobre los ángeles está atravesado por la fractura moral que significó el surrealismo. $O$, si se prefiere, las diversas crisis personales que subyacen al texto se encauzan a través de los caminos que el surrealismo entrevió para responder las grandes preguntas y desazones de la modernidad. La historia íntima se expresa, en tal caso, desde el desgarramiento del hombre que ha dejado de tener las riendas del universo y de sí mismo.

Es indiferente que Alberti no siga fielmente el automatismo psíquico; no reiteraré los análisis de la métrica que demuestran el empleo de versificación tradicional, al menos en las dos primeras secciones de Sobre los ángeles. Aun en lo momentos de mayor inorganicidad no se aleja del metro y de la rima. Sirva de ejemplo que en el libro tercero, cuya estructura más disgregada tiende al versículo y al verso libre, Gimferrer ha rastreado rimas asonantes. Sólo en las páginas finales el escritor catalán ha visto una "mezcla de coloquialismo aparente con la materia alucinada, que es en el fondo una variedad peculiar de escritura automática". [Gimferrer, 2000: 240]

El mismo crítico ha descubierto huellas de la tradición en poemas que podrían entenderse como originados en el discurso del insconsciente. Así sucede con "El alba denominadora", bajo cuya apariencia onírica se encierra un madrigal que recurre al motivo trovadoresco de la senhal para nombrar a la amada. 
A embestidas suaves y rosas, la madrugada te iba poniendo nombres:

Sueño equivocado, Ángel sin salida, Mentira de lluvia en bosque.

Al lindero de mi alma que recuerda los ríos, indecisa, dudó, inmóvil: ¿Vertida estrella, Confusa luz en llanto, Cristal sin voces?

No.

Error de nieve en agua, tu nombre.

[SA, III, "El alba denominadora": 129]

Son varias la lecturas autorizadas de Sobre los ángeles que han rastreado los rasgos específicamente surrealistas del poemario ${ }^{23}$; el objeto de estudio y los diversos autores abordados en esta tesis impiden un tratamiento detenido de tales aspectos. Me limitaré a ilustrar aquellos más sobresalientes: Agustín Sánchez Vidal otorga particular importancia al tratamiento de los objetos, en tanto expresan la disolución del individuo en el mundo como un objeto más: los signos más visibles son la mutilación, el vacío, la mecanización, el anonimato. La falta de identidad se refuerza con la angustia del hombre perdido en la ciudad moderna, la cual ahora sí se ha vuelto inhabitable, hostil, desolada.

\author{
Llevaba una ciudad dentro. \\ La perdió. \\ Le perdieron. \\ Solo, en el filo del mundo, \\ clavado ya, de yeso. \\ No es un hombre, es un boquete \\ de humedad, negro, \\ por el que no se ve nada. \\ Grito. \\ ¡Nada! \\ Un boquete, sin eco.
}

[SA, Huésped de las nieblas, !. \&, I: 77]

${ }^{23}$ Debe mencionarse no obstante que lecturas bastante recientes continúan rechazando la huella surreal: "Ya se ha hecho sobrado hincapié en los supuestos engranajes que aproximan esta actitud creadora a ciertas normativas de la vanguardia de los años 20 . Es posible que alguien prefiera emparentar algunas variantes de esa alucinación expresiva, de ese 'empuje espontáneo', con los usos y consumos propios de los surrealistas. Pero no creo que nada de eso tenga mucho que ver con el Alberti de Sobre los ángeles". [Caballero Bonald, 1990: 298] 
Los motivos, que no son totalmente nuevos ni en Alberti ni en la literatura de vanguardia, adquieren en Sobre los ángeles una intensidad inusitada, fortalecida por la acumulación de imágenes sombrías, cercanas a la pesadilla onírica, y por la ruptura del orden lógico que anula toda referencia a un mundo organizado racionalmente. De manera inversa a lo que se espera hallar en una obra surrealista, Alberti no fuerza excesivamente la estructura gramatical, que no constituye un obstáculo para el lector; aunque aparecen usos cercanos a la agramaticalidad, no es lo más frecuente.

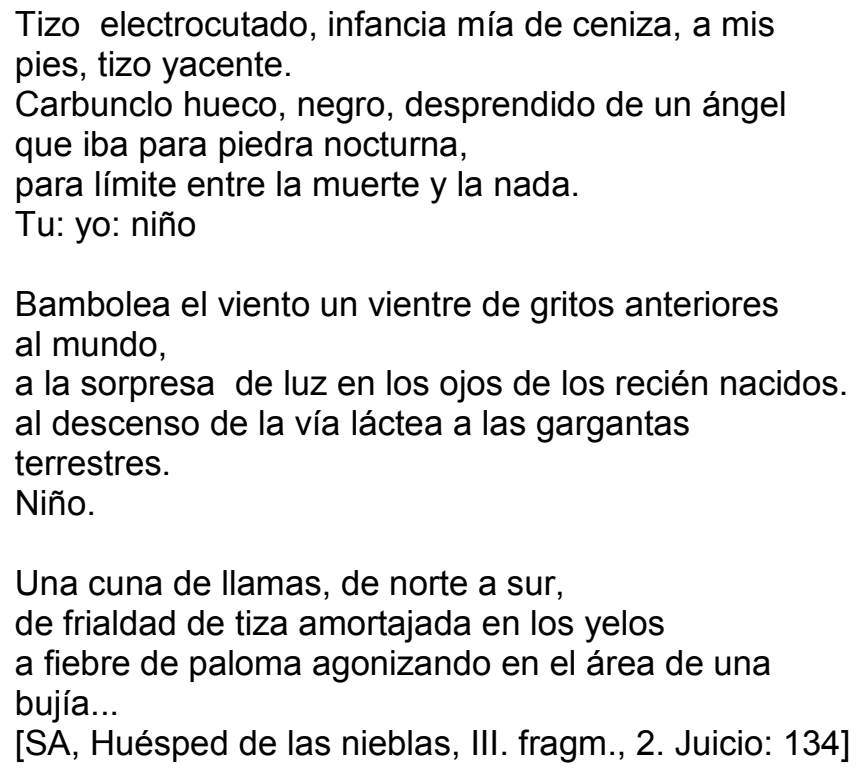

La crucial impugnación de la civilización occidental encarnada en el orden burgués que el surrealismo llevó a cabo derivó en un intento de conciliar la rebeldía con el proyecto revolucionario del Partido Comunista. La convivencia no fue duradera pero representó un punto de inflexión en el arte de vanguardia. Creo que se sobredimensiona la influencia del gesto de Breton, que conlleva ignorar que los mismos desplazamientos se realizaban en otras zonas del campo artístico y literario. El gesto del escritor francés es indicador de que la preocupación por las relaciones del arte con lo social era una marea que crecía imparable en todos los ámbitos de las sociedades occidentales. Dentro mismo de la vanguardia, otros artistas se habían sentido llamados por igual imperativo. 
En la que fue década prodigiosa para la cultura en el Moscú de la revolución (1918-1928), principales creadores europeos acudieron a aquella meca en busca de sí mismos. Si Kandisnsky acepta inicialmente dirigir la política artística o Le Corbusier y Benjamin viajan a la que consideraban plataforma de lanzamiento de un profundo cambio mundial, no lo hacen para hacer turismo revolucionario o para demostrar su solidaridad benefíciente como intelectuales pertenecientes a la cultura burguesa, sino porque han soñado un nuevo destinatario social, el proletariado; un nuevo cliente que les permitirá realizar todos sus sueños, los que no les permitía el cliente burgués filisteo. [Vázquez Montalbán: 1999: 51]

Creo igualmente que se valora excesivamente el lazo entre surrealismo y y la búsqueda de una función social para el arte, como sucedió en sonoros casos, llámense Aragon, Paul Éluard o el mismo Breton. Esta interpretación ignora que muchos poetas surrealistas no abrazaron ni estética ni ideológicamente las propuestas de arte social ligado a una militancia explícita, en el Partido Comunista especialmente. Ni Aleixandre, ni Dalí, ni el mismo García Lorca, VER aunque lo hayan fusilado por "rojo", suscribieron abiertamente a una militancia política y de izquierda. El mismo José María Hinojosa ofrece un contraejemplo, pues después de haber introducido el surrealismo en su país junto con Juan Larrea, abandonó la literatura en 1931 a causa de un desengaño amoroso y se entregó a actividades políticas de signo conservador primero y luego nacionalista. Fue elegido diputado en 1936, colaboró con la rebelíón militar y fue fusilado por los republicanos junto a su padre y hermano.

Otorgar al surrealismo la llave de la "rehumanización" del arte conlleva ignorar otros procesos culturales y estéticos que sucedían al margen de los núcleos hegemónicos vanguardistas y significa, además, simplificar y reducir a un trayecto lineal tendencias que fueron, como queda visto, de gran complejidad

\subsection{Poeta sin aureola}

El itinerario de Alberti sin embargo, es emblemático para explicar el efecto revulsivo y perturbador que el surrealismo ejerció sobre la conciencia del artista. Según afirma Jason Wilson, el surrealismo representa la forma radical en que un poeta asume la modernidad hasta sus últimas consecuencias, de manera que ya no puede volver sobre el camino, sólo le queda entregarse a otra práctica artística 
y social. La poesía albertiana se puede leer como el más cumplido "resultado del deseo de asumir plenamente la modernidad, sus riesgos y sus peligros" [Wilson: 1990: 59].

El itinerario estaría marcado por un primer momento de fascinación por el ritmo acelerado de la vida moderna, los inventos y el cine; el segundo por la soledad y la angustia del hombre desamparado en la metrópolis, y por último, una superación en que el marxismo y el internacionalismo darían la respuesta a los cuestionamientos. Wilson encuentra que los sucesivos momentos comienzan muy temprano, pues en los primeros poemarios aparecen diferentes motivos ligados al progreso y a las formas de vida moderna, puestos de manifiesto a través de una estética de la velocidad y la superficialidad, que se irá incrementando hasta llegar a la máxima concentración formal y temática en los libros 5,6 y 7 de Cal y canto.

El segundo momento se manifiesta de forma intensa y atormentada en Sobre los ángeles, donde el surrealismo le proporciona los procedimientos pero sobre todo, la materia ideológica para tomar conciencia del enorme desamparo a que ha llevado al hombre la modernidad regida por la cosmovisión burguesa. Al enfrentarse a las preguntas sobre la existencia Alberti, frente al metafísico "¿quién era yo?" se preguntará "¿qué era yo?", cuestionamiento nuevo acerca del linaje que pone de relieve la pérdida del lugar del escritor en la sociedad burguesa y sus propias penurias para sobrevivir sin renunciar a la vocación.

El problema viene de lejos. Desde el Romanticismo el poeta siente que no tiene un lugar entre los hombres, su carácter excepcional lo convierte en un ser desarraigado, exiliado de la prosaica sociedad burguesa. Pero en Sobre los ángeles el estatuto del vate excluido también ha perdido vigencia; los últimos dos versos concluyen con la imagen del ángel sobreviviente, que ha perdido las alas, pero sobrevive, "alicortado".

Todos los ángeles perdieron la vida.

Menos uno, herido, alicortado.

[SA, "El ángel superviviente": 158]

El ángel, según Wilson, símbolo de la continuidad de la vida después de la devastación, se carga de connotaciones éticas y estéticas: ya no sirve la alegoría 
del poeta alejado del mundo terreno, ahora el exilio es inverso, porque se ve obligado a regresar, a convivir con los seres corrientes. Y será necesaria una nueva poética.

Otros pasajes del mismo libro refuerzan esta idea: en el canto final son varias la alusiones metaliterarias que enlazan con la admiración de Alberti por Bécquer, a quien el poemario alude desde el comienzo, con los tres subtítulos "Huésped de las nieblas"24. Pero los ángeles son feos y crueles; la simbología de la lírica etérea y sublime ha cambiado de signo y ahora se revuelca en el fango la rosa y se ensucian de lodo la luna y la nieve.

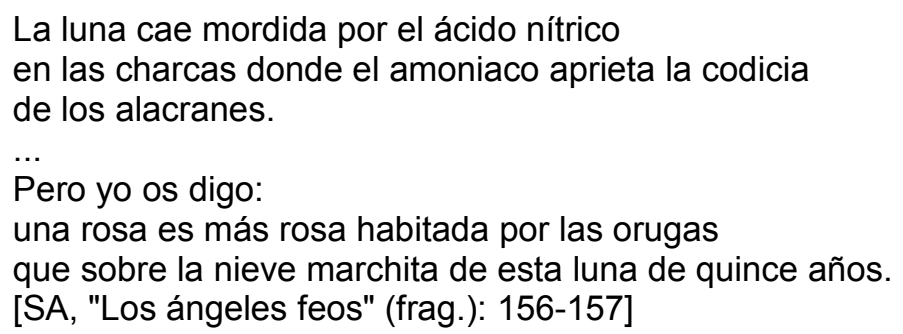

La luna retorna sugestivamente en la composición dedicada al arpa, motivo romántico y becqueriano por excelencia que ya había aparecido en la lírica de Alberti. En el libro primero de Marinero en tierra dedica un soneto "A Rosa Alberti, que tocaba, pensativa el arpa". Y añade un subtítulo, "(Siglo XIX)". La vaporosa mujer es evocada mediante una serie de motivos románticos: "cuello blando de moaré", "bucle de nieve", "suavidades y carmines", "vaga y voladora" "querubines".

En "Invitación al arpa" Alberti retoma varios de aquellos motivos y añaden otros nuevos ${ }^{25}$. El clima deletéreo es el mismo, pero aumentado ahora por notas de inutilidad y consunción final que aluden a una poética agotada. La reflexión de Alberti puede aludir tanto a la propia poética anterior como a toda la lírica introspectiva e individualista. Considero que la composición reviste interés suficiente como para transcribirla en su totalidad.

${ }^{24}$ La expresión está tomada de la rima LXXV, "¿Será verdad que cuando toca el sueño...?". La composición hace referencia a la huida del espíritu, que por las noches abandona el cuerpo-prisión y sale a recorrer libremente el mundo. El desdoblamiento y la existencia de otros "yo" y otros "tú" constituyen el motivo central del poema.

${ }^{25}$ Los dos poemas han llamado la atención de los críticos. Gullón y Vivanco (1963) le dedican sendos comentarios. 
Invitación al arpa

1

Lejos, lejos.

Adonde las estancias olvidan guantes de polvo

y las consolas sueñan párpados y nombres ya idos.

Un sombrero se hastía

y unos lazos sin bucles se cansan.

Si las violetas se aburren,

es porque están nostálgicas de moaré y abanicos.

Lejos, más lejos.

A los cielos rasos donde las goteras

abren sus mapas húmedos para que viajen los

lechos.

Adonde los muelles se hunden sin esperanza

y rostros invisibles avetan los espejos.

Al país de las telas de araña.

2

Más lejos, mucho más lejos.

A la luna disecada ente la hoja de un álamo y la pasión de un libro.

Sé que hay yelos nocturnos que ocultan candelabros

y que la muerte tiembla en el sueño movible de las

bujías.

Un maniquí de luto agoniza sobre un nardo.

Una voz desde el olvido mueve el agua dormida de los pianos.

Siempre, siempre más lejos.

Adonde las maderas guardan ecos y sombras de

pasos,

adonde las polillas desvelan el silencio de las

corbatas,

adonde todo un siglo es un arpa en abandono. [SA: 144-145]

En respuesta a la poesía caduca y envejecida surge Sobre los ángeles, verdadera puesta a prueba de su talento y de su futuro. Como explicará en $\mathrm{La}$ arboleda perdida, comenzaba a ser hostigado por las preguntas sobre su estatuto de poeta y de hombre que descubría a los otros, separados en clases sociales. Sus pasos futuros comienzan a trazarse entre las nieblas y ruinas de lo que queda del paraíso, tras el descubrimiento de que el aura del poeta construido hasta ahora ya no lo conforma.

Nadie me seguía. Un poeta antipático, hiriente, mordaz, insoportable, según los rumores que me llegaban. Envidiaba y odiaba la posición de los demás: felices casi todos; unos, con dinero de su familia; otros, con carreras, para vivir tranquilos: catedráticos, viajeros por universidades del mundo, 
bibliotecarios, empleados en ministerios, en oficinas de turismo... ¿Yo? ¿Qué era yo? Ni bachiller siquiera; un hurón en mi casa, enemistado con los míos, yendo a pie a todas partes, rodando como hoja y con agua de lluvia en las plantas rotas de los zapatos. [AP II: 265]

Para Wilson el interrogante abre las puertas a la respuesta que encontraron muchos escritores a la situación de marginalidad del artista en el orden burgués: el trabajo por una causa que justificara nuevamente su lugar en la sociedad. Bretón en Francia y Alberti en España se afilian al Partido Comunista. El poeta gaditano escribirá la Elegía cívica: Con los zapatos puestos tengo que morir (1931) y buscará formas poéticas que lo ayuden a alcanzar otros cometidos; ya no la exploración formal que contravenía el canon de la tradición sino los versos que lo llevan a comunicarse con un nuevo público al mismo tiempo que socavan los fundamentos del orden vigente.

La consecuencia, siempre según el mismo especialista, es la combinación de la poesía "con una política que mantenía sus ganas de ayudar a un cambio pero que no tenía nada que ver con la estética" [Wilson, 1990: 66]. Es esta última una visión que me parece discutible, y que ha suscitado y suscita aún espinosos debates, en tanto pone en primer plano dilemas siempre reiterados en torno al arte. Subsiste en ella el viejo criterio de juzgar el valor del arte según criterios universales y perennes. Será necesario retomar más adelante la controversia; antes considero preciso analizar otros factores que, según creo, intervinieron en el cambio de rumbo.

Para comprender la transformación estética e ideológica de Alberti la crítica se apoya fundamentalmente en el giro formal de Sobre los ángeles, acentuado en Sermones y moradas, y seguidamente, continúa con el análisis de su poesía de compromiso. Para subrayar el estado de desasosiego e incorformismo del poeta, se suele traer a colación su propio relato vertido en El poeta en la España de 1931, publicado en Buenos Aires en enero de 1942. Narra, entre otros episodios, el estado de conmoción en que escribió en 1930 la Elegía cívica y Con los zapatos puestos tengo que morir. En los momentos culminantes del fin de la dictadura, Alberti se siente identificado con las gentes que se movilizan contra el régimen, muchos de ellos, intelectuales y amigos. 
Hacía ya muchos meses que me sentía un poeta en la calle, un poeta "del alba de las manos arriba", como escribí entonces. Intenté componer versos de trescientas o cuatrocientas sílabas, para pegarlos en los muros. Explotaba en mí, confusa y anárquica, mi conciencia política. (...) Y sentí lo grande y hermoso de caer en las calles, entre las piedras levantadas, con los zapatos puestos, como desea el héroe de la copa andaluza:

Con los zapatos puestos

tengo que morir.

que si muriera como los valientes,

hablarían de mí. [EPE: 19-20]

Sin embargo, estas aproximaciones, con ser enriquecedoras, pecan de otorgar a la autobiografía y a la palabra autoral un valor de verdad sin tomar en cuenta lo tautológico del método, pues para comprender un hecho literario se busca el apoyo de otro hecho igualmente signado por la convención, aunque bajo otra modalidad y género. Si bien considero que tales materiales contribuyen positivamente al conocimiento del autor, es recomendable situar las obras en un contexto más amplio así como atender a las pugnas y definiciones que tenían lugar en el campo de las letras. En este sentido, Alberti vuelve a presentarse como un escritor muy atento a las tendencias dominantes, movido, como se ha dicho de Lorca y de otros poetas de la vanguardia, por un incansable interés por "estar al día". Sobre los ángeles y el surrealismo constituyen una síntesis afortunada en que Alberti conjuga sus dos tendencias antagónicas: por un lado, el inconformismo -insolentándose con las instituciones como los hiciera en el Lyceum, o exhibiendo su talante de muchacho hambriento y generoso que se gasta en helados el dinero de un premio- por el otro, la lucidez para comprender las tensiones dentro de la institución arte y captar las crisis del canon, sumada a la intuición para seguir, a veces anticipar, las tendencias estéticas que serán dominantes. Conceder excesiva trascendencia a la descripción del estado anímico del poeta conlleva ignorar que Alberti no se entregó a la desesperación como lo haría un romántico o un bohemio; por el contrario, estaba muy atento a las resonancias que los versos violentos y desafiantes de Sobre los ángeles provocaban en el inquieto y versátil ambiente literario de finales de los años veinte. Consciente de ser "un suceso", en La Gaceta Literaria del 1 de enero de 1939, el autor emite un dictamen de su 
producción poética, desde Marinero en tierra hasta el presente. Al referirse a su poesía más reciente dirá:

\begin{abstract}
1927-1928. Sobre los ángeles (Editorial Ibero-Americana. Se publicará en breve). He rasgado mis vestiduras poéticas (porque las tuve). Cubrí mi cabeza con ceniza. Me estoy quemando vivo. Saco un pañuelo rojo trompeta final. Y del chiqueron [sic] salen Bosco, Brueghel (viejo y joven), Bouuts [sic], Swedenborg, W. Blake, Baudelaire y el águila del apóstol. Atufadme de braseros y rodeadme de infiernillos azules, porque estoy de muy mal humor. Sobre la importancia de este libro, consúltese a Pedro Salinas, Jorge Guillén, Antonio Marichalar, Dámaso Alonso, Juan Chabás y José. [Alberti, Rafael, "Itinerarios jóvenes de España. Rafael Alberti" en La Gaceta Literaria, 49,1 en. 1929 (citado por Connell, 1975:156)]
\end{abstract}

De la misma manera que concilia Alberti la marginalidad con la incesante actividad de escritor, crítico y hombre destacado del campo de las letras, también en 1930, mientras expresa con vehemencia su protesta y desencanto, no deja de cultivar formas menos atormentadas aunque igualmente rupturistas e iconoclastas. Ejemplo de una búsqueda que tomaba rumbos diversos era Yo era un tonto y lo que he visto me ha hecho dos tontos, obra lúdica y de tono gozoso, pese a su tristeza subterránea. El desconcierto por el cambio de disposición llevó durante muchos tiempo a los críticos a fechar esta antes de Sobre los ángeles, pues era más coherente pensar en Sermones y moradas como la continuación "natural" del gran libro surrealista. También en 1929 pronuncia la famosa conferencia en el Lyceum Club Femenino de Madrid cuyo título, "Palomita y galápago (no más artríticos)" demuestra que el poeta incursionaba en otra dirección surrealista, la de la insolencia y la burla de los valores más caros de la mentalidad burguesa: la circunspección, la sensatez y la idea de cultura consagrada fueron objeto de mofa.

Con el poemario sobre los tontos, escrito en plenda rebeldía surreal, Alberti demuestra que se ha hecho eco de la repercusión el cine en la vida moderna y de su fuerte impacto en las distintas artes. Su cultura de espectador cinematográfico se evidencia en los homenajes a famosas películas y actores anunciados en títulos que se han hecho famosos: "Buster Keaton busca por el bosque a su novia, que es una verdadera vaca", "Cita triste de Charlot", composición con que abre el libro dedicado al cine y manifiesta su admiración por La quimera del oro. 
Mi corbata, mis guantes,

mis guantes, mi corbata.

La mariposa ignora la muerte de los sastres, la derrota del mar por los escaparates.

Mi edad, señores, 900.000 años

¡Oh!. [YET, Fragm.; 161]

El seguimiento de la doble andadura de Alberti, rebeldía y protesta por un lado, práctica literaria sintonizada con los movimientos de más rabiosa actualidad por otro, me lleva a mencionar que en los años de la Elegía cívica publica en El sol una prosa risueña, aunque con intención crítica e irónica, titulada "Se reciben bahías" en la cual se mofa del canon clásico. El tono es opuesto al de la Elegía, al de Sermones y moradas y no trasunta la agitación espiritual que evocara en sus memorias. El diálogo entre un probable jefe de redacción y una bahía se sirve del absurdo para desarrollar una breve sátira del arte clásico sin atisbos de preocupaciones sociales o políticas, como no sea la burla a las diputadas republicanas recién electas ${ }^{26}$. El breve relato incluye además una autorreferenciala alusión al Lyceum Club femenino, el auditorio de la resonada charlaprocedimiento muy del gusto de los cultivadores del arte nuevo.

Bahía Norte.- Quiero ser inmortal, pero en versos medidos.

Yo.- Para hoy ser inmoral, amiga mía, en esa clase de versos que me pide, necesitaría usted nada menos que ser la esposa de algún embajador de la República. ¡Ser embajadora! Algo así como vocal, secretaria o socia transeúnte de algún lyceum femenino. Me es imposible, por lo tanto, complacerla. Puede matarse cuando guste.

Bahía Norte. - ¡Oh, es usted muy cruel!

Yo. -Como deben ser los poetas de hoy: crueles, violentos, demoníacos, terribles. ["Se reciben bahías": 91-92]

Lo distintos rumbos que Alberti explora al final de los veinte terminan por reducirse y adquirir coherencia en la década siguiente, del mismo modo que se definen y polarizan las tendencias estéticas e ideológicas en el continente europeo.

..el cambio de orientación de las letras españolas a principios de los años treinta responde a un fenómeno generalizado en toda Europa: Cocteau,

\footnotetext{
${ }^{26}$ La mención dice exactamente "A la sombra de las feas muchachas en flor", en referencia a las socialistas radicales Victoria Kent y Clara Campoamor y de la socialista Margarita Nelken. [Nota de la editora]
} 
Morand o Giraudoux han pasado de moda, mientras en el último gran movimiento de vanguardia le ha cambiado el título a su revista, que de $\mathrm{La}$ revolución surrealista ha pasado a llamarse El surrealismo al servicio de la revolución. [Jiménez Millán, 1990: 146]

\section{Los zapatos de la poesía}

Los debates sobre el cambio en la estética del Alberti no están cerrados. Quizás ya no haya lugar a posiciones como las de Vivanco, quien descalifica la producción posterior a Sobre los ángeles desde el historicismo fenomenológico ${ }^{27}$. Jiménez Millán [1985] ha rebatido lúcidamente estos argumentos demostrando además, en una proyección muy necesaria, que postulados de esa naturaleza alimentaron la doctrina académica y escolar durante el franquismo, que se valió de la estilística como único modelo crítico.

De todos modos subsisten algunos preconceptos que paulatinamente son reconsiderados por las aproximaciones más recientes. Creo que las herramientas teóricas fueron durante mucho tiempo insuficientes para analizar una poesía que produjo una profunda revuelta en una tradición regida por la idea de autonomía.

En principio, se debe revisar la idea de la poesía "comprometida" de Alberti como un todo homogéneo, pues presenta tanta variación y registros como la de su primera etapa ${ }^{28}$. Alberti durante los casi diez años que concibe el arte en simbiosis

${ }^{27}$ En distintos momentos he citado observaciones de Vivanco, que revelan al poeta sensible y sutil, aunque regido por una concepción idealista del arte que lo lleva a desatender los condicionamientos ajenos a la esfera estética, como lo demuestra su negativa a reconocer la presencia del surrealismo en Sobre los ángeles. Otra consideración de igual naturaleza surge al valorar la poesía albertiana posterior a 1930: "Sin embargo, [en Poeta en la calle] por primera vez desde que ejercita su don gratuito de imaginación verbal, tropieza contra dos obstáculos invencibles que impiden la constitución de una auténtica realidad poética: las ideas convertidas en ideología y las consignas más o menos oportunistas". [Vivanco, 1975: 201-202]

${ }^{28}$ En una investigación cómo la presente, que no se ocupa primordialmente de procedimientos formales, sólo puedo recomendar una lectura atenta a la utilización del lenguaje poético más acrisolado en el emblemático poema, "Galope" [CG, 244-245], donde el ritmo, la anáfora, los paralelismos, la aliteraciones, las oposiciones y contraste intensifican en el plano del significante el sentido épico de cabalgata triunfal. La sola detención en el verso central, "galópa cabállo cuatrálbo" permite comprobar la concentración de recursos: ritmo dactílico que reproduce el galope, aliteración de //, /II/, fonemas líquidos (semivocálicos) laterales, que proporcionan efectos musicales y luminosos, reforzados por la eufonía y la denotación de 'cuatralbos", esto es, caballo de patas blancas. El verso asociado con la serie del mismo paradigma semántico y fonológico "al sol y a la luna", "caballo de espuma", "las grandes, las solas, desiertas llanuras", produce un efecto contrastivo muy acusado con la serie determinada por la aliteracción "oscura" producida por los fonemas vibrantes dobles, la palatal /ñ/, las velares /j/, /g/ y la implosiva labial sorda /p/: "Las 
con la militancia política cultivó formas diversas, que van desde las "letanías" impregnadas del discurso agresivo y atormentado de los "sermones" hasta el romance -metro hispánico por excelencia- de fácil difusión y memorización, concebido para ser recitado más que leído, razón que posiblemente llevó al autor a no recogerlos en las compilaciones posteriores. El talante combativo y el contenido testimonial, bien para alentar el espíritu revolucionario, bien para atacar al enemigo burgués o fascista, no impide que Alberti mantenga fidelidad a la tradición literaria y beba en sus fuentes: ya no será Góngora sino Lope, y la lírica popular no reproducirá los motivos amorosos o pastoriles sino que recuperará la queja del labrador o del minero, presente también en la copla andaluza ${ }^{29}$.

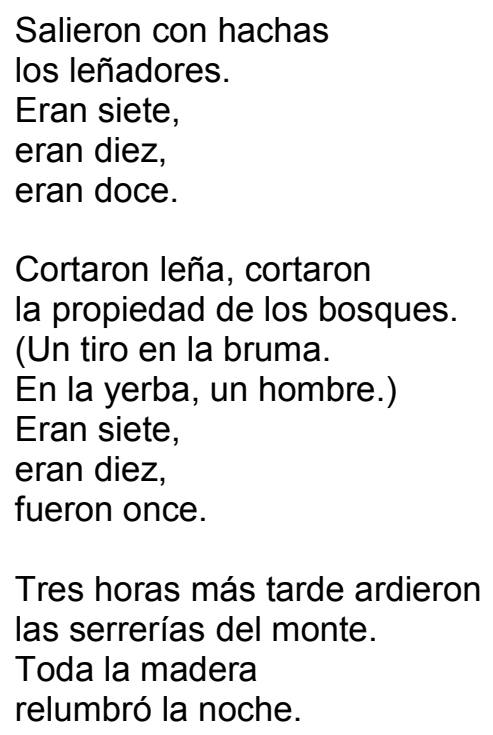

Entre los materiales de la tradición recuperados merece un capítulo aparte la poesía satírica, de vieja estirpe en la literatura española aunque no siempre bien considerada. Los poemas burlescos de Alberti, con resonancias quevedescas pero también del cancionero anónimo y de las Cantigas de escarnio y maldizer, han

tierras, las tierras, las tierras de España", "A galopar/ a galopar, hasta enterrarlos en el mar!", etc. ${ }^{29}$ Pienso en cantares populares de segadores y mineros, tales como "No madrugaría tanto, si el sol fuese jornalero/ no madrugaría tanto y andaría más ligero", o el conocido "En el pozo María Luisa/ murieron cuatro mineros. Mira Maruxiña, mira,/ mira como vengo yo/ Traigo la cabeza rota/ que me la rompió un barreño/ mira Maruxiña, mira, mira cómo vengo yo". (Muchas veces me he preguntado, sin encontrar una respuesta cierta, sobre la protesta que parece encerrar la difundida canción infantil "Los maderos de San Juan", que "piden pan/, no les dan/, piden queso/, les dan hueso"). 
recibido tratamiento de segunda categoría por parte de la crítica. Como curiosidad, merece citarse una parodia de las tablas de multiplicar, "Tabla de dicterios (para cantarla a Franco en las escuelas"), que ahora está al alcance del lector gracias a la edición de García Montero: "1x1, esputo; 1x2, hijo de puto; 1x3, cabrón; 1x4, maricón; $1 \times 5$, pajero; $1 \times 6$, trasero ... etc. La última, la tabla del 9 , cambia de tono:

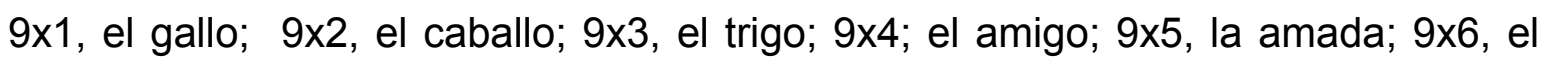
camarada (...) 9x10, el nuevo día" [PEC: 567].

En estudios anteriores me he referido a la postergación que sufren las modalidades que recogen la tradición carnavalesca. Pese a la fuerte presencia de la sátira y la parodia en España, no gozan de la aquiescencia de los especialistas $^{30}$. Alberti emplea con maestría la saga satíricoburlesca para denostar a burgueses, fascistas, dictadores americanos o europeos.

No faltaron las composiciones de circunstancias, loas a figuras políticas 0 revolucionarias más tarde muy cuestionadas por la historia -Lenin, Stalin--, versos que junto a los que vituperan al enemigo, concentran la atención de la crítica adversa a esta modalidad, hasta convertirse en la parte que representa al todo de la producción de los años treinta. La práctica y los resultados merecen después el epíteto "de época del 'deshonor de los poetas'" [Paz, 1981: 207].

Sería conveniente que con el tiempo pudiéramos acercarnos estos estos poemas de la misma manera que hoy lo hacemos al soneto "Al Emperador " de Hernando de Acuña, o el de Cervantes "A la entrada del Duque de Medina", incluidos en las más escolares antologías del Siglo de Oro.

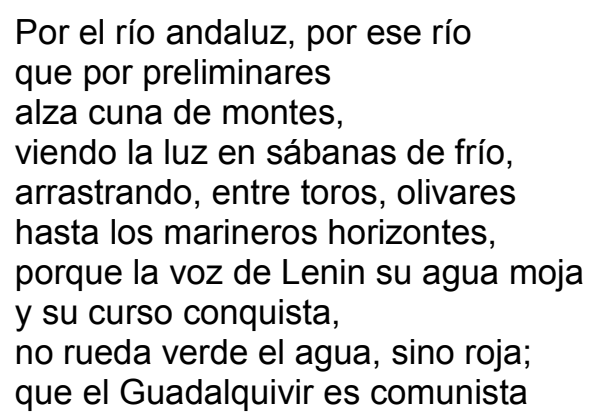

${ }^{30}$ Quizás puede hacerse extensible a la historiografía española la afirmación de Josefina Ludmer con respecto al tratamiento que recibe la sátira en las historias literarias argentinas: "Y también hay una cosa que la historia literaria argentina reprimió, que es la sátira. Es muy difícil, siempre están en segundo plano, siempre son olvidados o quedan enterrados en la historia. Esa tradición para mí era importante. La tradición cínica y la tradición satírica". [Encuentro, 2000: 214]. 
y la Giralda espera

rizar pronto en su frente esa bandera.

[PP, "En la entrega de la bandera que el C.P. de Sevilla y el C.C de las juventudes regalaron al Comité Central del Partido Comunista" (frag.): 765]

Sería conveniente, porque algunas composiciones son de gran calidad, aún aplicándole las reglas de la "alta" poesía. Y si el problema es ético, ("Lo más grave no fue falta de tensión poética, sino moral" [Paz, 1981: 207]), paradójicamente fue una conquista de la autonomía artística la no consideración de preceptos morales para juzgar una obra. Por otra parte, juzgar la moral de un poeta es una difícil cometido; condenar por falta de moral a todos los poetas que loaron a una personalidad, un acto de suprema arrogancia ${ }^{31}$.

\subsection{Derroteros de las vanguardias}

El lector que se acerque a los poemas del treinta percibirá una fractura, una notable distancia con los de la primera época. Es frecuente encontrar que la diferencia se explica por el final de las vanguardias y el triunfo de una opción estética de signo opuesto. Vuelvo a insistir en que el problema es arduo y la fórmulas categóricas no satisfacen. En gran medida dependerá de la idea que se da por sobreentendida al hablar de vanguardia.

Indudablemente, si se acepta -como he venido argumentando- que al principio se asoció la categoría vanguardia a las versiones españolas más tempranas, ultraísmo y creacionismo- y que con posterioridad sirvió para identificar las teorías y prácticas del arte nuevo impulsado por Ortega y Gasset y su grupo, es aceptable entonces que al finalizar la década del veinte se produjo una fractura con el arte concebido como cultivo refinado de las formas, indiferente

${ }^{31}$ Las perspectivas del poeta mexicano sobre la guerra de España convocan el debate y la réplica. . Véase la respuesta que originó su discurso en el Congreso de Intelectuales celebrado en Valencia en 1987, conmemorativo del homónimo de 1937. "El primer día, en el brillantísimo discurso inaugural, Octavio Paz aportó una espléndida licencia poética -yo temo que el destino de muchas licencias poéticas sea el de convertirse en licencias históricas-, y ese licencia poética fue que, finalmente, el vencedor de la guerra civil o los vencedores habían sido la monarquía y la democracia, hermosa licencia poética.

Sin embargo, yo, recuperando de pronto mi memoria sacudida por el impacto y la belleza de las palabras, recordé que durante treinta y seis años tuve la sospecha de que quien había ganado la guerra era Franco". [Vázquez Montalbán. (Citado por Caudet, 1993: 543] 
a la realidad cotidiana y destinado a espíritus selectos e instruidos, únicos con capacidad para comprenderlo en su justo valor.

Por vanguardia se entiende, en el sentido amplio de la crítica anglosajona, movimiento equivalente a arte estetizante, de filiación modernista, heredero del torreburnismo, derivado después en arte puro, cuya manifestación más excelsa es la poesía de Juan Ramón Jiménez, es notorio que en los años treinta una impetuosa corriente de arte impuro, abanderada por Pablo Neruda terminó por imponerse pese a la resistencia de "la inmensa minoría" ${ }^{2}$.

Si vanguardia se asocia a la idea primordial sostenida por Peter Bürger, según la cual el rasgo determinante es el cuestionamiento de la institución arte, se ha visto que no es factible hallar esa voluntad visceralmente iconoclasta en España, ni antes ni después de 1930. Los embates contra el canon y la tradición no cuestionaban desde las raíces las instituciones artísticas.

Pero si se considera que además de socavar la institución arte, desde una radicalidad hasta entonces desconocida, las vanguardias buscaron ligar nuevamente arte y vida a través de una nueva praxis; si se considera que el arte volvió a concebirse, como en la utopía moderna, como un pilar insustituible en una sociedad que se pusiera al servicio del hombre y no de los intereses de una clase; entonces, la vanguardia, lejos de desaparecer en los años treinta, recupera nuevas fuerzas mediante la alianza con la vanguardia política.

Hasta dónde fue conscientemente asumida la alianza; hasta donde las circunstancias favorecieron la suma de unas voluntades de naturaleza dispar, y por eso mismo, destinada a no perdurar; hasta dónde -con palabras de Vázquez Montalbán- se puede decir que la causa del fracaso fue "una apropiación indebida del impulso revolucionario más generoso y total", es un debate que permanecerá abierto mientras haya artistas cuyas preocupaciones no obtengan todas las respuestas dentro del campo de la autonomía del arte.

\footnotetext{
32 Pablo Neruda realizó un primer viaje a España en 1927 sin demasiada repercusión. Volvió en 1935 y se convirtió rápidamente en el abanderado de la poesía impura. Alberti refiere en sus memorias que intentó en 1930 y 1931 hacer publicar en España, sin resultados, Residencia en la tierra. Es notorio que para su segundo viaje, el poeta chileno ya contaba con un amplio público.
} 
Finalmente, es preciso recordar, como ha demostrado con rigor Peter Bürger, que la autonomía no debe tomarse como una estado definitivo del estatuto del arte en la sociedad burguesa ${ }^{33}$.

Alberti, como muchos de sus contemporáneos, lejos de abandonar la vanguardia la asumió bajo una nueva forma, con la lucidez y plasticidad con que siempre había recogido el reto de los sucesivos ismos: no a partir de la reproducción obediente del modelo sino tomando conciencia de lo que en cada movimiento había de pronunciamiento crítico y oportunidad estética. Nunca le faltó la intuición pronta y certera para notar las tendencias del canon y dónde se situaba la institución hegemónica en el campo intelectual de cada época.

En 1930 la Elegía cívica pone de manifiesto el paso del artista satisfecho en su ámbito específico, al artista que desea participar de los acontecimientos sociales y políticos de su época. Jiménez Millán ha desandado el proceso que un año después madura hacia la militancia política, sumándose a la tendencia generalizada de los artistas e intelectuales europeos que se afiliaban al Partido Comunista, quebrantando la fórmula mediante la cual Zola fundara la figura del intelectual al lanzarse a intervenir en la política desde la propia esfera estética. Renunciaba así a la íntima inclinación anarquizante preferida por los surrealistas franceses, porque "aspiraban a una racionalidad con capacidad transformadora de las condiciones materiales esenciales de una nueva libertad total, a la medida de un supuesto hombre total". [Vázquez Montalbán: 1999: 51]

El año decisivo para el cambio será 1932. Entonces Alberti recibe una beca de la Junta de Ampliación de Estudios que lo lleva a París, junto a su compañera María Teresa León. Desde la capital francesa tendrán oportunidad de viajar por otros países centroeuropeos y por la Unión Soviética. Toman contacto con personalidades del mundo de las letras y del pensamiento en un momento en que confían en realizar una verdadera revolución cultural. Son algunos de ellos Alejo Carpentier, César Vallejo, Miguel Ángel Asturias, André Gide, Johanes Becher,

33 "[La singularidad de la categoría autonomía] consiste en que describe algo real (la desaparición del arte como ámbito particular de la actividad humana, vinculada a la praxis vital), un fenómeno real cuya relatividad social, sin embargo, ya no se puede percibir, hecho éste que tampoco escapa al concepto. Como el público, la autonomía del arte es también una categoría de la sociedad burguesa, que desvela y oculta un real desarrollo histórico". [Bürger, 1987: 84] 
Henri Barbusse, Louis Aragon. También conocen a destacados representantes de las artes plásticas: Picasso, Chagall, entre otros.

La trascendencia de estos contactos tiene directa relación con el papel que Alberti y María Teresa desempeñarán como introductores de una nueva poesía al servicio de la causa proletaria. Tal vez se puede decir que Alberti fue a la literatura comprometida lo que Larrea al surrealismo en España; esto significa que no estamos ante un poeta de los muchos que adscribieron a la nueva estética del compromiso, sino ante quien desde un lugar destacado, en estrecha colaboración con los movimientos internacionales y con apoyo moral y material, encabezó con una energía desusada y de forma inclaudicable, el proyecto revolucionario en su doble vertiente estética y política.

Además de unir las dos caminos en circunstancias excepcionales, tuvo el don, no siempre frecuente, de la palabra encendida, el gesto escenográfico y la la capacidad de para transmitir a las multitudes la literatura de la nueva era.

Aunque he anticipado la idea, creo preciso volver sobre el significado de la Unión Soviética para los distintos sectores de los países occidentales que rechazaban el orden burgués. El país de la revolución bolchevique era el símbolo de la resistencia frente al nacionalsocialismo en alza, y el "topos" donde se hacían realidad los sueños y esperanzas que en las demás sociedades todavía se situaban en el futuro. Como señala Beatriz Sarlo, Rusia hace resurgir el mito de las sociedad sin conflictos, sin diferencias de ninguna naturaleza -laboral, sexo, edad, origen. La gente del arte encuentra además que, para ellos específicamente, se supera el problema de la marginación de la cultura en la sociedad. La pregunta de Alberti, "¿qué soy?" allí no tiene sentido, porque el escritor tiene un lugar y una misión.

No existen [en Rusia] artistas desempleados a la búsqueda de un público o negociando con el mercado; tampoco existen artistas que trabajen guiados por la voluntad individual, único motor de producción en las sociedades de clase. Los artistas trabajan para el pueblo y ocupan en la nueva sociedad el lugar que, en la vieja, obturan las relaciones mercantiles. El arte ha encontrado por fin un espacio universalmente reconocido. [Sarlo, 1988: 127] 
Sin duda el viaje europeo y soviético constituyó para Alberti la posibilidad de un nuevo ordenamiento de sus incesantes exploraciones. La protesta desbocada que inicia en Sobre los ángeles se orienta hacia la acción revolucionaria. Su papel de escritor en ambivalente relación con las instituciones literarias, dentro de las que se guarecía pero a cuyos ámbitos no se sentía pertenecer totalmente, encontrará la justificación buscada al ponerse al servicio de la revolución ${ }^{34}$.

La experiencia [el viaje a Centro Europa] debió ser muy interesante, sobre todo si se tiene en cuenta que la literatura española no contaba con modelos inmediatos para este tipo de poesía: existía, eso sí, una fuerte polémica en torno al compromiso en la literatura, pero los primeros intentos se empiezan a dar de forma aislada y por caminos puramente individuales; no sólo es Alberti, sino también Emilio Prados y Pascual Pla y Beltrán los que abordan un proyecto de poesía comprometida, con diferentes resultados. [Jiménez Millán, 1990: 149]

Suelen abundar los especialistas en las dificultades con las que chocó Alberti al introducir el nuevo molde estético; sufrió diversos ataques y desprecios, de los que sus memorias y las revistas de la época dan cuenta. Sin embargo, si nos atenemos a los estudios existentes, los episodios suscitados deben entenderse como la previsible respuesta de los defensores de la autonomía artística, que ya no encontraban un campo propicio, y era desplazados a los márgenes del campo intelectual junto con las figuras faro de esa concepción de la literatura ${ }^{35}$. En este cruce de fuerzas deben encuadrarse los enconados conceptos de Juan José Domechina ante la aparición de Consignas en 1933. La posición de Domechina pone a dura prueba a los historiadores de la literatura, pues su defensa acérrima del arte puro no le impide figurar como amigo de Azaña, fiel republicano,

${ }^{34}$ En El poeta en la España de 1931 había renegado de su poesía anterior por burguesa e individualista. En 1935 confirma la finalización del ciclo publicando una antología, Poesía (1924-1930) en cuyo prólogo informa: "Publico la mayor parte de mi obra poética comprendida entre 1924 y 1930, por considerarla un ciclo cerrado (contribución mía, irremediable, a la poesía burguesa)", es decir, renuncia a su obra al mismo tiempo que la institucionaliza.

${ }^{35}$ Cano Ballesta también ilustra esta situación unos años después, en 1935, cuando llega a Madrid Pablo Neruda y constituye el polo antagónico a Juan Ramón Jiménez. Pablo Neruda, con sus escandalosos manifiestos de "poesía impura" impresiona fuertemente a ciertos poetas jóvenes, que comienzan a publicar en Caballo Verde para la Poesía y se van agrupando en torno al cónsul de Chile. El nerviosismo y alarma de Juan Ramón Jiménez (...) es un testimonio elocuente de que éste veía peligrar su posición de pontífice supremo de las musas (...) Juan Ramón percibía indudablemente que en torno suyo iba abriéndose el vacío [Cano Ballesta, 1972: 205]. La visión que brinda Andrés Trapiello [1994] es opuesta, pues atribuye el origen de la discordia al afán de portagonismo del chileno. 
más tarde colaborador de Hora de España ${ }^{36}$ y El mono azul, circunstancias que lo llevaron a morir en el exilio mexicano en 1959. Entre los juicios vertidos para referirse a la nueva poesía abundan expresiones como "la fruición verbenera y en mangas de camisas de los flamantes derechos ciudadanos". Refiréndose al "poeta del pueblo", "charlatán de plazuela", dirá que "ya han prescripto los milagrones, y están en baja los fenómenos de sugestión colectiva". [Citado por Cano Ballesta, 1975: 220]

Domechina establece una rigurosa separación entre los tribunos y hombres públicos, a quienes respeta en su misión, y los poetas, que deben mantenerse en el ámbito privado guardando la llama de su voz desinteresada y limpia, no comprendida de inmediato pero fecunda a largo plazo.

El poeta no es uno de esos verbos perentorios, de urgencia, para el mitin o el motín que se improvisan. La función magistral del poeta sólo a la larga repercute en la sensibilidad del pueblo. Su intuición, progenerada, por lo mismo que invade los planos del futuro, carece de contemporaneidad. [Domechina, Juan José, 1931. "Los poetas y los tribunos" en La Gaceta Literaria, 110, 15 jul. 1931 (citado por Cano Ballesta, 1975: 220-221)]

Pese a los ataques, Alberti recibió un rápido reconocimiento internacional, pues una vez más unió a su proverbial talento una posición, anticipada, doblemente "avanzada" -poética y política- a la hora de asumir una nueva estética. Se vio favorecido en esta circunstancia por un emplazamiento aventajado en el campo intelectual, al que se sumará, en la época del Frente Popular, la disposición de una sólida base partidaria -la del Partido Comunista de Españapara proyectarse en el plano político.

El prestigio de Alberti en los distintos ámbitos de la política y de la cultura sin duda le fue de una gran ayuda, pero de poco hubiera servido sin su singular capacidad para nuclear a su alrededor y de la revista Octubre a un alto número de

${ }^{36}$ Es la revista más renombrada del sector republicano durante la guerra civil. Los subtítulos enuncian sus cometidos: Revista mensual; Ensayos. Poesía. Crítica; Al Servicio de la Causa Popular. Apareció entre 1936 y 1937 en Valencia. En todos sus números colaboró Antonio Machado, además de numerosos intelectuales reconocidos que intentaron continuar con una oferta de alta cultura a pesar de los acontecimientos, razón por la cual es adjetivada de elitista por parte de algunos investigadores. Algunos de los escritores que publicaron en Hora de España: su director, Sánchez Barbudo, Serrano Plaja, Zambrano, Gil-Albert, Dieste, Altolaguirre, León Felipe, Navarro Tomás, Moreno Villa, Xiaru, Riba... [V. Caudet, 1975] 
poetas consagrados. Debe señalarse que varios de ellos, como Cernuda, coincidieron ideológicamente pero no secundaron la estética revolucionaria.

\begin{abstract}
Rafael Alberti, el indiscutible iniciador de la poesía revolucionaria en España, tiene sobre Emilio Prados -que tal vez cronológicamente se le adelanta en alguna composición- la ventaja de haberse convertido desde el primer momento en jefe visible de esta nueva orientación de las letras. Sus poemas no se mantienen entre reducidos círculos de oyentes -los de Prados eran recitados a grupos de obreros y no hallaron en su mayoría publicación inmediata- sino que aparecen muy tempranamente en las páginas de revistas y en formato de libro suscitando gran escándalo en círculos literarios y llamando la atención de un amplio público sobre la posible función social de la poesía. [Cano Ballesta, 1975: 227]
\end{abstract}

Una vez producida su "caída del caballo", el poeta gaditano dio muestras de fidelidad a las ideas, que se aunó con una energía inagotable y una capacidad privilegiada para desarrollar una tarea cultural y política de gran proyección. Una breve relación de sus cargos y actuaciones no vinculadas específicamente a la creación literaria dan justa cuenta de la dimensión de su intensa labor: desde 1933 en adelante se registra: participación en el Primer Congreso de Escritores Soviéticos, fundación de Octubre, primer exilio y gira por América después de la revolución de 1934, participación en la campaña del Frente Popular en 1936. Durante la guerra, junto a su esposa, figuró entre los principales impulsores de la Alianza de Escritores Antifascistas y de El Mono Azul. Dirigió el Museo Romántico durante el asedio de Madrid, integró el $\vee$ Regimiento comandado por Líster, participó activamente del Congreso de Intelectuales Antifascistas celebrado en Valencia y veló en forma personal por el patrimonio artístico del Museo del Prado, participando del traslado a Francia de los principales cuadros.

Ningún otro escritor encarna en apariencia mejor que Rafael Alberti el compromiso político de la literatura en la España del siglo XX. Casi siete décadas de vinculación con la fe del siglo, el movimiento comunista, multitud de poemas de movilización o de denuncia, la actuación al frente de la Asociación de Escritores y Artistas Revolucionarios, en la órbita de la Internacional Comunista, luego de la Alianza de Intelectuales Antifascistas, en tiempo de guerra, hacen de él una figura emblemática, tanto de los sueños revolucionarios como de la resistencia republicana y del largo exilio. [Elorza, 1999: 24] 
El rumbo que elige Alberti no es excepcional ni inexplicable, aunque es quizás el más sobresaliente debido a la profunda coherencia de su proyecto creador. No por mil veces repetido debe olvidarse el significado de la revolución de 1934 primero y de la guerra de España después, para los amplios sectores de los países occidentales que se identificaban con la construcción de una sociedad libre de injusticias y con la batalla que se libraba contra el fascismo. En el campo del arte, nunca las vanguardias se sintieron más cercas del cumplimiento de su programa, la integración del arte en la vida.

Los escritores que apoyan a la república ven, quizás por primera vez, a su discurso circulando en medio de una sociedad que lo juzga audible y necesario. [Sarlo, 1988: 136]

Los escritores se debatían entre su intención de que desaparecieran las barreras entre autores consagrados y creador "incipiente" pero según demuestra Caudet [1993] prevaleció la idea de que el artista se encontraba en un lugar "avanzado" y con una misión que cumplir. Los testimonios coinciden con la visión de Sarlo, ya que el artista siente la nueva y gran responsabilidad de hablar para un nuevo público que los escucha.

María Zambrano, al referirse a la experiencia de El Mono Azul, transmite la especial emoción que le producía el acercamiento con el pueblo.

\footnotetext{
Muchos no sentíamos escuchados por primera vez por una masa de oídos, de inteligencias, atentos a nuestras palabras con esa atención densa y perspicaz de los niños y los pueblos. [Zambrano, 1936: nos 3-4. (citado por Caudet, 1991:43)]
}

La edición de la poesía completa de Alberti ha permitido apreciar que el poeta gaditano pensaba en lectores inexpertos que necesitaban de su guía y que requerían de más notas aclaratorias. Existen testimonios del poeta que recuerda los pedidos de la gente sencilla para que le prestara su voz, componiendo poemas sobre determinados temas y situaciones, generalmente relacionados con la guerra. Sobre esta misión didáctica y populista es interesante recordar el comienzo de 13 bandas y 48 estrellas: 
(Quizás muchas de estas notas no sean necesarias, por sabidas. Pero las dejo, pensando antes que nada en que puedan servir de orientación a los obreros que lean este poema). [Alberti, 1988: 661]

Las críticas que desde los fueros del arte se levantan a menudo contra la literatura testimonial suelen desconocer el contexto excepcional de los sucesos de España. El afán de objetividad busca hoy un justo medio que favorecido por la distancia temporal de los hechos y por la voluntad conciliatoria de la posmodernidad, pero a riesgo neutralizar los conflictos sociales y de postergar o desdeñar el vigor de las opciones morales que intentaron cambiar el mundo. Es imprescindible entonces tener en cuenta la ingente empresa moral y política que desde los postulados de la modernidad intentaron llevar a término artistas e intelectuales. La convergencia de sus fuerzas alcanzaron un punto tal vez irrepetible. Los planteos fundados en los valores universales del arte resultan entonces parciales y carentes de la perspectiva necesaria para comprender la fecundidad de aquel momento histórico, tal como lo manifiesta la siguiente reflexión de Manuel Vázquez Montalbán.

Una mirada, aunque sea ligera, hacia aquel fascinante período de entreguerras mundiales de este siglo (...) revela la cantidad de evidencias inaplazables, pero aplazadas, que aquellas gentes reunieron, en un esfuerzo de comprensión de la vida y de la historia realmente gigantesco. Cualquier causa hoy reivindicada, sea individual o colectiva, ya era una reivindicación en los años veinte y treinta (...) Y no era una cuestión baladí el tema del compromiso de los sacerdotes de la cultura y que ese tema, inicialmente inscrito en la parcela de la moral y el talante, acabara llevando al de la función social de la creatividad. [Vázquez Montalbán, 1989: 22] 


\section{DESPUÉS DE LAS VANGUARDIAS: EL UMBRAL DEL EXILIO}

\section{1. "Final de plata amargo"}

Ramón Gómez de la Serna, Francisco Ayala y Rafael Alberti vivieron la experiencia del desarraigo en un mismo país, Argentina. Las discusiones sobre la categoría exilio $y$, en particular, sobre quiénes tienen verdadero estatuto de exiliado, han sido arduas entre los investigadores y entre los propios damnificados. En el momento de elaborar un registro, numerosos nombres son cuestionados; Gómez de la Serna es sin duda uno de los más polémicos. Para algunos era una persona cuyo manifiesto temor -rayano en lo efermizo- a cualquier tipo de alteración o desorden lo llevó a convertirse en una víctima temprana de la violencia que se desencadenó en su patria. Juan Gómez Pereira, sin profundizar en el debate, habla de su "exilio"1:

En el exilio progresivamente irá interiorizando, aún más si cabe, su sentir y la escritura se volverá autobiográfica" [Pereira1993: 61]

Por su parte, José Luis Abellán lo incorpora al índice onomástico "La emigración republicana de 1939" incluido en su señera obra El exilio español de 1939. Ignacio Soldevila en cambio introduce matizaciones: no le concede el mismo rango que a quienes abandonaron España después de la derrota de la República.

Su ausencia de España en los años de postguerra, hasta su muerte, no es asimilable al exilio de los escritores politizados.Tras los miedos en el Madrid en guerra sinceramente narrados en su autobiografía, que le llevaron al país de su esposa, su ausencia fue voluntaria y en resistencia a reiteradas invitaciones a un regreso triunfal. [Soldevila,1980: 30-31]

Desde mi punto de vista, existe una diferencia radical, de orden moral si se quiere, entre quienes salieron de España andando por los Pirineos, o en improvisadas embarcaciones o azarosas avionetas, con peligro de sus vidas y con

\footnotetext{
${ }^{1}$ Gómez de la Serna se había mostrado en desacuerdo con la vinculación de los escritores al orden republicano. En sus Automoribundia justifica el abandono de España en el verano de 1936 después de dos episodios que según él, le atemorizaron: la visión del poeta de segunda fila Pedro Luis Gávez paseándose por Madrid armado y con uniforme de miliciano, y el comentario de Delia del Carril, esposa de Pablo Neruda, acerca de que lo convertirían en el Gorki español.
} 
altas posibilidades de desembocar en un campo de concentración francés, y quienes pudieron alejarse planificadamente antes de la catástrofe final. Pero la dificultad de establecer una categoría rigurosa, definitivamente válida permanece, y con ella, la pregunta; ¿hasta que punto son equiparables los exilios de Pérez de Ayala, Manuel de Falla, Guillermo de Torre, del mismo Ortega, con los de Antonio Machado, Francisco Ayala, Rafael Alberti, María Teresa León, Max Aub, y tantos otros? (por hablar sólo de artistas e intelectuales²). Para evitar reincidir en interminables controversias, creo más esclarecedor seguir indagando la línea de análisis desarrollada en mi estudio: declinar toda aspiración a establecer categorías y conceptos definitivos y monolíticos y poner el énfasis en observar el modo en que los artistas e intelectuales se situaron ante determinados acontecimientos, sean estéticos -la vanguardia-, o político-sociales -la guerra civil- e indagar los posibles modos en que sus actitudes se proyectaron en sus obras y proyectos creadores de cada literato. En esta dirección, el capítulo final de esta tesis se abocará a analizar los primeros pasos de la expatriación de Gómez de la Serna, Ayala, Alberti y establecer la continuidad con sus derroteros anteriores así como las transformaciones fruto de la brutal cesura que significó la derrota del bando republicano, el alejamiento del suelo natal y la implantación de un régimen dictatorial en España.

Parto, por lo tanto, de una nueva circunstancia que reúne y da identidad. En este sentido, el exilio plantea a la historiografía un conflicto semejante al de la inclusión o la exclusión en la lista de la diáspora ${ }^{3}$. No es en sí mismo una categoría literaria, y el confinamiento de las letras producidas fuera de España en capítulos independientes, a veces como anexos, simples apéndices, -cuando no sufren flagrantes omisiones- ha causado más perjuicio que justo reconocimiento. Francisco Ayala es pionero en reclamar un trato no marcado en la serie literaria.

\footnotetext{
2
}

Caudet [1995: 31-55] ha cuestionado reiteradamente la tendencia de los refugiados españoles a identificar exiliados con intelectuales, ignorando a la gran masa de perseguidos y desterrados de oficios varios, en muchas ocasiones, más indefensos y librados a su suerte, sin el apoyo del mundo de la cultura que ayudó a los primeros en sus lugares de acogida. Recientemente, en abril de 2002, en el "Primer Coloquio Historia y Memoria: perspectivas para el abordaje del pasado reciente organizado por la Universidad Nacional de La Plata, ha insistido en el tema.

3 Se puede encontrar un enfoque lúcido y actualizado sobre el problema de lo universal y lo particular de los exilios, con específica atención a la literatura española en, Ugarte, 1999. 
Nidia Tagliabue ha extractado de memorias y ensayos la posición del autor granadino sobre los temas más relevantes, entre los cuales se halla la denominada literatura del exilio, acerca de la cual considera

no constituye categoría fundada en características literarias intrínsecas, sino que es fruto de circunstancias extrínsecas y adventicias -las derivadas de la guerra civil-, sin apenas otra repercusión sobre el contenido de las obras concretas que la meramente temática, y aun ésta, cuando se da, en manera acaso incidental. [Ayala, Palabras y letras, citado por Tagliabue, 1989: 488]

En la historiografía literaria sobresale Ignacio Soldevila por su pionera posición contraria a las inclusiones ad-hoc, justificada lúcidamente en diferentes ocasiones $^{4}$ y puesta en práctica en su propia historia literaria ${ }^{5}$. Sin embargo, el mismo profesor de la Universidad de Laval ha señalado oportunamente que la vivencia del exilio y sus consecuencias -muy prolongadas en el tiempo- tuvieron tan vasto alcance que configuró una nueva reagrupación del campo intelectual, ya delineada a comienzos de los años treinta y en consecuencia, deber ser estudiada en su merecido contexto.

\begin{abstract}
Desde el estallido de 1936, la generación, físicamente dispersa a los cuatro vientos del mundo, mermada de hombres tan importantes como García Lorca en la poesía y la dramaturgia, no será ya más que memoria de una edad de oro. Pero la historia de la literatura se escribe sobre pautas rutinarias y a nadie le choca que, por ejemplo, Arconada y Sender, por una lado, Aub y Ayala, por otro, sigan estudiándose, por lo que toca a su obra de postguerra, en función de criterios válidos para 1929 y 1932, pero no para los años cuarenta s sesenta. [Soldevila,1980: 24]
\end{abstract}

Partiendo entonces de la existencia de un corte abrupto de incalculables consecuencias individuales y colectivas, analizaré las respuestas de los escritores a la nueva circunstancia en los primeros años de su llegada a Argentina. No me centraré en los motivos del destierro más estudiados, esto es la especial presencia de un tiempo y un espacio "otros" en la poesía y en la narrativa ${ }^{6}$. El centro de mi atención lo constituirá una circunstancia devenida de la anterior, vitalmente menos significativa, pero crucial para un escritor desvinculado de su medio, me refiero a

\footnotetext{
${ }^{4}$ V. Soldevila, 1995.

${ }^{5}$ Id. id., 1980.

${ }^{6} \mathrm{~V}$. Blanco Aguinaga, 1991.
} 
la pérdida del público y de las instituciones literarias que respaldaban su ejercicio de la literatura.

La manera en que los escritores sufrieron ese cercenamiento y los diferentes caminos para enfrentarse a esta pérdida no son separables de las características del país de asilo, Argentina en este caso. Acerca de esta coordenada concreta, debe tenerse en cuenta que

\begin{abstract}
Las mayores o menores facilidades para reiniciar su vida que se ofrecen a los emigrados, dependen, naturalmente, en gran medida, de la configuración y las vicisitudes históricas del país de residencia. Han sido generalmente más duras en Europa, donde los exiliados empalmaron nuestra guerra con la mundial y donde las reglamentaciones de trabajo y la competencia profesional son más severas que en las repúblicas latinoamericanas, tradicionalmente abiertas a todo tipo de emigración. [Tagliabue, 1989: 477]
\end{abstract}

El propio Ayala describe la realidad argentina que le tocó vivir: el gobierno del presidente Ortiz restringió la entrada de los refugiados, motivo por el cual entre los que lograron ingresar figuraban muchos intelectuales que contaban con invitaciones personalizadas de distintas instituciones culturales o educativas. En compensación, a la falta de apoyo estatal, "las oportunidades económicas que la sociedad argentina ofrecía eran muy superiores, sin comparación posible, a las de la sociedad española previa a la guerra" [Ayala, "Entrevista" (citada por Tagliabue, 1989: 482)]

Añade la misma especialista, citando las impresiones de Ayala, que a esta coyuntura favorable se unió que antiguos emigrantes, expulsados por la pobreza de la Península, se transformaron en prósperos comerciantes y ayudaron a los recién llegados. Al mismo tiempo, en Buenos Aires se desarrollaba una actividad cultural muy intensa y la educación había alcanzado un nivel superior al de otros países de Latinoamérica. Por último, el medio intelectual fue sumamente generoso con los recién llegados.

Con independencia de que otros exiliados puedan haber sobrellevado el desarraigo con más dificultades materiales y morales, el clima cultural que me interesa rescatar es el que muy bien rememora Ayala. Diferentes estudios proporcionan un detallado registro de las actividades a que se abocaron los emigrados. Merece un capítulo aparte la presencia en distintas editoriales argentinas, que recibieron un inapreciable impulso con la participación de los 
exiliados, cuando no fueron creadas por ellos ${ }^{7}$. En otros casos, será su producción intelectual la contribución más significativa. En esta dirección las colaboraciones en Sur constituyen objeto de singular atención, ya que la revista de Victoria Ocampo presenta la particularidad de haber proporcionado espacio en sus páginas, junto a otros escritores del destierro, a los tres autores que convocan mi estudio. ¿ampliar?

\section{Ayala. Revisar el pasado, recuperar la institución}

Ayala demuestra precozmente, en distintos artículos posteriores a 1939, su preocupación por la pérdida del conjunto de instituciones que sirven de marco de referencia a la producción científica y cultural ${ }^{8}$. De todos modos, su situación personal privilegiada lo ayudó no perder los lazos con las instituciones culturales: al momento de llegar a Argentina tuvo un espacio permanente en Sur, frecuentó el círculo selecto de Victoria Ocampo y de mano de los principales integrantes del "grupo" -Eduardo Mallea, Francisco Romero, Atilio Rossi- se incorporó a la vida cultural argentina.

La inquietud que le producía la desmembración del campo cultural de su país convivió, como en la mayor parte de los desterrados, con la reflexión sobre la guerra y la historia reciente de España. No fue Ayala partidario de alimentar un pathos del destierro doliente y nostálgico

El exilio es uno de tantos mitos (...). Cualquier español que se trasladaba a
un país iberoamericano estaba menos exiliado que los que se quedaron
dentro (...). Es un poco irritante que se lloriquee por la patria ausente y esas
bobadas cuando los que verdaderamente podían quejarse eran los que
estaban allí. [Entrevista. Citado por Tagliabue, 1989: 482]

No obstante, el tema de España estuvo presente desde los primeros días. En "Carta literaria a Hugo Rodríguez-Alcalá", publicada en 1963, explica la motivación íntima de Los usurpadores.

Cuando, pasada mi juventud, volví yo a producir obras de imaginación, la experiencia que debía elaborar era la de la Guerra Civil española sobre el fondo de la Segunda Guerra Mundial. Si para elaborarla elegí por lo pronto

${ }^{7}$ V. Matamoro, 1982; Pochat, 1991 y Zuleta, 1999.

${ }^{8} \mathrm{~V}$. Macciuci, 1997. 
episodios del pasado histórico fue, claro está, para tomar distancia frente a esa experiencia y procurar desentrañarla, es decir, objetivarla en formas artísticas.

El "Diálogo de los muertos" es su primer intento de buscar una explicación a la tragedia: dos combatientes, víctimas pertenecientes a distintos bandos y enterrados en una fosa común, conversan sobre la igualdad del los hombres ante la muerte. El relato actualiza el motivo medieval de la danza macabra. En la fosa común las diferencias que enfrentaron a nacionales y republicanos se convierte en una conversación sobre la inutilidad de los enfrentamientos fratricidas y en un repaso de las responsabilidades de cada bando. La perspectiva de Ayala en el exilio refrenda la visión equidistante de los hechos de la que ya me he ocupado. Cabe señalar que cuando recibió el premio Príncipe de Asturias, Don Felipe de Borbón elogió su equilibrio frente a las opciones radicales y violentas ${ }^{9}$.

Los primeros pasos de la recuperada vocación literaria coincidieron con la preocupación, bien fundada, sobre las adversidades con que se chocaba una obra producida en territorio ajeno. El libro así nacido

no halla el ambiente que le sirviera de supuesto y punto de partida, o no lo halla en las condiciones de plenitud apetecibles: discusiones de cátedra, de seminario y de revista especializada, polémica científica. [Ayala, 1984: 188]

Las circunstancias se vuelven más adversas para el escritor literario, porque

también, aunque sutil, la invención literaria se cumple y ha de cumplirse bajo el supuesto de un cierto ambiente, y sometida a las condiciones que éste le impone". [ld. id.: 196]

La situación, por razones distintas, afectaba tanto a la literatura del exilio como a la que se producía en España; en el destierro actuaba la distancia, la interferencia deotras tradiciones culturales, la pérdida del público. En el interior, la medianía, el control de la censura y la manipulación del arte por la dictadura. El análisis de este contexto desfavorable lo lleva a la convicción de que se debe refundar la institución literaria a partir de las condiciones un poco más ventajosas del escritor exiliado, en tanto goza de una libertad de expresión de la que carecen los que permanecieron en España. Esta diferencia a su favor lo compromete a tratar de

\footnotetext{
${ }^{9}$ Cito de memoria el concepto central.
} 
conectarse con las manifestaciones independientes, no serviles al régimen, que poco a poco fueran abriéndose camino en el suelo patrio.

Ayala aborda conscientemente la misión de reunir y refundar la tradición dispersa o perdida y se atribuye, explícita o implícitamente, un papel central mediante un recurso tautológico: producir una obra de calidad y constituirse en comentador de la misma. Su condición de crítico y especialista lo llevan a afirmar que la mediocridad de la literatura de posguerra requiere nuevas creaciones, no sujetas ni a la mediocridad y controles de la Península ni a la propensión a la nostalgia o el nacionalismo que experimentaban gran número de desterrados. Con respecto al estado de la crítica, literaria sostiene que en los países de asilo era mala o inexistente.

Sin embargo, sé que esas novelas [Los usurpadores] están por encima de la opinión común y que -desde luego- pertenecen a un plano literario muy alto. Precisamente he escrito ese prólogo [el de Los usurpadores] con el designio de decirle a la gente que el libro es bueno, que se fijen en esto, y en lo otro, y en lo de más allá; en fin, con ánimo de orientar al lector, para emplear una fórmula decente. CoMo NO EXISTE CRÍTICA, Y LA VIDA LITERARIA ES PAUPÉRRIMA, UNO TIENE QUE SUPLIR A TODO ${ }^{10}$. [Ayala. "Desdoblamiento", Diario íntimo, "Primavera de 1948". (Citado por Richmond: 1992, 20)]

El escritor granadino cree que puede suplir ambas falencias con éxito; la simbiosis entre escritor y auto-crítico de su obra, entre productor y lector privilegiado de sus textos, se constituirá en rasgo permanente de Ayala y su autoridad será punto de partida para numerosos lectores y especialistas de su obra. La fusión escritorinstitución legitimadora tendrá relaciones bienavenidas durante su extensa trayectoria. Los juicios del autor sobre su propios textos han sido tan decisivos que rara vez la crítica deja de citarlo en un lugar central del análisis. Así ocurre con la ya aludida explicación sobre el tema central y el título de Los usurpadores, "el poder ejercido por el hombre sobre su prójimo es siempre una usurpación") que el autor realiza a través de la voz "prestada" de un prologuista amigo".

En otras ocasiones, el mismo autor, además de constituirse en prologuista de sus obras reedita juicios propios ya vertidos -cita textualmente varios párrafos del "Proemio" a La cabeza del cordero- junto a otros inéditos. En la "Introducción" a Mis

${ }^{10}$ Subrayado mío.

${ }^{11} \mathrm{Cfr}$. Amorós, Richmond, Irizarry, Zuleta y contratapa de Los usurpadores de editada por Cátedra. 
páginas mejores [Ayala, 1991: 7-20], su voz adquiere un lugar privilegiado al lado de otros especialistas prestigiosos -Fryda Shultz de Mantovani, Hector Murena, Keith Ellis, Enrique Pezzoni- quienes, dada la circularidad del procedimiento, son también legitimados mediante la sanción del prologuista-autor. Por lo tanto, a la función de crítico de sus propios textos se suma en esta ocasión, la de crítico de sus críticos. La mayor parte del prólogo a Mis páginas mejores reproduce una carta literaria a R. Rodríguez Alcalá en la cual rebate varios conceptos sobre determinados rasgos de su obra. La preocupación por dejar sentada su postura ante el mencionado especialista se vuelve el motivo estructurante y decisivo de la "Introducción".

Como he anticipado y señala también Carolyn Richmod, Ayala expresa a menudo su respeto por el lugar del lector, "la invitación al lector para que juzque por sí mismo corresponde, por lo demás, a la actitud liberal del autor y a su respeto por las capacidades e independencia crítica de los lectores" [Richmond, 1992: 29]. Afirmaciones de esa naturaleza ponen aún más en evidencia la autoridad que se concede el autor granadino, ya que después de las vanguardias el rango del lector es tan soberano que no necesita reconocimiento. Su mención adquiere, por tanto, rasgo de elemento marcado, revestido de connotaciones opuestas a las declaradas $^{12}$. No obstante, como el papel del lector es, en definitiva, inalienable, mediante otra operación titulada sugestivamente de "Desdoblamiento" -el título es por sí solo muy esclarecedor-, se convierte ahora en lector, no en uno más, sino en un lector privilegiado. Mediante esta operación, Ayala instaura la auto-crítica de su obra.

He anticipado en el capítulo correspondiente que Los usurpadores no es obra de fácil recepción, por lo tanto presenta riesgos de una lectura deficiente, "desviada" de los "propósitos" del autor. En el contexto de pérdida de la institución literaria, considero que Ayala refuerza las zonas que han quedado debilitadas para una aceptable difusión de su obra; me detendré en algunas de sus estrategias.

Para favorecer la lectura "correcta" dispone un prólogo, espacio apropiado para la introducción de la voz autoral, de una auctoritas que imparte orientaciones de

12 Richmond es consciente del "exceso" pues agrega que la mención del público "tampoco debe hacernos olvidar la firme confianza que el pseudo prologuista expresa en las dotes del narrador y, por consiguiente, en la calidad literaria del volumen que le ha tocado presentar". [1992: 25]. 
lectura. En este caso el novelista se oculta mediante el recurso clásico de la firma apócrifa, "F. de Paula A. G. Duarte"13, tras la ficción de un prologuista amigo, quien se presta a anticipar una lectura crítica del texto desde la situación privilegiada de la cercanía al autor- es quien más lo conoce. De esta manera, el desdoblamiento del autor en amigo bajo la apariencia de un sujeto-otro, más imparcial y objetivo, refuerza y otorga mayor peso a las recomendacines vertidas. La factibilidad de su misión no es puesta en duda, por el contrario, se subraya:

\footnotetext{
Que el autor del presente volumen (...) haya recurrido a mí (...) para que explique a sus lectores en un prólogo el significado de la obra de ficción que aquí les ofrece, es cosa desde luego que hace honor a nuestra vieja amistad. [LU: 31]

Mi función [es] tratar de poner en claro sus motivos e intenciones.[LU: 32]
}

Pese a que el prologuista finalmente reconoce que la evaluación definitiva sobre los logros estéticos de la obra corresponden al lector -"sea pues el lector quien, por su cuenta y riesgo, lo compruebe" [LU: 37]- a lo largo del prólogo abundan instrucciones para allanar el camino de la lectura que trascienden los límites del anunciado objetivo de aclarar los propósitos y motivos del autor. Las incursiones en el terreno de la valoración y apreciación estéticas son constantes y taxativas.

El autor/amigo comenzará explicando "los rasgos internos" de Los usurpadores, "obra de bien trabada unidad" [LU: 32] previa explicitación del tema central común a los ocho relatos y de la proyección simbólica de los contenidos explícitos.

Su tema central (...) pudiera formularse de esta manera: que el poder ejercido por el hombre sobre su prójimo es siempre una usurpación. [LU: 32]

Del tema central se desprenden motivos recurrentes que contribuirán al logro de "tan honda unidad de sentido". A la reseña de los elementos llamados ideológicos sigue la categórica formulación de las intenciones del autor, "ofrecer ejemplaridad",

${ }_{13}$ Salvo excepciones, la crítica reconoció rápidamente el nombre completo del propio autor Francisco de Paula Ayala García-Duarte- en la firma apócrifa. 
de cuyo éxito es prueba el resultado obtenido, haber logrado entreabrir "un cauce piadoso a la naturaleza humana para salvarse de la desesperación".[LU: 35]

Seguidamente, el prologuista conectará la serie literaria y la serie social para explicar que la marcada presencia de "lo demoniaco, engañoso y vano de los afanes dominadores" se debe a los excesos de nuestra época y a las experiencias personales de Ayala. Las mismas razones justifican igualmente que el autor vea "la salud de espíritu en la santa resignación". [LU: 35]

El siguiente aspecto que el prologuista aclara al destinatario es la causa por la cual los relatos se sitúan en el pasado y la manera como, mediante esta elección, se logra una tratamiento artístico nuevo y más apropiado para transmitir "las intuiciones esenciales". Subraya además que tal empresa no fue fácil debido al desgaste que el género histórico alcanzó en el siglo XIX. Al respecto informa que Ayala recurrió al género previendo sus riesgos, logrando así sortear "con éxito" los aspectos menos reputados del relato histórico -evasión, deleznable fantasía, arqueología idiomática. Su lenguaje, lejos de incurrir en pastiche', sabe encontrar el tono de discurso apropiado a la atmósfera de cada cuento: enfático en "San Juan de Dios", sobriedad rayana en la pobreza en "El hechizado", barroco en "Los impostores". De la misma manera, el autor amigo ha sabido adecuar la técnicas a los requerimientos internos de los relatos: crónica, compostura erudita, cambios de perspectiva, etc. Nuevamente, mediante un discurso elíptico, el prologuista elabora un velado "orden de mérito" y concede a Ayala un lugar sobresaliente, si no el más alto, en la galería de autores.

En los párrafos finales hace referencia al papel activo del lector, quien será "capaz de reparar" "sin ajena ayuda en cómo los requerimientos internos de cada relato han determinado la técnica de su desarrollo literario" [LU:37]. Sin embargo, el prologuista continuará conduciendo la lectura a través de formas verbales intermedias entre lo imperativo y lo inevitable: la eventual lectura independiente parece disolverse tras la modalización imperativa que puede encerrar el futuro imperfecto: el lector “Reparará”, “comprobarÁ”, “observarÁ”...14 [LU:37]. Cuando en el párrafo final se devuelven al destinatario sus prerrogativas y el prologuista se

\footnotetext{
${ }^{14}$ Subrayado mío.
} 
repliega a los supuestos reducidos alcances de su misión, resuena como un tópico de humildad acorde con el estilo clásico de todo el texto preliminar.

Carolyn Richmond, una de las más reconocidas especialistas en la obra de Ayala, advirtiendo la singular superposición de autor y crítico, ha realizado una serie de inferencias que la explicarían: necesidad de presentar ante el público argentino a un escritor exiliado que era más conocido como sociólogo y profesor, cierta soledad resultado de la pérdida de contacto con sus lectores a raíz de la guerra, lucidez de escritor- crítico muy consciente de su oficio

\begin{abstract}
La redacción por un autor -a posteriori, claro está- de un prólogo a un libro suyo puede responder a diversos impulsos y obedecer a una pluralidad de intenciones, desde lo informativo hasta lo apologético y justificatorio. En el caso de Los usurpadores, el supuesto "amigo" portugués del autor Francisco Ayala pretende estar cumpliendo en su prólogo un doble encargo suyo: el de recordar -en verdad, informar- a los lectores (argentinos) de la previa trayectoria narrativa del un escritor español conocido de ellos entonces sobre todo por sus numerosos trabajos de teoría política, sociología y crítica literaria, y a la vez, el de explicar los "motivos e intenciones" del volumen prologado. [Richmond, 1992: 28-29].
\end{abstract}

Más adelante, la misma especialista abundará en otras posibles razones:

... evidencia en Ayala, escritor intelectual después de todo, plena conciencia, no sólo de sus intenciones originales y medios operativos, sino también del resultado artístico de su obra. [Richmond, 1992: 29].

La última hipótesis reconstruye la singladura de Ayala desde sus primeras obras, pasando por su manera de entender la vanguardia, aspectos en los que me extendido con anterioridad: Cazador en el alba también lleva un prólogo con aportaciones personales: el desdoblamiento de autor-crítico no obedece sólo a la segregación de su público natural, está en las bases mismas de su proyecto creador, ligado a una misión formativa, en definitiva, a una vanguardia ilustrada.

\title{
3. alberti. Claveles y espadas, viejos y nuevos lectores
}

La crítica ha mencionado reiteradamente el decisivo valor del poema "De ayer para hoy" que abre Entre el clavel y la espada. La composición había sido publicada con el título "Para luego" en 1938 en Hora de España. Su importancia 
se intensifica por haber sido seleccionado para pasar de la transitoriedad del periódico a las páginas iniciales de su primera obra larga del exilio, integrándose en un manifiesto poético que funciona como bisagra entre su obra anterior y la que inicia en Sudamérica. El momento de tránsito se resume en la mención del ayer, "el desorden impuesto", "la prisa", "la urgente gramática necesaria" y la aspiración del presente, "vuelva a mí toda virgen la palabra precisa/ virgen el verbo exacto con el justo adjetivo". Entre ambos, el hoy, "en que vivo" donde confluyen el desorden pretérito y la esperanza de otro futuro aún por realizarse, pues el verbo está en subjetivo, "vuelva". ["De ayer para hoy", ECE: 11]

También ha sido subrayado con insistencia el papel clave de Entre el clavel y la espada como poemario que sintetiza la fusión de dos componentes esenciales de la poética albertiana, la sumisión al rigor de la poesía y de las exigencias compositivas $y$, por otra parte deber de ser fiel a la memoria del drama reciente $y$ el propósito de no dejarse vencer por la derrota y el desarraigo.

Hincado entre los dos vivimos: de un lado, un seco olor a sangre pisoteada; de otro, un aroma a jardines, a amanecer diario, a vida fresca, fuerte, inexpugnable. [Segundo prólogo, ECE: 12]

Entre los dos requerimientos puede leerse además la percepción, quizás no consciente del final del proyecto vanguardista en su estado más genuino.

El cambio de su poesía en esta etapa es sustantiva, quizás la mayor de toda su biografía literaria. Cabe dudar si tras el profundo giro formal y temático experimentado en los años treinta subyace un cambio tan determinante como el que inaugura el destierro. Pero no es sólo el exilio -condición abrumadora, sin lugar a dudas- la única circunstancia decisiva. Detrás del nuevo rumbo que inicia Entre el clavel y la espada se encuentra el naufragio del proyecto utópico de la vanguardia y el desmantelamiento de su campo específico, tal como lo describe Ayala.

En la lengua poética albertiana del exilio la consecuencia formal evidente es el abandono del discurso más señaladamente combativo y la recuperación de un registro de mayor lirismo. Para su estatuto de poeta, el efecto más significativo es 
el fortalecimiento de sus lazos con la institución literaria y la reconciliación con la esfera autónoma.

Alberti no deja de escribir poemas de circunstancias muy apegados a la realidad inmediata, pero ya no abarcarán el universo total de su creación, como sucedía en los años treinta, en que dio por finalizada su etapa de poesía burguesa. A mi juicio, la recuperación de su pasado poético no obedece tanto, a una velada autocrítica ni al final de la guerra civil, sino a la evidencia del ocaso -o el fracaso- de la praxis vanguardista.

Francisco Caudet ha analizado el debilitamiento del proyecto cultural de El Mono Azul, en su prentensión de romper las barreras entre poetas "incipientes" y poetas de renombre. El mismo Alberti los convocaba en el primer número: "Tu fusil/ también se cargue de tinta/ contra la guerra civil/" [Citado por Caudet,1993: 48]. El proyecto revolucionario no pudo evitar ser reemplazado por la lógica del poder y la propaganda política. Por otra parte, como en otras versiones de la utopía de la vanguardia, nunca lograron una verdadera "desprofesionalización" del escritor. La contradicción intrínseca a la vanguardia, proyecto antielitista desde las elites; buscadores de lo nuevo pero ligados a la autoridad de los esclarecidos, no logró resolverse tampoco en esta ocasión.

\footnotetext{
Nos encontramos, en definitiva, con una creación artificial, programada por una intelectualidad que reaccionaba positivamente ante el heroísmo de la calle, pero que no se fundía totalmente con este río, con esa vitalidad sorprendente, insólita. El intelectual no dimite de su condición hermeneútica, sino que se adaptó a la nueva situación y se erigió dómine. [Caudet, 1993: 43]
}

En 1940 Alberti retorna a los fueros de la poesía trazando nuevamente la linde entre el ámbito público y el del arte. Aunque no abandonará su "compromiso" con la realidad inmediata -arte y vida seguirán siempre intercomunicables- ya no se fusionarán en una praxis única.

Alberti seguirá explorando y experimentando en el campo de la poesía, pero sin la mecánica de buscar, experimentar y abandonar como sucedía en el tiempo de los ismos. Se podría decir que el hombre que al regresar a España después de casi cuarenta años de exilio anunció "Yo me fui con el puño cerrado y vuelvo con 
la mano abierta en señal de concordia entre todos los españoles" buscar cita, en 1940 era un poeta que volvía con la mano abierta al campo del arte.

Creo que debe reconsiderarse $-\mathrm{y}$, una vez más, no tomar al pie de la letra las manifestaciones de un escritor- la idea de que Alberti retorna "a la palabra precisa", como si no fueran precisas y poéticamente eficaces las composiciones del período anterior. El cambio fundamental no se debe tanto a la finalización de la contienda bélica como a que el final de guerra concluye el proyecto de borrar la frontera entre arte y vida.

Los primeros pasos de Alberti en Argentina tienden a fortalecer la esfera artística: paralelamente a la publicación de Entre el clavel y la espada inicia su actividad profesional en Argentina, intensa, repartida entre múltiples conferencias y colaboraciones en revistas culturales. Al mismo tiempo, en 1940, Losada edita, junto con su primer libro en el exilio argentino, una compilación de la poesía anterior, desde Marinero en tierra a De un momento a otro, es decir, la de su etapa burguesa y la de su etapa revolucionaria. También ejercerá una fecunda labor como editor. En Pleamar, fundada en 1941 por otro exiliado, Manuel Hurtado de Mendoza, dirige una cuidada colección, "Mirto", dedicada a poesía castellana de diferente época, desde Fray Luis, Garcilaso y Góngora a Bécquer, Machado, Juan Ramón Jiménez ${ }^{15}$. El poeta vuelve a las sendas más firmes de la literatura. El impulsor de Octubre y El Mono Azul reparte sus colaboraciones entre revistas culturales argentinas de reconocido prestigio, Sur, Nosotros, Los anales de Buenos Aires, dirigida por Jorge Luis Borges; y españolas del exilio: De mar a mar, a cargo de Lorenzo Varela y Arturo Serrano Plaja, Correo literario, bajo la responsabilidad de Lorenzo Varela, Arturo Cuadrado y Luis Seoane.

Las vanguardias habían sacado el arte de sus soportes tradicionales, el teatro a los caminos, la poesía a las trincheras, la pintura a los carteles. Es oportuno recordar aquí la célebre polémica llevada adelante en Hora de España por Ramón Gaya y Josep Renau acerca del valor artístico de los carteles, cuya presencia durante la guerra civil alcanzó cotas inéditas ${ }^{16}$. Los dos afamados pintores confrontaron sus respectivas posiciones sobre el estatuto del cuadro; el

${ }^{15}$ V. más información en Pochat, 1990: 25-34.

${ }^{16}$ V. Tomás, 1998a: 240-259 y Carteles, 1981. 
primero era partidario de preservar la expresión tradicional, aurática, como actividad selecta, alejada del mundo corriente; el segundo era partidario del cartel como forma que ligaba arte y medios técnicos y, por otra parte, acercaba el arte a la cotidianeidad. El conflictivo tema del original y la reproducción técnica quedaba superado con el cartel, para el que sólo rige la reproducción. Si menciono aquí el debate es porque, salvando las distancias entre pintura y literatura, existe cierto paralelismo entre la discusión sobre el cartel frente al cuadro y el auge de las revistas como Octubre y El Mono Azul como canales de participación literaria abiertos a firmas no consagradas y en un soporte ajeno al libro, el medio consagrado de las bellas letras. Se establece cierto paralelismo también entre la exhibición pública del cartel y la lectura de poemas en plazas o regimientos rompiendo con el ritual de la recepción solitaria y silenciosa. Las distintas rupturas acercaban el arte a la cotidianeidad, quitándole "el marco".

La asimilación de las vanguardias por el museo, las bibliotecas y la academia, despojadas de su espíritu subversivo y de su proyecto transformador viene acompañada, en el caso de los escritores exiliados, con la toma de conciencia de la pérdida del público lector y de las instituciones que arropan al escritor y dan acta de bautizo a las obras literarias ${ }^{17}$. Las reflexiones de Ayala brindadas páginas atrás constituyen el testimonio más lúcido de esta nueva situación. No debe sorprender entonces que los tres escritores estudiados coincidan en Argentina en las páginas de Sur, pariente cercano a Revista de Occidente y vigorosa representante de la institución literaria. Difícilmente la revista de Victoria Ocampo los hubiera reunido en los años treinta ${ }^{18}$. No causan extrañeza los nombres de Francisco Ayala y Ramón Gómez de la Serna en sus páginas, pero el director de Octubre y de El Mono Azul podía "refugiarse" en sus páginas sólo mediando la conciencia del final de un proyecto estético como el

17 Recuérdese que Bürger define la institución arte como las condiciones estructurales que establecen la consideración de una obra de arte, pues "las consecuencias observables o infalibles del trato con la obra no se deben en absoluto a sus cualidades particulares, sino más bien a la clase y manera en que está regulado el trato con obras de este tipo en una determinada sociedad". [Bürger, 1974: 48]

${ }_{18}$ En los años inmediatos al final de la Guerra de España -tomo estrictamente 1939 y 1940 , Gómez de la Serna escribió dos artículos y cuatro reseñas; Francisco Ayala cuatro artículos y tres reseñas, Alberti cuatro artículos y recibió una reseña de Entre el clavel y la espada. Varios de estos artículos son primeras ediciones de cuentos o capítulos de obras posteriores. 
vanguardista. Alberti, clavel y espada, se volcará a las revistas de los exiliados españoles que desde el transtierro continúan la lucha, ahora contra la dictadura de Franco; pero se inclinará también a aquellos órganos que recogen la herencia cosmopolita de la vanguardia, más restringida ahora a la idea de arte moderno o arte nuevo, de cualquier modo; la literatura con mayúsculas y otra vez en el marco.

La posición de Sur, claramente antifranquista y partidaria de la legalidad republicana -no así del Frente Popular- pudo conciliarse con un Alberti a su vez reconciliado con los imperativos de la lírica más prestigiosa de la poesía "deshumanizada"19. Su confianza en la hermandad del arte y la cultura por encima de diferencias ideológicas, de raza o religión permitía una vez más el acercamiento de escritores ideológicamente alejados de Victoria Ocampo ${ }^{20}$.

Sin embargo, la estratégica convivencia de Sur y el poeta comunista tuvo sus dificultades. King explica por qué Alberti nunca formó parte del plantel. Había sido aceptado merced a su esfuerzo por recuperar el ritmo y la libertad de su verso pero "el grupo mostraba una relación ambigua con su poesía, elogiando su

\footnotetext{
${ }^{19}$ Refuerza esta hipótesis, que por sí misma abre otro campo de investigación, la singular ausencia de Miguel Hernández de las páginas de Sur, frente a los diferentes homenajes y evocaciones de otros poetas víctimas de la barbarie fascista, como García Lorca y Machado, a quien el mismo Alberti dedica diferentes artículos y poemas: "Imagen sucesiva de Antonio Machado", Sur, 108, oct. 1943, pp. 7-16: "De los álamos y los sauces; en recuerdo de Antonio Machado", Sur, 72, sept. 1940, pp. 7-15; reseña de Poeta en Nueva York, de García Lorca, Sur, 75, dic. 1940, 147-161, y, de forma indirecta, tratados también en la reseña de su Imagen primera de... Federico García Lorca, Juan Ramón Jiménez, Antonio Machado [y otros]... (1940-1944) realizada por César Rosales, Sur, 138, abr. 1946, pp. 93-98.

${ }^{20}$ El riguroso trabajo de King realiza un análisis de la agudización de las contradicciones que llevaron al distanciamiento definitivo de autores que aunque adversos al liberalismo, fueron estrechos colaboradores y amigos de Victoria Ocampo: "...para Irazusta, podían discutirse las ideas en competencia entre una minoría civilizada, al menos a comienzos de los treinta. Las ideas acababan por degenerar en ideologías y política, pero durante algún tiempo el intelectual aún pudo flotar libre, relativamente alejado del poder y de sus implicaciones" [King, 1989: 96] La situación internacional impidió la ideal convivencia: "Ideologías y política se mezclaron con la creciente crisis europea y la Guerra Civil Española" [Id., id.: 97]. Quizás a la II Guerra mundial se deba el enfriamiento de las relaciones con escritores partidarios de posiciones decididamente torremarfileñas como las sostenidas por Ramón.
} 
intensidad lírica, pero incapaz de apreciar su poesía comprometida"21. [King,1989: 134]

Si se analiza el primer poemario de Alberti en Argentina a la luz de las coordenadas reseñadas, se puede apreciar que reúne elementos valiosos para abrir una nueva etapa en la vida del poeta. El libro eslabón entre la época que se cierra y la que inicia se construye como un sumario de sus distintas estéticas, desde Marinero en tierra hasta Capital de la gloria (Madrid, 1936-1938); una especie de "Summa albertiana" o de galería de sus momentos poéticos más representativos. No es la primera vez que Alberti realiza una operación de revisión y síntesis, (García Montero '[1988; I, LXXVI] cita las observaciones de Salinas sobre Verte y no verte, la elegía escrita en ocasión de la muerte de Ignacio Sánchez Mejía en 1935, obra que supone "un recuento poético de todas sus etapas anteriores, desde el neopopularismo hasta el surrealismo"22.

La situación del poeta al llegar a Argentina sin duda favorece la mirada retrospectiva sobre la propia obra, síntesis que en un momento de quebranto y pérdida cumple un doble proyección: conjura la fractura que el exilio provocó en la mayoría de los escritores de la diáspora e intenta compensar la pérdida de su público lector y de las circunstancias de producción impuestas por la guerra, abriéndose a un nuevo espacio literario. El primer Alberti del exilio no se cristaliza en la imagen del poeta más difundido en los años treinta, el combativo y revolucionario de los romances y denuestos antifascistas, del tipo de los que en Argentina daba a conocer Claridad ${ }^{23}$. Sin renegar de su compromiso con una

${ }^{21}$ King cree que el final del poema Picasso (Sur, 130, ag. 1945, pp. 40-44), "Y aquí el juego del arte comienza a ser un juego/ explosivo" fue el origen de un progresivo distanciamiento. Sin embargo, se puede comprobar que Alberti continuó colaborando en la revista hasta el número 182, de diciembre de 1949. De todos modos, la relación ambivalente que describe King se verifica en 1963, en un homenaje dedicado a Alberti, coincidiendo con la partida del matrimonio de Rafael y María Teresa hacia Italia. A pesar de la trascendencia que implica ser objeto del reconocimiento de Sur (Sur, 281, marzo-abril de 1963) las intervenciones no dejan lugar a dudas sobre el aspecto de la poesía albertiana que interesaba: En esa ocasión González Lanuza sostiene que "el volumen de los versos de Alberti sobre pintura es el más significativo de toda su oeuvre ulterior, ya que es el menos interesado en la secuela de la guerra, y en la necesidad de un compromiso. González Lanuza refiere que Alberti llega a obsesionarse por el exilio, causando daño a su poesía; en cambio, los poemas sobre pintura se deleitaban en el formalismo y en el oficio de la cultura, "pues los dos principales intereses de Alberti siempre habían sido la pintura y la poesía..." [King, 1989: 134-135]

${ }^{22}$ V. también "Dos elegías a un torero: García Lorca y Alberti", Salinas, 1949.

${ }^{23}$ Perteneciente al grupo de Boedo, Claridad, fue continuación de Los pensadores. Pretendía ser un órgano del pensamiento de izquierda, ideológicamente cercano al socialismo. Se vinculaba, 
causa ahora trastocada en la causa de los prisioneros y perseguidos del régimen franquista, Alberti recupera el registro lírico culto de mayor pureza en algunos casos, lúdicos en otros, construyendo de esta manera lo que será el entramado ético y estético de su producción exiliada.

En este sentido, considero que la estructura de Entre el clavel y la espada ${ }^{24}$ y la diversidad de sus discursos poéticos cifran la continuidad de la producción de antes y después de la guerra que ha señalado tempranamente Zuleta y recogido García Montero:

\begin{abstract}
En su trabajo, Emilia de Zuleta destaca lo siguiente: "A diferencia de lo ocurrido con otros poetas españoles exiliados, el destierro no produce una discontinuidad en la poesía de Alberti, ni desde el punto de vista del ritmo cronológico, ni desde el punto de vista de la evolución interna". Aunque puedan reconocerse distintos detalles de cambio, a los que después res referiremos, es evidente la unidad profunda con la poesía anterior al año 1939. [García Montero, 1988: I, LXXXIII]
\end{abstract}

El verso breve y ágil propio del neopopularismo, el refinamiento del metro clásico de los "Sonetos corporales", de la silva en el "Diálogo entre Venus y Príapo", en el apartado dedicado a Antonio Machado muestran su dominio poético. El repertorio de registros albertianos adquiere total coherencia al conciliarse con motivos y temas caros al mundo poético del autor, muchos de los cuales habían permanecido ausentes o en un segundo plano a partir de la Elegía cívica: el mar asociado al mundo de la infancia, el toro y el caballos ligados a impulsos atávicos y misteriosos; el juego y la palabra infantil risueña y sin sentido La enigmática presencia de motivos populares, en ocasiones atravesados por

desde el nombre, con el movimiento francés "Clarté" y con Henri Barbusse, quien había intentado, sin éxito, la conformación de un movimiento internacional que superara las rivalidades que habían llevado a Europa a la ruina. En América tuvo importantes conexiones, en Perú con el grupo "Claridad", al que pertenecía José Carlos Mariátegui, y en Brasil con el grupo "Clarté". En Argentina Claridad estuvo dirigida, igual que Los pensadores, por Antonio Zamora, socialista independiente y apareció desde 1927 a 1941. Algunos de sus miembros más conocidos fueron Leónidas Barletta, este se alejó después del primer año a causa de diferencias políticas-, César Tiempo, Roberto Mariani, Elías Castelnuovo, Alvaro Yunque. Siguió muy de cerca la Guerra civil española en sus aspectos políticos, militares y culturales y desplegó una sostenida campaña de apoyo al gobierno republicano. Durante la guerra publicó romances y composiciones alusivas.

${ }^{24}$ Entre el clavel y la espada está dedicado a Pablo Neruda y se compone de dos prólogos y ocho partes: 1) Sonetos corporales, 2) diálogo de Venus y Príapo (añadido posteriormente, se suprime en muchas ediciones debido a su contenido erótico): 3 ) Metamorfosis del clavel 4) Toro en el mar (Elegía sobre un mapa perdido) 5) De los álamos y los sauces; 6) Del pensamiento en un jardín; 7) Como leales vasallos; 8) final de plata amargo. 
imágenes irracionales de linaje surrealista, los ecos de Góngora y la combinación libre de versos y estrofas, hasta llegar al verso libre con reminiscencias de Sobre los ángeles conforman un conjunto heterogéneo pero armónico.

Reparecen también los motivos y preocupaciones más recientes, tamizados ahora por la experiencia del exilio político, continuación de los sucesivos desarraigos del poeta. El soldado muerto, la amante que llora su ausencia, los poetas desaparecidos o desterrados, España contemplada desde la otra orilla como emblemática piel de toro $\mathrm{y}$, por último, la apertura a lo nuevo, al mundo americano, generoso y esperanzador.

Con el ejercicio evocador aparecen los signos de transformación, la búsqueda de nuevos rumbos. Sobresalen como temas tratados con una visión renovada el erotismo de la primera y segunda parte y la glosa del Cantar de Mio Cid de la séptima, en donde el tributo a la tradición se inclina por una intertextualidad nueva en Alberti, la épica, muy apropiada para tratar el exilio y la guerra.

No podría pedirse una síntesis más acabada de la trayectoria de Alberti que Entre el clavel y la espada, una verdadera autobiografia poética y memoria literaria, una inmejorable tarjeta de presentación para darse a conocer al nuevo público. También una forma distinta de revisar el pasado y arrostrar el futuro.

\section{Gómez de la Serna. Sin Pombo, bajo el signo del aislamiento}

El caso de Ramón Gómez de la Serna va por caminos opuestos a los de Ayala y Alberti. No debe sorprender que el escritor que en los años treinta elevaba su voz a favor de las vanguardias y continuaba su ejercicio literario ciego a los acontecimientos políticos y a los debates sobre la función del arte en que se sumergían sus colegas, haya continuado en el destierro defendiendo a ultranza el estado idílico en que el escritor vive por y para la literatura. Su deseo de preservar un ámbito incontaminado le llevó mantenerse al margen del Frente Popular, de la República y de la guerra civil. Su actitud fue absolutamente excepcional, contraria a la asumida por la mayoría de los escritores. 
Lo usual y normal es que fenómenos como la Segunda República, la guerra civil y las abortadas revoluciones libertarias, comunistas y nacionalsocialistas que durante ella se intentaron, el advenimiento del régimen franquista y el exilio de los republicanos modifiquen en gran medida tanto la trayectoria literaria de los escritores como la humana. [Soldevila,1980: 35]

Los resultados de su pretendido aislamiento ya se han anticipado. Me interesa indicar que Ramón también gozó de los favores de Sur, pero las buenas relaciones que desde los primeros números había mantenido con Victoria Ocampo no se prolongaron en el destierro. Es manifiesto que a partir de 1940 la amistad comienza a enfriarse, con lo cual se duplica su aislamiento, ya que en los ambientes propiamente españoles republicanos también había perdido consideración. De esta manera, el escritor que más se empeñó en crear un espacio autónomo para la creación pagará con su total aislamiento en el campo literario, rotos los lazos con las débiles y quebrantadas instituciones literarias del exilio. Es conocido que añoraba enormemente sus tertulias, con gusto hubiera hecho renacer su Sagrada cripta de Pombo. Si se tratara de escribir sobre los espacios del exilio, la extrañeza de Ramón en Buenos Aires sería un tema interesante y conmovedor. Así como no pudo resignarse a que la literatura cambiaba de rostro, nunca comprendió que Pombo era un "lugar" que no podía revivir.

No acuerdan los críticos acerca del valor de las novelas, cuentos y relatos posteriores a 1936; para algunos, aportan pocas novedades; otros, como Francisco Umbral, sitúan en estos años su mejor novela, pero subrayando un aire arcaico, propio "de quienes se repiten a sí mismos interminablemente, por cuanto la lengua es una cosa viva y ellos han de escribir en la lengua ya muerta que es la de su partida", pues "el castellano que se habla en Argentina, y concretamente el porteño, poco tiene que ver con el castellano de Madrid".[Umbral, 1978: 217] Aislamiento, lengua detenida, quizás por eso su gran obra del exilio sea Automoribundia, la dilatada autobiografía de estremecedor título, continuada en libros posteriores.

Pero volviendo a los umbrales del exilio, son iluminadores dos de los artículos que publica en Sur, donde Ramón era una figura mimada. En el número 
2, del otoño de 1931, aparece su primer artículo, "Riverismo", tomado de Ismos (1931), semblanza y elogio del pintor mexicano Diego Rivera. Desde entonces, durante toda la década del 30 , el escritor madrileño será un colaborador frecuente de la revista: hasta el número correspondiente al mes de noviembre de 1940 firma al menos ocho artículos centrales -aquellos de tipos de imprenta más grandes y situados en la primera sección- y seis notas sobre libros. Sin duda se trata de una presencia destacada, más aún si se tiene en cuenta que durante los primeros años de Sur prevalecieron los artículos ensayísticos por sobre los literarios. A partir de 1940, sólo reaparecerá con motivo de algunas reseñas, bien escritas por Ramón, bien dedicadas a alguna de sus obras.

Hacia 1936, cuando desembarca nuevamente en Buenos Aires, mantenía el halo del escritor venerado por el grupo martinfierrista por su talante cosmopolita y por su título de iniciador de las vanguardias en España. Su primer trabajo en el número 2 de Sur aparece acompañado, a manera de carta de presentación, por el artículo de Victoria Ocampo "Ramón Gómez de la Serna en Buenos Aires". Se trata de una justificación de la presencia del escritor español a través de una de las formas de legitimación más frecuentemente utilizada por la revista, el aval de su propia directora. La incorporación de Ramón al grupo de colaboradores asiduos parece responder tanto a su reconocida trayectoria de escritor vanguardista, como a su situación destacada en el horizonte cultural europeo con el cual Sur trataba de estrechar lazos:

Como en un album de instantáneas reveo a Ramón en Pombo, a Ramón en la redacción de la Revista de Occidente, a Ramón en su casa, a Ramón en una 'repetition genérale' en París, a Ramón comiendo en mi casa con Cocteau, a Ramón en la estación Quai d'Orsay". [Ocampo, 1931]

Un año después de haber huido de la guerra civil escribe el primer artículo en que, elípticamente, se refiere a la situación en su patria. Dos años después publicará la continuación. Se titulan "Sobre la torre de marfil", de febrero de 1937, y "Más sobre la torre de marfil", de enero de 1933.

Son dos artículos-manifiestos-autojustificación én los cuales defiende el espacio autónomo de la poesía y del arte como única vía de combatir un mundo 
hostil y violento. En un contexto en que el aumento de las confrontaciones obligaba al intelectual y al artista a repensar su función social, la mención de la torre de marfil para defenderla, como hace Ramón, representa un gesto infrecuente, con cierto cariz anacrónico.

...el hombre de la Torre de Marfil sabe [...] que para conseguir la paz hay que llenar la vida de sentido y eso sólo lo logrará de nuevo la grandeza del arte, la pasión por la literatura, el don elocuente del monólogo. O se complica la vida, se la llena de entusiasmo, de nuevas curiosidades, de nueva poesía o los homicidas podrán sobreponerse a los pacíficos" [STM, 937, 60]

El gesto era, sin duda, inusitado y contracorriente: en los dos artículos apela a los denuestos típicos de la bohemia finisecular contra el orden burgués, responsable de erigir torres miserables "que suponen a un habitante que sólo dedica a acaparar, a sumar, a esconder sin mayor consecuencia la riqueza que no verán los otros y que sólo ha de gozar él" [ld. id., 60]. A estas diatribas impregnadas de cierto retoricismo, añade el rechazo a subordinar el arte a los intereses de la revolución con este nombre genérico designa los acontecimientos sucedidos en España desde 1936. La reafirmación de estas convicciones en Sur y la apelación al olvido, en febrero de 1937, cuando la guerra recién había comenzado, ponen de manifiesto la inamovilidad de un pensamiento detenido en las premisas de fin de siglo cuando el artista se proponía huir de la realidad inmediata como forma de rebelión contra la creciente mesocratización de la sociedad burguesa.

La afirmaciones sorprenden todavía hoy por la ingenuidad y por la insistencia en confiar en la capacidad del arte para dirimir las graves confrontaciones políticas y sociales que estaban cambiando el rostro de su patria y de Europa.

He sentido en la calle a la multitud armada, he andado por en medio de ella y sin embargo creo más que nunca en la Torre de Marfil y creo que lo único reconstructor, que nos puede hacer olvidar lo sucedido y que cree la fórmula de otra ilusión, será la inspirada Torre de Marfil. [STM: 60\}

Y unas páginas más adelante:

Sólo la Torre de Marfil hará mansos a los jóvenes que sin la obra poética se dedicarían a la rebelión descabellada o al señoritismo escandaloso y cruel que trae la revolución... [ld. id. 62] 
Cuando escribe los dos artículos mencionados, su concepción de la obra de arte había declinado en España -y se puede afirmar que en todos los países que habían visto florecer la modernidad estética: o se aceptaba la separación del subsistema social artístico o se entendía la articulación arte vida como participación en las luchas sociales.ver Ramón, bebiendo en los discursos sobre el arte elaborados por diferentes corrientes desde el siglo XIX -romanticismo, bohemia, esteticismo, arte nuevo- propugna una intervención del arte en la vida sin sustentación alguna en el contexto inmediato y ajeno al proyecto modernizador y utópico de la vanguardia. Con una dureza inusual que no utiliza con el bando rebelde, el autor de Ismos contrapone al "obrero de la guarda", y a "los intrigantes del abominable comisariado", la Torre de Marfil, único lugar donde

se puede afinar el alma para no sentir las resacas de fuera, para no oír los gritos de los legitimistas y de los ilegitimistas de todo tiempo, saciándose con el cuadrángulo de la mesa o el cuadrángulo del libro. [MSTM: 39]

Luego de deambular por bares y mesones, el artista se encierra en la Torre de Marfil, pura y sobria, pone en duda el aparente orden del mundo y busca la parte no visible de la realidad -¿qué es si no la greguería? Más allá de la inmediata materialidad de las cosas más cercanas surge, en las horas robadas al sueño, "la idea de los trenes celestes, de las cosechas de lluvia para los que tenemos silos en el alma y la invención del conmutador para apagar los ojos de los gatos cuando nos vayamos a acostar". [STM: 63]

Consecuente con una actitud sostenida durante toda su vida, que, quizás por su mismo carácter anacrónico y cristalizado, derivó en gestos políticos censurables. Defendía la independencia del artista de todo compromiso que no fuera lo que consideraba su única misión, "aumentar la sensibilidad y la belleza de la vida", "dar el ejemplo de lo que es vivir, de cómo contemplar una grieta es como contemplar el esqueleto de una enredadera...", [STM: 68-69] ${ }^{9}$ y denunciaba aquello que juzgaba iniquidades de los políticos, la democracia, los comités, la revolución, las doctrinas civiles o las teoría económicas. Busca el exilio y descubre que "la Torre de Marfil era volante y traslaticia", y que podía pasar el mar intacto sin perder 
la libertad de decir y escribir lo que deseara. En el contexto histórico en el cual Ramón pronuncia estas palabras no se podía asimilar una posición que iba a contracorriente no sólo de las tendencias estéticas y políticas dominantes sino de la solidaridad que el humanismo clásico brindaba al país en guerra. Ver

Si el discurso de Ramón era dis-cordante en el marco de la Guerra civil española, más lo será a partir de la segunda mitad del año 1939 por dos hechos no desvinculados entre sí. En el mes de abril Franco había derrotado definitivamente a las tropas republicanas y cientos de exiliados españoles comenzaban a dispersarse por el mundo; en segundo lugar, en el mes de septiembre se había desencadenado la II Guerra europea y la neutralidad o la indiferencia se volvieron muy difíiciles de sostener.

Ramón volvía a asimilar vanguardia-ya sin posibles ecos y desprovista de sus elementos iconoclastas- a intrascendencia y experimentación formal. Apartado en Buenos Aires, se inviste del aura de los, proponiendo la salvación por el arte.

En aras de un universo artístico refractario a toda filiación política, pocas veces se ha otorgado una función más clara a la literatura ni se ha elaborado un discurso más político sobre la guerra civil española sin la mención de una sola coordenada histórica.

Al contrario de las vanguardias, que aspiraron a acercar el arte a la vida, Gómez de la Serna quiso transformar la vida en arte, en literatura.

Mientras en Buenos Aires Gómez de la Serna se erigía en último y solitario defensor de las vanguardias, es oportuno recordar que los vanguardistas de España y Francia y los artistas "sociales", trabajaban juntos en el pabellón de la República española de la Exposición Internacional de París de 1937, en el mismo año de la aparición del primer artículo sobre la torre de marfil. Otro importante sector de artistas e intelectuales se entregaba en el mismo momento a la organización del "Il Congreso Internacional de Escritores Antifascistas", acontecimientos tratados en el capítulo III.

Ramón, refugiado en su torre de la porteña, no comprende, o no ve, o no mira. Cuando termine la guerra, quizás como una forma de recuperar su público 
disgregado y maltrecho, ofrecerá su arte al régimen que durante cuarenta años trató al arte con rigor de cuartel y moral de convento. 
9. 


\section{OBRAS CITADAS}

A continuación se proporciona una lista de las obras citadas. El criterio seguido es el mismo que el empleado para con la bibliografía general: si se cita por un edición distinta de la primera, la segunda fecha figura al final de la referencia. Además, cuando es necesario, se añaden las abreviaturas que se utilizan en el cuerpo de la tesis cuando se transcribe un fragmento.

Alberti, Rafael, 1927. Cal y canto. En Poesía (1924-1944). Buenos Aires: Losada, 2a ed., 1946. CC

------, 1936-1938. Capital de la gloria. Madrid (Madrid, 1936-1938). En Poesía (1924-1944). Buenos Aires: Losada. Op. cit., CG

-----, 1926. El alba del alhelí. En Poesía (1924-1944). Op. cit. EAA

------, 1942. El poeta en la España de 1931 seguido del Romancero de Fermín Galán y los sublevados de Jaca. Buenos Aires: Patronato Hispano-Argentino de Cultura. EPE

------, El poeta en la calle. En Obras completas. Poesía, 3 vols. Madrid: Aguilar. Op. cit. PEC

------, 1940. Entre el clavel y la espada. Buenos Aires: Losada, 1976, $3^{\mathrm{a}}$ ed. ECE

------, 1925. La amante. En Poesía (1924-1944). Op. cit. LA

------, 1959. La arboleda perdida. Libros / y II de memorias. Barcelona: Seix Barral, $7^{a}$ ed., 1989. AP1

------, 1987. La arboleda perdida. Libros III y VI de memorias. Barcelona: Seix Barral, $7^{a}$ ed., 1989. AP1

------, Marinero en tierra,1924. Pról. de Pere Gimferrer. Barcelona: Lumen, 1977. MT

------, 1988. Obras completas. Poesía, 3 vols. Madrid: Aguilar. Op. cit.

------, 1933-1937. Poesía política (1933-1937). En Obras completas. Poesía, 3 vols. Madrid: Aguilar. Op. cit. PP

------, "Se reciben bahías", 1931. en Rodríguez Fischer, Ana (ed.), 1999. Prosa de vanguardia española. Madrid: Castalia, pp. 90-94.

------, Sobre los ángeles, 1929. Yo era un tonto y lo que he visto me ha hecho dos tontos, 1929. Ed. de C. Brian Morris. $4^{a}$ ed., Madrid: Cátedra. 1989. SA - YET.

------, 1935. 13 bandas y 48 estrellas, en Obras completas. Poesía. Op. cit. 13B

Alvarez, Valentín Andrés, 1925. "Telarañas en el cielo", en Rodríguez Fischer, Ana (ed.), 1999. Prosa de vanguardia española. Madrid: Castalia, pp. 120-141.

Amorós, Andrés, 1978. Intr. a Ayala, Francisco, 1949. Los usurpadores y La cabeza del cordero. Madrid: Espasa-Calpe. U - CC

Antología Cátedra de Poesía de las Letras Hispánicas, 1998. (Selec. e intr. de José Francisco Ruiz Casanova. Madrid: Cátedra. 
Ayala, Francisco, 1965. "Carta literaria a Hugo Rodríguez-Alcalá" en Mis páginas mejores. Op.cit. MPM (Ayala)

-------, 1929, Cazador en el alba. 1928, El boxeador y un ángel. Introd. de Rosa NavarRo Durán. Madrid: Alianza, 1988. CA

------, 1991. "Discurso en la entrega del Premio Cervantes 1991" en VV.AA.,1997. Imágnes escritas. 20 años del premio Cervantes. Op. cit., pp. 281-289. Reproducido en Anthropos. Francisco Ayala. Barcelona, 139, dic. 1992 pp. 28-29.

-------, 1952. "El escritor en lengua española" en La estructura narrativa y otras experiencias literarias. Op. cit., pp. 205-221]

1928. "Hora muerta" en Cazador en el alba,1929 y El boxeador y un ángel 1928. Introd. de Rosa NavarRo Durán, pp. 119-131. HM

1984. La estructura narrativa y otras experiencias literarias. Barcelona: Crítica. LEN 1949. Los usurpadores y La cabeza del cordero. Introd. de Andrés Amorós. Madrid:

Espasa-Calpe, 1978. LU - CC

1965. Mis páginas mejores. Madrid: Gredos. MPM

-------, 1928. "Medusa artificial" en Cazador en el alba,1929 y El boxeador y un ángel 1928.

Introd. de Rosa NaVARro Durán, pp. 149-159. MA

1948. "Para quién escribimos nosotros" en La estructura narrativa y otras experiencias literarias. Op. cit., pp. 181-204.

-------, 1982. Recuerdos y olvidos 1. Del paraíso al destierro. Madrid: Alianza, $2^{a}$ ed., 1984.

------, 1982. Recuerdos y olvidos 2. El exilio. Madrid: Alianza, 1983.

------, "Polar estrella" en Cazador en el alba,1929 y El boxeador y un ángel 1928. Introd. de Rosa Navarro Durán, pp. 133-144.

Díaz Fernández, José, 1930. "El poder profético del arte", Nueva España, Madrid, 11 de diciembre, en BRIHUEGA, Jaime, 1970. Manifiestos, proclamas, panfletos y textos doctrinales. Las vanguardias artísticas en España (1910-1931). Cátedra, Madrid, 1982, 2da. ed., pp. 232-436. PPA

Gómez de LA SeRnA, Ramón, 1948. Automoribundia 11. 1888-1948. Madrid: Guadarrama. $2^{a}$. ed. 1974. A1

------, Automoribundia /2. 1888-1948. Madrid: Guadarrama. 2a . ed. 1974. A2

------, 1923. Cinelandia. Intr. de Francisco GutiérRez CARbajo. Madrid: Valdemar, 1995. C

------, 1928. El caballero del hongo gris. Pról. de Gaspar Gómez dE LA SERna. Madrid, Salvat Eds., 1982. CHG

------, 1923. El Chalet de las Rosas. Ed., introd. y notas de Francisco GutiéRrez Carbajo. Madrid: Castalia, 1997. ChR

-------, 1922. El secreto del Acueducto. Ed. y estudio crítico de Carolyn RICHMOND. Madrid:Cátedra, 1986. SA

------, 1927. El torero Caracho. En Obras completas. Tomo II, op. cit. 2000.

------, 1927. La mujer de ámbar. Madrid, Espasa Calpe. Austral: 1947, $5^{a}$ ed. MA

-------, 1930. La Nardo. Madrid, Bruguera, 1980. (Contiene además La hiperestésica, LH; Las consignatarias, LC; Se presentó el hígado, SPH; Pueblo de morenas; PM).

-------, 1923. La Quinta de Palmyra. Ed. y estudio crítico de Carolyn RICHMond. Madrid: Austral, 1982. QP

------, 1957. Mis mejores páginas literarias. Madrid: Gredos. MPL

-------, 2000. Obras completas. Ed. de loana Zlotescu. Revisión de textos por Juan Pedro Gabino. Coordinación documental de Pura Fernández. Con el asesoramiento de José-Carlos Mainer. Barcelona: Círculo de Lectores - Galaxia Gutenberg.

, 1927. 6 falsas novelas. Incluye María Yarsilovna (Falsa novela rusa) FNR, Los dos marineros (Falsa novela china) FNCh, La fúnebre (Falsa novela tártara) FNT, 
La virgen pintada de rojo (Falsa novela negra) FNN, La mujer vestida de hombre (Falsa novela alemana) FNA, El hijo del millonario (Falsa novela norteamericana) FNN. Buenos Aires, Losada: 1945.

------, 1937. "Sobre la Torre de Marfil", Sur, VII, 29, jun. 1937, 58-79. STM

------, 1939. "Más sobre la Torre de Marfil", Sur, IX, 52, en. 1937, 32-58. MSTM

Hernández, Miguel, 1937. Viento del pueblo en Obra poética completa. (LuIs, Leopoldo de y URRUTIA, Jorge, eds.). Bilbao:Zero, 1979, $5^{\text {a }}$ ed. VP

------, 1937. El hombre acecha en Obra poética completa / DE LUIS, Leopoldo y URRUTIA, Jorge, eds.). Bilbao:Zero, 1979, $5^{a}$ ed. HA

Ocampo, Victoria, 1931. "Ramón Gómez de la Serna en Buenos Aires", Sur, I, 2, (otoño 1931), pp. 205-208.

Ortega y Gasset, José, 1925. La deshumanización del arte y otros ensayos de estética. Madrid: Austral, $3 \uparrow$ ed. 1993. DA

------, 1925. Ideas sobre la novela. Madrid: Revista de Occidente en Alianza Ed. 1982. ISN

VALLE InCLÁN, Ramón, 1905. Sonata de invierno. Madrid: Austral, 11ª ed., 1983. SI

V.AA.,1997. Imágnes escritas. 20 años del premio Cervantes. Alcalá de Henares: Universidad en Acalá - Caja España. Obra Cultural - Instituto Cervantes. IE 


\section{BIBLIOGRAFÍA}

Debido a la magnitud del material existente sobre el tema, sólo se proporciona la bibliografía la citada en el cuerpo de la tesis. Cuando se ha utilizado una edición distinta de la primera se proporciona la fecha al final de la referencia y a esta remitirán las distintas citas. Para el caso de las traducciones se ha procurado, en la medida de las posibilidades, brindar en primer lugar la fecha de publicación en el idioma original y al final, la de la versión en castellano.

ABC LITERARIO. Homenaje a Rafael Alberti, año 1992, pp. 13-22.

Abellán, José Luis, 1976. El exilio español de 1939. Madrid: Taurus. 6 tomos.

Abellán, José Luis y Monclús, Antonio (coords.), 1989. El pensamiento español contemporáneo y la idea de América. T II. El pensamiento en el exilio. Barcelona: Anthropos.

Adorno, Theodor W., "El artista como lugarteniente" en Crítica cultural y sociedad. Sarpe, Madrid, 1984. (El artículo fue publicado en Prismas. La crítica de la cultura y la sociedad, 1955)

-----, 1970. Teoría estética. Barcelona: Orbis. (Trad. de Fernando Riaza, revisada por Francisco Pérez Gutiérrez). 1983.

Albornoz, Nicolás, 1991. El destierro español en América. Un trasvase cultural. (Con la colab. de María Teresa Pochat). Madrid: Siruela.

AltamiRano, Carlos, Sarlo, Beatriz, 1983. Literatura/sociedad. Buenos Aires: Hachette, 2a ed.

------, 1977/1991. Literatura y sociedad. Goldmann, Escarpit, Hauser y otros. Buenos Aires: CEAL.

Amorós Andrés, "Bibliografía básica de Francisco Ayala", en VV.AA., Francisco Ayala. Premio Nacional de las Letras Españolas 1988, Barcelona: Anthropos-Ministerio de Cultura, pp. 123-127.

------, 1978. Pról. a Ayala, Francisco, 1949. Los usurpadores y La cabeza del cordero. Madrid: Espasa-Calpe, pp. 9-28.

------, 1969. Pról. a Ayala, Francisco, Obras completas. México, Aguilar. 
Anthropos. Francisco Ayala. Barcelona, 139, dic. 1992.

Anthropos. Suplementos. Francisco Ayala. Antología de su producción literaria. Barcelona, 40, SEP. 1993.

Anthropos. Francisco Ayala. Premio Nacional de las Letras Españolas 1988, AnthroposMinisterio de Cultura.

ANTHROPOS. Guerra civil y producción cultural. Teatro, poesía, narrativa, 148, sept. 1993.

ANTHRopos. Número especial: "Jean-Paul Sartre. Filosofía y Literatura. Un compromiso crítico e intelectual", 165, feb.- abr. 1995, Barcelona.

AzNAR Soler, Manuel. "Bohemia y burguesía en la literatura finisecular" en Rico, Francisco, 1980. (Ed.) Historia y crítica de la literatura española, t. VI, Modernismo y 98. Al cuidado de MAINER, José Carlos. Barcelona: Crítica, pp. 75-82.

-------, (ed.),1998. El exilio literario español de 1939. Actas del Primer Congreso Internacional (Bellaterra, 27 de noviembre-1de diciembre de 1995). Barcelona, Gexel.

, (ed.),1995. Las literaturas exiliadas en 1939. Barcelona: Gexel.

------, 1978. II Congreso Internacional de Escritores Antifascistas (1937). Vol. II: Pensamiento literario y compromiso antifascista de la inteligencia española republicana. Barcelona: Laia.

Aznar Soler, Manuel y Schneider, Luis Mario (eds.), 1979. II Congreso Internacional de Escritores Antifascistas (1937). Vol. III: Ponencias, documentos, testimonios. Barcelona: LAIA.

AzoRin, 1989. La voluntad. Madrid: Castalia.

BarReneChEA, Ana María,1985. "Unamuno en el movimiento de renovación de la novela europea" en El espacio crítico en el discurso literario. Buenos Aires: Kapeluz, pp. 33-44.

Barroso Villar, Elena, 1998. "Cazador en el alba: Novela lírica y humanismo" en Vázquez Medel, M. A. (ed.), 1998. Francisco Ayala y las vanguardias. Op. cit., pp. 89-116.

BARTHES, Roland, 1967. El grado cero de la escritura. México: Siglo XXI

-----, 1970. "El efecto de realidad" en VA.AA. Lo verosímil. Buenos Aires: Tiempo contemporáneo.

BENDA, Julien, S/A. La trahison des clercs. Paris: Bernard Grasset.

------, 1974. La traición de los intelectuales. Madrid: Efecé.

Benjamin, Walter. Poesía y capitalismo. Iluminaciones II. Taurus, Madrid, 1980.

- - - - . - - - "El autor como productor". En Tentativas sobre Brecht. Iluminaciones III. Taurus, Madrid, 1991. 
- . - . - - - "La obra de arte en la era de la reproductividad técnica". En Discursos interrumpidos. I. Taurus, Madrid, 1989].

- - - - - - - - Iluminaciones II. Poesía y capitalismo. Taurus, Madrid, 1980. Aclarar art.

Berman, Marshall, 1989. Todo lo sólido se desvanece en el aire. La experiencia de la modernidad. Buenos Aires: Siglo XXI, 3^ ed.

Bértolo, Constantino, 1989. "Introducción a la narrativa española actual" en Revista de Occidente. Número extraordinario: Narrativa española actual, $n^{\circ} 98$ - 99, jul.-ag. 1989, pp. 29-60.

Blanch, Antonio, 1976. La poesía pura española. Conexiones con la cultura francesa, Madrid: Gredos.

Blanco Aguinaga, Carlos, 1991. "Otros tiempos, otros espacios en la narrativa española del exilio en América" en Albornoz, Nicolás, 1991. El destierro español en América. Un trasvase cultural. Op. cit., pp. 23-31.

Boвbıo, Norberto, 1993. La duda y la elección. Intelectuales y poder en la sociedad contemporánea. Barcelona: Paidós. 1998. (Trad. de Carmen Revilla Guzmán)

Bonet, Juan Manuel, 1995. Diccionario de las vanguardias en España. 1907-1936. Madrid: Alianza.

Bosı, Alfredo, 1991. "La parábola de las vanguardias latinoamericanas", pról. a SchwARTZ, Jorge. Las vanguardias latinoamericanas. Textos programáticos y críticos. Madrid: Cátedra.

Bourdieu, Pierre. 1992. Las reglas del arte. Génesis y estructura del campo literario. Anagrama: Barcelona, 1995. (Trad. de Thomas Kauf).

BozAL, Valeriano, 2001. "Arte, identidad y política en trono al 98" En TomÁs, Facundo, (ed), 2002. En el país del arte. $2^{\circ}$ encuentro internacional: Literatura y arte en el entresiglos XIX-XX. Celebrado en la Academia de Roma. 6-9 de julio de 2001, op. cit. pp. 33-50.

------, 1993. Pról. a Ortega y Gasset, José, 1993. La deshumanización del arte y otros ensayos de estética. Madrid: Austral, 3^ ed., pp. 8 - 41.

BRIHUEGA, Jaime, 1982. La vanguardia y la República. Madrid: Cátedra.

- - - - - , 1970. Manifiestos, proclamas, panfletos y textos doctrinales. Las vanguardias artísticas en España (1910-1931). Cátedra, Madrid, 1982, 2da. ed.

BuCKLEY, Ramón y CRISPIN, John (selec. y comentarios), 1973. Los vanguardistas españoles (1925-1935). Madrid: Alianza.

Bürger, Peter. 1974. Teoría de la vanguardia. Península: Barcelona, 1987. (Trad. de Jorge García).

Caballero Bonald, José María. "Sobre los ángeles" en Cuadernos Hispanoamericanos, 485-486, nov. 1990, Op. cit., pp. 296-298. 
Calinescu, Matei, 1987. Cinco caras de la modernidad. Modernismo, vanguardia, decadencia, 'kitsch', posmodernismo. Madrid: Tecnos, 1991. (Trad. de María Teresa Beguiristain)

Cano Ballesta, Juan, 1971. "La poesía revolucionaria e Rafael Alberti (1929-1933)" en Durán, Manuel, (ed.), 1975. Rafael Alberti. Op. cit., pp. 219-231. [Tomado de Cano Ballesta, Juan. La poesía española entre pureza y compromiso, op. cit.]

Carteles de la GUeRRA CIVIL española, 1981. Madrid: Urbión.

Castañar, Fulgencio. El compromiso en la novela de la ll República. Siglo XIX, Madrid, 1992.

Casullo, Nicolás (Comp.), 1991. El debate modernidad pos-modernidad. Buenos Aires: Puntosur.

CatÁlogo, 1995. "Los putrefactos de Salvador Dalí y Federico García Lorca". Exposición de la Huerta de San Vicente. Casa- Museo García Lorca, oct. nov. 1995. Madrid: Residencia de Estudiantes.

Caudet, Francisco, (ed.), 1993. "España: estética de la resistencia" en Las cenizas del Fénix. La cultura española en los años 30. Op. cit., pp. 407-435.

------, 1995. "Dialogizar el exilio" en Aznar Soler, Manuel (ed.),1998. El exilio literario español de 1939. Actas del Primer Congreso Internacional (Bellaterra, 27 de noviembre -1 de diciembre de 1995), Op. cit., pp. 31-55.

------, 1993. "El mono azul y el romancero de la guerra civil" en Anthropos. Guerra civil y producción cultural. Teatro, poesía, narrativa, 148, sept. 1993, pp. 43-51.

------, 1975. Hora de España (Antología). Madrid: Turner.

------, 1998. Introd. a Blasco Ibáñez, Vicente. La bodega. Madrid: Cátedra.

------, "La goma de borrar" en Las cenizas del Fénix. La cultura española en los años 30. Op. cit., pp. 534-527.

------, 1993. Las cenizas del Fénix. La cultura española en los años 30. Madrid: Eds. de la Torre.

------, 1995. Zola, Galdós, Clarín. El naturalismo en Francia y en España. Madrid: Eds. Universidad Autónoma de Madrid.

Cerezo Galán, Pedro. "Ortega y la generación de 1914: un proyecto de ilustración", Revista de Occidente, 156, mayo 1994, pp. 5-32.

Соцомві, Beatriz. "Decadentismo: Consideraciones sobre su definición y recepción en América". Cátedra de Literatura Latinoamericana II, Inédito, artículo interno, Facultad de Filosofía y Letras, Universidad de Buenos Aires.

ConnelL, George W., 1963. "Los elementos autobiográficos en Sobre los ángeles" en Durán, Rafael Alberti, op. cit. pp. 155-169.

Corella LaCASA, Miguel, 2000. "Ernesto Giménez Caballero, o la estetización de la política", en Olivar, Revista de literatura y cultura españolas, I,1. Centro de Teoría y Crítica Literaria, Universidad Nacional de La Plata, Facultad de Humanidades, pp. 123-142. 
CózAR, Rafael de, 1998. "Los inicios vanguardistas de Francisco Ayala: Cazador en el alba y El boxeador y un ángel" en VÁzquez Medel, Manuel Ángel (ed.), 1998b. Francisco Ayala y las vanguardias. Op. cit., pp. 33-44.

Cuadernos Hispanoamericanos. Homenaje a Rafael Alberti, 485-486, dic.-nov. 1990.

Cuadernos Hispanoamericanos. La generación de 27. Número monográfico, 514-515, abrilmayo 1993.

Dalí, Salvador, 1928. "Carta de Dalí a Lorca". Cadaqués, principios de septiembre de 1928", transcripta en CATÁlogo, op. cit., pp. 35-37. (Tomada de Revista Poesía, 27-28, pp. 88-94).

Dalmaroni, Miguel, 1993. "Transformaciones ideológicas en la poesía argentina de los años sesenta. Las obras de Juan Gelman y Alejandra Pizarnik". Tesis doctoral inédita. Universidad Nacional de La Plata.

DíAz FERnÁndeZ, José, 1985. El nuevo romanticismo. Madrid: José Esteban.

-------, "Poder profético del arte", Nueva España, Madrid, 11 de diciembre de 1930, en BRIHUEGA, 1983. Manifiestos, proclamas y textos doctrinales (Las vanguardias artísticas en España: 1910-1931), op. cit., pp. 432-436.

DieGo, José Luis de, 1994. "La novela argentina. 1976-1983". En Estudios e investigaciones. Homenaje a Manuel Puig. $\mathrm{N}^{\circ}$ 21, 1994, La Plata, Facultad de Humanidades, Universidad Nacional de La Plata, pp. 81-102.

------, 2001.¿Quién de nosotros escribirá el 'Facundo'? Intelectuales y Escritores en Argentina (1970-1986). La Plata: Al Margen.

DurÁn, Manuel, (ed.), 1975. Rafael Alberti. Madrid: Taurus.

El Pais, Cultura, "Luto por un poeta universal", 29 oct. 1999, pp. 50-54.

"Encuentro con Josefina Ludmer", 2000, Orbis Tertius, Revista de Teoría y Crítica Literaria, Universidad de La Plata, Ediciones Al Margen, La Plata, IV, 7, pp. 197-227.

Elorza, Antonio, 1999. "Alberti en los tiempos heroicos", ABC Cultural, 13 nov. 1999, p. 24.

Esconotado, Antonio, 1989. Historia General de las drogas. 3 vol. Madrid: Alianza.

------, 1994. Las drogas. De los orígenes a la prohibición. Madrid: Alianza.

Esteban, José, 1993. "La narrativa de la generación del 27" en Cuadernos Hispanoamericanos, 514-515, op. cit., pp. 81-92.

Esteban, José y Zahareas, Anthony N, 1998. Los proletarios del arte. Madrid: Celeste Ediciones. 
Fortes, José A.; Hernández, Juan A. y Sánchez Garrido, M. "Francisco Ayala: una bibliografía" en Anthropos. Suplementos. Francisco Ayala. Antología de su producción literaria. Op. cit., pp. 65-85.

FreIXA, Mireia (ed),1982. Las vanguardias del siglo XIX. Barcelona: Gustavo Gili.

Fuentes, Víctor. "Novela y vanguardia política (1926-1936)", en Pérez Bazo (ed.), 1998. La vanguardia en España. Arte y literatura, op. cit., 275-290.

García, Michel, 1977. "El Mono Azul" en Marc Hanrez (ed.), 1977. Los escritores y al guerra de España. Barcelona: Monte Ávila, pp. 226-233..

Garcia de Cortázar, Fernando y González Vesga, José Manuel,1993. Breve historia de España. Madrid: Alianza, 1994.

García de la Concha, Víctor (ed.), 1982. El surrealismo. Madrid: Taurus.

García Montero, Luis, 1988. Ed., intr. y notas a Alberti, Rafael. Obras completas. Poesía. 3 vols. Madrid: Aguilar.

------, (coord.), 1983. “Memoria viva del 27. Conversación de Luis García Montero con Francisco Ayala, José Bello, Rosa Chacel y Rafael Alberti” en Cuadernos Hispanoamericanos. La generación de 27. Número monográfico, 514-515 (abrilmayo de 1993), op. cit. pp. 10-23.

------, 1988. "La poesía de Rafael Alberti" en Alberti, Rafael. Obras completas. Poesía. 3 vols., Op. cit., t. I, pp. XXIX-CLXXII.

------, 1999. "Poeta con vistas al mar" en EL País, Cultura, "Luto por un poeta universal", op. cit., p. 52.

García Montero, Luis, Elorza, Antonio, 1999. "Alberti en los tiempos heroicos", $A B C$ Cultural, 13 nov. 1999, p. 24.

García Queipo de Llano, Genoveva,1988. Los intelectuales y la dictadura de Primo de Rivera. Madrid: Alianza.

Garrido Gallardo, Miguel Ángel, (Comp.), 1996. La moderna crítica literaria hispánica. Antología. Madrid: MAPFRE.

GeIST, Anthony L., 1993. "El 27 y la vanguardia: una aproximación ideológica", en Cuadernos Hispanoamericanos. La generación de 27. Número monográfico, 514-515 (abrilmayo de 1993), op. cit. pp. 53-64. Reproducido en WentZlaff-Eggebert, Haral, 1999. Las vanguardias literarias en España. Bibliografía y antología crítica, op. cit. pp. 429-441.

- - - -, 1980. La poética de la generación del 27 y las revistas literarias. De la vanguardia al compromiso.(1918-1936). Madrid: Guadarrama.

Gimferrer, Pere, 1977. Intr. a Alberti, Rafael, 1924. Marinero en tierra. Barcelona: Lumen, $3^{a}$ ed., 1998. 
------, 2000. "Sobre los ángeles y Sermones y moradas de Rafael Alberti" en Gimferrer, P., 2000. Radicalidades. Barcelona: Península. (Existe una edición bajo el título "El alma deshabitada" en $A B C$ literario. Homenaje a Rafael Alberti, año 1992, pp. 14-15. De Radicalidades existe una ed. de 1978, Barcelona: Antoni Bosh, pero no incluye el citado artículo).

Giner, Salvador, "Final de siglo: La España posible", en Rıco, Francisco, 1992. (Ed.) Historia y crítica de la literatura española, t. IX, Los nuevos nombres: 1975-1990. Al cuidado de VillanueVa, Darío y otros. Barcelona: Crítica., pp. 46-53.

GoldARD, Esteban, 1986. Los argentinos y la guerra civil española. Buenos Aires: Contrapunto.

Gómez de la Serna, Ramón, 2000. Obras completas. XII tomos. Ed. de loana Zlotescu. Revisión de textos por Juan Pedro Gabino. Coordinación documental de Pura Fernández. Con el asesoramiento de José-Carlos Mainer. Barcelona: Círculo de Lectores - Galaxia Gutenberg.

Gonzalo Sobejano, 1967. "Épater le bourgeois en la España literaria de 1900" en Forma literaria y realidad social. Madrid: Gredos, pp. 179-223.

Grahan, Helen y Labany, Jo, 1995. Spanish Cultural Studies. An Introduction. The Struggle for Modernity. New York: Oxford University Press.

Gramuglio, M. Teresa, 1992. "La construcción de la imagen" en La escritura argentina, Entre Ríos: Universidad del Litoral. Eds. La Cortada, pp. 37-64.

Granjel, Luis S. , 1963. Retrato de Ramón. Madrid: Guadarrama.

Gubern, Román, 1999. Proyector de luna. La generación del 27 y el cine. Madrid, Anagrama.

Gullón, Ricardo, 1963. "Alegrías y sombras de Rafael Alberti (Primer momento)" en Insula, 198, mayo 1963. Reproducido en Durán, Manuel, (ed.), 1975. Rafael Alberti. Op. cit., pp. 65-74.

1971. Direcciones del modernismo. 2da. ed. aumentada, Madrid: Gredos.

-----, 1982. ¿"Hubo surrealismo en España?" en GARCíA DE LA ConCHA, Víctor (ed.), 1982. El surrealismo. Op. cit., pp., 77-89. (Tomado de Surrealismo/ surrealismos. Latinoamérica y España. University of Pennsylvania Press, Philadelphia, 1977, pp. 118-120).

------, 1969. "La 'generación' poética de 1925" en La invención del 98 y otros ensayos, op. cit., pp.126-161.

------, 1969. La invención del 98 y otros ensayos. Madrid: Gredos.

Gutiérrez Carbajo, Francisco, 1995. Intr. a Gómez de la Serna, Ramón, 1923. Cinelandia. Madrid: Valdemar.

------, 1997. Introd. a Gómez de LA SeRna, Ramón, 1923. El Chalet de las Rosas. Madrid: Castalia, pp. 9-58.

Hintehäuser, Hans, 1985. "El concepto de modernismo como época", en Carnero, G., (ed.), 1987. Actas del Congreso Internacional sobre el modernismo español e 
hispanoamericano (Córdoba, octubre de 1985), Córdoba: Excma. Diputación Provincial de Córdoba, pp. 9-13.

IRIZARRY, Estelle, 1971. Teoría y creación en Francisco Ayala . Madrid: Gredos.

JakoBson, Roman,1969. "El realismo artístico", en realismo: ¿mito, doctrina o tendencia histórica? Buenos Aires: Tiempo contemporáneo, 149-166.

Jauss, Hans Robert, 1976. "Tradición literaria y conciencia actual de la modernidad" en La literatura como provocación. Barcelona: Península.

Jiménez Millán, Antonio, 1999. "De la vanguardia al nuevo romanticismo: la crisis de una ideología literaria", en WentzlafF-EgGeBert, Haral, 1999. Las vanguardias literarias en España. Bibliografía y antología crítica, op. cit., 607-633. Tomado de MoRELLI, G. (coord.), 1991. Treinta años de vanguardia española. Sevilla: El Carro de la Nieve, pp. 251-271.

------, 1990. "El compromiso en la poesía de Alberti (República, guerra, exilio)", Cuadernos Hispanoamericanos. Op. cit., 145-161.

-------, 1985. "Literatura, ideología, compromiso. (Lecturas idealistas de la poesía de Rafael Alberti)" en VV.AA., 1985. Eternidad yacente. Estudios sobre la obra de Rafael Alberti, Granada, Universidad de Granada, pp. 97-110.

------, 1984. Vanguardia e idelologías: aproximación a la historia de las literaturas de vanguardia en Europa: (1900-1930). Málaga: Universidad de Málaga.

JITRIK, Noé, 1996. "Canónica, regulatoria y transgresiva”, Orbis Tertius, I, 1, Universidad Nacional de La Plata, Centro de Estudios de Teoría y Crítica Literaria, pp.163-166.

-------, 1995. "Las dos tentaciones de la vanguardia", en PIZARRo, Ana (Coord.), América Latina: Palavra, Literatura e Cultura. Vol. 3. Vanguarda e Modernidade. Sao Paulo: Memoriail; Campinas: UNICAMP, pp. 57-74.

Jover Zamora, José María (Director), 1994. Historia de España Menéndez Pidal. 39 tomos. VII, t. XXXIX. La Edad de Plata de la Cultura Española (1898-1936). Letras. Ciencias. Arte. Sociedad y Cultura. (Cord. José Carlos MaINer) Madrid: Espasa Calpe.

KING, John, 1989. Sur. Estudio de la revista argentina y de su papel en el desarrollo de una cultura.1931-1970. México: FCE.

Koselleck, Reiner, 1993. Futuro pasado. Barcelona: Paidos.

KRYSINSKI, Vladimir, 1983. "La expansión semiótica de la figura del ángel en Sobre los ángeles" en Garrido Gallardo, Miguel Ángel, (Comp.), 1996. La moderna crítica literaria hispánica. Op. cit., pp. 23-30.

LamanA, Manuel, 1971. "Ortega y Gasset: concepto de circunstancia y circunstancia propia" en Literatura de Posguerra, Buenos Aires: Nova, pp. 111-128.

Lateral. Especial Ramón Gómez de la Serna. Barcelona, dic. 1996. 
Levin, Harry, 1977. "La literatura como institución", En Altamirano, C. y Sarlo, B., 1977/1991. Op. cit., pp. 193-106.

LıTVAK, Lily, 1990. España 1900. Modernismo, anarquismo y fin de siglo, Barcelona: Anthropos.

LóPEZ CRIADO, Fidel, 1988. El erotismo en la novela ramoniana, Madrid: Fundamentos.

LukÁcs, Georg. Historia y conciencia de clase, México: Grijalbo, 1969.

------, "¿Narrar o describir?". En Altamirano, Sarlo, Literatura y sociedad, op. cit., pp, 33-66.

- . . . . . , 1938. "Se trata del realismo"

LleRA, Luis de, 1991. "El vanguardismo, punto de confluencia humana y cultural entre Ramón Gómez de la Serna y José Ortega y Gasset. Ramonismo esencial y orteguismo", en Ortega y la edad de plata de la literatura española (1914-1936). Roma: Bulzoni, 123-145.

MAccIUCI, Raquel, 1997. "El escritor y su exilio: construcción del lector y lugar de la institución en Francisco Ayala". Orbis Tertius, 1997, № 5, Universidad Nacional de La Plata, Facultad de Humanidades, Centro de Estudio de Teoría y Crítica Literaria, pp. 127-139.

2001. "Geografía peninsular y construcciones imaginarias: una lectura de Camino de perfección de Pío Baroja". En Tomás, Facundo, (ed), 2002. En el país del arte. $2^{\circ}$ encuentro internacional: Literatura $y$ arte en el entresiglos $X I X-X X$. Celebrado en la Academia de Roma. 6-9 de julio de 2001, op. cit. 209-228.

------, 1998a. "Instituciones, literatura, conflictos canónicos: Una mirada a la figura de Vicente Blasco Ibáñez" en Oleza, Joan y Lluch, Javier (eds.), 2000. Vicente Blasco Ibáñez: 1898-1998. op. cit., pp.732-742.

------, 2001. "La Guerra civil española en Sur". Art. solicitado por los compiladores. Edición especial Orbis Tertius, La Plata, FHCE. UNLP. En prensa. Uniformar cita Orbis Tertius

-------,1998b. "La quinta de Palmyra de Ramón Gómez de la Serna: la vanguardia desde el ventanal". Orbis Tertius $N^{\circ} 7$, Universidad Nacional de La Plata, Facultad de Humanidades, Centro de Teoría y Crítica Literaria, pp. 139-155.

------, 1996. "Manuel Vicent: Héroes de 1936 re-tratados en el final de siglo" en PAYERAS Grau, María y Fernández Ripoll, Luis Miguel (eds.), 2001. Fin(es) de siglo y Modernismo. Congreso Internacional Buenos Aires - La Plata, Agosto de 1996, Vol. II. Palma: Universitat de les Illes Balears, pp. 785-791.

------, 1995. "Ramón Gómez de la Serna en Sur", en Actas IV Congreso de Hispanistas, Mar del Plata: Universidad de Mar del Plata, pp. 394-398.

MaIner, José-Carlos, 1981. 1990. "Cultura y vida nacional (1920-1939): la época de Alberti" en Cuadernos Hispanoamericanos. Homenaje a Rafael Alberti, 486-486, nov- dic. 1990, pp.69-80.

-------, La Edad de Plata (1902-1939). Ensayo de interpretación de un proceso cultural. Madrid: Cátedra.

1998. "La imaginación moral de Francisco Ayala" VÁzquez Medel, Manuel Ángel (ed.), 1998a. Francisco Ayala: el escritor en su siglo. Op. cit., pp. 47-52. 
------, 1996. "1915-1930: Vísperas de gloria" en Lateral, op. cit. p. 6-7.

-------, 2000. Prólogo a Gómez de LA SeRna, Ramón. Obras completas. Tomo IV. Espacio literario del Novelismo. El caballero del hongo gris, La Nardo, Policéfalo y señora, ¡Rebeca!. Op. Cit.

Martín Casamitjana, Rosa M., 1996. El humor en la poesía española de vanguardia. Madrid: Gredos.

Martínez-Collado, Ana, 1996. Ramón: teoría y práctica del arte nuevo. San Lorenzo del Escorial: Acción Paralela.

Matamoro, Blas, 1982. "La emigración cultural española en Argentina durante la posguerra de 1939" en Cuadernos Hispanoamericanos, 384, juni. 1982, pp.576-590.

Mıgnolo, Walter,1984. "La figura del poeta en la lírica de vanguardia. (V. Huidobro, O. Girondo, O. Paz)". En Textos, modelos y metáforas. México, Univ. Vercruzana, pp. 61-75.

Molno, Mauricio, 1977. "1. Cinco lecciones sobre el 'Buscón'" en Semántica y poética (Góngora y Quevedo). Barcelona: Crítica, pp. 89-131.

MoRRIS, C.B., 1995. "La generación del 1927: de la vanguardia al surrealismo" en Rico, Francisco, 1995. (Ed.) Historia y crítica de la literatura española, t. VII, dirigido por Sánchez Vidal, Agustín, Época contemporánea 1914-1939, op. cit. pp. 162-178.

-------, 1995. "Ramón y la vanguardia" en Rıco, Francisco, (Ed.), 1995. Historia y crítica de la literatura española, t. VII/1, Época contemporánea 1914-1939, op. cit., pp. 132-146.

Navarro Durán, Rosa,1988. Introd. a Ayala, Francisco, 1929. Cazador en el alba. Madrid: Alianza.

Navarro Durán, Rosa y García Galiano, Ángel (eds.), 1996. Retrato de Francisco Ayala. Barcelona: Galaxia Gutenberg-Círculo de Lectores.

Nicolás, César, 1991. "(Al margen) de la Greguería". Introd. y edic. a GómeZ DE LA SERnA, Ramón, 1940. Greguerías. Selección 1910-1960. Madrid: Espasa Calpe, Colec. Austral, 9a ed. 1991, pp. 9-44.

-------, 1999. "Las paradojas del paseante", en Wentzlaff-Eggebert, Haral, 1999. Las vanguardias literarias en España. Bibliografía y antología crítica, op. cit. pp. 355-386.

------, 1998. Prólogo a Gómez de La SeRna, Ramón. Obras completas. Tomo III. Ramonismo I. El rastro. El circo. Senos. (1914-1917). Op. Cit.

-------, 1988. Ramón y las greguerías. Morfología de un género nuevo. Cáceres: Universidad de Extremadura. (Extraído de la tesis doctoral dirigida por Ricarso Senabre: Ramón Gómez de la Serna y la Generación del 27. 3 vols. Cáceres, Universidad de Estremadura, 1983). 
Nieto Nuño, Miguel, 1998. "La imagen en la prosa vanguardista de Francisco Ayala en VÁzquez Medel, Manuel Ángel (ed.), 1998b. Francisco Ayala y las vanguardias. Op. cit., pp. 45-55.

OlezA Simó, Juan, 1993. "La disyuntiva estética de la postmodernidad y el realismo", Compás de Letras. Monografías de Literatura Española, Universidad Complutense, Madrid, 3, dic. 1993.

------, 1984. La novela del siglo XIX. Del parto a la crisis de una ideología. Barcelona: LAIA.

------, 1999. "Novelas mandan: Blasco Ibáñez y la musa realista de la modernidad" en debats, 64-65, Valencia: institució alfons el manànim, invierno/primavera, pp. 95-111.

------ , 1996. “Un realismo posmoderno” en Insula, 589-590, en. feb., Madrid, pp. 39-42.

OlezA, Joan y Lluch, Javier (eds.), 2000. Vicente Blasco Ibáñez: 1898-1998. La vuelta al siglo de un novelista. Actas del Congreso Internacional celebrado en Valencia del 23 al 27 de noviembre de 1998. Valencia: Biblioteca Valenciana- Generalitat Valenciana.

Ortega y Gasset, José, 1925. La deshumanización del arte y otros ensayos de estética. Madrid: Austral, 3a ed. 1993.

------, 1925. Ideas sobre la novela. Madrid: Revista de Occidente en Alianza Ed. 1982.

Osma, Guillermo de, 1995. Prólogo a Bonet, Juan Manuel. Diccionario de las vanguardias en España. 1907-1936. Madrid: Alianza.

Osuna, Rafael, 1986. Las revistas españolas entre dos dictaduras: 1931-1939. Valencia: Pre-Textos.

PARIente, Ángel, 1999. "La poesía surrealista en lengua española" en en Wentzlaff-Eggebert, Haral, 1999. Las vanguardias literarias en España. Bibliografía y antología crítica. Op. cit., pp. 463-476. Tomado de PARIENTE, ángel (comp.), 1985. Antología de la poesía surrealista en lengua española. "Introducción". Madrid; Júcar, pp. 21-42.

PAz, Octavio, 1954. El surrealismo en GARcía de la Concha, Víctor (ed.), 1982. El surrealismo. Op. cit., pp. 36-49. (Tomado de PAZ, O. La búsqueda del comienzo, 1974, pp. 7-27)

Pereira, Juan M., 1993. "Esbozo de Ramón". Quimera, 117, Barcelona, pp. 56-61.

Pérez Bazo, Javier (ed.), 1998. La vanguardia en España. Arte y literatura. Toulouse: Cric \& Ophrys.

Pérez Firmat, Gustavo, 1982. Idle fictions: The Hispanic Vanguard Novel, 1926-1934, Durham: Duke UP.

Personneaux, Lucie. 1983. "El surrealismo en España: espejismos y escamoteos" en Wentzlaff-Eggebert, Haral, 1999. Las vanguardias literarias en España. 
Bibliografía y antología crítica. Op. cit., pp. 455-462. Tomado de Kossoff, David A (coord.), 1986. Actas del VIII Congreso de la Asociación Internacional de Hispanistas (1983), 2 tomos. Madrid: Istmo, tomo II, pp. 447-454.

Pierrot, Jean, 1977. L'imaginaire décadent (1880-1900). Paris: Presses Universitaires de France.

Pino, José Manuel del, 1995. Montajes y fragmentos: Una aproximación a la narrativa española de vanguardia. Amsterdan- Atlanta: Rodopi. El Cap. 3, "Desarrollo y límites de la narrativa española de vanguardia" fue reproducido en WENTZLAFFEggebert, Haral, 1999. Las vanguardias literarias en España. Bibliografía y antología crítica. Op. cit., pp. 477-505.

Pochat, María Teresa, 1991. "Editores y editoriales" en Albornoz, Nicolás, 1991. El destierro español en América. Un trasvase cultural. (Con la colab. de María Teresa Pochat). Op. cit., pp. 163-176.

------, 1990. "Rafael Alberti en la Argentina (1940-1963)" en Cuadernos Hispanoamericanos. Homenaje a Rafael Alberti, 486-486, nov- dic. 1990, pp.25-34.

------, 1995. "Ramón Gómez de la Serna en Argentina" en Actas del III Congreso Argentino de Hispanistas. Mar del Plata: Universidad de Mar del Plata, mayo 1995, pp. 472-476.

Poggioli, Renato, 1964. Teoría del arte de vanguardia. Madrid: Revista de Occidente. Traducción de por Rosa Chacel.

PRAZ, Mario, 1942/1976. La carne, la muerte y el diablo en al literatura romántica. Barcelona, El Acantilado. 1999. (Trad. de Rubén Mettini

Proudhon, Pierre-Joseph, 1868. "El principio del arte y su destino social" en Freixa, Mireia, 1982. Las vanguardias del siglo XIX, op. cit., pp. 158-168 y 332-235

Ramos, José Ignacio, 1980. Mi amigo Ramón. Buenos Aires: Ed. Temas contemporáneos.

Ramos Gascón, Antonio, 1989. "Historiología e invención historiográfica: el caso 98", en REYES, Graciela (ed.). Teorías literarias de la actualidad. Madrid: El arquero, 203-228.

-------, "La revista Germinal y los planteamientos estéticos de la 'gente nueva' " en VV.AA., 1975. La crisis de fin de siglo: ideología y literatura. Barcelona: Ariel, pp.132-138.

Rey Briones, Antonio del, 1998. "Novela de vanguardia: Ramón Gómez de la Serna" en Pérez BAzo, Javier (ed.), 1998. La vanguardia en España. Arte y literatura, op. cit., 227-250]

RICHMOND, Carolyn, 1998a. "De mitos y metamorfosis: las constantes vanguardistas en la obra narrativa de Francisco Ayala" en Vázquez Medel, Manuel Ángel (ed.), 1998b. Francisco Ayala y las vanguardias. Op. cit. 15-31. 
------, 1998b. "¿Para qué, entonces, afanarse en vano?": el acto de escribir en la obra de Francisco Ayala" en VÁzquez Medel, Manuel Ángel (ed.), 1998a. Francisco Ayala: el escritor en su siglo. Op. cit., pp. 11-27.

------, 1992. Pról. a Ayala, Francisco, 1999. Los usurpadores. Madrid: Cátedra, pp. 9-96.

-------, (ed.), 1986. Gómez de LA SeRna, Ramón, 1922. El secreto del Acueducto. Madrid: Cátedra.

------, (ed.), 1982. Gómez de la Serna, Ramón, 1923. La quinta de Palmyra, Madrid: Austral.

------, 1997. Prólogo a a Gómez de LA SeRna, Ramón. Obras completas. Tomo X. II. Novelismo. Cinelandia y otras novelas (1923-1928). Op. Cit. pp.13-44.

Rıco, Francisco, 1980. (Ed.) Historia y crítica de la literatura española, t. VI, Modernismo y 98. Al cuidado de MAInER, José Carlos. Barcelona: Crítica.

--------, 1984. (Ed.) Historia y crítica de la literatura española, t. VII, Época contemporánea 1914-1939. Al cuidado de García dE LA ConCHA, Víctor. Barcelona: Crítica.

--------, 1992. (Ed.) Historia y crítica de la literatura española, t. IX, Los nuevos nombres: 1975-1990. Al cuidado de VillanueVA, Darío y otros. Barcelona: Crítica.

-----, 1995. (Ed.) Historia y crítica de la literatura española, t. VII/1, Época contemporánea 1914-1939. Primer suplemento. Al cuidado de SÁnchez VIDAL, Agustín. Barcelona: Crítica.

RIDAO, José María, 2000. Contra la Historia. Barcelona: Seix Barral.

RódenAs de Moya, Domingo, 1998. Los espejos del novelista. Modernismo y autorreferencia en la novela vanguardista española. Barcelona: Península.

Rodríguez Fischer, Ana (ed.), 1999. Prosa de vanguardia española. Madrid: Castalia.

Romero, José Luis, 1937. "Sobre el espíritu de la facción", Sur, 33, jun., 5-77.

Sabugo Abril, Amancio, 1990. "Alberti en las revistas literarias del 27" en Cuadernos Hispanoamericanos, 485-486. Op. cit., 87-94.

SALAÜN, Serge, 1995. "La literatura entre pureza y revolución. El teatro (1914-1936)", en Rıco, Francisco, 1995. (Ed.) Historia y crítica de la literatura española, t. VII/1, Época contemporánea 1914-1939. Primer suplemento, op. cit., 512-522.

-------, 1998. "Las vanguardias políticas: la cuestión estética" en PÉrEz BAzo, Javier (ed.), 1998. La vanguardia en España. Arte y literatura, op. cit., pp. 209-225.

Salinas, Pedro, 1935. "Dos elegías a un torero: García Lorca y Alberti" en Literatura española siglo XX, México, Antigua Librería Robredo, $2^{\mathrm{a}}$ ed. aumentada, 1949, pp. 205-210.

------, 1943. "La poesía de Rafael Alberti" en Literatura española siglo XX. Op. cit., pp. 193-197.

Salinas de MARICHAL, Solita [1968]. El mundo poético de Rafael Alberti. Madrid: Gredos.

Samarach, Juan Antonio, 1994. Nace el deporte moderno, en Jover Zamora, José María (Director), 1994. Historia de España Menéndez Pidal. 39 tomos. VII, t. X. El deporte (Coord. Juan Antonio SAMARACH). 
Santiáñez, Nil, 2002. Investigaciones literarias. Modernidad, historia de la literatura y modernismos, Barcelona: Crítica.

Sánchez Trigueros, Antonio y Chicharro Chamorro, Antonio (eds.), 1992. Francisco Ayala. Teórico y crítico literario. Granada: Diputación Provincial de Granada.

Sánchez Vidal, Agustín, 1989. "La cultura española de vanguardia" en Albaladejo, F. J. y de LA Fuente, Blasco R. (coords.), 1992. Las vanguardias. Renovación de los elnguajes poéticos (2). Madrid: Júcar, pp. 13-29. Reproducido en WentzLafFEgGebert, Haral, 1999, op. cit. pp. 341-354. Publicada originalmente en japonés en el catálogo de la exposición "Spanish Masterpieces of the $20^{\text {th }}$ Century", inaugurada en junio de 1989 en el Seibu Museum of Art de Tokyo.

Sanguinetti, Edoardo, 1965. Vanguardia, ideología y lenguaje. Caracas: Monte Avila Editores.

SARLO, Beatriz, 1991. "Literatura e historia", Boletín de historia social europea, 3, Universidad Nacional de La Plata, Facultad de Humanidades y Ciencias de la Educación, La Plata, pp. 25-36.

------, 1988. Una modernidad periférica: Buenos Aires 1920 y 1930. Buenos Aires: Nueva Visión.

SARTRE, Jean Paul, 1950. ¿Qué es la literatura?. Buenos Aires: Losada, $7 ₫$ ed. (Trad. de Aurora Bernárdez).

SCHWARTZ, Jorge. Las vanguardias latinoamericanas. Textos programáticos y críticos. Cátedra, Madrid, 1991.

Siebenmann, Gustav, 1984. "El concepto "vanguardia" en las literaturas hispánicas", en Rico, Francisco, 1995. (Ed.) Historia y crítica de la literatura española, t. VII, Época contemporánea 1914-1939, op. cit. 179-182.

SILVER, Philip, 1969. "La deshumanización del arte" en Rico, Francisco, 1984. (Ed.) Historia y crítica de la literatura española, t. VII, dirigido por GARCiA DE LA CONCHA, Víctor, Época contemporánea 1914-1939, op. cit. pp. 34-39.

SoldeVILA Durante, Ignacio, 1988. "El gato encerrado. (Contribución al estudio de la génesis de los procedimientos creadores en la prosa ramoniana)" en Revista de Occidente, 80, enero, pp. 31-62.

------, 1995. "La literatura del exilio en la historiografía" en Aznar Soler, Manuel (ed.),1995. Las literaturas exiliadas en 1939. Op. cit., pp. 11-15.

-----, 1980. La novela desde 1936. Madrid: Alhambra.

------, 1973. La obra narrativa de Max Aub (1929-1969). Madrid: Gredos.

Soria Olmedo, Andrés, 1990. "La depuración de la mirada. En torno al neopopularismo en Rafael Alberti", en Cuadernos Hispanoamericanos. Homenaje a Rafael Alberti, op. cit. pp. 109-118.

Soriano, Osvaldo, 1991. "Rafael Alberti, años de guerra y años de paz" en Página 12, 21 abr. 1991, pp. 22-25. 
SuBIRATS, Eduardo, 1989. El final de las vanguardias. Anthropos: Madrid.

------, 1991. "Transformaciones de la cultura moderna", en CAsullo, Nicolás (Comp.), 1991. El debate modernidad pos-modernidad. Buenos Aires: Puntosur. (Publicado en Leviatán, 20, verano 1985).

Tagliabue, Nidia, 1989. "El exilio español en Argentina: la labor de Francisco Ayala, Luis Jiménez de Asúa y Lorenzo Luzuriaga" en AbelLÁn, José Luis y Monclús, Antonio (coords.), 1989. El pensamiento español contemporáneo y la idea de América. T II. El pensamiento en el exilio, op. cit. pp. 477-495.

TejadA, José Luis,1977. Rafael Alberti, entre la tradición y la vanguardia. (Poesía primera: 1920-1926). (Pról. de Francisco LóPEz EstradA). Madrid: Gredos.

Todorov, Tzvetan, 1993. "Los tábanos modernos" en Las morales de la historia. Barcelona: Paidós. (Trad. de Marta Bertran Alcázar), pp.

TomÁs, Facundo, (ed), 2002. En el país del arte. $2^{\circ}$ encuentro internacional: Literatura y arte en el entresiglos XIX-XX. Celebrado en la Academia de Roma. 6-9 de julio de 2001, op. cit. Valencia: Bilbioteca Valenciana.

------, 1998a. Escrito, pintado (Dialéctica entre escritura e imágenes en la conformación del pensamiento europeo). Madrid, Visor.

--------, 2001. Formas artísticas y sociedad de masas. Elementos para una genealogía del gusto estético: el entresiglos XIX-XX. Madrid: La balsa de la Medusa.

------, 1998b. Intr. a Blasco IBÁñEz, Vicente. La maja desnuda. Madrid: Cátedra.

-------, 2000. Las culturas periféricas y el síndrome del 98. Barcelona: Anthropos.

TORRE, Guillermo de, 1965. Historia de la literaturas de vanguardia. Madrid: Guadarrama.

------, 1925. Literaturas europeas de vanguardia. Madrid: Caro Raggio.

-------, 1937. "Por un arte integral" (Carta a Don Antonio Sánchez Barbudo. Secretario de Hora de España).Sur, Polémica, 37, VII, oct. 1937, pp. 52-63.

Trapiello, Andrés, 1994. Las armas y las letras. Literatura y guerra civil (1936-1939). Barcelona: Planeta.

Tuñon de Lara, Manuel, 1970. Medio siglo de cultura española (1886-1936). Madrid: Tecnos.

Tusell, Javier y G. QueIPo de Llano, Genoveva, 1990. Los intelectuales y la República. Madrid: Nerea.

Ugarte, Michael, 1999. Literatura española en el exilio. Un estudio comparativo. Madrid: Siglo XXI.

UmBRAL, Francisco, 1978. Ramón y las vanguardias. Madrid: Espasa-Calpe. 
VÁzquez Medel, Manuel Ángel, 1994. "El proceso de subjetivación en la crisis de la modernidad" en Bargalló, Juan (ed.), Identidad y alteridad: aproximación al tema del 'doble'. Sevilla: Alfar, 55-69.

-------, (ed.), 1998a. Francisco Ayala: el escritor en su siglo. Sevilla: Alfar, 1998.

------, (ed.), 1998b. Francisco Ayala y las vanguardias. Sevilla: Alfar.

-------, 1998c. "Técnica y estilo en El boxeador y un ángel" en VÁzquez Medel, Manuel Ángel (ed.), 1998b. Francisco Ayala y las vanguardias. Op. cit., 73-88.

VÁzquez Montalbán, Manuel, 1989. "El escriba sentado" en Revista de Occidente. Número extraordinario: Narrativa Española actual. Jul-ag. 1989, pp.13-26. (Recogido en Vázquez Montalbán, M., 1997. El escriba sentado. Crítica, Barcelona).

-------, 1999. "Vanguardia poética y vanguardia política" en EL PAís, CuLtURA, "Luto por un poeta universal", op. cit., p. 51.

Vega DíAz, Francisco, 1984. "La amistad entre Ortega y Ramón Gómez de la Serna” en Cuadernos Hispanoamericanos. Número Homenaje a José Ortega y Gaset, 403-405, pp. 317-328.

VICENT, Manuel, 1984. Inventario de otoño. Madrid: Debate, 2a. ed.

VIDELA, Gloria, 1963. El ultraísmo. Estudios sobre movimientos poéticos de vanguardia en España. Madrid: Gredos.

Vivanco, Luis Felipe. 1963. "Rafael Alberti y su palabra acelerada y vestida de luces" en Durán, Manuel, (ed.), 1975. Rafael Alberti. Op. cit., pp. 181-204.

V.AA., 1985. Eternidad yacente. Estudios sobre la obra de Rafael Alberti, Granada, Universidad de Granada.

WILSON, Jason, 1990. "'Más o menos surrealístico': la modernidad de Rafael Alberti” en Cuadernos Hispanoamericanos, 485-486, nov. 1990, Op. cit., pp. 59-67.

Wentzlaff-Eggebert, Haral, 1999. Las vanguardias literarias en España. Bibliografía y antología crítica. Madrid, Frankfurt: Iberoamericana-Vervuert.

WolfE, Tom, 1988. El nuevo periodismo, Barcelona: Anagrama, $4^{\mathrm{a}}$ ed.

Yhanl, Roberto, 1995.. "Ramón Gómez de la Serna introductor de las vanguardias en España en Actas del III Congreso Argentino de Hispanistas. Mar del Plata: Universidad de Mar del Plata, mayo 1995, 591-593.

Zardoya, Concha,1974. Poesía española del siglo XX. Estudios temáticos y estilísticos. Madrid: Gredos.

Zlotescu, loana C., 1989. Introducción a Gómez de la Serna, Ramón, 1927. 6 falsas novelas. Madrid: Mondadori, pp.5-33. 
Zuleta, Emilia de, 1971. Cinco poetas españoles (Salinas, Guillén, Lorca, Alberti, Cernuda). Madrid: Gredos.

-------, 1999. Españoles en la Argentina. El Exilio literario de 1999. Buenos Aires: Atril.

------, 1984. "Historia y ficción: dos versiones de 'La campana de Huesca'", Revista de Literaturas Modernas, XVII, 95, Universidad Nacional de Cuyo, Mendoza, pp. 77-97.

-------, 1983. Relaciones literarias entre España y la Argentina. Madrid: Ed. Cultura Hispánica del ICl. 